


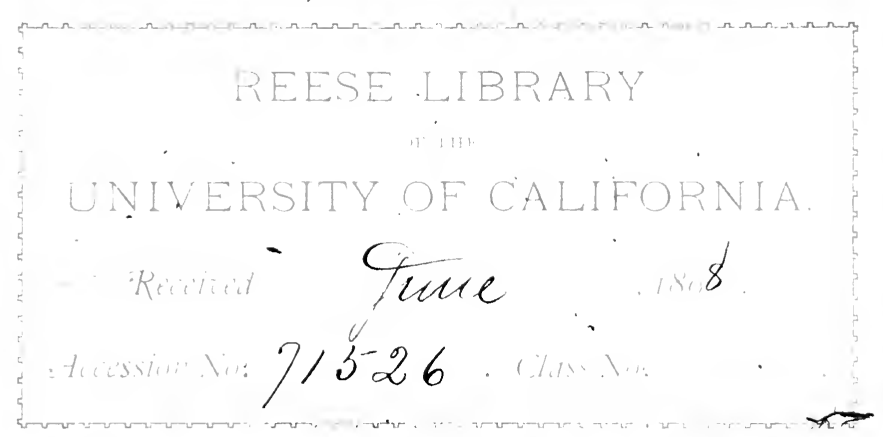


Digitized by the Internet Archive in 2007 with funding from Microsoft Corporation 


\section{RECENT ADVANCES}

IN

\section{THEISTIC PHILOSOPHY OF RELIGION}





\title{
RECENT ADVANCES IN
}

\section{THEISTIC PHILOSOPHY}

OF RELIGION.

BY

\author{
J A M ES L I N DSAY \\ M.A., B.D., B.Sc., F.R.S.E., F.G.S.
}

CORRESPONDING MEMBER OF THE ROYAL ACADEMY OF SCIENCES, LETTERS, AND ARTS OF PADUA;

AUTHOR OF 'THE PROGRESSIVENESS OF MODERN CHRISTIAN THOUGHT,'

'ESSAYS, LITERARY AND PHILOSOPHICAL,' 'THE SIGNIFICANCE

OF THE OLD TESTAMENT FOR MODERN THEOLOGY,'

ETC., ETC. ;

AND MINISTER OF ST ANDREW'S PARISH,

KILMARNOCK

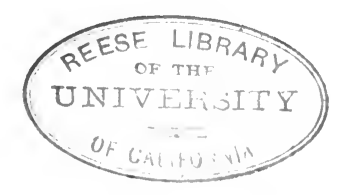

WILLIAM BLACKWOOD AND SONS

EDINBURGH AND LONDON

M D C C C X C V I I 
$P D 555$ 45

71526 


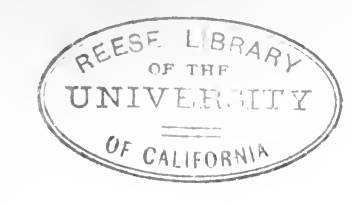

\section{P REF A C E.}

THE unusually favourable reception accorded in the most competent quarters to my former work on 'The Progressiveness of Modern Christian Thought' has led me to prepare the present and much larger volume. As that work sought to vindicate the Progressiveness of Christian Theology in general, so this contends for the Progressiveness of Theism in particular, and seeks more especially to prove the actual progressiveness of recent theistic thought. This I have deemed worthy of separate endeavour for reasons that seem to me to be specially weighty in connection with theistic thought. Besides, I certainly do not know any more important inquiry in itself for our race than that which concerns itself with those theistic beliefs which are the basal truths of all religion; and this inquiry has in recent times "become shifted from the search after a revelation by an acknowledged Creator, which marked the days of Deism, to the 
prior and deeper problem whether there be indeed any real personal Creator at all. I hope I may be allowed to say that no conviction has for a long series of years been more firmly rooted in my mind than that the religious thought of our time has no deeper needs than these two,- - first, to have the bases of religious belief broadened, the theistic foundations deepened, extended, strengthened; and, secondly, to have the abiding progressiveness of such belief explicitly recognised and thoroughly demonstrated. The second of these needs I took first-in my "Progressiveness" work-as having been practically an untraversed field. I now desire to bear my part towards the accomplishment of the first in such a manner that these two efforts shall not be disconnected and unrelated. In both cases I have tried to remember that, while there is no lack of analytical power to-day, the great need-the prime want-is, as I believe, synthetic power and constructive intellect. I trust that the discussions on the Being and Attributes of God, the Causal, Ontological, and Teleological Arguments, will be found not unworthy of one who believes the post-Kantian depreciation of them a huge speculative mistake.

I have judged it desirable to treat, in the course of the present inquiry, of subjects of such deep speculative interest as Pérsonality, Freedom, Reason, the Reign of Law in Man, the Spiritual Nature, Needs, and Goal of Man, the Philosophy of His- 
tory, and Immortality, the treatment of which, I venture to hope, will be found not less suggestive or new than other parts of the work. The Personality of God, indeed, I have deemed of such surpassing importance as to call for a line of treatment such as will not, so far as I am aware, be found anywhere else, even though space-limits have curtailed my treatment of this transcendent and inspiring theme to a degree that little represents my likings. Not less important, from some points of view, will be found, I believe, the treatment here given to Personality in Man.

Without entering into all the reasons which have weighed with me in this attempt, I would point out that the endeavour is one of paramount importance and urgency, so long as theistic writers of undoubted ability are to be found who certainly succeed in creating an impression so unfavourable to the Progressiveness of Theism as to be precisely the opposite of that which it is my desire to deepen and produce by trying to establish and exhibit the progressive character of recent Theistic Philosophy. For, progressive in a most real sense I maintain it is, as I hope in succeeding pages to make evidentin a way different from what has before been done,when we shall have viewed the new vast increase of knowledge with its wealth of scientific result for theistic thought, and surveyed the new views of the methods of development of the physical universe in their bearings upon the intellectual 
exposition of the Cosmos. One may surely be excused if in this connection he confesses to a feeling of amazement and even dismay that distinguished writers on theistic themes should so often seem to think that nothing of more modern interest is needed than the belated treatment which only loves to dilate on the oft-criticised positions of Descartes, Hume, and Kant. Judging from almost anything they make appear, the thought of the world might since have relapsed into slumber, or have become shorn of progressive power and expanding content. Does it need to be said how far otherwise it has really been-how intense have grown the activities, and how immense the results, of thought, with the advance of the nineteenth century, so that the difficulties of the theistic philosopher are-even with the dearth of constructive elements-such as really spring from an embarras de richesse? It ought not to be necessary to say that I am not here supposing anything so absurdly optimistic as that all recent movement has been towards strengthening theistic thought: the case is simply that it is with the advances of theistic philosophy I have desired to deal-that is to say, with its continuity and development through all checks and reverses.

I think enough has been said to show that, in following a critico-speculative mode, it is not my purpose merely to add another to existing exposi- 
tions of Theism or the Philosophy of Religion: rather, the present work presupposes them, and, taking critical account of them, proceeds to cast its own distinctive contribution on to the slowly rising pile of theistic knowledge. In addition to the considerations already mentioned, I may say that, while it has been a loud and incessant reproach against theistic works that they have quite inadequately kept - when keeping at all - before them the bearings of evolution on the form and content of what they often presented, I have steadfastly sought, even while not unduly dealing in detail with evolutionary bearings, to write as one conscious of the evolutionary atmosphere in which the thought of our time lives. For it might almost be now asked, Who can think at all, and not think thus to-day? How else can present and actual issues be faced, except along these evolutionary lines of treatment? I seek to yield to science all that belongs to it: I only claim, at the same time, for God on the one hand, and for man on the other, what may be quite as rightfully claimed for them.

The task I have set myself has been not less difficult than distinctive, but I have not been unmindful of the fact that thought, too, has its risks which must be run. Further, I think I have, with deeper consciousness of the imperfection of my work, always more fully appreciated the spirit of 
Goethe's saying that "the deed is everything," for, far more than all else, its performance has become a pleasurable necessity to me; and if-as I hope -my work should bring light, inspiration, stimulus, to others, I shall therein find additional satisfaction. Theistic philosophy has - as it seems to me-one method and one hope, the same which are expressed in the poet's line-

"Painstaking thought, and truth its dear reward."

The three divisions of the work-Recent Philosophy of Natural Theology, Recent Philosophy of Theism (God), and Recent Theistic Philosophy of Religion (Man) - are not meant to be taken in any other sense than as a convenient general arrangement, and are not designed to convey that what stands under any one of these divisions may never have real and intimate relations to either of the other two divisions. An imperial chord subsists through all, which is that of theistic principle.

One thing only remains for me to add. Though the number of thinkers and writers referred to is so great, yet these are but a small part of those who, abroad and at home, have claimed my interest and attention. But I have not found it practicable to make explicit reference to them all without interfering with the natural order and course of my treatment, and, while maintaining its scientific and philosophical character, I have not felt called to give 
the work an unnecessarily mechanical and pedantic appearance by resorting to appendices and footnotes. Deeply conscious of its defects, I send it forth, not without deep thankfulness to God that He has permitted me to take part in what is to me the greatest of earthly causes.

$$
\text { JAMES LINDSAY, }
$$

Kilmarnock, December i8g6. 



\section{O N T E N TS.}

\section{CHAPTER I.}

INTRODUCTORY.

The Progressiveness of Theism maintained . . . . I

Current misconceptions touching theistic philosophy . . I

Desiderata of modern theistic philosophy . $\quad$. $\quad 2$

Its relation to the advances of scientific knowledge . . 2

Call for a thoroughly rational, and not merely ethical, theism . 2

The present positive task of theistic philosophy. . . 2

The reason and relatedness of the World-Ground to be set forth 3

The real relation of God to the world in theistic philosophy . 3

Importance of the task here attempted . . . . . 3

Ritschlian attitude towards Natural Theology . $\quad$. $\quad$. 4

$\begin{array}{lllllllll}\text { Vindication of the natural pieties } & \text {. } & \text {. } & & & & & & \end{array}$

Claims of a progressive Natural Theology urged $\quad$. $\quad$. 4

Theistic philosophy not lacking in intellectual humility . 5

Recent troubles of theistic philosophy . . . . . 5

What Natural Theology really is . $\quad$. $\quad . \quad . \quad . \quad 5$

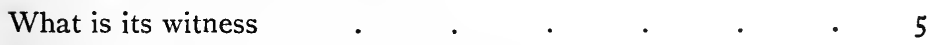

Professor Flint's view of its relevant facts . $\quad$. $\quad$. 6

Relation of Natural Theology to Dogmatics $\quad$. $\quad$. $\quad$. 6

The actual Progressiveness of Natural Religion presented . 6

What a true Philosophy of Natural Theology will maintain $\quad 7$

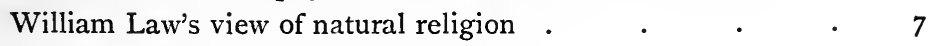


The category of substance as a starting-point . $\quad$. 7

Its relation to God the Absolute Personality . $\quad$. 7

$\begin{array}{llllllllllll} & & & \\ \end{array}$

Place of real or ultimate Personality in our philosophy . $\quad 8$

God as the Absolute Consciousness in relation to philosophy

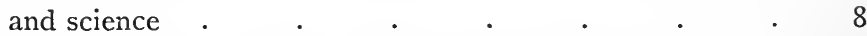

The transcendence of Deity in the theistic philosophy . 9

Reality of the human self and its relations . . . 10

Agnosticism not a possible halting-place . . 10

The sweep and range of the theistic philosophy set forth . Io

The categories of physical science and their metaphysical im-

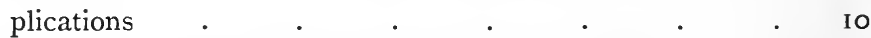

Difficulties of theistic philosophy enormously increased . . II

Quest of an Urgrund or fundamental ground its primal task . I I

What a thorough Apologetic will mean . . . . II

Its imperative necessity . $\quad$. $\quad . \quad$. $\quad . \quad$ I I

Its avoidance of the extremes of subjectivism and objectivism . I I

Rational religion not to be deemed a scientific impossibility . $\quad$ I2

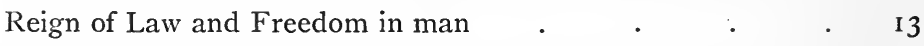

Theistic possibilities of a Philosophy of History. . . I 3

Immortality in the synthetic philosophy . . . . . $\quad$ I3

View of it in theistic philosophy . . . . . . 14

Reflections on the scope, spirit, and method of theistic thought and inquiry . $\quad . \quad$. $\quad . \quad . \quad . \quad$. $\quad$ I4

PART FIRST.

RECENT PHILOSOPHY OF NATURAL THEOLOGY.

CHAPTER II.

RECENT PHILOSOPHY AND THE NATURE OF RELIGION.

Method of History of Religion . . . . 2 I

Mozley on relation of natural and revealed religion . 2 I

Newman and Ritschl in relation to natural religion . $\quad 2$ I

Need for reconstruction in Natural Theology . . . . 22

A less mechanical method adopted . . . . 22 
Universal religious experience to be consulted . . . 22

Importance of the study of the ethnic religions . $\quad . \quad{ }^{2}$

Teaching of the science of Comparative Religion . . $\quad 22$

Professor P. D. Chantepie de la Saussaye on natural development 23

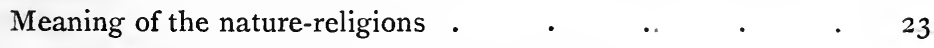

Psychological processes in the nature-religions . . . 23

Religion wider than theistic conception . . . . 23

Notion of self-existent Cause or Creator in Natural Theology . 23

Significance of the History of Religions for theistic study . $\quad 24$

Hegel on the idea of God . $\quad . \quad$. $\quad$. $\quad . \quad 24$

Place of the theistic conception of God in the history of the race 24

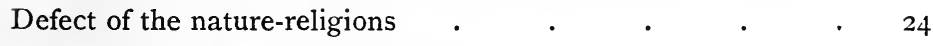

Implications of Natural Theology $\quad \cdot \quad$. $\quad . \quad 24$

Pure or natural theism inadequate . . . . . 24

Such natural theism lacks the dignity and inspiring powers of real religion . . . . . . . 25

Scientific study of nature and the transcendence of God . $\quad 25$

Forces of nature demand the Infinite Wisdom and the Absolute

Power . . . . . . . . 25

Ethnic inspiration beyond the bounds of Christianity's working 25

Rudimentary theistic belief . . . . . 26

Animism, Polytheism, Monotheism . . . . $\quad$. 26

Inadequacy of naturalistic explanations of religion $\quad . \quad$. 27

Critical remarks on Professor Edward Caird's scheme . $\quad 27$

Race-relation to the Absolute . $\quad . \quad$. $\quad . \quad 28$

Attempts to trace out the theistic evolution of natural religions 28

Dr Kellogg on the thought of India $\quad . \quad$. $\quad . \quad 28$

Religious Spirit of the Vedas $\quad . \quad$. $\quad$. $\quad$. $\quad$. 29

Professor Pfleiderer and primitive naturism $\quad$. $\quad . \quad$. 29

Recognition of the Absolute Spirit or Reason in primitive

religion $. \quad . \quad . \quad . \quad$. $\quad . \quad$. 29

Principal John Caird on Religion $\quad . \quad$. $\quad$. $\quad$. 30

Personal character of the religious relation . . . . 30

Critical remarks on Hegel's view of religion . . . . 30

The true determination of religion $\quad . \quad$. $\quad . \quad$. 30

Schleiermacherian dependence eschewed . . . $3 \mathbf{I}$

Faith a basal activity of man's spirit . . . . . $\quad$ 3I

One-sidedness of definitions of the nature of religion . . $\quad 3^{\text {I }}$

The double aspect or total content of religion . . . . $3 \mathbf{I}$

Rothe on the religious self-consciousness . . . 3 I 
Personal nature of the Absolute Spirit . . . . . 32

Criticism of Professor Edward Caird's principle of unity $\quad . \quad 32$

Lotze's ultimate in the explanation of things . . . $\quad 34$

Religion set forth as spiritual communion . . . . 34

Objective character of the religious relation . . . . $\quad$. 34

Criticism of Dr Bender, of Bonn . $\quad . \quad$. $\quad . \quad$. $\quad 35$

Principal Caird on the religious basis . . . . . $\quad$. 35

Religion as whole and perfect $\quad . \quad$. $\quad . \quad$. $\quad . \quad 35$

God as its metaphysical Urgrund $\quad . \quad$. $\quad . \quad$. 35

A higher fulfilment of Schopenhauer's contendings for religion 36

Dr James Martineau on the religious relation . . . $\quad 36$

Complex character and dynamic force of religious faith $\quad 36$

Widest acceptation of the term religion . . . . 36

Parallel between the basis of science and that of religion $\quad 36$

Duty of recognising personal relation to the Highest . $\quad 37$

Religion in its highest form and reach to be considered . 37

Insufficiency of mere religious feeling . . . . . $\quad . \quad 37$

Place and function of the Incarnation . . . . . 37

The task of anti-theistic theories . . . . . $\quad 38$

Rev. James Tait, of Montreal, on the theistic conception - $\quad 38$

Criticism of the theism of the work entitled 'Natural Religion' 38

The supernatural in theistic philosophy . . . . 39

Real outcome of the scientific study of nature . . . $\quad$. 39

The synthesis sought by theistic philosophy . . . 40

Its hold upon the supersensuous . . . . . . 40

Natural Theology as a constructive science . . . . 40

What the evolution of life really means . . . . 40

Strauss and his Glaubenslehre . . . . . . . $4 \mathrm{I}$

Teleological aspects in theistic philosophy . . . 4 I

Christianity the most truly natural religion . . . $\quad$. $4 \mathrm{I}$

The services of pantheism in respect of immanence . $\quad 4 \quad 42$

Criticisms on John Fiske and on Principal Edwards, of Bala . 42

A true transcendence for Deity to be maintained by theistic philosophy . . . . . . . . 42

Criticism of the Deity presented in pantheism . . . . 43

Mediations of the historic process of revelation . . . . 43

Necessity of the personal subjective activity of faith . . 44 


\section{CHAPTER III.}

RECENT THEORIES OF THE ORIGIN OF RELIGION.

Lack of data as to empiric origin of religion

The philosophy of religion goes deeper than outward historic

forms . . . . . . . . . 46

How it deals with the facts of religious history . . . 47

Maintains the present philosophical value of religion . . 47

Naturalistic views of its origin rejected . $\quad . \quad$. $\quad .47$

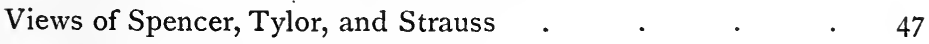

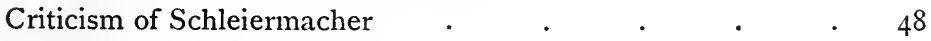

Criticism of theories tracing religion to fear, ignorance, dread, \&c.

Criticism of attempts to set the stages of religion in serial order 48

An objective reality related to religion in its cruder forms.

Speculations as to prehistoric origin of religion over-estimated

A more important inquiry here than the empirical or historical beginning of religion. . . . . . 50

Considerations urged towards a rational interpretation. . 50

Evolution of religion in the view of our theistic philosophy . $\quad 50$

Recent philosophy on our normal self-consciousness and supernatural revelation

Professors Robertson Smith, Pfleiderer, \&c., on place of mythology

Relation of our natural or world-knowledge to origin of the concept of God

Views of Réville referred to

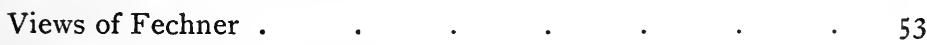

Views of the question held by the present writer . . $\quad 53$

Results of inquiries into tribes wholly without religion . . 54

Views of Roskoff, Peschel, Hellwald, Tiele, Quatrefages,

Réville, and others . $\quad . \quad$. $\quad . \quad$. 54

Lotze's view of the attempt to base Divine Belief on the agree-

ment of mankind . $\quad . \quad$. $\quad . \quad$. 54

A higher and more relevant inquiry here $\quad . \quad$. $\quad . \quad 55$

Universality of the religious instinct-how viewed . . 55

Difficulties raised by the Naturvölker . $\quad . \quad$. $\quad . \quad 56$

Distrust expressed in theories of origin . . . . 56 
True naturalness of religious perception in man . . $\quad 56$

Psychological and objective development in the race and the individual . $. \quad . \quad . \quad . \quad . \quad 56$

Place for the personal element on the human side . . 57

Place for supernal advance on the Divine side . $\quad$. $\quad 57$

Revelation of the Divine in the finite spirit or consciousness . $\quad 57$

Gods of the oldest religions really spirits $\quad$. $\quad . \quad 57$

Religious aspects converging towards the theistic conception . $\quad 58$

The palæontological races in relation to religion . $\quad . \quad 58$

What stable consciousness of the gods implied . . . 58

Dr J. G. Fraser's 'Golden Bough' . . . . 58

No adequate origin to be found without the attributes of the superhuman being kept in view . . . . 58

What Nature meant for primitive man . $\quad . \quad$. $\quad .59$

C. I. Nitzsch on inward religious susceptibility as a primary element in man $. \quad . \quad . \quad . \quad . \quad .59$

The theism of nature alone insufficient . . . . 60

Religion not the mere goings forth of man's finite faculty . 60

Reason sought for naturalistic theories as to its origin . . 60

Writer's view of recent tendencies of thought . . . 60

Creative presence of the Urgrund to be maintained . . 6I

Parallel between possibilities of scientific and of religious evo-

lution . . . . . . . . 6 6 I

Inwardness of Hebrew monotheism . . . . 6I

Historic beginnings-how antedated . . . . 6I

Relations of religion and morality $\quad$. $\quad . \quad . \quad . \quad 62$

Religion not to be merged in ethics . . . . 62

Distinctive character of religion set forth $\quad . \quad . \quad . \quad 63$

An exclusively religious basis not to be posited for morality . 63

Moral consciousness not at the mercy of religious beliefs . 63

Pfleiderer on the historic genesis of morality . . . 63

Critical comments on Dr James Kidd's view of morality in relation to religion $\quad . \quad . \quad . \quad . \quad . \quad . \quad . \quad 63$

Tendencies of Greek and Hindu thought $\quad$. $\quad .63$

Ethical Hebrew pre-eminence . . . . . 64

Hebraism and Hellenism . $\quad . \quad$. $\quad . \quad$. 64

Professor Toy, of Harvard, on Hebrew immanence . $\quad$. 64

Considerations as to Old Testament transcendence . . 64

Function of Christian thought to-day . . . . . 65

Man's development in the knowledge of God . . . 65 
Fitting synthesis in a pure anthropocosmic theism . $\quad 65$

Unification of Aryan and Semitic conceptions . . . 65

Christianity as itself a direct and independent revelation . 66

Presence of supernatural elements . . . . . 66

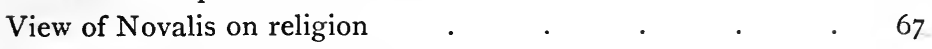

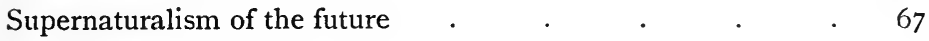

CHAPTER IV.

RECENT THOUGHT AND THE PERMANENCE OF RELIGION.

Numbing and retarding effects of sin on development of religion 69

Perpetuity and progress of Natural Theology . . . . . 69

The future of religion $\quad . \quad$. $\quad . \quad$. $\quad . \quad$. 70

View of Theodore Parker . $\quad . \quad$. $\quad . \quad$. 70

Hartmann on the religion of the future . . . 70

Christianity the "fittest" religion to "survive" . . . 70

View of Schweizer. $\quad . \quad$. $\quad . \quad$. $\quad .70$

Teleological character of the Christian religion . . . 70

Religion a human and abiding characteristic . . . 7 I

The religious function a normal one in humanity's development 7 I

Principal Fairbairn on the subject . . . . $7 \mathrm{I}$

Claims of culture considered . . . . . 7 I

Schleiermacher's appeal to the cultured . . . . 72

True religion conditions culture . . . . . $\quad$. 72

The altruism of the future. $\quad$. $\quad . \quad 42$

Inadequacy of the Positivist ideal . . . . $\quad$. 73

Possibilities of Christianity $\quad$. $\quad . \quad$. $\quad . \quad$. 73

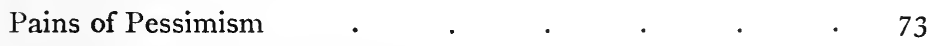

Goethe on progress of humanity . . . . . $\quad$. 73

Lewes on the persistence of religion . . . . . $\quad 43$

Theistic philosophy has its own Weltanschaunng of the future $\quad 74$

Religion never to be displaced by science $\quad$. $\quad$. 74

The teaching of Spencerianism . $\quad$. $\quad$. $\quad$. 74

Unsatisfactoriness of the Absolute of Agnosticism • $\quad 75$

Unreasonableness of conflict between science and theology . 75

Science and the supernatural . . . . . . 76

Needs of the intellect to be met in religion . . $\quad 76$

Worth of theoretic elements or values . . . . . $\quad 76$

Place of ritual in a progressive system of religious thought $\quad$. 77 


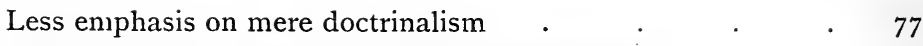

Greater ethical emphasis in religion of the future $\quad$. 77

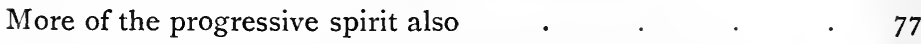

Permanence of the philosophy of religion . . $\quad 78$

Trendelenburg on this philosophical permanence . $\quad 78$

Abiding essence and permanent elements in religious evolution $\quad 79$

Foundations of the philosophical permanence . • . 79

The contributory influences from Germany, Holland, France,

Britain, and America . $\quad$. $\quad$. $\quad$. $\quad .79$

What the philosophical permanence will imply . . . 80

A true idealism to be maintained . . . 80

Christianity as truth . . . . . . 80

F. A. Lange on the permanence of religious doctrines or ideas 80

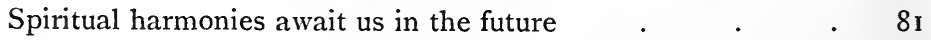

Janet on the permanence of the religious sentiment . $\quad 8 \mathrm{I}$

Not a permanence only, but also a perfection, of religion to be

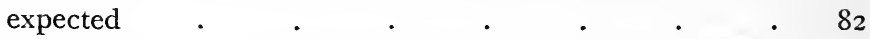

Theodore Parker on its naturalness and progressiveness $\quad$. 82

\section{PART SECOND.}

\section{RECENT PHILOSOPHY OF THEISM (GOD).}

\section{CHAPTER V.}

RECENT THOUGHT ON THE BEING AND ATTRIBUTES OF GOD.

Power and implicates of Christian Theism . $\quad$. $\quad 87$

Larger apprehension and truer representation of the God idea. $\quad 88$

Reasonableness and scientific character of the theistic hypothesis 88

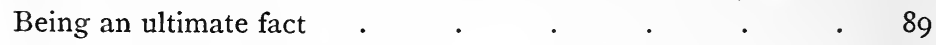

God as the Unconditioned Being . $\quad . \quad$. $\quad . \quad$. $\quad 89$

Infinite and unconditioned reality as goal of theistic philosophy $\quad 89$

The Kampf found in Nature in recent philosophy of theism . 89

Modern theistic philosophers on the knowableness of the In-

finite Being . . . . . . . 90

Why God is to be taken as the First Principle of all things . 90

Attitude of theistic philosophy towards agnostic, pantheistic, and idealistic representations of Deity . . . $9 \mathbf{I}$ 
Criticism of recent attempts to explain the world as the selfevolution of Absolute Being . . . . . 9 91

Attributes of the World-Ground . . . . . . 91

What metaphysics can do for us here.$\quad$. $\quad . \quad$. 91

On the treatment of God as the principle of unity $\quad . \quad$. 92

Theistic philosophy on the conception of Force . . . $\quad$. 92

Bearings of the immanence of God . . . . . $\quad$. 93

Criticism of Hegel's treatment of being . . . . . . 93

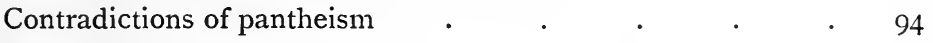

Purgation of anthropomorphism . $\quad$. $\quad$. $\quad$. $\quad$. 94

The Divine Attributes-how viewed . $\quad$. $\quad$. 94

Criticism of Kant's treatment of the concept of God . $\quad 95$

The knowableness of Deity conserved as against Spencer . 95

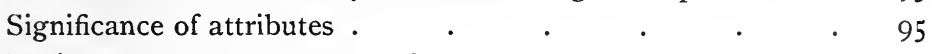

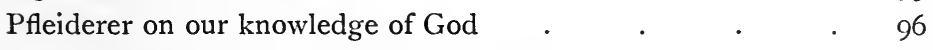

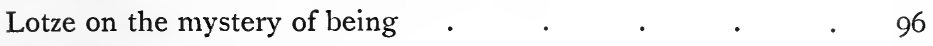

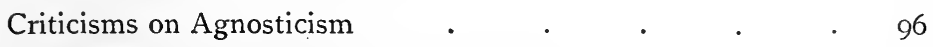

The speculative impulse not to be fettered . . . $\quad 97$

Presumptive evidence afforded by the theistic hypothesis $\quad 97$

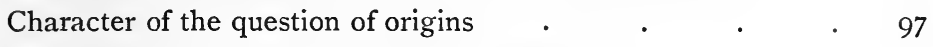

How the theistic problem should be dealt with . . . $\quad 98$

Priority of mind to matter still maintained $\quad . \quad$. $\quad .98$

Tyndall, Fiske, and Haeckel on the passage from matter to mind . $\quad . \quad$. $\quad . \quad$. $\quad . \quad$. 98

Monistic interpretations of Professors Romanes and Lloyd

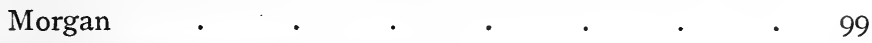

Scientific method of theistic procedure . $\quad . \quad$. $\quad . \quad$. 99

Irrationalities of primary impersonal force $\quad . \quad$. $\quad . \quad$. 99

Triumphs of philosophic theism . $\quad . \quad$. $\quad . \quad$. 99

Criticism of the phenomenalism of Kant . . . $\quad$. 100

Ultimate dualism of mind and matter untenable . . $\quad$ I00

Knowledge-in what sense relative . . . . . IOI

Place for mind in the philosophy of theism . . . . IOI

God as Spirit the intelligent Force of the universe . . 102

Virtues of Hegelian speculation acknowledged . . . 102

Reflections on natural and spiritual laws . . . . 102

Considerations on the relations of matter and spirit . . 103

Value of the spiritual realism of Lotze . . . . . . $\quad$ I03

Professor Campbell Fraser on the theistic result . . 103

Criticisms on Rothe and Weisse . . . . . . 104 
Criticism of Hegelian unity betwixt man and God . . 104

Positions of Ulrici, Chalybäus, and Günther . . . 105

Criticism of monistic extremes . $\quad . \quad$. $\quad . \quad$. 105

Non-eternity of matter not to be surrendered . . . 106

Mind and matter-how joined $\quad . \quad$. $\quad . \quad . \quad . \quad 106$

Superiority of theistic hypothesis over materialistic alternative . I06

Monistic theories make a philosophy of nature impossible . $\quad$ I07

Belief in the eternity of matter as compatible with theism . 107

Creation out of nothing-its interpretative significance. . 107

Criticism of the Entheism of Dr Paul Carus . . . $\quad$ I08

The personal and self-existent Being as transcendent . . I09

Theistic philosophy on the regularity and uniformity of nature $\quad$ I09

Considerations as to necessity of object to love in God . I IO

View of Franz Hoffmann . . . . . . . . I IO

Criticism of Principal Fairbairn's view . . . . . I IO

Relation of attributes of Power and Love . . . III

Love of the Unconditioned . . . . . III

Rothe and Dr Fairbairn on the activity of Divine creative love III

Divine Wisdom and Power not to be unduly subordinated . II2

Criticisms on Mill and Professor Schiller . . . II2

Justice not a superfluous attribute of Deity . . . $\quad$ II2

Necessity of Justice exemplified . . . . . . . II3

Greatness of the theistic argument set forth . . . . II4

Importance of implicit proofs . $\quad . \quad$. $\quad . \quad$ II4

Deductive demonstration of Divine Being impossible . . II5

F. W. Newman on such syllogistic reasoning . . . 115

Elements in theistic conviction . . . . . . 115

Cumulative nature of the theistic proof . . . . II6

Depth and variety of theistic sources of belief . . . II6

Manifoldness of theistic methods and processes . . II6

Place and scope of the spiritual reason and the emotional nature . $\quad . \quad . \quad . \quad . \quad . \quad . \quad$ II7

Emerson on the affectional nature $\quad$. $\quad . \quad$. $\quad$ II7

Irrationality of scientific absolutism . . . . . II7

Professor William James, of Harvard, on the truth-seeking spirit . . . . . . . . . II

God is more than all our arguments . . . . 118

Greatness of the proofs of His being . . . . . 118

Professor Flint on comprehensiveness of idea of God . . 119

Services of Ulrici and others in respect of theistic proofs . II9 
Schopenhauer on theistic proofs . $\quad . \quad$. $\quad . \quad$ II9

Kuno Fischer on the reality of God for Kant . . . 120

Zeller on Kant and the Being of God . . . . . 120

Criticism of Kant's procedure $\quad . \quad$. $\quad . \quad$. $\quad$. 120

Pfleiderer on the theistic arguments . . . . I2I

How these proofs are related and are to be regarded . . I2I

Not a mere synthesis to be sought, but a satisfying standpoint

in anthropocosmic theism . . . . . . ${ }_{122}$

Agnosticism and the theistic proofs . . . . $\quad$. 122

What alone renders Agnosticism possible . . . $\quad$ I23

Professor Knight on the Intuitional Argument criticised . $\quad$ I 23

Krause and Lowell on intuition . . . . . . . 124

Criticism of Dr W. L. Davidson's theism . . . I $\quad$ I24

Function of the God-consciousness in man . . . 125

Value of our intuitive perception . . . . . . . $\quad$. $\quad$ I26

In what sense God is the Infinite $\quad$. . . $\quad$ I26

Unity and perfection of the Divine Being . . . $\quad$ I $\quad$ I26

Recent stress on personality $\quad$. $\quad . \quad$. $\quad . \quad$. $\quad$ I27

Historic treatment of theistic proofs . . . . $\quad$. 127

Difficulties in reconciling evil with the goodness and power of

God . . . . . . . . . . 128

Undue stress on the pain and suffering of the world . $\quad$ I $\quad$ I28

Life struggles of animal world sentimentally overdrawn _ $\quad$ I29

Considerations urged in mitigation of painful aspects . . I30

Progressive forces in nature . $\quad . \quad$. $\quad . \quad$. I3I

Theistic philosophy appreciates pressure of Pessimism on us . I3I

Criticism of the optimism of Rosmini . . . . . $\quad$ I 132

Pantheism and meliorism..$\quad$. . . . $\quad$. 132

Last word on world-imperfection not spoken . . . $\quad$ I33

Hegelian treatment unsatisfactory . . . . . . 133

Character of Christian optimism . $\quad$. $\quad$. $\quad$. $\quad$. $\quad$ I33

Shortcomings of Pessimism $\quad . \quad$. $\quad$. $\quad . \quad$. 133

Merits of Schopenhauer . $\quad$. $\quad$. $\quad$. $\quad$. $\quad$. 134

His defects and those of his disciples . . . . . 134

Results on theistic philosophy . $\quad . \quad$. $\quad . \quad 2 \quad$ I 35

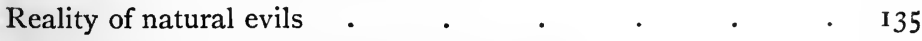

Evolutionist argument capable of inversion . . . . I35

Theism holds much in common with Pessimism . . 136

Theistic considerations as to beneficent purposes subserved by pain and suffering of the world 
These do not mean unreality of evil a . . $\quad$ I $\quad$ I37

Evil not good in the making, nor a necessity of development . 138

Our relativity carries only a liability to evil . . . $\quad$ I 38

Criticism of Biedermann's view of metaphysical aspects of evil I38

Moral evil to be interpreted in full light of such facts as free-

dom and moral responsibility $\quad . \quad$. $\quad . \quad$. $\quad{ }_{3} 38$

Action morally evil in rejecting the ideal good for us . . $\quad$ I39

Real character of moral evil as rebellion against Divine Will . $\quad$ r 39

That evil is overruled for good does not make evil contributory

to good . $\quad . \quad$. $\quad . \quad$. 140

The laws of our spiritual being point to God as Perfect Good-

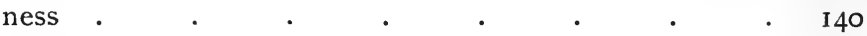

The problem of evil has proved no unfruitful inquiry . $\quad$ I40

\section{CHAPTER VI.}

RECENT STUDY OF THE COSMOLOGICAL PROOF.

Significance of this proof more acutely determined

142

Mansel on the principle of causality . . . . 142

Real philosophical advances in the sphere of causality . $\quad$ I 42

The metaphysic of causality (Urgrund) . • . . 143

Criticisms on Sir William Hamilton and J. S. Mill . . 143

\begin{tabular}{l} 
Character of the proof from causality . . . . $\quad$ I43 \\
\hline
\end{tabular}

Relation of actual world to the Urgrund. . . . 144

Evolutional science and phenomenal sequence . . . 144

The notion of power in causation . . . . . 144

Impotence of science as to causal idea . $\quad . \quad$. $\quad$ I44

Arbitrariness and futility of the usual Causal Argument $\quad 145$

First Cause in a relative sense . . . . . . I45

Criticism of Spencer's view of the causal axiom . . . 145

Romanes on Hume, Kant, and Mill, in respect of causality . $\quad 146$

Criticisms on Kant's and on Mill's treatment of causality . I46

Virtues in the Kantian speculation . . . . . 146

Kant's advance on Leibnitz and on Hume . . . . 147

Defects of Mill and Spencer in respect of causality . $\quad$ I47

The problem of knowing and being . • . $\quad$ I47

Views of Maine de Biran and Hume noticed . . . 148

The causal law as necessary postulate of science . . 148

Kantian apriorism in recent German thought on causality . $\quad 148$ 
Need of a psychological basis for apriorism

148

Eternity of the universe discredited by science and philosophy

Criticisms on causal proof as usually presented .

Defects in the First Cause of this proof .

Criticisms on Herbart and on Lotze

Ulrici on causal energy

150

Dr Martineau on notion of cause .

Services of Wolff and Crusius

I 50

Kant and the work of his forerunners

150

150

Superiority of Christian Theism to this proof of causation . I5I

Defects of causal argument by itself . . . . I5I

Its relation to the ontological argument . . . . I5I

Advances beyond the Kantian position . . . . I II

Infinite Spirit as ground of sense-phenomena . . . $\quad$ I52

Limitations of physical and mechanical categories . . $\quad$ I52

Absurdity of making the Absolute one of world-series of contingent things . $\quad . \quad . \quad . \quad$. 152

Wherein our aim outreaches Kant . . . . 152

The Ursprung and the Ursache . . . . . . 153

Difficulty of our conceiving the All-Perfect becoming Cause

at all. . . . . . . . . 153

As to impossibility of explaining the origin of causal action . I53

Aspects or phases of ontological and cosmological proofs . $\quad$ I 54

Christian conception of God owes little to causation . . $\quad$ I55

Intelligence and self-consciousness in any possible First Cause 155

Causal proof points towards the path that leads to personality. $\quad$ I 55

Principle of causality not enhanced in this very proof . . 156

Infinite Spirit as immanent Ground of the world . . $\quad 156$

Insufficiency of syllogistic reasoning on cause . . . $\quad$ I56

Synthetic unity for the finite and contingent . . . 156

Need of Self-existent Cause . . . . . . $\quad$ I 56

Illogical character of customary form of the causal presentation $\quad{ }_{157}$

Professor Minto on cause $\quad . \quad$. $\quad . \quad$. $\quad . \quad$ I57

Criticism of Professor Flint's treatment of causality . . $\quad 157$

Science and theistic speculation . $\quad . \quad$. $\quad . \quad$ I 157

Dr James Croll's theism . $\quad . \quad$. $\quad . \quad$. $\quad{ }_{158}$

Disadvantages of the causative notion applied to Deity . 159

Dualistic character of the causative principle . . . $\quad$ I59

Diverse aspects of causation . . . . . . $\quad$ I60

Immanent energy of the Absolute . . . . $\quad$ I60 
Unsatisfactoriness of James Hinton's view . . . $\quad$ I60

Modern influence of the causative principle . . . 160

Objective validity for the causal law . . . . . I60

Ends subserved by the Causal argumentation . . . 160

Criticism of Kant's mode of using the Cosmological argument . I6I

Abortive character of the causal argument . . . I6I

Theistic philosophy and the idealism of Professor Royce, of

Harvard . . . . . . . I6I

The category of causality not to be eluded . . . 162

Recent treatment of the causal problem . . . . 162

Criticism of Professor Riehl's results . . . . . $\quad$ I62

Attitude of other modern German thinkers . . . $\quad$. 163

Result claimed for theistic philosophy . . . . . . $\quad$ I63

The causality of self-consciousness $\quad . \quad$. $\quad . \quad$. $\quad$ I64

The volitional type of causation . $\quad . \quad$. $\quad . \quad$. $\quad . \quad$ I64

Romanes on causation $\quad . \quad$. $\quad . \quad$. $\quad . \quad$ I64

Matter, cause, and effect in recent philosophy of theism . 165

Importance of ontological aspect. $\quad . \quad$. $\quad . \quad$. $\quad 165$

Metaphysical necessity and Personality . . . . 165

Emanative theory to be eschewed . . . . $\quad$ I66

Presupposition of a Spiritual Absolute . . . . . $\quad$. 166

Will as Ultimate Principle . . . . . $\quad$ I66

An ever-present Ground of all things . . . . . $\quad$ I66

The natural as witness to the spiritual . . . . 167

Defect of the category of causality $\quad . \quad$. $\quad . \quad$. $\quad$ I67

Transcendent activity of the Absolute . . . . $\quad$ I68

Progressive as well as regressive movement . . . $\quad$ I68

The thought of Evolution overpassed . . . . . 168

Plea for speculative flights of reason . . . . . $\quad$. $\quad$ I69

$\checkmark$ What the Cosmological Argument still does for us . . $\quad$ I69

\section{CHAPTER VII.}

RECENT LINES OF TELEOLOGICAL ADVANCE.

Serviceableness of the Eutaxiological Argument . . J70

Defective presentations of final causes . . . . . I7 I

Undue stress to-day on efficient cause . . . . I7I

Aspects of the Paleyan argument $\quad . \quad$. . . $\quad$ I7I

Facts of adaptation and evolution $\quad . \quad$. . . I7 I 
How the philosophy of theism must here proceed . $\quad$ I 172

Criticism of Professor Flint's dealing with order and design . 172

Relation of Teleological to Cosmological Argument . . $\quad$ I73

Difficulty of dismissing design $\quad . \quad$. $\quad . \quad$. $\quad . \quad$ I73

Loose scientific thinking here $\quad . \quad$. $\quad . \quad$. $\quad$. 173

Former faults of the teleological presentation . . . $\quad$ I73

Criticism of Kant's mode of dealing with this proof . . $\quad$ I73

Considerations as to the purport of this argument $\quad . \quad$. 174

Kant's 'Critique of Judgment' $\quad$. $\quad$. $\quad . \quad$. $\quad$. 174

Theistic advances in view and in method . . . 175

Ethological aspect of the proof . . . . . . $\quad$. 175

Ætiological, nomological, and teleological lines of inquiry . I75

Misconceptions as to teleological argument removed . . 175

Kant's 'Critique of Pure Reason' . . . . $\quad$. 176

Considerations as to relation of form and essence or substance $\quad 176$

Relation of Teleology to Eutaxiology $\quad$. $\quad . \quad$. $\quad . \quad$ I77

Criticism of Kant's errors and confusions as to finality . $\quad$ - 177

Immanent purposiveness of nature $\quad . \quad . \quad . \quad . \quad$ I78

Criticism of Professor Flint's attitude to purpose or intention . $\quad 178$

Remarks on position of Rev. J. Morris . . . . $\quad 178$

Criticism of Professor Flint's treatment of analogy of nature

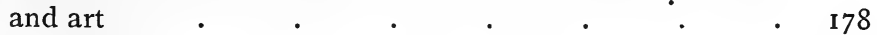

Evolutional considerations to be allowed due weight . . 179

Futility of the rejection of final causes . . . . . I80

Criticism of the theory of natural selection . . . $\quad$ I80

Its inadequacy perceived by John Stuart Mill . . . I80

Relation of design and evolution . . . . . . 180

Natural selection and contrivance or design . . . I8I

Question of environment . $\quad . \quad$. $\quad . \quad$. $\quad$ I8I

Higher aspect of the survival of the fittest . . . I8I

Criticism of Lotze's teleological view . . . . . 182

The true tendency of the argument as expressed by Pro-

fessor Flint . $\quad . \quad$. $\quad . \quad$. $\quad . \quad$. 182

Trendelenburg's philosophy of design . . . . . 182

Possibilities of theism $\quad . \quad$. $\quad . \quad . \quad . \quad . \quad$. 182

Breadth of the teleological vision . . . . . 183

Narrowness of earlier modes of view . . . . . . . $\quad$ I83

Possibilities of questioning remain $\quad$. $\quad . \quad$. $\quad$ I84

Criticism of Principal Caird's view $\quad . \quad$. $\quad . \quad$ I 184

Moral aims of the Will in nature and in man . . $\quad . \quad 184$ 
The strange anomalies of Nature

Arraignment of the order of nature by Mill, Hartmann, and others .

The darkest facts must be faced .

Discriminations and considerations in the problem of suffering I 85

Teleological traces not lost in residual shadow or mystery . 185

The whole ground-plan of creation not ours . . . 186

Relative character of the present $\quad . \quad$. $\quad . \quad$ I87

Importance of spiritual evolution as against pleasure or happiness

Criticism of Rev. J. Morris on the actuality of the universe

I 87

Ideality in our view of the universe . . . 187 I 87

Bearings of the Darwinian speculations on creation as a pres-

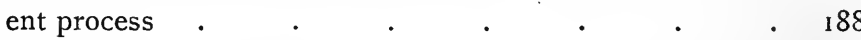

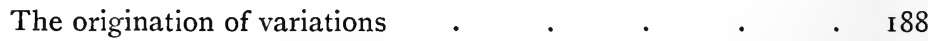

Large synthetic movement of thought and final causes . $\quad$ I 88

Criticism of Professor Royce on design . . . . . $\quad$ I88

Design in creation, taken in whole $\quad . \quad \ldots \quad . \quad . \quad$ I 88

Design argument purged of its accidental and external character $\quad$ I 89

Science and the immanent rationality of nature $\quad . \quad$ I90

Criticism of Professor Huxley's view of nature . . . . I90

Direction of the Evolutionary Force by Intelligence . • I9I

Criticisms on Professor Royce and evolution . . . . I9I

Critical reflections on the phrase "final causes" . . I9I

Is final cause an a priori principle? . . . . . I9I

The apotheosis of accident $\quad$. $\quad$. . . . $\quad$ I92

Theistic philosophy not lacking in appreciation of natural selection

192

A true interpretation of the law of survival of the fittest $\quad$ I93

Meaning and merit of the Darwinian teaching . . . 193

Theistic philosophy and variation . . . . . 193

Insufficiency of theory of natural selection $\quad . \quad$. $\quad$ I94

Criticisms on Professor Huxley and others on variation $\quad$ I94

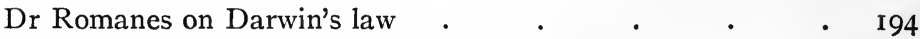

J. Arthur Thomson on Weismannism . . . . $\quad$ r94

Darwin's modified notions of scope and power of natural selection $\quad 195$

Criticism of Darwin's view. of variations . . . . . 195

Theistic philosophy and variation . . . . . 195

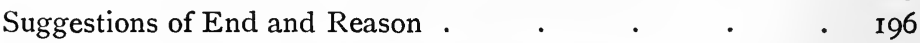

Criticism of theological search after final causes $\quad$. $\quad$ I96 


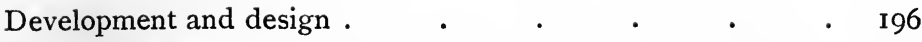

Criticism of scientific exclusive preference for efficient causes . 196

How the teleological plea for intelligence is to be maintained . 197

Blind forces associated with intelligence $\quad . \quad$. $\quad . \quad$ I97

Theory of "blind immanence" insufficient . . . . 197

Criticism of the philosophy of the unconscious . . . . 197

Criticism of Paulsen's treatment of the theistic view . . $\quad$ I 98

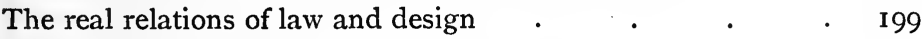

What world-governance by law really means . . . $\quad . \quad 199$

Absurdity of Comtean view of nature sequences . . 200

Trendelenburg on nature conformity . . . . . 200

Nature of law and results of law . $\quad . \quad . \quad . \quad . \quad 200$

Benignity of world laws . $\quad . \quad$. $\quad . \quad$. $\quad . \quad$. 200

Beneficial effects of suffering $\quad$. $\quad . \quad$. . . 200

Inadequate theological realisation of the difficulties involved . 200

Mistaken expectations from law . . . . . . 20I

Inwardness and naturalness of teleological working of nature . $20 \mathrm{I}$

Natural law as expression of purpose . . . . . 20I

Teleological reference of universe taken as a whole . . 20I

Criticism of Agnosticism in relation to final cause . . 201

Pervasive Divine Reason in the world's beauty and order . 202

Proper attitude to be assumed to-day . . . . . 202

Theism past and present . $\quad . \quad . \quad . \quad$. 202

Man as end and final form in creation . . . . . . 203

Professor Jevons on place of man $\quad . \quad$. $\quad . \quad . \quad 203$

Dr George Matheson on the designing principle in man . 203

Criticism of Büchner's views . . . . . . 204

The central power postulated by Trendelenburg . . 205

Order in, and Power behind, the protoplasmic evolutionary

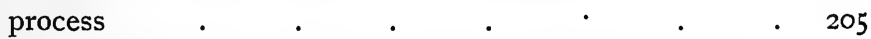

Psychological aspects as real as any facts of the physical and protoplasmic order . $\quad . \quad$. $\quad . \quad$. 205

Criticism of Professor Knight's treatment . . . 205

An Intelligent Creator in theistic philosophy . . . . 206

Dr Carpenter on Order and Cause in Nature . . . . 206

What we claim for theistic thought on purposeful activity of the Designing Intelligence . . . . . 207

Final cause and beauty, order, and harmony of nature . . 207

Weisse on the danger of the argument from order . . 207

Constructive working of the forces of science . . . 207 
No scientific advances can sweep away teleological view

Postulation of Supreme Intelligence demanded by well-ordered intellect

Larger claims for teleology than before . . . . . 208

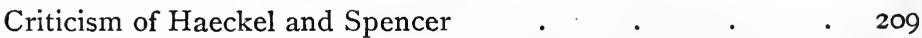

The teleological argument and implications of Personality . 209

Criticism of Professor Romanes on the evidences of design . 210

The universe as unfinished . . . . . $21 \mathrm{II}$

Permanent guiding influences presupposed . . . 2II

Limitations of the argument and its implicates . . . 2II

Difficulties remaining in the presentation of this proof . . 212

Mere intelligence insufficient, but intelligence need not be by itself . . . . $\quad$. . . . 2 I2

Agreement with Rev. J. Morris on nature as process . . 212

Nature processes to be more deeply studied . . . . 213

Dr F. E. Abbot on the bearings of teleology on personality . 214

Ripest results of the teleological argument still to appear . 214

Argument points to Immortality for man . . . . 214

\section{CHAPTER VIII.}

RECENT THOUGHT AND THE ONTOLOGICAL ARGUMENT.

Ideal aspect of the ontological proof . . . . . 216

The Absolute not a barren conception of metaphysics . . 216

Failure yet fascination of the argument . . . . 217

Criticism of the Anselmic mode of presentation . . . 217

Criticism of Kant's treatment of the Anselmic position . . 217

Criticism of argumentation of Descartes . . . . 218

Various forms of its presentation. . . . . . 218

Virtues and defects of Kant's criticism of the ontological proof. 219

Why Kant's criticism could not be final or conclusive . . 219

Kant's strange shortcoming in respect of a posteriori side of

the argument . $\quad . \quad . \quad . \quad . \quad . \quad .219$

Wherein the real shortcoming of the proof lies . . . 219

Need of metaphysics $\quad . \quad$. $\quad . \quad$. $\quad$. $\quad .220$

Criticism of recent metaphysic . . . . . . 220

Features of a true metaphysic . $\quad . \quad$. $\quad . \quad$. 220

Refutation of Comtean view of metaphysics . . . 221

Ritschlian depreciation of metaphysic unavailing . . 221 
Coleridge and Paulsen as to metaphysic .

Relation of theology and metaphysics .

Significance of the ontological principle .

Criticism of the view that ontological conclusion lands us in mere idealism

Necessary idea of the Absolute more carefully differentiated than by Kant

Fortunes of the proof in post-Kantian philosophy $\quad \cdot \quad \cdot \quad 223$

Merits and defects of Hegelian speculation . . . . . 223

Ontological lack of speculative warrant . $\quad . \quad$. $\quad . \quad 223$

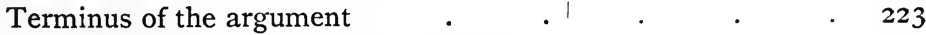

Proof not sufficient to exclude Pantheism . . . 224

Thought and the Absolute . . . . . . . 224

Reason for persistence of this argument . $\quad$. $\quad . \quad$. 224

The real questions to be faced to-day on the subject . . 224

RECENT ONTOLOGICAL SPECULATION IN GERMANY • • 225

Excellence of Hegel's services to ontological thought . . 226

Advances since Hegel's time . . . . . . 226

Criticism of K. Phil. Fischer's speculative thought $\quad$. 226

Views of Hettinger and Luthardt $\quad$. $\quad . \quad$. 226

Ulrici and the results of his speculations from the scientific side 227

Rothe on speculative knowledge of the Absolute . $\quad . \quad 228$

Dorner and his differences from Pfleiderer and Biedermann . 228

Dorner's advance of the ontological problem . . . 228

Dorner's view of the relation of the a priori and a posteriori argumients $. \quad . \quad . \quad . \quad . \quad . \quad . \quad 229$

Biedermann on this proof. $\quad . \quad$. $\quad . \quad$. $\quad . \quad 229$

Theistic good accruing from Schopenhauer's teleological emphasis . $\quad . \quad$. $\quad . \quad$. $\quad . \quad$. 229

Professor Günther Thiele on this argument $\quad . \quad$. $\quad 230$

RECENT ONTOLOGICAL SPECULATION IN FRANCE . $\cdot 230$

Malebranche on all things as seen in God . . . . 230

Criticism of conclusions of Malebranche . . . . $\quad 230$

Fénelon and his advance . $\quad . \quad . \quad . \quad . \quad . \quad 23 \mathrm{I}$

Further advance by Leibnitz $\quad . \quad$. $\quad . \quad$. $\quad$. 231

The personal element in Maine de Biran's philosophy . . 23I

Criticism of the position of Cousin $\quad . \quad . \quad . \quad . \quad 231$

Theistic tendencies in Maret and Lerminier . . . 232 
Gratry seeks the Infinite by negation of the finite

M. Saisset on Kant's treatment of the ontological proof

Criticism of M. Vacherot's idealism

\section{RECENT ONTOLOGISTIC SPECULATION IN ITALY}

The subjectivity of Galuppi

Criticism of the ontologistic positions of Gioberti

Criticism of the ontologistic presentations of Rosmini

Characteristics of Rosmini's philosophy .

Rosmini's philosophical merits .

Anselmic influences in Mamiani .

Mamiani's positions on the Being of God . . $\quad 236$

Merits and defects of the positions of these Italian thinkers

RECENT ONTOLOGICAL THOUGHT IN BRITAIN • • • 237

Ontological cast of Ferrier's thought . . . . $\quad$ • 237

Merits and defects of Principal Caird's treatment of this proof 237

Thompson, Tulloch, and Cazenove on the argument . $\quad 238$

Services of Professor Flint to ontological thought . . 239

Considerations here urged as to the recent course of philosophic thought on this proof . $\quad . \quad$. $\quad . \quad$. $\quad .239$

The idea of God in this argument . . . 240

Values of the ontological proof . . . . . 240

Ideal character of this form of proof . . . . 240

What the proof really amounts to in its ultimate essence . 240

Deeper meaning of the proof . . . . . 24I

The $a$ posteriori argument and the metaphysical process . 24I

Can ontological proof be deprived of real significance? $\quad$ ? 24 I

The Belief in God as self-conscious and personal Spirit $\quad$. 242

A rational conception of Deity deducible . . . 242

\section{CHAPTER IX.}

RECENT PHASES OF THE MORAL ARGUMENT.

The growing importance attached to this argument . $\quad 243$

Limitations of the proof declared . . . $\quad 243$

Undue dependence on the argument by Schenkel, Newman, and others . . . . . . . 
Suggestions as to the presentation of moral faculty called conscience . $\quad . \quad$. $\quad . \quad$. $\quad . \quad$. 244

Mansel on the moral argument . $\quad$. $\quad$. $\quad$. $\quad 244$

Connection of this proof with the argument for final causes . 244

Kant's reasoning in the 'Critique of Judgment' . . 244

Purport and scope of the proof . $\quad . \quad$. $\quad . \quad$. 245

Professor Rauwenhoff, of Holland, on the moral imperative . 245

Larger and more impressive grounds of the argument . $\quad 246$

Assumption of the moral sense and its ideals . . . 246

A moral or personal Lawgiver sought to be deduced . . 246

Kant's 'Critique of Practical Reason' . . . . 246

Merit of Kant's adhesion to the absolute worth of the moral ideal . . . . . . . . 247

Moralistic service of Kant's 'Religion within the Limits of

Pure Reason' . . . . . . . . 247

Defects of Kant's system . $\quad$. $\quad$. $\quad . \quad$. $\quad 247$

Kant's shortcoming in respect of the moral argument . . 247

Criticism on Professor Knight on place of felicity with Kant . 247

Merit and defect in Bishop Butler's treatment of conscience . 248

Nobleness of Kant's strain in the 'Critique of Pure Reason' . 248

Conscience and revelation $\quad . \quad$. $\quad . \quad$. . . 249

Function of conscience in the theology of to-day . . 249

Criticism of Kant's 'Metaphysic of Ethics' . . . . 249

How far Kant is a destroyer $\quad . \quad$. $\quad . \quad$. $\quad . \quad 249$

Criticism of Kant on Divine Will and moral Law . . $\quad 250$

Criticism of Kant's method of dealing with moral obligation

and Divine Existence . . . . . . 250

Criticism of Wuttke's treatment of conscience . . . $25 \mathrm{I}$

Newman on conscience . $\quad . \quad$. . . . . 25I

Conscience as the vehicle of revelation . . . . $25 \mathrm{I}$

Dr William G. Ward and Newman . . . . $25 \mathrm{I}$

Dorner on complexity of conscience . . . . . 252

Conscience as a differentiating faculty in man . . . 252

Conscience and reason or intellect . . . . . $\quad .253$

Aim of the philosophy of theism to-day . . . . . 253

Origin and value of conscience . $\quad . \quad$. $\quad$ : $\quad$ : $\quad .253$

Implicates of the moral elements in man . . . 254

Evolutionary view of conscience . . . . . . . 254

God as Founder of Moral Law . . . . . . . 255

Dr Chalmers on conscience $\quad$. $\quad . \quad$. $\quad . \quad$. 255 
Theistic philosophy and conscience . . . . 256

Erskine of Linlathen on this proof . . . . . 256

Powerlessness of Science here . . . . . . . 256

Significance of the ethical law operative in conscience . . 256

Dr James Martineau on conscience . . . . . 257

Appraisement of Dr Martineau's contentions . . . $\quad 258$

Critical reflections on the significance of proof from moral ideals 258

Relative values of morality and religion . . . . . 258

Worth of the moral argument set forth . . . . . 258

Professor Bavinck on undue stress on this proof in the

Netherlands . . . . . . . . 259

A true value for this proof notwithstanding . . . $\quad 260$

Relation of Divine character and Divine existence . . 260

Shortcoming of Kant in respect of the imposition of moral law 26r

A serious issue suggested $\quad . \quad . \quad . \quad . \quad .261$

Kant raises a dire alternative . . . . . . 26r

How the moral facts and relations point to Personality . - 262

How mere phenomena are here transcended . . . . 262

Cumulative force of the theistic evidence $\quad$. $\quad . \quad 263$

The theistic postulate as demanded in our God-consciousness . 263

Nearness to God attained through the moral nature rather than the intellect $. \quad . \quad . \quad . \quad . \quad . \quad 263$

\section{CHAPTER X.}

RECENT THEISTIC PHILOSOPHY AND THE PERSONALITY OF GOD.

Fundamental significance of the question . . . $\quad$. 264

Unique character and greatness of personality . . . $\quad$. 265

Spirit as presupposition of personality . . . . . $\quad$. 265

Parallel of our procedure with that of science . . . $\quad$. 265

The problem of personality in Deity of fundamental moment

for all speculative interest $\quad . \quad$. $\quad . \quad$. $\quad . \quad 266$

A positive attitude here assumed. $\quad$. $\quad . \quad 266$

Being interpretable only in terms of personality . . . 266

Vast and multiform character of the inquiry . . . $\quad$. 266

Primal Being in the light of Personality . . . . $\quad$. 266

Concern of reflective thought with Personality . . . 267

Fascinating power of Personality $\quad . \quad$. $\quad . \quad$. $\quad 267$

Relation of Divine and human personality $\quad$. $\quad$. $\quad 267$ 
What our idea of human personality does for our notion of the

Divine. $\quad . \quad . \quad . \quad . \quad .267$

Divine Personality as essential to religion and virtue . . $\quad 267$

A Subjective certainty of Divine Personality in the living re-

ligious consciousness . $\quad . \quad$. $\quad . \quad$. $\quad 268$

Blind, unconscious world-mechanism transcended . . 268

Possibilities that lie in the Divine Personality . . . 268

Personality and the Unity of God $\quad . \quad$. $\quad . \quad$. 268

Thinking being or essence and personality . . . . $\quad$. 269

Self-activity in Kant's Transcendental Æsthetic . . . 269

Criticism on Lotze as to personality $\quad . \quad$. $\quad . \quad 2 \quad .269$

Criticism of Green's treatment of personality . . . . 269

Self-active Being posited as Ground . . . . $\quad$. 270

Wherein an impersonal primitive Ground (Urgrund) fails . 270

Elements and implicates of personality . . . . $\quad .270$

Meaning and possibility of self-determination . . . 270

Personality and the manifestations of Deity . . . $27 \mathrm{I}$

A psychology of the Eternal not attempted . . . 27 I

Personality in the Highest in relation to all the theistic proofs. $27 \mathrm{I}$

Absurdity of treating the impersonal as higher than the personal $27 \mathrm{I}$

Impersonal and unconscious World-ground of Schopenhauer

and Hartmann rejected . . . . . 272

The non-personal regarded as sub-personal . . . 272

Ends here sought are living and rational . . . . 272

The warfare one of pure thought . $\quad$. $\quad$ . . . $\quad$. 272

Criticism of the Absolute of the Philosophy of the Unconscious .

Justification of theistic philosophy in its rejection of this Absolute

Hartmann on the religious interest and the teleological principle . . . . . . . . 273

Criticism of Hartmann's position . $\quad$. $\quad$. $\quad . \quad 274$

Criticism of Fiske's treatment of Personality in his cosmic theism .

Need for setting the Personality of God on truly philosophical basis .

Harmony of the Absolute Personality with the postulates of the religious consciousness . $\quad . \quad$. . . 276

Necessity of a personal Absolute . . . . . . 276

Absurdity of treating personality as limitation . . . 276 
Absurdity of the mortality and corporeity postulated for Personality in the work 'Natural Religion' . . . 277

Misapprehensions of Personality corrected • . . 277

Free, volitional, self-determination of Divine nature as well as character

Advances of theistic philosophy in apprehension of Divine Personality . . . . . . . . . 278

Basal hold of personality on thought $\quad$. $\quad . \quad$. $\quad 278$

Need for realisation of the Divine Presence as Person . . 278

View of Lipsius as to personality overpassed $\quad$. $\quad$. $\quad$. 279

Personality since Mansel's time . $\quad$. $\quad$. $\quad . \quad$. 279

Lotze on personality and what it really involves. . . 279

Claim for theistic presentation of Personality in Deity . . 280

The quantitative infinite in modern philosophy . . . 280

W. S. Lilly on Personality in God . . . . 280

Bearings of Personality on the presentations of theistic philosophy 280

Position assumed in present work as to Personality in Deity in

respect of the scientific view of the Universe and the future $28 \mathrm{I}$

Historic treatment of the subject in Germany . . . 28I

Helpfulness of the Personality conception . . . 282

Critical appreciation of Kant's treatment of personality. . 282

Tendencies of Jacobi and Baader $\quad . \quad$. $\quad . \quad$. 283

Views of Fichte on Personality set forth in extenso . . $\quad 283$

Criticism of Fichte's Absolute . . . . . . . $\quad 285$

Criticism of Schleiermacher's treatment of Divine Personality . 286

Place of Personality in Deity of Krause . . . . $\quad 286$

The latest phase of the transcendence question in Germany . 287

Elucidation of Personality by Julius Müller . . . 287

Weisse on Divine Personality $\quad . \quad$. $\quad . \quad$. $\quad .288$

I. H. Fichte's speculative theism and Personality . . 288

Dorner's claim for Absolute Personality from sides of Will and

$\begin{array}{lllllllllll}\text { of Knowledge . } & \text {. } & \text {. } & \text {. } & \text {. } & \text {. } & & & 288\end{array}$

Dorner and Frank on Triune Deity and Personality . . 289

Earlier conceptions of Divine Essence by Nitzsch, Rothe,

Thomasius . $\quad . \quad$. $\quad$. $\quad$. 289

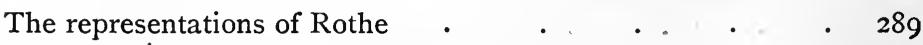

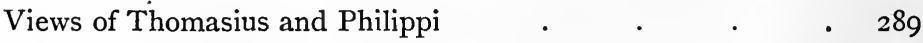

Virtues of Kahnis and Frank $\quad . \quad$. $\quad . \quad 2 \quad . \quad 290$

Significance of the concept of Div ne Aseity in later German

Theology . . . . . . . 290 
Lotze and Strauss compared and contrasted as to Personality in God

Criticism of Fechner's views $\quad . \quad$. $\quad . \quad . \quad . \quad 290$

Acknowledgments of Fechner's advances and merits . . 290

Personality in Deity as championed by Chalybäus and Ulrici . 291

Criticism of Hartmann's treatment of Personality in Deity . 29r

Ritschl and the Divine Personality . . . . . 292

Criticism of Professor Pfleiderer's mode of holding Personality 292

Phases of the problem in the speculative thought of America . 294

British developments of the theme . . . . . . 294

Nature and value of Dr Martineau's contributions to Personality . . . . . . . . . 294

Professor Andrew Seth on Personality . . . . . 295

Dr Sterrett's criticism criticised . . . . . . 296

Criticism of Mr Fairbrother on the Seth-Balfour positions . 296

Critical reflections on the recent course of thought . . 296

Elucidation of Personality by Professor Flint, Dr Matheson,

Mr Illingworth, and others . $\quad . \quad$. $\quad . \quad$. 297

Possibility of a psychic unity cosmic and higher than ours . 298

Criticism of Dr Bradley's work, 'Appearance and Reality' . 298

Ontological and historical aspects of personality . . . 299

Worth of the historic treatment . . . . . . . 299

Question of the end of history . $\quad$. $\quad$. $\quad . \quad . \quad$. 299

Criticism of Spencer's treatment of the Personality of the

Absolute . $\quad . \quad$. $\quad . \quad$. $\quad . \quad 300$

Pfleiderer and Paulsen on the Personality of Deity . . 300

Criticism of Lotze's positions on Personality in God . . 301

In what sense God may be viewed as Ultra-Personal . . 30I

Criticism of Scientific charges of subjectivism . . . . 302

Grounds on which theistic philosophy retains Personality . 302

Criticism of German subjectivism . . . . . 303

Criticism of Supra-personal mode of conceiving Deity . . 303

Professor James Seth, of America, on the true Absolute . 304

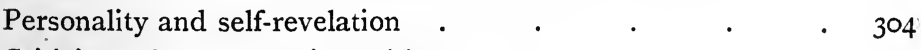

Criticism of the Agnostic position . . . . . $\quad 305$

The question of Miracle . $\quad$. $\quad$. $\quad$. $\quad$. 305

Personality of God imperilled by idealistic Evolutionism . 306

The scientific realism of our time . . . . . . 306

Meritorious function of the philosophy of Hegel . • $\quad 307$

Criticism of the Absolute of Neo-Hegelianism . . . . . 307 
Franz Hoffmann on the Personality of God

M. Saisset on the defects of Pantheism in respect of Personality .

John Fiske's "Idea of God" and Personality

Criticism of Vatke and Biedermann on Personality in God

Arbitrary and inconsequential attitudes assumed by Biedermann .

Criticism of the positions of Lipsius on the Divine Personality 309

Critical reflections on the religious relations as viewed by Lipsius

Criticism of Pfleiderer's treatment of Personality in God

Pantheistic representations and religious inwardness .

Criticism of these pantheistic representations of Deity .

Warrant for Dr Martineau's Transcendency considered

Transcendence of Deity as maintained in present work $\quad$ 3I3

Criticism of pure immanence systems . • . . 314

Criticism of Absolute as Spirit but not yet Personality • . 3I4

Criticism of the pantheistic conceptions of Infinite Personality 314

Denial of Divine Personality as the true limitation . $\quad 315$

Infinity of being . $\quad . \quad+\quad . \quad 315$

God and the world . . . . . . . . 315

Relation of finite and infinite . . . . . . 316

What the Infinite implies . . . . . . 316

The Absolute and the relative . . . . . 316

Criticism of the Absolute of Dr Paul Carus . . . 317

Personality and reality (or illusion) . . . . 317

Absoluteness of Deity forced upon us . . . . 318

Personal Deity to be preserved . . . . . 318

Time-question in respect of Deity . . . . . 319

Pfleiderer and Lotze on temporal succession for Deity . $\quad 319$

Criticism of Professor Veitch's "Dualism and Monism" . 319

On Time as necessary presupposition . • • • 319

On Divine acting within the time-process . . . 319

On the freedom of the absolute and independent Being $\quad 320$

Question of spatial form in relation to Deity . . 320

Space category and things mental and moral . . . 320

On Divine working within world-space . . . 320

Professor Royce, of Harvard, on space and time in relation to

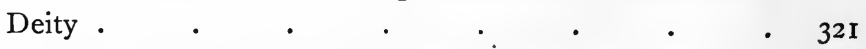

Critical reflections as to the categories of space and time $\quad 32$ I 
On Kant's treatment of Spatial relation . $\quad$ • $\quad$ • 322

On Kant's treatment of Time . • • • • • 322

Criticism of Kant's procedure . . . . . . 322

Can we know God out of all Space and Time? . . . 323

Criticism of the objection that personality pertains to time $\quad 323$

Schiller's representation of Divine Personality • • • 323

Personal attributes in the Absolute purified rather than annulled $\quad 324$

Helpfulness of Trinitarian conception to our apprehension of

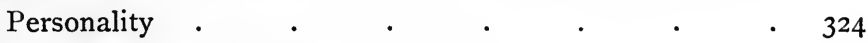

Spinozan conceptions of Substance avoided . . . 324

Fundamental grounds for the Absolute Personality . $\quad 324$

The Personality of God the crown and summit of our thinking $\quad 325$

Criticism of the pantheistic rejection of Personality as involving

limitation in Deity . $\quad . \quad$. $\quad . \quad 325$

The self-limitation of the Absolute Personality in theistic phil-

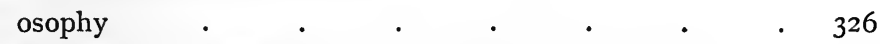

Reality of the Absolute Personality of theistic philosophy . 326

A Being-for-Self claimed for this Personality • • $\quad 326$

Limitation involved in personality only in its finite aspect $\quad 327$

That Personality may not exist as absolute, speculatively un-

warranted . . . $\quad . \quad$. $\quad . \quad$. $\quad 327$

Perfections of Personality in the Absolute • • • $\quad 327$

Definite and positive character of the Absolute Personality . 328

Critical reflections as to Personality in God . • 328

Personality as supposed limitation of Deity due to a radical

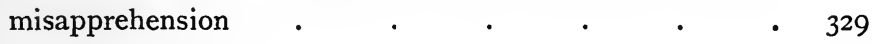

\section{PART THIRD.}

RECENT THEISTIC PHILOSOPHY OF RELIGION (MAN).

\section{CHAPTER XI.}

RECENT THEISTIC THOUGHT ON FUNCTIONS OF REASON IN MAN.

Professor T. H. Green on philosophy . • • • $\quad \cdot 333$

Reason in the ancient world . . . . . $\quad . \quad 333$

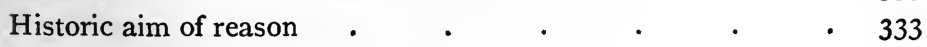

Postulates of Reason to-day . . . . . . . . 334

Witness of Reason in this time . . . . . $\quad$. 334 
Power and functions of Reason and their theistic bearings . 334

Relation of reason in man to the Supreme Reason . . 334

The Ultimate and Eternal Reason . . . . . 334

Professor Samuel Harris, of Yale, on finite and Universal

Reason . . $\quad . \quad$. $\quad . \quad$. 334

Cousin's impersonal reason rejected $\quad . \quad$. $\quad . \quad$. 335

Merit of Cousin's psychology . . . . . . . 335

Reason as personal at the heart of the Universe . . 335

Objective and Ultimate Reason as Ground and Cause of all . 335

Unity and conscious spiritual energy of the Absolute . . 335

Theistic philosophy and the Infinite Reason . . . 336

The constructive Reason of the Universe . . . 336

Immanent rationality of nature $\quad . \quad$. $\quad . \quad$. $\quad .336$

Rational interpretation of the intellectual and moral order of

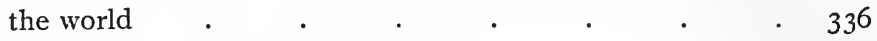

The interpreting and synthetising reason . . . $\quad .336$

Metaphysic and the perfection of the human reason . . 337

The amazing functions of reason $\begin{array}{llllllllll} & & & & & & & & & \end{array} 337$

Reason as central category of reality $\quad . \quad$. $\quad . \quad . \quad 337$

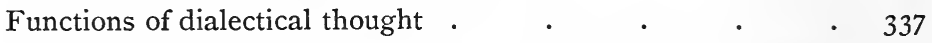

Scientific character of Knowledge gained through reason's pivotal movement $\quad . \quad$. $\quad . \quad$. $\quad . \quad$. 338

Value of the pure or Knowing Reason . $\quad . \quad$. $\quad . \quad 338$

Advance on the Kantian view of Reason (Vermunft) . . 338

Relations of the rational and the ethical . . . . 338

Rationality of the spiritual and moral $\quad . \quad$. $\quad . \quad 3338$

Reason as characteristic of man . $\quad . \quad$. $\quad . \quad 3338$

Man's rational superiority to the animal world . . . 339

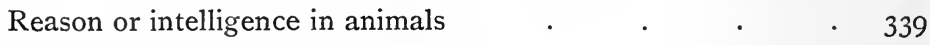

Professor Lloyd Morgan's researches . $\quad . \quad$. $\quad . \quad 339$

Professor Calderwood on Man's place in Nature . . 340

Man's connection with nature in theistic philosophy . . 340

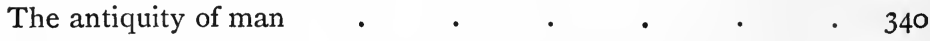

Man's inclusion within the boundaries of animal life . . 340

Professor Huxley on gulf between man and brute . . 340

Wallace on higher faculties of man $\quad . \quad \cdot \quad \cdot \quad \cdot 34 \mathrm{I}$

Grounds of differentiating man from the animal world . $\quad$ 34I

Professor Calderwood on rationalised character of man's physical life . $. \quad . \quad . \quad . \quad . \quad .34 \mathrm{I}$

Fiske on man's superiority $\quad . \quad$. $\quad . \quad . \quad . \quad$. $34 \mathrm{I}$ 
Reason as highest power of spirit in man

Professor Laurie on Reason in 'Metaphysica Nova et Vetusta' 342

Faith as a synthesizing power $. \quad . \quad$. $\quad . \quad$. 342

Relations of faith and reason $\quad . \quad$. $\quad . \quad$. $\quad . \quad$. 343

Rational grounds of faith set forth $\quad$. $\quad$. $\quad$. $\quad$. 343

Reason involves faith element $\quad$. $\quad . \quad$. $\quad . \quad$. 343

Faith as itself the highest reason . . . . . . 343

Harmonious results attained between reason and faith . . 344

Time-elements in rational belief . . . . . . $\quad . \quad 344$

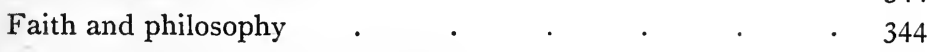

Reason and the unification of belief . . . . . 344

Drs Christlieb and M'Cosh on faith and reason . . . 345

Advances of theistic philosophy in virtue of reason . . 345

Relations of Reason and Authority . . . . . 345

Theistic philosophy and Positivism . . . . $\quad .346$

Criticism of Reason in the idealism of Professor Royce . 346

Criticism of the Absolute in systems that resolve it into all-

devouring intellection or reason . . . . . 347

Acknowledgment of Hegel's merit . . . . $\quad$. 347

Our Primordial Reason not the Absolute Reason of Hegel 347

The Absolute or Universal Reason of theistic philosophy - 347

Rational processes throughout the spiritual realm . . 348

The endlessly progressive movement of reason in man . $\quad 348$

Amiel on the ideal and the real . . . . . . $\quad .348$

Reflections on basal workings of reason . . . . . 349

Criticism of Ritschlian depreciation of reason . . . $\quad$. 349

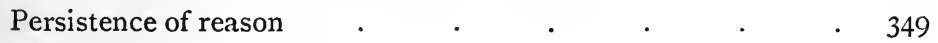

Reason and personality . $\quad . \quad$. $\quad . \quad$. $\quad . \quad 350$

Reason and religion $\quad . \quad$. $\quad . \quad$. $\quad . \quad 350$

Place and primary functions of reason in Christianity . . 350

The Universal sway and sweep of Reason . . . $35 \mathrm{I}$

CHAPTER XII.

RECENT THEISTIC PHILOSOPHY OF PERSONALITY IN MAN.

Superiority of Man to Nature . • . . . . . 352

Mansel on personality $\quad$. $\quad . \quad$. $\quad . \quad$. $\quad . \quad 352$

A true ego rescued from subjectivism . . . . . 353

Issues raised by genetic psychology $\quad . \quad$. $\quad . \quad$. 354 


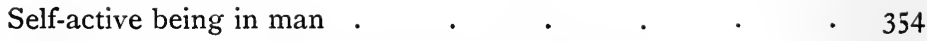

What a philosophy of consciousness would imply . . 355

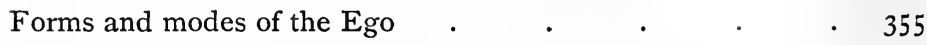

Mill on unconscious mental modifications . . . . . 356

Consciousness in the analysis of the ego . . . . . 356

Cousin on consciousness . $\quad . \quad$. $\quad . \quad . \quad . \quad 356$

Historical consciousness of the genesis of the conscious ego not possible . . . . . . . . . 357

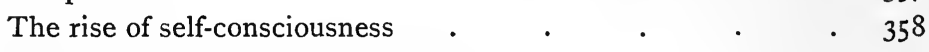

Fiske on the origin of consciousness . . . . . . $\quad . \quad 358$

The genesis of personality-how to be accounted for . . 359

Consciousness grounded in the nature or essence of the Absolute 359

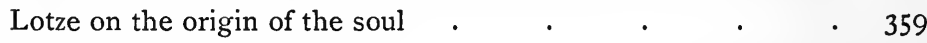

Personality as ultimate $. \quad . \quad . \quad . \quad . \quad . \quad 360$

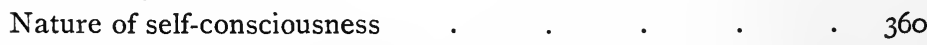

Du Prel on self-consciousness . $\quad . \quad$. $\quad . \quad$. $36 \mathbf{I}$

The development of the ego $\quad . \quad . \quad . \quad . \quad$. $36 \mathrm{I}$

The true unity of the person $\quad . \quad . \quad . \quad . \quad .36 \mathrm{I}$

The self-activity of the soul $\quad . \quad$. $\quad . \quad . \quad . \quad 36 \mathrm{I}$

Directness of our knowledge of self . . . . . $\quad$. $36 \mathbf{r}$

Persistence of the individual or unit $\quad . \quad$. $\quad . \quad$. 362

Criticism of Professor James, of Harvard, in respect of consciousness 362

Untenableness of his conclusions as to thought being itself the

thinker . . . . . . . 363

Origination of idea of personal being in self-consciousness $\quad . \quad 364$

Professor Harris on personality in man . . . . . $\quad 364$

Race-consciousness not excluded . $\quad . \quad$. $\quad . \quad .364$

Criticism of Lotze on personality . . . . . . . 365

Self-consciousness in modern philosophical idealism . . 365

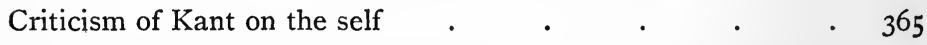

Science unable to explain personality $\quad . \quad$. $\quad . \quad$. $\quad .366$

Evolution and personality. $. \quad . \quad$. $\quad . \quad$. $\quad .366$

Need of a philosophy of consciousness to positive science $\quad$. 367

Criticism of monistic theories of the soul . . . $\quad$. 367

Professor Ernst Mach on personality . . . . $\quad .368$

The psychology of M. Ribot criticised . $\quad$. $\quad$. $\quad 368$

Criticism of Identity theory of Professors Höffding and Clifford $\quad 369$

Relative importance of physio-psychological inquiries . . 370

Inferential character of our knowledge of beings or objects other than self 
Anthropomorphism in science $\quad \cdot \quad$. $\quad . \quad$. $\quad .37 \mathrm{I}$

Criticism of Dr Shadworth Hodgson . . . . . . $37 \mathrm{I}$

Consciousness as the "undecomposable unity" . . . . 37I

Criticism of Dr F. H. Bradley on the self or ego . . 372

Eduard Zeller on mental phenomena $\quad$. $\quad . \quad$. 372

Relation of the psychical to the physical . . . . . 373

Testimony of consciousness both to the ego and to its states . 373

Criticism of Kant's treatment of the ego . $\quad$. $\quad . \quad$. 373

Merits and defects of Kant's transcendental ego . . $\quad$. 374

Criticism of Professor Bain's disposal of the ego . . 375

M. Janet on the unity of the ego . $\quad$. $\quad$. $\quad . \quad 375$

Dante on double ego or consciousness $\quad . \quad$. $\quad . \quad$. $\quad . \quad 375$

Virtue of the transcendental ego . $\quad . \quad$. $\quad . \quad . \quad 376$

Criticism of Dr Maudsley . $\quad$. $\quad$. $\quad$. $\quad$. $\quad . \quad 377$

The human ego as a dynamic centre $\quad$. $\quad$. $\quad$. $\quad 377$

Criticism of Dr Bradley on the soul . . . . . $\quad .378$

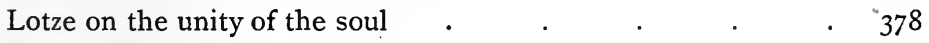

Personality as an organic unity . $\quad . \quad$. $\quad . \quad 378$

The background of self-consciousness $\quad$. $\quad . \quad$. $\quad$. 379

Highest phase of self-consciousness $\quad . \quad 3 \quad$. $\quad . \quad 379$

The ego and the non-ego . $\quad$. $\quad . \quad$. $\quad . \quad 380$

The bases of self-consciousness and world-consciousness . 380

Development of our consciousness of God . . . 38I

Criticism of Spencer's thought of the Absolute Being . . 382

Possibilities of a Philosophy of the Christian Consciousness . 383

Formation and vindication of the Christian Consciousness . 383

What rational psychology will do for us here . . . 385

Significance of the scientific treatment of the History of Doctrine 385

Advances on the subjectivism of Schleiermacher . . 385

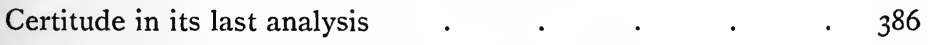

Fearless and determined appeal to consciousness $\quad 387$

The quality and conditions of consciousness . . . . $\quad$. 387

Claims of the Christian consciousness to a true autonomy . 388

Criticism of Julius Müller's position on the subject . . $\quad 388$

Criticism of Dr F. H. Bradley on the personality of man . 389

Pantheistic identification or fusion avoided . . . 390

Maintenance of the integrity of the central self . . . 390

Criticism of Professor Royce on the individual . . . 390

Man as a true infinite $\quad . \quad . \quad . \quad . \quad . \quad .391$

Prime significance of personality in man $\quad . \quad$. $\quad 391$ 


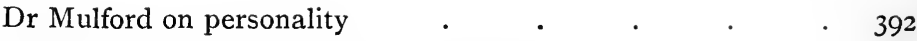

Witnesses to the reality of the mind or self . . . . 393

Relation of the ego to the One, Absolute Personality . . 394

Complexity of the notion of personality . . . . . 394

Its place within the sphere of experience . . . . 395

Man's spiritual perihelion reached through personality . . 395

Mechanical philosophy and pantheistic philosophy alike overpassed . . . . . . . . . . 396

Personality as seen in our faith in the ideal and eternal . 396

Culmination of personality in the Person of the Son of Man . 396

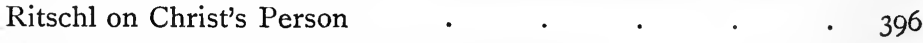

Meaning and reach of our moral development . . . $\quad$. 397

Ideal moral personality our life's crowning achievement . 397

\section{CHAPTER XIII.}

\section{RECENT STUDY OF HUMAN FREEDOM.}

Theistic doctrine of freewill

Historic hold of the freewill problem $\quad . \quad$. $\quad . \quad 399$

Compatibility of Determinist view with a theistic position . 400

Fortunes of Freewill in recent philosophy . . . 400

Lotze on the reign of law . $\quad$. . . . . 400

Present philosophical position of theism . . . . $40 \mathrm{I}$

Freedom and moral responsibility . . . . 40I

Mansel on the freedom of the will . . . . $40 \mathrm{I}$

Difficulties faced by modern philosophical theism . . $40 \mathrm{I}$

The widespread Naturalism of to-day . . . . 40I

Our opposition to these naturalistic tendencies . . . 402

Determinism of Huxley, Spencer, Bain, and Mill . . 402

Necessitarianism since Edwards in America . . . . 402

Espousal of the Libertarian side in present work . . 403

Positions of Lotze, Fischer, Zeller, Martineau, James, Balfour,

Upton, the brothers Seth, Schiller, and others . . 403

Professor James Seth on the question . . . . . 403

Indeterminism of Renouvier, Fonsegrive, and Dr Mach . 404

Character of Ribot's Determinism . . . . . 404

Differentiation of man in respect of rational choice . . 404

Criticism of the Spencerian psychology as to freewill . . 404

View of F. A. Lange and others . . . . . . 405 
Criticism of Professor Huxley on freedom of will . 405

Huxley on man's ethical progress . . . . . 405

Professor James, of Harvard, on Determinism . . . 406

Correction of the misconceptions of Diderot and of Tappan . 406

Claim for freedom of velleity $\quad . \quad$. $\quad . \quad$. $\quad . \quad 406$

Recent advance in Indeterminist presentation . . . . 407

The reasonableness of relative Determinism . . . . 407

On inhibition and self-realisation. . . . . . 407

Freedom as highest form of causation . . . . . 407

Presence of Law does not mean Determinism . . . 407

Freedom and the question of motives $\quad . \quad$. $\quad . \quad$. $\quad 407$

Dr William G. Ward on our supreme volitional efforts . . 407

Advance in the discrimination of determinative and executive acts of the will . $\quad . \quad . \quad . \quad . \quad . \quad 408$

Real contingency of voluntary decision . . . . 408

Position maintained in present work as to freedom . . 409

Dr Carpenter on will and body . $\quad . \quad$. $\quad . \quad 409$

Criticism of Dr Maudsley as to body and mind . . . 409

The theistic position nowise invalidated . . . . . 409

Close relation of physical and mental activities . . . . 4 410

Janet on rational Determinism . . . . . . . . 4IO

Martineau on reality of self-determination by permanent self-

identical ego . $\quad . \quad$. $\quad . \quad$. . . . 4 Io

Personality and freedom . . . . . . . 4I0

Advance beyond the phenomenalism of Kant . . . 4IO

Real freedom of man as a spiritual personality . . . 4 II

Merits and defects of Professor T. H. Green's teaching on

freedom . . . . . . . . $4 \mathrm{II}$

Critical reflections on the contingency issue . . . 4 rI

Criticism on Professor J. S. Mackenzie . . . . 4 412

Professor Caldwell on determinism in the individual . . 412

Relation of man's volition to law . . . . . . 412

Freedom and spontaneity in man as compared with the animal $4 \mathrm{I} 3$

Criticism of positions of Professors Royce, Höffding, and

Romanes . . . . . . . . . 413

Mozley on freewill as not an absolute truth . . . . 4 4 3

Man's self-determination and the causative agency of God . $4 \mathrm{I} 4$

Renouvier on Divine foreknowledge and human freedom • 4I4

Trendelenburg and others on freedom as subject to development $\quad 4 \mathrm{I} 4$

Freedom as an unattained goal . . . . . . . 4 415 
Ethical emphasis on will by Kant and Herbart .

Rothe on actual power of self-determination only through moral development

Physical and moral aids to freedom

Relation of freedom to education, heredity, and environment

Limitations of the doctrine of heredity

Limitations in range of liberty .

Causal circumstance not ignored .

Unsatisfactoriness of Professor Sidgwick's neutral position

Freewill and evolutionary theories as to rise of freedom and responsibility .

Persistence of true freedom

Positions of Hamilton and Mill referred to

418

418

Zeller on ourselves as cause

$4 \mathrm{I} 8$

418

Advance by Green on Mill

418

Sidgwick on freewill and new Determinist senses of words . 419

Freedom as proved by history of humanity . . . . 419

Will and the law of causality $\quad . \quad$. $\quad . \quad$. 420

Pfleiderer on the place of character . . . . 420

Schiller on negation of absolute freedom . . . . 420

Professor James Sully and Volkmann on the action . . $42 \mathrm{I}$

Balfour's criticism of the emphasis on character . . $42 \mathrm{I}$

A real freedom to be maintained . . . . . . 421

Professor Alexander's undue stress on character . $\quad .422$

Unsatisfactory attitude of C. E. Plumptre . . . . 422

Criticism of Professor Clifford on volition and matter . . 423

Dr George Matheson on man's sense of freedom . . . 423

Lotze on the incomprehensibility of this freedom . . 423

Criticism of Mr G. F. Stout's attitude to the contingency ques-

tion . . . . . . . . . . 424

Criticism of Kant's inconsistent treatment of the question . 424

Reasons for the defect and inadequacy of Kant's doctrine of freedom . . . . . . . . . . 424

Kant's sense of the worth of human personality. . . $\quad$. 425

Onesidedness of Kant's mode of conceiving freedom . . 425

Determinism of Schelling. $\quad$. . . . . . . 426

Freedom in Fichte $\quad . \quad$. $\quad . \quad$. $\quad . \quad$. $\quad .426$

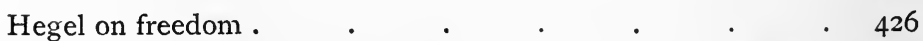

Hegel on universal and particular . . . . . $\quad$. 426

Hegel on the individual and the Absolute . . . 426 
Nature of Schopenhauer's determinism . . . . $\quad$. 427

Criticism of Schopenhauer's treatment . . . . . 427

Professor James on Schopenhauer $\quad . \quad$. $\quad . \quad$. $\quad .427$

Criticism of Dr Paul Rée on freedom . . . . . $\quad . \quad 428$

Misconception and absurdity of Rée's absolute beginning • 428

Relation of character and physical necessity . . . . 429

Critical reflections on character and freewill . . . . . 429

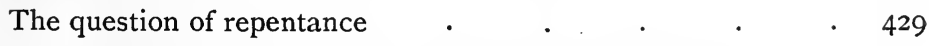

Place must be left for unexpected moves of will upward . 430

Criticism of Rée on responsibility as illusion . . . . 430

Criticism of Professor Paulsen's positions on freedom of will . 430

Criticism of Professor Höffding on freedom . . . . 430

Misconception of Höffding as to the individual . . . 4 43

Minimising of responsibility by Höffding . . . . . 432

Criticism of Professor Riehl on freedom . . . . . 432

Riehl's novel treatment of responsibility . . . . . $\quad$. 432

Riehl's treatment of consciousness animadverted upon. . 433

Critical reflections on consciousness and freedom . . . 433

Fatalistic character of Riehl's determinism . . . . . 434

Beneficial aspect of determinist theory . . . . . . 435

Criticism of DrF. H. Bradley on freewill . . . 435

Criticism on Dr James Croll's philosophical determinism • 435

On free self-activity, character, and mechanism. . . 435

Freedom and the law of causation . . . . . 436

Dr Matheson on the necessity of freedom to the evolutionist . 436

Simmel on the unprovable character of Determinism . . 437

Professor William G. Ward on the place of training . . 437

Need of freedom to ethical and religious vitality $\quad . \quad$. 437

In what way our freedom is conditioned . $\quad . \quad$. 438

Professor A. Dorner, of Königsberg, on individual personality 438

Injurious tendency of present-day Determinism . . 439

Man's freedom and personality in respect of both God and

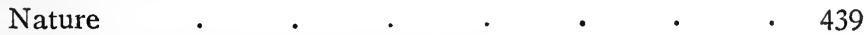

Freedom not the ultimate category of life $\quad . \quad$. $\quad . \quad 433$

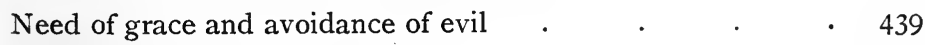

The determinism of religion $\quad . \quad$. $\quad . \quad$. 440

The ideal self and the actual . . . . . . 440

Freedom as forecast of the glorious liberty awaiting the sons

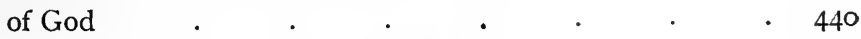




\section{CHAPTER XIV.}

RECENT SURVEYS OF THE REIGN OF LAW IN MAN.

Widening conviction of the reign of law . . . . 44I

Consequent confusions of thought . . . . . $44 \mathrm{I}$

Fact of recognition of cosmic law . . . . . 442

Laws of persons, ideas, and things $\quad . \quad$. $\quad . \quad$. 442

Kant on the philosophy of law $\quad . \quad$. $\quad . \quad$. $\quad .442$

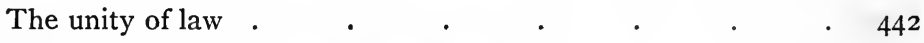

Zeller on divine law and natural law $\quad . \quad$. $\quad . \quad$. 442

Law as thought or relation . . . . . . 442

Fichte's conception of law $\quad$. $\quad$. $\quad$. $\quad$. 443

Law as it appears in modern jurisprudence . . . . 443

Divergence of spiritual from physical law . . . . . 443

Reign of law in spiritual world . . . . . . $\quad$. 443

Dr Carpenter on reign of law in the physical world . . 444

Relation of law and personality . . . . . . . 444

Law and a personal Lawgiver . $\quad . \quad$. $\quad . \quad$. 444

Law of right as moral law $\quad$. $\quad$. $\quad$. $\quad$. $\quad$. 444

Dorner, Passavant, Auberlen, Schöberlein, and others, on law of conscience . $\quad . \quad$. $\quad . \quad$. $\quad . \quad$. 444

Ethical obligation and Ultimate Reality . . . . 445

Law as operative in rational beings . . . . . $\quad$. 445

Hofmann on Conscience and duty . . . . . 445

Critical reflections on moral law . $\quad . \quad$. $\quad . \quad$. 445

Relations of law and reason $\quad$. $\quad$. $\quad$. $\quad$. $\quad$. 445

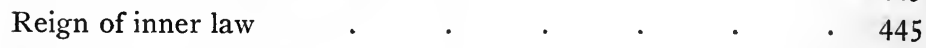

Kant on moral fanaticism $\quad . \quad$. $\quad . \quad$. $\quad .446$

The Universality of ethical law . . . . . . 446

Julius Müller on law of the moral order . . . . . 446

Theistic philosophy and ethical law under present aspects . 446

Internal law of duty and a Moral Governor . . . 447

Our claim for reign of spiritual law $\quad$. $\quad$. $\quad$. $\quad$. 447

Material laws and Deity . $\quad . \quad$. $\quad . \quad$. $\quad . \quad 447$

The natural and the spiritual $\quad$. $\quad$. $\quad$. $\quad$. 447

Mansel on morality and Divine command . . . $\quad$. 447

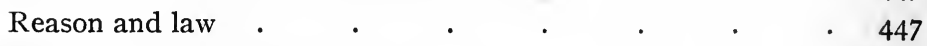

Kant on personality and moral law $\quad$. $\quad . \quad$. $\quad .448$

Personal Deity and ethical standards $\quad . \quad$. $\quad . \quad$. 448 
Criticism on the Spencerian treatment of conscience . . 448

Conscience no expression of mere external law . . . . 448

Martineau on sense of moral obligation and Higher Personality 448

Impersonal law no resting-place of thought $\quad . \quad$. $\quad .449$

Conscience in the individual and the objective law of right . 449

Theology and inherent character of law . . . . . 449

Universe as grounded in reason . $\quad . \quad$. $\quad . \quad$. 449

Dr W. L. Courtney and others on ethical law and its presuppositions . $. \quad . \quad$. $\quad . \quad$. 449

Dorner on moral goodness and the personal God . $\quad$. 450

Ethical law viewed as principle of life and love . . . . $45^{\circ}$

Spiritual source and authority of interior law . . . . 450

Advance in recognition of ethical law . . . . . . 450

Need of reconcilement of religious truth with ethical law . $45 \mathrm{I}$

Kant on ethics and religion $\quad . \quad . \quad . \quad . \quad . \quad 45 \mathrm{I}$

True differentiation of rational life $\quad . \quad . \quad . \quad .45 \mathrm{I}$

Frank and Wuttke on moral conflict . . . . . . $45 \mathrm{I}$

Wordsworth on law of duty $\quad . \quad$. $\quad . \quad$. $\quad . \quad$. 452

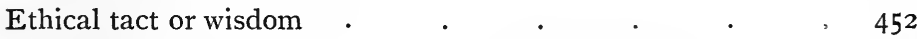

Vindication of man's powers of rational self-direction . . 452

Idea of right rooted in the Universe . . . . . 453

Implications of a Supreme Governor in notions of duty and obligation 453

Need of conscience culture emphasised by Gass . • 453

Martensen and Hofmann on conscience development . • 453

Martineau on the validity of conscience in view of evolution . 453

The moral consciousness and Ultimate Reality . . . 454

Progress of the ethical spirit $\quad$. $\quad . \quad$. $\quad . \quad$. 454

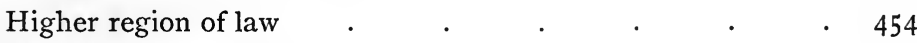

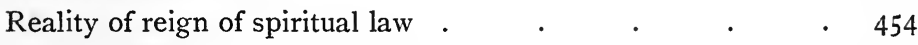

Law as promise of immortality $\quad . \quad$. $\quad . \quad$. $\quad . \quad$. 454

Redemptive forces of Divine law in man $\quad . \quad$. $\quad .455$

Faith transcends thought of the worlds as ordered by law . 455

Deity not disavowed in our recognition of law . . . 455

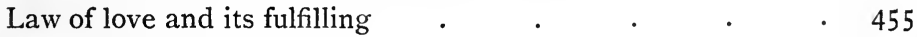

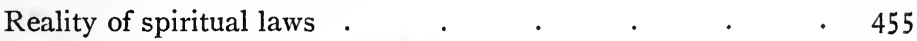

Compatibility of grace with law . . . . . . . $\quad .456$

Absolute character of the reign of spiritual law . . . $\quad 456$

Christ and the physical and spiritual orders . . . . 456

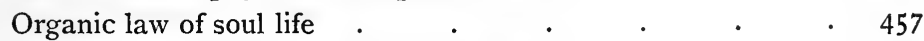

A true and spiritual survival of the fittest $\quad . \quad$. $\quad .457$ 


\section{CHAPTER XV.}

RECENT RECOGNITION OF MAN'S REDEMPTIVE NEEDS.

Need and hope of redemption more clearly discerned . $\quad 458$

Rise of ideas of shortcomings and propitiation . . . . 458

Deliverance less as external than moral . . . . . 458

William Law on ground and nature of Christian mysteries . 459

Theistic philosophy and the consciousness of God . . 459

Need of restoration and redemption . . . . . . 459

Redemption and its relation to $\sin \quad . \quad$. $\quad . \quad$. 459

Redemptive culmination of religion of revelation . $\quad$. 459

Spiritual elements in non-Christian religions . . . 460

F. W. Newman on theology and sin . . . . 460

Redemptive methods not laid down in a priori manner $\quad . \quad 460$

Redemption of Jesus and its light on the revelation of God . 460

Reality of the fact of $\sin$, in the race and the individual, to

be faced . . . . . . . 46r

Our primary relation to personal Deity . . . . . $46 \mathrm{I}$

Moral evil the sore of the ages . . . . . $46 \mathrm{I}$

Redemption not by mere self effort . . . . $46 \mathrm{I}$

Man's capacity for redemption . . . . . . $46 \mathrm{I}$

Universal facts of sinful need and inability . . . 46I

Deep-seated effects of sin . $\quad . \quad$. $\quad . \quad$. $\quad .462$

Moral evil in experience and observation . . . . 462

Impossibility of self-forgiveness . $\quad . \quad$. $\quad . \quad$. 462

Remorse and repentance as present-day facts . . . 462

Need of redemption as deduced from study of non-Christian religions . . . . . . . . 463

Need of redemptive influence for society as for the individual . 464

Failure of the ethnic faiths in respect of the problem of evil . 464

Mozley on Christianity and natural religious needs . $\quad 464$

Christianity, par excellence, the religion of redemption . . 465

Negative aspect of redemption . . . . . . $\quad .465$

Positive form of the redemptive working . . . . 465

The redemptive indwelling of God in man . . . 466

Infinite longing after purifying effects of redemption . . 466

The redemptive vocation in relation to man's spiritual ideal . 467

Pfleiderer on reverse side of sin and universal need of redemption 467

More than self-effort needed $\quad$. $\quad . \quad$. $\quad$. 467 
Criticism of Professor Pfleiderer on ethical conception of education 468 Merit of Schopenhauer's insight here . . . . . 468

Revelation for redemptive ends, and not for education only . 468

Active working of God for our redemption . . . . $\quad 468$

Amiel on man's moral needs $\quad . \quad$. $\quad . \quad$. $\quad . \quad$. 468

Science and the mediatorial functions of Jesus . . . . $\quad$. 469

Insufficiency of mere subjective change in the sinner . . $\quad 469$

Objective grounds of redemption . $\quad . \quad$. $\quad . \quad$. 469

Natural basis of mediation $\quad . \quad$. $\quad . \quad . \quad . \quad .470$

Need of moral recuperation $\quad . \quad$. $\quad . \quad$. $\quad . \quad$. 470

A philosophy of atonement as possible and justifiable . . 470

Historical and ethical aspects of Christ's redemptive work . $\quad 470$

Criticism of Ritschlianism in respect of sin . . . . 470

The historic basis in relation to our speculative and ethical philosophy . . . . . . . . $47 \mathrm{I}$

The individual operation of redemption . $\quad . \quad$. $\quad$. $47 \mathrm{I}$

The redemption of the body $\quad . \quad$. $\quad . \quad$. $47 \mathrm{I}$

Unity of the great redemptive process . $\quad$. $\quad$. 472

The conflict of flesh and spirit . . . . . 472

Futility of the notion that the redemption of Jesus was for the creating of moral power $\quad . \quad$. $\quad . \quad$. . 472

Godward aspect of the sacrificial work . . . . . $\quad$. 472

God in midst of the principles of atonement . • . 473

Schleiermacher, Rothe, Macleod Campbell, Edwards, and others, on Christ's sympathy with men . . . 473

Dante on the two complementary natures of Christ _ . $\quad$. 473

Critical reflections on the redemptive process as now conceived 474

Twofold purpose of the redemptive process . . . $\quad$. 474

Character of Christ's vicarious suffering . $\quad$. $\quad$. 474

The principle of sacrifice in redemption . . . . . 474

Schopenhauer on the Cross $\quad . \quad$. $\quad . \quad$. $\quad .475$

Criticism of Rev. C. Voysey on the God of the Christian . 475

Dr R. W. Dale on the God of the Theist . . . 476

Christ Jesus as Ideal of Humanity realised . . . 476

The spiritual harmony effected by Christ . . . 476

Criticism of Mainländer's philosophy of redemption • • 477

Theistic philosophy finds the highest flowering of redemption in development, not destroyal, of personality $\quad$ • $\quad$. 477

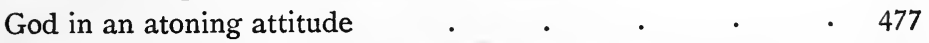

Facts of redemption as facts, and not speculative doctrines . $\quad 478$ 
Possibilities of progress that remain $\quad . \quad$. $\quad . \quad .478$

Fragmentary character of revelation in view of Mozley . . 478

Fear of Patripassianism dispelled . . . . . 478

Broken lights of redemptive principle $\quad$. $\quad . \quad$. $\quad . \quad 479$

Transcendent and ideal character of redemption . . . 479

Remedy for the wrestlings and perplexities of this time. . 479

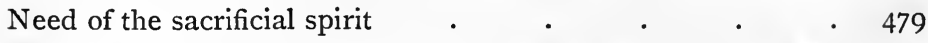

Transfiguring influences await our speculative thought on redemption $\quad . \quad . \quad . \quad . \quad$. 480

\section{CHAPTER XVI.}

RECENT THOUGHT ON THE SPIRITUAL NATURE, AFFINITIES, AND GOAL OF MAN.

Recent difficulties in maintaining the spiritual nature of man . $\quad 48 \mathrm{I}$ Changed opinions wrought of science . . . . . 48I Effects on Church and Theology . $\quad$. $\quad$. $\quad . \quad$. 482

Spiritual unity of the Cosmos $\quad$. $\quad . \quad$. $\quad . \quad$. $\quad .483$

Influences of modern Biblical Criticism . $\quad$. $\quad$. $\quad$. 483

Theistic philosophy and the spiritual nature and capacities of man . . . . . . . . . 484

Immanent relation of God to humanity . $\quad$. $\quad$. $\quad$. 484

Professors Calderwood and Caird on Man's place in Nature . 484

The spiritual man and the natural . . . . 485

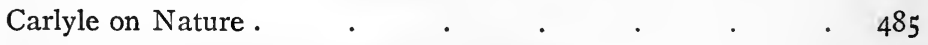

Virtue of the Hegelian conception of nature . . . 485

Science and the greatness of things spiritual . . . $\quad$. 486

Mind and matter . $\quad . \quad$. $\quad . \quad$. $\quad . \quad 4886$

Nature as instinct with spirit $\quad . \quad$. $\quad . \quad$. $\quad . \quad 486$

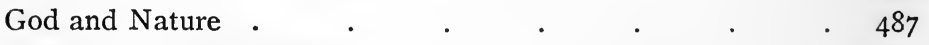

God as the unifying Spirit $\quad$. $\quad$. $\quad$. $\quad . \quad$. 487

Spiritual and personal elements in Nature . . . $\quad 488$

God as Personal Reason . . . . . . . 488

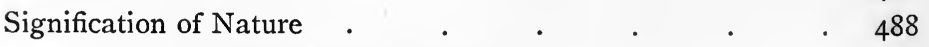

The Creative Worker and His Work . . . . 488

Spiritualistic interpretation of Nature . $\quad . \quad$. $\quad .488$

Thomas Hill Green on nature and mind . . . . 489

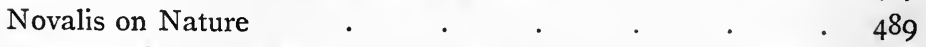

God as ground and centre of Nature's Unity . . . . 489 
Christ as needed Revealer of the Father

The spiritual essence of Divine Fatherhood . . . . 490

Unity of all things in the Divine Fatherhood . . . 49I

Superiority of theistic philosophy to fear of charge of Mysticism 49I

Mysticism and essential religion . . . . . . 4 49

Dialogue in spiritual communion . . . . . . $49 \mathrm{r}$

The essential meaning of prayer . $\quad$. $\quad$. $\quad$. $\quad .492$

Free relation of God to the world $\quad . \quad$. $\quad . \quad$. 493

Our free spiritual thought not to be overridden by science . 493

Man's capability of transcending Nature . . . 493

Need for critical interpretation not superseded . . . . 494

Moral greatness of man as indwelt by Christ's spirit . . 494

Gratry on the greatness and the growth of the soul . . 494

Partial truth of Pessimism . . . . . . . 494

Character of the Optimism of theistic philosophy . . 495

Quickening of religion, as of theology, through the advances of

the theistic faith $\quad$. $\quad . \quad$. . . 495

Theistic idea in the Philosophy of History . . . 495

Unity of God and Unity in History . . . . . 496

Scope and function of the philosophy of History . . $\quad 496$

The philosophy of religion and the philosophy of History . 496

Predestined goal of men and nations $\quad . \quad$. $\quad . \quad .496$

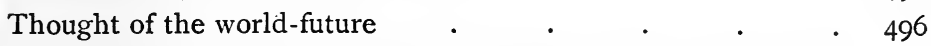

Criticism of race-future of Kant, Jouffroy, Herder, Guizot, and

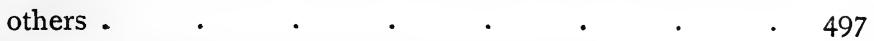

Difficulties that beset a true philosophy of History . . 497

The true end of History . $\quad . \quad$. $\quad$. $\quad$. $\quad$. 497

Criticism on Professor Clifford's position . . . 497

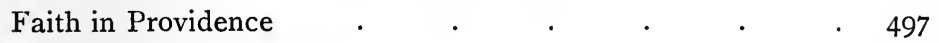

Kingdom of God as goal . $\quad . \quad$. $\quad . \quad$. $\quad . \quad 498$

The philosophy of History in its actual relations . . $\quad .498$

Insufficiency of the world's history as the world's judgment $\quad 4 \quad 498$

History not to be divorced from Philosophy, and brought under

Physics . $\quad . \quad$. $\quad . \quad$. $\quad . \quad$. 498

Criticism of position of M. Thiers $\quad$. $\quad$. $\quad$. $\quad$. $\quad$. 498

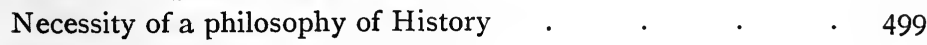

Diversity of philosophies of History $\quad . \quad$. $\quad . \quad 3 \quad . \quad 499$

Facts, as with Guizot, need not be visible and material in character 499

Theistic philosophy and positions of Comte and Buckle • 499

Hegel and Conte on the philosophy of History . • . 499 
Criticism of Comte's undue intellectualism . . . $\quad 500$

Critical estimate of Hegel's treatment of progress . . 500

Advances claimed for theistic thought . . . . . 500

Merits of Hegel as set forth by Pfleiderer . . . . 501

The opposing estimate of Hegel by Karl Schwarz . . 501

Fruitfulness of Hegel's treatment of rational freedom . . $50 \mathrm{r}$

Hegel's view of the justification of God in History . . 502

Broadening character of the historic movement . . . 502

History as process of education . . . . . . 502

Advances in setting forth the necessity and rationality of the

world's historic movement $. \quad . \quad . \quad . \quad 502$

Gloatz on History as presupposition of philosophy of religion . 503

History of Religion and History of the Philosophy of Religion $\quad 503$

Freedom and necessity of the historic movement . $\quad . \quad 503$

Historic progress not even-paced and mechanical . . 503

Wherein progress is taken to consist . . . . 504

Reactionary moments or factors-how viewed . . . 504

Consideration of theory of an absolutely continuous progress . $\quad 504$

Stress on ethical freedom . $\quad . \quad$. $\quad . \quad . \quad .504$

Bolingbroke on History . $\quad . \quad$. $\quad$. $\quad . \quad$. 504

Mechanical or material forces duly recognised . . . 505

Spiritual forces as the highest . . . . . . 505

Dynamic Reason in the Universe . . . . 505

Ideal plan and law in the history of man . . . 505

Recent European history an insufficient basis for philosophy . 505

Irrationality of the denial of the Divine Revelation in History . $\quad 506$

Claims for theistic interpretation of History . . : 506

Presupposition of Personality as lever of History . . 506

Criticism of the Spencerian mode of treating History . . 506

Ultimate grounds of historic advance sought by theistic philosophy . $\quad . \quad . \quad . \quad . \quad . \quad 507$

Altruistic and harmonising influences from love in God . $\quad 507$

Teleological view of History $\quad . \quad$. $\quad . \quad$. $\quad . \quad 507$

Belief in Immortality as rationally necessary and consistent . 508

Faith in Immortality as culmination of a spiritual philosophy . 508

Science not really adverse to spiritual nature and destiny of

$\operatorname{man} . \quad . \quad . \quad . \quad . \quad . \quad .508$

Relations of Immortality and Revelation . . . . 508

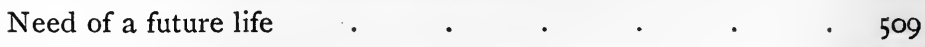

Kant's treatment of the soul's immortality . . . 509

Joubert and materialism . $\quad . \quad$. $\quad . \quad$. 509 
Advance in recognition of the naturalness of man's longing after immortality . . . . . 509

Vogt, Moleschott, Büchner, Spencer, and Huxley, on immortality 5 ro

The real relation of science to the subject . . . 5 Io

Science and the soul . $\quad . \quad . \quad . \quad . \quad . \quad .510$

Criticism of Hettinger's position on immortality . . 5 I0

Science and immortality . $. \quad . \quad . \quad . \quad .510$

Ethical elements in the quest of truth . . . . 5 II

Metaphysics and psychology and Immortality . . . 5II

Tendency of recent scientific research . . . . 5 II

Criticism of scientific objection to the soul . . . 5 II

Professor Huxley on the aim of Science. . . . 5 II

Impulses towards thought of Immortality . . . 5 I 2

Herder on forces that make for Immortality . . . . 512

Theistic philosophy and the law of the conservation of energy $\quad 512$

The law of evolution and Immortality . . . . . . $\quad .513$

Darwin on Immortality . $\quad . \quad . \quad . \quad . \quad . \quad 513$

Immortality and the evolutionary interpretation of man's life . $5 \mathrm{I} 3$

Necessity of Immortality to future progress and culture . $\quad 513$

Immortality and man's relation to God . . . . . 513

Growth of our knowledge of immortality . . . . . 514

Immortality at the basis of rational life . . . . $\quad 5^{14}$

Dr Elisha Mulford on immortality . . . . . 514

Rejection of physical theories of the seat of the soul . . 5 I 4

Difficulty raised by scientific thought . . . . 515

The soul itself claimed as the seat of the soul . . . 515

John Fiske on the soul . $\quad . \quad$. $\quad . \quad$. $\quad$. 515

Theistic philosophy and immortality in light of our rational and spiritual constitution . . . . . . 515

Fichte and immortality . . . . . . . 516

Faith in immortality and belief in God . . . . 516

Benefits of our not having God and Immortality forced upon us 517

Man's true ideal more real and vivid in this time . . 517

Faith in immortality strongest where spiritual development is

largest . . . . . . . 517

Evolution and the development and capabilities of the race . 517

John Stuart Mill on the future life . . . . . 5 I8

Individual and race immortality . . . . . 518

Criticism of Emerson on persistence of personality . . 518

Criticism of Haeckel's view of immortality . • • $\quad$ 5 19

Immortality as the bloom of evolution . . . . 519 
Motive power of Immortality for humanity . . . 520

Hettinger on man's immortal destiny . . . . . $\quad$. 520

Fiske on materialism and immortality . . . . . 521

Professor Le Conte on Spirit-immortality . . . . 521

Defects of Materialism . $\quad . \quad$. $\quad . \quad 52 \mathrm{I}$

Metaphysical basis of the future life . . . . . 522

Dr Matheson on Immortality $\quad$. $\quad$. $\quad$. $\quad$. 522

Insufficiency of pantheistic and materialistic contention that

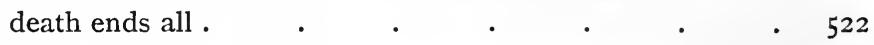

Criticism of recent pantheism . . . . . $\quad$. 522

Psychological aspect of the possibilities of immortality . . $\quad 522$

Immortality not a fanciful possibility . . . $\quad . \quad 523$

Comtist subjective immortality . . . . . . . 523

A true Himmelfahrt for the spirit of man . . . $\quad 523$

Doctrine of immortality as purified by modern influences . 523

Individualism and pantheism $\quad . \quad$. $\quad . \quad$. 523

Criticism of Hegelianism and the individual . . . 524

Inadequacy of language for theistic fulness . . . 524

$>$ Inadequacy of mere argumentative theism . . . 524

Growth of the argument as it takes hold upon us . $\quad 525$

Réville on belief in the future life. . . . $\quad 525$

Lotze on faith in the future . $\quad . \quad$. $\quad . \quad 525$

Last word on subject not spoken . $\quad$. $\quad . \quad$. $\quad 526$

Certainty of expansion and completion of our present . $\quad 526$

Necessity of immortality to our moral sense and rationality . $\quad 526$

Criticism on the Conditional Immortality position . $\quad 527$

Man's nature prophetic of immortality . $\quad . \quad$. $\quad 527$

The only theory of conditional immortality possible . $\quad 527$

No contradiction to science $\quad$. $\quad . \quad$. $\quad . \quad 528$

Personal immortality-why maintained . . . $\quad 528$

Supreme reasonableness of the belief in immortality . $\quad 529$

Ulrici, Fechner, Lotze, and Teichmüller, on proof of immortality 529

Criticism of Professor Pfleiderer's view of immortality . $\quad 529$

Criticism of Dr Bradley on the future life . . . $\quad 529$

Possible reasons for future life being no more disclosed $\quad$. 530

Divine Fatherhood and the future life . . . . 530

Advances of the theistic philosophy in this time . . $53 \mathrm{I}$

Geibel's prayer and its theistic sentiment . . . 532

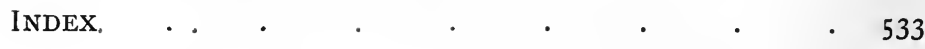




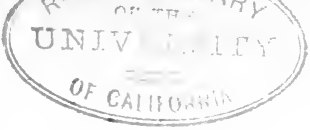

\section{RECENT ADVANCES}

\section{THEISTIC PHILOSOPHY OF RELIGION.}

CHAPTER I.

INTRODUCTORY.

The Progressiveness of Theism! That is the thesis which, in its modern aspects, we seek to present and enforce as against the common but loose assumption - what should be ein iiberwundener Standpunkt - that theistic philosophy has no more inspiring function than ever-renewed presentation of arguments whose cogency and content remain for ever unchanged-no more and no less. Here, too, in the philosophy of theism, it must be said that the schools have known no lack of commonplace-was uns alle bändigt, unfortunately without feeling it, like Goethe, - das Gemeine. Our knowledge of the deeps of Being in God is never 
perfect, is always human and progressive, and, while consistent and intelligible, is subject to ever-increasing enlargement as our insight grows into thought of God always more accordant with objective truth. That vast and cumulative proof of the Divine Existence which is but our spiritual exegesis and our intellectual interpretation of the Universe, cannot but be extended with every increase of our knowledge, and heightened by every advance in our insight and purity. We believe that theistic philosophy is still far too scholastic, has come far too little under the modernising spirit of science, and has, in its basis, method, and mode of development, too little followed any course that can be regarded as thoroughly scientific.

If, however, as it has been said, "the whole spirit of modern science is towards the extrusion of every theistic interpretation of the world from the domain of scientific knowledge," then assuredly it is time to vindicate a rational, and not merely ethical, theism - to realise to what a chaotic condition thought would become reduced without such vindication of rational theism as a thoroughgoing scientific hypothesis, supported by cosmical evidence no less than by the moral evidence furnished by the nature of man. It becomes the great positive task of philosophy to show that, into whatever conventional disrepute theism may have fallen, the conclusions most in harmony with reason as with feeling are still those which are termed theistic. It must not 
only set forth for us the Ultimate Ground of all things, but must also show what eternal reason resides in that World-Ground. That Primal Ground does not stand unrevealed and unrelated to our conscious experience, and, when it is revealed, the ground of religion in us is seen to consist not in anything extrinsic. When we think of this Primal Being, we think of Him as always and necessarily related to us, no abstraction of pure thought, no ultimate of simple homogeneous matter, but One in Whom such fulness dwells as makes Him Source of all this diverse universe and Strength of all our conscious experience. When shall theistic philosophy escape the injustice of being viewed as formally defective, simply because it makes God "supramanent" as well as immanent? By what right do men speak of theistic philosophy as viewing God outside of the world, as though that were ever at any moment regarded as His sole or whole relation to it? When are men ever entitled to speak of theism as binding us in a merely external way to God? Surely the theism of to-day never holds us as only so bound, and should not be treated as if it did.

We, for our own part, are certainly not to be deterred from undertaking our present task-seeing it is of so great consequence to rational thought, being indeed one of prime living interest-by any possible indifference to it from any side. We have in view, for example, the indifference that leads to 
the agnostic denial by the Ritschlians of the right of Natural Theology, and also any other that may possibly spring up-

"Cras ingens iterabimus æquor"-

in the legitimate endeavour to build up theology on truly Christian basis, freed from metaphysical conceptions which may be alien to it, when we say that the best theological thought of to-day cannot allow, and will not, that the interests of faith and theoretic reason should be sundered. What wisdom can there be in treating the natural pieties with scorn or distrust? What is there to justify either distrust in the processes of reason or disbelief in the voice of conscience? Yes, and what rational justification for the conventional contempt of Natural Religion as a bare and lifeless metaphysical residue? Does a religion, because it happens to have given us its light through natural processes, require to remain as religion in its lowest terms, and be incapable of a most real and spiritual progressiveness? We, for our part, boldly meet Ritschl's disavowal of natural religion by a more sublime faith in its reality and possibilities, for it is the fault of theologians, and not of natural religion, if such a faith cannot be found to justify itself. It seems to us high time for theistic philosophy, if it has any worthy confidence left in itself, to gird itself for the great work of self-justification before it, since it has actually been maintained, from the Ritschlian side, 
that, so far as the maintenance of the impulse to religious faith is concerned, pantheistic or materialistic conception will serve equally well with theistic.

We cannot admit that, in taking up the position we do, we are exposing the theistic philosophy of the day to any warrantable charge of lack of intellectual humility. In this connection we rejoice to believe that one of the remarkable recent advances of theistic philosophy has been that those injunctions to heed the utterances of the heart-whereby deeper truths might be voiced than by the deliverances of the intellect-which non-theistic writers hardly a generation ago sometimes laid upon theistic thinkers, have been carried to their highest fulfilment by a theistic philosophy which, recognising the pre-eminent place of the moral sentiment, has sounded the moral difficulties and possibilities involved more deeply than has before been done. The course of the theistic philosophy of religion has in recent times not run smooth; but we claim that, in its best trends and essays, it has been finding higher paths of interpretation, larger adjustment, reconcilement, and synthesis. Natural theology is no more than ultimate human thought exercised upon what man himself and his surroundings may teach or imply as to the Primal Reality known as God. We may surely say it has become more clearly manifest that what such thought testifies to is, above all else, the fact that such Inscrutable Reality, or the Unknowable, does undoubtedly exist. 
As Professor Flint has very properly said: "The relevant facts of Natural Theology are all the works of God in nature and providence, all the phenomena and laws of matter, mind, and history, and these can only be ascertained by the special sciences. The surest and most adequate knowledge of them is in the form called scientific, and therefore in this form the theologian must seek to know them." While Natural Theology no more occupies its former position of indispensableness to the investigator of Christian Dogmatics-since his starting-point is now acknowledged to be such as raises him above such help as Natural Theology can afford-the study of Natural Theology is yet seen to be both helpful and needful in some senses as an introduction to Dogmatics. For this reason we have deemed it desirable to treat of the recent philosophy of Natural Theology, the God of whose partial and inadequate revelation is the same God as the God of full-blown Christian Theism. We maintain that, wherever the subject has received careful attention, there has been a growing sense of appreciation of the progressiveness of Natural Religion during the closing decades of the century-a progressiveness realised, as we account the matter, in our increasing knowledge of nature, with the proofs she affords of uniformity, adaptation, interdependence, and combination. For by these we are led up to enlarged knowledge and conceptions of the attributes and of the providential modes of working of the Deity. And, while such 
a Theism, as the world without and within us may reveal, is insufficient and awaits the filling up or completion of a higher revelation, yet no true philosophy of Natural Theology can fail to recognise and maintain the truth and value of that revelation given us in the inner world, wherein God is enshrined in conscience, and in that outer world, wherein causation and finality everywhere appear. If we loose ourselves from conventionalism, a religion, as William Law was able to say, "is not to be deemed natural because it has nothing to do with revelation; but then is it the one true religion of nature when it has everything in it that our natural state stands in need of, everything that can help us out of our present evil, and raise and exalt us to all the happiness which our nature is capable of having." We deem it now necessary, in the interests of theistic thought, to start from the point of view of substance, opaque though that be, and to lay new stress, in our subsequent inquiry, on the conception of God as the Absolute Personality which determines substance, and on the implicates of this doctrine, so central and essential. Not that the category of substance is without difficulties any more than that of causation, for the permanent or substantial substratum assumed, in our notion of substance, so to persist, is not an assumption free from trouble. It is, moreover, attended with the disadvantage of drawing thought off from the intellectual world of relations or the thought world, to the substantial 
world or that of being. And it must be confessed that thought and its relations must do more and higher things for us here than any study of substances and their nature can achieve. Thought must remain a more transparent term than that opaque thing called substance, and we do not see any reason why we should not frankly and fully allow that this is so. For to us it remains a supreme virtue of idealistic philosophy that it never wavers in its faith in rational power and process. But, that our thought may not become lost in the endless flux of Becoming, the one real Ground of all existence and action must be seized as presented to us in the Absolute Personality. In fact, real Personality is just the last word of our philosophy; but where shall we find a higher? What other central unifying principle can match it? Infinite Personality, as base and bottom of all this wondrous world we see-have we not in this conception the most real and the most rational open to our advancing knowledge and thought? It has become necessary to consider such questions as whether we must speak of God as a consciousness; whether also we can, without inherent contradiction, speak of Him as the Absolute Consciousness. We are not in the least prepared to regard the philosophical consideration of such matters as at all so barren as they suppose, who seek to interpret the Universe only with such aids as empirical science may furnish. The implicates of consciousness - consciousness 
which is perceived to be an element in the origin of the universe - are in our judgment too significant for the Divine Being and Attributes for them to be put aside in this way, no matter what more may be learned of Deity through other modes of inquiry or appeal. Nor must such questions as that of the transcendence of Deity be left unnoticed - the question of Some-transcendency in relation to that of All-Immanency. For if excesses have been too often witnessed in the direction of transcendence in the past, this would afford no ground for justification if we allowed ourselves to be wholly swept away on any crest of immanence waves in the present. Our theistic interpretation of the Universe may find it still needful to maintain that, while there is a sense in which it is true that-

"All are but parts of one stupendous whole, Whose body Nature is, and God the Soul,"-

there is yet real need to uphold the fact of a Deity who is distinct and separate from us, and to Whom we are responsible. Otherwise, it may find the sense of guilt dissolved, and sin quietly resolved away. But shall not the recovery and maintenance of these, under the greatly increased difficulties and complexities of the time, prove the very power and triumph of theistic philosophy? There must be no shirking the full force of the difficulties, so grave and real: the way out shall be cut by a deepening process. It has grown 
more incumbent upon us to inquire, in more searching manner, into the Reality of the Self, and the present relations of Man to God, to the Cosmos, and to Immortality, as to which things the possibility of real knowledge has been discredited from so many sides as must be held none too creditable to the thinking capacities of the age. Thought must inevitably chase these problems in their latest phases, in the sure conviction that, if this knowledge be not possible, there awaits us, not any halting-place called Agnosticism, but what the Germans would call the Abgrund or deeper abyss of Scepticism. And we do not know any reason why, in this quest, theistic philosophy should not, like many another to-day, reap in fields where she has not sown, and gather where she has not scattered. For all things are hers - hers with a propriety that none of earth's philosophies can feel, in so far as she shall claim and make them her own by actual conquest and possession. From such pantheistic developments as those of Haeckel and Paulsen she may gather truth and glean wisdom no less truly than from the theistic teachings of Ulrici and the spiritual aims of Lotze. Theistic philosophy has been perfectly justified in taking opportunity, amid the recoil from a priori attempts at world-construction, to do better justice by the categories of physical science in the way of educing their metaphysical implications. For, in the vastly enlarged area of scientific or empirical fact, the 
task of constructive theistic philosophy cannot but be a much less easy one than formerly. Its primal task we shall find to be none other than the quest of an Urgrund or fundamental ground of all other proofs or grounds of religion. This is but to say that it seeks some first principle of so universal and organic character that from it our theistic philosophy of religion becomes evolved. Clearly nothing less than such a vital ground or generic principle will suffice to-day. Retreating from any merely abstract particulars or purely external evidences, we must ground all our grounds in such an organic, constitutive, and immanent principle as the Urgrund of which we have spoken. Then we shall have something like a true and thoroughgoing Apologetic, giving religion its true and necessary place in the life of man, and also giving Christianity its real place as crown and flower of all religion. Such a theistic philosophy of religion as that of which we have spoken is an imperative necessity, for what should our Christian faith do in such a time without the thoughtful and rational comprehension of experience on which we insist? It must steer a wise and thoroughly legitimate course between the extremes of objectivism and subjectivism-a course, too, that is not in the least impracticable. For it should not be unmindful of the truth and force of what Professor Eucken, of Jena, has said, in his judicially written work on 'Die Grundbegriffe der Gegenwart,' that “in the 
final result we come to this, that a detached and self-directed. Subjectivity, even with the utmost elevation (enhancement) of the conception, affords our life neither a firm foundation nor a sufficient content. Still less," he adds, "is this obtainable from mere objectivity." It must transcend the confusion and helpless despair of agnosticism, and lay to heart the brave prophetic utterance of Emerson that "there is a statement of religion possible which makes all scepticism absurd." No doubt, we have been lately told that such a rational religion is a scientific impossibility and represents an inherent contradiction of terms, and this attitude has been based on the ground that religious beliefs or doctrines are inaccessible to reason, and require ultra-rational sanction. No popularity of the sociological manuals in which such assertions appear should for an instant make us forget that they contain no more than the proverbial grain of truth needful to give them a certain currency. Hence, however, we must give some place to discussing the functions of Reason in religious and theistic philosophy, that religion may no more appear the non-rational sort of thing it has been depicted to be. For a true universality is to be claimed for reason. Reason will neither be subdued nor silenced, but will assert, through and after all, the all-comprehending character of its powers. The age of reason is not yet; reason, in our philosophy, is only becoming. So, too, the Reign 
of Law within, and not merely over, man, we must consider, with a view to bringing out his free, spiritual nature and characteristics. We say "free," and indeed his Freedom we shall separately discuss, for to those philosophers who cut away the ground from the fundamental truth and reality of freedom we can yield subjection, no, not for an hour. So far as may be, we are anxious that all mere arbitrariness be removed from the freedom of the will, and that freedom be truly grounded in the spirit, but we cannot allow man's free personality to be merged in the mechanism of nature. As free spiritual being, we claim to have real choice and freedom, and to transcend mechanical necessity. Notwithstanding the usurpations of prejudice and opinion, we must also, in the course of our investigations, inquire into the theistic possibilities of a Philosophy of History, a Philosophy which shall take due account of the History of that Spiritual Kingdom whose realisation theistic philosophy takes to be the ultimate purpose of God. Touching the goal of all things, we may not shrink from uttering our voice on the great theme of Immortality. The synthetic philosophy may have seen fit to tell us of the gradual harmonising of life with environment as the only goal to which it can point, and its picture of endless evolutions of eternally persistent force is one which lacks not in daring and boldness. But the theistic philosophy of religion reaches beyond to a faith in Immortality 
which sees the soul of man "survive the wreck of material forms" and endure in a true spiritual and eternal existence, which is one of fellowship with the Father of an infinite majesty, but also of an infinite tenderness and love. Its faith is that-

"Though suns stand still and time be o'er, We are, and shall be, evermore."

Of that immortal fellowship it may find presages here rather than proofs, but the coming glory which these presages of immortality foretell it will not allow us to mistake. No, not even if "it doth not yet appear what we shall be," when we shall be no longer "here in the body pent."

Such a programme as that we have now marked out for theistic philosophy can only be realised by its gathering all things-all special disclosures and partial truths or revelations-in one, in the unity of truth. Then the physical and the spiritual will coalesce, and revelation will be one. Such a philosophy can surely not be without vision; and is it not true that, where there is no vision, philosophy must perish? It is a vision of no monistic reduction of all things to one, but a sublime theistic fusion of all things in one. A forward unity is that we seek, not the backward search of men who are lost in thought of efficient cause. No striving after the ultimate of all thought-no endeavour to ascend from varied phenomena to the ultimate unity of all being - has ever yet been crowned, inductively, 
with success. But these very strivings, these theorisings and postulations and aspirations after this $x$ or unknown ultimate, all have their value, and cast a light that upward slopes towards that Perfect Being, of Whom all our conceptions are but fragmentary and partial. There are no blind alleys in our inquiries, but the rectifications and the completions of our knowledge leave us as far from finality as before. There is nothing discouraging to the individual philosopher in this. His work has its own place, and an abiding one too - a place of permanent value, as he is wise enough to see. For he surely sees that there is at least far more truth than men are, for the most part, able or willing to believe in the words of the philosopher who said that "even should future ages transcend the knowledge which is revealed in his work, still in that work he has not recorded his knowledge alone, but also the fixed and settled character of a certain age in its relation to knowledge; and this will preserve its interest so long as the human race endures. Independent of all vicissitude and change, his pages speak in every age to all men who are able to realise his thought; and thus continue their inspiring, elevating, and ennobling work, even to the end of time." This, we say, at least marks the faith in which we ought to work. And it is not meant that the individual philosopher, in so doing, should isolate the great problems with which he is here called to deal, or 
should fatuously limit the range and sphere of his observation in any individual or technical manner whatsoever. How should it be so, when he is called to deal with the universal and eternal functions of reason, functions even higher than international-in truth supernational? Theistic philosophy must, of course, appropriate whatever-being true-is local and temporal, but it does so only, as demanded by the true philosophic spirit, to transcend them. And we venture to say that the theistic philosopher-like every other true philosopherwill regard his philosophy as rather less the creation of his age, and more his own independent product, than Hegel was willing to allow. "Its methods, principles, formulæ, arguments, are all philosophical: the systems it criticises are the philosophies: the authorities it invokes are philosophers." His claim for it will be that it alone is adequate to the facts of knowledge, being, life, change, progress, as we witness these in the being, history, and movements of the Universe. Yes, and, as touching those points at which his theistic study must pass upward into the truths and implications of a distinctively Christian Theism, he will maintain and pursue a method not merely scientific but one which carries within itself, in the highest possible manner, a rational self-justification. And so he will perceive, in words which Wilfrid Ward in his recent 'Witnesses to the Unseen, and other Essays,' has used, a far deeper truth and force than has always been un- 
derstood or realised by those who undertook to shape the course of theological thought: "Viewing the evidences as consisting both of internal and external evidences, of the personal examination of one's spiritual nature as well as of history, of $a$ priori assumptions, of the necessity for a religion, of the meaninglessness of life without one, of the improbability that God, Whom we have learnt to know, would leave us in hopeless darkness, of the nature of the Christian law and Christ's characterboth felt by meditation and study to be unearthlyof these and the like motives for belief, added to the historical evidences, and all felt to converge upon the truth and knowableness of a fact of supreme present importance to be known, and calling, if true, for immediate and constant resulting action, we have quite a different set of principles to apply. It is both absurd and useless to ask any one who is led to love Christianity and to see reasons for thinking it not improbable that it may be true, to be indifferent as to the result of his further study: absurd, because if it offers knowledge satisfying his whole nature, he must hope that he shall find it true; useless, because if he realises the supreme importance to himself of a true conclusion, he has a security for impartiality far higher than that afforded by indifference." This is but "the concrete activity of the abstract wish for religious knowledge," and it seems to us an utterly untrue and unscientific 
procedure to treat religious inquiry as a thing of simple logical apprehension and scrutiny of exterior evidence, forgetful and inexcusably negligent of all that lies in the region of fact beyond-in the deep sphere of personal realisation, inward appreciation, and spiritual mastery. This spirit and method may, no doubt, render our task more difficult of perfect attainment, but we cannot but hold any less deep and thorough a method as necessarily defective and inadequate. And there is really nothing in this to deter us from seeking in our philosophy those two main requisitions laid down by Ferrier in respect of every philosophical system-namely, that it should be both true and reasoned, indeed by all means reasoned, as becometh a system. But true and reasoned our method and system may thus be, without being narrow and exclusive. In fact, we claim for it that it is an ideal method we pursue, when we seek to follow the clue of theistic principle, in our search for a synthesis that shall satisfy the demands for comprehensiveness and unity thrust upon us by the facts of the universe. 


\section{PART FIRST}

\section{RECENT PHILOSOPHY OF NATURAL}

THEOLOGY 



\section{CHAPTER II.}

RECENT PHILOSOPHY AND THE NATURE OF RELIGION.

IF God's revelation of Himself has its commencement in nature, it is fitting that we should first notice the tokens of advance afforded by recent philosophy of natural theology. For the history of religion, in which we broadly include its host of recent philosophic thinkers and inquirers in Germany, Holland, France, Italy, Britain, and America, renews for us the method of creation in thus bringing to us first that which is natural, then that which is spiritual. And, as Mozley said, the Christian mind has perhaps no greater satisfaction than that which comes of perceiving that the revealed system is rooted deep in the natural course of things. This, in our view, abides none the less true because of the circumstance that it was Newman's dictum that to deny revelation is the way to deny natural religion, or because the denial of natural religion has been seen, in the case of Ritschl, as it consorts with the magnifying of revelation. Natural theology is pos- 
sessed of no critical apparatus whereby it is to judge revealed theology. Revealed theology will yet be found reasonable, and none the less so, we believe, because it brings to us the mind of God. In no department of theological science has the need for reconstruction been more deeply felt than in that of natural theology, for just here have former notions been most completely overthrown. Modern theistic philosophy of religion has very rightly felt that it must follow a less mechanical method of inquiry. Knowing that it holds in hand the physical and spiritual worlds, it has wisely not restricted its attention to that religious knowledge or experience which is distinctively Christian, but has turned its scrutiny on the general or universal - " universal," we mean, in the only sense in which modern theism feels any serious interest-religious experience or knowledge. Its sympathetic and systematic study of the ethnic religions has been rewarded by the discovery of the relations they sustain to each other and to Christianity, of which, as their crown and flower, they are taken to be prophecies. The view formerly taken by natural theology of these religions of nature as being unmixedly false-the outcome of credulity and imposture-instead of really grounded in spiritual wants and aspirations common to the race, and developed in accordance with environment-as they are now seen by the science of Comparative Religion to be-has been increasingly felt to have been inadequate. At the same time we be- 
lieve the best of recent thought upon the subject to be with Professor P. D. Chantepie de la Saussaye in explicitly recognising the insufficiency of purely natural development to explain the phenomena of religion, while yielding to nature what we may call the "yearnings she hath in her own natural kind." In the light of these nature-religions being thus the natural product of the religious instincts of the race, it has become more fully recognised how-

"In even savage bosoms

There are longings, yearnings, strivings,

For the good they comprehend not."

These religions are thus seen to be capsules in which are hidden seeds of true religious thought. Indeed it may almost be now said to be more clearly perceived how the idea of Godhead or a Supreme Power on which all creatures do depend appears, whenever we pierce below the psychological processes in search of the objective basis, to underlie and give shaping to all these forms of religion. This, however, is quite consistent with religion, as what we may call man's underlying sense of the Eternal Spirit in all things, being seen to be wider in its nature, not merely than Christianity, but than that theistic conception with whose explicit form we are here concerned. We must indeed postulate for all human life such a background as religion is. It is not to be supposed that, in this idea of God anything more is implied, on behalf of natural theology, than the notion at present of a self-existent First 
24 PHILOSOPHY AND THE NATURE OF RELIGION.

Cause-Creator and Ruler-an idea valid enough for the purposes of natural theology, however short of the fulness of theistic conception. From the recent interest in the science of the History of Religions have sprung advances in the study of the theistic bearings of the world's ethnic religions, of which religions the Christian Faith has been always more distinctly seen to be the goal, not the denial, the fulfilment and not the negation. Hence we may say that the significance of such a saying as Hegel's, that the idea of God constitutes the general basis of a people, has, as we take it, come to be more fully appreciated, for we think it cannot be doubted that modern thought has increasingly found the theistic idea to be central and vital in the history of the race, of which the proof lies in the newer forms-now more robust and now more refined-in which it has appeared. At the same time there has been a clearer consciousness that natural religions, no matter how monotheistic may have been supposed their trend, are lacking in moral stability. Their position, at the highest, has been always more conspicuously seen to be one of unstable equilibrium. And so, alike the need for natural theology, with its suggestions at least of the wisdom, power, and unity of the personal God, and the incompleteness of that same theology - the inadequacy of a system of pure theism for the loftier ends of man's life-have been more abundantly acknowledged. This insufficiency of natural theism has been, we think, more fully 
appreciated in recent philosophy of natural theology, which has realised with what good reason even the author of 'Supernatural Religion' recognised the presence of higher than strictly natural elements in all great religions. Philosophic thought has understood how a thoroughgoing natural theism, denuding its Deity of all personal powers in its enslaving adherence to the natural order of things, and reducing the nature of man, in its psychological aspects, purely to terms of law, can never minister to the needs of faith and worship in any way worthy to be dignified with the name of a religion. We think that recent theistic philosophy has more clearly observed that the study of nature, as pursued by modern science, has been begetting a more distinct sense of the transcendence of God-of the truth that God is above and beyond Nature. For, has not science brought to light forces in nature which only the Absolute Power can explain, disclosed reality which reaches beyond the penetration of the finite mind, and unveiled mysteries for whose solution only the Infinite Wisdom will suffice? The theistic thought of to-day less than ever denies the light of the Eternal Logos, as it shines through the forms of the reason, to the nations and peoples unto whom the Scriptures have not come. It less than ever feels disposed to deny the fact of ethnic inspiration, whereby may come to pious heathen, amid the many millions who have never heard Messiah's name, the guidance and illumination of God's Eter- 
26 PHILOSOPHY AND THE NATURE OF RELIGION.

nal Spirit in its universal and unrestrained working. Its belief Tennyson has voiced, that men of every race-

\section{"In some way live the life}

Beyond the bridge, and serve that Infinite,

And vaguer voices of Polytheism

Make but one music harmonising 'Pray.' "

The idea of theism with which we are at this moment concerned includes, of course, only such real belief in God as may be possible where the truths of the Christian revelation have not come, - belief which may be real as implying in worship communion in some sort between two living minds, even where the expression of theistic belief seems not very free of superstitious elements. We are by no means sure of the wisdom of those presentations that seem sometimes unduly to press inferences of a theistic character from observed tendencies in primitive religions. We are not anxious, for example, to make theistic capital out of such a possible circumstance as that it might be urged that even in the form of religion or primitive philosophy called Animism - the first theory indeed of the world-there has been more plainly discernible, in its unconscious craving for ultimate reality, a seeking after the supernatural-that which is above nature-as an invisible and spiritual power present everywhere. No : spiritual thought is here -though it be a religion of spirits-still too chaotic for religion in real theistic sense, and so it merges 
into Polytheism, whence it may issue in Monotheism. It is enough for us more broadly to remark that recent theistic philosophy has more fully exposed the inadequacy of the naturalistic explanations of religious facts and phenomena, and has proved them explicable only through the presence of the self-revealing God. It does not even find perfect satisfaction in such a philosophy of development as that of Professor Edward Caird's scheme or preconceived theory for vainly trying to make of all religious history one vast evolutionary process, with " necessary stages" supposed to be traced through the world's variant forms of religion. We are not to be thought, while speaking thus, to deny a real evolution of religion, when religion is taken in its broadest, most inclusive, sweep-both natural and revealed-for we hold such a progress perceptible towards the ethical and spiritual, in midst of all reversions and catastrophic results. But whether it has been so traced for us in any tenable and consistent way is another matter. As in the individual, that was not here first which is spiritual, but that which is natural. What, in fact, seems to us of supreme interest and moment for theistic philosophy of religion is just the distinctive or differentiating element present in all forms of religion in the world, so far as that underlying principle or originating power-not to be confounded with a merely common element-emerges in the personal relation 
that subsists - and subsists anterior to, or apart from, the advent of Christianity-between the God worshipped and the man who worships. The humanity with which in its race-aspect we have to do is a humanity which, in its own profoundest interpretations of its existence, continually looks up to the Absolute, and says-

"All my springs are in Thee."

We say that we feel impelled for our present purpose to leave quite aside consideration of such facts as that recent religious inquiry has not shrunk from the complex and intricate undertaking by which, entering into the regions of ontological speculation, it has sought to trace out the theistic evolution of the better developed of these natural religions. Of these Buddhism may serve as an example, whose cult, developed through a long course of ethical culture, has been at times declared to be in essence theistic, though in character the theism is taken to be incomplete or even unconscious. For we cannot disguise from ourselves the fact that such conclusions rest on far too slender and precarious a basis to deserve to be mixed up with the solid and weighty considerations that must occupy us in succeeding divisions of our subject. It appears to us the more desirable to abstain from introducing such considerations since we have writers, like $\mathrm{Dr}$ Kellogg of Toronto, who think the progress of the highest thought of India has been from, not towards, 
conceptions of God as one and personal, and since it is not to be denied that such thought, in so far as it assumed a pantheistic hue, gave but little colour to real relations of moral and affectional sort.

When we turn to the Vedas, we see that no beauty of the religious spirit which may be found in them could avert what Bunsen terms the "great tragedy of India and of humanity," for we cannot but think that the Vedic poets came rather short of grasping, in any clear manner, the God they sought after. We come back to say that, apart from the position Dr Kellogg assumes as to the development of religion, he seems to postulate at least a residual theistic element real enough to be that which most concerns us here. So, too, the primitive naturism which Professor Pfleiderer postulates - somewhat gratuitously low in type, it would almost seem-as the original religion, must be left as matter of speculative conjecture, theistic philosophy of religion premising only that quickened moral feeling or an indefinite calling forth of the spiritual ideas was not without a place in religion as it existed prior to the earliest form of it known to us. It is, however, hardly too much to say, what we have just hinted, that not even in those known forms of religion that seem to us most primitive and incomplete, is wanting some recognition, beyond the vague sense of the Infinite - unseen and Infinite Power-and the bare notion of the spiritual, of the Absolute Reason manifested 
30 PHILOSOPHY AND THE NATURE OF RELIGION.

in the Universe; not even there is wanting some impulse of the finite spirit to communion with the Absolute and self-revealing Spirit, as a communion which is felt, though dimly, to be the vital destination of man's rational nature. Hence Principal Caird has spoken of religion as something which "may be said to consist" in the capacity which is ours of "self-abnegation and self-surrender to an Infinite object." In fact, precisely as he so surrenders himself is a man religious. Religion, however it may be mediated for us by the Church or community, remains to the end a personal relation - the surrender of the finite to the Infinite Person, so that, not absorption and not annihilation of the finite shall be the result, but intercommunion and mutual commerce of the finite and the Infinite spirits. All this in virtue of the indefeasible consciousness of relation to God which we claim for man, to whom the Power, by which all things consist, is inwardly manifested. So truly has religion been seen to be what Hegel said-a relation of spirit to spirit, even when Hegel's view may not be taken to be adequate. By it religion, represented as perfect freedom, would be too much confined to the volitional. Yes, although the persistent tendency of Hegelianism is to resolve the volitional into the intellectual. We say, then, that religion is seen to be determined by its springing from the nature of man as a dependent, imperfect, progressive creature, living not by his own life, but in strength derived from 
the Absolute. Not of course in any Schleiermacherian dependence, but only in virtue of that faith which is the subjective side in the process of reciprocal relations wherein revelation is the objective form in which God stoops to show Himself to man. A basal activity of our spirit is such faith, carrying within it elements of willing and of thinking, as well as of feeling. Those religious needs of which we have already spoken, and man's sense of such needs, must be said, certainly, to have been deepened by the presence of sinful elements. What concerns us primarily in definitions of the nature of religion is their one-sidedness - their tendency to look at single characteristics rather than at total contentwhich is to-day as comically true of Ingersoll's making others happier, if it can be done easily, as it was seriously true of Schleiermacher's resolving it into the feeling of dependence. But we have just seen how the self-revelation of God has been met by a complete self-relation of man to God. Only in this union of the two factors is religion's content complete. And so, taking for the present no account of all that can be urged against religion being restricted to explicit recognition of God, we ask, Has there not in all this been somewhat of a realisation of what Rothe said when he affirmed that the religious self-consciouness is immediate consciousness of relation to God as a reciprocal fellowship, a communion with God which, however, is possible only with a per- 
sonal God? For, "only if God is an I, can $\mathrm{He}$ be to us a Thou, as He always is to the religiouseven at the lowest grade of religion; for at this grade it is essentially praying." But it is precisely as a Thou that God is known to us: no longer does the universe signify for us merely an $I t$; and, as a consequence, all the free relations predicable between person and person may obtain between us and the universe so personalised in God. It can hardly be needful here to insist on the intimacy of relation subsisting between this knowledge man has of God, and his knowledge of himself and the world:

Theistic philosophy, it seems to us, insists very distinctly on this Absolute Spirit, Who is, in fact, the absolute ground of the human soul, being personal and self-conscious being. It may be quite true that we must begin with the bare fact of unity as the universe may seem to witness of it to us, but it does appear a very defective and halting result to which we are led in the 'Evolution of Religion' by Professor Edward Caird, when we are brought to "an absolute principle of unity" without the essentially spiritual and personal character of this unity being in any satisfactory form set forth. The world of reality is of small consequence to Professor Caird, if only he may reach his bare and abstract principle of unity, and it sounds curious to find the universal, supposed to be reached in such a manner, gravely spoken of as "the ground on which we 
stand, the atmosphere which surrounds us, the light by which we see, and the heaven that shuts us in" (vol. i. p. I 53). In no case could such a form of knowledge, devoid of all real content, satisfy us; and when it does come to filling in with content, Professor Caird has not realised that the idols of space and time must be forgotten, and spiritual unity be interpreted as becometh the spiritual. Our "ultimate attitude towards the universe" is an attitude towards something infinitely more inspiring than a mere abstract and impersonal unity. Only the unity of the Infinite Spirit, the supreme Personality, can possibly bind "all thinking things, all objects of all thought," in one. We gladly allow with Schiller, in one of his fine philosophical letters, that "the Divinity is already very near to that man who has succeeded in collecting all beauty and greatness, all excellence, both in the small and great of Nature, and in evolving from this manifoldness the great unity." Certainly we make no objection to this principle of unity "in the first instance," but no worthy theistic philosophy can abide content to have its ultimate unity-a unity for it ethical no less than intellectual-invested with so little that is explicitly personal and distinctively spiritual. We gladly keep in view how far we are at one with Professor Caird in his aim, as expressed in the lengthy note of the second volume of his 'Evolution of Religion,' to “think of God as $\mathrm{He}$ must be thought of -as the principle of unity in 
all things, and yet conceive Him as a self-conscious, self-determining Being." But Professor Caird seems fearful of allowing too much to man's individuality, and his thought, while not welcoming God as the absolute subject, yet fails to enter into and penetrate the glories of personality, as we claim it both for God and man. Such recognition of personality is not consistently possible to Absolute Idealism. And though the term personality has its difficulties in such a connection, yet we need not be too easily scared by a word, especially since, as Professor Caird himself admits, the matter itself is the real and important thing. God is still God to us, and there is none beside $\mathrm{Him}$, when we set our individual personality in relation to Him. We think Lotze has done better, in making personality his ultimate in the explanation of things, and in treating the highest being or the Absolute as personal -though unlimited-no less than spiritual. Religion, then, may fairly be taken to be the communion between God and man, or their reciprocal relation. No mystical communion is this, such that its tenuity need make it elude spiritual grasp; it is simply adoring intercourse or religion made real; it is no mere passiveness on our part, but implies the intensest energy of all our being. Recent theistic philosophy of religion has been laying needed stress on the fact that religion is not illusion, but something which calls for a philosophical showing of the objective character of the 
religious relation. It cannot be said to rest with any satisfaction in such efforts as that of Dr Bender of Bonn, who, as becomes the left or radical Ritschlian wing, in dealing with Das Wesen der Religion, treats of the psychological process of religion, as though this last were something that lacks objective basis or cosmic warrant. For it sees the question of real importance to be what relation universal and objective reality sustains to our religious ideals and beliefs. Principal Caird truly says that "the basis of religion lies in the very essence of man's nature as a thinking, self-conscious being," and that the religious appeal must be "to an objective standard. That which enters the heart must first be discerned by the intelligence to be true. It must be seen as having in its own nature a right to dominate feeling, and as constituting the principle by which feeling must be judged and regulated."-('Philosophy of Religion,' pp. I60, I74.) Religion is never whole and perfect until the powers of the whole man are thus called forth; then only is it in affinity with reason, no less than with feeling; then also has it brought us to know, no less than made us willing to worship, the Infinite God who is the Absolute Personality, eternal, just, and good. But at least to God, as thus its ultimate Ground-if you like, its metaphysical Urgrund-must it backward come through all psychological processes and all historical stages. Then shall it know, alike in thought and for thought, what it had earlier known 
only in feeling. Then, too, shall theoretic cognition pass outward into willing or doing, for only in such doing can we know the truth. In this best of ways will thus be fulfilled all that is needful and true in Schopenhauer's contendings for religion as rooted in the will rather than the intellect, even while we may not enlist under his banner in the warfare against rational religion. All religion is seen to be constituted, as Dr Martineau has said, by a conscious relation to a higher than we, and-on the part of the rational universe at large-to a Higher than all. We find a more satisfactory recognition, in recent philosophy of religion, of the complex nature of religious experience. So apparently simple an activity of man's spirit as faith, is seen to be yet most complex of his activities. Without being itself any special organ, it is seen to be the dynamic for all his faculties.

We find, too, a broader recognition of the fact that it is enough for religion, in the widest acceptation of the term, that it include man's relation, as a being of feeling, intellect, and will, to an Unseen Power or Powers able to affect his destiny, and not to a clearly defined God or Gods. This personal relation of man to the universe-and the Highest in it-is the foundation or basis of religion. To recognise this relation is clearly a prime duty incumbent on all rational beings. Just as science has the permanent relation of things for its basis, so is religion based on this personal relation of 
souls to the Highest. The saint, the savage, and the seer, all alike find their inspiration in some form of consciousness of this relation. Not far from any one of them is the feeling of obligation impelling to perfect fulfilment of the relation so recognised. Yet we certainly believe that not from any partial and inferior forms or manifestations of the religious feeling shall religion be most truly understood by us, but only as we view it in its highest terms and utmost reach in man. Nor must we ever be swept away by the current of religious feeling, but have the bases of our religious life sunk deep in the mind's views of the truth of God, in the heart's convictions of His holiness and love, and in the fixed and firm determinations of the will as made one with $\mathrm{Him}$ by faith and joyous self-surrender. Religion thus becomes to us a feeling of confidence, of trust, and of freedom in God. It is thus evident with what truth Professor Eucken remarks that "the growing life of the spirit is fundamentally distinct from any translation of reality into mere feeling. It produces of its own activity a new reality, and thereby strives to change the existing situation. Only at the height of such activity has man the full assurance of truth." The Incarnation is just a medium whereby we apprehend and realise as we could not intuitively and directly do, the nature of "that God which ever lives and loves." It must, in fact, be claimed that the theistic conception is, by 
immemorial inheritance, in the seat or place of possession, and that it is for anti-theistic theories to displace it from the position which by natural right it holds in man's normal faith. But that place, it must be clearly remembered, is, as the Rev. James Tait, of Montreal, in his 'Mind in Matter' remarks, not that of "a mere conclusion resting on a logical premiss. It is a truth impressed"- as we believe to be now better understood-" by the self-revealing God." Nor is there any really valid reason why we may not go on to add, with him, that "He who created the instrument by which human spirits communicate, can penetrate the seat of conviction and demonstrate Himself." The strange and tenuous Theism, which, however, in reality is mere æsthetic agnosticism, supposed to underlie the attempt made in our time-with, it ought to be said, no small literary charm and no lack of comprehensiveness of view-to exhibit a purely "Natural Religion," so called, cannot be said to have greatly troubled the vigorous theistic philosophy it was meant to affright. That philosophy rather seems to have left it dying of sheer inanition on the field. We think it hardly too much to say that "Natural Religion" has been mainly a contribution to the confusion which already exists in the sphere of religious thought; and that, while psychology has been teaching us to recognise the vague no less than the definite in the soul's life, theistic philosophy has always more deeply felt how 
impossible it must remain for religious thought to rest in anything so vague, and even inconceivable, as that which purports to be a purely "Natural Religion" poised on the negative science of the time. It cannot be content with this conception of Nature, out of which-when only personifiedis conjured up such a Deity as is supposed to be Inspirer of Kings, Revealer of Laws, Reconciler of Nations, Redeemer of Labour, Reformer of Churches. No; for this Deity has come out of only the physical order of things, and, all fine phrases notwithstanding, can lead us to no higher life than that which lies ensphered therein. Is it only thus, we ask, that this wondrous age of ours has been able to interpret its own needs? If so, theistic philosophy can find little to inspire and satisfy in such worshipful scheme. Theistic philosophy has, in fact, been realising the necessity of the supernatural, of which it is itself the supreme expression, and has been more vigorously asserting and vindicating for it a true place and sphere, in the face of those presumptions against the supernatural afforded by the stress of science on the universality of law. In fact, that philosophy has been drawing thought towards a larger and more inspiring Theism as the legitimate conclusion of the vast unity and unbroken continuity of $\mathrm{Na}$ ture, and as the necessary culmination of scientific thought. Its endeavour has been to take up the problems of Natural Theology, in the light of 
recent biological and geological science, and to reach through study of man's nature within-for truth is found within, as Augustine said-no less than the world without, a true synthesis of Natural Theism. To it religion remains, what Plato so finely said of the Divine, the power of the wing for the soul of man. It consists of some way or form in which, in personal experience; there is recognition of the supersensuous, so that emotion is stirred and life reacted upon. Yea; there is stirred that Divine striving, that strange emotion which mere Nature, as Matthew Arnold truly says, does not avow-

"There is no effort on my brow,

I do not strive, I do not weep;

I rush with the swift spheres and glow

In joy, and when I will, I sleep.

Yet that severe, that earnest air,

I saw, I felt it once, but where?"

And, whereas Natural Theology was so long wont to spend its strength in the study of form in nature as seen in adaptation and design, the constructive science of Natural Theology has in recent time evinced a rather slowly growing consciousness that, more important than form, is the force of nature. It has come to see, in fact, that the question of the evolution of life is, as we know it, really a question of the evolution of life with the further question involved of the adaptations of life, such power of adaptation being clearly present as a conditioning 
factor. By Strauss, in his 'Glaubenslehre,' it was profoundly said that life is an end that creates its own means from within and realises itself. Yes, the life of the self is essentially teleological, and justifies itself. Hence theistic philosophy has been coming at length to feel that life is more than form, that in the processes of life and the outworking of its divinely inwrought energy we have revelations of God, more real, more wondrous, than any presented by the structure of crystals, the wings of insects, and the plumules of plants.

"Oh, yet we trust that somehow good

Will be the final goal of ill,

To pangs of nature, sins of will,

Defects of doubt, and taints of blood;

That nothing walks with aimless feet;

That not one life shall be destroyed

Or cast as rubbish to the void,

When God hath made the pile complete;

That not a worm is cloven in vain;

That not a moth with vain desire

Is shrivelled in a fruitless fire,

Or but subserves another's gain."

We do not wish to say more in anticipation of those teleological matters which shall engage us in a subsequent chapter; but it seemed of consequence to remark that it has been no slight advance which has led natural theology beyond artificial and mechanical conceptions of the Deity and His working, till Christianity is seen to be the most truly " nat- 
ural religion" in its complete restoration of the immanent God in nature and in man. Yes, for in such ways we are made to see how the final tendency of things leads us towards God; we are shown not merely fitness and relation in this system of things, but the tendency and purposive design of which we have spoken. Theistic philosophy has unquestionably accorded ampler recognition to the immense service rendered by Pantheism in the re- . covery of this long-lost truth of the Divine Immanence, though it sees no occasion to allow itself to be overborne by the truth in question. We firmly maintain the absurdity of what Fiske assumed, when he lightly supposed-as so many have done with him-that the conception of immanence must do away with that of transcendence. Principal Edwards, of Bala, puts it rather weakly when, in his interesting lecture on "The God-Man," he says the latter conception is "equally necessary"; it is, if it came to that, the more essential truth of the two for the Christian religion. For, when we have asserted to the full the immanence of Deity in nature and in man, we yet need a transcendence for God, who, in the totality of His being, is more than any partial and fragmentary revelations of $\mathrm{Him}$ can possibly be. Such a transcendent existence we postulate for Deity, Who is to us a true personality and must be allowed such a real existence for Himself. What right have any to say that such a transcendence implies a gulf or dualism that must remain un- 
bridged save in a mechanical way? His individual personality we maintain, as we do our own, even though we are in God, yea, move and have our being in Him. We cannot allow the religious interest to be simply swept into a pantheistic abyss as the price paid for immanence: the Deity of pantheism we have too well learned to recognise as invalid, indifferent, abstract, and unreal. Yes, and this, too, while the world-process abides real. The all-embracing whole of pantheism is clearly no real whole, is not one whit more real, in fact, than the parts of which it is simply the sum. Had it been a real whole, it would at once have included all the parts and been more real than they. We dare to say that it was just in order that the religious nature of man might find this Deity to be its true, immanent, and transcendent environment that, as the poet has so finely put it,-

"Out of darkness came the hands

That reach through Nature, moulding men."

Yes, but "moulding" their faith, in the interaction of self and its spiritual environment, not through nature alone, but through countless mediations in the historic process of revelation. When all due value has been assigned to these objective and universal media, when the full opulence of the heritage into which we have come has been recognised and acknowledged, we must still hold fast and firm to the prime significance of our subjective faith, where- 
by we seize and claim these as our own. Our own subjective personal activity in such faith, wherein we thus appropriate and realise, or, in other words, the subjective self-affirmation of our own spiritual consciousness, is still a thing of vital moment. For it is in such faith that religion culminates. Its true home is in the heart, however it may need to be purified and made rational.

We account it a standing virtue of Hegel's philosophy, that it has so emphasised the propriety of resolving emotion into thought. We may yet escape any blindness to the easily gained limits beyond which the emotional cannot be translated in terms of the rational. What cannot thus be put in terms of thought may still, in its lack of rational equivalents, be so interpreted in terms of feeling as to cast light on the nature of that from which it has sprung. Such feeling may sometimes furnish a clue amid the bewilderments of thought. Not in anything intellectual, volitional, or emotional, do we locate its seat, but only in the spirit or the person, in whom it is the power that gives colour and direction to all else. Religion, as denoting for us the personal relation that subsists between God and man, can only signify a communion with Him of so deep-seated and spiritual a character, in which we are both active and receptive. Not in our individual experience alone do we so seek God, but also in the life and history of mankind. And the 
relations $\mathrm{He}$ sustains to us are such as no man can number. Why then should we not seek to know Him? Is $\mathrm{He}$ not nigh to us, and even within our hearts? Is $\mathrm{He}$ not always to be better known by us in the ever-living, ever-enlarging revelation that comes from $\mathrm{Him}$ ? Impavidi progrediamur. 


\section{CHAPTER III.}

RECENT THEORIES OF THE ORIGIN OF RELIGION.

THE insufficiency of data in the earliest historic inquiry we can make, with a view of ascertaining the empiric origin or genesis of religion, is now, we think, frankly enough acknowledged, and the need for inferential processes of thought, as to the known and available facts, admitted. This is, of course, a different thing from saying that its origin can be determined by speculation. The philosophical question of the origin of religion is, of course, to be sharply differentiated from the question of its historic appearance or genesis. Beyond the empiric view of its origin-with which the philosophy of religion cannot take to dophilosophy concerns itself with its ultimate grounds or bases. It is with the significance of its interior phenomena that the philosophy of religion presses beyond its outward historic forms to deal. It is not meant, of course, in saying this, that the philosophy of religion must not work upon the facts 
of religious history-which are indeed its presupposition-or must not educe from them the principles of which they testify. These facts are the staple of the philosophy of religion to be rigorously dealt with apart from preconceived theory, so that the principles which inhere in them shall be construed, not constructed. It is to be remembered, too, that no uncertainty of ethnographical theory, and no crudeness of our knowledge of its origin, can rob. religion of its present philosophical value for us. The theistic philosophy, discarding naturalistic explanations of the origin as insufficient and artificial, has more clearly seen what objective reality - even the presence and agency of God Himself-must be postulated behind the variant forms and modes of religion as that, in fact, whereby the maintenance of this true, original, personal relation between God and normal man, of which we have already spoken, is indefeasibly secured, no matter how scarce the traces of religion may sometimes be in empirical man. The ghost-theory or ancestral worship of Spencer's 'Sociology'founded on the widespread fact of ancestor-worship -with its failure to discriminate between the form of worship and the religious feeling itself, or, in other words, to account for the genesis of the very category of divinity in which the dead are placed; the animism of Tylor, to which, as one of the earliest, if also most crude, forms of religion, a relative truth may be allowed; and the God- 
begetting, though hardly man-honouring, fear of Strauss, have all been felt and shown to be notoriously inadequate to explain "the complex feeling of religious devotion." Recent theistic philosophy of religion has been more percipient of how far the origin of religion-with its ideas of responsibility and sin-has been from being found when religion, "dread arbitress of mutable respect," has been ascribed to the fecit timor of Strauss just alluded to, or set down to superstition or the fraudulent inventions of priestcraft, or accounted for by the Schleiermacherian feeling of absolute dependence, or by resolving it, with Jacobi, into a thing of the heart. Theistic thought recognises that such a sense as that of dependence must continue to be an integral part of religion, but it also sees how hypothetical, mysterious, indefinite, and incomplete such state or stage of religious feeling is. May we not say that it has distinctly felt how much greater is man, transcending objects of sense as religious, than any mere sensations or feelings of fear can suffice to show him? Does it not find the real marvel to consist-not in any fear with which man was early inspired but-in the fact that, before the appalling magnitudes of the universe which his eye beheld, he dared declare a faith in his own superior greatness and destiny, which a Pascal ages afterwards has been no more than able fully to utter? May we not say that it has more deeply felt, with Fechner, 
that "the grand fable of God and the life to come" would never have attained the hold or extent it has, "had it been but a fable"?

We claim that it has found all those theories which ascribe the origin of religion on its objective side to a phantom Deity born of ignorance and dread, and on its subjective side to such inferior faculties and feelings as fear, priestcraft, ancestral reverence, sufficiently refuted by the way in which religion not only persists, but becomes clarified in conception and worthier in import, with every advance of knowledge and culture. We, for our part, attach exceedingly little value to the attempts that have been made to set the religious consciousness in its fetichistic, totemistic, atavistic, polytheistic, henotheistic stages in definite and serial order, for they are vain and lacking in reality. We claim that theistic thought has more decidedly repelled the hypothesis that behind the variant forms of crude religion, no objective reality related to them exists, and has more laboriously traced the rise of religion back to the sense of world confusion-shall we say?-and personal nothingness, out of which the religious instinct leads man up through freedom into communion with the Source of his being. And for such an inquiry as the present it seems to us unwise and inexpedient to dwell so much as has often of late been done upon unsatisfactory speculations as to the prehistoric origin of religion in most primitive man, where it appears so difficult to find 
terra firma for philosophic thought. Why should there have been so little upon what we cannot but regard as the much more important subject of the relation of cultured man to natural theology? To put the matter plainly, it is of infinitely less moment for us in our present purpose to think about the historical or empirical beginning of religion-since it cannot be determined how far nature without revelation can carry us-than to know about its origin in the thought and experience of enlightened and developed man. For the one Reality which theism postulates in the enlightened conceptions of to-day is surely the not less necessary presupposition of any attempts to explain the origin of religion in primitive man, and its evolutional stages of development.

Certainly the genesis of religion carries us back to those primal deeps of feeling wherein the soul is only learning to distinguish itself from the vast non-ego without it. The latest and most enlightened stages of theistic theory have been more freely allowed to carry for us a far higher and more significant clue to a rational interpretation than those which were earlier: explanations of the genesis of the idea of God, early and late, must all remember that, whatever the occasions of the birth and development of the idea, its genesis must certainly be within the soul and mind of him who, opposing his ideal of the good to the merely actual, so comes to recognise the self-revealing God as God. It will thus be seen how thoroughly we hold by the view 
that inquiries into the crude and mystical notions of the beginnings of belief are of small consequence for the purpose of those who would make the religious sentiment justify itself in the living present. Leaving to all such investigations of the historic genesis their own importance, we are concerned, not with how the beliefs arose, but rather with what they are in themselves - with their truth, validity, and significance. No evolution of religion is, to our theistic conception, possible which does not proceed by the free play or intercommunion of the soul of man, with its transcendent ground, that Absolute Whose immanent spiritual energy develops spirituality and evolves religious consciousness in us. Without some such idea of communion with God on the part of man there would be simply no religion at all. Hence it is never wholly wanting even in the religions designated heathen.

Recent philosophy of natural theology has rightly paused, as we believe, before postulating that "original atheism of consciousness" which should be involved in too great disregard of the normal self-consciousness of mankind, and a too complete dependence on supernatural revelation for the idea of God. It sees, in fact, that its more essential contention here is for an objective revelation in some sort of the Supernatural Power to which man stands related, as something so palpable and persistent as to be past denial. Professors Robertson Smith, Pfleiderer, and others who might 
be named, have supplied the needed correctives to the mistaken importance so often attached to mythology in the scientific study of the ancient religions. Under the comparative method and the idea of natural evolution, these mythical Products have been increasingly shown to be merely natural phenomena, explicable under the working of psychological laws, however they may point back to some primal idea of a divinity. Mythologic systems are seen to have been, at best, but endeavours to give some sort of formal expression to relations that were obscurely felt to subsist between man and unseen supernatural powers. We deem ourselves justified in saying that recent philosophy of Natural Theology has found more favour for the position that the idea or concept of God is originated in us by the natural knowledge which comes to be ours as placed in this actual universe. It has found the prevalence of the idea, on any theory of its origin, a presumptive evidence of its truth not by any means to be despised. The validity and scientific character of such evidence have been more correctly estimated by Réville and others, who have exhibited the irrationality of supposing such a need as the religious one to be correspondent to nothing, and of assuming such a tendency as that towards religion to be destitute of a goal. We, however, have no wish or inclination to press such a line of argument too far. It rests, of course, upon mere ground of analogy, and 
cannot be placed on the same plane as that which admits of direct proof or scientific evidence. But still it must be said that the forcible grounds of argumentation of Fechner and those who, with him, hold that religious faith would not be such a need, as it is to man, did its objects not really exist, seem not to have been always fully appreciated. We say this without meaning thereby to place the yearning after God or the testimony of conscience on the same kind of footing for our knowledge of the objects presupposed as we would the observable functions or provable purposes of the bodily organisms.

Fechner's view of the origin of religion, as traceable to divinely given revelation of a primitive sort by means of nature and the soul, is not without much to commend it. Supernatural revelation, in some sort, is what seems to us to lie at the root of the belief in God within the furthest historic limits, and it seems to us always more certain that, if we could burst these historic limits and find the religion of prehistoric nature, the philosophy of religion would get but little reward for its trouble. So important is the historical method here. A more truth-seeking spirit and scientific attitude have been evidenced by recent philosophical theism as to the inquiry whether tribes do not exist without religious sentiments. There can be no doubt that the results of the recent researches have been re- 
markably unfavourable to the contentions of those who claim that there are tribes wholly wanting in religion. Roskoff has declared that no tribe has yet occurred without trace of religious sentiments. Peschel has decidedly denied any tribe having been found quite without religious emotions and ideas. Hellwald, in like vein, affirms that no tribes completely without religion have thus far been met with. From these and similar declarations by Tiele, Quatrefages, Réville, and others, the real results of recent research on this interesting and important question may be gathered. Lotze, in the first volume of his 'Microcosmus,' says : "We must give up the attempt to base belief in the existence of God upon the agreement of mankind. Moods and presentiments that point to something unknown and invisible are indeed developed in every human soul under the influence of the experience of life ; but, except under favourable conditions of development, they hardly produce more than a state of objectless fear, to which brutes also would be subject if they were not too devoid of thought to collect into a permanent group the individual frights which they experience."

But it has now become, we take it, better recognised how little really depends on whether tribes occur without actually realised religious relation, since it is the true relation and destiny of man as evidenced in the positive and practically world-wide phenomena of religion, with which theistic phil- 
osophy is concerned. It is, as we suppose, seen to be a matter of no practical moment that there has been a time in humanity's development when religion has seemed to be a quantité négligeable. A time there was when science and philosophy were in a like state of crudeness. Such things but prove that the glory of their later states has outshone that of their earlier. The great power and hold of primal religion on man are not in all this called in question. This religion is just the wonder to himself in the case of primitive man. Of no slight importance is this wider acknowledgment that the universality of the religious instinct, called in question by Gruppe and others, is no whit impaired or curtailed in its essentialness to man in his normal development-essential as an original element of his being, and not merely as a fruit of his development-by any possible occurrence of tribes without traces of religious sentiment. For, it is surely of significance for the philosophy of natural theology that it has come, as we believe, to be more clearly realised that, even if such religionless people had been found as Azara, Crantz, and the instances cited by Sir John Lubbock-on such really baseless grounds as Flint and Roskoff have shown-would represent, this fact of its abeyance or non-manifestation in such peoples would no more invalidate the truth that man has really a universal destination for religion than does the fact that there are secularistic unbelievers at home who 
reduce religion from its place among the primary instincts and powers of the soul. And, in sum, it is to be said that, if the Naturvölker cause us the greatest trouble and difficulty to reach their notions or beliefs, the obstacles are, it seems, next to insurmountable when we try to pierce to the origins of their theories or traditions, in hope of anything like sober certainty. We confess ourselves haunted by a wholesome distrust of attempts at interpreting the world based upon theories as to origin which have not the semblance of right to be treated as assured truths, and on which far too much has been rested. From all that has now been advanced, it will be seen how, in the wider and truer recognition of the universality of religion and in the firmer place found for the spiritual faculty in man, the subjective side or factor in the genesis of religion has been more adequately recognised. We may surely affirm that spiritual perception has, in recent philosophy of religion, been more clearly seen to be not less natural to man than either self-perception or sense-perception. We may surely say, further, that, hardly less congenial and proper than is the notion of self to the individual, is the propriety which humankind in its race-aspect has in the idea of God, a result inconceivable to us without original aptitudes in the soul for Theism.

It has been well said that "there is more than an analogy - there is a real kinship between the psychological and objective development in the 
individual and the race. So we may trace a common outline for both. Indeed its development in the individual is only rendered possible through connection with a communal life." Need we say that the personal element is not suppressed-in this interaction of the universal and the individual? We certainly deem ourselves justified in claiming, on behalf of our late philosophy of religion, a more decided utterance in favour of the universality, in a true and real sense, of spiritual perception or the religious sense. Can anything hinder that the Divine, the supernal, should make approach unto man and be revealed in him? In our view it has grown more evident that nothing advanced either by Pyrrhonism or by Agnosticism can so hinder. That to which the whole philosophy of religion is seen to witness is just this revelation of the Eternal and Divine in the finite spirit or consciousness. And it may not be amiss to recall the remark of Tait that "direct revelation of a spirit can never rise above self-assertion in the conscience." We may here call to remembrance - what Tiele has properly emphasised - that the gods are, even in the oldest religions, really spirits or lords that rule the phenomena of nature, and are not the " natural phenomena themselves." Deepening reflection, succeeding the personification of objects in nature, separated spirit from object and gave rise to fetichism. Such advances naturally followed as are implied in worship of the 
spirits of ancestors, and of mythological divinities or great nature-spirits. The dependence on nature grew less, and on the moral and social institutions of civilisation grew greater. These things, with the fact that Waitz has affirmed "the religious element" which races "in the lowest grade of civilisation" in their beliefs "undoubtedly" possess, constitute aspects which might be taken as converging towards, if not yet confirmatory of, what we take to be the necessary theistic conception of the phenomena of religion. We may perhaps be suffered to say that it has been shown how little that is unlikely resides in the suggestion that " the palæontological races either had no religion, or apprehended only in dim fugitive outline the elements out of which religion was afterwards to spring." Further, we may be permitted to say it has been shown how good the reason to suppose that, stable consciousness of the gods being attained, "these gods were personifications of natural objects, conceived as superior to men, and, to some extent at least, as arbiters of their destiny."

Dr J. G. Fraser, in his 'Golden Bough,' avers that to savage or primitive peoples "the world is mostly worked by supernatural agents." We believe it is being more clearly realised how, in all such attempts to explain the genesis of religionwhich last is not to be taken as constituted by such prehistoric belief in spirits-the attributes of the superhuman must be kept in view, no less 
than the notion of spirits, if any adequate origin is to be adduced. How could anything less be able to inspire even germinal religion? Such superhuman power stood not far from primitive man, as he looked on Nature, the visible garment of Deity: the heavens declared it most of all for his awakened self-consciousness-for awakened it first must be. The fact is, that men, in the childhood of the race, personified the things of nature just becaue they in some dim fashion realised that Nature meant for them a certain contact with Will, with Personality, of transcendent sort.

But why should man so perceive and interpret the facts of nature, and his nature-contact, but for what is to us here the important fact that he has a sense of the Divine, a certain power of religious perception, in virtue of which nature brings to him some revelation of the Divine? Yes, it is this informing influence of our own religious being that makes Nature appear to us in the religious aspect she wears. That inward susceptibility to which as a primary element (ein urspriing-liches Gottesbewusstsein) C. I. Nitzsch so well directed attention, is now, we believe, far more intelligently perceived as operative, in a deep and basal way, in religion. With the growth of reflection co-operated the growth of social order in fashioning the beginnings of religious belief. Still, passing up to modern aspects of the matter, recent philosophy of natural theology has, it must be said, only 
more clearly brought out the fact that, in face of the pain, malignity, and waste to be seen in nature, the theism of nature alone is insufficient to carry us out of the region of suspense as to the character of the God with Whom we have to do. It has with very great clearness seen that nothing like adequate or full conception of $\mathrm{Him}$ is to be drawn from study of nature alone, but also that the real teachings and true tendency of nature are ours only as that study scientifically deepens. It has more unequivocally declared its belief that religion has had its origin in no mere goings forth of man's finite faculty, but in the upbursting in the soil of the human and finite, of the life and energy of the Infinite Essence-the soul and substance of all things - though we are inclined to claim for it that it has not held this belief in any way that should relax the need of the severest intellectual effort to bring under scrutiny the parts played by these two distinctive elements or factors.

It is the appearance of what man has, by his own inward striving and effort, been able to reach, which has led naturalistic writers to go-whither theistic philosophy has not been able, in a naturalistic sense, to accompany them-so far as to maintain that man's whole religious beliefs can be traced back to their origin in the human heart and mind, and can be brought under rigorous laws of evolution like any other product of man's intelligence. May we not say, however, that the tendency of the most recent 
and reliable Philosophy of Religion has been towards grounding the genesis of religion, not alone in this unaided effort of man, but also, and more deeply, in God and the approach of His self-revealing Spirit? Has it not been with Baader and all who since claim that never without God can we know either God or truly about Him? Has it not rightly felt the need to maintain the creative presence of the Urgrund before the rise of consciousness? "To desire to know God without God is impossible; there is no knowledge without Him Who is the prime source of knowledge." But theistic philosophy has not failed to keep in view, amid the historic growth of religion, the non-progressive and even retrogressive, possibilities in the course of the evolution, just as has been done by science in the organic world.

We shall revert to this point when, in our closing chapter, we come to deal with the bearings of evolution on Immortality. Such monotheistic tendency -if not yet theistic philosophy-as the Hebrews reached, they are now more clearly seen to have arrived at in ways that-not without analogy among the heathen races-were increasingly inward, and proceeded from the commandment of the moral imperative in deepened ethical directions. But theism has not forgotten that these historical beginnings, in which we see the rise of the recognition of the immanence of God in the conscience, were antedated by the image of God, in which man had been made. 
We are thus brought to allude to those relations of religion and morality which have received so great attention in our time. Theistic inquiry has not failed deeply to recognise the personal and responsible relation we in morality sustain to the truth, and how objectively real and eternal morality must be in the last and deepest view of things. It has not lowered the place of ethical impulse and energy in man, as part and parcel of his true being. Nor has it been betrayed, by the clamourings of those whose espousal of the cause of ethical thought and feeling takes the form of merging religion in ethics, into forgetting that religion has always more conspicuously stood out as radically distinct-distinct in origin and historic basis-and permanently separable from ethics. This need not hinder our claiming the same ultimate and essential basis-a theistic one - for religion and morality. It has surely been better seen that to rob religion of its distinctive character in the interest of ethics would be to misconceive their immemorial relations, and to do ethics no good service. It has surely been learned that, essential as morality is to the religious interest, the moral consciousness cannot be completed save in religion. Morality is but the real manifestation of religion, which is ideal. The ideal law revealed in conscience is fully realised only as religion possesses the soul. Religion is the deepest well of ethical inspiration. It may be said that the moral problem is now more clearly 
seen to have its ultimate ground or metaphysical basis in the Absolute. If we say that morality is the deeper term in the sense explained, we should also claim religion as a term higher and more inspiring. At the same time no exclusively religious basis is to be posited for morality, for, while religion may still be the highest sanction of morality, morality must be clearly maintained to possess independent and, so to speak, extra religious sanctions. There seems no real reason why religion, as the highest development of our consciousness, should not be allowed to rest on the certainties of a moral consciousness which is no more at the mercy of religious beliefs. We have no great fault to find when Pfleiderer places the historic genesis of morality in religion, though where such religion is, morality is not generally wanting. But we certainly regard Dr James Kidd's argument on the subject as strained in the religious interest, and as failing to do scientific justice to all that can be urged on the side of the moral consciousness as, when properly apprehended, setting religion on stronger or securer basis.

Again, looking back upon such theism, or too often pantheism, as Greek and Hindu thought attained, we very plainly perceive it to have been developed-in ways that still too little found the Divine resident in the course and constitution of the world-from the speculative side which saw God as immanent in Reason or Thought. For 
here, in so far as theistic tendency was reached, we apply the words of Schiller, in his "Gods of Greece," to this ethical Hebrew pre-eminence,-

"To enrich, amongst the whole, but One, All this godlike world was doomed to death."

"Einen zu bereichern unter allen, Musste diese Götterwelt vergehn."

Hebrew history may have been marked by less of "progressive expansion and orderly development" than that of the Hellenes, but there is no doubt as to the richly developed type of the later ethical monotheism of the Jewish religion. Their theism-with the hope in God and coming destiny which it carried-was at least a thing by itself, and without parallel elsewhere. And their theism was one in which, as Professor Toy, of Harvard, has rightly claimed, the Divine immanence was accentuated, and small tendency shown to anything like metaphysical dualism. And yet may one not ask whether in Judaism God was not too often conceived as existing beside the world? A one-sided transcendence must plainly be said to have found its way into Judaism, even supposing this did not attach to the Old Testament idea of God itself. Its entrance was the result of Israel's opposition to the confounding of God and the world in the nature religions. The distinctive feature in Israel's development we now clearly perceive to have been the fact of Israel's 
making-despite all retrograde tendencies-rectilinear progress towards a predestined goal.

Now it has become more patent that it is the high office of Christian thought to harmonise, unify, and perfect these different lines of development of which we have been speaking, and this it does in a way which Greek and Hebrew knew not, in the undying hope that, through the idea of God given to us in the consciousness of Christ, our thought shall not be put to permanent religious confusion. This perpetuation and expansion of whatever monotheistic belief did early exist has been more clearly shown in late years to constitute the crown of Hebrew and Christian religion. So have we found more of man's development in the knowledge of God in lines that tell how-
"Quickened by the Almighty's breath, And chastened by His rod, And taught by angel-visitings, At length he sought his God;

And learned to call upon His name, And in His faith create

A household and a fatherland, A city and a state."

And it does not seem too much to claim for recent philosophy of natural theology, that it has been pressing on to such a pure and worthy anthropocosmic theism as may prove a fitting synthesis of the Aryan conception of God as Ground of the world of nature and the Semitic stress on a God 
Who is Lord over nature and Father of spirits. Has not the Christian philosophy of our time been endeavouring to show how truly the God of the universe is one with the God of the religious consciousness? At the same time Christianity has been more carefully-although not always-exhibited as other and more than merely the consummation of the world's other religions - as itself, in fact, a direct and independent revelation given in the manifold wisdom of God. "Such a religion," as Professor Edward Caird has well said, "must see God at once without and within us, yet it must be able to discriminate the higher sense in which $\mathrm{He}$ is within and not without." We cannot think the most spiritual and thoughtful philosophy of religion has been able to do otherwise than, in a deeper way than before, maintain the presence, in the evolutionary process of revelation, of supernatural elements in the working of the one living Spirit of God. Much, no doubt, has been achieved, but not a little, we cannot but think, still remains to be done in fully and satisfactorily setting forth the place and nature of that revelation which constitutes the objective factor in the genesis of religion-in what sense objective, and within what limits supernatural. We say "supernatural," for we agree with those who think that this term may be advantageously retained, so long, indeed, as we retain the term God itself, to mark off that which does not belong to the natural, as we view it. This is so even if the lines 
of demarcation between these two cannot always be clearly drawn. There is no reason why religioneven the highest-should not partake of a double nature, and evince a twofold aspect, an earthly or natural side as truly as a divine and supernatural one. When Deity appeared on the earth, did He not do likewise? Was He not all the more Son of God for us because He was so truly Son of man? No doubt, He was from above, but $\mathrm{He}$ never could have become for us the Perfect Saviour $\mathrm{He}$ was had there not also been senses in which $\mathrm{He}$ was from beneath. Of the earth earthy $\mathrm{He}$ became, that we might become one with the Divine and heavenly. When Novalis made religion embrace in itself "the whole sphere of the so-called supersensible and super-terrestrial," he occupied (overstrained nature as men have thought him) ground substantially at one with that which the best philosophy of religion has since taken. No spiritual faculty on our part could possibly suffice for the ends of religion without the self-revelation of Deity. There is, as we must hold, a religion, no less than a morality, of which Matthew Arnold's lines may be used to express the view of Nature herself-

“ 'Ah! child,' she cries, ' that strife divine,

Whence was it, for it is not mine?'"

But there is no reason why the supernaturalism of the future should not--as appears to us growingly needful-have its affirmation in the spirit of man, 
not less truly than in the objective evidences of revelation. Yes, for man is creative no less than created, co-worker with that Lord of the world Whose sovereignty over nature he shares, and shares so that he is shaping the great courses of evolution. Thus, though the historic power or Grösse, with which we have here to do, may not be able, from any of its sources, to take us clearly into the light of the absolute beginnings of religion, we are able to maintain through all a place for progressive development on the side of man, and a sphere for active participation on the part of God. The Divine Father worketh hitherto : we also work. And we have seen how the historic beginnings are no sooner reached than these unfoldings or paths of development grow marked and impressive, whereby the mind of man increases in correspondence with the Eternal Mind, and the Divine Mind communicates of itself always more largely to man. 


\section{CHAPTER IV.}

RECENT THOUGHT AND THE PERMANENCE OF RELIGION.

IT may be allowed here, as the matter is one of transcendent moment and interest, to give expression, under this division of our subject, to some reflections on the recent course of thought as to the probable permanence of religion. Theistic philosophy has justly not suffered the recent deepened study of the History of Religions to remain unmindful of the great influence of sin, with its numbing and retarding effects, on the growth and development of religion. The persistence and progress of religion have been seen : what now of its perpetuity? May we not say that recent study leads to the belief that Natural Theology will not only remain with Nature herself, but will also increase with the increase that is of Nature, as she progresses towards manifoldness and perfection? Though it doth not yet appear what Natural Theology shall be, we know 
that it is not without an eschatology of its own, from which the promise of an endless perfection is not absent. Recent theistic thought has more unequivocally, we think it must be said, declared its belief that, however religions may fade, religion itself, in its spirit and power, will lastnay, lead a transfigured life. And no wonder, when it has found even a vaunted Monism, declaring that "dogmas will be forgotten but religion will remain," and that "all the creeds will die away, but faith will live for ever." So was it that Theodore Parker said that as religion is the first spiritual thing man learned, so is it likewise the last he will abandon. In its inner and imperishable essence, it will abide, and that essence will be what the living and reigning Christ shall make it. Even Pessimism has been recognising, with Hartmann, the need of a Religion of the Future, which, in its own way, it thinks to supply. Theistic thought has believed that the religion of most transforming influence-the "fittest" to "survive" - will continue to be the Christian religion in its living and purified essence. It has come to hold more undoubtingly, with Schweizer, in the closing paragraph of his 'Die Zukunft der Religion,' that it is this religion which will to-day as yesterday effect that elevation (Erhebung) of nature or disposition (des Gemiiths), which all need more to-day than yesterday. It has seen that Christianity is teleological as no other religion is, 
and carries with it the promise and the potency of a future for humanity which make it singular among religions in its power to inspire to progress.

It expects religion to remain as a human characteristic, only with a newer sense of the Divine within ourselves as forming the strength and substance of this world where the Immanent Reason is ever working by law. The activity of the religious function will certainly continue in humanity at its normal state: it will do so just because God is the ultimate basis of man - the continuously sustaining power of man's being. Recent philosophy of religion has been encouraged in this view by the recollection of what an apparently "indefectible and perfectible attribute" of man religion in the past has seemed, so that every suggested substitute for it has proved but a succedaneum that has failed to satisfy. To use words of Principal Fairbairn, it sees that "what so permeates all sections and subjects of human thought, has a deep root in human nature and an immense hold on it. What so possesses man's mind that he cannot think at all without thinking of it, is so bound up with the very being of intelligence that ere it can perish, intellect must cease to be." Hence it abides calm before those claims of culture to supersede religion which are a patent and serious sign of the age, for it knows that there is no such impassable gulf between Christianity and modern culture as Hartmann and others repre- 
sent. It sees no reason merely to upbraid and despair of its own time, for it believes in the sure self-destructiveness of every attempt to which can be applied "toute cause qui hait son temps se suicide." It has learned that antagonisms belong to the accidents, not the essence, of the case, and, while concerned for religious depth and reality, it accords all of freedom, breadth, and humanness, which culture may justly claim, in the sure confidence that no researches of science or advances of culture can make the religious sense wax old or decay. May we not add that it feels the question of Schleiermacher to the cultured still to have force: "Must you not rather long all the more for that universal union with the world, which is only possible through feeling, the more you are separated and isolated by definite culture and individuality?" Hence it treats religion in its essential sense-its spirit, substance, or principle, not its forms - as even conditioning true culture, far from opposing it. It does so the more because it finds itself but too often compelled to say concerning religion as it actually appears, in the distich of Schiller,-

"Welche Religion ich bekenne? Keine von allen

Die du mir nennst.—Und warum keine? Aus Religion."

It has taken more careful note, in view of the claims of those who think altruistic ideals and sentiments might fitly supersede religion, of what 
writers like Comte and Büchner have had to say as to the strength and assertiveness of the egoistic tendency in man, and has come, as we believe, to the conclusion that the altruism of the future, soaring beyond such socialistic ideals as may live by bread alone, will have more, and not less, need of the inspiration and support of religion. It is persuaded that the spiritual consciousness of man will not be able to rest in the Positivist ideal, which is content with a merely naturalistic basis. It is unable to shake off the significance of the fact that, as it has been put, "une immense espérance a traversé la terre." It is well assured that Christianity, having survived so many changes of culture in the past, will survive those storms that seem to await this present time. Who shall say that, with its infinite potentialities, new and vast developments of its life draw not near? Who shall say that out of the pain and conscious need of the Pessimism of to-day shall not be born a more vigorous use of the religious sense, and a more richly developed type of religious personality? It may be as well to remember that, when Goethe said of humanity that it is always advancing, but in "spiral" lines, he spake that which is more true of our actual religious progress than may be to our credit, and it must be ours to see to it that, in widening around the past, and drawing inspiration from it, we do not simply lean too much upon it. There have been those-Lewes may serve as example-who, 
in opposition to others who have argued that religion has played out its part as a "provisional" organ in the evolution of humanity, and must now be displaced by a "final" organ, have clearly maintained that "religion will continue to regulate the evolution," even though this may require widening of the life and thought of religion in accordance with the needs of enlarging experience.

We mean to claim for ourselves, as religious philosophers, a Weltanschanung of the future, as truly as do the high-priests of science,- -one, too, which will continue to satisfy the demands at once of conscience and of intellect. Our divergence is only from the thought of such of these thinkers as appear to opine that Theism may yet be transcended in science, for we cannot overlook how clear has been made the impossibility that science should ever become possessed of such absolving and consoling power as to supplant or overthrow that universal sway and sweep of reason which, besides being the very soul of Theism, is that by which science itself lives and moves and has any worthy being. Nor can we overlook how truly Spencerianism has been tending to prove that no progress of science shall be able to dispense with supersensible Reality, or to displace metaphysical intuition or belief. The problems of religion lie outside the region of sensible proof-belong to a realm, in fact, into which science cannot enter. They pertain to the deeper science of the heart. 
Yes, the science of our time may announce to us what sensibly exists, and may enunciate her own criterion of what is to be taken as truth or fact, but she is simply powerless to estimate and decide for us in respect of the worths of things, the kinds of truth to be most sought after. There is nothing in all this that makes for the depreciation of intellect, but only the proper adjustment of our criteria of the end or good in things men seek. A more rational basis for religion must be sought than is supplied in the unintelligible Absolute of Agnosticism, with its ultimate refuge in the mere sense of mystery. With reason in science, which, by enlarging study, purifies and amplifies, and with reason in theology, which, by means of the theistic idea, interprets and integrates, it grows evident with what good confidence recent theistic philosophy has asked, How should these two mutually dependent forces of human progress ever seek to overreach or destroy each other, as together offspring of a Reason that is ultimate, transcendent, one? Is not real science itself natural theology, with teachings and inspirations for us in our progressive mastery of truth? Has not the supernatural been seen to be no destroyer of the natural, only its fertiliser and fulfiller? Is not real religion - the religion of Jesus-something which, as death to self and sin, and life unto God and righteousness, no true culture or science shall ever be able to overpass? 
Theistic philosophy has, we take it, more freely recognised that, between science and the supernatural, there neither has been, nor will be, any great mutual liking, and this fact-so largely due to loose and unphilosophical thinking-has rightly led it more carefully to define the abiding necessity and true sphere of the supernatural. But it would be another, and very different, thing to say that, when science comes in at the door, religion should fly out of the window. But what shall science tell us of things that run up into the supernatural? The religion that remains will, we venture to think, be more a thing of spirit-living spiritual religion -and Christian no less than theistic. For, as Emerson says, only that can now hope to abide which is its own evidence. "The religion which is to guide and fulfil the present and coming ages, whatever else it be, must be intellectual. The scientific mind must have a faith, which is science." It need hardly be added that we do not thus mean to make men Christian by intellectual compulsion rather than by spiritual newness of life, but rather to add to the deepest and fullest religious life the strength and knowledge that come of intellectual system or doctrinal demonstration. No; but because we try to do justice by the claims of the practical reason, and the demands for religion that reside in our nature, there is no reason why we should not also acknowledge the worth of theoretic elements or values. In its intellectual growth and 
movement, the religion of the future will more distinctly relegate ritual or spectacular religion to such place as its rudimentary position in the history of religions or the evolution of religion can alone claim for it in a progressive system of religious thought. It will even make less of "creedal" or doctrinal religion, will accord larger freedom and welcome to new interpretations, and will lay more stress on spiritual religion-the religion of life and spirit. For it will surely not be unmindful of the truth resident in certain words of Goethe that "it is not always needful for truth to take definite form (sich verkörpere); enough, if it hovers about us like a spirit (geistig) and produces harmony.". With this deepened spirituality shall be united in its inspiration a larger measure of the progressive moral spirit of the time. The Christian religion will still be, what it hath ever been, the religion of the progressive portions of the race, with whose progressiveness it has evinced a natural and true affinity. Already indeed we seem to see how-

"Upon the glimmering summits far withdrawn God makes Himself an awful rose of dawn "-

the dawn of a universal religion, the far-off shining of whose perfect day cometh in the long course of religious development, when the world's religions shall have poured the rays of their relative values into the central Christian sun. Now, the philosophy of religion is something which is always and clearly 
the offspring and product of religion, not something, therefore, which has any taint or trace of proud superiority to religion, on which, in fact, it does depend. We retain for religion its own primal value, therefore, and do not merge it into philosophy.

But there is not only a permanence of religion; there is also a permanence of the philosophy of religion, which is to be achieved like the permanence of all philosophy. That philosophical permanence, as Trendelenburg properly pointed out, must be the result of a growth like that of other sciences, of a truly historic laying hold of the problems, and an historic developing of them. His exact.words in the preface to his 'Logische Untersuchungen' are: "Philosophy cannot regain its former power until it acquires permanence, and permanence it cannot gain until it grows in the same manner as the other sciences, until it develops continuously, not beginning and ending in every head, but historically taking up the problems and unfolding them." This continuous development is, then, the work which has been given the philosophic mind to do, and nothing but the philosophic mind can do it. Theology liveth not by or unto itself: its roots are always more clearly seen to lie deep in philosophical soil. We are of them, however, that distinctly object to any sacrifice of the present-as a primary end in itself-before the evolutional shrine of the future. Of course, we grant the great self-moulding process 
that goes on in evolutionism, but we are not so carried off our feet by it as to forget the permanence which this very evolutionism must maintain amid all change. Abiding essence or reality there must still be, and an intrinsic value or worth will thereby be given to the present. The permanence we seek for the philosophy of religion has been pursued in recent times from the foundations laid by Kant and Hegel, Jacobi and Fichte, Schelling and Schleiermacher.

Among German contributors to an enduring philosophy of religion have been such minds as Lotze and Lipsius, Rothe and Dorner, Gloatz and Zeller, Trendelenburg and Teichmüller, Biedermann and Ritschl, Krause and Kaftan, Pfleiderer and Fechner, Seydel and Siebeck. Holland has furnished a Rauwenhoff and France a Réville. In Britain, Mansel and Morell, Green, Seth, Caird, and Campbell Fraser, Max Müller, Martineau, Stirling, and Wallace, Fairbairn and Flint, Matheson, Bruce, and Orr, Cave and Banks, have maintained the quest. America has yielded Harris and Royce, Bowne and Fisher, Kellogg and Sterrett. It is, of course, with no idea that these names are anything like exhaustive of the list of those who have helped to give our modern philosophy of religion the permanence it needs that they are now mentioned, but only as indicative of the reasonableness of the expectation that such philosophical permanence will be fully and finally attained. When 
it shall be attained, it will assuredly be by no resolving of ourselves and our activities in the present into mere points, in the evolutionary time process, that only minister to the future development, but it will rather be by the exercise, within the sphere of time, of our power as spiritual beings to contemplate the world-process from virtually non-temporal standpoint. Of course, we realise what we spiritually are within the historic world-process, but that does not make us merely of it and for it. No; with every justice to the realism of world facts and processes, we must maintain the inner core of reality which-for an idealism substantial and true-abides in the timeless present of the spiritual reason. Amid all apparent difficulties and discomfitures of religious truth, our comfort is that-

"Truth crushed to earth shall rise again;

The eternal years of God are hers." .

Yes ; and if, as we are bound to maintain, Christianity is truth no less than it is life, then no weak dread of intellectualism must keep us from exercising thought and reason upon the Christian content. Truly enough does F. A. Lange say, near the close of his 'History of Materialism,' that " those simple fundamental ideas of the redemption of the individual man by the surrendering of his own will to the will that guides the whole; those images of death and resurrection which express the highest and most thrilling emotions that stir the human 
breast, when no prose is capable of uttering in cold words the fulness of the heart; those doctrines, finally, which bid us share our bread with the hungry, and announce the glad tidings to the poor - they will not for ever disappear, in order to make way for a society which has attained its goal when it owes a better police system to its understanding, and to its ingenuity the satisfaction of ever-fresh wants by ever-fresh inventions." No; from

"Siloa's brook, that flowed

Fast by the oracle of God,"

there shall still and always flow forth those waters that shall be as truth and life to men and nations that are worn and weary. We refuse to believe that our only advance is towards doubt, sterility, and religious decay. Our face is towards the light : the spirit of true search is with and within us; and where such seeking is, there also will true finding be. Harmonies of the theological disciplines and of theoretic speculations still lie before us : let us await them in patience and in joy. We know no reason - for none with any semblance of substantiality has been adduced - why the religious needs of man should not persist, and also deepen. Then will they support the philosophy of religion, as it bravely tries to satisfy them. Janet has said that the only truly philosophical inquiry here is, whether religion is rooted in the very nature of man, or is but a passing 
and ephemeral state, to disappear as a higher stage of civilisation is reached. But it has already been made very manifest that, so rooted is religion in the fundamental nature and constitution of man, so related to his normal development, that it must persist through every period of mortal progress, and perfect itself with the growing perfection of the life and personality of those in whom it dwells. It will perfect its form with the perfection of Society, will renew itself from its own exhaustless deeps, but perish-never! And if it could perish, where, then, would regenerative power be found? On what firm foundations would the social fabric then rest? As Theodore Parker, when speaking of speculative atheism, said: "Religion is natural to man. Instinctively we turn to God, reverence $\mathrm{Him}$, and rely on $\mathrm{Him}$. And when reason becomes powerful-when all the spiritual faculties get enlarged, and we know how to see the true, to will the just, to love the beautiful, and to live the holy - then our idea of God rises higher and higher, as the child's voice changes from the baby's treble pipe to the dignity of manly speech. Then the feeble, provisional ideas of God, which were formed at first, pass by us ; the true idea of God gets written in our soul, complete beauty drives out partial ugliness, and perfect love casts out all partial fear." There are always those who will try to forget religion rather than fight with it, but it will never be possible wholly to forget God. 
Nowhere is the saying, Naturam expellas furcâ, tamen usque recurret, in such place as here. Man is destined for religion : eternity has been planted in man's heart; and the guarantee of man's continuance in religion lies not merely in man's remaining man, but in God's free gracious communication of the gifts and powers of His life Divine. 

PART SECOND

RECENT PHILOSOPHY OF THEISM

(GOD) 



\section{CHAPTER V.}

RECENT THOUGHT ON THE BEING AND ATTRIBUTES OF GOD.

We have now to speak of the advances of recent theistic philosophy, as touching the proofs of the Being and Attributes of God, not confining ourselves to "natural theology," or a priori natural knowledge of God, but, passing outward and upward at length into the impregnable positions, wise interpretations, and rich moral demonstrations, of Christian Theism. In them the true strength, and, we will add, originality, of theistic thought, are reached. For what indeed is Christian Theism but Theism in the highest-Theism, that is to say, raised to its highest power? Or who that has followed the course of recent thought can feel otherwise than that there have been both a deepening sense of the impotence and insufficiency of Natural Theism, and a quickened desire for a Theism that leads not a still life, but is of such real and living sort as is Christian Theism, with its ethical and not 
merely metaphysical attributes? It was the philosopher Braniss who said that "the conceptions of speculative philosophy, where they are most profound, come nearest to the Christian doctrine; nor need we be anxious lest speculative philosophy should ever reach a height from which it may look down and say that the Christian element is left behind. No thought can transcend the Christian idea, for it is truth in itself." There can be no doubt of the advances made in recent theistic philosophy in the larger apprehension and truer representation of the God idea, for it has happened according to the words of Goethe, in our late philosophy of theism -and it is no unimportant, though still incomplete, result that it should be so-

"That every one on the best of what he knows The name of God, yea, of his God, bestows."

"Dass jeglicher das Beste, was er kennt, Er Gott, ja seinen Gott benennt."

So necessary, indeed, is God to every man. "If he does not believe in the Eternal Reason, he believes in unreason; if he does not accept as the truth the living God, he believes in the idol of inanimate matter." Nothing has been wanting in the way the theistic hypothesis of a self-existent Deity has had its reasonableness and scientific character set forth, with a view to reducing the mystery of self-existence-which must meet us somewhere at last-to its lowest terms. There does not seem to be for 
us any more ultimate fact than that of being: the that of being is for us most certain of all things; but the how of being remains inscrutable. I, as a finite being, may not be able to find out how being comes to be, or is made, since-for anything I know -only the Infinite may be capable of comprehending this. But thought has felt ever more surely drawn to postulate the necessity of independent, self-existent being, if the perceived fact of being is to become intelligible. Hence it has held fast to the unconditioned Being called God as, in fact, first and deepest implication of our being. Fichte was able to say: "We must end at last by resting all existence, which demands an extrinsic foundation, upon a Being the fountain of Whose life is within Himself; by allying the fugitive phenomena which colour the stream of time with ever-changing hues to an eternal and unchanging essence." The ultimate goal of theistic philosophy has been clearly realised to be infinite and unconditioned reality, which is found in God, Whose action is always perfect. Than such perfect, unconditioned action as we find in Him, there is for us nothing more ultimate. We deem ourselves justified in saying that, in recent philosophical thought, there has been clearer emphasis laid on self-activity as the essence of being, so far as the conception of being has in philosophy reached its highest. Recent philosophy of theism, in trying to deal with the ever-pressent Kampf that is found in Nature, has advanced 
beyond a one-sided spiritualism or a merely abstract Theism towards a conception of God more real, more full, more complete-an all-sided conception which takes perfect cognisance of the results of the empirical sciences, and treats spirit and nature no longer in the former fashion, as distinct and separate layers, but as together bodying forth the fulness of the Deity in their close connection and harmonious agreement. It has not forgotten Goethe's advice that, if you would penetrate into the Infinite, then must you press on every side into the finite; in his own words-

"Willst du ins Unendliche schreiten, Geh nur im Endlichen nach allen Seiten."

It holds, with Trendelenburg, in his 'Logische Untersuchungen,' that now the infinite appears to us in the glass of the finite (im Endlichen wie im Spiegel). It has found a true knowableness of the infinite and absolute Being advocated by Ulrici, I. H. Fichte, Pfleiderer, Lotze, and others in Germany; by Ferrier, Martineau, Caird, Seth, Flint, Balfour, Matheson, Calderwood, Bruce, Iverach, Upton, among the many British writers; and by H. B. Smith, Diman, Harris, Littlejohn, Morris, Abbot, Welch, Porter, and others in the American phalanx. It sees God to be self-existent for us in a way which the world-no self-caused entity-is not, for that $\mathrm{He}$, as Being not Becoming, is its cause. It takes Him not to be the First Principle 
of all things merely in virtue of any abstract $a$ priori conception, but because it is driven to $\mathrm{Him}$ as the ultimate and the presupposition of all that makes experience possible to us, in the way we actually find it. Its Absolute is " not mere indifference, or substance homogeneous and indiscrete, but infinite differences belong to His nature." Herein it differs from Agnosticism, whose Deity cannot but be unknown when it is so very abstract and unreal. Shunning a self-destructive pantheism, theistic philosophy has been pressing beyond idealistic representations that would reduce God to an empty abstraction by making $\mathrm{Him}$ the mere unifying principle of Nature's multiplicity, or would merge His Absolute Personality in that created whole of the universe from which $\mathrm{He}$ still stands distinguished. It feels the futility of the recent attempts to explain the world as the self-evolution of Absolute Being, for it sees that an Absolute which should so evolve itself could evolve only the absolute, and would be incapable of explaining why the universe is relative. It has, we think, clearly seen that, so far as God may be conceived, in a metaphysical manner, to be the Ground of all existing things, He must possess, as attributes, power, self-consciousness, self-existence. More than this metaphysics, as the philosophy of the real, may not give, but the importance of what is so given is in our time often too little realised. To rob spirit as absolute of its distinctive charac- 
teristics in the interests of a unitary consciousness or an abstract spiritual substance is plainly to carry through a procedure in disregard of the truth that God has no right to be thus practically identified with the principle of unity. Distinct and real individualities and consciousnesses are not to be denied or dismissed or undervalued in the interests of a unitary bond by which the dualism of subject and object may be transcended.

Our recent theism has, without doubt, in its best essays taken braver hold of the conception of Force which pervades the universe everywhere, and manifests itself in an infinite variety of forms, and it has thus gained, we may say, a more scientific conception of God. A result, we say, not unimportant in view of there being those whose mingled attitude towards theism might be voiced in the words, $\mathrm{Nec}$ tecum vivere possum nec sine. We believe it has been helped to this by the increasing recognition, with certain great scientific investigators themselves, of the impossibility of natural science understanding matter and force, on the one hand, or comprehending spiritual processes, on the other. "The forces of nature," as has said Le Conte, "I regard as an effluence from the Divine Person-an ever-present and all-pervading Divine energy. The laws of nature are but the regular modes of operation of that energy; universal because $\mathrm{He}$ is omnipotent, invariable because he is unchanging." The uniformity of nature, as shadowing forth the steadfast 
purposes of a reasonable Being, theism now more clearly apprehends as pointing to the existence of an infinite and immanent Deity. It has brought the immanence of God, then, more clearly to light, so that $\mathrm{He}$ is seen to be an ever-present and all-inspiring Force in the universe, in which $\mathrm{He}$ is not yet pantheistically dissolved. Not "pantheistically dissolved," we say, for the philosophy of theism courageously discerns and declares pantheism to be logically as disastrous to religion and morality as atheism itself. In all this, it must be clearly kept in view that theistic philosophy, in its conception of being in God, has shown itself ill content to rest in the Hegelian translation of the entire activity of being in terms of monistic and immanent self-evolution-being, under Hegel's disrobing hand, appearing but as a naked abstraction, from which every attribute of reality has been stripped. It has paused to consider how little the imprisoned Deity of immanence can do for us in respect of our spiritual needs, how little His pure immanence can satisfy the demands of the spiritual nature, in its cravings for grace and guidance, forgiveness, help, and superintendence. It finds, with Chalybäus, that Hegel assumes "a pantheistical identity of man and God, in which, at least if strictly and conscientiously carried out, the Deity attains consciousness only by virtue of human agnition - a solution which indeed perfectly accounts for absolute knowledge in us, but comes up 
so much the less to the religious representations, and, let us add, the philosophical idea, of the Deity." It has sought to escape the contradictions of a pantheism that supposes there can remain to us a Supreme Being after all things have, as Professor Caldwell has very recently remarked, been taken to be one and to be God. It has also more unhesitatingly ascribed to Him certain attributes in keeping with the properties of the one protean Force behind all nature-manifestations, and which serve to purge our conception of God of anthropomorphic elements of objectionable character. In so doing, it has not been without even a quickened sense of the justice also needful to that matter, which is everywhere the basis of such energy. Recent theistic thought has, in fact, continuously advanced in its idea of God towards less anthropomorphic notions, a most warrantable result not without its parallels in the history of modern science.

Not, of course, that all anthropomorphism is done away, for recent theistic philosophy, more openeyed, has with truer discernment, in reasoning up to the Divine Attributes, ranked man, with mind and conscience, first among the manifestations of the great World-Force. That philosophy has not made God so much a God of mere "attributes," in the sense of casual increments, as was the former wont, but has, as we conceive, dwelt in less external ways on God as $\mathrm{He}$ in $\mathrm{His}$ essence is, and as $\mathrm{He}$ in the multiplicity of His attributes is construc- 
tively known by us. We take it to have avoided associating its conception of God with the noumenon of Kant's transcendental 'Analytik,' for it regards them as perfectly disparate notions. It does not say that they both designate something that cannot be known, for it is not so far left to itself as to follow Kant in including the concept of God among Noumena, and so set God out of all relation to us. It prefers to remark of both merely that they do not mark something perceptible. It knows better how to conserve the knowableness of the Supreme Reality (die Erkennbarkeit Gottes), than to lose sight of the active, self-revealing God for a conception fundamentally false. It very plainly sees how much of the current Agnosticism of our time "possesses all the elements of a scientific worldconception, but does not possess synthetic ability enough to put them together or see the whole in the sum of the parts." It has, in our view, very properly refused to own for its Deity the ens rationis or mere abstraction into which, as pure Being void of attributes, Herbert Spencer unwarrantably resolves the Ultimate Reality, for it has, we take it, very distinctly realised that it is its attributes that make it what it is. It has seemed to discern in deeper mode a spiritual substance disclosed through its attributes as the underlying and abiding essence behind all the manifestations of force and energy. For, "if the Absolute is to be mere substance, its idea remains incomplete; 
because then the subjective spirit and the finite personality of man appear'as something higher." It has felt, with Professor Pfleiderer in a recent article, that "we comprehend only that side of God which is turned toward us, His essence in so far as it manifests itself as the active principle of the Universe. The inner nature of God, His Beingfor-Himself, the inner reflection of His causality, we can as little know as we can perceive the side of the moon turned away from us." And it has discerned more clearly how little we finite and contingent beings shall ever be able to discover of the way in which essence or existence is called into being, but at the same time how this is, as Lotze has in a certain place remarked, of less consequence for us, seeing we are called to deal with a world already existent, and have not ourselves to create - with the result, however, that being remains for us a mystery. Its grasp, then, has grown stronger in its hold upon the fact that dependent being has for its necessary presupposition Being that is independent and self-determined. Even the doctrine of the correlation of forces is seen to presuppose a personal power which transcends the forces involved. There was certainly neither occasion nor need that the abstract critical activity of our time should, through having lost faith in itself as the organ of truth, have displayed the senility and dreary pedantry of Agnosticism. Spencerianism, yielding what might prove a basis 
for theism, but instantly prohibiting any process of raising superstructure thereon, is clearly convicted of but too easily lending countenance to that radical scepticism of our time which, as Professor Pfleiderer puts it, sees in religion only an irrational pathological phenomenon. What such abstract thought or reason stands most in need of is just the concrete reason-which it spurnsthat is presented to us in the Incarnation, for there reason is seen healing the wounds that have been made by reason. What we are here most anxious to maintain is, as against metaphysical agnostics, that " there may be no means of demonstrating that a particular metaphysical theory is true, and yet we may have a perfect right to speculate. Till we are quite sure that we have no such right, we ought to resist all attempts, whether in the interests of a positive or of a negative creed, to fetter the speculative impulse which is inherent in the higher races of mankind." No question can be made of the more forceful manner in which the presumptive evidence, which the superiority of the theistic hypothesis affords, can now be set forth for the explaining of those origins-whether of life, sensation, consciousness, personality-with which science abounds, in a way at least with which no other interpretation may compare. We do not mean, of course, in saying this, to dispute the really philosophical, rather than scientifically interpretative, character of the question of origins, for these 
investigations of ultimate origin cannot be said to belong to the region of assured and definite truths, scientifically ascertained.

There has been a growing sense that, insoluble as the origin of the universe may appear, the problem must be faced in a positive and rational manner, and not after the too purely negative and destructive mode of creationist theories generally, and of theistic expounders almost without exception. Recent philosophy of theism, while it may have dwelt in new ways - not, some may still think, without savour of ostentatious variation - upon the omnipresent Force which, in its constructive agency, began from the spiritual Centre of all things, has not less effectively maintained the priority of mind to matter, alike in respect of time and of importance, as the only theory in which it can find rational satisfaction. It takes the passage from matter to mind to be no more thinkable to-day than it was when the late Professor Tyndall pronounced it unthinkable. It has even found the supposition of it relegated by John Fiske to the limbo of absurdity, while it has noted how Ernst Haeckel has found himself unable to do without postulating qualities for matter which are practically subversive of the materialist position. It has observed the objection taken within recent years by the late Professor Romanes to philosophical spiritualism, because of its holding to the precedence and independence of mind. He does 
so in the interests of monism and the scientific doctrine of the conservation of energy. Such monistic interpretation makes mind, in Professor Lloyd Morgan's phraseology, neither "extra-natural nor supernatural, but one of the aspects of natural existence." But we do not think theistic philosophy is likely to abate any of its claims for mental operations and phenomena, as being due to that reality known as spirit or mind, for anything that has yet been advanced from the monistic side. In refusing to resolve mind into any material elements or terms, and in postulating the reality of mind itself as the only adequate cause of mental operations and effects, it must be held as acting in perfect harmony with scientific method. Recent philosophy has repudiated the irrationalities that would be involved in the notion of an impersonat force, and has sought the co-ordinating force of the universe in the ever-living Will, the supreme and originating Mind, which the theist calls God. Not less certainly has the philosophy of theism outgrown the agnosticism of Huxley than it has the sensationalism of Hume and the equally onesided rationalism of $\mathrm{Kant}$, for it has more triumphantly maintained the possibility of our knowing God-though Him no science has seen or handled - the all-embracing and Infinite Personality, not less truly than we know finite persons, both of whom indeed we know only in indirect and inferential ways. We do not, in saying this, mean to 
exclude an immediate and real-though mediatedknowledge: we only mean to exclude such immediate or direct intuition of God as would conflict with the essential subjective conditions of our knowing all objectivity. It has rejected the sheer phenomenalism of Kant-so distinctly set forth by Fortlage, Windelband, and other writers-for it holds that though there be objective realities which only perception or consciousness has been able to discover, these realities do not depend for their existence on such consciousness or perception. Such phenomenalism must remain to it really subversive of science, which, when it knows what it is doing, maintains a real objectivity for relations-not a reality of them merely within the sphere of consciousness. The activity of being-rather than of thought-must be held by it to be the logical prius, and the grand objectivism on which science tacitly and practically proceeds must be more carefully investigated and elaborated by philosophy than modern phenomenalistic tendencies have ever yet allowed. Theistic philosophy has dismissed as untenable any such dualistic basis, for the ultimate analysis of the universe, as would be implied in the independence of mind and matter, and, taking matter as the instrument and expression of mind, has more convincingly shown, as against that Materialism which even Büchner admits to be " far from being universally accepted by scientists of the present day," how futile must be every attempt 
to evolve mind out of matter, seeing that mind is for us that without which matter has not even an existence. Not, of course, that we mean to resolve all knowledge into pure subjectivism, or to deny an objectively valid knowledge of the world, or to impugn the objective reality of relations, beyond the bounds of the objective experience of the individual, for this would be to succumb to the prevailing unwisdom of philosophic tendency to-day. We insist on the relativity of our knowledge only in a true sense, remembering, with Ferrier, that non-relative knowledge is a contradictio in adjecto, since, as he says, to know a thing per se, or sine me, is impossible and contradictory, the mind, by its own law and nature, knowing the thing cum alio - that is, along with itself in knowing it. We may surely say that the philosophy of theism has made manifest how little mind is to be confounded, either with matter, or with forceactivities, or even with life, or any vital activities. No philosophical evolutionism has been able to substantiate any postulation of the mental and the physical orders being but subjective and objective aspects of one and the same thing. With all its dependence, in certain well-defined respects, on matter, mind maintains a wondrous independence of the physical order of things, in the exercise of its own strangely unifying power. Tentative remains any knowledge we think we have of matter or its essential nature; but of the world of thought, 
emotion, volition, within, we know there must be cause, and adequate cause. That cause we call spirit, and the intelligent force of the universe is also such that the most advanced science-no less than the broadest human belief-says, God is Spirit. But it is not enough to listen to the voice of mind on these matters : we must also heed what the manifestations of mind tell us concerning the Eternal, for these surely have their own message to deliver. It has been in such corrective tendencies, exerted on the old views of matter as a substance strangely diverse from mind, that we have seen some of the virtues of Hegelian speculation shine out.

According to Hegel-Professor Henry Jones has lately said- "if reality reveals itself in thought, it does so because it was thought from the beginning," the real or existential relation between man and the world revealing itself for him "as the relation of thought to thought." May we not affirm that the tendency of our present knowledge is towards the thought that deeper and more spiritual relations obtain between mind and matter than we as yet know, and that, however little we may now identify the laws of the physical and the spiritual worlds, we can set no bounds or arbitrary limits as to possible identifications of them in the future? May we not say that matter is to theistic philosophy, so far from something whose ultimate mystery lies open to sense scrutiny, more than ever the passing 
aspect of an eternal process, indeed simply a form of manifestation, the immanent God being the reality thereof, and the ground of nature's spiritual unity? May we not affirm that, since matter seems always to recede before the approaches of science, eluding its grasp, it has seemed a less incredible thing to late philosophy of theism that spirit may act on matter, and that spiritual energy, focussed in a Will invisible and supreme, may permeate the whole exterior mechanism as its soul or vital breath? May we not say that the ultimate elements of the Cosmos have seemed to it always more essentially spiritual or psychical in principle, grounded as they are, each and all, in that perduring and invisible substance which we know as God or the self-existent Life? To such issues the theistic philosophy has been helped not a little by the spiritual realism of Lotze, which, while doing less justice, possibly, to thought than either Kantianism or Hegelianism, has done better by the facts of our spiritual experience and religious consciousness.

The total result is one which may be not unaptly expressed in the words of Professor Campbell Fraser's recent 'Philosophy of Theism'-namely, that in our deepest thought " the natural universe is conceived as the immediate manifestation of the Divine or Infinite Person, in moral relation to imperfect persons, who, in and through their experience of what is, are undergoing intellectual and spiritual education in really divine surroundings." When 
Rothe affirmed that matter is the non-ego of God, and when the speculative theism of Weisse declared matter to be the externalised will of God, which has come into conflict with $\mathrm{His}$ personal will, they took up positions which theistic philosophy has left behind, because these involved a lack of real and effective supremacy, on the part of Deity, over that which $\mathrm{He}$ had called into being. To us it would seem strange to withhold this from Deity, when we find Fichte, in a bold saying, claiming even for us that the world must be made to subserve what we wish as really as our own bodies serve us entirely as we will. And Schenkel claimed that "the already existing harmony of nature is as little annihilated by the appearance of an absolute creative act of God in the world, as is humanity itself by the entrance of a new personality." It has been, on the other hand, for the too great supremacy and overshadowing influence of the Divine Mind and Absolute Life, in respect of the finite mind and human individuality, that theistic philosophy has been compelled to reject what in other respects has been most needful, most beautiful and true, in recent Hegelian portrayal of the essential unity betwixt man and God. Our individual selves, on the philosophy of Hegel, are, and can be, no more than simple moments or phases of His concrete Universal. However any "coming-to-itself of the Idea" might have been supposed to represent the personality of God, any real claim for finite person- 
ality becomes dissipated in a system which is marked by such continual Becoming and such dialectical passing over of forms one into the other. We cannot allow that we should have an Absolute, which so swallows up and consumes our selfhood or personality that we exist only for that

"One undivided Soul of many a soul

Whose nature is its own divine control,

Where all things flow to all, as rivers to the sea."

Ulrici, with a dualistic tendency meant to counteract pantheistic influences, has maintained the independence, and even superiority, of Deity over against the creation, which latter is to him both rational and real. With like dualistic leanings and with anti-Hegelian tendencies, Chalybäus, and also Günther, make the world so little an emanation from God that it is really rather a contraposition of God-objectively upheld by $\mathrm{Him}$ as a kind of antithesis to Himself. Of course, speaking with a general reference, extremes of monism have no more been wanting than extremes of dualism.

But every form of monism is valueless which does not turn its face towards the future rather than the past, and seek a true harmonisation of the spiritual and the material-such as the God-Man gives-in the evolutionary course of things. Says Le Conte: "To the deep thinker, now and always, there is and has been the alternative-materialism or theism. God operates Nature or Nature operates itself; but 
evolution puts no new phase on this old question." No, but what only too many have not understood is just this separateness of evolution from materialism. Though haltings may sometimes be seen in its thought upon the subject, our late philosophy of theism has, we think, seen what disastrous result must accrue to theistic thought from the surrender of the non-eternity of matter, with its properties and forms. It has, of course, treated eternal matterlying outside of Deity-as a manifest contradictio in adjecto, and claimed an absolute self-origination for God alone. It has viewed the relinquishment of the non-eternity of matter in the light of the issue when, to matter already so furnished, the powers and processes of evolution are added, so that God, if " in His world" as Browning affirmed, is so as a mere day-labourer rather than a true World-Ground. Since, as we have affirmed, theistic philosophy firmly maintains mind to be the logical prius rather than matter, it has rejected the idea that matter-though a mode of the manifestation of Deity - is to be viewed as eternal. It refuses to put asunder the matter which has been eternally joined together with mind. If matter or creation is to be viewed as eternal, it can only be as dependently eternalthe effect of Divine Will. The worth of the theistic hypothesis of a necessary, personal, eternal, and infinite Being, over the materialistic alternative of matter as necessary and eternal has, in recent philosophical thought, been set forth in more rational 
terms and on more explicit grounds, as being the surest clue we possess to the interpretation of the world's beautiful order and wonderful adjustments. "Through the whole range of our experience the active or 'quasi-spiritual' principle has its concomitant in the material, and the material its concomitant in the active or 'quasi-spiritual.'" It has been growingly perceived, we believe, how impossible a philosophy of nature, as finite and relative, is on those monistic theories that set out by postulating absolute being, and explain the world as the self-evolution of such being.

Perhaps we should also say that recent philosophy of theism has, at the same time, more freely recognised that belief in the eternity of matter is not yet incompatible with a theistic position, on which supposition the eternal universe, as the scene of God's free creative activity, ever existed in esse as in posse, the home and dwelling-place of God. We find creation out of nothing more keenly felt by recent theistic philosophy to mean, as Pfleiderer put it, an enchanted nothing or an illusory phantasm, for the "nothing" out of which theological thought has ordinarily made creation come is simply unable to explain anything. But can the last fruit of philosophic thinking remain the relegation of creation to the region of mere unthinkable mystery? We incline to think that the theory which finds the motive, will, and energy, of the creation entirely within the Divine Nature has at least more to be said for it 
than is always understood where the supposition is urged of primary and eternal matter. We take occasion here to notice the recently published views of $\mathrm{Dr}$ Paul Carus, who in his 'Idea of God' propounds a view of his own which he terms "entheism," and for which he claims that it "contains all that is true in the old views" of God, which are therein "purified by critique." Dr Carus takes God to be what Kant contended-_"a noumenon which we must of necessity conceive," but his monistic conceptions of God in his so-called Entheism are less distinct than his criticisms of the more prevalent views. When he makes God in the "usual" sense an "idol," and prayer to Him a "detestable" thing, he had need to take much more full and thorough account alike of the facts of the Christian revelation itself, and of the needs-also facts-on which it is based, than he here does. He gives us too little beyond the mere assertion that Entheism, which appears to contain a considerable infusion of Buddhistic sentiment, "clearly denotes the conception of a monistic God, Who is immanent, not transcendent, Who is in many respects different from nature and yet pervades all nature."

Let it not be thought there is not a "truly personal relation" to this External of nature, for our confidence in the unbreakable laws of existence is to bring us into this intimate and scientific relation of religion. We are in this work concerned with what we believe to be "Recent Advances in 
Theistic Philosophy," and cannot be expected to follow a writer whose complaint against Seeley and Arnold is that "they are not yet fully free from [italics ours] the theistic conception," and who himself betrays signal inability to do that conception justice. But we take leave to remark that it has grown always more evident that no Philosophy of Religion can be satisfying to the most clearsighted thought of to-day, which, while postulating personal and self-existent being as the immanent principle of the world and the world's development, fails to pass outwards and upwards to the conception of this personal being as transcendent. Yes, even though it be true, as Dr Ludwig Busse has recently remarked, in his 'Philosophie und Erkenntnisstheorie,' that we shall never be able to describe how God can be in the world and Ground of the world - immanent and transcendent - at one and the same time. Recent philosophy of theism has more successfully urged, as against Positivism, the significance for a true theism of the regularity and uniformity of nature, in which contendings it has had the support of Fiske and other thinkers. In treating of the attributes of Deity, it has placed the absolute ground of moral obligation in the actual perfectness of God. It regards the attributes, with Martensen, not as human modes of apprehending God, but as God's mode of revealing Himself. It surely sees how little real need there is to give way to the anthropomorphic 
tendency to attribute a necessity for an object to love in God, seeing His egoistic perfection is capable of realising love's infinite ideal in itself, and without dependence on such object. But there is every reason why, being in Himself love, He should create; and the contention of Franz Hoffmann is not without force, that, in the theistic interest, creation should not be taken simply as a contingent or accidental act of God. This view Principal Fairbairn shares when he urges that "creation was necessary while the Creator was not necessitated," and it may serve to obviate some of the difficulties raised by the poet Schiller, for example, when he asks, "If the fabric of the world is a perfection of the Creator, was His perfection incomplete before the world's creation?" At the same time, we are by no means clear that Principal Fairbairn, in desiring to gain an advantage over pantheism, does not carry the theory of an ethical necessitation too far, and make it unduly trench on the Divine Aseität or eternally independent and allsufficient existence. Dr Fairbairn at least grounds creation in the Divine nature rather than the Divine volition in a way we cannot quite accept. We cannot ascribe the creative act to anything but the self-conscious volition of Deity: this is not yet to make it matter of absolute contingency or indifference to Deity; but it is both to conserve a true freedom for God, and to escape the difficulties of 
grounding cosmical existence in the nature of Deity. Of arbitrariness or caprice there is none. Theistic thought has more strenuously insisted that the attribute of Divine Power or Will shall not take its former precedence over the attributes of Wisdom and Love. It has become touched with the spirit which, in Shelley's "Prometheus Unbound," teaches-

"To defy Power, which seems omnipotent;

To love and bear; to hope till Hope creates

From its own wreck the thing it contemplates."

We cannot think of God as the unconditioned Person, which we shall in a subsequent chapter represent $\mathrm{Him}$ to be, without attributing to $\mathrm{Him}$ love as an infinite quality. Only such love suffices to represent $\mathrm{His}$ perfect nature or unconditioned Being. His love is shown in His self-determining action. God is to be thought of as more than the Unconditioned: $\mathrm{He}$ is the all-conditioning power, Whose perfect action works through love. Rothe finely conceived the whole life and activity of Deity ad extra as a loving, and Principal Fairbairn has properly shown the consistency of such love in its creative outgoings with non-physical necessity. We claim that, even when it seeks to harmonise the goodness of Deity with His power, it does not always fail to see how ill-advised and short-sighted it would be to do so in a way or spirit that might seem to treat 
His Wisdom and His Power as of inferior account or secondary moment. The effects, for the relations of religion and culture, could then only be disastrous. We should need to know a great deal more than is known of this imperfect universein its ultimate no less than its present unfinished condition-before we could be content to postulate a Deity of limited power, as does Professor F. C. S. Schiller, apparently in sympathy with John Stuart Mill. There is no reason, however, why we should not join the poet Browning in viewing the conception of God, when taken to be one only of Power and Wisdom, as an isosceles deficient in the base. Love is, of course, the copestone and completion.

We are not, for our part, prepared to follow those recent theistic thinkers who treat justice as a superfluous attribute of Deity, and who postulate love as the one needful moral attribute of God, on the ground that $\mathrm{He}$ is our loving Father. "In proportion as we grow in habits of obedience, far from our vision of the eternal Justice of God vanishing from our minds, and being disowned by our feelings, as if it were but the useful misconception of a less advanced virtue, doubtless it increases, as fear is cast out." We are of opinion that they make a large and unwarranted assumption in treating this fatherly relationship as swamping all those considerations by which necessity can be shown for 
God remaining Absolute Justice-just in Himself, just in $\mathrm{His}$ relation to others, and Inspirer of the love of justice in the world. The love which to these thinkers is the Divine fulfilling of the law is to us too empty of content if no room can be found in it for Justice or the Divine Self-Preservation, that Justice which is, in fact, the guardian of the Highest Ethical Goodness. Justice not only spiritualises the Divine Omnipotence, but secures for Divine Goodness its needful and absolute basis. When God, as our Father, ordains what is best for us, has $\mathrm{He}$ ceased to do other than compass for us a justice which shall be perfect-perfect in its wisdom and its love? We grant that such an attribute recedes from view the deeper we look into the spiritual nature of things, but we see only that which is misleading in making Justice appear to conflict with Love in God, which preserves and perfects that Justice which is no transient and incompatible attribute. When we so predicate Justice of the Absolute, we do so really in virtue of that inner yearning of which George Eliot said that justice is not without as a fact, but within us as a great yearning. The truth is that "our very consciousness of being free, and so responsible, includes in it the idea of an unchangeable rule of Justice, on which the judgment is hereafter to be conducted; or rather excludes, as far as it goes, the notion of a simply benevolent, Governor; a simply benevolent 


\section{THE BEING AND ATTRIBUTES OF GOD.}

end being relinquished by the Creator, so soon as He committed the destinies of man to his own hands, and made him a first cause, a principle of origination, in the moral world."

We contend, then, that recent philosophy of theism has been fully alive to the enlargement of the data for building up its proofs for the Being of God, which the advance of knowledge and the evidence of history have brought. And it has, to its credit, always more keenly felt the burden imposed upon its rationally constructive power in giving proper interpretation to these facts of the universe, and worthy presentation of the enlarged and reconstructed grounds of belief, of which it has come into possession. For, advance as it may in the presentation of its great argument, it knows it can always render but scant and partial justice to the thought in God and concerning Him on which rests the highest glow of reason. Hence its feeling of the imperfection of language, akin to that of the poet of the "Paradiso" when he sings-

"Trasumanar significar per verba Non si poria," -

since things Divine lie so high beyond the possibilities of "words." It finds itself in agreement with those thinkers who maintain that those proofs of the Divine Being which are for us only implicit, and do not belong to the ratiocinative process, are both deeper and more satisfying than those with 
which the discoursings of reason are concerned. We have had occasion in a former work to point out the growing recognition of the impossibility of deductive demonstration of the Being of God, and we are in agreement with the statement of a recent able writer that "a science of concrete existences cannot be demonstrative." God, who is "the ground and source and moving Spirit of all reality, must be the most concrete object of our thought. By no possibility, therefore, can a theology or science of God follow the demonstrative method of mathematics." Logical demonstration is here out of the question, for where should we find a major premiss for such a conclusion? This impossibility of syllogistic proof for God or for an outer world was insisted on by F. W. Newman, in his work on 'The Soul,' in connection with which he remarks that "perhaps there is no outer world, and our internal sensations are the universe." Further, "There are persons who say that substance and matter are illusive terms, and that a substance is nothing but a congeries of forces, coherent and repulsive." Yes, but the soul or thinking self at least is real, and it were irrational to suppose the Infinite Mind, the Energising Reason, to be other than real. Theism has no wish to do other than freely acknowledge how much of our theistic conception we owe to tradition and inheritance, as well as to education and personal reasoning-how much of it has been the result of gradual expansion for 
us and communication to us, as well as of our own mental and moral evolution. The theistic argument has more and more been seen to rest on solid basis of cumulative proof, and to be reached by methods of proof of most comprehensive, subtle, and unwonted character. Not forgetful is the philosophy of which we speak of the truth of the poet's words-

" Nor less I deem that there are Powers

Which of themselves our minds impress :

That we can feed this mind of ours

In a wise passiveness.

Think you, 'mid all this mighty sum

Of things for ever speaking,

That nothing of itself will come,

But we must still be seeking?"

Surely we have come better to appreciate the fact that the proofs of God stand out for us not along the mere lines of ratiocinative faculty, but within the inner realm of spirit in man; not within the sole compass of the physical world, but much more in the deeps of our own nature. Yes, until we seek God in this inward way He must remain to us a veiled Deity-the so-called Deus absconditusa hidden God. The manifold processes involved, intuitive, empirical, reflective, inspirational, inductive, deductive, intellectual, ethical, and emotional, have all been more adequately recognised in recent times in their partial but essential working towards the one all-embracing conclusion. May we not say 
theism has come, largely through the wondrous feeling of being which is ours, to ask, with Goethe-

" The All-Embracer,

All-Sustainer,

Holds and sustains $\mathrm{He}$ not

Thee, me, Himself?"

" Der Allumfasser,

Der Allerhalter,

Fasst und erhält er nicht

Dich, mich, sich selbst?"

We believe it may be justly said that recent philosophy of theism has more correctly appreciated the fact that the proofs for the Being of God are not to be understood in the mere lumen siccum of reason, but through the insight of the spiritual reason-reason, that is to say, not as it might appear in " an intellectual all in all," but as influenced in its movement by the sweep of man's purest and largest affectional nature. Emerson was not wrong when he said that "the affections are the wings by which the intellect launches on the void, and is borne across it." The words of Pascal have lost none of their truth, save for a sheer barren intellectualism, when he says, "Le cœur a ses raisons, que la raison ne connaît pas," for reasons the heart still has, of which reason, as such, may know nothing. Truly has it been averred that our beliefs here are built upon no dry strand of reason, but ride upon the flood of our affections. Surely the absurd and irrational character of the scientific 
absolutism that would allow no risks of belief, no ventures of faith, however the heart might impel or the will incline, save in so far as the scientific method of verification or objective certitude may be applied, has been made sufficiently manifest. Are we really to come to this, that no truth shall be of interest for us, save that which has been thus verified? If so, then, as Professor William James has lately remarked, "the truth of truths might come in merely oracular or affirmative form, and she" (the spirit of scientific absolutism) "would decline to look at it."

The philosophy of theism is surely bound to maintain belief in things in this connection which it may not be able so to raise from being matters of faith as to make them matters of rational tabulation or philosophical testing. God exists prior to, and is more than, all our arguments, and nothing less than Himself is able to prove Him to us, which indeed $\mathrm{He}$ does by and in life. Theistic philosophy sees and feels, as we believe, that if God is God, the proofs of His Being and working must meet us, not here and there, but throughout all time, and over all creation, so as to make "one thing of all theology." Hence, as matter of fact, we do find a strong stress laid by it on God as the Prius, and the Immanent Principle, and the Final Cause of all this mighty world we see. To it all knowledge, as Professor Flint has said, implies and may contribute to the knowledge of 
God. It understands, as he suggests, how liable so comprehensive an idea as that of God is to be assailed from such standpoints as those of infinity, or of being, or of causality, or of personality, or of rectitude. Consequently it is not dismayed if many fail to rise to the height of its great argument. It remembers the words of Ulrici, that "modern theology, which so readily gives up the proofs for the existence of God, abandons thereby not only its own position as a science; but also, in principle, annihilates faith, and the religion of which it is the theology." And so it has taken heart, believing that to it belongs that genuine knowledge which is of God as $\delta a^{\lambda} \lambda \eta \theta$ เ $\nu$ ós-the true God-and has sought to rescue the theistic arguments, in the way Ulrici and others so nobly exemplified, from the confusion of thought which has so often rested upon them. It has, in so doing, been more careful, at least in its wisest representations, to seek and exhibit the true and real in which they have had their rise, and to be little content with the treatment that left us nothing but criticism of them as logical proofs, and even that criticism as often as not of a rather cheap sort. It thus tries to carry out what may be of truth in Schopenhauer's contention, that the proofs for the Divine Being are "keraunological" rather than theoretic, based upon needs of will rather than notions of the intellect. This place and importance, for theistic belief, of will, affection, emotion 
-equally with bare intellect-must be evident to all not clinging to garments of outworn scholasticism. We venture to suggest that it may be due to the memory of the destroying Kant-that Universal Crusher (zermalmen), as his countrymen call him-that better remembrance should be had of the contention of Kuno Fischer that, however Kant may have varied in his thinking about the knowableness or demonstrability of God, "there was not a moment in the course of the development of his philosophical convictions when he denied, or even only doubted, the reality of God." Not less striking and emphatic is the testimony of Zeller to the way in which Kant at every time held thus to the Being of God (das Dasein Gottes). Kant's own view of the matter was that "it is indeed necessary to be convinced of the existence of God, but it is not equally necessary to demonstrate it." It should not be overlooked how, in the section of the 'Critique of Pure Reason' dealing with the "criticism of all theology," he maintains the faultlessness of the ideal which the Supreme Being affords to the speculative reason, even though only an ideal. The fact remains that with a glorious disregard of consistency or fitness of things permissible only in philosophers, Kant avows his belief in a God Who had, according to him, set the pure and the practical reason at such variance, and Whose existence Kant had been at such 
pains to prove incapable of demonstration. These proofs, so called, have, no doubt, since Kant's day sunk to the position of being regarded as more of the nature of confirmations of the idea of God when already in the mind than as independent proofs of the existence of Deity. With the fine lucidity and directness characteristic of all his writing, Professor Pfleiderer has defended these proofs, alike in the interests of the historical spirit of humanity and of the needs of reason. "Kant notwithstanding, they will always occupy human thought. And it is right that they should do so. They certainly cannot, and are not intended to, engender the faith of the heart; yet they certainly serve a need of reason, which requires that faith be justified to thought." Kant's arguments did avail against a Deity that stood in mechanical and external relation to the world. But such is not the God of theism, Who, as selfconscious and personal Spirit, is at once immanent and transcendent. It is not pretended that these proofs are complete and final, for theistic philosophy has increasingly realised that they are but part of that whole and entire demand of man's spirit, in which place must be found for our moral yearnings and our æsthetic longings. It has certainly been an advance that these proofs of the Divine Existence are seen to be capable neither of separation nor identification, and have 
come to be considered, in the way they have, as organically related, as, in fact, constitutive elements of one grand comprehensive whole of argument. As Professor Diman, of America, put the matter: "The argument for the Divine Existence is complex and correlative. Not from one, but from many sources is the evidence derived; and its force lies in the whole, not in any of its parts." The true wisdom, then, is that which sees in this final result, woven out of all the partial and separate evidences, the real theistic proof-not something dependent on a single line of evidence but -the full sum of all that nature, history, and thought can teach us of God. What we mean to assert, in saying this, is not so much that any mere synthesis of these different arguments, even as complementary to each other, will suffice, as that such a lofty viewpoint of anthropocosmic theism must be gained as shall prove all-satisfying and all-inclusive.

In recent times the Agnostic tendencies due to Hamilton, Mansel, Spencer, and others, have stimulated theistic thought to higher effort in respect of these proofs, whose demonstrative force has been so often disallowed, that it might in newer forms of presentation redeem them from discredit; might turn Spencerianism itself to account in laying a basis for positive theistic belief, and, apart from that, might better exhibit what truth and value they possess. For, truth and value they do possess in 
what they teach at least of immanent causality, of immanent teleology, and of immanent rationality in man as in nature. The God Who is here and now known as the Infinite Spirit, the Absolute Ground of all things, the Eternal Self indwelling in all finite selves, is so infinitely knowable as to render Agnosticism for ever impossible. But, as Professor Flint has properly pointed out, the very wealth of contents in the idea of God inevitably exposes it to Agnostic assaults. But in our view Agnosticism is a possibility only where hypertrophy in some aspect of the thinking capacity exists.

The proofs of the Divine Existence we shall in their recently advanced forms consider in subsequent chapters devoted to them, but we take occasion here to say of the Intuitional Argumentwhich is not to be separately so dealt with-that it has by Professor Knight and others been more lucidly expounded of late years, though whether with the result of showing itself able to bear by itself all the strain sometimes put upon it, is a much more doubtful matter, even to those who may be disposed to grant, as we are, what a high criterion of truth such spiritual intuition is. It is a rather large order to ask us to surrender our knowledge of Deity wholly to an intuitional theism, even though we may feel the mystical attractiveness of the "wise passiveness" needful to this end. Recent theism has in its faith, as we think, been 
more clearly conscious of itself, through all, as no result of a logical process, but of the inward seal of the self-revealing God. For intuition implies direct beholding or vision of the truth, and, unlike reasoning, is an act rather than a process. This is that Schauen - vision or intuition - of which Krause loved to speak. It has no finer expression than the poet's lines :-

"As blind nestlings, unafraid, Stretch up wide-mouthed to every shade By which their downy dream is stirred, Taking it for the parent bird;

So when God's shadow, which is light, My wakening instincts falls across, Silent as sunbeams over moss, In my heart's nest half-conscious things Stir with a helpless sense of wings, Lift themselves up, and tremble long, With premonitions sweet of song."

The Intuitionalist position is so far clearly vindicated that the soul is seen to sustain a closer cognitive relation to Deity than should be implied in knowing Him merely by remote inference-as Dr W. L. Davidson would make it appear in his 'Theism'-even if its immediate-but not unmediated-consciousness of the Absolute be not without elements of vagueness and indefiniteness. No doubt, Dr Davidson asserts that the idea of God inevitably arises in man, but he does extremely little in the way of showing by psychological analysis that theism is really " grounded in human nature,' 
which it is his professed aim to show. He brings not out in its modern bearings and relations the significance of the fact that-

" Lebt' nicht in uns der Gottheit eig'ne Kraft, Wie könnte uns die göttliche entzücken."

"If in my soul dwelt not God's might, He ne'er could quicken me."

It has been by another truly enough noted that " if it be said that faith in God is never actually the result of reasoning, it may be replied that, as matter of fact, such faith usually comes by instruction, and is verified by reasoning; not to insist that there are implicit, unconscious acts of reasoning, in which some of the steps are left out." Hence it is no marvel that recent theistic philosophy has more trustfully turned to that vague and somewhat illdefined yet real spiritual faculty in man, termed the God-consciousness-in virtue of which we have the secret presage of the Infinite-for its certification of the Being of God, Who is increasingly verified to the soul through this God-recognising faculty as $\mathrm{He}$ comes through the revelation that is in Christ. Yes, for as one of strong reflective power has in our time said, "the passionate religious tendency is not a sentiment fluttering round a fancy, but is a feeling rooted deep in the structure and mechanism of consciousness." There can be no doubt that, with more fruitful result, rational reflection has been exercised on such content of the Christian con- 
sciousness as is given us in our intuitive perception or primal mysterious notion of God, so that, our idea of God having received explication, development, and adjustment, God has become better known to us as the Absolute Personality. And, as Professor J. S. Banks has said, "The fact that intuitive truths are involved in the proof, and that we so seldom need to examine the grounds of our faith, is perhaps the reason why the conclusion has come to be regarded as itself belonging to this class." God is to be less thought of as the Infinite, in any sense that would imply that $\mathrm{He}$ is an empty abstraction or such an indeterminate Being as Pantheism has made $\mathrm{Him}$, and is to be regarded more as the Infinite in the sense of the Absolute Being, the Unconditioned Source of all existence. "In real knowledge, Theism and it alone enables us to comprehend the multitude of individuals in a system in which we find at once the unity of thought and the unity of being, and thus solve the ultimate and inevitable problem of the Reason. It builds on the knowledge of determinate beings; not on-

' Intuitions, grasps of guess,

That pull the more into the less,

Making the finite comprehend Infinity.' "

Nay more, God is to be conceived as, in $\mathrm{His}$ Divine Essence, the positive fulness and perfection of all goodness and truth-the one infinitely perfect Being in virtue of the internal interdepend- 
ence and unity of His attributes. No sesquipedalian negations are the attributes of the Deity Whose Divine self-revelation has made Him thus known to us. It is no disparagement of metaphysics to say that recent philosophy of theism has laid its stress, in treating of the Triune Being, in terms that savour of life and personality rather than of being. Its God is a positive and infinite Personality, and not a mere aggregate of attributes. Its completely ethicised Deity, as it seeks to expound the Godhead, mitigates, as Principal Fairbairn puts the matter, the gravest of the initial difficulties of theism-a mitigation which, though no more than a mitigation, represents a great gain to thought. Not only have the proofs for the Being of God been viewed more helpfully and suggestively in their organic relation, but, as we must also note, have been of late more adequately recognised at least, if not actually treated, on the historic side. This line of treatment, whereby they have been examined in the light of their genesis and development, and of the historic evidence which they furnish of the persistent endeavour of the race to grasp and explain the transcendent reality - the notion of which they embody-has already borne fruit, and yielded much philosophical promise, from its study of the arguments as they thetically appear in the course of history. More or less historic approaches have, it may be remarked, without going back upon the labours in this line of Bobba, Bouchitté, and 
earlier workers, been made in late years by Dorner, Pfleiderer, Dr Stirling, Professor Flint, and others, both in Germany and Britain.

There can be no doubt that recent philosophy of theism has acutely felt the difficulty of working its way through the selva oscura of reconciling evil with the goodness and power of God, especially in the light of the contradictions of actual experience. It has noted how absurd often are the pessimistic expectations from Omnipotence. It has, as we think, more carefully discriminated existent suffering, however, from the intentional plan and law of organic being, and has more forcefully exhibited the rational and moral grounds on which the permissive agency of evil can be conceived as perfectly consonant with an entirely benevolent Deity. We are bold enough to claim that, to the most clear-sighted thought of recent years, the suffering, which painfully obtrudes itself everywhere in the world, has yet been allowed to obscure the goodness, and to strain our belief in the beneficence, of the Deity, to so needless and unwarrantable extent, that these sufferings have made this become to us no more a world in which "thorns are mixed with flowers."

\section{"Diffugimus visu exsangues, illi agmine certo Laocoonta petunt."}

We have, in consequence, a state of things, as regards the race alike of animals and of men, that may well serve to remind us of the dread 
smitings and death agonies of which the 'Iliad' spake-

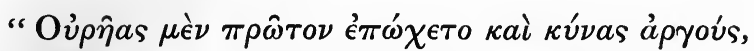

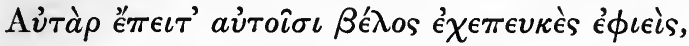

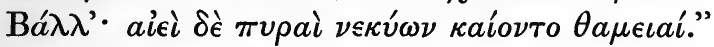

"First attacked he the mules and the swift dogs, but afterwards despatching a piercing arrow against themselves [Greeks], he smote them, and thick funeral-piles of dead were continually burning." But there are facts of new life and beauty, of rest and progress, no less than those of destruction and decay, and these we must carefully consider, even in aspects and relations that may not be fully known to us, before we give way to a materialistic mode of interpreting the world as charnel-house. Have not the life struggles, in which the animal world has seemed to revel, been seen to have been overdone, in their having been contemplated, quite frequently, with an almost morbid sensitiveness, in the light of our own higher, more painful experiences, until resultant perfection was lost sight of, and judgment remained no more clear, nor thinking robust? Has not the time come to ask with the poet-

"Who knows but that the darkness is in man?"

Has it not been more open to observation what an immense proportion of the sufferings of life man himself may, if he will, prevent or avert, and furthermore, what a large purpose the residue 
of real suffering serves in the way it ministers to man's moral growth, his secular knowledge, and his spiritual advancement? The sensitiveness of animals to pain is far less than it has often been pessimistically pictured, and the real pain experienced by man is chiefly due to his being a personality, capable of looking before, after, and upward. It is time to note how suffering really leads man to a knowledge of the way in which God cosmically manifests Himself; to recall how the evils of our world-system are such simply as possibilities, the actual result resting with man himself; and to heed the poet's word-

"Doubt no longer that the Highest is the wisest and the best;

Let not all that saddens Nature blight thy hope or break thy rest."

Even a Rousseau was able clearly to perceive how little these physical evils would mean for us but for our moral evils and shortcomings.

It is very possible that theistic philosophy may have sometimes seemed insufficiently to reckon with the suffering and pain of the world; but, even if this casual effect be not disallowed, it must still be undoubtedly held that recent theistic thought has made noteworthy advance towards a sounder adjustment of modern modes of viewing the conflicting moral attributes involved. A gratifying result of the way in which in man's narrow

" circle of experience burns

The central truth, Power, Wisdom, Goodness-God." 
It has, too, in the outlook on the progressiveness of nature which, amid the pain and suffering of the world, evolution has given it, more clearly seen that the difficulties which seem to exist in creation are being gradually surmounted-

"For the loving worm within its clod

Were diviner than a loveless god Amid his worlds."

This is quite compatible with our contention that the philosophy of theism to-day perfectly appreciates the difficulties of reconciling such a world as ours with the fact of a Perfect Being for its Creator, and of maintaining our freedom from the world-woe (Welt-Schmerz) whose melancholy contagion has caught and clouded so many noble spirits of our time. Yes, it would be strange if it had been otherwise-if, that is to say, it had not so entered into the divine meaning of the German poet's lines-

"Wie nie sein Brod mit Thränen ass,

Wie nie die kummervollen Nächte

Auf seinem Bette weinend sass,

Der kennt Euch nicht, Ihr himmlischen Mächte."

For though Pessimism may not provide our restingplace, it is impossible in this world of mania and monstrosity, of frustration and fatuity, of misery and microbe, not to see how much of the truth it carries with it. And we, for our part, do not think the pessimistic factors grow less or fewer as one deepens his study of men and of institutions of 
every sort. We do not believe that, when we have, with Dr E. Pfleiderer, charged home the pessimistic trends of thought on the indolent eudæmonism of the age, we have done anything like full justice to the facts, or said all that is to be said. However, we pass from that. Though we cannot forget that the physical universe " has fixed, unaltering laws, we cannot help seeing God's hand in events. Whatever happens, we think of as His mercies, His kindness; or $\mathrm{His}$ visitations and $\mathrm{His}$ chastisements ; everything comes to us from His love." We believe that a patient study of all that can be philosophically advanced in its favour will tend to modify our view of what might otherwise seem the extravagant optimism in which rested that most distinguished Italian thinker, Rosmini, who in his 'Teodicea' maintains that this world is the sole one worthy of the goodness of God (degno della somma bontà and il solo possibile are his expressions, $\S 65 \mathrm{I}$ ). And yet it would be a hard thing to agree to Rosmini's restrictions on the Divine possibilities and freedom.

It is in the love which is in God that the springs of possibility for objective reality must be taken to lie. Precisely in the lack of such altruistic power is the shortcoming of pantheism seen. Theistic philosophy has been content to claim the working of the world, on the melioristic theory of an "increasing purpose," as good in relation to the end for which it has been destined. It forgets not that, imperfect our world may be, and yet be thoroughly suited to 
the purposes for which it has been ordered. No more does it forget the saying of Strauss that a true philosophy must naturally be optimistic, or it cuts away the branch on which it sits. The last word is yet very far from having been spoken by philosophy as to why a world, grounded in the Absolute, is not perfect; but at least it has given a less uncertain sound as to the unsatisfactoriness of Hegelianism in its mode of dealing with the opposite of Absolute Being, and its making opposites pass-as in this system they do-into each other. Christian theism has been satisfied with such tranquillity of soul as Christianity brings as its gift in virtue of its chastened optimism, which does not tend to an always greater flatness, but sees all things work together for good only through suffering being turned into sacred joy, loss into spiritual gain, misery into interior happiness, pain into priceless power. This it is which has averted for it the otherwise inevitable seeming that earth is

\section{"darkness at the core}

And dust and ashes all that is,"

even while it has felt the impossibility of theoretic demonstration of its optimism. Yes, for, however it may be with the theist, it is impossible for the Christian theist to find rest in pessimism. That mental disorder is, according to Max Nordau, one of the philosophic forms of ego-mania, and certainly the pessimist is prone to project his own dark shadow on the world. 


\section{I34 THE BEING AND ATTRIBUTES OF GOD.}

We are not, for our part, disposed to admit that the religious mind in its best outgoing will be content to rest in the equally real ego-mania of any shallow, visionary, airy optimism. It is the glory of Schopenhauer to have made any Leibnitzian, happy-go-lucky optimism impossible for us. His also has been the folly to set the entry of reason and order so late in the world's day as to reduce earth to a reign of irrationality and caprice, and his the mistake to confound being with evil. We admit the service he has done in laying stress on the individual or finite existence as part of the will to live, even while we share neither his apotheosis of selfishness nor his hostility to a really rational religion. Such disciples of his as Bahnsen and Deussen have not failed, with certain divergences, to maintain the dark hues of their master, as has also Frauenstädt, who has affinities with Hartmann likewise. Nor has anything been lacking to the thoroughness of the unreasoned Pessimism of the Italian poet Leopardi, who has told us-

"Our life is valueless; for it consists Of nought but ennui, bitterness, and pain. This world of clay deserveth not a sigh!

Now calm thyself; conceive thy last despair, And wait for Death, the only gift of Fate."

There never were stronger temptations than in this time for men to cry, as Shakespeare's sonnet has it-

"Tir'd with all these, for restful death I cry." 
It is something that theistic philosophy will no more under-estimate the power of evil, the misery of man's will, and the force of the struggle by which the godless world shall be overcome, in the teleological movement by which all things conspire towards the good. The reality of evil has been very seriously faced by it, but without any giving way to absolute and Parsee-like dualism, in which the unity of being shall be violently rent and broken. It does not forget how the pain and anguish, the fret and unrest, of life had been already declared by Kant, Fichte, and Schelling. It has profoundly felt how paradoxical the power and goodness of God must appear in view of so much natural evil as this world of ours presents, causing the escape from a despairing Pessimism to be now no longer easy. Yes, for it is bound to admit, as we hold, even the possibility of the evolutionist argument being inverted in the pessimistic interest, and the progress of the world held, not without show of reason, to be at last swept away. Then, from the cheerless summit of our thought, we should find to be ours the vision of the poet who sang-

"Worlds on worlds are rolling ever

From creation to decay,

Like the bubbles on a river,

Flashing, bursting, borne away."

It has, however, in its philosophy of evil, laid less stress on the results or effects than on the principle of evil. And, if the Pessimism of the time has not 
been able to shun a certain morbid sensitiveness in its contemplation of such natural evils, our philosophy of theism has, in more calm and frank manner, acknowledged how far it can accompany the pessimistic philosopher, and has proceeded to point out, as far and as effectively as its partial knowledge will permit, how many are the compensations and how weighty are the reasons that may be adduced to justify the permissive agency of evil. We say how far it can accompany the pessimist philosopher, for it surely never entered more deeply than now into the spirit that says-

"Up from Earth's Centre through the Seventh Gate I rose, and on the Throne of Saturn sate, And many a knot unravell'd by the Road;

But not the Master-Knot of Human Fate.

There was the Door to which I found no Key; There was the Veil through which I might not see:

Some little talk awhile of $\mathrm{Me}$ and Thee

There was-and then no more of Thee and Me.

Earth could not answer; nor the Seas that mourn In flowing purple, of their Lord forlorn;

Nor rolling Heaven with all his Signs revealed And hidden by the sleeve of Night and Morn."

No vaunted enlightenments of our time have been able to silence-only to deepen-the despairing sounds of a creation that groans and travails in pain, ever crying, How long, O Lord, how long! But we have also said that there are compensations, balancings that make our short-sighted conclusions 
not very safe or sure. And while Pessimism is not the last term in our message to men, it will have a place there to the end. Yes, and that because we are spiritual, and spiritually idealist.

Our theism has recalled, with a modern poet, how true it is of Nature that, despite these opposing facts and pessimistic moods-

"She sees with clearer eyes than ours

The good of suffering born,

The hearts that blossom like her flowers,

And ripen like her corn."

It has more forcefully, we think, set forth, for example, the beneficent purposes subserved by pain and suffering in the world as a safeguard, a stimulant, and a cement of mutual sympathy. It has been to it no Jesuitical task to set forth suffering as, in fact, a really necessary condition of, and a powerful incentive to, all higher growth, in which growth and exercise of our moral powers our true satisfaction is found. For, with Goethe, it says that-

"Was im Leben uns verdriesst. Man im Bilde gern geniesst."

But, however true these things may be, no true philosophy of theism will construe them into the unreality of evil. Nor will it interpret evil as simply good in the making or in the training, but will hold to the reality of evil so that this last shall be for it something that must be overthrown or cancelled. It will see, too, how needless it is to 
confound evil with imperfection and development, how unnecessary evil is to being that is relative, though there be those who do not so view the matter. All that our relativity ought to be made to bear is the mere tendency, proneness, liability to evil. Our imperfection, metaphysically taken, is, as Biedermann has said, evil in a sense which essentially belongs to the finite universe: "a universe without it is no longer a universe distinct from God, but would be nothing but the universe taken back again into the absolute being of God." But to treat evil as simply the pressure of our own finitude is surely to come far short of probing the problem of evil, with its issues of profound moral significance, for these moral aspects do not permit us to rest in evil as simply inevitable. So to rest would not be theodicy enough to satisfy any worthy theistic philosophy. Recent theistic philosophy has not relaxed its grasp on the clue to understanding the presence and possibility of moral evil, which is found in those facts that must be saved-the facts of freedom and true moral responsibility, the former of which carries of necessity for us a liability to evil. It thus very clearly sees how moral action, with the optional character it implies, is, as Rothe finely pointed out, constituted by our own self-determination. It recognises how infinitely superior, even with its implied possibility of evil or moral transgression, is a system of freedom to any system of automatism or mechanicalism, so that it is no 
ground for wonder if God did not care to reign over a kingdom merely of this latter sort. It perceives how luminous the problem of moral evil grows as a truly ethical theism views it in the light of its relation to the element of choice and to the free causality of man, whose freedom Deity must conserve to the highest possible spiritual ends. It holds, with Busse, that freedom justifies the existence of moral evil, since freedom without the possibility of evil is not thinkable, and merit and dignity are without it not possible. It must, of course, take cognisance of the fact that only in virtue of that mutability in us, which brings in its train liability to evil, exists the contingency of freewill in us any more than in the freedom of the Absolute. No true philosophy of theism must fail to observe how our action grows morally evil because of the fact that we reject the ideal good which is yet the law of our being, and choose to drop into a lower than our normal orbit. But this is not to say that it regards our evil as only shortcoming in respect of such ideal, or as mere mistaken course, and not also spiritual disorder seen in the form of real rebellion against the personal will of the Lord of life.

No; evil is real, and good is real, but it is the good which we identify with the Absolute Being Who is Ground of all things. Yes, for otherwise the ideal or better self in us would be more inexplicable to us than the mystery of evil itself. 
The ethical verdict against moral evil sounds on in the soul of man for ever. Out of our evil God may, no doubt, bring good; but evil is never, on that account, of itself contributory to good. It would be absurd to account it so. Our theistic philosophy can give it no necessary place in the plan and purpose of God: it is, as disobedience to the law of God and our own spiritual being, only evil and that continually. It holds this to be so, no matter how God our Saviour, Merciful and Almighty, may permit and overrule it for good. It asks, too, how we could ever think of that Primal Reality which called us into being, and made love the supreme law of our life, as Itself unloving, or other than Perfect Goodness. It says with Whittier, in his "Eternal Goodness"-

"Yet, in the maddening maze of things,

And tossed by storm and flood, To one fixed stake my spirit clings,

I know that God is good."

From all which it must surely be evident how little disposition has been shown by recent philosophy of theism to leave the problem of evil aside as a mere unsolvable and unfruitful inquiry, though it has a clearer sense, no doubt, that the final judgment must, in such a problem, be a teleological one. Meanwhile, the world is for it so far from a meaningless thing that "it means intensely, and means good." Yes, and if we cannot at present speculatively solve all the difficulties of 
the case, that is only because here we know but in part. But we know enough to give us refuge from pessimistic despair, and inspire us with such a faith in the future as will at least make it for us no longer impossible that the pessimist's view of the facts of life and the world should not be the only true or possible one. To us all the issues and ends of the present so run up into the future life that the speculative terminus for our problem may not be capable of being finally reached. But in our latest philosophy of theism we find deeper cause for holding fast the confidence that the facts presented by physical nature need not, and ought not, to overbear the suggestions of conscience, of revelation, and of our own hearts, which bid us believe that all things work together for our good. 


\section{CHAPTER VI.}

RECENT STUDY OF THE COSMOLOGICAL PROOF.

ThE Cosmological Proof has, in recent theistic thought, had its true significance more acutely determined, and the reasons for its miscarriage more carefully defined. We regard the course of recent speculation as tending to prove the wisdom with which Mansel spoke when he declared the principle of causality to have been, and likely always to be, the battle-ground on which philosophy must fight for dear life in the struggle with scepticism. We do not think there can be any doubt of the real philosophical advances made in the sphere of causality - the progress in interpreting natural law or the observed order of Divine Action, and in laying down the logic of scientific thought or conception. In fact, the continuity traceable in the philosophical development is quite impressive. The self-evident character of the principle of causation has been properly insisted upon, and the metaphysic of causality has 
been more profoundly investigated with a view to the bearing on theistic thought of substance as the ground of phenomena. Not a mere foundation of being in the abstract does it seem in our view to have sought, but a real, actually existing, primitive ground (Urgrund) of all reality. The law itself has received more careful enunciation as having for its terms that every event - not effect-must have a cause. The validity of the law has been more strongly vindicated alike as against those who, with Sir William Hamilton, gratuitously assume-in oversight of the positive character of its thought-affirmation-the law to be due to the impotence of the mind to transcend experience, and in opposition to those who, like J. S. Mill and others, have taken it to express only a time-relation or observed order of succession, so failing to keep in view the active power or efficient energy involved in relation to a real result. The causal problem is to be viewed as very different from any method of proof that makes the Divine existence a postulate-lacking therefore in sure basis - for the proof from causality grounds itself on given facts, and follows the actual lines which causality leads, be they up from individual facts to the universal order and history of the world. The law is seen to be bound up in the bundle of fundamental knowledge in the sphere of science. The causal-and dynamical-power involved is discriminated as work- 
ing through all Nature, not as resident in its single objects, and the antecedents brought into play are differentiated as the conditions, but not the real causes, of the results. The actual world is taken to be but a perceptible unfolding, an appearance (Erscheinung), of the Urgrund or Primal Ground, but not for that reason unreal. With the world, in which $\mathrm{He}$ exhibits or represents Himself to us, $\mathrm{He}$ is, of course, not to be confounded.

The artificiality of our whole phenomenal sequence has been thoroughly laid bare before our evolutional science, with its correlation and convertibility of forces. The inadequacy of any scientific interpretation of phenomena, and the impossibility of any philosophical explanation, have been irrefragably shown to be the result, so long as power, creative or formative, is excluded from our notion of causation. Hence the absurd and meaningless aspect of cause when taken simply to signify antecedents, rather than the relation of phenomena to that which is real. The sheer impotence of science to do anything more for us than take us to the succession of antecedents and consequents cannot be too plainly expressed, and metaphysics must come to the rescue, if the idea of cause is really to be understood at all. While she tarries-

"Philosophy, that leaned on heaven before, Sinks to her second cause, and is no more."

Power, and not mere antecedence, is what the meta- 
physical idea of cause proclaims, and even from the scientific side recent writers like Le Conte have held to our consciousness of will-power as the source of the idea of causality rather than trace it to observations of external sequences. It has become always more evident that the transition of the Causal Argument to what, by a self-contradictory phrase, is designated a First Cause- $\dot{a} \pi \lambda \hat{\omega} s$ or absolutely taken-is impossible, since it is an arbitrary procedure to stop at any point in the endless regress of finite causes, and make an unknown leap of speculative reason. Theistic thought has seen how the very notion of causation itself, with which, in the plexus of causes and effects in the universe, the reasoning began, is at length summarily dismissed, and that, too, without an infinite and necessary Being having been reached. There is, of course, nothing absurd in the conception of a First Cause, in the relative sense merely of God's being First Cause of the world-process, for the notion of becoming or coming into being would in the case of so remote and ultimate a presupposition as God -a case so different from that of the phenomenal world-be a simply inane and inapplicable inquiry. We have no right to think, as do Spencer and others, that the causal axiom can be deduced, in respect of the sequences here involved, from the law of conservation of energy, in forgetfulness of the qualitative differences that may remain among phenomena amid sameness of quantity of energy. 
We do not, however, in saying this, mean to deny to laws of conservation a real importance for the scientific interpretation of causation, expressive as they are of nature's uniformity. The repugnant character of the philosophical theories of causality of Hume, Kant, and Mill, in the view of reason, has been plainly expressed by George John Romanes, when, in his 'Thoughts on Religion,' he objects to their running counter to the very objectivity in the relation of cause and effect which all physical science is trying to discover.

We have come to recognise how Kant is not to be thought of as always viewing causation in a single consistent sense, for consistency has clearly not been to him a jewel here: to Mill it was matter of indifference whether cause and effect be synchronous or successive, while to Kant their simultaneity was in some degree evident. But recent philosophy of theism has not otherwise than more severely treated the Kantian conception of causal law-when taken as mere phenomenal sequence or order in time-as lacking in genuineness, and has more decisively repelled the Kantian doubt of the objective validity of this form of thought as utterly subversive of all knowledge. Not that we are without need of return to-day upon the Kantian positions, that influences from Lotze, Mill, Comte, and Herbart may be rectified, though it is to be claimed that large advances have, in matters of detail, been made since Kant. Such 
need there is, for philosophic rationalism haswith all that is praiseworthy in its method-come short in not keeping its study of natural process in constant touch with experience. We certainly take Kant to have made philosophical advance on Leibnitz by his hypothesis of synthetic knowledge $a$ priori in place of purely analytic mind function, as he also did upon Hume in getting rid of that thinker's scepticism, and making causation necessary in a way it could never be for the pure experientialist. What has been seriously charged as defect in Mill and Spencer has been their not seeking for the element that lies, in the causal connection, beyond given experience, a logical no less than a psychological justification.

Certainly we have with us that denial of causation which, in the interests of a pure phenomenalism, insists that things as they are do not correspond with things as they appear to us, and which sets aside the law of our thought from being also a law of things, but it has not gone without having had the arbitrary and unwarrantable nature of the position it takes up-in discrediting our knowledgelaid bare. Well might it be so; for what greater progress has philosophical thought made than towards establishing the principle that the secret and ground of our knowing (ratio cognoscendi) is just real being (ratio essendi) - in other words, that all true knowing is fundamentally knowledge 
of real being? Wundt has said that high as experience may be rated by our natural science, not a few physicists hold that, in our knowledge of nature, certain a priori elements-particularly the principle of causality - are actively concerned. Jevons, among others, has expressed a contrary conviction for himself. We take it to have been more clearly apprehended by recent philosophy of theism that, whether, from a psychological point of view, we accept such a theory as that either of Maine de Biran or of Hume-whether we root the belief in causation in volitional experiences or ground it merely in observed external sequences - the important fact abides that the causal law is to be maintained as a necessary postulate of science, one, too, confirmed by experience, even though the logical possibility of departure from it cannot be put away. The way of escape from this logical possibility which has been sought in some of the most competent German thought of recent years, has lain in Kantian "apriorism." When such "apriorism" is held not to mark out the causal relation or connection, even as to its form, apart from an appeal to experience, it is obvious that a serious obstacle to the acceptance of the Kantian position is removed. But the need of a psychological basis to such "apriorism," no less than to experientialism, has not always been duly recognised. The eternity of matter, it may be here said, is clearly seen to be no necessary postulate of the cosmos. An eternal 
spirit-factor is that which must be taken as really necessary. The origin of the universe lies beyond itself: The whole tendency and direction of recent science and thought have been towards discrediting the view of the eternity of the universe-its eternal succession or mere ceaseless transformations, as some have supposed, on really slender warrant. It has, no doubt, been more pointedly urged that personal being at the end of the series of things or events is an illegitimate displacement or unwarranted substitution - that the argument, in fact, does not suffice to set up the personality of the self-existent First Cause ; and this is to be freely granted. And it has been more explicitly shown that an infinite Being, who is a' $\rho \chi \eta^{\prime}$ or causa sui, cannot be reached by this process of merely negativing the finite.

Besides all which it has come to be more correctly understood than in the days of Hobbes, Locke, Clarke, Grotius, Leibnitz, Wolff, and Cousin, that this First Cause, even when reached, was but an external Creator or Prime Mover, not the everpresent Governor of all things, and the ever-active World-Ground. Among post-Kantian views that of Herbart was perhaps too strongly rationalist, reducing the causal connection to forms of strictly logical thought. Nor can the metaphysic of Lotze be here viewed as intellectually satisfying, for, in his limited rationalism, his metaphysical comprehension of what is given finds less favour in our eyes as it grows evident that it acquires new ideas only as it re- 
cedes from rationalist and stays itself upon positivist thought. In fact, it does not seem open to doubt that such departure, without sufficient motivation, from rationalist direction to that which is positivist, constitutes the weakness of Lotze. The weakness of Lotze's grasp on Will or outgoing causal energy is at once apparent if we turn, say, to Ulrici, who relates finite existences, in a more satisfactory way, to absolute and creative energy than does Lotze with his whole-and-part method. Dr Martineau has powerfully shown how the notion of cause means always more than the sensationalist notion of mere relation-the uniform time-relation of Hume, Mill, and Bain,-among phenomena; means, in fact, the presence of efficient power or force, the notion of which "cannot be served with a writ of ejectment," but is retained by the human mind in its idea of cause in the most natural and instinctive manner.

The rigour of the Leibnitzian rationalism was relaxed under Wolff's more explicit appeal to experience, and under the co-ordination of Crusius of the real ground with the ideal. It remained, of course, for Kant to reduce philosophical rationalism still further by setting out the causal connection, even as to its form, as given in experience. That the causal relation is a necessary one is simply an a priori affirmation contributed by the mind above and beyond such experience. What is here a priori is merely the inner constraint by which the causal 
order becomes converted into a necessary relation or connection. Strictly taken, this argument from the notion of causation, inadequate to bring us to such an origin of the creation as is postulated by Christian Theism, is in its idea unable to expound creation for us in any spiritual and worthy sense. It is surely a thing to be clearly now recognised that the absolutely necessary being of this argument is a thing of many possibilities-a dim Spencerian Unknowable, for instance, or the world itself taken in its totality-so long as this proof remains unconnected with the ontological argument. Connected with the ontological argument it must thus become, since the conception of a being in whom all and real existence are found can alone be held to determine that of a necessary being. We dare to claim, however, in saying so much, a great advance in our possibilities of thought to-day over those of Kant, who restricted causality to sensible phenomena, maintaining the impossibility of founding any argument from a principle which, with him, did not hold "except in relation to the world of sense," for a world that shall lie, as he puts it, "beyond the world of sense." When Kant restricts the validity of the principle of causality to the sensuous world, he overlooks how synthetic thought is of itself, and how unwarranted is his denial of every sort of causality save that only which finds play within the range of experience. For our thought is not now content without piercing behind and beneath 
these sensible phenomena, until it reach, in fact, infinite spirit as the one underlying Reality, the ultimate Ground of these sense-phenomena. The spiritual character of the infinite and all-causing Force is thus brought into view - a constitutive mark of the conception of God. When we enter thus into the realm of spirit, purely physical and mechanical categories cannot have place, and so the Cosmological Argument does not set them to do metaphysical-and for them impossible-feats. These categories are real and valid so far as they go, but they are not yet the highest categories open to us, and the philosophy of theism rejects as groundless the Kantian supposition that principles are to be treated as only subjective, because they happen to transcend the sensuous sphere. It has left behind the obviously absurd mode of trying to think the Absolute as we would one of that very world-series of contingent things for which a basis other than themselves is just the thing sought. No more is our thought denied, with Kant, from extending the causal relation to the universe, taken in whole; its stand-still to-day is reached rather in trying to find a point in time when this whole comes into view as an effect-a feat only abstractly possible to us. What is not only possible, but real and necessary to our thought to-day, is such an extra-mundane Cause or World-Ground as Kant, in his strivings against an external World-Maker, never knew. Kant, however, did feel the inevit- 
able character of the question as to the Source (Ursprung) of the Unconditioned. A Primal Cause (Ursache) beyond itself-and not the mere being of the world itself - the world must have, for, as finite world, it cannot be its own ground, and cannot be the cause of spirit. This material want and ő $\rho \xi \xi$ ıs we find fulfilled only in God, as ultimate Source and Sustainer of the finite creation, which rests on the bosom, we may say, of the Divine Potentiality. It is an inexorable law of thought that such finite and dependent being should have Being that is Absolute as its basis and correlate. The law of causation leaves the whole realm of spontaneity which overlies the physical sphere, in the view of theistic philosophy, untouched, for that philosophy has been as far as possible from admitting the law of causation to be universal in its application.

The philosophy of theism to-day is not without a consciousness of the difficulty of our conceiving a Being, taken as really perfect and all-sufficing, becoming an active Cause at all. Such an absolute cause explains nothing for us, for if anything we can possibly think of should cause this Absolute First Cause to act as cause, it should-in being so compelled-cease to be First Cause. Nor has there been wanting to recent philosophic thought a clear consciousness of the impossibility of our explaining the way in which causal action works or comes into force. It has had to be content 
to accept the unquestionable fact of efficient causation, and to postulate, on behalf alike of the religious and the philosophical consciousnessas the ultimate Ground or immanent Cause of the world-an Infinite Spirit Whose Will is supreme.

We have seen it lately said that there is clamant need for exposition of the genesis of the causal idea, that its nature and jurisdiction may be better determined. We shall welcome the exposition when it comes, but it is meantime better to know and realise what has been actually done. It is well to remember that the causal principle does not thus depend on its origin for its place of importance to-day, but on its necessity and value as a postulate of science-one, too, which no experiential test has overthrown. We cannot allow easy and vague groping after desiderata to hamper our appreciation of recent and fine attempts at analysis of the idea of causality, here and in America, or of masterly endeavours in Germany to exhibit both the genesis and historical development of the Causalbegriff. Let mention of such work as that of Dr Koenig for the present suffice as an example. Kant, while remarking the incompleteness of the cosmological argument without dependence on the ontological, failed to recognise what, we believe, theistic philosophy is now trying to do, that the cosmological proof is just an objective mode of asserting such identity between the idea of God and that of primal or 
self-existent being as we find, subjectively, in the ontological proof. The idea of causality, no doubt, is one which enters into the conception of God as Author of the worlds, but the Christian conception of God has of late been better recognised to be ill served by having stress laid upon the principle of causation. For when the element of mind, self-conscious mind, in the universe is taken into account, the First Cause we seek must be an intelligent, a self-conscious one. Not as inferred from causal sequences, but as a necessary postulate of thought and an ultimate principle of reason, do we present the Divine Existence. And we present it as that of an Infinite Personality, for rationality is so involved in the phenomena that we can do no otherwise. Destructive of all knowledge whatsoever must remain every attempt to refute or discredit consciousness, on which knowledge still must rest. Hence it will be seen how the Causal Argument leads us up the path that conducts towards the proof of personality -a self-existent some One, not merely something. Can we blame reason if, dissatisfied with a Primal Cause, which should be only abstract and unreal and finding its own existence unaccountable, it posits something rational in the First Cause? But it should be said that it has been always more lucidly made manifest in recent thought that, in reaching the Uncaused Cause, which this argument essays to reach, the value of the principle 
used is not enhanced, since it becomes at length really superseded and dispensed with. For instead of the ordinary law of cause and effect as found among things finite, we pass upward to the universe as an expression of the Will of that God Who, as the Infinite Spirit, is its immanent Ground.

Recent philosophical theism, it must be said, not sharing the attitude of Mansel, has regarded the Deity as Absolute Reason and Infinite Spirit, Whose infinite power is spiritual and potential. It must here be observed how persistently recent philosophical theism has felt dissatisfied with judgment of the causal argument founded simply on laws of the syllogism, and has maintained a conviction that not all involved in the principle of causation finds explication in the logical process. As we have had occasion to remark elsewhere, theistic thought has not discovered any invalidity in the synthetic movement whereby thought seeks a unity -for such the Urgrund or primal cause must be, though not a unity without quality or difference - to which the finite and the contingent may be referred. For, an infinite series of dependent existences or things is, at least in the theistic and philosophical sense, however it may be in the scientific, unthinkable, and for such a series, and for the universe taken in whole, an independent and self-existent Cause or Ground must be postulated. This holds true for any stage in the regress of antecedents-to posit any one of which 
as the primal link or beginning is illogical-since such cause stands as the noumenal to the phenomenal. Professor Minto endeavours to show, when dealing with Mill's definition of cause as the sum-total of all things, that the term cause is always used in one and the same sense. But it may be both necessary and advisable to discriminate between cause, as here, in a scientific and a philosophical sense. Both in treating a selfexistent cause and an infinite regress of causes as alternatives, and-still more-in putting nature, as an effect whose cause is God, on apparently the same level as any ordinary event, which is the effect of some other like occurrence, we are compelled to think Professor Flint less cogent in reasoning and less successful in issue than is usual with that distinguished theologian. It would be hard to find any proper warrant for thus assuming that to hold good of the relation of phenomena, when viewed in their totality, to an external cause or source, which happens to hold good in the case of phenomena which are finite and interdependent. Nor can we find any great conclusiveness in the way it is sought to find by examination an absolute beginning for the universe, in such a scientific age as ours, by reasoning back from mere individual effects or objects, or even from supposititious states of the universe that end in pristine mist or ether. It is hardly to be expected that science should turn theist, and search for causes outside and be- 
yond the universe of things. It is only a higher and more philosophic science, than that which is commonly so designated, that will do so.

We are not saying that science may not bring forth a theism of its own, born of realistic contact with the actual universe, for we are by no means sure that discredit does not attach to the science of our time in having done so little in that direction. We are simply pointing out that science, commonly so called, is content to confine itself to the presentation of truths which it views as cosmical facts, and grounds in realism of its own. And it is still true too often of the tendencies of science that they

"Make Nature still encroach upon His plan, And shove Him off as far as e'er we can, Thrust some mechanic cause into His place, Or bind in matter and diffuse in space, Or, at one bound, o'erleaping all His laws, Make God man's image: man the final cause."

Dr James Croll, eminent in geological inquiry, has, in treating of the "philosophical basis of evolution," argued to a beginning of the world from the extreme difficulty, if not impossibility, of conceiving an infinite past regress, and theism is then called in by him to explain its determination.

Theistic philosophy has not shrunk from asking whether it may not infer, seeing that will is the one true cause, knowledge of which is ours, not only causation in God, the self-related causality, but also an Infinite Will as the necessary fundamental cause 
of all things. Only, it must be remembered in a way that has not always been done, that this will of ours, taken as type of Cause, operates $a b$ extra, and hence we may carry over the notion of First Cause to Deity in a way that may suggest a wrong notion of His working, or give a defective idea of His immanence.

We are inclined to think philosophical theism has been more distinctly perceiving how unfortunate are the physical associations of the notion of causation in a region where such spontaneous and creative power must be held to reign, as in the sphere of that ens realissimum, the Absolute Life. Hence it appears to us to have made a gain, in point of clearness, when it has more carefully differentiated its own philosophical view of cause or causation from the scientific idea of it, on which latter, reasonably enough from its own standpoint, the First Cause called God seems to be quite needlessly assumed. There can be no doubt that the science of our time, in its most thoughtful aspects, very truly apprehends the dualistic character of the causation principle, by which it is seen to mean, on the one hand, sequence, dependence, manifestation, and, on the other hand, to signify substance, continuity, a persistent dialectical core of being through all phenomenal changes. Nor have explicit endeavours been wanting to set forth-in Germany and elsewhere-the temporal aspects of the causal problem, also its view as the causality 
of relation, whereby the world is no infinite sum of isolated existences, and, once more, the lights in which it is seen, as involving energy of being. Why should we not see in this ultimate core of being, to which reference has just been made, that which our philosophic thought can connect with the immanent energy of the Absolute in a world like ours? Retaining, in the theistic sense, a true ultimate Ground or Cause, our thought has not been able to rest in the view of James Hinton, who, in the earliest and metaphysical part of his 'Philosophy and Religion,' disposes of the category of causality as " nothing real," but only "a form of thought," in fact, an "absolute nonentity," so putting the copestone on Kantian scepticism. There is for it no mistaking the imperial sway of the idea of causation, which, under the influence of modern science, has more than ever become inwrought in our experience as, in fact, an axiom of the reason, to which, we cannot doubt, justice - if not more than its due-has been done.

It has become more manifest that, if we would not treat our own thought-activity, our own consciousness, and the active subjects we ourselves are, as so many illusions, we must recognise causality as an objective law of the world. No logical demonstration of God was possible to the Causal Argument, but it is now more freely recognised what helpful ends it served in bringing into bold relief such matters as the insufficiency of the materialistic ex- 
planation, the dependence of the world, and the transcendence of the Deity. The law that dependent being demands Being, which shall be absolute, as its support and its correlate, is plainly seen to be an inexorable one in human thought, and no possibility here obtains of confounding the Primal Cause with nature itself. Kant ought to have seen that the Cosmological Argument is only an inference to the existence of a necessary Being, and he should not have piled the Ontological Argument in its a priori aspect upon the Cosmological proof in the way he has done. It is another and very different procedure, if the Cosmological Argument should turn, from the mere existence of its necessary Being, to the Ontological Argument, that this latter may make some determination of the nature of this Being as Infinite in its attributes, should such a Being exist. In the endless regress of the usual form of the argument, we reach an end of efficient forces in the physical realm, and therewith causation, as sharply distinguished from spontaneity, ceases, leaving the attempt-as ought to have been seen-to prove an Absolute Cause, abortive. But, since matter could not yield us a true Infinite, theistic philosophy, nowise disconcerted by such recent efforts as that of Professor Royce, in the direction of the rejection of the category of causality in the interests of idealistic thought, has turned to mind, in its unmeasured spontaneity, alike for the unity of the universe in 
the unity of Reason, and for the conception of supreme Personal Being and Potency, wherein to find rational satisfaction and repose.

It has, we may make passing remark here, perceived how thoroughly futile must remain any endeavour of modern thought to flee the category of causality. Hence its perception of what a chief, or, as the Germans say, Haupt problem in religion and philosophy causation really is, and hence its more adequate treatment of the causal problem-in Germany at least, where, as we have indicated, work of notable excellence has recently been done-from the historical and systematic side, with which, however, we are here less concerned than with the critical and speculative aspects. Not only the metaphysical side of the causal problem has, as in pre-Kantian days, received attention, but the theoretic problem, from the side of knowledge, has, in post-Kantian philosophy, received much more adequate treatment. For Professor Riehl the causality principle remains only a subjective one, a necessary postulate to thought, as it seems, for the working out of our experience problems, but not a law of objective Giltigkeit or validity. $\mathrm{He}$ distinguishes between the law of causality and the concept of causality, the former being to him valid only for appearances, the latter not being limited to appearances. The causal law, with him, gives form to our experience, and determines its universal form (allgemeine Form) for natural law. But his 
thought oscillates between positions somewhat akin to those of Kant, on the one hand, and to those of Spencer, on the other, with whom he subsumes the causal axiom under that of the conservation of energy, so that we have no thoroughgoing result. Among those who are more or less with Riehl in respect of the intellectual rise-the logical (as by Herbart) and not merely (as by Spencer and Mill) psychological justification - of the causal concept, are Lotze, Wundt, Hartmann, and Volkelt. Comte, and those who are to-day descended from him by intellectual generation, regard, in their antagonism to the intellectualist theory, the causal connection as logically without value and superfluous from the scientific side. Riehl stands with Trendelenburg, Herbart, Goering, Spencer, and others, who bring cause and effect into a relation of identity, and make the highest of natural laws entirely matters of course.

It would take a historico-critical survey, out of keeping with our present purpose, to show with what keenness the core of the causal concept has in recent philosophical development been sought in connection with the determination of the ontological significance of the concept of causality. Theistic philosophy has not, we come back to say, found any more reason why God should not exist through all the physical energies of that world-order whereby God phenomenally presents Himself to us, than why the spirit of man should not exist in 
controlling sway over his own physical powers, correlated as these are to the world-forces. In this necessary and natural rise to a Supreme Mind, in which the thought and force of the world harmoniously centre, as our mode of interpreting the phenomena of the universe, we seem to have an always increasing argument for the Being of God, as the free First Cause and the self-determining Will. "The causality of self-consciousness-the causality that creates and incessantly recreates in the light of its own Idea, and by the attraction of it as an ideal originating in the self-consciousness purelyis the only complete causality, because it is the only form of being that is free." This is, however, very far from the confinement or restriction of cause as something which subjectivism allows not beyond or without the sphere of subjective consciousness. Nor should it remain unsaid that the emphasis which has not been wanting on the significance of the volitional type of causation, as that with which we are in our own actual experience familiarised, has been justified by the needs of the time. Yes, even though we grant that the validity of the causal law may not be proved by such theories of its psychological origin as that, for example, of Maine de Biran-the "French Kant." George John Romanes has recently, in his "Thoughts on Religion,' given decided adhesion to the doctrine that all causation is volitional, "derived from that known mode of existence which alone gives us the 
notion of causality at all." The mystery of matter theistic thought may have still with it, but, as it has more fully studied the sway which finite mind exerts over it, it has cherished a more reasoned conviction that no limitations can by us be rationally placed on the relations of matter to Being that is infinitean infinite Personality. So that we feel justified in saying that recent theistic philosophy has, to much better purpose, kept in view the unfree nature and merely physical connection of such relations as those contained in the idea of cause and effect. It sees of how little advantage the desired external Prime Cause could here be. Such cause, if made manifest to us in the effect, would no longer be mere cause. Such cause, if not made manifest to us in the effect, remains without being known or understood. Because it may be doubted whether the causal phenomena of the world exhibit in any sufficiently intelligible manner the Divine objective activities, this doubt has driven some to rest more, by reason of such indeterminateness, in the ontological sphere.

Theistic philosophy has better remembered the fact that the world, as here, is to be referred to Personality, and not to metaphysical necessity. For this end it has held so firmly, spite of all scientific depreciation of metaphysic, to the principle of a Primal Force or Power, a Supreme Energy or Essence, in, of, and unto which all things are. It has not, we venture to think, felt 
under necessity to regard the Divine Causality as working in Creation according to any modern emanative theory and quantitative mode. It has, in fact, treated the world-as Christianised cosmology must do-as other than an effect, and has referred it in its ultimate principle to the selfdetermined action of the Supreme Will. It has thus postulated a Spiritual Absolute as the presupposition of natural causation and mechanism. And indeed we shall see, in a later chapter, in connection with the personality of God, how modern theological thought has been seeking to advance from the Divine Aseity, by which God is causa sui, and to retain for will a place as an essential moment in its conception of Deity. The truth, in our view, seems to be that our latest philosophy of theism has been gradually perceiving the value of the Cosmological Argument really to lie far less in any logical presentation of past or primal Cause than in its hold upon the mind's search for an ever-present Ground of all things, Whose self-determining causality conditions, from the centre of the cosmos outwards, every other cause. For it still abides true that, as the poet of the "Paradiso" says-

"The glory of Him who moveth everything

Doth penetrate the universe, and shine

In one part more and in another less."

"La gloria di Colui che tutto muove

Per l' universo penetra, e risplende

In una parte più, e meno altrove." 
May we not say that too long has theistic thought allowed the fact to be obscured that this argument from causality really shows what a witness to the spiritual may be found in the natural? May we not say that the real need of to-day is less a miraculous creation-as from the outside-of a world that was not, than a true and rational interpretation of the world which here and now is, with God in the midst of it? "Active eternally in the Trinitarian mode of His own glory, God also of $\mathrm{His}$ free Will becomes active by calling into existence temporal kingdoms, relative natures, and conditioned personalities. Finite existences presuppose the ground of finitude in the will of Infinite Being. Absolute freedom is unchangeably the condition of relative freedom; self-existing autonomy the condition unchangeably of the autonomy of the creature. Thus related, the infinite to the finite, as Christianity affirms and sound philosophy unavoidably postulates, the nature of God's activity ad extra necessarily transcends the province of logical analysis."

The philosophy of theism looks, therefore, upon the cosmos as the free and independent creation of One Who is unconditioned save by the laws and resources of His own personal Being-a very different connection, in point of quality, it must be said, from that of the mere category of causality. It finds not any ground of self-existence or true selfsufficiency in beings or things finite. "We are no 
more able to believe of cosmical substance than, for instance, of the sun, that it is per se a necessary eternal being; for this cosmical substance possesses no understanding; it is not spirit." And the appeal of the Cosmological Argument never came to us with more power than in its present craving for such an ultimate rationale of the world as is found in the transcendent activity of the Absolute-such an Absolute Ground as is found in God, the selfexistent Life and the Eternal Causality.

Hitherto we have been following the regressive movement of thought in the Causation Argument as usually set forth; but it is, as we think, of no small consequence to keep in view its forward or progressive aspect also, as that appears in theistic evolution. This forward aspect lies, as we take it, at the very basis of science, though science may not often take time so to think of it. As for the philosophy of theism, that must in our view remain inadequate, so long as it fails to reach forward to this synthetic view of the future of the world's being and development, in which teleologic development the creative energies of the Absolute Being are still that which grounds and rationalises all. Such a philosophy has manifestly overpassed the thought to which evolution yet remains the largest term in the realm of reality. Why should we restrict the causal principle to the actual, and not let it run out to the conceivable? Is our thought straitened in God and His Divine Potentialities? Is 
FORWARD ASPECT OF THE ARGUMENT. I69

all speculative flight of reason to be here restrained, and all the possible discounted because it does not narrow itself within the scope of the actual? Surely in this contingent world, where all is changing, transitory, and incessantly dissolving away, we might well bear more vivid sense of God as Ever-present Cause and Sustainer of Creation; and it is this swifter, more direct sense and vision of His everlasting power and working that the Cosmological Argument still brings to us. Him-God of gods and Potentate beyond all others-it reveals to us as the enduring but not impersonal Substance; in fact, as that Absolute Personality that lives and works in all things as their very soul and substance. 


\section{CHAPTER VII.}

RECENT LINES OF TELEOLOGICAL ADVANCE.

IT appears to us a decided theistic advance that the Eutaxiological Argument, drawn from the order and harmony of nature, as betokening plan and bespeaking intelligence, has had its relations and its serviceableness, as a preliminary to the Teleological proof, more exactly defined and more fully described, ere this latter in its turn sets out to seek the purposes subserved by such plan. In a vastly higher way it has been seen by the Eutaxiologist how, in the words of Dante-

\section{"Among themselves all things}

Have order; and from hence the form, which makes The universe resemble God."

\section{"Le cose tutte quante}

Hann 'ordine tra loro; e questo è forma, Che l' universo a Dio fa somigliante."

These twin arguments have better recognised each other as theistic allies, and have dwelt in larger unity. And as the strength of both these arguments, in their recent forms of presentation, has 
been drawn from the resources of modern science, so we cannot doubt that a yet fuller presentation of them will one day result from the more developed science of the future. Recent philosophy of theism has far more fully and frankly acknowledged the just ground of offence too often given formerly to minds of empirical turn by the uses to which final causes were put, and the arbitrary direction which such causes were made to give the Divine working and procedure. But the engrossing interest and attention which, through the progress of modern science, have been bestowed upon efficient causes have been leading to quite as unwarrantable an excess in the opposite direction, the result of which is seen in a defective appreciation of the purposes subserved by things viewed in the light of their constructive worth. This holds true although we agree with those who perfectly recognise the entirely changed aspect of the Paleyan argument from adaptations, when these adaptations are viewed in the light of their being issues of a process of evolution in time. Certainly Paley's facts belong to the case for evolution, and as belonging to this case and irradiated by this light they must be viewed. For this former method of proof falls within the sphere of things where the words of Schiller apply, that "assiduous Form can sometimes cause the massive truth of Matter to be forgotten." We cannot be allowed to detach the facts of adaptation from 


\section{I72 RECENT LINES OF TELEOLOGICAL ADVANCE.}

the main sweep of evolution, but must treat them as bound up in the one great bundle of evolutionary life. We must believe it the need of the philosophy of theism to-day to dismiss the idea of design to begin with, and to lead up whither the teachings of evolution may direct. We are far more inclined to think than some are that, so doing, we shall be led from study of conditions and ends to a recognition of designing Intelligence as the result. The defective view of those whose evolutionary teachings come short here is that which recent philosophy has been too little seeking to rectify, and, though we are here concerned with the results rather than with the reasons and processes of its effort, we will yet say that it has far too little shown the rational and necessary interest in the relation of things to the future, as implied in constructive purpose, than it ought to have been doing, and doing in always more cogent ways. Hence we cannot follow Professor Flint, in according so much stress to the presence of order, and practically dismissing design from all real foothold. We certainly insist on all rational caution in the divining of final causes or intrinsic ends, but it is another and larger demand which requires of us practical abandonment of all belief in ends that have been devised by intelligence. True, we may not thus be carried far on our theistic way, since such ends cast little or no light on 
the nature of the conceiving or devising intelligence-say, as to the unity or the immanence of said intelligence. For the argument here calls for supplementing by the Cosmological argument, as that leads us up to the one ground of all existence. Every attempt, however, to expel purpose or design from the universe has proved vain: too deeply graven it lies in the mind of man. View the design argument anew in purest evolutionary light, and we cannot doubt that design will once again appear. There is good reason to lament that not more has been done to enable design to reassert itself amid all evolutions in time. Only those who have followed the course of recent theistic endeavour know how much loose thinking has had to be cut away from scientific sophistry as to final causes in order that those composite and purposive results, without which science itself would speedily crumble to pieces, might be reached.

Theistic philosophy was till lately wont to lean too largely on the teleological line of argument, as founded on adaptation and adjustment to ends, as these were seen, in a too direct and narrow appeal, in connection with the phenomena of the external world. Intelligence alone, it was thus contended, sufficed to explain these appearances of the outer world, as a product permeated with thought. Recent philosophy of theism has recognised the manifest unfairness of the Kantian treatment of 
this argument, which did not allow this proof to rest content with evidencing Intelligence, but sought, in fact, to make it fulfil the function of other proofs as well. In fact Kant failed to perceive that, although the argument. from final cause may seem at certain points to touch and lean upon what is to be found in the ontological and cosmological proofs, it yet really proceeds-not analytically as they-to build up its case in a synthetic way from the principle of sufficient reason. It has recently been the aim of theistic thought to concentrate its attention mainly on the field of organic nature, as being that wherein adaptations to internal ends or evidences of will-purpose are most palpable. Most carefully has it remembered that materialistic explanations of ultimate reality are excluded by such proving of Intelligence. Theistic philosophy has clearly noted Kant's failure, in his 'Critique of Judgment,' to keep in mind that the a posteriori argument ought not to be expected to bring forth Infinite Intelligence, but merely to show intelligence in the Primal Cause of all things. It should never have been forgotten that the argument does not pretend to divine ultimate ends in nature, but merely concludes from observed adaptations in nature. And it concludes only to a finite cause adequate to the phenomenal world, for that is all that can be here legitimately inferred. It is a decided advance which has recognised that the theistic idea is no such simple and separate thing as this procedure supposed, and which has recognised, further, 
how little relation a method that drew its theistic conception of God from an appeal to exterior nature had for the interior life of man-for the religious and not merely logical part of his nature. As to this last point, may we not say that there has been a more careful recognition of that ethological aspect of the teleological mode of proof, in which the ought of our aspirations as rational creatures is set forth, and the end which is ours by individual right is declared? For if valid, this alone of our first three arguments or proofs of Divine existence would yield some real insight into the nature of the Deity with Whom it has to do.

Recent theistic philosophy has purified itself of many former philosophical indiscretions in the sphere of teleological inquiry, and has more cautiously pursued its researches into the evidences of purpose or design. It has, besides, shown keener appreciation of the fact that all those lines of inquiry into the causes, laws, and ends of phenomena which are designated respectively ætiological, nomological, and teleological, are needed in order to completeness of investigation. The teleological argument is now no longer made to carry a burden greater than it can bear, as in days when, as a single argument, it was, according to Kant's representations, expected to yield a direct and entire demonstration of God. Now, at least, this argument is not considered apart from its organic connection with the other arguments: the Teleological argument but infers that the Necessary Being of the Cosmolo- 
gical proof is possessed of large intelligence-so large, indeed, that in the a priori Ontological proof it is seen to be infinite. Theistic thought has not been able to forget what Kant said in his 'Critique of Pure Reason,' to the effect that the order which reigns in the world proves at most the existence of an Architect, who fashions all with materials ready prepared to his hand, not that of a Creator to Whose idea all is subject, or Who is the Absolute Master of all that exists. It perfectly recognises the fact that the material with which he works must have a limiting effect for the Designer. But it has found time to remember that the form of things here meant, as involving intention, is that inherent and essential form of things which is bound up in their very essence and inseparable from their idea, and to remember, therefore, that One who impressed form of such interior and substantial sort must have fixed also substance or essence-in other words, must have been Creator no less than Architect. For, in the spirit of the ethics of Aristotle, it sees purpose combining with all action, sees some end or good for every movement. So that here we are in substantial agreement with Dr Hutchison Stirling when he says: "Notion without perception is empty: perception without notion is blind. This he [Kant] said once, and it is identically the same principle that is potent and at work when we say, Form without Matter is empty, Matter without Form is blind. A matterless form would vanish, 
and a formless matter never even be. Either, in fact, is but an element of the other." As Eutaxiology has been better seen to have but a partial though definite aim to serve, in viewing the world considered as a cosmos, so we believe it may be said that Teleology has more clearly realised that it, too, has a further, but still partial, purpose to fulfil in viewing it under the category of finality, and must not be expected, as before, to bear the strain, practically, of the whole theistic proofs.

Recent philosophy of theism rejects the mode by which Kant in his 'Critique of Judgment' tries to derive-for it really amounts to that-the principle of finality in nature from the a priori concepts of morality. It does so because it sees Kant to have unwarrantably confounded finality in natureas an a posteriori thing, based simply on observation, on probability, on inference, in presence of the adaptations in nature-with the a priori principle which, drawn from the spiritual sphere, refers to ultimate ends which are moral. Kant erred when he began by connecting nature with freedom as necessary to produce finality. Kant erred when he ended-for he never got further in real objection to finality than the plea of its subjectivity-by making finality no objective result such as that of which we have spoken, but a merely subjective necessity. For the said subjective necessity existed only in Kant's imagination. Kant lays himself open to the contradiction, which has been so well pointed 
out by Trendelenburg, that the object itself is, after all, needed, according to Kant, to say when this wholly subjective principle of finality is required. Recent teleology has, wisely, we think, restricted itself to proving volition in nature, the rational product of such volition being properly purpose. The immanent purposiveness of nature we cannot doubt, but we may not assume the impress of an external will at some particular time. Theism will be slow, as we believe, to admit any justification or necessity for sitting so loosely to such purpose or intention, as Professor Flint appears to do. Yes, even though it should take a view of the design argument not so nearly preevolutional as his must, in some respects, be admitted to be. We are in large agreement with the Rev. J. Morris in his recent work 'A New Natural Theology,' as to how little we know of final purpose as bounded by the present, but we are inclined to believe it quite likely that the full evolutional view may lay more stress on purpose plainly discernible now than $\mathrm{Mr}$ Morris thinks. Theistic philosophy will also be slow to regard Professor Flint's treatment of the analogy or "supposed" analogy between the works of nature and the products of human art-his denial, in fact, that "the design argument rests on the analogy between the works of nature and the products of art "- -as altogether satisfactory. For it will not forget that, in the case of both of these, the reasoning really is to 
a conceiving intelligence, since both are - with whatever differences - products permeated with reason, which works through them, but are nowise results of any self-conscious intelligence or reflection on their own part. We are not, in saying this, forgetful of what Schelling once said, that "the peculiarity of nature rests on the fact that with all its mechanism it is yet full of purpose. The difference between the products of art and those of nature is, that in the former the notion is only impressed on the surface of the object, while in the latter it has entered into the object itself, and is absolutely indivisible from it." Of course, the reason of this last result is found in the immanence of the world-reason. But we come back more closely to the point in hand. We see the Intelligence in nature working as from within, and in ways that only the higher - the mental, non-artificer-like-works of men resemble. There is no reason why the co-ordination of conditions which we find in works of art under man's intelligence should not lead us to the possibility that like results in Nature should be due also to co-ordinating Intelligence. The "designing intelligence," too, which Professor Flint infers from order and adjustment, must certainly, in fairness to the evolutionist view, be viewed far more closely under the light of the conditions that mark its manifestation than seems to have been done by him, or indeed by the customary theistic philosophisings of the past. 
And late theistic philosophy has shown how futile and blind is the fight with final causes which has been witnessed in the theory of natural selection, or the doctrine compounded of accidental variation, and that survival of those favoured ones termed "the fittest" which has even been taken by some to mean really the survival of those that do survive!

Recent theistic philosophy has made what appears to us a very decided critical advance in the way it has discriminated the principle of what is known by the unfortunate phrase "natural selection "- the rather negative principle, for so it really is, of eliminating the unfit-from a real producing principle or true positive cause, and has shown what good ground existed for misgiving, such as John Stuart Mill was not without, as to the "adequacy" of natural selection to account for the admirable adaptations of nature. In fact, it does not seem too bold a claim to put forward that theistic philosophy has taught science to think what it means by "natural selection"; if cause, what sort of cause; or if effect; or if both, at once natura naturans and natura naturata in Spinozan style. And, now that recent philosophy of theism has come more distinctly to see how needlessly antithetical are design and evolution, it has grown more evident how little altered the principle of natural selection, which was supposed to have done so much, by its processes of specialisation, for our teleological wonders, has left the design argument. 
It has become more manifest how no possible demonstration of natural processes, whereby Design might be dispensed with, would disprove the presence of an intelligent Creator, or do more, in fact, than present another version of the same affair.

Theistic philosophy has sometimes seen Natural Selection to be itself only a form or species of contrivance, and has then vigorously driven home the onus probandi upon those who deny that the progressive issues of the harmonious working of external and internal relations are the legitimate results of design. It has, of course, in doing so, more freely acknowledged how largely organisms are shaped by their environment, but has more decisively rejected the assumption that they are not, for that reason, made for their environment. It has not shrunk from seeing how greatly applicable to the struggle for existence under natural selection are the words of Schiller-

"Meanwhile until Philosophy

Sustains the structure of the world, Her workings will be carried on By hunger and by love."

"Einstweilen, bis den Bau der Welt Philosophie zusammenhält, Erhält sie das Getriebe Durch Hunger und durch Liebe."

Yes, for the persistence of true altruistic love is for us the real " survival of the fittest." It has not, let it be here remarked, denied that the strength 
of the design argument is, as Lotze said, the improbability of certain results being found in nature if they were not designed - a position which, of course, is not without an open door for denial of said improbability. But it has maintained, as against Lotze, that the design argument rests upon unbiassed observation of nature, and not upon this preconception or that other presupposition. Thus we are brought to see the significance of what Professor Flint has so well expressed, when he says that "the argument is not from but to design." We suffer the real drawback of being liable to uncertainty that the design we discover is that which the Designer had in His mind, but at any rate the right track lies in reaching towards design rather than starting from it in the shape of adaptations of parts.

Theistic philosophy has felt the fact to be not without significance, that thinkers like Trendelenburg and others of equal distinction have held a philosophy of design to the effect that, as the thinker just named put it, wherever design is found realised in the world, it was preceded by thought as its first Cause. But, of course, we must see that there is design, and not the fact of actual fitness or adaptation merely. It has to be pointed out what an open door all this still leaves for Theism; and if we then leave the region of mere externality, and take account of all we find within man, the theistic result will not be doubtful. Says 
Fiske, in his 'Idea of God': "That which the pre-Copernican astronomy naively thought to do by placing the home of Man in the centre of the physical universe, the Darwinian biology profoundly accomplishes by exhibiting Man as the terminal fact in that stupendous process of evolution whereby things have come to be what they are. In the deepest sense it is as true as it ever was held to be, that the world was made for Man, and that the bringing forth in him of those qualities which we call highest and holiest is the final cause of creation." It may be perfectly true that we are called to reason from the present life and no other; but under what compulsion must our view of the present life be confined to what is merely external? Why must I gaze on death and devastation without, and not look on equally patent facts of moral yearning and uprising aspiration within? And if I should even be told that this strange world-order, with its pain and perplexity, plague and pestilence, is for man, exists for his good or growth, why should I give way to thinking of such a teleology as petty, tasteless, and senseless, as men have sometimes done who short-sightedly lost vision of man's own teleological reference as a being formed for eternity?

It deserves to be noted, then, that recent philosophical theism has steadily grown in the conviction of the unwisdom of the former method of reasoning on a narrow basis to a Contriver from observed con- 
trivance in nature, such appeal having been set in far too exclusive a relation to the intellect as though it were an isolated and self-sufficient proof. It is inevitable that such inferior designs and purposes should be for ever open to question, in view of other phenomena that may appear antagonistic to the inference of purpose or design. "Not only is it impossible," says Principal Caird, " to trace everywhere the marks of design amidst the seeming imperfections and terrible anomalies of the present system of things; but, as we have seen, all the adaptations and contrivances of which the argument speaks presuppose the existence of matter or material forces, of which it can give no other account than to ascribe them simply to creative will or power." Now, the first part of this is in a certain sense true and relevant, but why should Principal Caird give way to the incorrectness of dwelling with such strength and exclusiveness on "will" or " power," when intelligence is really that which the argument essays to prove? Why does he insist on Infinite intelligence being proved, when the aims and ambitions of the argument do not professedly extend to infinity? Is the proof of pure intelligence an unimportant element in days when impersonal and unconscious World-Grounds are so much in vogue? As little as may be can it be questioned that the moral aims of the Will Supreme, alike in external nature and in man, have had larger importance assigned them, and have had their significance more 
fully understood. Not, of course, that the strange obtrusive anomalies with which nature, " red in tooth and claw," is replete, have had more-but this is much-than the moral uses they possibly subserve more clearly discerned, and their anomalous character more carefully defined. We are certainly inclined to think that those evidences of natural evil which have led to such arraignments of the actual order of nature as have come to us from J. S. Mill, Hartmann, and others, have pressed not less heavily on our late theistic thinking, which, as it appears to us, has really felt more profoundly than ever the perplexing problem so presented to it. For recent theistic philosophy sees clearly enough that the time has gone by when it can, even if it would, shirk the difficulties presented in what Nature, tormenting and devouring, with, according to Mill, "the most supercilious disregard both of mercy and of justice," offers to our view. It is to be plainly said that there must be no blinking the strange sad facts of plague and tempest, of dearth and disaster, of disease and death, which can, to no natural scrutiny, be evidential of any particularly benevolent Deity. Even as to man, we must behold him

"Stretched in disease's shapes abhorred, Or mown in battle by the sword."

But we claim for that philosophy that it has more carefully distinguished the suffering animal world 
from the world of suffering man, recognising in how many different ways the former is exempt from troubles that belong to man as a being gifted with rational foresight, and beset with so many hopes and fears. We believe it has more successfully shown how the seeming rapacities and cruelties of earth mean for man but such wholesome severity as may compel him to spiritual advance. We claim for it, too, that it has done more to vindicate and explain these painful conditions as involved in the slow working, towards good and worthy ends, of the law of growth or progress. Nature, no doubt, may seem to threaten or crush the good man equally with the wicked, but it has surely come to be better understood how little of sweet reasonableness there can be in our reaping the untold advantages that spring out of nature's uniformity, without making allowance for some disadvantageous aspects and incidental evils in a world where all things are finite. Recent theistic philosophy has rightly protested against thought fixing its gaze with such intensity on any possible residuum of shadow or mystery which may remain after every discrimination and abatement, that for it, purblind, there shall exist in vain the multiplied and diverse proofs of creative goodness, the exquisite and infinite tokens of end, harmony, and ideal purpose. It has recalled us to the fact that ultimate ends are not ours to scan, as though the whole groundplan of creation lay before our view. It does not 
suffer us to forget that it does not seem as if we had any right to expect complete beneficence in the life that now is ours, where everything is relative, and where God's final purposes with us are so largely hid from view. It has more wisely insisted upon the immeasurable importance of moral discipline and spiritual evolution in the history of the world, as against the mere background of pleasure or happiness or justice. It has emphasised the difficulty of those, who are such interested parties, as we, being any impartial or capable judges of what is wise and good in Divine methods of compassing that moral and spiritual growth in man which is of prime moment to an ethical philosophy that stands about as high above the classic utilitarianism of Mill as the heavens are above the earth. This universe as conditioned in suffering, waste, ignorance, and evil, is not only actual as $\mathrm{Mr}$ Morris so strongly insists, but is, in ways which we hardly think he and others fully realise, the only ideal universe-with all its progressive issues - that we can conceive. Yes, and extremely grave as are the difficulties and anomalies presented in such facts as sin and sorrow, disease and death, famine and catastrophe, yet these all become more intelligible to him for whom life means the subjection of the actual to the ideal, and they are illumined, as we believe, in forms that are higher than any that lie open to mere argument, to him who is enabled to live the life of progressive faith 
in Christ, precisely as he does so. In the fearful strain between the ideal and the actual, we, for our part, believe the conscious and unswerving devotement to the spiritual and ideal a requisite of deep and ever-pressing urgency. We believe we are warranted in saying that such speculations on the origin of species as those of Darwin have been rightly caught up by theistic philosophy as really emphasising creation as a present process, in accordance with the better view of creation that prevails in modern theology. Our philosophy of theism has very properly insisted on the origination, and not merely the preservation, of variations being accounted for by any theory that would displace the theistic hypothesis, which keeps ever steadily before it the problem of the ruling Power in the Universe that now is. For, as has been said, "modification as modification is never a First, it is always process, movement between-movement of something into something." Yes ; whereas the real quest is still one of origin, not modification.

Recent philosophy of theism, knowing the necessity of search into final causes to any large synthetic movement of thought, has maintained a theistic evolution in which design is not superfluous, at least to any comprehensive and thoroughgoing interpretation of the phenomena of nature and life. Professor Josiah Royce, in his 'Religious Aspect of Philosophy,' will have none of "empirical teleology," and with, it must be said, no overplus of 
philosophic calm, spurns all such notion of design as may be thought to be inwrought in the structure and story of created things; but while he has much to say on the "confused hum" of nature's voices, his own idealism has really gotten such invincible mastery that he is nowise free to note the real significance of voices that tell of unity and purpose. And the teleological character of nature in its totality is what recent theistic philosophy has with especial care and power emphasised, with a view to raising thought to the conception of one grand design which reaches over unbounded space and runs through unlimited time. This has been to enrich thought, through the inner or essential teleology involved in such a position, with a wider and worthier teleological view of the world, as an organism having an end in itself, than was possible to the older theory of it as a machine of so many parts, indwelt by no principle of life. Particular events, individual organisms, difficult, it may be, to reconcile with order and design, are seen to be less deservedly allowed to conflict with the evidence of harmony and design which recent thought has found in creation, taken in whole. We are not saying that teleological significance may not be attached to these, but we certainly are affirming that presentday philosophy of theism has found a more excellent way in the larger teleological sweep of its thought. Modern thought has, as already we have shown, purged the design argument of its old ex- 
ternal and accidental character, and has recognised the immanence of design, though, as we shall see later, not viewing this as settling the question of intelligence.

While thus abolishing externality from Design, it has duly kept in view the fact that the scientific account of nature has more than ever become based upon the assumption of purpose, upon the immanent rationality of nature, whose signs of purpose as seen in adaptations, contrivances, expedients, are nowhere more strikingly exemplified than in such writings as those of Haeckel, Büchner, and Darwin. It has certainly found the cosmic processes of nature marked by deeper purpose, greater rationality, and, we venture to add, stronger ethical tendency, than Professor Huxley represents in his recent Romanes lecture, even though he talks of the "rational order" which "pervades" the changeful processes of nature. And, while it may have grown more careful not to draw more out of this rationality and purposiveness of nature-this cosmic nature which is " no school of virtue"- than would be warranted, it has yet laid firmer hand upon the aspects thereby presented as confirmatory of the theistic trend or ground. Such evolutionists as Spencer and Huxley have not called in question the compatibility of evolution with teleology of the newer or higher sort, and theistic philosophy has, with increase of power, contended that Divine ideal, end, or plan has not been wanting, in accordance with which the Force 
manifesting itself throughout evolution has been directed by intelligence. A Designer who works this evolution is one who, Dr Royce exclaims, with an air of incredulity, "shows wonderful foresight and mastery." But, we ask, why so wonderful in a World-Designer? Do not even our idealistic philosophers themselves show the same? Our theistic thought of late has shown a decided inclination at least entirely to discard the phrase "final causes," since end is not properly cause at all, and since, even in the hands of Janet, the distinction between efficient and final cause cannot be said to be too satisfactorily maintained. By this we do not, of course, mean that reason has grown other than more imperious in its demand or inquiry into single and conjoint purpose, though it dwells less on the evidences of small separate contrivance, and more on those broad constructive lines along which the world is upbuilt. Trendelenburg, Dorner, and others among recent theologians and philosophers, have regarded final cause as an a priori principle, but it seems beyond doubt that recent theistic thought has preferred to view end or purpose in an inductive light rather than in an a priori aspect, and has, we may perhaps say, more carefully differentiated the design principle as lacking in the universal character that pertains to the principle of causation. Still, recent philosophy of theism has kept in view the clue to the difference between causes and final causes supplied in spontaneity as that which final 
causes demand. It has urged, with not a little cogency, the part played by motive in mind-activity -open as that is to the scrutiny of rational insight -as placing the notion of final cause on like ground of necessity in human thought with the idea of cause. It has accentuated the truth that any absence we may find of particular purpose or design, such as would render luminous and intelligible to us the parts of nature, nowise militates against the fact of purpose in the whole, or against the existence of one all-embracing design. But, whilst this is so, it has also to be said that the latest philosophy of theism regards the relegation of those innumerable traces ( $` \chi \nu \eta)$ or signs of purpose-selection, combination, gradation-which science is for ever increasing, to the chapter of accidents, as quite beyond the bounds of rational probability. What an apotheosis of accident, which has thus become the great creative agency, our grand progressive power! Was ever knowledge like this, based upon accident - upon accident whose results are regular, definite, curiously continuous, and strangely constructive? But we may as well remember that "a world of accident could not be an object of cogitation. If the world around us be not a system of thought, whence comes the need we feel for thinking about it?" True, in all this it may at times have seemed as though theistic philosophy were rather wanting in appreciation of the Darwinian discovery of natural selection, but we cannot think this has been more 
than merely the result in appearance of a law so potent and-as Wallace has contended-beneficent as that of Natural Selection having been pushed to such extreme lengths from the scientific side that its limitations had to be rather sharply drawn from the theistic standpoint, to which the "fittest" does not mean the physical but the spiritual. The law of survival of the fittest-love, based on faith, remains the true "fittest" - has been seen, we take it, to be unrealisable so long as the powers of nature are left to themselves, and the law is viewed as really coming into play only under the ceaseless supervision of intelligence which marks what is fittest, not under the reign of accident.

We may here remark that recent philosophy of theism, separating the essence of teleology from its accidents, has clearly distinguished the Darwinian view as affecting really the mode in which ends are realised, and not the real issue as to purpose or intention. And theistic philosophy must certainly give Darwinian teaching the credit of having, in a negative manner, made the theory of late materialism less tenable, as represented, say, by Czolbe when (in his 'Neue Darstellung des Sensualismus') he propounds the eternity of species. It may do for science, possibly, to say, with Wallace, that variation is the mere absence of identity, and calls for no further explanation, but it will not do for philosophy which wants to know why the variations have always been so apt and 
I94 RECENT LINES OF TELEOLOGICAL ADVANCE.

profitable for life rather than otherwise. So insufficient, indeed, has Natural Selection been shown, in recent inquiry, to be to compass the results attributed to it, that we see it have recourse to the phrase "survival of the fittest," which, though little better than a truism, has served as fig-leaf to hide the nakedness of the theory; which is virtually one of chance.

The rather unwarrantable procedure has been laid bare of those who-like Huxley and otherstry to escape the irrationalities of this chance theory by claiming variation as neither indefinite nor fortuitous, the while that they seek to extract such fortuity from the argument as may be to the detriment of design. The difficulties, from the biological side, of accepting Darwin's law as the exclusive one of the protoplasmic order have been forcibly pointed out by the late Dr Romanes, who has sought to supplement it by the hypothesis of physiological selection, or " the segregation of the fit." By other evolutionists also its insufficiency, as the one and only cause of the transformation of species, has been distinctly maintained. And as for Weismannism, we may quote the words of $\mathrm{J}$. Arthur Thomson, in a recent paper before the Royal Society of Edinburgh, that Weismann's theory, carrying with it denial of all inheritance of acquired characters, and excluding the direct assistance of environmental and functional variations, "throws a still heavier burden than Darwin did on the 
shoulders of Natural Selection, which many believe to be already somewhat overweighted." It is due to Darwin, of course, to remember that he not only recognised the benevolent intent of Natural Selection, but also modified his notions of the scope and power of Natural Selection, as the law of the development of adaptations, before the results of Nägeli, Broca, and others, who neither admitted his original cause of mutation nor the "unlimited" character of variability, thus contenting himself with having helped, as he said, to overturn the dogma of separate creations. Nor does Darwin appear to us to have considered how those very variations, which Natural Selection makes use of, may have been subserving real intrinsic and predestined ends, the while that they might also be turned to extrinsic designs. May we not, then, say that recent theistic philosophy has not been content without seeking some higher principle of development which, carrying with it, it may be, the presupposition of conscious preconceiving intelligence and creative cause, will determine the "direction" and limit "the amount of variability"? May we not affirm that the notion of end inherent in the being or essence of all struggling world-existences has been more wisely shown to be something which neither is, nor should be, evitable? Yea, and that, however the inexorable laws of causation have been present in all the results reached by the way of Natural Selection, there must be far more than 
blind mechanical necessitation of the whole, even underlying, end-positing Reason as root and base of all ?

It may, then, be now said that recent thought has come to regard the former method of theological movement after final causes as faulty, less on the ground of its falsity than of its lack of due proportion, the thought and the energy of God in it lacking in fundamental depth. And that, further, the modern theory of development, far from dispensing with design or intentionality, calls anew for it. In the deepest view of it, evolution must mean, behind order and change, those ideas which are really endforming - and Divine. But these ends or purposes which are being subserved by creation we have no right to assume as lying completely spread out before us in the order of things as at present known to us. While recent philosophical theism has, as we judge, freely admitted what good ground science had to be hostile to final causes, with the insufficient explanations that issued therefrom, it has yet set its face more firmly against lending any countenance to the summary and superficial dismissal of final causes sometimes to be seen in scientific inquirers, who would confine attention exclusively to efficient causes in the interests of matter, as against mind in its primary working in the universe. For it has clearly seen what an arbitrary and irrational procedure it would be to stifle the presumptions in favour of final causes which the world presents, 
and so it has sought a surer place for these more comprehensive and remote ends by setting them in juster relations to the efficient causes or causes proper which they carry with them as their immediate explanation. It maintains the teleological plea for intelligence, but does not transcend the premises from which it was formerly sought to extract nothing less than intelligence, infinite, personal, free. It keeps men fast to the essence of the argument, which is not one of the Infinite at all, but really one of MindMind as the inferred result of design. It has acknowledged with more candour that intelligence here can only be viewed as associated with, and dependent upon, blind agents and necessary forces, not in connection with the spontaneity and voluntary action which are a primal feature of true personal consciousness. Still, it has felt that to claim for the purposes found in nature only a blind intelligence, or to take refuge in a theory of "blind immanence" for nature's designs, does not settle the question of intelligence involved at all, since, if it is blind in its working, we are the more necessitated to think foreseeing intelligence beyond, no matter whether that intelligence has effected its ends from without or from within. So we claim for the modern philosophy of theism that, while it does not forget how the modern philosophy of the unconscious rejects the idea of conscious intelligence in nature, it yet keeps in mind how. contradictory must remain to human reason the firm insistence of that philosophy 
on ends as being realised by nature in its blind working, while there is rejected the conditioning intelligence which alone makes those ends conceivable to us. We must reject an unconscious finality as foreign to all our experience. We must postulate supreme self-conscious Intelligence as immanent in nature and in man, while transcending them. We retain a Deity who is, in fact, less the Architect than the $\pi$ o $\eta \tau \eta^{\prime}$ s of the universe as now known by us, shaping its endless developments by laws of ordered and constructive intelligence. We do not forget, with some present-day theistic philosophers, that nothing in the world is single, not even the teleological argument. But it is a rash and illogical leap, to think that that argument may have no function to fulfil because it must be related to other proofs before a full effect is reached. We deny Paulsen's right to any such mechanistic view of the universe as would imply that the theistic view postulates an Intelligence working only from the outside: if he chooses such a one-sided view, and regards not the Intelligence as immanent no less than transcendent, he has no right to make it a ground for rejecting theism. It has yet to be shown why scientific or naturalistic pantheism, such as Paulsen embraces, must, in the vaunted name of evolution, have will which is blind. Yet a blind striving of wills after an unconscious ideal is the immanent tendency by which he metaphysically interprets evolution and maintains his so-called 
æsthetic teleology. The natural causes, one would think, must be in a very bad way, when they are best helped by blind will or impulse (Trieb), instead of being allowed to have intelligence working through them-and not merely from without, as Paulsen incorrectly apprehends the theistic view -no less than will.

Law, too, concerning which, let it be said, there has been so much confused thought in this connection, has been more truly perceived to be, in its recovered force and sweep, but the servant of design, not its antagonist. It has grown more evident to recent philosophy of theism that design is not excluded by any pre-ordained results being brought about through the instrumentality of law, and that what needs to be explained is just law itself. It forgets not that what the law cannot do here is just to tell us why the actual facts are what we find them to be. We have still to know whether they are due to chance or to purpose. And may we not, from the regularity of law implying plan, infer design in law? Theistic philosophy has not been betrayed into forgetting that, though the world is ruled according to law, it is really not governed by law, as though that were any metaphysical entity, or were self-explanatory, but by Will behind those unvarying sequences of nature which are insufficient to explain themselves. It remembers that Law is really a thing of method, the method by which force works, and consequently 
a thing that tells us about the how rather than the why. It has in recent years more decisively rejected the Comtean absurdity that a Deity is not necessary as the explanation of the sequences of nature, merely because these are regular. It has, with Trendelenburg, found the very fixedness and conformity characteristic of nature's forces to be, in fact, further argument for a determining cause. It has more firmly demanded of those who flout the idea of design in nature a reason for the reign of law being so fruitful in order, method, beauty, and harmony, if law itself, which men have too often hypostatised, be not that which has its seat in "the bosom of God." It has, more pertinently than before, observed the benignity that runs with prevailing purpose through the laws of the world, reducing the fortuitous elements of life's discipline to their proper place of subordination to the purposes of virtue, moral growth, and training. It has, too, we believe, more earnestly striven to exhibit what a spring of constructive energy to the minds and souls of men the suffering of the world, which is incident to law, has been, and what a great lack of insight and discriminating power has underlain much of the strongest modern writing of the sentimental sort on the overdrawn subject of suffering-in animals as in man.

At the same time we admit, though we thus speak, what a vice it has so often, been in the presentation of the theological argument, that it 
has so little felt, or at least faced, the difficulties suggested by the cases that appear of maladjustment, wastefulness, and purposelessness. It mistakes not law, under the scientific idea of it, for cause when it is only method, and it escapes the folly of expecting law to explain a creation which is inexplicable save on hypothesis of controlling Intelligence, of which law itself, as something in which reason leads us to find satisfaction, serves as a proof. It militates nothing against what has just been advanced if we say that the teleology of our time has, to keep itself right with science which everywhere postulates causality, viewed ends as realised in nature, not in the former fashion of interference with nature from without, but in ways which are inward and natural. But there is no sound warrant for supposing that the philosophy of theism to-day does not take such natural law as an expression of the purpose of the intelligence that works behind and through it. And so we deem ourselves entitled to say that, in the principle of teleology considered with reference to the universe as a whole, theistic philosophy has, with fuller warrant, referred the reason or intelligence, found as an objective product in nature in its entirety, to a sufficient and final origin in Reason as a subjective and personal power. Final purpose or design, with its implicates of intelligence, power, and will, those attributes of personality, has been with but ill success impugned by Agnosticism, 
driven to the dernier ressort of ascribing to matter in an inherent way those very qualities which everywhere presuppose personality. If we find coherent rational construction everywhere in that world in which we move and have our being, why should we flee final causes and not feel the pervasive Divine Reason, in all the mighty universe we see, to be the explanation of its beauty and its order? There is no reason why our abandonment of the old illustrations of special adaptation-presented in the theism of Paley with a skill that must always appear for his time astonishing - as less forceful and less necessary under the march of science and our extended knowledge of natural laws, should leave us blind to a Wisdom, to Whose scope we can set no lines of limitation anywhere throughout Creation's extent, and Whose presence we cannot evade in the world's great foundationlaws.

If we have still those with us, who shall say, with that great French critic Edmond Schérer, "Does not, for instance, the theist also look at her [Nature] from the outside, as at an object which is exterior and foreign to himself?" we surely can have no difficulty in saying plainiy that they who so speak are dealing still with a theism of the past, not that of to-day. Thought may so contemplate Nature as ab extra, but theism regards us as in. Nature, and sees Nature as in God, though not as God. Nor is there any 
reason why the philosophy of theism, in leaving behind those narrow and contracted views of design, which made the great and increasingly apparent waste in nature always more difficult of explanation, should not more fully perceive, as we believe it has done, how far such waste is from being real in a system which makes for an end so wondrous as man. Here Natural Selection is at an end: we see that all things have been for free self-conscious man; we cannot complete our thought of final cause without recalling that man is all for God. For, what end has the universe which may be compared with God's communication of Himself to man-His life, His mind, His Spirit? By the late Professor Jevons it was asked, "If men do act, feel, and live, as if they were not merely the brief products of a casual conjunction of atoms, but the instruments of a farreaching purpose, are we to record all other phenomena and pass over these?" This would be to stamp our procedure with unfaithfulness to scientific method. Hence the pertinence of what Dr Matheson, giving a cosmological turn to the argument, has said: "We find within ourselves the operation of a designing principle so distinctly selective and voluntary that we give to it the name of will. We meet in that personal experience which is to us the final stage in the development of nature, with a power whose distinctive feature is the conception of a purpose, 
and a faculty whose distinctive end is the ability to select its own end." If Büchner, speaking in the name of "modern natural science," has been able, in face of such results as we have referred to, to pronounce theological teachings to be "empty notions" suited to those who contemplate nature "rather with the eyes of the feelings than with those of the intellect," one cannot but feel curious to know of what sort scientific reason may be. We have been wont to regard scientific reason as having respect, before all, to theory which best fits in with facts, and every hypothesis save the theistic theory is to be taken as admittedly insufficient. For the most rational theory has been very clearly shown to be that of theistic evolution, in which the presence of a spiritual agency renders explicable the order of the organic world, the continuous character of the results of its growths amid variation, and other phenomena which no other hypothesis has been able to explain. And one should like to ask, as touching Büchner's view, whether it is only illusory feeling which has seen, in the ineffable beauties of earth and the unmatched sublimities of the heavens, that which has in late times so inspired thinkers the most diverse with reverence and wonder as to lead thence, by deeper inference than before, to devising and guiding Reason as the ultimate ground of such beauty and order? Is it to be wondered at if recent theistic philosophy has preferred to 
postulate what Trendelenburg, in the second volume of his 'Logical Investigations' ('Logische Untersuchungen'), was pleased to call a central Power (umfassende Macht) for such predetermined harmony (praestabilirte Harmonie), a Power dominating and uniting all, and a Power in which thought (der Gedanke) is the prime power?

Surely we do not mean to view the continuity and progression in all the protoplasmic evolutionary process and not see inherent and underlying order, or feel need to postulate some such Power, as that of which we have just spoken, superintending the adaptative traits of the protoplasmic process. It may be perfectly true that, so long as we confine our scrutiny to the physical and protoplasmic order of things, no trace of an occult and spiritualistic Power may be evident, but this scrutiny does not exhaust the case, for there are psychological aspects or evolutions to be added aspects of mind certainly as real and ultimate as those of matter-which take us beyond where we now stand, beyond the Power of Nature, infinite and eternal, to the Power of Being, which is spiritual and personal, of Love which is Divine. Professor Knight has declared that this "ascent and survey" can only be allowed "after we have discovered, from some other source, that a Divine Being exists." But what good purpose is served by blaming this argument for not effecting what it does not profess to accomplish? It professes 
to give us Mind, and nothing else. Why then should we rail at it because it does not furnish other things-the Divine Self-Existence or the Infinite? Professor Knight says "it is not accumulation of facts that we need, but relevancy of data": it seems to us there is even greater need of a just inference or legitimate expectation from data perfectly relevant to what is proposed. The presence of mind is one thing: the extent and the character of the mind are other matters. Recent theistic philosophy has, in our view, taken the world, so brimful of purpose, to be a thought, and has postulated, as the correlate of the thought so involved in its ubiquitous design, a Thinker who is Framer of the universe-not necessarily an infinite Maker, it is true, but, more relevantly, an intelligent Creator. That philosophy has not, we believe, forgotten that when science passes beyond its own proper sphere, and thinks to erect its own conception of the order of Nature into a sufficient account of its Cause, it is, as Dr Carpenter once observed, "invading a province of thought to which it has no claim." We are bold enough to claim, on behalf of theistic thought, that its march has been a magnificent progress in vividness and grasp of the glory and grandeur of an illimitable working. Yes, one, too, the conformity to purpose (Zweckmässigkeit) of whose beauty and sublimity reason has stubbornly refused to regard as explicable otherwise than as 
the expression (Ausdruck) - objectively existent after every allowance for what has been contributed by the mind of the subject - of Designing Intelligence.

We may take occasion here to note that philosophical theism has gained a juster perception of the unwisdom of pressing out the theory of final causes to an interpretation so rigid that the spontaneity and inherent worth, of the activity, beauty, and sympathy, of nature, are lost. That is to say, it has perceived that such things as the beauty, order, and harmony of creation do not exist merely for purposes beyond themselves, but carry their own end and justification with them. It is still open to us to ask, "Does not this harmony demand Another besides the organic subject as its cause? This question we may leave on one side, as, if one grasps the notion of an organism, this development of teleological adaptation is a necessary consequence of the vitality of the subject." Theistic thought appears to us also to have, in this newer and inner teleological view, found a better door of escape from that Deistic view of a hermit-like or monkish Deity which Weisse declared to be the danger of the argument from order. And because it has not been able to overlook the fact that the order which science has been more fully unravelling in the world points to forces that have a relationship to the future in that they are seen to work constructively, it has held that we are, more 
clearly than perhaps ever before, though in a different manner, led up to a theistic conclusion. It seems to us to be of the utmost consequence to remember what is so often overlooked, that no scientific advances of the future can possibly rob us of the teleological view of the world as a whole. For no reductions of the phenomena of life and mind in terms of the material world could really render the need and the faith of one Infinite and self-conscious Being at base of all, less urgent or less rational than before, however they might alter our modes of setting or interpreting the primal elements of which self-conscious spirit is the efflorescence. It may very well be doubted whether, in fact, any state of mind save that of a perverted and petrified condition of intellect-an $\dot{a} \pi \circ \lambda i \theta \omega \sigma \iota s$

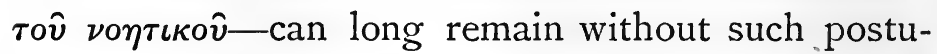
lation of Supreme Intelligence in presence of the order, harmony, adjustment, and ends, towards which " the whole creation moves."

So little able has recent inquiry been to elude the grasp of rational purpose or final cause in its comprehensive researches into the world's structure, that our late philosophy of theism has found the theistic idea involved in final cause more persistently present than was always from the scientific side expected. For has it not more clearly found the august processes of evolution to be so rational, so eloquent of mind or intelligence, that we are left with not less teleology than before-only with tele- 
ology of a vaster sort? It quite remembers that this argument is not one that makes the strongest appeal to men's minds in this time, when, in fact, the presence of Mind in nature is so widely recognised, but it insists on the fact that the proof is now stronger. And has it not, as we in perfect keeping with all this have tried to show, more distinctly felt design to be the very presupposition of that law of development which is the basal law of all living beings? The truth is, it has found writers like Haeckel and Spencer-the former of whom is professedly so strong on the purposelessness or dysteleology of Nature-quite unable to work out their fundamental conceptions here without really assuming the very teleology they profess to reject. Why did Spencer talk of adjustment in the way he did when he wished to banish teleology? And why did Haeckel give to adaptation and inheritance the really teleological significance he has done? But still, theistic philosophy has more boldly and frankly acknowledged, we believe, that no replacement of suppositions of chance by purpose or law can suffice to lead as of necessity up to a personal Deity. Yet these evidences of the purposiveness exhibited by nature may lead the way thitherward, and may serve no unimportant function in theistic thought in doing so. For still it must be asked, Is it so easy to stop short of Personality, and rest in so. abstract a conception of Intelligence? Are we not 
brought, in so far as we come into grip of reality, to an acceptance of such intelligence as is really a mode or aspect of an intelligent and self-conscious Personality? What possible conception can we have of purposive design without a personality which is its agent? Neither experience, nor any analogy derived from it, affords warrant for such impersonal basis. If, as Professor Romanes recently appears to think, the religious mind should not care to preserve the evidences of design unless they testify at the same time to the nature of that design as beneficent, we hesitate not to say that that could only be because the religious mind was very ill advised, and retained too limited a horizon to be able to interpret its own best interests and needs. For, if the inference of our knowledge taken in whole be, as he thinks, towards establishing the fact that design-if operative in naturemakes for animal improvement or evolution rather than for animal enjoyment or wellbeing, why should such a conclusion appear so distasteful to theistic thought as he presumes? Has theistic philosophy any interests more dear than improvement or growth in the highest? Are not the things which make for such end to be thought of as beneficial? And, if so, are they not better than beneficent in the sense implied, even if theistic thought has been too little wont to view the matter thus? Things and reasons there may be still hidden from us, and we admit that there are senses in which, as Professor Romanes truly 
.

21

and finely says, "it remains for Faith to answer now, as she has always answered before-and answered with that trust which is at once her beauty and her life-Verily Thou art a God that hidest Thyself."

We think that philosophy of theism has not been altogether remiss in suggesting the need for greater caution in judging of the seeming failures, and apparent wastes in nature, whose ends and uses may only be hid from us for a season, as they have so often been before, until knowledge grow from less to more. May we not even ask whether it is not irrational to indulge unspoken hopes of a full and perfect philosophy of a universe which evolution proclaims unfinished? But we have meanwhile been concerned to show how, as a recent American writer has said, "in the study of the successions exhibited by animals and plants it has been perceived that the march of events from the primitive simplicity towards greater and greater complication, culminating in man, requires us to assume the existence of something like permanent guiding influences operating in the world of matter"-permanent guiding influences that bespeak Mind behind all we thus see. But suppose these teleological effects in nature be granted to have taken place, it has yet been urged that the cause or intelligent being by which we account for these need not be a personal one. Whereas that intelligent being could only bear a personal character if all nature-reality possessed a final end or design, it has been declared that no 


\section{RECENT LINES OF TELEOLOGICAL ADVANCE.}

such final purpose can be affirmed, or in general maintained.

Without, then, detracting from such validity as we have claimed for the teleological principlethat is, in its inner view, its comprehensive sweep, and its ultimate reach-we may say that this path is not one to be looked to by itself, to conduct us up to certainty of the personality of God. It does not seem a very possible thing for us to know that the progressive ends and issues of a creation which, for this purpose of ours, must be taken over all space and through all time, have been deeply laid with a view to compass those higher ends we see-and to compass this in such an inherent manner that design can be inferred. That is to say, there seems left the possibility of question here. Of course, even if we got so much of personality as design implies, bare creative energy, mere intelligence, in a Deity would be a cold and unsatisfying thing to these hearts of ours. At the same time, we regard it as mere arbitrariness to assume, in a perfectly needless way, that the intelligence behind all phenomena is intelligence simply by itself-dissociate, that is to say, from anything affectional or moral. We may, in fact, express our cordial agreement with the Rev. J. Morris, in his 'New Natural Theology,' in respect of the need to view nature less as product than as process, seeing that the drift of all our argument lies towards full and explicit 
recognition of the fact that we are here, in an evolutional state of things, wherein we see but a small way into the purposes and ends of God that lie as yet all unfulfilled. We certainly believe that a less gnostic attitude becomes the teleological argument than has been prevalent; we recognise the liability to error and mistaken interpretation in our finding the marks of Mind in Nature; we admit that larger scope must now be found for the unintentional in the realm of nature. It is Lotze who has said that "it is not in accordance with the facts of experience that all parts of nature point to ideal significance and definite aims. Along with a thousand appearances which give this impression go a thousand others which look like aimless by-products of an accidental self-formed combination of atoms, which by no means ought to arise under a preconceived plan, and which have arisen and maintained themselves in being because they did not contradict the mechanical conditions of continued existence." We are at one with $\mathrm{Mr}$ Morris in thinking that the true path of theistic progress lies to-day in trying to discern the nature of the end for which things subsist by deeper study of the nature of the processes that make for the end-make for it, too, in a world that is quite unfinished, indeed is far more truly progressive than almost any of us ever realise in sufficiently vivid way. Such teleology, presupposing, as it does, feeling, thought, and will, is of the 
very essence of spiritual personality: it is, as $\mathrm{Dr}$ F. E. Abbot has said, " the decisive battle-ground between the personal and the impersonal conceptions of the universe. There is no such thing as unconscious teleology." We agree with him when he says that "ends and means are inconceivable and impossible, except as ideal or subjective relational systems which the creative understanding absolutely produces, and which the will reproduces in Nature as real or objective relational systems : hence the recognition of Teleology in Nature is necessarily the recognition of purely spiritual Personality in God."

What we have been showing in this chapter has just been the utter impossibility or futility of trying to escape a true and real teleology in Nature, as it appears to any scientific or organically evolutional view of the universe, and, consequently, the place and purpose still subserved in the theistic philosophy by the teleological argument. But it must still be said that the ripest results of that argument are yet to be found. That, however, is no reason why we should not now rejoice in that immortality for man to which its newer presentation, in its idea of Divine Eternal Purpose, points. If the contact of God with individual and fragmentary things of the world has seemed to grow more remote or less direct, His presence and agency have yet been shown to be, when taken in respect of the whole, more real and more near. 
It was a true divination that enabled a great theological scholar years ago to say that the argument, ancient as it is, would become "constantly more forcible in the degree in which successive generations know the universe better. Thus nature, in proportion as it unrolls before our eyes its diverse aspects, gives us an accumulative revelation of the harmonious life of the world." To which we add that the accumulations of science render less reasonable the position of Strauss that, though the world has the highest reason for its goal, it was not planned by a highest reason. For it would be difficult to over-estimate the significance of those pointings to a reason-an Absolute Reason under whose dominion all things are, and of which Nature is for us the embodiment-that lies beyond the present sphere of things, for which eternal sway and perfect sweep of reason the present upward progress of reason is preparing the way. Of that eternal day of reason we are as yet but at the dawn, but dawn it still is, in which the worldorderings are to our metaphysical philosophy more than a playing of tricks upon reason. 


\section{CHAPTER VIII.}

RECENT THOUGHT AND THE ONTOLOGICAL ARGUMENT.

The last two chapters have been concerned with arguments which have been very clearly seen to belong to the real side of the world-order: that order has been no less firmly grasped in recent theistic thought on what is regarded as the ideal side by the ontological argument. We do not think that recent theistic philosophy can be justly said to have regarded the conception of the Absolute as a barren branch of metaphysics, or to have become dissuaded, through Hamiltonian teachings as to the limitations of our powers, from at least learning all that the conception of the Absolute can now suggest to the speculative reason. It is, no doubt, perfectly true that the ontological or $a$ priori argument has with ever-increasing clearness been seen to be utterly unable to bridge the abyss between a mere idea and a fact, but stilland in spite of its ordinarily confounding concep- 
tual existence and existence in re-its speculative fascination abides.

Recent theistic philosophy has quite discarded the mode of passing, as in Anselm's famous 'Proslogion,' from the idea of perfect Being-an idea supposed to carry with it that of necessary existence-as this idea was found existing subjectively in the mind to its existence objectively in fact, under the logical penalty of leaving an objective Being-one who exists not "in intellectu solo" -who should be greater than an existence in the mind alone. Anselm's quantitative mode of conceiving the matter was unfortunate, hence he missed seeing that the self-existence, which is the original datum or final presupposition of all philosophical thought, is a thing which belongs to primal being as spirit. The Anselmic mode of reasoning has nothing greater wherewith to justify itself than the impossibility which meets us when we try to conceive its opposite. Hence we find it, for example, said in the third chapter of the 'Proslogion,' "So truly, therefore, does something exist, than which a greater cannot be conceived, that it is impossible to conceive this not to exist." And again, "Thou alone, therefore, of all things hast Being in the true sense, and consequently in the highest degree; for everything else that is, exists not so truly, and has, consequently, being only in an inferior degree." Kant is, we conceive, convicted of setting out under misapprehension when he begins 
by criticising the Anselmic position as drawing the correspondence between thought and things not by examples taken from things but from judgments. For, it is now better remembered that Anselm did not really assert that what exists in intellectu exists also in re, but rather maintained that existence is of necessity in the concept of God. Kant was not without a sense of this, however, when he directed himself towards showing-with entire success here-that existence is not a real predicate, and that analytic judgments must not be confounded with those that are synthetic. The elaborate argumentation of Descartes failed to recognise that the question was one of connecting and identifying the idea of God-as self-active spirit-with that of His assumed self-existence, rather than of establishing mere existence. We are not here quite concerned, however, to review the modes of presentation of the a priori argument by Descartes, Spinoza, Cudworth, Leibnitz, Clarke, Wolff, Kant, Hegel, Gillespie, and others, since its passage per saltum from an inwardly coherent idea to the existence of corresponding fact of objective reality has been so pronouncedly declared impossible. Kant viewed the ontological argument-on which, be it remembered, he took the cosmological and the physico-theological proofs ultimately to hang -as a simple begging of the question, covertly introducing actual existence under an abstract conception of a being that gathers into itself the sum 
of all reality. It is, of course, unquestionable that Kant has for ever laid this spectre of abstract thought as something that had no relation to the realm of reality. Yet it seems needful to say that, all-availing as Kant's reasoning was against the Anselmian and Leibnitzian modes of presentation, it is futile if we take the a priori aspect of the argument, not to demonstrate existence a priori, but merely to connect the idea of Deity-as we conceive Him in His Perfection-with the Necessary Being which the Cosmological Argument gives. The truth of the matter is that Kant's criticism could not be final or conclusive, just by reason of the fact that his thought did not stand on a plane where it could be seen that the argument, with the relation of ideality it involves, can be construed in terms of the self-assertion of spirit. It argued, too, a strange shortcoming in Kant that he dealt not with the a posteriori side of this argument which Descartes had emphasised. For it cannot be doubted, we suppose, that the ontological argument has given expression to the very real truth that God is nigh the religious consciousness-that consciousness which in humanity carries with it a Divinely given idea of God.

Recent theistic philosophy seems to us to have more firmly apprehended the fact that the ontological argument has its shortcomings in not furnishing full warrant and perfect certainty for the position that we have, in no a posteriori manner, but, 
purely without consideration of contingent things, an idea of an Infinite Being. For, has it not more clearly perceived what a wide door of possibility is left open on this supposition for our idea of an Infinite Being becoming a screaming contradiction or a patent impossibility?

More than ever, we believe, has theistic philosophy felt the need-Ritschl, Comte, and Littré notwithstanding - of a philosophia prima, a true Metaphysic, as, not less than in Kantian days, a defence (Schutzwehr) for religion against the speculation which, "since Metaphysics of late without heirs (unbeert) to its fathers is gathered," denies God, freedom, and immortality. For such metaphysic, as recent times have seen, has been but a metaphysical abortion, consisting of a theory of evolution which is almost all-embracing, but evolves no possible communion with God. Such a Metaphysic as we in this time crave will ground its laws, not in any molecular movements of things physical, nor even in any mere volitions of the Will Divine, but in the Divine Nature or Essence.

An ethical metaphysic that ultimate metaphysic must be, as part of its endeavour to be a true metaphysic. For the Unconditioned Being with Whom we have to do is One wholly ethical in His nature. But in what has just been said we, for our part, have no wish to suggest any pursuance of metaphysics merely for the satisfaction of ethical needs, and apart from their sheer intellectual worth 
and discipline. There is not the slightest sign that theistic philosophy will allow such a metaphysic as we desiderate, with its vision and faculty for what we may here without misunderstanding call the Divine Noumenon, to be displaced by Positivism. We see, in fact, Comtean prophecy as to metaphysics in course of strange refutation of late. We see metaphysics, in face of the Ritschlian depreciation of its worth and function, in course of being justified of her children, and gaining in strength and solidity what it has lost in appearance and repute. We see the need of the science of metaphysics still more deeply felt, that it may determine for us, as Coleridge so well put the matter, what can and cannot be known of being and the laws of being a priori, -in other words, from those necessities of the mind, or laws of being, which, though first revealed to us by experience, must yet have pre-existed, in order to make experience itself possible. Chastened and critical, the metaphysic of the time is such that Paulsen has said "there is to-day probably not a metaphysician who believes that he has the key to unlock the mysteries of the world." But, for all that, it is well to remind ourselves that, when we think we have done with metaphysics, we arewhether we understand it or not-done with Deity. We need the light which their metaphysical treatment alone can shed on the basal problems of theology, just as truly as any perfect and thoroughgoing metaphysic needs theology-although in no servile 
or unduly dependent way-as its touchstone and support. The rejecters of metaphysics will doubtless be found to mean the acceptance, as M. Fouillée has put it, of a metaphysical system which is their own.

We are here still called to consider what significance the principle underlying the ontological argument, notwithstanding the imperfection in the logical form of its presentation, has had for recent philosophy of theism in its quest for truth as to the highest unity of thought and being. And, in the first place, we must remark that, while the ontological conclusion may be said to have been always more distinctly affirmed to land us in mere idealism - to bring us an ideal end, but one without any necessary validity in the realm of the real,-this affirmation has been very clearly shown to be made in mental oversight of the fact that the idea involved is, neither in itself nor even in its history, capable of being classed with the ideas born of individual fancy. That is to say, we feel bound to maintain that such a conception as the necessary idea of the Absolute has been more carefully differentiatedthan by Gaunilo and Kant - from the incidental conception of something that is merely relative. Kant's criticism about the conception of a hundred dollars not implying a corresponding reality in his purse is pointless, when it is remembered that these do not represent necessary being at all, which is the case in point. Hence, as touching the fact that the 
corresponding existence of a thing is not guaranteed by its conception, it has been remarked that "the proposition is true except in the case of this one ontological thought of the totality of the thoughts that can be logically deduced from it." In the idealistic developments of post-Kantian philosophy, the Kantian "thing in itself" is seen to have been cashiered, and the ontological argument has become rehabilitated - so far at least as an Absolute is concerned, if not a God of the religious consciousness-with thought's gradual recovery of confidence in itself. We are of them that hold Hegelianism to have touched the high-water mark of modern speculation, yet we cannot but say that the Hegelian effort to make the notion carry actual existence with it has been felt not only to fail of reaching more than a purely idealistic issue, but also to avoid, with ill success, the objection of losing finite and infinite in each other. The ontological mode of dispensing with the facts given in actual experience, in order that it may set out from the bare notions of the intellect, has been seen to be no proper start for any interpretation of the universe that could be deemed even speculatively warranted : its necessary entity, even if it could in this way be found, would, it is most surely believed, still stand at a vast remove from the Theistic God Who is the Infinite Personality and the Absolute Intelligence, although it must be allowed to take us beyond the finite and contingent. As a modern apologist has 
said, "The perception of his own relativity leads man to the idea of some higher Being on Whom his own existence depends, and this Being he can only conceive as One that is absolute-above himself and above nature-that is, God." This Absolute Being is the necessary correlative of our own finite and conditioned being, and our idea of Him is developed along the lines of our personality and world experience. The mode of reaching self-existent being would in this proof manifestly not suffice to exclude Pantheism, for its reasoning does not make the universe stand out with sufficient distinctness from God. We are not admitting the discomfiture of the Absolute as necessarily known to our thought; we are, however, disallowing a world of reality different from the world as it is to thought, and to which thought-conditions might not be applicable. Recent philosophy of theism has been inclined to regard the persistence of the argument as accountable only on the supposition of its carrying with it in some way, after every theoretic disclaimer, the basal form of actual Reality, so that not merely the idea, but also the existence of God, has been found necessary to reason. Hence we think ourselves justified in claiming that it has not been content with the procedure of those who have had much to say of the oft-criticised Cartesian argument while neglecting the weightier matters of the contentions of those who think Kant missed seeing that Being is given, not predicated, in this idea of God; who 
allow the rightness of Kant from the point of view of abstract thought, but maintain his neglect of the volitional element in the assertion of the actuality of its infinite ideal by spirit; and who claim reality for what is a necessity to thought, a datum of feeling, and a necessary offspring of reason-in fact, regard it as the great reality, in another than the restricted Kantian sense of the term. It abides, as the great merit of Kant, to have cut away defective metaphysics, and paved the way for the juster conception of the Divine Being which is ours. And may we not still fitly apply to this conception the words once used by Dr Scholten, of Holland, as "the revelation of the One unique Infinite Being, Who acts in fixed laws which the human mind becomes acquainted with and systematises; Who manifests Himself to our reason as the Supreme Reason; Who specially manifests Himself in the moral world as Holy Love; Who, without being abstractedly separate from nature and man, lives and acts in nature and man, in ten thousand indefinitely diverse manners; and, at the same time, superior to the continual ebb and flow of finite forms, the Absolute Mind, the self-conscious and Supreme Personality, is all in all." Having said so much of the mauvais pas recent ontological thought has had to face, we now look on some of the more acute of its recent representations.

The recent thought of Germany in the region of ontological speculation has been fruitful of result 
as to the idea of God. Hegel had done excellent service in criticising Kant's criticism of the ontological proof. But the impossibility of any such intuition of the Absolute Being as would enable us thence to deduce the course of the world has certainly been far more clearly seen than in Hegel's time, and there has very properly been stronger effort to do justice to the widened range of scientific or empirical fact. Weisse, with the aim of reaching all Being through freedom, put the conception of the possible on a higher ontological plane than that of Being. Weisse viewed the ontological argument as unconsciously linking truth and beauty in its union of existence and perfection. German speculation, as represented by $\mathrm{K}$. Phil. Fischer, laid stress on that whole which is no sum of the parts, but a qualitative thing - a whole under whose particularising the parts first have being, and under which God is man's Ideal. But, while God is thus duly exalted as the highest, it does not seem as if justice were done to Him as the all-grounding Essence. To Fischer the truth and reality of the idea of God are derived by the ontological argument from reason itself : that argument proves them by an inherent necessity of thought: the truth of such thought for him includes, on this argument, reality or existence in itself, else we do not, he holds, escape inner contradiction. Hettinger and Luthardt have taken somewhat similar views as to God being found in our own 
minds. Hettinger has argued from truth - as objectively existent before and above our reason, and therefore eternal and absolute in its nature - that truth, which has its abode in the human mind, presupposes an Eternal Mind or Supreme Intelligence, which is called God. Hence this Supreme Reason is to Hettinger no mere abstraction, but something so real and independent of the mind of man that to Hettinger truth is God, and God is Truth.

With Luthardt, the idea of God, like other ultimate truths, is held to be the work of truth itself, the product within our minds of objective reason. Our intuitive idea of God is thus to Luthardt the proof of His existence, for we are here engaged, he holds, with a real God and not a mere idea.

Ulrici-whom Erdmann blames somewhat heavily for the British rather than German cast of his work-upholds the ontological Argument in the manner of one to whom God is the Creative Author of Nature and the absolute presupposition of natural science itself. He takes the conditional atoms which he postulates as the last elements of existence as here given, necessarily to presuppose an Unconditioned as Ground of their conditionality and existence. This conception of the conditioned powers of nature and their effects leads to the disclosure of an Unconditioned Cause, which is the Original Force mediating and determining 
all that now is. But in such conception we are brought by Ulrici up to the ontological Argument as approached from the side of the scientific conceptions of matter and force-a result, it is to be observed, which brings us no more than the nature side of the Divine Essence, or, as it has been termed, Nature in God.

Rothe clings to a speculative knowledge of the Absolute, and thinks it strange that men find it so hard to believe-what to him is the kernel of the ontological Argument-in the original existence of that which is perfect or God, since the perfect is that which most nearly approaches the idea of self-existence.

Dorner places the ontological Argument first in his order of treatment, herein differing from Pfleiderer, Biedermann, and others, in that he claims a dependence on the ontological Argument for what the other proofs may be able to accomplish, as a reason for such priority. Hence the strength Dorner puts forth in its presentation, which in our view certainly marks a speculative advance. He has, it seems to us, helped recent philosophy of theism more surely to grasp the principle that what we necessarily think, and think as necessarily existing, has a title to validity. We are surely entitled to say that, as it has become more clearly perceived that not save in and through God are we able to reason or to think, it has become more evident how futile must remain our endeav- 
ours to set God over against ourselves and make Him a wholly distinct and separate object of our thought. Dorner maintains that the Supreme Being can only be thought as Absolute or Unconditioned, as self-existing or objectively existent. Further, to think an Absolute is to him matter of necessity, and the Absolute so thought by us must be thought-if thought at all-as existent or possessed of being. The very possibility of rational thought is conditioned, with Dorner, by the Absolute, so that without it intellect is no longer itself. He goes on to show what a necessity of our rational nature is the recognition of the basal elements or ideas of the other proofs - those $a$ priori elements in them, as he conceives; and these a priori and inherent elements or aspects of the arguments, he thinks it perfectly natural and feasible so to combine with the a posteriori aspects, as that, in the presentation of the ontological proof, intellectual dualism shall be transcended, and enrichment shall ensue.

The incompleteness of the ontological Argument, taken as a thing capable by itself of furnishing the true conception of God, has been explicitly shown by Biedermann, whose own conception of the argument was yet not very fortunate. We should like to add in this connection that even Schopenhauer has done some service in the way he has given to ontological speculation a teleological turn, and the needful stress he has laid on the regulative value 
of the concept. Professor Günther Thiele, of Königsberg, in his 'Philosophie des Selbstbewusstseins,' has very recently maintained a validity (gute Berechtigung) for the cosmological proof, taking the basis of all things (Urgrund aller Realität) to be the self-subsisting, or substance as causa sui. Then he connects this independence or self-subsistence of the absolute Substance, with the absolute necessity for an Unconditioned postulated by the ontological argument-in fact, the simple self-subsistence of the absolute substance is taken as meeting the necessity for an Unconditioned in the ontological argument.

In France, it would take us too far back for the purposes of this work to do more than make passing remark on Malebranche, who, by his doctrine of all things being seen "in God," took up a position often enough severely criticised, but of which the sufficiently accepted idea of God being the "masterlight" of all our seeing is in reality simply a modification. Malebranche held not that the truths we see "are God," but that "the ideas on which these truths depend are in God." The idea of the infinite was to him the best proof of the Divine Being, Who is Being universal and infinite. The idea of God, to him inseparable from $\mathrm{His}$ existence, is clearly seen to have been only haltingly carried out in its implications in the thought of Malebranche, to whom things are known only through the idea of God. To him God is He Who is, and to him the 
idea of God was an immediate knowledge of $\mathrm{Him}$, Who touches us, he says, with His efficacious realities. Fénelon advances on Malebranche by his analysis of reason, in which, passing up from the inferior in us to the Supreme Reason without us, he concludes that this Supreme or Perfect Reason must be "real" - must be God. We may here interject the remark that to the process whereby man thus rises to know the infinite it remained for Leibnitz, whose impress on France is well known, to give greater precision. In the philosophy of Maine de Biran, based upon volo ergo sum, there is a fine and growing personal element, a personal power that was felt by minds like that of Cousin, which need not be wondered at, seeing that personality becomes, in fact, the central and vital conception in his system. We find the idealism of this original and abstruse thinker outrun, however, the bounds of eclecticism. Passing on to the eclecticism of Cousin-really, as Edmond Schérer said, the negation of philosophy-we find him hold that " the single fact of the conception of God by reason, the idea alone, of God, implies the certainty and the necessity of the existence of God." This autocrat in the philosophical sphere claims to reach the absolute, the infinite, through what he calls the impersonality of reason, in a way whereby he seems to identify, in pantheistic mode, reason and God. He shows not sufficiently, as to finite and infinite, how one springs from the other, and in what way 
we are to think of the one as involved in the other. M. Maret inveighs against Pantheism in general, these eclectic philosophers sharing his sweeping condemnation. But he has not remained without rendering philosophic service, despite his desperately churchly tendencies. Among Cousin's followers, Lerminier was able to see in the mind of man a revelation of God at once necessary and perpetual. Gratry, in his 'Connaissance de Dieu,' has lines of thought which may fitly follow those to which reference has now been made. The position he occupies will be seen when it is remembered that he declares that "the entire proof (toute la preuve) consists in rising from the finite to the infinite by the negation of the limits of the finite." Again, he affirms that "we apply to the finite this process of elimination, which gives us the idea of the infinite; that is, the idea of God, which, so soon as it is obtained, of itself proves that God exists." The last part of the sentence just quoted runs, in his own words, "C'est-à-dire l'idée de Dieu, laquelle dès qu'elle est obtenue, prouve par ellemême que Dieu existe." He goes on to say that "from this point of view, there is but a single proof of God's existence," and that "everything is that proof" (tout est cette preuve). It is Gratry, too, who, speaking of man's desire of the Eternal, says : "I necessarily seek something greater than any given greatness. But what exceeds all greatness known or assignable is the Infinite alone. Thus 
my life leads ever to the Infinite, and it does so because, being in myself finite and imperfect, I am drawn towards Him Who is infinite and all-perfect, as the primal centre of my being, and the source of my life." M. Saisset, in dealing with modern Pantheism, refers to Kant's treatment of the ontological Argument with the view of showing that Kant has clearly not proved the "inability of the human mind to grasp the first principle of thought and being." This he does by showing how the practical reason exists side by side with the speculative, and supplements it-since man "is not pure intellect"-with such a priori elements as the conceptions of duty and liberty. Concerning which we must be content here to say-if we may introduce such a reference while French thought is our theme. -that Kuno Fischer has, in his 'Critique' on Kant, remarked on the "logically consistent advance" in the different views of Kant, those of the pure and of the practical reason. With a spiritualistic bent, Vacherot has, after the footsteps of Cousin, tended to give an ontological turn to psychology, and has sought to prove, as it has been-none too sympathetically-put, that "the idea of perfection is God, but that perfection has no existence." M. Caro, in his 'L'Idée de Dieu,' has conclusively dealt with Vacherot's positions, leaving to him only a shadowy Deity - a God Who is a figment of the imagination. The infinite is, with Vacherot, simply the all : it is the all, or it is nothing-an alternative 
to which a vulgar pantheism has made us not strangers. The Deity of Vacherot's idealism is, when developed, a merely ideal one: he cleaves to the notion of a perfect Deity Who does not really exist, for a true God cannot, with him, be living and real! M. Caro, on the other hand, contends that a God Who does not exist is no God at all. As against Vacherot's contention that he yet guards the objective reality of Deity as perfectly independent of the mind, Caro retorts that Vacherot's God-as the Supreme Ideal-is a purely abstract and subjective conception, the mere product of human reason, the pure and simple result of our own intellectual operations.

Our late philosophy of theism has viewed as able, but not yet satisfying, the speculative thought of the chief Italian philosophers, which has partaken so strongly of an ontological character. Passing over the interesting theism of the too subjective-though realistic in tendency - philosopher Galuppi, it is necessary to indicate the grounds on which the philosophy of theism has done so. It has done so, because unable to follow the valorous lead of the typical Italian ontologist, Gioberti, when he takes up such positions as that "Being creates existences." So, too, is it unable to acquiesce when this thorough realist gives us to understand that existences or creatures are utterly dependent on "Being" or the self-existing Deity, and do have a direct intuition of the Divine Being Who is their 
primal source or cause. Such is the judgment defended by Gioberti in his 'Introduzione allo Studio della Filosofia,' and on the basis of which he proceeds, in his 'Della Filosofia della Rivelazione,' in which latter it is again maintained that l'Ente crea lesistente (p. 18). Theistic philosophy, so far from having found man's knowledge of God to be such plain sailing or effortless motion as Gioberti's nonidealistic theory of an all-comprehending object supposes, has rejected the hypothesis of this suggestive writer as utterly at variance with the nature and experience of man, to say nothing of its lack of selfconsistency. Other thinkers have here arisen who have held to the direct intuition of the Infinite as being natural to man's mind, only pursuing a modified path from Gioberti in regarding the idea of the Infinite as, though born with us, formed out and filled only in the course of reflection and the educative processes of life. We turn to the great Rosmini, trained at Padua. Rosmini, with the abstract ideality which characterises him, maintains in his 'Theosophy' ('Teosofia ') what we may perhaps be allowed for the moment to call a softened form of Ontologism when he propounds, in his quasiMalebranchian fashion, that the idea of being, which, with him, is really innate, can only be the idea of the Creative One by Whom finite beings have been called into life. Not indeed that Rosmini postulates for man the direct perception or vision of God, but only that self-subsistence, 
or reality, is to Rosmini an essential attribute of Deity, for he cannot admit that God can be thought save as real. The nature of that reality of God Rosmini very strongly held to be something which only in God's light could by us be clearly seen. But he gave reasoning and reflection place, and not simply natural intuition, in the way we come to know the Infinite Reality called God. Reality was, with him, the object of all our knowledge, and the notion of being was fundamental in his philosophy, in which it becomes, in fact, the womb of all knowledge, the spring of all truth. In the three books of his instructive 'Theodicy' ('Teodicea'), the Divine attributes and the dependence of the creature (limitazioni dell' umana ragione) are by him developed (p. 39). It is no small philosophical merit of Rosmini that he deals so suggestively with the logic of Hegel, and its problems in the sphere of being. The idealistic-realist philosopher Mamiani, who is not without intellectual kinship to Galuppi, has been able, in his metaphysical confessions, to approve an ontological position not unlike that of Anselm, and to maintain for us ideas that are immediately connected with the Absolute Reality-the most real Being (Ente realissimo). Mamiani posits the being of God on the basis of primitive intuition, but finds room for reflection as that through which alone we come to know the Infinite Reality. Religion he works out in its subsequent bearings in his interesting 'Religion of the Future' (' $\mathrm{La}$ Re- 
ligione dell' Avvenire'), in which he again professes to proceed in a manner "severo ontologico," and to rise at once to the cause and reason of all things (la suprema ragione e cagione di tutte le cose-p. 52). Interesting and ably sustained as such outgrowths of Italian thought undoubtedly are, it cannot be said, after the attentions which Kleutgen, Stöckl, and other writers have given to the positions involved, that recent theistic philosophy has found, in the ontologistic hypothesis, any firm resting-place for the sole of its foot. It has, in fact, more decisively proved how far we are from having found any psychological basis for the notion that the spiritual things hidden from sense-perception-among which must be reckoned the immediate vision of Godcan by any manner of man's thinking be directly intuited and immediately known, as things are perceived in primitive acts of perception by the senses.

In Britain not only has Ferrier, in his acute and forcible manner, given speculative thought an ontological cast by his setting forth of the one necessary Absolute Existence, which is the External Mind "in synthesis with all things"; but Principal Caird, maintaining that "we cannot think save on the presupposition of a thought or consciousness which is the unity of thought and being, or on which all individual thought and existence rest," has, in his own powerful way, presented us with that modified form of the ontological argument in which it appears as an inference from 
thought to being. The ontological proof has, on his interpretation, the meaning that "as spiritual beings our whole conscious life is based on a universal self-consciousness, an absolute spiritual life, which is not a mere subjective notion or conception, but which carries with it the proof of its necessary existence or reality." For our own part, hardly any portion of Principal Caird's work has for us more interest than the rare ability and skill with which he presents and endeavours to sustain this view, in which we rise to "a universal point of view, from which our individuality is of no more account than the individuality of any other object." At the same time we record, in passing, our emphatic dissent from the way in which it is here sought to depersonalise man and make him no more than an aspect of Deity like "any other object" in Nature. Man has then no more than a phantom personality-personality becomes an appearance and nothing more in a system with such tendency. To it, as we shall later see, the Universal or Divine Self is really all in all.

Of the Ontological Argument, Thompson, Tulloch, and Cazenove are among those who have thought favourably. We find R. A. Thompson, in his two-volumed work on 'Christian Theism,' able to regard Kant's treatment of pure reason as unwarrantable and unsatisfactory. Tulloch was able to put the position so lucidly as to call it one in 
which the infinite was " not logically but instinctively given," apprehended indeed "as a fact in the truthful mirror of intuition," and not in a set of mere abstract ideas or as a mere logical necessity. Dr Cazenove, in his 'Being and Attributes of God,' claims a high value for the ontological line of proof, more almost than is claimed for it by Dr Flint, whom, in the main, he seems to follow. Flint has, with his accustomed acuteness, shown the Anselmic position to be by no means so wanting in residual truth as has often been imagined. It is Professor Flint, indeed, who has said that this proof has "at least succeeded in showing that, unless there exists an eternal, infinite, and unconditioned Being, the human mind is in its ultimate principles self-contradictory and delusive." It may not be too much, we think, to say that recent philosophy of theism has rendered it more evident that the theory which supposes the existence of the particular thought or idea of God here involved to be due to its existence " in $r e$," is that which best accounts for the appearance of the idea itself, when the true nature of that idea is-in the solitariness and uniqueness for which Anselm contended-completely remembered.

It can hardly be questioned that no faultiness of this argument in its progress as a logical evolution, no defectiveness of it as a demonstration, has kept the philosophy of theism from more keenly discerning how God is necessary-necessary existence as 
implying actual existence being the point in question - to the reason no less than is the idea of Him. For it has well pondered to what meaningless confusion thought, in its ultimate principles and working, must be reduced if it should be held-as Anselm deemed impossible (nequit Eum non esse cogitare) - that God can be "conceived as nonexistent," and that an idea so indigenous to man's mind as the idea of infinity can be treated in the fictitious Kantian mode that makes it merely regulative and thereby leaves it really unexplained. In any case there has been clearer recognition of the value of the ontological argument as testifying, apart from any established metaphysical validity in the way of proving the existence of the Infinite Being, to the tendency of human reason in its search for the absolute and unconditioned as being in perfect consonance with the idea of such an Infinite Being. Indeed, it is to be observed that, from the very form of the argument-its hypothetical condition as to what is a necessity to thought - the result is seen to emerge that it must remain without being proved, save under its assumed form, while its ideal character is more clearly discerned. "If the Greatest did not exist, there would be no Greatest; and it is surely impossible that the Greatest of all imaginable beings should not exist." So it has come to be, as we take it, maintained that this proof, stripped of all that does not belong to its essence, amounts really to an assertion, on the 
part of the human spirit, of the actuality of its ideal, which is a self that is perfect and infinite. Not without force has it been asked, "Is it not an immediate certainty that the greatest, most beautiful, and most valuable object must be a reality, and not a mere matter of thought; for it would be utterly intolerable to believe our highest Ideal to be a mere conception of our intellect, without actual existence, power, or validity?" Does not this feeling persist though we have granted that actual existence may not be logically inferred? We take it that the deeper meaning of the proof has been seen to be that the self-existence it assumes is existence which is spiritual. It deserves to be said that it has been better observed also how the metaphysical process here - as indeed we have tried to show-gains proper supplement and strengthening, when to logical or geometrical necessity are added the material aids which the a posteriori argument affords. For still the deepest and most spiritual consciousness of man has its idea of God and its aspiration after $\mathrm{Him}$, and finds its abiding inspiration in $\mathrm{His}$ fellowship as the Father of Spirits. Can we deprive the ontological proof of real significance so long as we find that consciousness implies, in man's case, a knowing of God in his very knowing of self? For such consciousness is, in an implicit form, a knowledge of self with God or the Divine Spirit. What semblance of ground is there for supposing that humanity's apprehension and belief in God as 
thus self-conscious and personal Spirit-an encircling Father-was ever saner or stronger than it is today? We maintain that the philosophy of theism finds that in the spirit of man which so transcends Nature as to make it utterly irrational to rest in a barren Rationalism, or in anything short of conscious communion with that Universal Reason which is the presupposition of all our thinking. And if the ontological demonstrations have been frequently carried further than was justifiable or legitimate, that, as we have seen, is no good reason why a rational conception of Deity should not be deducible. 


\section{CHAPTER IX.}

RECENT PHASES OF THE MORAL ARGUMENT.

WE believe it cannot be disputed that there has been a growing sense of the importance of that aspect of theism which-among the deepest though not earliest sources of theistic belief-has its rise in the moral consciousness of man, with its living and progressive ethical ideals. Indeed, so strong has grown the sense of its importance that to us it seems now needful to recall what a mere portion of the great cumulative proof for the Being of God the moral argument is, and what a brief survival ethical theism, standing by itself, would be, when the God of rational theism should be abstracted from the outer world of Nature. This undue dependence, as we account it, on the Moral Argument has not passed without reference, in the case of Schenkel, Newman, and others, in the excellent chapter on this proof in Professor Flint's 'Theism,' where the authoritative character of conscience is presented in, no doubt, wise, if any should 
think, sufficiently strong, terms, and its claim held to be "implicitly admitted even by those who have most interest in denying it." In our view, however, and speaking with a general reference, there is need to present conscience less as something external to our personality, less as something detached from all other parts of our ethical experience, less as something that we obey in a merely blind fashion, than has been customary in theistic presentations.

Mansel it was who said that "those who lay exclusive stress on the proof of the existence of God from the marks of design in the world, or from the necessity of supposing a First Cause of all phenomena, overlook the fact that man learns to pray before he learns to reason; that he feels within him the consciousness of a Supreme Being and the instinct of worship, before he can argue from effects to causes, or estimate the traces of wisdom and benevolence scattered through the creation." Hence more stress has been laid on what is really a part - the highest part - of the argument for final causes, for an end is, with the fact of moral law in us, given for the world. As Kant has it, in his 'Critique of Judgment,' for this world, with such end as it bears, a moral authoror God-is to be acknowledged. Professor Edward Caird has, in terms that need not be here reproduced, admirably set forth the way in which God comes to be thus a postulate of the Practical Reason, that He may satisfy a pure moral need 
in us. No ultimate harmony of the natural and moral worlds is conceivable to us save by the Creator and Governor of the world being also its moral Legislator. There can be no doubt of the significance of the truth thus brought out by Kant.

So then we here take conscience to be a link binding sinful man to God, and God-consciousness to be something naturally enjoyed by every soul. For in our moral intuitions we are borne beyond the bounds of self, and beyond the scope of phenomena, and pass into the sphere or realm of the Infinite or Unconditioned. Surely from our moral life the Highest is in self-evidencing ways not excluded; but, if the Infinite so reveal itself in us, why should we not infer that it exists? Or why not even think $\mathrm{Him}$ at least personal as we are? Moral He must be. This is that ethical argument which sees the end of our being in the inward law of right written with invisible ink on the heart of man, and which perceives, with Emerson, how

"near is God to man,

When duty whispers low, Thou must,"

and how truly the revelation of God had come to man when the candle of the Lord was lighted in his conscience. This consciousness of duty, which formed the subject of Kant's famous apostrophe, has been finely shown by Professor Rauwenhoff, of Holland, to be quite unique in us, and he depicts 
how this Thou must passes into the imperative Thou shalt. Larger and more impressive have become the grounds on which recent philosophy of theism has based its witness drawn from the ethical argument. In this argument we take, for the Ground and Cause of all things, a Person, righteous and supreme, making this Eternal SelfConsciousness or Will the necessary assumption of the moral sense and its authoritative ideals, and we reach after that ideal spiritual world in which His rule is perfectly realised, as it cannot be here and now. Not that His righteousness is an unknown ultimate to us, for that righteousness, which is an absolute imperative in us, forms $\mathrm{His}$ nature and secret and method. From the fact of moral law in us this argument seeks to deduce a moral or personal Lawgiver above us-not from finding Him in the sense-world, of which we are creatures (Sinnenwesen), but in our active moral consciousness. Yes, for $\mathrm{He}$ it is Who, in the difficulty of getting happiness and its outward conditions to correspond with virtue, must, as actual moral Governor, compass the harmonious agreement of the order of nature with the moral world. In God being thus, as Kant puts it in his 'Critique of Practical Reason,' a postulate of the moral law in us, nothing is added to our theoretic knowledge. So Kant insists, urging that we are thereby enabled only to make for the moral aim.

We take it that the philosophy of theism regards 
with satisfaction the way in which Kant-in advance really of some in our time-held to the absolute worth of the moral ideal. It cannot be said to be wanting in just and intense admiration of what Kant did for the moralistic theory of religion, which he held we must guard as the apple of the eye, in his 'Religion within the Limits of Pure Reason.' But it has surely seen how impracticable it must remain to ground any adequate philosophy of religion in a system which, with its fine moral postulates, yet falls sadly short on the metaphysical and speculative side of its knowledge of God. It laments the mistaken course Kant pursued in introducing into his system of thought eudremonistic considerations, which, imparting an aloofness to Deity in respect of the moral life, were in perfect contradiction to his ethical positions. He laid himself open to the criticism of Strauss that the harmony between happiness and virtue which he sought is a proper enough aim, but that the always imperfect realisation of this aim or endeavour is not to be met by postulating a Deus ex machina, but by taking a right view of the world and of fortune. Hence he leaves us with no Deity save one who deals out the rewards of virtue in an eternal future, and with no proof save one which is manifestly hedonistic rather than moral. It is, no doubt, true that rightness and happiness must at last coincide, but it would be another thing to agree with Professor Knight that considerations of felicity played no larger a part in Kant's system than he 
seems inclined to argue. The tendency of the most recent research in Germany has just been to emphasise the part played by happiness (Gliickseligkeit) in Kant's thought, where it at times appears as the goal of our conduct or action. All we are concerned now to say is that the more rigorous representations of Kant's hostility to "happiness morals" must become somewhat modified in view of the difficulty in ruling out happiness as an end with which Kant seems to have been haunted.

Noble were the foundations laid for the modern superstructure of religious philosophy by Bishop Butler, whose declaration was, as touching conscience, that, "had it strength, as it has right; had it power, as it has manifest authority; it would absolutely govern the world." But Butler does not seem explicitly to recognise the feeling of imperativeness we find usually attributed to conscience in its working. We should like here to recall what Kant so nobly says in his 'Kritik der reinen Vernunft' (ed. Hartenstein, p. 588): "Belief in God and in another world is so interwoven with my moral nature (Gesinnung), that the former can no more vanish than the latter can ever be torn from me. The only point to be here kept in mind is that this act of faith of the intellect assumes the existence (Voraussetzung) of moral dispositions. If we leave them aside and suppose a mind quite indifferent with respect to moral laws, then the inquiry raised by reason becomes merely a subject for speculation, 
supportable, as such, by strong arguments from analogy, but not by such that to them the most stubborn scepticism must yield." Here theology as intuitive has been more lucidly shown to find its ultimate basis and support in conscience as the touchstone of revelation, though by no means its sole source. The theistic intuition of the Infinite, as so given in conscience, has had no lack of justice done to its free, authoritative, and abiding nature, and to its scientific credentials.

Is it too much to say that recent thought, in view of the need that theology to-day be a theology of conscience, has sought, in a worthier degree, to escape deistic distance by viewing conscience as an instinct declaring less the primitive agency of the Deity in man's creation than the perpetual presence of the Infinite Personality in man? Undoubtedly it views Kant's Deity as standing, in his 'Metaphysic of Ethics' and his 'Critique of Practical Reason,' in a relation to ethics which is still too external and, it must be said, superficial. This is so, while we yet admit the real and final outcome of the Kantian philosophy to be a moral, and, so far, a personal and theistic interpretation of the universe. Despite his damaging criticism of the traditional theistic proofs, Kant is not to be thought of as ultimately the destroyer he is often taken to be, for it is just he who has helped us to the moral confidence, to that trust in the universe, which we of this time so much need. Kant has surely 
been seen to cherish, for all that, a quite too great horror of bringing in the will of God to explain moral law, as if such laws could be other than reflect, or do other than harmonise with, His nature. Kant's method is so arbitrary-even though arbitrariness seems to be the bete noire of the Kantian theismas really to expunge rather than explain moral obligation, and to introduce Deity merely in order to effect a reconciliation or adjustment in dealing with the difficult elements that go to make up the summum bonum. It was, in fact, just this desire to determine and maintain the harmony between happiness and morality which led Kant to postulate the actual existence of God-that is to say, between these two in what Kant represented as their real, not their phenomenal, relation or connection. Sounder than the instinct of the Königsberg philosopher was that of the Ayrshire poet who, yielding to no hedonistic tendency, wrote in his "Epistle to a Young Friend"-

"Where you feel your honour grip,

Let that aye be your border :

Its slightest touches, instant pause-

Debar a' side pretences, And resolutely keep its laws,

Uncaring consequences."

Kant, however, has the merit finely to preserve the worth and reality of personality by his postulations for the moral consciousness. But it must be 
said that his is a line of proof that takes us but little into the theoretic sphere, and leaves us in the realm of faith.

As for Wuttke, it should perhaps be said that he took a too theological view of conscience as being the revelation of God given in our rational self-consciousness, thereby setting it too much in relation to exterior authority. It cannot be forgotten that man bears, as Goethe puts it, "a God within the breast." It cannot be said that theism has turned a deaf ear to such voices as that of a Newman saying that, "were it not for this voice, speaking so clearly in my conscience and my heart, I should be an atheist or a pantheist or a polytheist when I looked into the world. I am speaking for myself only, and I am far from denying the real force of the arguments in proof of a God, drawn from the general facts of human society; but these do not warm me or enlighten me; they do not take away the winter of my desolation or make the buds unfold and the leaves grow within me, and my moral being rejoice." Not, of course, that it has taken conscience to be itself the voice of God, or the maker of moral law, but that it has more clearly seen what a vehicle of revelation it is to us in respect of the All-Righteous One, Who is thereby evidenced to us in our moral life. $\mathrm{Dr}$ William G. Ward, in the beginning of his second volume on the 'Philosophy of Theism,' tells us 
that he heartily follows Cardinal Newman in regarding "men's natural sense of right and wrong as by far the strongest of those foundations on which belief in God is reasonably built." What a complex organism conscience is, and how comprehensive are the functions it fulfils, Dorner has set forth with surpassing skill. $\mathrm{He}$ has given needful reminder, too, that "if all natural moral knowledge should be denied, the transition to Christian faith could be made only by an act of moral caprice. To reject redemption would be excusable-yes, natural."

Theistic philosophy now recognises more fully the power of conscience in determining the ideal, and how far it is from being the simple power it was so often taken to be. But it declines to make conscience come down, without any adequate reason either in fact or in logic, from the pedestal on which it stands, and to treat it as merely the capitalised or consolidated experience of the tribe or race. It sees how this superb faculty of conscience in man has raised him above the animal creation - how, but for it, man had but known the

"Mere fellowship of sluggish moods,

Or, in his coarsest Satyr-shape,

Had bruised the herb and crushed the grape,

Or basked and battened in the woods."

It perceives that conscience, if it is not to work as 
a mere irrational instinct, calls for a God who is moral as its postulate and support. Yes, these things are so even while it abides true that conscience awaits the enlightenment of reason before it commands. It is, in fact, illumination, and not loyalty, that conscience in us lacks. When what is right has been by the intellect perceived or found, conscience supplies us-we are, of course, speaking ideally-with the moral impulse we need for the carrying of the right into effect. Conscience just represents our ethical energy, and it is an energy that impels us to know the truth and the right as well as to do them - functions whose importance are thus not easily measured. Conscience is not a cognitive faculty, but it is yet able to be a proof to reason of moral law.

May we not say that the philosophy of theism has been striving more earnestly to find whether the universe be not really moral at heart, and capable of evincing a perfect harmony with man's ethical ideals? It has more distinctly proclaimed the worth of this argument to be unaffected by any theories which may have been put forward as to the origin and nature of conscience, since conscience is a unique fact which it sets forth in its eternal distinction of right and wrong - a distinction which, passing beyond the bounds of the individual, it has found so graven on the whole moral life and order of the world, as to feel more 
fully warranted in joining with the poet who, addressing Duty, said-

"Thou dost preserve the stars from wrong;

And the most ancient heavens, through thee, are fresh and strong."

Those moral characteristics, which are but the reflections of the Divine image in us, are clearly perceived to have, "as their implicate, a Divine Something-rather Some One-corresponding in spirituality and moral nature to what we find in ourselves. They tend to conserve for us the personality of Deity. Hence they have been embodied in an argument which has taken this form : "To mark the step of thought which crosses the line into the hemisphere of religion, it is made when we affirm that over us, and in relation to us, the all-perfect Mind exists. Devout faith is a belief of real Being on the strength of what ought to be. If you look at it from the outside, you may call it the apotheosis of moral aspirations; if you name it from the interior, you will say, it is the revelation of God in the conscience. The former expression describes the ascent of my thought to its object; the latter, the descent of its object into my thought."

It must have become more apparent, we imagine, that the very survival of conscience would, from an evolutional point of view, be but a tribute to its transcendent present value. May we not dare to say that theistic philosophy has been gradually perceiving of late that no evolutionary teachings 
as to the development of conscience are of consequence in comparison with the reality and character of conscience as it now appears, and stands related to the actual universe, and is eloquent of authority which is that - for us at least - of the Author of nature? May we not claim it as right to affirm that in this great and significant fact of conscience we have a far greater obstacle to atheistic triumph than anything that can be presented by intellect? The Power not ourselves which seems to be making for righteousness, in midst of the apparent presence of moral law in the world and the imperative voices of conscience in the human breast, has been always more distinctly seen to be quite raised above the powers of the physical world - to be by no possibility any other, in fact, "from worlds not quickened by the sun," than God as Absolute Founder of that moral law which claims such absolute authority over us. Dr Chalmers was able, when treating of "Natural Theology," in words still significant to ask- " Had God been an unrighteous Being Himself, would $\mathrm{He}$ have given to the obviously superior faculty in man so distinct and authoritative a voice on the side of righteousness? Would He have so constructed the creatures of our species as to have planted in every breast a reclaiming witness against Himself? Would he have thus inscribed on the tablet of every heart the sentence of His own condemnation?" Recent theistic philosophy appears to have become more deeply im- 
pressed with the fact that this august authority of the moral law is not set up by man himself, but is, originally at least, imposed from without quite independently of him, and conditions his moral life without his consent-even against his will. Yes, for it is a "practical commander" rather than a "theoretical instructor." How much of this was already present to Erskine of Linlathen may be inferred from the way in which he wrote: "When I attentively consider what is going on in my own conscience, the chief thing forced on my notice is, that I find myself face to face with a purpose - not my own, for I am often conscious of resisting it, but -which dominates me and makes itself felt as ever present, as the very root and reason of my being." And he goes on to add that this is his first firm footing in the religious region, and that the Divine Purpose so impressed within him is an unmistakable indication for him of the Divine Character of Him Who so imposed it.

The theistic philosophy of religion finds no potencies to have been as yet discovered by science in virtue of which the origination of moral idea and righteous imperative can be explained. It takes the ethical law operative in conscience, with its ideal of moral perfection, to point us to the Perfect Personality in Whom all ethical ideals are supremely realised. It views the moral administration, which extends over all history and experience, as indicative of the presence and purpose 
of a moral Lawgiver and Governor. The venerable Dr Martineau, in his own forceful manner, once said: "No ethical conceptions are possible at all, except as floating shreds of unattached thought, without a religious background; and the sense of responsibility, the agony of shame, the inner reverence for justice, first find their meaning and vindication in a Supreme Holiness that rules the world. Nor can any one be penetrated with the distinction between right and wrong without recognising it as valid for all free beings, and incapable of local or arbitrary change. His feeling insists on its permanent recognition and omnipresent sway; and this unity in the moral law carries him to the unity of the Divine Legislator. Theism is thus the indispensable postulate of conscience; its objective counterpart and justification, without which its inspirations would be illusions, and its veracities themselves a lie." In the second volume of his 'Study of Religion,' Dr Martineau puts the case for conscience strongly, saying that the revelation of God to us through conscience is not less real and direct than is the revelation of an external world by means of senseperception. "The dualism of perception, which sets ourselves in the face of an objective world, and the dualism of conscience, which sets us in the face of an objective higher mind, are," he holds, "perfectly analogous in their grounds." If it should be thought that his argument, power- 
ful in its presentation of "the externality in the one case, the authority in the other, the causality in both," fails of proving the Divine Existencethat $\mathrm{He}$, the One Infinite Spirit, is - there can be no manner of doubt as to the luminous way in which it shows of what sort $\mathrm{He}$ is, Who is God of righteousness, if haply we have found Him. That which here concerns us is the moral character of the God with Whom we have to do: other questions, such as those of His personality and self-consciousness, are to be separately dealt with. May we not just as well recognise that, though we grant full claim of the moral consciousness, yet from the line of our moral ideals, metaphysical proof for the Divine Being there can be none? Must not the true path and course for our philosophy of theism lie in taking conscience to be a moral power or capacity pertaining to the human spirit, as such, and for which a true ground must be sought in the one eternal and Infinite Spirit Who gives us being? Must not the very concept of morality be taken by us as possible only under acceptance of such self-activity of the human spirit? Must we not say that the course lies for our moral argument, with its promise and presentiment of a Judge of all the earth, not in seeking a retribution yet to come, but in the recognition of the demands of retributive justice here and now? And must we not say that while our self-activity persists before the mechanism of an 
all-devouring Nature, it is yet from the religious, rather than the moral, needs, that the advance to a personal God must be made? Yes, for there can be no doubt that the range of Kant's practical reason is ethical rather than religious. Conscience, with him, was concerned with duty, to which the categorical imperative impelled. But religion calls us to devotion to that which is personal. All the same, we must hold fast to the Absolute Moral Ideal which we find in God, without Whom we have no adequate goal for our earthly and imperfect morality. We cannot conceive that the Divine Being who planted conscience or the moral faculty in us can be Himself other than One Who is righteous in all $\mathrm{His}$ ways and holy in all $\mathrm{His}$ works. His moral nature makes it impossible that He should do otherwise than what is perfectly right. No such original and self-dependent being is man, who feels and knows that he is neither ground nor law to himself. The fact that this argument or aspect of theistic truth has sometimes been overpressed in recent times must not be allowed to detract from what worth or value it may bear. This undue stress has been conspicuous in the Netherlands, where the tendency has been described by Professor Bavinck, of Kampen, in these terms: "Even though we should be able to reach, by means of reason, God as the Absolute, yet this Absolute would not be the God which our heart stands in need of. Creation does 
not proclaim a God of love. The God we need is not to be found outside of ourselves, but within. Religion is consecration to the moral ideal, to the power of the good, to the Thou shalt of conscience. Religion is not science, not a view of the world, but a specific conception of life. Pure morality, holiness is the content of religion." Or as a writer of our own has put it: "The newest philosophy of Holland deems it enough that the morality shall be ideal; not the prosaic will of duty that toils under the burden and heat of the day, but the free flight towards visionary perfection to which midnight contemplation invites. Religion, we are assured, is Moral Idealism. In this definition the modern tendency finds its most exact expression."

Easy as it may be to carry such positions to undue lengths, we must not allow these excesses to keep us from finding a real basis for theistic belief, and a real vantage-ground for conflict with materialistic thought, in the moral elements to be found in man. We cannot but flee spiritual atrophy, and follow after that faith of the heart which believes unto righteousness. Yes, and it is impossible here to forget how men have persisted in mixing up the very existence of God with His righteous character, for they have strangely passed, in their moral difficulties, from any disbelief in His righteousness to stark doubt of $\mathrm{His}$ existence. This righteousness of the Divine character we trace to those moral principles of the Divine nature which 
make God what $\mathrm{He}$ is. There is here no thought of any sort of necessity, but His will ever chooses to be in action what $\mathrm{He}$ ethically is by nature. And for ourselves, the ethical ideal in us, whose absolute worth, we have shown, is to be maintained, runs back into an Absolute Being in Whom it is grounded, and in Whom it may become perfected. Yes, for Kant came short in so thinking that we impose the moral law upon ourselves, when it is really put upon us from without and beyond us. And if it be from above us, then we clearly must put ourselves into harmonious relation with the higher order above us - the Divine Source of moral strength. Is not all this most natural, most probable, most harmonious with reasonable expectation? Or would it be more so if our moral consciousness and experience were related, not to a Personality in the way we have described, but to some abstract and impersonal entity, as unlike ourselves as possible?

Of course, the moral argument of Kant does not bring us to such a Personality as One whose existence is, from the mere fact of man's highest nature requiring it, demonstrated; but it does bring home to us, in most forcible manner, the dire alternative that conscience and moral obligation are shams or lies, and all our virtue the most unreliable thing in the world. And if we cannot choose but repel so dire an alternative, then the strange authoritative sway of conscience, as it 
works through all the exercise of our freedom and self-determination, may drive us ever upwards towards an alter ego, an Infinite Personality Whose mind is for us represented within us by the moral imperative. Clearly, mere phenomena are seen to be transcended in the resultant sacred union with the Perfect Mind, and the ethical ideal is perceived to work in us in the most living and vital way. Yes, for nothing less than personal relations can satisfy the workings of the moral order: the relation we sustain to the truth is in things moral a personal one: every impersonal tendency is in the last result swept away by theistic philosophy as defective and unsatisfying. It postulates a Lord of the conscience, just as conscience is lord of man, for it holds that sense impressions, and intellectual reasonings, so blend in us with the intuitions of the conscience that our supposed autonomy gives way before a real theonomy. Is it not with justice that the need and importance of free ethical obedience on our part to these eternal laws of righteousness have been emphasised? For how, save in this free ethical region, shall man raise himself from mere phenomena to the heights of moral personality? From the failures and defects of hedonism theistic philosophy still turns to say, to that Supreme Being who is its Ideal of Goodness no less than its Power of Life, "In THy Presence is fulness of joy; in THy right hand there are pleasures 
for evermore." Yes, for God is more clearly seen by it to be not only a necessity of man's reason and a moral postulate, but also the indispensable basis of universal human morality and of the whole moral order of the world. It is, in fact, on this cumulative aspect and not on mere testimony of the isolated consciousness, that the force of theistic evidence has been felt to depend. For, as $\mathrm{Mr}$ Balfour has said, when "we have been moved to postulate a rational God in the interests of science," we can "scarcely decline to postulate a moral God in the interests of morality." No, the witness of conscience or our God-consciousness will not allow us to do otherwise than postulate the presence of One Who is not only the Oversoul, the Architect of the universe, and the Overseer of our activities, but also the Father of our spirits, God of truth and righteousness. Whatever clouds and darkness intellect may find round about $\mathrm{Him}$, the moral sense within us is still sure that righteousness and truth are the habitation of His dwelling. And not the notions-even the profoundest -of the intellect bring God near us, but only those sighings of the heart and those outgoings of the spiritual nature in which the soul becomes lost in wonder, love, and praise. 


\section{CHAPTER X.}

RECENT THEISTIC PHILOSOPHY AND THE PERSONALITY OF GOD.

THE question of the personality of the Infinite God, with the modes of His manifestation to mankind, has, in recent philosophy of theism, more and more assumed the aspect of being one of fundamental significance, in view of the contentions of those who have declared personality, in the case of the Deity, a vague, unverifiable idea, and who argue for a vapid, absurd, infinite non-personality. Personality has always more manifestly appeared to be no "incompatible attribute" of the Absolute, but something which pours meaning into what would otherwise remain meaningless and abstract. Neither being, nor substance, nor force, nor cause, nor extra-mundane forms of Deity, will suffice for our conception of God-such conception of Him as may make great realities like creation and incarnation possible. We do crave, behind all these, an Eternal Self-Consciousness or Absolute Person- 
ality, of Whom, in man and the world, we have manifestations. That personality by which we philosophically signify selfhood, or self-realisation by a true self, must always remain much more than any formal definition of it: futile it must be to render personality in any abstract terms, if we would preserve its essence. Personality is, in fact, that which alone can explain and interpret itself. The activities of personality certainly presuppose spirit, a presupposition quite as rational as any of those to which we are accustomed in science. "In each case that which science finds as the essential reality of matter and energy is that which is imperceptible by sense. The essential reality of the tangible is the intangible; of the audible is the inaudible; of the visible is the invisible; of the divisible is the indivisible; of the perceptible is the imperceptible. Thus underlying or within the gross matter and its motions which we perceive, is a world of atomic, molecular, and ethereal matter which no human sense can grasp. In this, science presents to our thought a reality of which we can have no perception and scarcely even a conception as matter." Perfectly consonant with scientific tendency and procedure, therefore, is the presupposition of spirit as at the base of personality. Far more than the fact that he thinks or wills, is the fact that man is a self or spirit. His various capacities and activities are only so many aspects or sidelights of this truth 
of his selfhood. The personality of God, so far from having become a maiter of mere abstract or academic interest, is, we feel bound to say, still one of fundamental moment for all speculative interest of whatsoever kind, giving, according as we posit a positive or negative attitude, a direction to all else, as has been far from sufficiently understood. We, therefore, assume a distinctly positive attitude, and maintain that nothing but true personality constitutes substantial being. It is because being can never become really intelligible to us so long as we view it only in the light of cause or of substance, or even as impersonal intelligence, that a true philosophy of theism must interpret it in terms of self-conscious personality. It is undoubtedly true that just in the personifying or personalising process did such a philosophy, and that by a psychological necessity, arise. The problem, affecting, as it does, the colligating hypothesis of the theistic philosophy, is now, we take it, seen to be one so vast, so multiform, so capable of enlightened inquiry from many points of approach, that its elucidation can only be the work of many minds.

We believe it to have grown very evident to theistic philosophy that the primal being which we call God must remain to us a sealed book, unless we are willing to read by the light which the category of personality affords. The personality of God may be no prime concern either to the documents of Christianity or to the unsophis- 
ticated Christian consciousness, but it is clearly seen, we believe, to be of vital moment for the religious life in the view of reflective thought. The truth is, there have seemed to be a power and a fascination in personality, which have only become the more strikingly apparent as science has pursued its determined way with self-sufficient air into the knowledge of the world, only to find salvation from utter blankness by falling back at last on some dim shadows cast of personal presence. The supernatural, carrying in its bosom personality, with all that of which personality is capable, has been saved unto us in modern thought with a great salvation. There can be no doubt that recent theistic thought, piercing what our late laureate poet calls "the abysmal deeps of personality," has, with far firmer grasp, apprehended the fact that, in the consciousness of our own personality, whence we rise to belief in the personality of God, theistic philosophy has found-

\section{"A tower of strength}

That stands four-square to all the winds that blow."

For it has gained a new percipience of the way in which the pregnant personality of man, that personality with whose idea we are in experience so conversant, saves the personality of God from sinking for us into meaningless jargon. It has, we claim, more deeply observed how essential is the Divine Personality to religion and virtue, which 
are, in their very nature and development, really impossible without the free, spiritual, and personal, to which in Deity the personal in man pays homage as to nothing beside. And indeed we take it that it has found the living religious consciousness not only crave the personality of God, but also carry in itself a subjective certainty of the Divine Personality. Such subjective certainty is a call, of course, to theoretic reason to scrutinise its bases, that it be not found to contain that which, objectively considered, is contradictory or impossible.

To a blind, impersonal, unconscious worldmechanism, the free personality of man instinctively and persistently maintains an attitude of superiority: the very result of the Divinely personal is just-contrary to what is so often imagined - that whereby issues of vast spiritual import are made possible or verifiable to us. We venture to think theistic philosophy has reached a richer appreciation of the fact that Absolute Intelligence, properly apprehended, carries with it, by implication, Absolute Will, or, in other words, Personality. Does not the concept of personality carry with it the bright possibility of the Deity making full and practical proof to us of His love and goodness? And do not such concrete forms of His goodness and love suffuse the concept of personality with the warm glow of life? The perfect indivisible unity of God has been more conspicu- 
ously presented as consisting pre-eminently of personality-personality signifying in this connection a thinking being or essence, as something which in itself (an sich) is. It has been more evident, particularly to German thought, how the conception of such a thinking being or essence carries with it all that is most important in such customary circumlocutions for personality as self-consciousness and self-determination. We are thus with Kant so far at least as when, in dealing with Transcendental Esthetic, he lays the emphasis he does on the selfactivity of the soul's life; and in self-consciousness rather than consciousness in general do we find the essential moment of personality. There is no doubt great force in Lotze's contention that just in "the true recognition of oneself as an $I$ " does personality consist, as soon as ever one knows himself as unitary subject in opposition to his own ideas and states. But this is still vague and unsatisfying. So is Green's contention that self-objectification or self-consciousness makes up personality, wherein the part is made to do duty for the whole. Those qualities of personality which wear a volitional or an ethical or an emotional character are all sacrificed on the view of Green and others, to those of a purely reflective cast. Surely a very dwarfed conception of personality. The "root element in all personality" is, no doubt, as Professor Knight has remarked, "consciousness," and selfconsciousness was allowed to man by Spinoza, who 
yet denied him self-determination and free-will. But we do not take self-consciousness to be the all of personality-that is, identical with it. For self-determination is personality, and infinite selfdetermination means for us the infinite personality called God.

The theistic philosophy of our time properly inquires, whether that self-activity, which is the property of spirit, is something that may be thought of by itself, or requires that we posit a self-active Being for its Ground. So far as it consists of mechanism, the outgoings of soul-life might conceivably be due to their being the expression of material workings dependent on an impersonal primitive Ground (Urgrund) of things. But it is otherwise with its self-activity, which cannot be founded or based but on a self-active Being. We take it to be now well understood that personality is, to theistic philosophy, that which gives to man his unity as an unanalysed self or individual consciousness; that its active elements are knowledge or intelligence, feeling or sensibility, and will or volition ; and that its implicates are inclusive of self-consciousness and self-determination or freedom. Personality is to it, in our view, nothing but the capability of a self-determination which shall include thought, selfconsciousness, and moral self-determination. The self-consciousness is for us condition and presupposition of this moral self-determination. And the power by which man is able so to resolve and de- 
termine, is just that freedom of his will which is later to occupy our attention.

Now, the manifestations of Deity are, as we judge, so grounded in self-determination as to presuppose the personality of God. These things we may surely say without professing to attempt a psychology of the Eternal. Hence to the theistic philosophy the Divine Personality, as ideal or absolute, represents, as the Eternal Energy self-determined in His own Supreme Reason, the essential elements in personality raised to their highest power or perfection. It seems to find beginnings of this personality in the Ontological proof of perfect being, to gather strength for its conclusion in the apparent cosmological craving for Will as the originative force or power, to gain confirmation from the Intelligence that marks the Teleological reasoning, and to reach the highest seal of self-existent personality in the evidences of man's mind and of moral law. As little as may be can it be questioned that recent philosophy of theism has stepped out in advance of the inherent absurdity of the position assumed by those thinkers who, in postulating that Deity, personally non-existent, may yet be higher than personality, place being plus intelligence below that which has it not, and who, in face of the selfevidencing power of the theistic idea, assign that which is self-conscious and self-determining to a lower platform than that which blindly moves on to its ends. A perfectly absurd and even impos- 
sible conception is this of infinite impersonal being, a conception which is quite incapable of being thought by any human mind. This impossibility of resting in any "World-Ground" that shall be impersonal and unconscious, say, the unconscious Will of Schopenhauer and Hartmann, as that with which, in the religious relation, the finite spirit is to hold commerce, has been strenuously declared by the theistic philosophy of late years, in opposition to pantheistic tendencies. What is non-personal it has felt compelled to treat as for it sub-personal, since it cannot suffice for the high ends and conscious relations of religion. It has not suffered itself to forget that the ends of which we have been speaking are ends living and rational; and it has not seen the wisdom of a philosophy which should postulate the evolution of spiritual qualities and the results of thought, while there should be no conscious apprehension of the former, and none of the attributes that should accompany the latter.

Theistic philosophy has been more sensibly aware of how truly her warfare must be waged on the field of pure thought, on which she must, perchance, engage the philosophy of the unconscious more seriously than has yet been done. Even now it is to be hoped she has been duly impressed with the wonderfulness of the unconscious Absolute, with which, however little intelligible, her thought has to do. For, has she not seen it to be an Unconscious which, as "by sorcery," is 
at any moment "able to destroy matter and to call it again into existence"; an Absolute which knows everything excepting always itself; an Unconscious "which is a spirit," and "not only possesses reason and intelligence, but is endowed with a clear-sighted wisdom infinitely superior to any conceivable consciousness," and which, without being itself personal, does everything we are wont to ascribe to personality? There is, in view of all this, perhaps little wonder that theistic philosophy has found it to have been declared-by Karl Peters, of course - that this philosophy of the Unconscious really represents a transition to theism. We cannot but justify her refusal to recognise this manifest self-contradiction called an Unconscious Absolute, or to sanction the separation of willthe irrational will of Hartmann's Unconscious under any form or circumstance from intellect, as only part of the groundless and arbitrary procedure of that philosopher. We think theistic philosophy may well stand excused if she insists on making her Deity more than a giant dreamer, doing He knows not what. We cannot but indorse her view of Hartmann's recognition of the presence and evidence of mind as disclosed in the universe, while he attributes them to nothing higher than an unintelligent and unconscious potentiality, as a contradictory and irrational position. What do we know of intelligence and will acting as severed from consciousness? Certainly we have 
activities of our own which, thanks to habit, have grown unconscious; but these activities themselves in their initial stages, and all our most real activities, are conscious activities. And if we know nothing of will and intelligence operating save as inseparably associated with consciousness, what warrant has our rational selfhood for reasoning up except as it reasons up from what is known? According to Hartmann, it is sufficient for the religious interest, which attaches itself to theism, to postulate an intelligent first being or principle (Urwesen) without self-determination : a reflectionless, intuitive intelligence is called in by him to explain the immanent, unconscious, teleological principle of the world. When he so tries to bridge the gulf between the real theistic position and the pantheistic leanings of his pessimism, we must be grateful to him, we suppose, for regarding us as products of an intelligence. But to the philosophy of theism it can be no great advance on a purely mechanical view of things if the intelligence from which we are sprung is so unconscious and unrelated to our life as neither to appoint its ends, nor impart its higher worth, nor lend supernal aid in the fulfilment of its imposed ends and aims.

We do not think theistic philosophy can be said to have found its mind expressed in the "Cosmic theism" of Fiske's 'Cosmic Philosophy,' in the second volume of which he inveighs against postu- 
lating rationality and personality for God on no better grounds than that he does not seem capable of conceiving Deity without attaching to Divine personality the merely contingent defects and limitations that pertain to rationality and personality as found in man. In consequence of this, he sacrifices "the symbol of personality, because personality implies limitation, and to speak of an infinite personality is to cheat oneself with a phrase that is empty of meaning." Not the only way, let it be said, of cheating oneself so long as such a phrase as "Cosmic theism" is allowed to dupe us by making us believe that such things as reason and righteousness, intelligence and freedom, cannot be ascribed to Deity save under the "quasi-human" forms Fiske would impute and assume. We believe that theistic philosophy is to-day more thoroughly alive to the necessity - a necessity arising out of the new unwonted endeavours to discredit theism on grounds specifically religious-of setting the consciousness and personality of God, Who alone is absolute end (Selbstziel and Selbstzweck), on a truly philosophical basis. Recent theistic philosophy has at least begun to sift to the bottom the specious arguments by which objection has now on speculative grounds been taken to the contradictions involved, as is alleged, in any possible construction of a conscious Divine Personality. And it has, as we think, more satisfactorily shown the real harmony of such a Divine Absolute as God the 
self-conscious Personality-the Personality with an

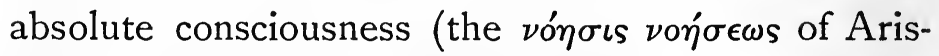
totle)-with the postulates of the religious consciousness. The feelings most characteristic of religion and worship are such as simply cannot breathe and act before a mere impersonal energy or unconscious power in nature. Should the actual results be by any accounted small, up to the present, the extreme difficulty of the new burdens and undertakings imposed upon theistic thought is not to be forgotten. That thought has remembered the need, of which Arnold spake, of our being "able to cleave to a power of goodness appealing to our higher and real self," but it has advanced into deeper insight of the truth that the powers in the world that make for righteousness, for goodness, never could be impersonal, without an immediate lowering effect on the aspirations and endeavours of the human personality, which instinctively reserves its highest homage for the personal. And so it has more explicitly recognised the essentialness of personality in the Deity to man's true fellowship with the Divine.

From this conception of personality the idea of corporeity is, of course, to be banished, even if this means a call to mental energy which not all are willing to meet in this sphere. From Spinoza to Matthew Arnold place has been found for the view that we limit the infinite when we regard it as personal-an absurd result of treating the infinite 
as a mere aggregate of things finite. When personality is viewed thus as necessarily limited, it is so as the unfortunate result of viewing personality after a quantitative mode of thinking. Here we may say that nothing could exceed the completeness with which recent philosophical theism has shown what gratuitous and unwarranted assumption underlies such asseverations as that of the author of 'Natural Religion,' that "personality involves a body and mortality." It has surely seen that personality, in its essential idea, involves nothing of the sort, and that its conscious self-hood has nothing essentially to do either with shape or outline or location in space, or any of the other conceivable limitations that mark personality in the usual sense. It has laid bare the contradiction clearly involved in the supposition of those who would condition Absolute Intelligence on corporeality or the possession of a brain. It has, we believe, been attaining firmer grasp of the fact that personality is properly apprehended, neither after quantitative dimensions nor qualitative degrees, but as a thing of free, original movement, a result of self-determining power. Personality it sees not to "depend upon a past or present contraposition of the ego to the non-ego; but, conversely, it consists in an immediate esse per se, forms the necessary prius of this contraposition wherever it takes place." Hence it reaches, in the case of God, unconditioned-because infinite- 
personality. Only, such free, volitional, self-determination must be premised, in His case, to extend to His nature no less than to His character. Therefore we say that the greater stress on personality, as it is claimed for the universal and omnipresent God, and on personality, as it is in man, marks for us a gratifying advance in the recent philosophy of theism, which has indeed more clearly seen how it is the very absence of personality in God-the lack of sensibility and self-determining powerwhich would really constitute limitation in $\mathrm{Him}$ as the impersonal. We see, then, how personality encompasses the path of our thought, and besets it behind and before. If thought ascends up into heaven, personality is there: if it makes its bed in Sheol, personality is there: if it takes the wings of the morning, and dwells in the uttermost parts of the sea, there also personality meets and holds it fast.

But, while personality thus lays hold upon thought, it has become always more apparent how possible it is for thought to rest in personality as a metaphysical conviction, without corresponding realisation of the encompassing presence of the God Who is a Person. And may we not say that this recognition has saved thought from remaining purely rationalistic? May we not, with the strongest reason, hope, too, that the Absolute Personality has been able, in $\mathrm{His}$ untranslatable fulness, to shake off the incubus of those specu- 
lative limitations, with which non-theistic thought has been pleased to invest $\mathrm{Him}$, yea, to do so "with as much ease as Samson his green withes"? Even theistic thought has advanced beyond the view of Lipsius - who retains so many points of community with his precursor Biedermann, to both of whom we shall again advert-that the Divine Essence is annulled when personalitywhich, on his philosophical presentation, means a necessary finitising of the Infinite - is predicated of it in the interests of practical religious needs. For, our late philosophy of theism has very clearly perceived how, in such a view, thought is confounded with mental representation (Vorstellung), and definition with limitation or lack of reality. Personality is still, as Mansel said, "the noblest of all existence of which men dream, for it is that which knows, not that which is known." Indeed, since Mansel, whose serviceable though not satisfactory representations may be acknowledged, the philosophy of theism has, with an almost wearisome iteration - we mean no blame to it, for it has been needed - shown that personality need not be finite, since the assumption that determinateness, as the essence of being, means limitation, is so unwarranted. Also since, as Lotze -according to Ladd - has said, "it suffices for laying the foundation" of personality " if a spiritual being has the faculty of apprehending itself as 'I' in opposition to its own states, which are only its 
states, and not 'I.' A relation to an external reality is not necessary; and, consequently, 'personality' also is not bound to the condition of finiteness - to wit, to that of being limited by another reality of the same kind."

Personality, then, in Deity has been very clearly relieved of those accidental limitations which confused thought had attached to personality, and which would have ended by destroying all knowledge of $\mathrm{Him}$ whatsoever. The Infinite "alone, therefore, is capable of a self-existence, which needs neither initiation nor continuous development by means of anything which is alien to it, but maintains itself in an eternal movement within its own essence." Disastrous to theology as anthropomorphism, under some current conceptions, might be, its charge clearly avails not in the light of all that has now been advanced against the supposition of personality as a thing of quantitative limitations. How difficult it is, however, to get rid of this quantitative infinite, modern philosophy bears abundant witness. We therefore believe recent philosophical theism to be with W. S. Lilly when, in his 'Great Enigma,' he has, in Lotzean strain, remarked that, in the proper sense of the word, "Personality (Für-sich-sein) can be predicated only of the Infinite," and that "perfect self-hood means immediate self-existence. What we call personality, self-hood, in man, is but the dimmest shadow, the faintest effluence from the source and fount 
of Being, in whom alone is perfect Reason, perfect Will." Further, "the Ultimate Reality contains within itself the conditions of its existence. Man does not; for he needs the stimulus of non-self to be conscious of his self-hood. He does not need that stimulus to become a person, for the non-self does not create consciousness; it merely manifests it; it is an occasion, not a cause. The idea of Personality, like all ideas, is realised only in that self-existent-the original of all existencewhich transcends those ideas, indeed, but in transcending includes them." To its deepened conceptions of personality, true, infinite, eternal, in God, real, abiding, supreme, in man, must be attributed much of the fulness and depth of recent theistic philosophy, and we, for our part, see no reason why greater richness may not yet gather around its conceptions in this sphere. It is, in fact, just here in our view that theistic thought has a great and inspiring work to do, for it is here-in personality-that potentiality, trueness, fulness, depth, infinitude, for us reside, though as yet by us imperfectly known. And we, for our own part, do not see how we can in the future face the scientific view of the illimitable universe, except as we think more profoundly along the lines of personality. This, it seems to us, we must do, or give up the faith-in fact, relinquish theology. There is no need to make impossible attempt here at historic treatment of this subject in recent theology and philosophy, seeing the theme has received 
attention on its historic side in Germany from Sengler, Wirth, Hanne, Pfleiderer, Drews, and others in our time of scarcely less consequence in our estimate, and since we are here concerned less with mere historical and systematic exposition than with critically estimating the advances made by theistic philosophy. We shall take leave to say, however, that the full results of recent German thought and research in this connection do not seem to us to have been at all fully assimilated in British theological scholarship and thought, which we account matter of extreme regret. It may be remarked that the older dogmatic interest in the perfection, infinity, and spirituality of God has given way to a more philosophic interest in the conception of personality in Deity. The personality conception was found helpful in bringing out the Divine superiority to, and independence of, the world, in the revulsion that took place against Spinozism. What in recent times has been most firmly held to in personality is undoubtedly related to Kant. Kant sees in freedom and independence of the mechanism of all nature the essential moment of personality. One-sided as his view of self-determination may be, there is yet more to be said for his than for many more recent representations of personality. He boldly elevates the notion beyond mere intelligence to something in which he sees the proof of a new and higher order founded in freedom. Man is to him, in virtue of personality, a 
being capable of life, of reason, and of forming judgments. There is now associated with the reflective subject, to which we attribute personality, such a practical activity that we see it marked by selfdetermination, and not by mere self-consciousness.

Recent philosophy of theism may, we suppose, be said to have carried its thought along the theistic lines of Jacobi and Baader, even though the positions of these thinkers may fall very far short of present-day conceptions of personality and proofs of the same. The former of these, Jacobi, was able on occasion to assert his belief-defective as its objective grounds might be-in an intelligent and personal cause of the world (verständige persönliche Ursache der Welt). Fichte expressly held that "in the conception of personality lie limits" (Schranken); that what we in our finitude apprehend never by any ascent (durch unendliche Steigerung) can be "changed into an Infinite," and that such ascent - since it never can be rid of limitation and finiteness - may bring us to a magnified man, but never to God. Both his theistic tendencies and his shrinking from personality in Deity appear in the sublime strains of his 'Vocation of Man,' wherein he breaks out: "Sublime and Living Will! named by no name, compassed by no thought! I may well raise my soul to Thee, for Thou and I are not divided! Thy voice sounds within me, mine resounds in Thee; and all my thoughts, if they be but good 
and true, live in Thee also. . . . That which I conceive becomes finite through my very conception of it; and this can never, even by endless exaltation, rise into the Infinite. Thou differest from men, not in degree, but in nature. In every stage of their advancement they think of Thee as a greater man, and still a greater; but never as God - the Infinite - Whom no measure can mete. . . . In the idea of Person there are imperfections, limitations: how can I clothe Thee with it without these? . . . Thou workest in me the knowledge of my duty, of my vocation in the world of reasonable beings: how, I know not, nor need I to know. Thou knowest what I think and what I will. . . . Thou willest that my free obedience shall bring with it eternal consequences. . . . Thou doest, and Thy will itself is the deed, \&c." With Fichte, indeed, when we have attributed consciousness and personality to God, we have not really thought God, as we wished to do, but have simply multiplied ourselves in our thought, and so finitised the Deity. The pure or absolute Ego, which Fichte speedily identified with God, is no determinate individual, but simply pure and infinite activity. To his stress on this principle of the ego, Fichte united emphasis on Will-an eternal, infinite Will-as, in his later writings, he did on Life-the Absolute Life-both of which he identified with God. To this principle in any of these forms determination is denied, and to that 
extent, therefore, infinity may be predicated of them. In short, determination is, on Fichte's system, synonymous with finiteness. His pure ego is too palpably conceived through abstraction ever to subsist really for itself, and in his search for the fundamental principle or "fact-action" (Thathandlung), which he sets out by seeking, he conducts us at once to a vain and void infinite and outgoing activity-a Being absolute, impersonal, and inconceivable. No satisfactory conception of personality may be reached by his process of hypostatising the Divine Self, but the honour is his of having looked the problem of Divine Being in the face, and grappled long and nobly with it. Having thus indicated so clearly our own view of his position, it will not be strange if we be found to agree with a judgment which says: "Fichte, the sublime idealist, was withheld from seeing God by no obtruding veil of a material universe. Fichte, if any man ever did, recognised the moral order of the world. But Fichte-living indeed the blessed life in God-yet annihilated for thought his own personality and that of God, in the infinity of this moral order." This practical denial of a personal Absolute by Fichte is growing more apparent to philosophical criticism, we certainly believe. Not less apparent ought also to be the facts of Fichte's implication in illicit ways of this very Absolute as personal, and the strangeness of such denial in a system that makes consciousness so absolute. 
As for Schleiermacher, his speculative power came short of wholly transcending the Spinozan influence, which in its idea of substance still clave unto him, causing him when dealing with GodWho is, to use a phrase of his own, "the absolutely spaceless causality"-to oppose personality in fact while not in name. He preferred stress on the living causality of God, the term "personal" carrying for him limitations of the Deity which he did not attach to the epithet "living." His is the merit of having rendered evident the need to construct a doctrine of Deity that should possess the virtue of consistency. The attractive and rational mysticism of Krause was able, at the beginning of this century, to embody a theism which recognised the Divine Immanence in all the wondrous manifestations of its life, as Krause's writings - though unfortunate in their terminology-show. It was Krause's aim to unite the pantheistic world-view of idealism with the conception of Divine Personality. The Wesen or Essence-as he likes to term the Deity-is to him no indifferent Reason, but the living and personal World-Ground. For personality-the thing if not without a certain aversion to the namehe found a place in God, when-like Baader-he would, in his " panentheism," seek a theism in which justice should be done to monistic elements. When Amiel, however, inveighs against what he calls the fanatical adherents of transcendence, than whose "dogmatic supernaturalism," he says, "the panen- 
theism of Krause is ten times more religious," it becomes necessary to ask whether the fanatical tendency-why should such be?-has not become transferred in our time to the direction of immanence.

Not without some interest as preface or prelude of personality have been certain very recent efforts in Germany to view the consciousness of reality or transcendence as a new kind of consciousness-to take consciousness for this end from its psychological (Erfahrung) rather than its metaphysical (Vorgang) side, and find in the consciousness of reality as a transcendent thing a strictly psychological datum-one, too, of prime significance. Of course this consciousness is not the reality, but reality-which is the transcendent-is that from which the consciousness springs. Reality or transcendence is taken on this view to be the something of consciousness in its primary psychological aspect. On the problem of personality on which we are here engaged, there is good reason for gratefully recalling the noble note sounded by Julius Müller when he showed how a philosophy which could not do justice to "personality and freedom" as principles of real life is the "born foe of Christianity and theology, and excludes the idea of their harmonious progress or their mutual enlargement." He declared that a philosophy which truly realises the principle of personality in God and in man is "the natural ally of Christianity." To him our belief in God springs out of the consciousness of our own personality as 
finite, yet as wholly unlike the world without us, and by him God is set above the laws of nature, so free and personal is He. Such were his affirmations touching theistic philosophy, even though it should, he said, be sometimes found to harbour contradictions respecting particular doctrines. Weisse, again, in his speculation-to which that of Rothe was so near of kin-held to an idea of Deity which made Him personal, but threefold was the personality in which $\mathrm{He}$ reached actuality-reached it in time as personality and love. I. K. Fichte was able, in treating of speculative theism, to postulate a rational and immanent, yet independent, Creator, and to speak of personality as the only real existence, the one true reality (das allein wahrhaft existirende). Dorner, Frank, and others have given explication to the positions of those who, recognising the merits of his idealism, cannot, with Hegel, make God only the World-Spirit (Weltgeist), and withhold from $\mathrm{Him}$ personality under fear of reducing or limiting $\mathrm{His}$ absoluteness. Finely has Dorner shown that definiteness in Deity does not mean limitation or imply imperfection, but the reverseperfection in $\mathrm{Him}$ on Whom all other existences depend. A limitation, he contends, God may be to us, but not we to Him, "the absolute Causality." Dorner contends for the Absolute Personality of God both from the ethical side of Will and from the side of Knowledge as Absolute Intelligence; and the guarantee of this Absolute Personality both 
he and Frank seek in the truth of the Triune God. This does also Sartorius,- - to whom "God is love - personal, primal love,"-after his own fashion. This principle of love it was which Liebner also invoked in order to solve the apparent contradiction of more persons than one in the Godhead, and to give them still full personality through their unity. The Divine Essence had been already conceived by Nitzsch as Spirit, as Love and as Lord, comprehended as personal goodness (unendliches persönliches Gute). "If God be conceived as the primal Ego, and from this basis begets an objective alter Ego, this thesis and antithesis still remain severed or incomplete until a third Ego proceeds from the Divine essence through the medium of the second, and thus the personality is fully consummated." Also, by Rothe and Thomasius, the Divine Essence was represented as having absolute or perfect personality entering into its definition. Starting, in the Schellingian style, from the Absolute as Causa Sui, Rothe works, from a Deity Who is primarily indifferent Being, up to His actuality-in a timeless process - in the twofold form of personality and nature. In his later positions, Rothe made the Divine potentiality-and not nature as he earlier held-the spring of His personality, which personality in its turn determined His further self-actualisation. Thomasius laid emphasis on the will element as an essential moment of the Absolute Personality, while Philippi-in an opposing spirit-emphasised 
the notion of substance in connection with the Absolute. Kahnis preferred to accentuate the idea of infinite spirit in his conception of Deity, and Frank had the merit to bring into prominence the absolute unity and perfect reality of the Supreme Being.

It has been the concept of the Divine Aseity, or Causality of Himself, which, in more clearly defined form, has been the starting-point of the later theology of Germany, in its maintenance of the Absolute Personality. The great advance in the ground covered is seen in the difference of the position, say, of Lotze from that of Strauss, to whom an Absolute Personality was something "incapable of being thought." Of Fechner, the senior of Lotze, and near of kin to him intellectually, mention must be made, and of his brilliant work on 'Three Motives and Grounds of Belief.' What here concerns us in Fechner's dealing with his three motives (drei Motive) — the historical, the practical, and the theoretic - is the way in which he rises from the ego which, in man's small world of thoughts, feelings, and strivings, gives unity to this manifoldness, to the thought of God as the "I" which gives unity to the great completed world of spirits. Just as our conscious ego stands to our body, is, in fact, above it, so does God stand to the world posited by Him-above it likewise. This analogical line of thought, however, as to this Divine Ego or "I" being the uniting, comprehending principle, seems to us to issue in 
so grave difficulties as to the relations sustained to all these spirits by the life of God, and by the life of these spirits to God, as to make satisfactory representation of Personality in our view here unattained. Still, Fechner marks an advance on the position of those who, like K. Phil. Fischer, maintain, from the presupposition of an absolute unity, that the reality represented by this unity must be a personal one. For their affirmation is by Fechner metaphysically grounded, and the personality of God expressly included. Among those who have stood for the personality of God should be mentioned Chalybäus, who said, "The fundamental presupposition of our personal existence, and personal self-consciousness, is the existence of the Divine Personality." Again, we find him saying, for example, in his "History of Speculative Philosophy,' that "God cannot be mere original ground, mere potence or power, but we have already developed that notion so far as to have been constrained to acknowledge $\mathrm{Him}$ as freedom, as will, and as spirit; as true Deity, we have found that in $\mathrm{His}$ existence and in actuality $\mathrm{He}$ is all that we have now stated." Ulrici also champions the personality of Deity, alike in relation to nature, of which $\mathrm{He}$ is the creative Author, and to man, whose human will is free. Hartmann plainly says that "God is raised above all limitation (Beschränkung) that lies in personality," so speaking in the interests of his unconscious spirit, with its attributes of will 
and idea. Potency he places above actuality, and indeterminateness he identifies with infinity. Hartmann, like Fichte and Schleiermacher, sets out from a preconceived notion of Deity, to which notion personality could only appear in the restrictive light it did to all three. But it does not seem to us that such a really dogmatist position has any good ground for assailing the theistic standpoint, with its Absolute Being, intelligent, self-conscious, free. It is a virtue in Ritschl that he adheres to the personality of God, Whose basal attribute for him is Love, though, of course, his position is open to the weakness arising from his theory of "valuejudgments." Pfleiderer, to whose notion of personality in God we shall again advert, is anxious to bring the will of God into closer agreement or identification with the world's conformity to law. Assuming a theistic position, personal Deity is not, with him, to be identified with the world order. God stands distinguished from the totality of $\mathrm{His}$ manifestations in the universe, according to him, though whether Pfleiderer's evacuating revelation of all real supernatural content and his rejection of miracle are, on such a view, warranted, are matters on which there is need to be at least of doubtful mind. God is, with him, now the ultimate law of all the world's phenomena, and now a personality seemingly capable of real personal communion - a not over-consistent presentation, it must be said. We retain, in our philosophy of 
theism, an Actor not ourselves Who is conform to world-law, only in the sense that $\mathrm{He}$ has chosen to observe a regular order in His workings. What Mr Balfour, in 'Foundations of Belief,' has well described as a real experience-against whose tendency, however, he shows us how to rise-seems to us very applicable as a description of the tendency of Pfleiderer's philosophy here: "The overwhelming force and regularity of the great natural movements dull the sharp impression of an ever-present Personality deeply concerned in our spiritual wellbeing. $\mathrm{He}$ is hidden, not revealed, in the multitude of phenomena, and as our knowledge of phenomena increases, $\mathrm{He}$ retreats out of all realised connection with us farther and yet farther into the illimitable unknown." Our only regret is in being compelled to declare our belief that, notwithstanding occasional references of this sort, the main defect of Balfour's own book is just its lack of any adequate recognition of a phenomenon so significant, homogeneous, and independent, as we take Personality to be.

It might carry us too far into side-paths to trace the courses of the thought of all who, in Britain, Germany, and America, have dwelt upon aspects of this great subject. The main current of thought, as we apprehend it, must be kept before us, and such remarks or individual references as we make must be made in elucidation of that merely which is to us highest and most essential. 
In America, it need hardly be said that Divine Personality found, in the speculative theism of Theodore Parker, far less clear and definite expression than might be wished. It may be recalled what extremely valuable service has been rendered, in the explication of the difficult and immense problem of the Divine Personality by Professors Harris and Fisher, both of Yale University, and by Professor Ladd, of the same University, from the philosophical side. And when we add the names of Professor Bowne of Boston, Professor Bowen of Harvard, and Dr Cocker, we have given but the barest possible representation of those who, in America, have, by their speculative power and metaphysical acumen, enriched the philosophy of theism, as touching the personality of the Absolute. Among the many recent American writers who have touched on the theme, Dr Francis E. Abbot, late of Harvard University, has insisted on the universe as "at once infinite machine, infinite organism, and infinite person-as mechanical in its apparent form and action, organic in its essential constitution, and personal in its innermost being."

In Britain, Dr James Martineau-clarum et venerabile nomen-has, with his wonted brilliancy and power, shown that there is not, in the known cosmos, any higher fact than that of personality. $\mathrm{He}$ has very finely shown the contrast between the physical and the spiritual spheres, in the former 
of which things tend to unity, in the latter to "new centres of self-consciousness and causality," and has strenuously resisted pantheistic depreciation of personality. He has guarded personality in created beings in presence of the immanence of God, insisting that it is not " $H e$ that, under the mask of our personality, does the thinking" and the rest. As against those philosophers who profess to be jealous for the infinitude of Deity, he has argued, on the very ground of $\mathrm{His}$ infinity, for power or right on the part of Deity to limit His infinitude in the interests of man's personality and freedom. He has protected personal possibility in Deity, Whose personality he takes to consist in His "voluntary agency as free cause in an unpledged sphere," against being measured by the actual cosmos. Theistic philosophy has thus come better to apprehend that there is no reason why we should not welcome the thought of self-imposed limitation or restraint in God. Do not we at least know how often restraint or self-limitation may be a mark of power, and a way to perfection of result? The ambiguity of Hegelianism as to the personality of the Deity has been keenly analysed by Professor Andrew Seth of Edinburgh, who holds it to fail of ascribing to Him real existence, so issuing in a breakdown of the system, which leaves us with "a logical abstraction styled the Idea, in which both God and man disappear." -We are far from insensible to the varied splendours of Hegel's system, 
and hence concede that Dr Sterrett's criticisms of Professor Seth's positions are at points not without skill and possible warrant, but we are compelled to think his success more verbal than real, and likely to have been not so partial had the influence of Hegel been-for one so finely gifted with the anima naturaliter Hegeliana-less manifestly overpowering. Times at least there are when Dr Sterrettdelightful as his work must be to every philosophic mind-seems to fail of doing perfect justice to the case for Seth's human personality, through bringing it, without sufficient regard to Seth's emphatic aspect of self-surrender, so much within the overshadowing influence of the Absolute Divine Personality. An able and still more recent writer of our own, Mr Fairbrother, in like manner tells how Green would have repudiated any philosophy in which this "individual self-hood is obscured or transformed into something else." Why, then, should Mr Fairbrother be so wroth with Professor Seth and $\mathrm{Mr}$ Balfour for insisting on this same retention of the self? Why should the "feeling of helpless bewilderment" on this writer's part fail to see that he leaves untouched the Seth-Balfour criticism in its most important points? He has done but little, if anything, to show that the self or human personality is maintained as intact in the $\mathrm{Neo-Hegelianism}$ as it should be, even in relation to the Divine. He has done nothing whatever to show that Green has done what Professor Seth 
properly demands-namely, maintained an essential "subjectivity" for God, a "real consciousness in God," a "Divine centre of thought, activity, and enjoyment" such as shall amount to a true and absolute Personality in God. Theistic philosophy seems to us to have very unequivocally maintained that what the human personality finds in the hour of deepest surrender is just perfection of the true self or completeness of personal being. It will have no construing of religion as the consciousness which the Absolute has of itself, and it will give way to no Hegelian proneness to annul, in virtual manner at least, the human spirit in its distinct individuality. It decisively rejects any ontologic idealism which sacrifices feeling and will on the shrine of abstract thought, for it has spiritual interests to be thus saved. Professor Flint has recalled thought towards a speculative theism in which the personality and transcendence of Deity shall not be sacrificed; and to a conception of Deity in which are ably exhibited the completeness and perfection of personality. Dr George Matheson, in his original and suggestive manner, has, in his reconcilings of theism with evolutionary science, finely preserved "the personality of the Power that transcends the world." Nor must we fail to speak of $\mathrm{Mr}$ Illingworth's well-conceived and beautifully written Bampton Lecture on the subject, even while we might have welcomed much stronger treatment on the speculative side. $\mathrm{He}$ 
has well declared how, while all around us seems rigorously finite, personality alone suggests infinitude of life. Among other writers, Miss Cobbe declares for the personality of God-urging prayer as an aid to the maintenance of this belief, as does also W. R. Greg, but in less assured strain.

We believe that the deeper study of the psychical and physical aspects or elements which coexist in ourselves has been begetting a more real sense of the possibility which exists of a psychic unity higher than ours which may be viewed as cosmic, and which may not be personal only on the supposition that it is more than personal-what is styled by Emerson "the super-personal Heart." This is the position advocated in Dr Bradley's recent 'Appearance and Reality,' where it is declared that fortunately the Absolute-the representation of Whose nature and relations to all things relative does not seem to us here specially fortunate-has so much more than personality that to call it personal would be no less absurd than to ask if it is moral. "It is better," says Dr Bradley, "to affirm personality than to call the Absolute impersonal. But neither mistake should be necessary. The Absolute stands above, and not below, its internal distinctions. It does not eject them, but it includes them as elements in its fulness. To speak in other language, it is not the indifference but the concrete identity of all extremes. But it is better in this connection to call it superpersonal " ('Appearance and Reality,' p. 533). We 
think it would be distinctly better rather to avoid calling it super-personal, and to make it simply full or perfect personality. Dr Bradley's conception of personality is lamentably defective and even conspicuously unjust, when he says we "want" a Deity "of course finite-a person much like" ourselves, "with thoughts and feelings limited, and mutable in the process of time." Defective, indeed, must the comprehension be which does not understand that we want nothing of the sort, but a Deity very unlike ourselves because purged of every accidental limitation we possess. That such a person can only, as person, be finite, is no more than an unwarrantable assumption that adds nothing to the credit of the speculative powers of those that make it.

The need has emerged for more thorough treatment of the ontological-and not merely historicalaspect of personality, in view of the contentions of those who, like Dr Bradley, profess to regard personality as illusion, and to view the question of personality in the Absolute as of no intellectual or practical consequence. But this is, of course, perfectly compatible with our acknowledgment of the worth of the historic treatment of the category of personality, the very wealth of which can only be exhibited by adding the experience of the race and its objective thought to the results reached, through subjective analysis, by the individual. Personality is a late result of prolonged experience and profound reflection, and no deeper unwisdom marks the age, 
in our view of it, than any tendency to sit lightly by personality. Could we see the immanent connection of history interrupted, or, better still, completed, by the encroachments of a Higher Power, that Power we might take as a personal one. But then there is the question whether the end of history need be set in relation to a Higher Guiding Power, or only viewed as an end realisable in the richest possible development of humanity. But the historic inquiry we do not here pursue.

Theistic philosophy has not forgotten that Spencer it was who knew enough of his Unknowable to be able to assure us that choice "lay between personality and something higher," and further, that there may be "a mode of being as much transcending intelligence and will as these transcend mechanical motion." It refuses, on such grounds, to lose the religious interest in the morass of the Unknowable, where foothold is clearly impossible. It is not unmindful of the fact that if $\mathrm{He}$ were not personal in a way to which we may not attain, then the progressive apprehension of His thought by our minds would be as meaningless as would the gradual embodiment of $\mathrm{His}$ will in our progressive civilisation. It recognises that it is in this high sense of personality that Pfleiderer and Paulsen aver the impossibility that God should be infra-personal. The same, it need hardly be said, holds true in the case of Lotze, who retains "perfect personality" as a special preserve of Deity. Not, let it be said, that 
we regard Lotze's treatment of personality as satisfactory, for we think Pfleiderer effectively criticises Lotze's speculative theism when he shows how the finite parts dwindle, in Lotze's hands, into differences of a merely ideal character in the Divine thought, in order that the personality of Deity may be maintained. Lotze appears to us to have been smitten with an excessive fear of conceiving the Divine Being as an "extra-mundane personality," which, among other unsatisfactory results of his system, led to finite spirits being subsumed under the one allembracing Whole in a strangely unreal manner. An unsatisfactoriness, of course, resulting from Lotze's treatment of the relation of absolute and relative too much as though it were but one of whole to parts, and leading to an oscillation between acosmism and pancosmism. But theistic philosophy, keeping in view all that has now been advanced, has also remembered, and yet more forcefully pointed out, that, as against the objection to our likening the Deity, as personal, unto ourselves, the personal representation of God-Who, in Christian Theism, is the Triune God-is the highest and worthiest, the fittest and most intelligible, we can form, and that, besides, in so forming it, we are still leaving open the full possibilities of belief in any attributes He may possess other and higher than those personal ones with which they yet cannot conflict. Ultra-personal $\mathrm{He}$ may thus be, but not in such sense that personality shall thereby be excluded. 
Dr F. H. Bradley says that "feeling, thought, and volition have all defects which suggest something higher." Yes, something higher, but not necessarily something different: the Perfect Personality is such just because these defects do not hide in Him. When we say $\mathrm{He}$ is personal, we do not deny the uncomprehended background of personality, to which we have just alluded. But we do say that, however certain scientific conceptions, such as force, law, matter, substance, may have purged themselves of anthropomorphic elements, they are yet no more supra-personal than is theistic philosophy. Whatever subjectivism is chargeable upon the one is equally chargeable upon the other. Of course this reference to the imperfection of scientific conception is now made only as a passing matter, and because it is so often but dimly perceived from the scientific side how incomplete its own position is. The needed completion or perfection of all our conceptions is that which religion professes to give, and which theistic philosophy professes to seek in its Urgrund or personal First Principle.

When we postulate the personal Deity, we know what we worship: we know how partial is our knowledge of Him, but yet how much more real and rational is our knowing $\mathrm{Him}$ after the analogy of all that is highest in our free, conscious, spiritual experience, than any blind taking refuge in the unimagined sublimities of the Spencerian Inscrutable Reality and Incomprehensible Power, which as- 
suredly could only mean a grand spiritual and philosophical anti-climax. Who would ever think of ascribing personality to such Unknowable reality? Or who could think of being satisfied simply with power, as the ultimate of ultimates in the synthetic philosophy? Reality remains for theistic philosophy bound up in the bundle of life with personality, for to that philosophy there is no more reality without a person who determines it than there is thought without a thinker who affirms it. Certainly the relative is to it real, and is not to be regarded as mere appearance-mere schein of the Absolute. And as to the Being of God, may we not say it maintains an objective reality of the personality of God, and is not content-with certain German and other thinkers-to postulate for His personality merely a subjective reality for the soul? Is it not just as our thought enters into those conceptions of personality which are the highest attainable to us that we come to any worthy sense of the transcendent nature and untranslatable fulness of the Absolute Being? Is not theistic philosophy justified in regarding the supra-personal mode of conceiving God as a way of dismissing Deity from human thought and experience altogether, and of neutralising the operations and sanctions of moral law? Is it not with reason that we have seen recent philosophy of theism more keenly demanding at once the Spencerian right to postulate super-personal life in such a way for Deity, and the mode or sphere in which 
such super-personal Presence or Life can be held to manifest itself? Is it any wonder that it should insist on God being in His nature capable of entering into relations that are inter-personal, on the ground that to think of Him otherwise would be to leave Him a Being so entirely without relation to all that is highest in us as really to be beneath, and not above, human personality? But in this connection we may say, as Professor James Seth, in a recent article, justly observes, that "surely the true Absolute, the true Noumenon, should rather be found in the completed system of relations than in the Unrelated; surely in the progressive apprehension of universal relations we are gradually advancing in the knowledge of reality itself."

If, then, God is, as one has expressed it, " in some high and intense sense personal-in possession of His own thought and character and will-is there no need that somehow at some stage His revelation should take personal character?" We venture to think it has been more clearly realised, in our late philosophy of theism, how it is of the essence of personality to overflow in self-communication, whence the self-revelation of Deity becomes explicable. Such outflow of the energy and the thought of the Absolute towards the human soul is seen to be possible, rational, and even probable. For, as it has been put, "how should related Spirits, joined by a common creative aim, intent on whatever things are pure and good, live in presence of each 
other, the one the bestower, the other the recipient, of a sacred trust, and exchange no thought and give no sign of the love which subsists between them ?." Yes, and from the other or human side the agnostic position is to be clearly taken as consisting of an unwarrantable arrest of reason's movement. For what right have we to maintain the truth and fact of the Divine Noumenon or Absolute Reality, as something that, though supersensible, lies open to our knowledge and view, and yet to ban all knowledge of the nature or character of said Noumenon? What need is there to give way to the imbecility of a philosophy that rears such unjustifiable barriers to reason or sets such bounds to knowledge, as though the universe were of a kind not to be everywhere penetrable by reason?

We may not here go into the related question of miracle, as the pledge of the reality of this revelation of Deity, further than to say that theistic philosophy has not failed to ponder in its heart the saying of Zeller, that the miraculous is an immediate consequence of theism. No, nor to retain in view the word of Steffens, who, in his philosophy of religion, says that "Christ could not be bound by any condition of nature, His entire significance consisting in this, that $\mathrm{He}$ proclaimed to us the unconditional freedom of spirit." Personality, it has been said, will express itself rather "by individual words and deeds" than "by eternal pro- 
cesses." Much more will it do so by these than by inanimate laws of gravitation and molecular attraction, since these latter are less in keeping with those analogies of personal life and consciousness which may be corrected in what they teach us as to how God may be worthily conceived, but which may not be abandoned. We do not forget, as has earlier in this chapter been made manifest, how the real personality of God is being imperilled by idealistic evolutionism : it were absurd to think of an immanent Cosmic Consciousness as though it were personal Deity. What other beings of thoroughgoing reality does it recognise? If it cannot, does not, recognise them as personal entities capable of reciprocal relations, wherein is its own essential personality? What psychic acting is there in this Cosmic Immanent Mind leaving to me, to all, the possibilities of real freedom ? We maintain that modern science has only more fully disclosed the wisdom, power, and goodness - the thought, will, and feeling-which form the essential manifestations of personality in the Infinite. The scientific realism of our time has certainly tended to cast idealistic evolution, with its treatment of the universe as purely phenomenal, into the background as so far unsatisfactory. It is but just to say, however, that it is precisely in depicting the living process of absolute spirit, and in tracing the inner movements of spiritual activity, that the philosophy of Hegel stands pre-eminent. We 
account it a notable advance in Hegel that the Absolute-the Ding-an-sich-was by him rescued from the shadows of cloudland and made to stand out in its reality, richness, and totality, to our wondering view. For, in his conception of the Absolute, all the actual world-processes of evolution and development are seen to be but externalisations of pure immaterial thought, which, dimly perceived by us, are, on the timeless view, fulfilments of an order that is Divine. But surely our anthropomorphism will have carried us an extraordinary length when it shall lead us to believe that only in the world can the Absolute realise itself, that only in man can it become self-conscious, and that our consciousness is indispensable to the growth and enrichment of the Absolute. A strange Absolute, verily, that is reduced to such a position of virtual dependence! A merely potential Absolute-than Whom there must be higher actuality-can be no God of any thoroughgoing theistic philosophy.

We believe our recent philosophy has indorsed what Franz Hoffmann so well pointed out, as to the personality-pantheism originated by Schelling, and exemplified in Lotze's not very self-consistent personal pantheism, that "if God is personality, the world cannot be $\mathrm{His}$ actuality or realisation, because, whilst a person may work and bring works into existence ad extra, $\mathrm{He}$ cannot have His own actuality outside; and if the world is the actuality of God, God cannot be personality, because a per- 
sonal being cannot be constituted by an infinitude of transient unconscious and conscious existences." By M. Saisset and others it has been rendered more manifest how the personality of God is maintained by pantheism only and always at the expense of personality in man, owing to its false emphasis or exclusive stress on the Divine term or form of personality. Not without satisfaction has recent philosophical theism found that expounder of late Spencerianism, John Fiske, say in his 'Idea of God' that " the final conclusion is, that we must not say that 'God is Force,' since such a phrase inevitably calls up those pantheistic notions of blind necessity which it is my desire to avoid; but, always bearing in mind the symbolic character of the words, we may say that 'God is spirit.' How my belief in the personality of God could be more strongly expressed without entirely deserting the language of modern philosophy and taking refuge in pure mythology, I am unable to see." We need not dwell on the vague and imperfect theism of the philosophic Vatke, whose concrete monism seemed to favour a suprapersonal view.

Recent philosophy of theism has been as little able to rest content with such meagre, abstract theism as that of Biedermann, to whom, in his able and too little studied treatment, the Godhead yet transcends the realm of Vorstellung, and in whose train Pfleiderer and others follow. Bieder- 
mann sharply distinguishes between spirit and personality, the latter of which he confines to finite spirit. He does not regard spirit and personality as identical conceptions, but attaches to the latter an individual corporealness. Theistic philosophy, however, does not transfer accidental limitations of personality to Deity. Biedermann, with his unwonted clearness, great warmth, and rich speculative power, dwells in his 'Dogmatik' on the irreconcilableness of absoluteness and personality, which latter is reached viâa eminentice. He thinks that, in the conception of personality, the mind objectifies the absolute and eternal nature (Wesen) of God. In the individual he finds potential finite spirit; in personality actual finite spirit. But absolute personality is to his view a contradictio in adjecto. Now, it is sheer inconsequence or arbitrariness for Biedermann to withhold predication of personality from the Absolute, when his admission of consciousness and self-consciousness-those essentials of freedom and intelligence-are considered. Nor does his position grow, less inconsequential when he-in spite of the impersonality of the Absolute Spirit-asserts the inability of the religious consciousness to do without the personality of God. If thought forbids us to view the absolute spirit as personal, why, we ask, not boldly drop the illusive glass with which religious experience vainly thinks to view the absolute object as objective fact? Does it not belong to the very essence of any living or worthy faith that it 
should not concern itself with mere subjective truths or representations, but with a real Divine Ego-One who can hear, and help, and save us? We have surely now seen that Biedermann's assumed freedom from arbitrariness (nicht willkiurlich) has not kept him from-arbitrarily, as we think-ascribing to spirit, since he so holds the Absolute to be spirit, a freedom from limitation which he inconsistently denies to personality. But in this way is it hoped to avert the reproach of pantheism while thus denying the personality of God. But when Biedermann allows personality to be the adequate form of representation for the Christian idea of God, is it not a poor Personality that is so easily dissipated before the thought process?

Lipsius holds to an infinite will and consciousness as necessary to our thought - to spirit which is personal, self-conscious, and self-determining. The thought of His personality we reach (viâ eminentia) on the path of gradation or ascent (Steigerung): the thought of $\mathrm{His}$ absoluteness we reach (viâ negationis) by the path of negation. , Lipsius sets forth at length the time and space difficulties in relation to the absolute consciousness and will. But he knows no way of reconciling the personality of Deity with His absoluteness, since our hold of the Absolute Personality is not due to objective theoretic knowledge of the Divine Essence-a knowledge which transcends us. Indeed, God's personality is to him a mere figurative 
expression (bildlicher Ausdruck), whose objective worth is not apparent to us. But then, the religious consciousness gives its testimony (Aussage) to the Divine Personality, and does so in the clearest possible manner, according to the language employed by Lipsius. In religious relations, according to him, God makes Himself known to the pious as personal Deity, as a THOU over against the human I, just as man in prayer places himself over against God. Yes, but if we can by no categories of thought lay hold of the transcendent reality, no immediate religious experience can prove the truth of the Divine Personality, or do more than bring us under the influence of a purely subjective illusion. Yet this is just the practical result to which Lipsius must be held to lead us, for he deems the critical understanding justified in all the artillery it directs against the notion of personality in God whenever that testimony of the religious consciousness is turned to metaphysical account in the interests of the objective being of God in Himself.

There need be no insensibility to the worth of Professor Pfleiderer's fine spiritualism in remarking that, while ranking himself among those who hold God as at least-whatever more $\mathrm{He}$ may be-personal, he straightway eviscerates personality in Deity of such real content as we find in the personality of man, self-determining and free. As to His freedom of agency, Pfleiderer's Deity stands 
related, in a system tinged with Naturalism, to the world in such wise that $\mathrm{He}$ is precluded under any circumstance from miraculous interference. Finely, no doubt-though with what self-consistency is another matter-has Pfleiderer said that "if we are shut off from each other by the limits of individuality, in relation to God it is not so: to $\mathrm{Him}$ our hearts are as open as each man's own heart is to himself; He sees through and through them, and $\mathrm{He}$ desires to live in them and to fill them with $\mathrm{His}$ own sacred energy and blessedness."

Let it be here said that we find no great colour of likelihood in the idea of those who think religious inwardness may be strengthened by the socalled pantheistic representations of God. To point to experience as showing the possibility of fervid surrender through the pantheistic intuition is to overlook of what weak sort such pantheism is. Such intuition, fancy-fed, as we find, where religious inwardness reigns, must be quite unacceptable to philosophic pantheism, which puts at a distance every determination of Deity. But can any philosophy of theism regard the religious interest as surrendering itself to denuded or undetermined Deity? Can it do without an actual Divinity, to Whom we owe not only life, but also the absolute worth imparted unto life by its supreme end being communion with the Deity? Can it forget that this implies such an active relation and influence, on the part of Deity toward us, as shall 
overpass any mere relation of causality? Theistic Philosophy has pressed on to such conception of absolute personality as shall, in a true elevation (Aufhebung) or reconcilement, satisfy the Christian concept of God, the Scylla of the naked transcendence of Acosmism being shunned equally with the Charybdis of the stale transcendence of Deism. We do not find any conclusive force in the exception which has been taken to Dr Martineau's doctrine of Some-Transcendency, because of his holding creation to be an eternal act. We grant that transcendence may, everything considered, be thereby more difficult of conception; but the reasons urged do not seem to us to be sufficient to warrant theistic philosophy in abandoning transcendence as belonging to its complete conception of the personality and freedom of God as the supra-mundane, selfexisting subject. We are, therefore, with Lotze when he asks whether it is not effrontery to narrow down the Spirit of the universe to a series of events on this planet. Such a true and transcendent existence for Himself we must postulate for Deity, if we would not have the immanence tendencies of to-day leave us with no Deity but the impotent God of pantheism. It does not seem as though our spiritual life could rise to independence without raising itself to a supernatural or transcendent connection, although it must, for the maintenance of real contents, instantly return to the world that is here. In fact, it is this ceaseless movement be- 
tween the two which seems to fill our spiritual life with real contents, and to bring a constant deepening of our being. Our fundamental conception of reality must be so vast that the supernatural or transcendent is no mere ulterior thing for us.

It should in this connection be borne in mind that the votaries of pure immanence-systems have not extricated themselves from the difficulty in which the fact of evil has placed them. For what place for evil should be found in a system of immanent reason only? It deserves to be more specifically noted than has yet been done by us that recent theistic philosophy has quite decidedly left behind the haltings of those who in recent years have predicated reason and freedom of the Absolute Being, to which they apply the term spirit, and from which they withhold true conscious personality. For it sees how manifestly they have failed as yet to distinguish with thoroughness between the accidents of personality and its essence, to the latter of which the limitation supposed to attach to personality does not belong. What more absurd than this treating personality as a limitation, when, in its self-developing and all-embracing activity, it really forms the outlet by which limitation is eluded! We regard the objections to the personality of God which have come from the pantheistic side as wanting in validity by reason of the fact that they set out from a representation of the infinity of God at once untenable - as we 
have shown-and unsatisfying to the religious need and interest. We hold that such knowing and acting as are involved in religious communion, when that communion is viewed in a pantheistic colouring - say, from Spinozan, Schellingian, or Schleiermacherian view - points - are not to be thought of without a fortunate subreption, an unperceived drawing upon theistic modes of representation. The infinity of God-an infinity which here means not something positive, but merely, let us say, the fact that God is not a finite entityhas been said to be endangered through personality. But it is not realised that it is precisely in denying Him the power of being personal, or of so limiting Himself as to allow us to be personal, that $\mathrm{His}$ infinitude is already parted with. This self-limitation of the Infinite-the great renunciation - is yet really its self-assertion and its selfrevelation. We cannot represent to ourselves an infinity of being, nor can we a qualitative infinity of force. Force has, for realistic thought, no meaning, so long as it remains a mere potence, and assumes not determinateness somewhere. Taking God as the principle in which the world is grounded, what then is it, it may still be properly asked, but a veiled dogmatism which proceeds from the contrast in which God stands to the world, to construe His relation to it as one simply of difference on every side? Why should it appear so credible a thing that God should sustain to the world a re- 
lation of simple difference on every hand? Has idealism no more truth for us when, in dealing with the living reality of the world, it sets it forth as what is known as objectified spirit? What sort of place shall yet be reserved for Him in our thought when the highest essence shall really appear to be the vast system of world-reality, eternally at rest, only appearing to us under guises of change and causal event? Is it only thus we have pressed beyond the region of pure unintelligibility to find in Nature the infinite organism which is the product of the Infinite and self-conscious Mind ?

We do not profess to share the position of those philosophers of our time who treat inquiry into the theoretic aspects of infinite in relation to finite as mere wandering in cloudland. We begin by accepting the Infinite as meaning not the really negative thing implied in mere indefinite extension beyond limits, but the positive conception of it as ground of all unity, root of all being, and condition of all consciousness. It is as sharers in the Infinite that the infinite is capable - by the "cognitive leap" - of being perceived by us. And we go on to ask, What valid title has ever been adduced to assume that the absolute consciousness in God cannot coexist with His relative consciousness, which latter is the source of all dependent being and result? By what right shall we deny this freedom of the relative to the Absolute, and that, too, without prejudice to His absolute perfection? Is $\mathrm{He}$ not still the 
Absolute Personality, when we have allowed Him in $\mathrm{His}$ objective action the freedom of the relative? And, if that be so, what is to be said of those who hold, with Dr Paul Carus, speaking in the name of monism, that "an absolute God, just as an absolute soul, is not distinguishable at all from a ghost," and that "the idea of a God, absolutely existing, has become a superstition"! Everything is thus plainly "a part of the All" in a sense in which the soul of theistic philosophy can take no pleasure. Undoubtedly the God set up by Dr Carus as super-personal and as the Eternal of nature is a Deity historically non-existent, even in the case of those who thought the super-personal conception was theirs. $\mathrm{HE}$ is set up, besides, as part of a system which is self-destructive and irrational; for to it personality belongs not to God, exists for science only as illusion, and yet-mirabile dictu!forms the basis of man's moral activity.

Not thus has theistic philosophy forgotten that it is just personality itself-the thing questionedwhich determines what is reality, and what illusion. For to it, amid those shifting illusions and changing theories which make up, in the world of thought,

"The infernal hurricane that never rests,"-

"La bufera infernal che mai non resta,"-

the personality of the Deity is that which abides as changeless soul and centre of all things. Seeing that we shall, in the chapter on the "Per- 
sonality of Man," build up an argument for the personality of Deity on the ground of our own true personality, let it be here said, to prevent misconception, that, in so doing, we are indeed far from wishing it to be thought that, in those hours when the sense of our own personality has least hold upon us, we may not adhere to the absoluteness and personality of Deity as forcing themselves upon us-in fact, peering through every pore of the universe. Woe is his who in those hours shall not find it so! The sense of self gone, and no Absolute Personality pressing any sense of Itself through the universe upon him, he, in a universe so mindless, can but fall a prey to a devouring Materialism or-if any prefer-an engulfing Pantheism. $\mathrm{He}$ is, in any case, left with nothing but what, in the most tragic issue that can present itself to any human being under heaven, the poet Shelley, not without touch of sublimity, styles,-

"The wide, grey, lampless, deep, unpeopled world!"

How then shall we represent to ourselves this personality of God? Do not the practical proofs of Himself given by God to us as $\mathrm{He}$ works in the world imply such a succession in these proofs or effects as already involves a time course-a course in which God may be said to be the moving impulse of

"Time's pauseless feet and world-wide wings"? 
To the postulation of such a temporal succession for the Deity both Pfleiderer and Lotze seem to feel pressed, the latter by statements of his own, although he has elsewhere advanced the timelessness of Deity. We are free to confess ourselves by no means so convinced of the inconceivability of the spirit positing "itself out of itself" and finding "itself submitted to the condition of time," as Professor Veitch, when inveighing against the Hegelian view in his 'Dualism and Monism,' seems to have been. This we say as to the root-question of the spirit's passing into time -the manifestation of the Absolute in the timeprocess, which else were illusion - without, of course, committing ourselves to the Hegelian philosophy of history in its entirety. Surely it has grown very clear that no evolution can really bring forth Time, and that Time is the necessary presupposition-thanks most of all to Kant-even of our understanding evolutionary processes themselves, or the successions that appear in consciousness. If the world-process must needs be in real time-time which is but the presage of eternityand if God should act upon the world within this time-process, what necessity exists for reason either that we should deny Him the power of any but an absolute mode of action, or make Him so subject to change by $\mathrm{His}$ objective action that $\mathrm{He}$ should be no more eternal while the time-process lasts? Is it to come to this that Deity shall not 
regard anything finite or do anything objective, but $\mathrm{He}$ shall thereby render His own absolutely self-determined nature subject to lessening change or modification? Is it only thus we have learned to think the freedom of the absolute and independent Being? The philosophical assumption that there can be no relative consciousness in God is, of course, a really gratuitous one. May we not say the incompleteness involved in the worldprocess disappears as we regard the ultimate and self-determining principle therein manifested?

The question, of course, also arises whether spatial form is not as necessary to Deity as temporal succession is, for how save in spatial movement shall His working be conceived? What do we know of spaceless movement? What has a spaceless thing to do with reality as we know it? What power of movement, it might be asked, has unextended being? Not that space is any limitation to Deity's working, for only of His free self-activity have the working and intuition of $\mathrm{Him}$ been set for us in spatial relations. Not that spatial relations, strictly taken, are thinkable of thought and things affectional, even in the case of ourselves, for to these mental and moral phenomena such a category as that of space can clearly not apply. The world-process would not therefore be meaningless, were its process not in space; but we cannot think - whatever may be as to the real world - of His working save as to our imperfect 
thought it appears in a world where space seems infinite. Space may be no thing, in the ordinary sense, but it does not follow that space does not denote anything real. For real it certainly is real as a quality-real in the only world known to us. It is, according to the saying of Joubert, "the stature of God." Whatever may be said of the ideality of space and of ideal time-extension -a difficulty sorely felt by Biedermann, Lipsius, and many other modern thinkers - it will be observed that we have made the foregoing remarks less as abstract metaphysical discussions of the points mooted than as indicating matters that must be considered in their bearings upon the great question of the personality of God, as apprehended by us.

Of Space and Time, in their relation to Deity, Professor Royce finely says, " $\mathrm{He}$ is their universal, they are not His prison." Space and Time, indeed, are never to be thought of save as the blank forms of the possibility of Being, not as limitations of it. They are the conditions of Being so universal that we cannot even speak of God as existing "outside of Space and Time," without flinging ourselves against a two-edged contradiction. In the very notion that God "exists," there is presupposed that element of Time which the thought of "outside" was supposed to banish. And the conception of the "outside" of space presupposes no less that element of Space which was to be done away. We must, in fact, never delude ourselves by supposing that ideal- 
istic philosophy has deprived the categories of every sort of real and objective existence, for it is impossible but that such forms of thought should continue to be real. So, then, no other being, and no forms in which the finite manifests itself, can limit Deity or reduce $\mathrm{Him}$ to the finite. We do not enclose the perfect Being Whom we call God in the infinite extension of space: we do not include Him in the infinite succession of time. No, we prefer to ground Space and Time in Him, rather than appear to set them above Him. Rooted in $\mathrm{Him}$ at last they must be, if any sort of objective validity or existence should be claimed for them. In relation to ourselves, we now recognise how, of these, Kant, victim of various untenable assumptions, treated space not as real mode of existence, but as its very condition; how he put all things for us in subjection to the laws of spatial intuition, since space is for him an $a$ priori form of cognition, not derived from objects in course of experience. As to time, how he failed not to appreciate how primitive is the idea of time-which, with him, is a priori in the mind -as to experience, which for us is only its illuminating power. No doubt, the finitude of the real can accord with its infinity in thought, but what we are now concerned with is the objective reality of space and time, that Being may not become to us inconceivable. For space and time, it must be said, are not the exclusively subjective things which Kant supposed, but are also, as actually perceived and 
known, objectively real. Obviously, for us, as being ourselves in time, no real or definite conception can be formed of timelessness, in the sense of out of time. We know God in the time-evolution, and this knowledge of $\mathrm{Him}$ is valid and real-the only one indeed possible to us. In fact, when we shall have succeeded in setting God out of all Space and Time, we shall have succeeded in banishing Him from the universe altogether, and it is just as well to realise the fact.

Our late philosophy of theism has profoundly recognised the fact, therefore, that it is an utterly invalid objection to Personality in Deity, when it is urged that personality pertains to time, whereas Deity is eternal in the sense of out of time. It has more truly welcomed the fact of the Divine Personality which in this connection has been so finely voiced for us by Schiller in his poem, "Die Worte des Glaubens":-

"And God is! a holy Will that abides,

Though the human will may falter;

High over both Space and Time it rides,

The high Thought that will never alter :

And while all things in change eternal roll,

It endures, through change, a motionless Soul."

"Und ein Gott ist, ein heiliger Wille lebt,

Wie auch der menschliche wanke;

Hoch über der Zeit und dem Raume webt

Lebendig der höchste Gedanke,

Und ob alles in ewigem Wechsel kreist,

Es beharret im Wechsel ein ruhiger Geist." 
Our late philosophy has also more deeply recognised the necessity laid upon theistic thought by the exigencies of the time to complete its conception of the Absolute, wherein personal attributes are purified rather than annulled, in the Christian doctrine of God, and to find the abiding guarantee - for intellect-of the self-conscious Personality of God in those Trinitarian conceptions of Deity which, in their amplitude and complexity, only mistaken thought has ever found other than helpful to a truly rational faith. May we not say that, resting rather in the concept of substance than in the notion of a Heraclitean flux or stream of being, recent theistic thought has based its conception of the WorldGround or Substance in the idea of the Absolute Personality-has indeed made the Personality of God stand out for us always more clearly as its fundamental or basal conception? Why should we not retain in such wise the notion of substance, avoiding the Spinozan conceptions of infinite substance, with kaleidoscopically changing performances, but no real capacity, in its timeless constancy, to prove the ground of a real and advancing development? What earlier metaphysical presupposition can we retain than just this of the Absolute Who, as self-existent Personality, is the supernatural Ground of the world, with which and the natural or phenomenal a synthesis is to be affirmed? Where, save in this personal conception of Deity, shall we find such warm breath of life breathed into 
the Divine Actuality as shall make the self-determination we postulate for Him a thing of living content? May we not say that no reason has been found why being - as internally personalised and externally individuated-may not embrace a plurality of distinctive and personal manifestations? May we not indeed doubt whether the conception of sole and eternal, unique and unrelated, Personality, ever assumes any perfectly real form for our thought so long as it does not carry within itself the essential conditions of Supreme Personality, conditions such as may conceivably be satisfied in the workings and satisfactions of Triune Love? This unity of Love Divine-the Unity of the Spirit-has surely been grasped as a far richer, more real, more profound unity, than any mere numerical oneness or arithmetical singularity that can be predicated of the Absolute.

In some such way, as we have tried to show, our late philosophy of theism has presented absolute, self-conscious personality in God as-in Hegel's fit and striking phraseology-the steepest and loftiest summit (die höchste, zugeschärfste Spitze) to which its thought has been able to advance, and has maintained for $\mathrm{Him}$ an absolute consciousness as a thing void of inherent contradiction. In doing so, it has fully met the pantheistic contentions that personality is a determination, and consequently a negation - a negation not fitly applied to describe One Who of all beings is the most 
real. It has opposed the use of the Spinozan saying, Omnis determinatio est negatio-every definition is a negation - in the hands of all who dismiss absolute personality as a mere contradiction in terms, and make it, with Strauss, a non-ens, something really unthinkable. Theistic philosophy has made it abundantly plain that personality, as involving limitation, is no more to be withheld from the Absolute than are some attributes which have not caused the same hesitation. It has shown, in fact, that it can be refused only with the consistent result of reducing the Absolute to purely indeterminate being, or to an empty abstraction, all the while that His supposed self-limitation is only a real perfection. But such a merely logical abstraction or being in no way definite, theistic philosophy refuses to recognise as its $\mathrm{Ab}$ solute, for its Absolute, as we have elsewhere maintained, comes into most real relations with us, takes the form of concrete being, and evinces its absoluteness by the fulness of its contents and the infinity of its power of self-determination. For its Absolute-the Infinite Personality-theistic philosophy postulates a Being-for-Self, which shall be wholly independent of anything that might be for it a not-self. Why should it not do so? Why should not the Mind of this Absolute be present everywhere in Nature as cannot be in the case of our limited and finite personality? Why should not the limiting and restrictive conditions of time 
and space, as we know them, be wholly wanting to the movement of this Absolute and Omnipresent Personality? Why should we unwarrantably persist in reading limitation into the notion of Personality, as if it had any place in the notion except in its finite aspect? Why should it be so hard to transcend our dualistic modes of thinking, and to see how, in the case of the Absolute and Infinite Being, the usual non-ego need not be called in, but His own activities may suffice for object? What need is there to suppose that, in the case of spiritual existences, the Infinite Being cannot pervade the finite, but $\mathrm{He}$ thereby becomes limited? Why suppose that the Absolute Being must be Himself all-inclusive existence, that nothing may so limit Him? The truth is plainly to be declared, that there is really no speculative warrant to assume that personality may not exist as absolute or infinite. It would indeed be strange to deny to the World-Ground-Source of all our knowledge and power - the power to know Itself and Its own cosmic or other activities.

Whatever force might be allowed to the contentions of those who refuse personality to the Absolute as bringing out the really incomplete character of finite personality, we cannot but reject them as unsubstantial in respect of Absolute Personality. Only in the Absolute Personality do self-determination, self-knowledge, and self-possession appear as really perfect and entire, wanting nothing, for our Abso- 
lute is a reality, and comes not in its infinite perfection under poor finite laws of development. Our Absolute is not the sheer nonentity of pure indefiniteness, not a void and self-destructive abstraction. It is an Absolute that feels no call to shun the definiteness which, as characteristic of all reality, never means limitation save in the most negative and absurd of senses. An Absolute, moreover, which claims only the absoluteness that reigns where self-hood, wisdom, will, and power are absolutely perfect and incapable of increase. Yes, intensive infinity is $\mathrm{His}$, and to $\mathrm{His}$ perfect Being no limitation or imperfection can be attached. Mere logical limitations are at length swallowed up in the abyss of reality that sums the theistic conception of the Absolute Personality, which is God. And why should it not be so? For, after all, why should we practically treat Personality in Deity as so different from personality in man?

Now, do we in any of those great forms of personal realisation or achievement that mean for us some form of self-imposed limitation, ever stay to murmur and complain of the so-called limitation as though it were to us a bondage and a humiliation? Do we not joyfully recognise that the laws of mind or of spirit under which we so rise to the personal realisation or accomplishment are not worthy to be thought or spoken of in their limiting aspect for the glory of the positive self-fulfilment and self-realisation which shall thereby be ours? 
Is it not equally absurd that this spectre of limitation should be so long in being laid with respect to Deity? The truth is that this bugbear of limitation is due to a radical misconception of what true personal being means. "Is it not a matter of fact," asks a modern apologist, "that the greater and higher a being is, the more perfect is his personality? Do we not see the creation struggling towards personality, and mounting step by step through the preliminary stages of the vegetable and animal world, until in man it actually attains to individual personality, and becomes a self-conscious mind? 'Whence this universal tendency of all that lives towards personality, if it be not the law of the world; and whence this law, if the Principle of the world is an impersonal one?' And if personality constitutes the pre-eminence of man over the inferior creation, can this pre-eminence be wanting in the highest Being of all? Can God, the most perfect Being imaginable, be devoid of personality, the most perfect form of being? Is God indeed the absolute and entirely perfect One, if $\mathrm{He}$ be wanting in any one excellence?" So, then, if we grant perfect existence to God, that existence is never to be viewed as perfect so long as we withhold from it absolute personality. By no other being can $\mathrm{He}$ be limited, to Whom all such being owes the very possibility of its existence. We therefore are in agreement with a German philosophical writer who has but lately said that 
"the Absolute can be thought to exist only as Personality, as a Spirit, Who in His Thought contains the Ground of all Truth, in His Feeling the Source of all Goodness, in His inner psychic Activity - His Will - the creative Ground of all Being, and, inasmuch as $\mathrm{He}$ enjoys the harmonious union of these three factors, $\mathrm{He}$ is also the Fountain-head of æsthetic Beauty." With such a Deity, we can, as theistic philosophers, look the whole speculative world in the face, and say,THIs is our GoD; we have waited for Him, and HE will save us: $H_{E}$ will be our Guide even unto death. 
PART THIRD

RECENT THEISTIC PHILOSOPHY OF RELIGION (MAN) 



\section{CHAPTER XI.}

RECENT THEISTIC THOUGHT ON FUNCTIONS OF REASON IN MAN.

IT was very well said by Professor Thomas Hill Green that philosophy is the result of a progressive effort towards a fully articulated conception of the world as rational. The ancient world seems to us to present nothing more striking than its faith in the greatness, power, and beauty of reason. We do not admit any purpose of the Divine Reason historically to dethrone reason in man from this sceptred sway. We even maintain the end to have been the stimulation of reason, "at the ultimate bound of her wit," to new flights in her sovereign greatness. To-day, no less than in Kantian days, the postulates of the reason are those which in this work we seek to maintain-God, Freedom, and Immortality. However splendid the testimony offered by character and conscience in the past, theistic philosophy has believed the time to have come for that testimony to be supplemented by a 
nobler witness of reason-as the universal element in all things, the unity which harmonises diversity -than any since the world was. Recent theistic philosophy has, we think it may be said, postulated with more firmness that the power and functions of reason in man - its creative power whereby it forms ideals intellectual, moral, and æsthetic, which it never ceases in the effort to realise, and its functions that disclose capacities for science and art, philosophy and religion-all point to a theistic interpretation. It has more boldly grasped the inherent force and universal sweep of the laws of reason, the essential oneness of reason in man with the higher reason in God, the Supreme Reason, Whose idea finds expression in all truths and laws. It has taken reason in us to imply an Absolute Reason, believing that

"The truth in God's breast

Lies trace for trace upon ours impressed;

Though $\mathrm{He}$ is so bright and we so dim,

We are made in His image to witness Him."

It has clearly seen the loving and eternal Reason that resides in the Sufficient Reason or Ultimate Ground it postulates for all other proofs or grounds. It has more truly found reason to be that which, as having its centre and source in God, hath no need of the sun, neither of that "sweet regent of the sky," the moon, for it is a light unto itself, and the final light of all things that are in the world. Hence the truth of what Professor Samuel Harris has said, 
" that man's reason sees the light of the universal reason; that what is the True, the Right, the Perfect, the Good which has true worth, to the reason of man, is the True, the Right, the Perfect, the Good which has true worth, to the universal reason of God."

Theistic thought has always more firmly grounded reason, as essentially active, in personality, for Cousin's impersonal reason it holds not in any sense that would rob us of responsibility for such gift. We grant, however, the merit of Cousin's psychology in his placing on reason, with its impersonal insight and absolute activity, the crown of mind, and in his endeavouring-not completely succeeding-to lead Knowledge beyond its merely local, relative, and personal character to forms that should be universal. The world's newer Theism has, in face of fearful odds, been seeking to enthrone reason as personal at the heart of the universein fact, so to recognise the omnipresence of reason as to render it co-extensive with creation and with thought. For that which it has found writ large over the whole of Nature's vast domain is just Reason-so large indeed as to lead our thought at length and irresistibly to an Objective and Ultimate Reason as Ground and Cause of all. Reason is for us that which interprets the primal self-activity, known as the Absolute, in terms of personal being-with the living unity which such being implies-and of conscious spiritual energy. We affirm that theistic philosophy has more vigor- 
ously asserted itself as heir of the Infinite Reason, and, as such, entitled to find in reason that which forms the key at once of reason itself and of all other things which the world can present. All which we regard as the result of its having more boldly believed, with Gratry, after Fénelon, that reason is even more wanting on this earth than religion. It finds, as touching all human and finite reasons, that the Infinite Reason, in Emersonian phraseology, carries them away as with a flood, but yet so that they renew themselves inexhaustibly by its inspiration. It has more clearly apprehended the constructive reason found in the universe as necessarily existent under such forms or conditions of reason as space and time, under which the Eternal Reason comes forth in Its constructive acts. Hence rationality is for it, we may say, something never fully reached, but to which it moves onward. Hence, too, the intelligibleness or immanent rationality of nature is for it always more truly the guiding light in nature's interpretation. It has more evidently seen the sway of reason as the seat and spring of orderly relations through which it finds expression for itself, and has more abundantly discovered the power of reason in the rational interpretation of the intellectual and asthetic order of the world. It has found the interpreting and synthetising reason more than ever making plain-and that in no manner of an easy-going Monism - the ultimate unity of truth, 
spite of the diverse elements and manifold forms in which it appears. The separate moments and conflicting opposites of the understanding are in this way taken up by reason and harmonised in a unity that seemed impossible.

The perfection of the culture of the human reason has been rightly sought by recent theistic philosophy in a genuine Metaphysic, capable of expounding for us that free and Universal Reason in which we live, move, and have our being. It has more wonderingly witnessed the functions of reason whereby the rational value of the worldsystem of interacting forces is apprehended, the conception of the universe as the thought of God assimilated, and the unity of general law grasped. What more central category of reality can we indeed suggest-speaking, that is to say, from the theoretic, rather than the ethical, view-point-than reason or thought? Under what higher authority or what more absolute obligations can man come than as he puts himself under reason? May we not say that theistic philosophy has been more clearly realising, and must still more clearly realise, the importance of that conception of God-the Omnipresent Ground and the indwelling Life of the finite -which is reached in obedience to rational and not merely emotional and practical needs-reached, that is to say, through what aid Dialectic may furnish, and not merely Apologetic-and in which He is apprehended as $\mathrm{He}$ appears in the timeless present 
and eternal activity of reason, so far as $\mathrm{He}$ can be thus apprehended by men who still stand within the world of experience? It claims such knowledge, of which reason is the pivot, to be truly scientific, since the process, by which the ideas of spiritual intuition are developed, proceeds according to the categories of thought, and is in character discursive and dialectic, no less than intuitive and ethical. However it may have joined hands with Kant in holding to the "primacy of practical reason," it does not - so we claim - sit loosely to the pure deliverances of the knowing reason. It has, in our judgment, advanced on the Kantian view of reason (Vernunft), for we are not of them that deny to theoretic or Pure Reason any of that ontological insight or vision which is so freely claimed for the Practical Reason. Nor is this to depreciate by a single iota the peerless function and worth of the Practical Reason.

Theistic philosophy does not allow that the rational is superseded by the ethical, but only that they dwell peacefully side by side as mutually complementary-the rational as much the complement of the ethical as the ethical is the condition of the rational. In fact, not only has the ambiguity of the term "reason". been more specifically brought out, but rationality has been more clearly shown to inhere as of necessity in that which is spiritual and moral, at least as much as in that which is ordinarily spoken of as merely or dis- 
tinctively rational. Nor does our philosophy allow otherwise than with Goethe that-

"Man, and man only, Achieves the impossible, He can distinguish, Elect and direct."

"Nur allein der Mensch Vermag das Unmögliche ;

Er unterscheidet, Wählet und richtet."

It is not too much to say that it has lately, with more skill and success, unfolded the immeasurable superiority of man's life, in its rational unity, to that of the animal, as that superiority is evinced in those lofty and self-directed functions of reason proper-what Rousseau styled the anti-natural state of conscious reflection-beside whose working within the sphere of truly spiritual law the so-called reasoning of animals, by means of recognised signs through laws of association, has not a shred of claim to be placed. These rudimentary types and foreshadowings presented by reason in animals it finds to be no more than-

" dim fragments meant

To be united in some wondrous whole."

"Ich sehe nicht die Spur

Von einem Geist, und alles ist Dressur."

Professor Lloyd Morgan, in lately dealing with comparative psychology, has, while claiming intelligence for animals, held that there is no proof of 
their perception of relations, and has denied to them the power of logical reason or inference. They may, in his view, inherit facilities for association, but no evidence is satisfactorily present of anything like hereditary experience, the associations being but individually acquired. Here in man, says Professor Calderwood, speaking of Evolution and Man's place in Nature, "in contrast with what is observed in lower types of life, both unintelligent and intelligent, reflection shapes the purpose which the agent afterwards makes an effort to fulfil. This is something entirely new in the activity of life; this presents the hardest problem in natural history" ("Proceedings of Royal Society of Edinburgh,' I 890). Though it has more freely granted man's connection, on his animal side, with nature, by ties of derivation, structure, and function, yet theistic philosophy has never found the animal overstep the limits imposed by natural law in its destitution alike of the unifying power and the spiritual possibilities of man. For it the antiquity of man has meant, not "the antiquity of the manape, but of the man-Adam; not of the man-like monkey, but of the God-like man." Of course, we do not mean that it has any hesitation or concern about man's inclusion within the boundaries of animal life or the range of animal inheritance. Why should it? Even Professor Huxley, while contending for " no absolute structural line of demarcation" between the animal world and man, 
and holding "the attempt to draw a psychical distinction" perfectly futile, asserts that "no one is more strongly convinced" than himself "of the vastness of the gulf between civilised man and the brutes," and no one "more certain that whether from them or not, he is assuredly not of them." Theistic philosophy finds, with Wallace, in his researches into Darwinism, that for the higher faculties found in man an adequate cause is only to be reached in the unseen universe of spirit. It finds, as we claim, such animal reasoning as exists to be quite lacking in the reflective ideality, and in the conceptual character, of reasoning or intelligence as it appears in man. It finds that not merely in virtue of our finely articulated psychic mechanism, but also in a qualitative manner through the capacity we possess of self-activity, are we differentiated from the animal world.

The rationalised character of man's physical life it finds properly emphasised by Professor Calderwood in his work on 'Evolution and Man's Place in Nature'-a power of rational discrimination whose significance is not to be mistaken. It has indorsed, as touching this "enormous psychical divergence," the position of Fiske when he affirms that " it is not too much to say that the difference between man and all other living creatures, in respect of teachableness, progressiveness, and individuality of character, surpasses all other differences of kind that are known to exist in the universe." 
That philosophy has been always more surely finding reason, which is grounded in will and forms the essence of personality, to be the highest power of spirit in man, with an imperative of its own which depends not on individual will but carries, as part of the natural order, the authority of objective truth. For, as Professor Laurie has well said in his 'Metaphysica Nova et Vetusta,' " it would be a strange thing indeed if the energy of Reason seizing the external found that the one did not answer the other-that the datum of sense defeated the process of dialectic, that the plastic power of Reason encountered material which it failed to mould." As he says later in the same work, "the outer is not merely an $x$ negating my self-consciousness," but, on the contrary, "it is Reason externalised"-_" as universal reason, it is one with the moments of my finite reason." The theistic philosophy has been still discovering its own vested interest in reclaiming every territory lost to reason. Even faith is seen to be something that must no more remain-as Mansel made it, like so many others-only receptive, but also be constructive, - in fact, must be a synthetising power that brings reason and will and conscience together, and out of their meeting finds ultimate and inexpressible ground for its convictions.

The march of theistic philosophy has been, and must still be, towards an absolutely fearless faith in reason, an unswerving confidence in the absolute 
harmony of true reason with faith, since reason is no more to be grounded in faith than is faith to be grounded in reason. These twain are no separable and independent-not to say antagonistic-organs or faculties. Hence reason, recovering itself from the intellectual impotence that settled on even Fichtean rationalism, now occupies a better defined relation to faith, which latter is always conditioned by prior and justifying assent of reason to its exercise. Yes; our faith is a thoroughly rational thing, for never do we allow it to rest in its reliance on the reason, wisdom, goodness, of any other without the sanction of reason to its confidence as based on adequate grounds and sufficient evidence. For all that faith receives on trust, a ground must instantly be found by reason. Differing as they do in their nature and scope, there is yet as little real antagonism between faith and reason-or faith and philosophy-as can be well imagined.

Simultaneously with what has just been advanced, reason, shunning the Nemesis that overtakes an all-inclusive reason in the Schellingian sense, has been more fully understood to involve an ultimate element of trust or faith, so that faith becomes what Pascal said, "the last step of reason." It still holds true that "faith is itself the highest reason, is simply obedience to the highest reason-the consummation and the crown of our intellectual activity. There is even more. Our primary beliefs, in the farthest analysis, are capable of being resolved into an inde- 
structible conclusion of the understanding. The deep, inward, ultimate ground, understood and felt by multitudes who cannot express it in definite words, is no other than this-our perceptions, our intuitions, our consciousnesses must be true, because otherwise our nature is a falsehood and our Creator a deceiver. This is the last, strong refuge of faith in the primary convictions." Surely the shallowness is past of men who deified knowledge and flouted faith, and knew not the scientific absurdity of what they did. Surely the day of faith-in its rationality and divining power-has slowly dawned, its light of knowledge born. Has not time been making always more manifest how, as one has said, "reason requires the nutriment and impulse furnished by faith," while "faith requires the discreet elaboration of reason"? But such faith is not the mere fruit of reason, as such: we must take account of the time-elements, the educative-elements, and the will-elements, which all go to build up rational belief in the soul. Can it be doubted that the appeal to this supreme faculty of faith-the faith of reasonis still-only more intelligently, perhaps, than ever before-the final resort of philosophy? But in all this the ideal of reason as "the unification of all belief into an ordered whole" which is "compacted into one coherent structure under the stress of reason," has been nobly-as, for example, in $\mathrm{Mr}$ Balfour's 'Foundations of Belief'-pursued in our latest thinking, even if it remain, and must ever 
remain, imperfectly realised. Such unification is to us at least a far more satisfactory thing to contemplate than merely such unity of a fancied spiritual wedlock as Christlieb depicted between faith and reason, so making faith the masculine partner of the union, while $\operatorname{Dr} \mathrm{M}$ 'Cosh precisely inverted this relation of things, making reason the masculine power, without which faith would be facile and impulsive.

Reason, intelligence; mind-it is this which the theistic philosophy has, in the way and sense now' indicated, more truly than ever enthroned; it is by such enthronement its largest advances have been made; it is with the numberless proofs of reason in its ever-widening range that the strength of the theistic argument has grown. For reason is, it must here be said, always the newest term in this world-one which has come to combine, fuse, interpret, and develop every existing term-and it has been the vast and fruitful undertaking of the theistic philosophy to sum up these growing triumphs of reason. There is no fear that, in doing so, it will be misled by any tendencies-and such are not wanting - to rob Reason in order to pay Authority. So far, however, as Mr Balfour's aim is concerned, we are in large agreement with Professor Andrew Seth that Mr Balfour has really sought to press home on science itself the need of the theistic postulate as against naturalistic assumptions. And whereas theistic thought has 
been witness to the "proud theologist" being told that the modern man is a Positivist, who has left the conception of God - that "long parenthesis," according to Positivist philosophy, between its two so-called normal modes of thought, Fetichism and Positivism - behind as a fictitious, unverifiable hypothesis, what it has really seen is the increasingly proved incapacity of science, - with its abstractions so ostentatiously dear to Positivism,either to outgrow the philosophy of theism, or to stop short of the theistic conclusion as its rational goal. Nor has the stress which the idealism of Professor Royce - as it has found expression in his able and delightful work on the 'Religious Aspect of Philosophy'-has laid upon Reason or pure cognitive Intelligence, at the amazing cost of Will, proved any more satisfactory to philosophic theism, which is to-day less than ever, we believe, prepared to make any such absolute sacrifice of the ethical attributes of the one Universal Will at the shrine of the "one Universal Mind." For theistic philosophy is well content to leave to Professor Royce a philosophy confessedly of a world other than the actual one which here and now is, and is more thankful to know that behind the shadow of the "Infinite Thought" of such tenuous metaphysical idealism, abides for men to whom that sort of idealism has brought but little light and less inspiration, the reality of a Will that reigns in righteousness, and makes Its agency actively 
and universally felt even in this strange sad world. Will, and the ethical qualities of love, may own thought as their logical prius, but not for that reason as their parent.

Theistic philosophy must therefore seek a more synthetic view than that which, in the alleged interests of thought, resolves the Absolute simply into an all-devouring intellection or reason. This we say, although none may compute how much we owe to Hegel for the splendid faith in reason he has helped us to cherish. The primordial Reason which theistic philosophy of religion postulates is also the primordial Force in such wise that the laws of reason entirely accord with the laws which we find in nature. But its primordial Reason is not the "absolute Reason" of Hegel, for all thought is to it that of determinate being, so that, fleeing purely intellectual abstractions, such absolute Reason as it believes in is definite and self-conscious. Its going forth, as finite reason, was to find reason immanent in nature, and it found God as well, Absolute Reason as $\mathrm{He}$ is Absolute Being. It is in that Absolute or Universal Reason alone that theistic philosophy finds man's reason live, as it becomes in him. Reason is to it, therefore, no lawless thing, but it is yet so internal in its rise as to pertain to the autonomy of the spirit. No doubt, it finds man's natural reason share in the vitiating results of $\sin$ - his false ethical attitude towards the Deity affecting for ill his native intui- 
tion, but it takes the whole realm of spiritual reason never to have been more properly regarded as subject to rational processes or the laws of thought.

From what precedes it will be easy to understand how it finds reason in man marked by an endlessly progressive movement towards the transcendent or ideal, which is as a spur to our growth, since it always lies in advance of our actual attainment. Reason must, from its very nature, reject every limitation that men set to it, and press on towards the unattained goal in the spirit of Schiller's "pilgrim "-

"Und das Dort ist niemals hier !"

The goal is still a dream or possibility of the future. Hence is realised that which the poet voices, at the close of 'Faust'-

“ Im Weiterschreiten find'er Qual und Glück, Er, unbefriedigt jeden Augenblick."

"In joy or torment ever onward stride, Though every moment still unsatisfied."

If this quest of the ideal is to be saved from ever growing sickly and languid, that can only be by our coming to see how truly the "gleaming Ideal is the Everlasting Real, no transient brush of a fancied angel wing, but the abiding presence and persuasion of the Soul of souls." Yes, and the words of Amiel are for our philosophy true, as touching this ideal-forming power so essential to man, when he says that "the ideal is a poison 
unless it be fused with the real, and the real becomes corrupt without the perfume of the ideal," for we do not admit such a necessary cleft between the real and the ideal as the antithesis sometimes expressed concerning them supposes. "It is only," as one has said, "in the maturity of actuality that the Ideal appears over against the Real, and that the former builds up the same world, apprehended in its substance, in the shape of an intellectual world." There is not a religious instinct-such as that of man's belief in immortality-and not a moral feeling - such as that of moral responsibility-of which the ground and sanction are not to be found in reason. However intuitively truth may be at last discerned, such almost instinctive knowledge is reached only as the ripest product of reason.

It may now be said that recent theistic philosophy has shown little disposition to rest in the depreciation of reason and of the activity of thought which marks the attitude of Ritschl, Kaftan, Herrmann, and Kierkegaard, for there is for it no part of the whole domain of religion and morality which is not swept by the eye of reason, and over which the sceptre of reason does not bear a true sway. For, has it not known that reason is too deeply rooted in the soil of man's nature not to return after every expulsion, and assert its place and its dominion more firmly than before? And why are these things so? Is it not because, just as the inseparability of conscience from all other parts of our 
ethical experience has been by us elsewhere maintained, so here reason is not to be treated as an abstract thing so much as has been the wont, but is to be regarded in relation to, and not as separable from, our personality. What is my reason, indeed, but just the reason of my personality when that personality is viewed in its aspect of intelligence? And theistic philosophy has found reason to be by no means so lacking in kinetic power as some have imagined, for it has no sooner discerned the good for man than it brings the sense of obligationwhich is certainly not devoid of rational elementsto bear upon the will. Hence for it the content of religion can be none other than "the truths, laws, ideals, and ends of Reason." In fact, nothing do we find more conspicuous in the Christian, as compared with other religions, than just the way in which the Christian revelation enshrines reason from the first, for, in its first approaches to sinful man, it will reach the conscience and the heart only viâ the reason, as it utters, "Come now, and let us reason together." Yes, it is in the secret temple of Reason its light will be set up. How precious, diverse, unrestrained, are the workings of Reason! How swift, bright, unexpected, are its visitations! "It may be with the volume of inspiration before us and its holy teachings lifting up our minds-it may be in the secret chamber, when we are upon our knees, before the AllSeeing-it may be on the lone mountain or in 
the deep forest wild - it may be in the silence and outspread darkness of midnight - alone, far from human fellowship! The eye of Reason sweeps the horizon all around, and the whole expanse of the concave, overhead. Like as some absorbed worshipper of science, in his solitary tower of observation, while all the world is asleep, directs his telescope, now to one quarter of the heavens and again to another; the eye of the spiritual seer, the spiritual seeker, gazes forth and upward. Thus it may have gazed, often and long, but in vain. At length the moment comes when a single, brilliant, glittering, spark-point, like a precious star, a solitary jewel on the brow of night, is descried. Perhaps another glints out, and perhaps even another still. It is rapture, worth all the gazing, and waiting, and watching, and disappointment, and frequent sickness of heart!" Yea, even so, O Father of lights, shall we still and ever in Thy light see light clearly! 


\section{CHAPTER XII.}

RECENT THEISTIC PHILOSOPHY OF PERSONALITY IN MAN.

WE proceed to notice, next, recent advances in theistic philosophy as it relates to man, as we find him in that Christian world where-as Martensen said-the infinite craving for Personality has been awakened, and as he appears in his essential connection with the theistic doctrine of God. The theistic conception of man - theistic, it must be clearly understood, because it is the correlate of the theistic conception of God-has, as voiced in recent philosophy of theism, more nobly proclaimed and contended that, while man is in and of nature, he is yet, in an intrinsic and absolute sense, above nature, superior to it in virtue of his spiritual qualities, while not supernatural in the usual sense of the term. In this endeavour, as against recent Materialism and Agnosticism, it has been aided not a little by Pantheism, though the parting of the ways is reached when it demands of idealistic pantheism 
explication of the Universal Reason, that airy phantom of abstract thought, or of that pure and absolute Being which, eviscerating Itself of all real content, is seen to be resolved into impersonal and unconscious Thought or Substance. To theistic philosophy personality comprises, as Mansel said, "all that we know of that which exists; relation to personality comprises all that we know of that which seems to exist." And when, as he remarked, "from the little world of man's consciousness and its objects we would lift up our eyes to the inexhaustible universe beyond, and ask to Whom all this is related, the highest existence is still the highest personality; and the Source of all being reveals Himself by His Name 'I am.'” Just as recent philosophy of theism has more nobly vindicated the personality of God, and, in vindicating personality, has opened the door for revelation, communication, adoration, and supplication, so has recent theistic philosophy of religion made, in our view, a praiseworthy progress in proclaiming and expounding the true personality it postulates for world-compelling men. It has triumphed over those philosophic influences which, flowing from Kantian sources, would have made it a prey to subjectivism, and has, in its severer analysis of the nature of consciousness and its more patient following of it through its less developed stages back to its rise, more effectively maintained the reality of the central self, the simple, indivisible ego. So, too, has 
it taken personality to be the ineffable qualityindefinable, as Mansel said, because "superior to definition"-in which that ego does consist. We are not going to be here overbalanced by the issues which, in the philosophy of evolution, have been raised by genetic psychology as to the genesis of mind itself: mind, soul, self, personality, - these things are here, and are here to abide, and we are not going to forsake a searching into what they are for an inquiry into how they came to be, though this last may be necessary and important too. We claim that recent theistic philosophy has been more keensighted than drop into the snare into which those philosophers have fallen who, failing to appreciate the full effects of will on the intellect, have treated the ego as only some sort of logical symbol for the unity of thought, instead of regarding it as something that implied personality.

True philosophy of theism sees that man's being is primarily and truly self-active, and that such self-active being can only be self-conscious and personal. It sees how little possible it is to preserve a true and valid personality for man, if we are content to follow those who claim not for man self-consciousness and self-determination that are really his own, and are not the mere projection in man of the self-determining idea or principle found in nature. No wonder it has set before it the large and patient task it has, for we think it may with truth be said to have been more percipi- 
ent of the fact that a philosophy of consciousness, which should be perfect and complete, would, notwithstanding "the narrowness of consciousness" (die Enge des Berensstseins), afford a sure and certain clue to the solution of our profoundest problems. The growth of consciousness means the increasing complexity of our problems, in the spirit of the saying, "Qui accroit la science, accroit le travail," and philosophy is seen to mean, as Ferrier said, "consciousness sublimed."

It is no part of our purpose here to follow the analysis of consciousness, as it yields its data in the triple forms of self, the world, and God; but we may very serviceably recall some of the results which that analysis of the Ego in its forms or modes has brought forth with increasing clearness, in so far as these results relate to that true personality with which we are here concerned. We cannot but think that, in the view of recent theistic thought, man is by all the processes of life driven back at last upon his own inner life as "the Archimedean point" from which as centre he has to unfold his world-a consideration which has served to make his need of a deeply grounded personality more truly felt. Not yet is his personality, with all its properties and implications, within near approach to being perfectly understood. But there has been a deepening and a widening process at work in our conceptions of human personality. Among the things now perfectly certain is the 
existence of those "unconscious mental modifications" which John Stuart Mill was able, three decades ago, to regard as beyond the reach of experiment. What is more, it is becoming rapidly manifest that these subliminal strata or subconscious elements in our being are vastly more important than they have been thought. And other things also we shall presently find to be more beyond reach of doubt than they were. The analysis of the Ego has taken consciousness to be the " necessary knowledge which the mind has of its own operations. In knowing, it knows that it knows. In experiencing emotions and passions, it knows that it experiences them. In willing or exercising acts of causality, it knows that it wills or exercises such acts. This is the common, universal, and spontaneous consciousness." More accurately defined, it is "the power and act of self-recognition; not, if you please, the mind knowing its knowledges, emotions, and volitions, but the mind knowing itself in these." Consciousness recent thought regards not simply as a "peculiar faculty," by which we are cognisant of our own mental operations, but views it as the universal condition of intelligence, the universal basis and inseparable element of human thought, the basal form of all the modes of our thinking activity. It accepts the words of Cousin: "We not only feel, but we know that we feel; we not only act, but we know that we act; we not only think, 
but we know that we think; to think without knowing that we think, is as if we should not think; and the peculiar quality, the fundamental attribute of thought, is to have a consciousness of itself. Consciousness is this interior light which illuminates everything that takes place in the soul; consciousness is the accompaniment of all our faculties ; and is, so to speak, their echo." In the triad, composed of self, the world, and God, as the necessary factors - the unchangeable elements-of consciousness, the consciousness of the last named, that is, of God, has been regarded by recent theistic philosophy as that wherein the consciousness of the other two - of self and the worldbecomes completely realised, while at the same time consciousness of self and the world has been viewed as forming the path by which we rise into consciousness of God. The relevancy and purpose of this insistence on these forms and developments of the consciousness of the single, permanent self-that is, the essential or noumenal self, which we take to be the indivisible unit in the sphere of personality - will speedily appear. It is not, of course, held that any historical consciousness of the genesis of the conscious ego has been possible to philosophy: all indeterminate lies the beginningan undifferentiated complex: forth from the abyss of nothingness-or, if any prefer, from the deep sphere of feeling or impression, where sub-conscious elements dwell-philosophy has seen the ego spring 
to learn the import of the saying, "I am I," as it sets itself to gather fruits of world-experience. For the self-conscious subject, which forms in itself the unity of thought and reality, knows itself as now existing, but memory does not carry it to the beginning of existence: there is a point beyond which Memory can no further go.

"No memory-haunted ways

Take our first footsteps; but in deep

And unremembered tracts of sleep

The immature creature dwells, nor can recall

Its former self or primal state at all."

Back to this point, however, at which we see self-consciousness rise-if we may be allowed so to speak-out of the loose sand-heap of unreflecting consciousness, or upon the crest of wavy sensations -or, in other words, back to the point at which we see the merely conscious individual emerge from consciousness in general (Bewusstsein überhaupt), and first become transformed by the assertion of will and reason into an ego or personality-we know that the self or unifying principle which has persisted through the long train of remembered experiences has been one and the same-an ever identical self. Even "the assertion of the evolutionist," as John Fiske in a certain place has said, "is purely historical in its import, and includes no hypothesis whatever as to the ultimate origin of consciousness; least of all is it intended to imply that consciousness was evolved from matter." Into 
that we may not now inquire; but we are led to say that the genesis of personality - with its rational powers and its ancestral similitude-is, in the view of that philosophy with whose latest developments we are concerned, due, not to physical force being transmuted into psychic states, but to a stage of development being reached at which the psychic aspects or elements of being run up into that unity which we call consciousness. But if consciousness is such a unity formed of psychic elements, why should we not say, as touching these psychic aspects or factors, that already they were there-truly preconditioning our consciousness?

We believe theistic philosophy has been always more firmly grounding consciousness in that only which is potentially conscious - in fact, in the world's immanent spiritual potentialities. Its ultimate basis, of course, must be found in the nature or essence of the Absolute. This is not to say that consciousness, as developed in us, is the consciousness of the Absolute, which must be allowed to have a consciousness of Its own, perfect and entire, wanting no development. We recall the words of Lotze, that " no necessity of reason constrains us to shun the thought of a beginning of the soul. The organic body in process of being formed, certainly does not educe it from itself; but the living body itself is no incoherent heap of atoms driven to a particular development by a universal law, in an otherwise empty world. As, 
on the contrary, every physical process, even the most minute apparently taking place between two elements, is likewise an event within the Eternal, on Whose constant presence all possibility of action depends, even so the quietly advancing formation of the organic germ is no isolated, independent event, but a development of the Infinite itself. Fostered by it, received by it into its own inner being, this natural event there excites the creative power to new development; and as our human soul receives stimuli from without and answers them by the production of a sensation, so the consistent unity of the Infinite Being lets itself be stimulated by this internal event of physical development to produce out of itself the soul appropriate to the growing organism." ('Microcosmus,' vol. i. p. 390. T. \& T. Clark.)

Does not philosophy of theism, however, seem haunted with a feeling that this very inquiry into the origin of our selfhood or personality - that possible ultimate here-may not be philosophical? If personality be such an ultimate, it must be vain to seek to reduce or explain it, attempt this as men may. It is only the person who can enter into the terms I and THou. We claim personality for ourselves because we know, and think, and feel, and will, as we do, and have the consciousness of being able to do all these. Self-consciousness is, then, just that intuitive knowledge of itself which mind or self as a permanent power or ex- 
istence possesses amid its own operations or activities. Of these mental acts and the mind's states we have knowledge in virtue of self-consciousness, which implies the knowledge, not of mere baseless and vanishing states, but also of an indivisible self or individual being, though a knowledge that is not complete. For, "self-consciousness," as Du Prel, in his 'Philosophy of Mysticism,' has strikingly said, " may be as inadequate to the ego, as consciousness to the world; or the ego may as much exceed self-consciousness as the world exceeds consciousness." Our notion of personality has thus become widened by the recognition of the fact that our whole or total self is so far from being fully manifested in any of the forms of consciousness known to us. That psychical phenomenon, which we designate the ego, is now more distinctly seen to be a developing rather than an original entity. The true unity of the person was never more clearly recognised as resting upon the unity of consciousness: This real unity is viewed as due to the self-activity of the soul in midst of the manifoldness of our impressions and those influences that are borne in upon us in experience. Our knowledge of self or the ego, which, as we have just seen, is so far from being an abstraction or mere ideal, is knowledge in a mode of consciousness which is immediate though imperfect. I know myself with a directness and positiveness which do not obtain in the case 
of my knowledge of any other. I do and must perceive myself as the perceiving self that I am. Hence I come to know myself as a centre of conscious and active power. Certainly I have no deeper or more abiding perception of my being than as an active, persistent individual or unit in midst of every change of feeling, thought, or action. Mind is the great reality: for anything I can know, matter and force may be no more than the "mere names for certain forms of consciousness." The consciousness of my knowing is - with that of my being-the only certitude I possess in the presence of reality.

Not alone the unity of our individuated being, but also the permanence of its self-identical, conscious subject, our late theistic philosophy has more successfully maintained against such recent efforts to explain the permanent identity of the conscious entity as that of the psychology of Professor William James, of Harvard. Not that it has any quarrel with the life of consciousness being, by Professor James, made up of a continuous "stream," since he preserves, in each successive consciousness, the truth of our self-identity. But we ask, has it not very clearly perceived that, in the stress which Professor James, in his reckoning with the facts of consciousness, puts on the state of consciousness by which the ego or subject is, on his theory, brought forward and transmitted from consciousness to consciousness throughout the long 
succession, we have a hysteron-proteron, in which the primacy of the subject has been shunted on to the state? Has it not kept in view, too, what power the conscious mind of man possesses of marking itself off in distinction from the "stream" already spoken of? It surely sees that these states are states of mine-that is, of my consciousness-and that without me they can do nothing,-in fact, do not exist. Certainly it has viewed as a reasonable expectation that Professor James and all who grant -as do not the followers of Hume-the ego, should go on to acknowledge how irrefragable has grown the proof of the producing ego as the primal and perduring reality. It plainly perceives that without such primal unit or essence as that which we call mind, with its unexampled unity, the very notion of stream or series or succession wouldin its dependence upon a constant - be rendered impossible to us. And it has very decidedly regarded as untenable, and quite unsupported by the facts of consciousness, such a position as that in which Professor James draws, from the "verifiable" character of the "passing thought," the disastrous conclusion "that thought is itself the thinker"! Unwilling as Professor James shows himself to postulate a permanent ego or soul as the basis of man's personality, he yet sends forth. his "thought" clothed upon with what are virtually so many of the wonted powers or rights of the soul as serve to show how difficult it has been 
for him to keep clear of spiritualistic implications and conceptions. There is absolutely no warrant for his treating thought-a mere faculty of mind -as though it were mind itself. It is utterly absurd to regard thought - the act or product of our spiritual entity - as the entity itself. The very laws of thought and the sure facts of consciousness proclaim it untenable and subversive of all knowledge that thought should be held as the thinker.

But to return to our own position. My idea of personality or personal being originates in my selfconsciousness, and is realised in myself, in my own intellectual personality as the ego that thinks and knows itself; it does not spring merely from my distinguishing it from the impersonal and irrational. Professor Samuel Harris says: "In his personality every man is individual and alone; others can approach the barriers of this solitude and send in intelligence, influence, or sympathy; but no man can scale the barriers into the personality of another to think, or feel, or determine, or act for him, to take his responsibility, or to participate in his consciousness" ('Philosophical Basis of Theism,' p. 4I4). No doubt my individual consciousness is enlarged by continuous contact with the consciousness of the countless selves of humanity making up the race, which race-consciousness penetrates and pervades mine, yet so as my own personality shall never be frustrated or neutralised. But personality 
in others we can recognise only after we have, each of us as a unitary power, found it in ourselves : only when we have so realised personality in our individual selves, as constituted by Will, can we recognise it even in God. Herein we, for our part, agree with the attitude assumed by recent philosophy of theism in repudiating the position of Lotze in reducing the finite personality to a pale semblance. Our agreement with the Lotzean view, however, is cordial in this respect, that, if choose we must, we should prefer to regard man as infra-personal rather than speak of God as suprapersonal, since, with Professor Upton in his recent Hibbert Lectures, we do not feel need or warrant to claim any further approximation to perfect personality than is compatible with such a view.

Theistic philosophy has not suffered itself to forget, when modern philosophical idealism has relied on "self-consciousness," as a term to conjure with, that the word for it means crux no less than lux; but it has been able to hold more firmly by the reality and integrity of man's personality, in face of every perplexity. For it has felt, with Lotze, the perpetual necessity which exists, in virtue of the "generic dissimilarity" between all physical processes and those of consciousness, to derive the "life of the soul from a principle peculiar to itself." We believe we are well entitled to say that nothing advanced by Kant against this reality of the self or personality avails to prove anything 
save the inadequacy of our abstract thought to do justice to the self in its all-embracing reality. What, to all primary intents at least, leads us to maintain the unity of substance is just the consciousness we bear of the unity of the self or ego. What, we ask, can the philosophy of theism do with such a supposition as that of Kant that, if we could get out of ourselves, and see the Self or soul-then no more what it is-it might be found composite, but relegate it to the limbo of philosophical nonentities or absurdities? It is not simply because-in Kant's fashion-I think, that I maintain I am. No; but because I am, I think, I feel, and I will. No mere ratio cognoscendi can satisfy the implicates of real being, however abstract thought may have to content itself therewith.

Turning from philosophy to science, we venture to say that here, too, our personality-that fact which science is helpless to explain-has been more clearly maintained, after every interrogation by evolution as to the how and the when of man's development. If he has been evolved, it has been as the person he now, after evolution has done its work, with undisputed right claims to be, freely acting-as a real, not phantom ego-under that moral government which is to him atmosphere and environment. We take it that it has been more adequately recognised, in recent thought, how incomplete the scientific view of the universe must be, dealing, as it does, with the phenomena of 
nature as objective realities, and taking no cognisance of the priority of consciousness to matter. No wonder that a philosophy of consciousness has become a necessity of positive science, since it has come to the impotent conclusion to view consciousness as a "function of nervous matter when that nervous matter has attained a certain degree of organisation," instead of going, in a conscious search for truth, to consciousness-and that not merely on its objective side-for an explanation of matter.

But recent theistic philosophy has very clearly shown how those monistic theories of the soul or mind, which have sprung up in the course of the psychological progress of the last quarter of a century or rather more, have, when pressed to definite issue, run into sheer materialism or a mere monistic idealism. We have in view, in saying this, such attempts to bridge the gulf between the material and the mental as have been made, with varying degrees of boldness, by such thinkers as Fechner, Lewes, Clifford, Bain, Wundt, Taine, Carus, and, less firmly, Höffding, and Spencer, and others. It would carry us too far afield to consider the positions of these thinkers in any particular or detailed forms, but the monistic theory which they advocate in common is neither so unsuggestive nor so unattractive as to warrant our omitting all reference thereto. Our reference is to say that it has completely broken down in the effort to justify itself at the bar of recent psychological inquiry. By a 
philosophical tour de force the monistic theory of the soul treats attributes the most dissimilar as only correlative aspects of one and the same thing. To Du Bois-Reymond "the world is a mechanism," and, to Dr Carus, consciousness is destitute of motor power, while to M. Taine, when our series of mental states ceases to be, "nothing remains of the mind or ego." The achievement of the monistic philosophy of to-day is seen in human personality being presented by Professor Ernst Mach and his sympathisers as "an indifferent symbolical thread on which are strung the valuable pearls of our real existence." Or, passing to France, it is seen in psychology like that of M. Ribot and others, which gives up the soul-the thing if not the name-by reducing consciousness to a physiological accompaniment, by interpreting personality in terms of purest heredity, or its equivalent, determinism, and by making the ego no entity producing our mental life. It becomes a mere result, as Dr Carus expresses it, of "countless complicated nerve-organisms in our body." So the only self or ego which this pretentious, unpitying philosophy will spare to us is, not that which is conscious of being an ego, but that which consists simply of our ideas or thoughts! Its advocates might have saved themselves a deal of trouble, for, as Lowell said, "the soul is still oracular," to which we add that it is altogether likely to continue so. As one has said, "the very act of denying it implicitly affirms its 
existence." So far is man's personality still from being resolved into the mere "synergy" of faculties into which Comte curiously sought to turn it. Our self or personality is so little to be confounded with our organism or organic functions, that the soul as indeed a separate existence is still the only sufficient theory for the facts of human life. Our latest theistic philosophy has, then, been successfully repelling the monistic teaching of the so-called Identity theory, according to which body and mind are not two substances, but only two aspects of the one substance. Professor Höffding, of Copenhagen, has finely set the theory forth in his 'Psychology,' where he represents their "material interaction" as "an outer form of the inner ideal unity of consciousness," and shows the grounds on which he holds this theory to furnish the only satisfactory basis for mental science. The late Professor Clifford drew a decidedly anti-theistic inference from the theory before us, and Professor Romanes has, in the theistic interest, very successfully assailed the contentions of Clifford, even while coming far short himself, logically, of the strength and glory of theistic belief as to the relation of the physical cosmos to self-determining Deity. The "doubleaspect" theory has been left behind by our latest philosophy of theism as virtually ascribing so much to matter that neither consciousness nor God nor causality can have justice or thorough treatment meted out to them. 
Theistic philosophy welcomes the relative importance of all physio-psychological inquiriesminus the over frequent gasconade-but it never with more reason believed such teachings, as those just alluded to, to be in loudest contradiction to the unequivocal testimony of consciousness, and never had better grounds for resting in the trustworthiness of consciousness, since our knowledge of matter is so clearly seen to be merely inferential. The entrance of all knowledge, indeed, is distinctly perceived to be through personality, whose limits no man may transcend. The knowledge which we have of ourselves in our own conscious and definite unity is such as clearly settles for us the fact or reality of being which is objective to God. Not by the same direct perception that we have of ourselves, but only by inference, do we conclude to the reality of other objects or beings. But, of my own individual being, of my dependence, and of my freedom-of these as lying without, or objective to, Deity-I have a knowledge so primary and direct as to be warranted in affirming my true selfhood or personality. It is, as has been said, "an indisputable truth that what we call the material world is only known to us under form of the ideal world." The studies of theistic philosophy in the organic realm have, no doubt, duly impressed it with the psychic or soul-bearing capacities of matter, which are very possibly much greater than we at present know. Its view of matter, however, is here very 
different from that of monistic realism, and its claim to knowledge even of the psychic life of others is that we know mind other than our own only in an inferential way, not with the directness that we know ourselves.

\footnotetext{
"We are spirits clad in veils ;

Man, by man, was never seen :

All our deep communion fails

To remove that shadowy screen."
}

Since, then, we know other persons and material objects only through our own ego and its properties, nothing has been made more thoroughly manifest to theistic philosophy than the delusive snare into which science falls when it fancies itself free from anthropomorphism. In saying this, we are not to be supposed to be falling into any solipsistic form of subjectivism. Indeed such forms of serious and universal contradiction as we find in Dr Shadworth Hodgson and others, who assume such an inherently self-contradictory view of the consciousness of the ego, theistic philosophy must decisively reject. It were logically better and more consistent just to declare ourselves, in such a case, the votaries of absolute egoistic idealism or solipsism pure and undisguised. But our philosophy does not forget that this would, of course, mean the total destruction or annihilation of science. That philosophy, then, takes consciousness to be the "undecomposable unity," as Kant styled it; an absolute unity of consciousness in the subject who knows. It 
finds, after every endeavour of recent years to resolve consciousness into a stream of states or a shifting of unconscious atoms, that a persistent self, that what we know as inward and personal identity, has affixed its seal to the whole troop of fugitive and vagabond sensations that mark our experience. It is this continuing self, this abiding spiritual unity-not Professor Clifford's "general stream of consciousness," and not the mental processes of Lewes which are only other aspects of "physical" processes - which theistic philosophy has, with self-justifying perseverance, invested with personality. And, after even the lavish endeavour of the learned and acute author of 'Appearance and Reality' to persuade us of the non-existence of any such fixed nucleus, theistic philosophy rejects, with him, those phenomenal selves which come short every one of a self an-und-fïr-sich, but still explicitly retains, as that thinker has not done, the reality of the thinking ego, and, we venture to add, of that really higher self styled by some philosophers the ideal or ontological self. For it regards the efforts of late years to dispense with consciousness as activity (Thätigkeit), and to explain mind-processes as merely phenomenal accompaniments (Begleiterscheinungen) of physical brain processes, as having proved singularly abortive. It finds no cause to disagree with what Eduard Zeller has said, at the close of the second volume of his 'Vorträge und Abhandlungen,' that between mental 
phenomena and the movements of natural phenomena in space, there is no such relation as to admit of their being compared (der Vergleichbarkeit), and the former found mere modifications or combinations of the latter. Or, as one of our own thinkers has said: "Since the psychical standpoint - the standpoint, that is to say, that the psychologist studies-is the real, if not the logical presupposition of the physical, to resolve it into the latter is tantamount to saying that there are phenomena that appear to no one; objects that are over against nothing, presentations that are never presented." So truly must the reality of the Self -a self that transcends the phenomena presented -be here maintained.

We take Spencer's account of the ego as "the permanent nexus which is never itself a state of consciousness, but which holds states of consciousness together," and we maintain not only this identity of the ego through successive mental states (in opposition to Kant), but also that consciousness testifies both to these states of the ego, and to the ego itself as existing in these states. We reject the transcendental ego of Kant, with, we believe, the best of recent theistic speculation, and, while denying both its real existence and its necessity to thought, we retain the undiscredited ego of consciousness as real, rational, free, and sufficient. For such theistic speculation has shown a growing disposition to agree with Dorner's attitude in 
his 'Glaubenslehre,' that, if we were to accept Kant's doubt as to the reality of the ego which is thought, self-consciousness itself would crumble to pieces, and all certainty about self or anything else would pass away. We do not of course mean to deny the virtue of Kant's transcendental ego, in so far as it may-viewed as the form whose content is the entire psychic life-secure that permanent being which unites our phenomenal states of being. It may, viewed as the ultimate reality in contrast to the partial, actual, and phenomenal self, prove a helpful conception. But this ultimate ego must not be separated and made something different from the self, which is supposed to approximate always more closely to the ego, for the "I" cannot be so rent in twain. Harmless enough as the transcendental ego may be when so viewed as, in some sort, an entire and ideal self, reality is yet something which pertains to the self as actual, and no ego is to be postulated which is so much a thing in itself as to be out of all relation to our faculties and their working. To make such an ego the only real ego were utterly subversive of all real knowledge, utterly fictitious and unnecessary. Reason neither demands nor sanctions it : the testimony of consciousness lends no warrant for it. Our philosophy of theism therefore refuses to have the ego of consciousness dismissed as a mere synthesis of apperceptions: it holds by the reality of the self or ego of consciousness as "the 
fullest of all conceptions, with a content coextensive with the whole world." Of course we leave the transcendental ego to fulfil a useful enough-and necessary-function for Epistemology, which, dealing with knowledge as such in abstracto, finds service for the formal unity of an abstract self.

True philosophy of theism sets aside the confusions of thought that are stamped upon such attempts to dispense with the real ego of personality as that of Professor Bain, and refuses to be content on his theory with a mind or ego which shall be merely the observed sum of its own states. It sees that this ego must be assumed as indeed the very principle whereby any aggregate of sensations, thoughts, emotions, volitions, can be ours. As M. Janet, in his 'Materialism of the Present Day,' contends, "The unity of the ego is an undoubted fact. The whole question is to know whether that unity is a result or a primary fact. But if the unity of the ego is a result, conscience, which attests to us this unity, is a result likewise; and this is indeed what is maintained, not only by the materialist, but also by the pantheist, school. Yet this fact has never been proved, nor even explained." In the indivisible ego of consciousness, we find the thinking ego as subject and the self which is thought as object, the "ego" and the "me" which make up this double ego being, not two, but one, which double consciousness has been strikingly represented by Dante-who is not solitary among 
poets in the matter-in the passage of the "Inferno" on Bertrand de Born, which concludes-

“ Di sè faceva a sè stesso lucerna,

Ed eran due in uno, ed uno in due;

Com' esser può, quei sa che sì governa,"

-which A. J. Butler has been pleased to render, "Of itself, it made a lamp to itself; and there were two in one and one in two; how it can be, $\mathrm{He}$ knows Who so orders." By this double consciousness "a double personality is not meant," as Kant rightly observes, despite his doubt of the objective reality of the ego which is thought. Indeed, one of the virtues of the Kantian transcendental ego is just the way in which it preserves that ego as sole and ultimate, so that, on this theory, which we do not accept, the phenomena of changing personality and secondary selves are at least intelligibly dealt with, for they are united and taken up in the all-including ego of Kant's theory. We do not quite admit the difficulty put forward by some philosophers in distinguishing the primary self or personality. Hence, with Dante-this time in the "Purgatorio"-we can truly speak of man as-

"An individual soul, that lives

And feels, and bends reflective on itself,"-

- "un' alma sola,

Che vive e sente, e sè in sè rigira."

What therefore is meant, simply is that in selfconsciousness, consciousness has, as in other cases, been capable of severance into subject and object, 
into thinker and thought, in virtue of the power which the conscious subject has of beholding things as opposed to itself, and of making itself its own object. "The coexistence of the subject and object is a deliverance of consciousness," says Spencer in his 'Principles of Psychology,' which, "taking precedence of all analytic examination, is a truth transcending all others in certainty." So, unaffected by the lame endeavours of Dr Maudsley to resolve the mind's intuitive conviction of the unity and personality of the self or ego into a dream or a delusion, we take this reality of knowledge-both of self, as moulding and organising principle, and of its environment-as a primitive datum of consciousness that lies beyond dispute.

This fact of man's personality lies, no doubt, hid from the analysis of the dialectician, but the fact of the human ego as a dynamic centre whence radiate powers psychical, pneumatical, and physical-powers which all presuppose the ego in its determinative force - is unquestionable. Through the manifold and diverse functions of personality the ego remains the one personal centre, related in a dynamical manner to all these functions in ways which may remain unexplained while the fact is spontaneously assumed as necessary and real. No possible phenomena, of which the mind or ego is the subject, can conceivably exist except for the central consciousness or ego, which, as energising agent, stands in the relation of the noumenal I to the phenomenal Me. 
And Dr Bradley has unwittingly done good service to theism by showing so clearly that to which his idealism would bring us, even to the position in which the soul is treated as no such ultimate fact, but as simple appearance. But though the Absolute is everything, and everything is for the Absolute, with Dr Bradley, we are not yet going vilely to cast away the self in us-our personality and freedomas a simple term in the process of the self-manifestation and self-realisation of the Absolute. Hence we stand ready to admit the lucidity and point of what Lotze has said, in the chapter on the existence of the soul in the first (Eng. ed.) volume of his 'Microcosmus,' that "our belief in the soul's unity rests not on our appearing to ourselves such a unity, but on our being able to appear to ourselves at all." And again, "What a being appears to itself to be is not the important point; if it can appear anyhow to itself, or other things to it, it must be capable of unifying manifold phenomena in an absolute indivisibility of its nature." Personality is to be taken as an organic unity, the diverse attributes and functions of which are indissolubly joined together in making up the personal synthesis. The entity or unity which, in the act of self-recognition recognises itself, can be no adequate cause of mentality in us unless it be indeed personal spirit. This we say in perfect knowledge and recollection of all that has been written of the correlation of such personal spirit here and now with the physical forces of the brain. 
The scientific spirit itself sees how little the brain can be taken as an adequate cause of the phenomena of personality, since it remains material, no matter how highly organised it may be. But we believe we are warranted in asserting that recent philosophical thought has advanced in the perception that self-consciousness has at once true background and real fastness in something higher than itself, even in God-consciousness, since it is in the consciousness of God Himself that self-consciousness comes to its strength and completeness.

We are thus introduced to self-consciousness in its highest phase, as the self appears, conscious of itself in its relation to God. The contents of such selfconsciousness are mediated in many ways, and so such self-consciousness cannot be regarded as purely subjective. Self-consciousness in man is explicable only on the presupposition of "an original, and unconditioned because original, self-consciousness ;" as it has been expressed, "the consciousness of God enters inseparably into the consciousness of self, as its hidden background. The descent into our inmost being is at the same time an ascent to God." It has been borne in upon our fuller knowledge that God, as Absolute Cause of all consciousness as of all existence, lies nearer in to our true ego than that ego does to its external self.

"Closer is He than breathing, and nearer than hands and feet."

But to this we shall return more fully presently. 
Meanwhile, we proceed to say that, while the ego can be experienced, it yet cannot be thought save in distinction from, or contrast with, a non-ego, and herein we agree, as to the way in which in our thinking we dichotomise the cosmos, with Lotze. When the great outer world has let loose upon us the stream of sensations, which marks our worldconsciousness, self-consciousness turns it to subjection and service of our will and understanding. The world by itself, and apart from the mind, is certainly no cosmos. The uncoördinated data of sensation are brought to order and unity by the activity of mind itself. We cannot rest in world-consciousness, and seek no more ultimate reality than the world. Our self-consciousness is founded, however, not upon the contrasted external world which becomes for it, but upon a prior and immediate certainty of self which, as a central vision and supreme oversight, is only more fully developed by later contrasts that present themselves to our self-consciousness. Selfconsciousness-the I-is, no doubt, stimulated and nourished from without, but it is not the product of the world-consciousness-the Thou-the ego having a certainty of self so immediate as not to wait in dependence on the opposition of the Welt or nonego. The reality, identity, and continuity, however, of this ego are attested, in what we think no unimportant manner, by the assured certainty of the sameness of objects which is ours in objectively recognising them, and ours because of the persever- 
ing identity of our own ego as the knowing subject. In our late philosophical thinking, it seems to us to be more fully understood how necessary this worldconsciousness is, too, to our realisation of Godconsciousness, since we could not without it rise above the animal creation. It is likewise seen that the world-consciousness rests on securest grounds only as it becomes interwoven with the God-consciousness, since it is then that certainty of the finite world reaches its highest.

"Dark is the world to thee: thyself art the reason why;

For is He not all but thou, that hast power to feel ' $\mathrm{I}$ am I'?"

But recent theistic philosophy has been able to find, in the unfoldings of consciousness in experience, a richer development of our consciousness of God, as well as of the ego and the world, as part of our normal development. Whatever opposition we might be tempted to give, as against idealistic tendency, to certain hazardous forms of transition from our own consciousness to God's, has here no relevancy or place. We shall take our own way of briefly showing how, in gaining the highest knowledge possible to his enlightened consciousness, man still maintains, through every stage of his union with the Highest Consciousness,-even the Divine, as that is realised through the continuous loyalty of his will,--the unity of that wondrous self-hood in which consists his self-conscious personality. "Though the Absolute cannot in any manner or degree be known," says Spencer in his 
'First Principles,' " in the strict sense of knowing, yet we find its positive existence is a necessary datum of consciousness; so long as consciousness continues we cannot for an instant rid ourselves of this datum; and thus the belief which this datum constitutes has a higher warrant than any other whatever." Spencer's thought of the Absolute Being as a Power recent theistic thought has, of course, retained, but under the conception of a rational Power, capable, as "a necessary datum of consciousness," of being truly thought and rationally known. It has not been content to know that $\mathrm{He}$ is without pressing on to know what $\mathrm{He}$ is. God is regarded by it as the prius of the universe, its Ultimate Ground and Fundamental Reality, as the Absolute Being that must be the living, personal God. God is known to it as $\mathrm{He}$ reveals Himself in the Universe; but also as $\mathrm{He}$ reveals Himself to the religious consciousness. Personality has now been more vividly realised, it appears beyond dispute, as the highest blossoming of man's conscious spiritual life.

Recent Christian Theism, we may remark, has, it seems to us, very distinctly gone beyond the declarations of the common religious consciousness, and has lent a more attentive ear to the claims of what calls itself "the Christian consciousness," as a new consciousness which Christianity has brought to our race. This has been, as we think will hardly be questioned, a most warrant- 
able procedure, philosophically, since philosophic thought cannot be exercised to highest purpose save as it seeks and finds access to the highest facts of knowledge and experience. To which we add, that we make fuller allusion to the matter because we are clearly of the mind that there has been a rather unapostolic, and not over-worthy, timidity, theologically, to face, in all its bearings and relations and implications, the fact of the common Christian consciousness as it springs out of specific experience and personal verification of the truths of Christianity. But we claim for our late philosophical thinking that it has, at the same time, more distinctly apprehended and recognised the impossibility of anything like what we will venture to call a Philosophy of the Christian Consciousness, except on the supposition of the natural consciousness, based, of course, on natural revelation. When it has cross-questioned man's natural consciousness, it has found a more or less developed sense of sin, craving for righteousness, and longing for harmony with God, and has perceived that the so-called Christian consciousness is nothing but the Christ-consciousness that supervenes on the replacing of this orphanhood of the spirit by the consciously realised sonship of the soul as it finds that "he that is joined to the Lord is one spirit." It has more carefully noted how this specialthat is, Christian-consciousness becomes formed, in historical psychological manner as "that know- 
ledge which the Christian has in himself of spiritual things," a more vital, less scholastic character, being thereby imparted to theology.

We are, of course, well aware of the objection taken to the phrase "the Christian consciousness," by those who have thought the historical and objective bases of belief were being brought into jeopardy. Whilst we look to scientific psychology as ultimate arbiter for us in questions that concern consciousness in any of its forms or modes, we yet take leave to say that we regard the phrase as scientifically legitimate and appropriate. More: not only does no reason appear why there should not be a thoroughly scientific psychology of the "Christian consciousness," but we are strongly inclined to think that the materials and encouragements for such real and thoroughgoing Philosophy of the Christian Consciousness, as we should like to see, have so greatly accumulated within recent times that whoso will may make the high attempt to show, as we think could be irrefragably proved, that the "Christian consciousness" has a title to scientific validity not inferior to that of any other form or mode of consciousness. Meanwhile, we are concerned to record it as a gratifying feature that recent theistic philosophy has shown itself more open-eyed to behold how naturally it obtains that the conscious life of the mind of man, when it has become spiritually renewed and enlightened, has a peculiar content, which, it sees no reason to 
doubt, must stand open to the scrutiny of trained thought, must be capable of being brought within the scope of scientific methods of psychological investigation. It has grown in its apprehension of the fact that it is not meant that rational psychology or the philosophy of mind, applying itself to the "Christian consciousness," will give us knowledge of God as mere subjective state of our consciousness, for the very phrase in question imports, as is now-we take it-better understood, the selfrevealing action of God in $\mathrm{His}$ objective reality within the sphere of our consciousness. It is surely a philosophical advance which recognises that, in contending for historical and objective revelation, the fact need not be blinked that such revelation comes to us, and is known by us, through those human channels or processes of the subject, the nature of whose contents and working it is the office of scientific psychology to investigate. The History of Doctrine, in its recent scientific treatment, is just an attempt to interpret the experience of revelation, gained in the way just described, by the Church as a whole.

Recent theistic philosophy of religion has left behind the subjectivism of Schleiermacher, and reached beyond a consciousness of redemption that concerned not itself with the objective contents of Christian Doctrine. It has pierced to the objective consciousness of God here presupposed, as the God manifested in history becomes immediately mani- 
fest to faith. It has laid hold of the fact that with the self-consciousness and the world-consciousness we already possessed there has become fused a God-consciousness, as consciousness has been more profoundly developed. It has seen Christianity seeking a point of union with man, and finding it in his spiritual aspirations, whereby an inner consciousness of the truth is begotten as the Christian contents are seized in living grasp. Certitude, it has been said, is, in its last analysis, "the relation of truth to knowledge, the relation of man to God, of ontology to psychology. When the human intelligence, making its spring, has seized Divine truth in identifying itself with reality, it ought then, in order to finish its work, to return upon itself, to individualise the truth in us; and from this individualisation results the certitude which becomes, in some sort, personal as knowledge, all the while preserving the impersonal nature of truth. Certitude, then, reposes upon two points of support, the one subjective, the other objective-man or the human consciousness; the other objective and Absolute-the Supreme Being. God and consciousness are the two arbiters of certitude."

Let it be said that recent theistic philosophy of religion has been fully percipient of the weakening of authority in matters of religion, which has been characteristic of our age, and of the growing disposition to find the grounds of belief in the testimony of consciousness as the true because the 
internal and immediate and unimpeachable authority. Let it be acknowledged that, in face of this fearless and determined appeal to consciousness, with which we confess ourselves to be in perfect sympathy, it has freely allowed that consciousness is the ultimate court of appeal, that consciousness has in its normal state a faculty of recognising and of unifying itself with all objective truth, all objects of thought. But let us not be kept from recalling how irrational it would be to think of consciousness here otherwise than as open to every enlightenment-nay, as losing its own life that it may win the truth which will be the nourishing soul of its existence. And we think recent theistic thought has been more careful to remember that the testimony of man's consciousness, in respect of religious beliefs, becomes of value only as we know the moral enlightenment to which the depths of his consciousness have been opened, and, what is still more, the moral quality his consciousness has acquired by the purity of its self-surrendering spirit in the quest for truth. For, what value should it attach to the testimony of consciousness where the forms of truth may only appear in consciousness without the subject making them his own in subtlest spiritual union? Or with what justice should those psychological laws be shirked which cannot but control a knowledge of the Personal God which is, and must be, personal? Or with what right should the fact be ignored that such personal 
knowledge of Him must be conditioned by our capacity for spiritual inspiration and insight?

We venture to think that recent theistic philosophy of religion has felt more deeply than before that it had not sufficient reason to refuse the claim of the Christian consciousness to a true autonomy. For, may we not say that it has been more observant of the truth that it has not been, as Julius Müller and others have regarded it, a question of establishing conclusions without Scripture by means of the Christian consciousness, but a question of authenticating the Scriptures, which we can only do by means of a spiritually enlightened consciousness. If consciousness is the only authentication the ego needs for its own existence, there seems no reason why an equally valid and irrefragable self-authentication should not be claimed for what we may call the dynamic centre of the Christian consciousness: God becomes to us, in spiritual union, a higher than merely self-consciousness becomes, so to speak, a Divine Alter-ego of the finite spirit, and His Being is authenticated to our God-united consciousness precisely as is the ego to our self-consciousness. God is thus known by His spiritual signs and effects in our consciousness -thereby a Christianised consciousness-and the reality and immediateness of our knowledge of $\mathrm{Him}$ are maintained, although we deem it far from being unmediated, since we forget not the subjectivity which is of the essence of our knowledge. 
While the complex character of the problem of personality has been more clearly seen by recent philosophy of theism, its real nature-the "reality" and not mere "appearance" of what we, with much more truth than Dr F. H. Bradley, may call those finite centres of experience meant when, by a real duality, we speak of soul or personalityhas at the same time been more truly discerned, and their rightful place assigned to conscious reflection and the free self-determining power of the Will. Hence the refusal to follow Absolute Idealism in making man no more than a term in the necessary evolution of the universe. The tendency is well exemplified in the chapter on "Goodness" in $\mathrm{Dr}$ Bradley's 'Appearance and Reality,' where it is said that "nothing is outside the Absolute"; that "the individual never can in himself become an harmonious system"; and that "in the complete gift and dissipation of his personality, he, as such, must vanish." It is here, in fact, that theistic philosophy finds our self-consciousness at its highest, as the ego reaches that completest knowledge or highest consciousness of our own personality, which knowledge or consciousness testifies to the true personality of man as that to which noblest witness is borne in that very unification of the human consciousness with the Divine, which only the self or will is competent to make, and which the self, persistent, real, unique, makes without sacrifice of a self-consciousness of its own. 
Recent theistic philosophy of religion has brought out with more distinctness the freedom there is in all this from any pantheistic identification or fusion of the finite spirit with the Infinite, since the individuality of the human spirit here reaches "its intensest specification," and its true personality is neither absorbed in a Deity purely personal, nor sublimated into an efflux of One with but quasi Personality. For it has more jealously guarded the reality of what Martineau styles the "causal self" or human will, while and after it has become in voluntary surrender unified with the Divine Will, and has more zealously maintained the integrity of the central self, through whose supposed extinction the living individual, fleeing a morally indefensible

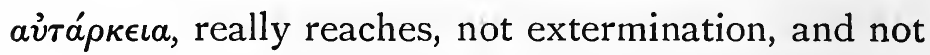
absorption, but perfection and supreme realisation. It maintains, as we believe, in its integrity the soul, which, in its end-positing power, yields us the possibility of a spiritualistic metaphysic. It has not been able to lend countenance to the line of thought whereby Dr Royce seeks to suppress our individuality in "a wholly impersonal devotion," and merge our separate selves, as having "in this world no rights as individuals," in the Life Universal, for its ideal of perfection is one in which, on the contrary, it can never be said that "the whole is perfect," so long as the separate individualities do not find freest scope for the development of personality, as something wherein man is truly self-contained, in 
the harmony to be attained with the Universal Will. That which is an ego stands on a higher level than that-materiality-which is not, for, unlike the non-ego, it is, so to speak, part of the Divine Essence, existing at once in God and for itself.

We are well aware of the objection to our personality, urged by some able philosophers to-day, that it appears to involve the contradiction of our being finite and infinite,--for infinite our ideal self certainly is,-at one and the same time. But it seems to us that the contradiction arises in reality very much from our conceiving progress of the finite individuality as a progressus ad infinitum rather than a progressus in infinitum. Why should there not be senses in which man, in virtue of his potencies and the earnest of his inheritance in the infinite, should be viewed as a true infinite? So, then, with whatever metaphysical difficulties beset, we hold fast to the fact of personality as, in our case, the great reality, and no mere appearance or transient phase. It is precisely through the depth and fulness of our grasp of this reality of the moral personality in us, that we come to an ever more profound hold of the Personality of God in all the glad strength of spiritual communion. And we are quite free to confess, for our part, that when our own thought has again and again confronted the vast nature - system opened for us by our modern science, which seemed ready to drop over spiritual thought an awful night-cap or perpetual pall of 
purest naturalism, and to render all supersensible realities as sheer a blank for us as for men covered in death's dreamless sleep, we have felt driven by always new and deeper necessities of thought and being to find our stay and corrective in falling back upon our own personality as for us the primal reality in which we confide, and on which we build a basis for our belief in the Divine Personality postulated by our self-conscious and rational thought. For if will, character, personality, belong to man, by what right shall we withhold these from that Eternal Self-consciousness which we call God? There is, in fact, nothing of greater consequence, whether for metaphysics or for religion, than just this maintenance through every difficulty of the supreme or final category of personality. It is the crown of theistic philosophy. Dr Elisha Mulford says, "As the personality of man has its foundation in the personality of God, so the realisation of personality brings man always nearer to God" ('Republic of God,' p. 28). Just as Corneille makes the heroine of his 'Médée' say, when confronted with direst misfortune, that there remained to her at least herself, so theistic philosophy claims, amid the losses and fortunes of our modern thought, that there remains to it the self or personality. Yes, for all our science is simply helpless to explain this great, persistent fact of personality in us. Our embryological and structural connections and affinities with nature may be traced to the utmost, but 
the unexplained fact of personality abides, persists, through and after all. If that which persists in consciousness is to be taken as real, then nothing is more distinctly testified to than the reality of personality in man. Hence we find Ulrici, for example, driven by a psychological procedure to regard the self as the presupposition of the activity which for him marks consciousness.

There follows that actualising of the capacity for personality in the sphere of social life on which Green and others have insisted. But we have been here concerned first really to get the personal self or ego. And it is in such ways, we venture to think, theistic philosophy must still progressively realise all that for it is implied in human personality - what Professor Seth calls the "infinite progress of approximation." Hence we take it that what we see in recent theistic philosophy of religion is the more emphatic assertion of the fact that no theory of the universe can be for it satisfactory which does not take proper account of the nature of the self-conscious, self-determining, selfidentical ego, which forms the reality of which above all else we are sure. To man, as consisting essentially of such ego or soul, all inductive investigation of the facts of consciousness and life does certainly lead, and the recent witness of such phenomena as hypnotism, telepathy, and the rest, to the independence of mind has certainly not been less emphatic. With this it must take full cognisance 
also of the relation which this finite but real personality of the ego sustains to that One, absolute, self-conscious Personality, Which, as we have now been insisting, becomes intelligible to it only as it has recognised its own positive personality - its relation, in other words, to that One self-existing Reality Which is the final resting-place of the severest rational thought. That knowledge of the being or self which is ours is a knowledge or perception of simple existence of the self, but it is a knowledge of the self which carries with it a conviction of self-existent being or self - sustained existence somewhere. For we are too consciously limited and dependent beings not to feel driven to the necessity of thinking such independent being on which the fact of our being depends. That independent or unconditioned and perfectly selfdetermining being is what we call God. As Lessing once said, "If I am, God is also: He may be separated from me, but not I from Him." My personality, as matter of fact, depends on $\mathrm{His}$ being a person. It is precisely here that the charge of vagueness and unverifiableness in the notion of personality in God has, as we believe, had its absurdity, in some measure, more thoroughly exposed, for the idea of personality is just one of the most real, rational, intimate, central, and abiding conceptions possible to us. No complexity of the notion can for a moment be allowed to obscure the fact that no notion stands more completely or more 
certainly within the sphere of experience than the idea of personality, which, at least in its centralness, we continually comprehend and verify. Clearly, then, there is no call to lay any such stress on the self-centredness of man's moral personality as shall obscure for us the pathway of self-realisation, which lies along the line of its realised relations to the Primal Personality, and to personalities that are finite.

We close this chapter by saying, therefore, that recent theistic philosophy has more than ever found reason for affirming, in a true sense, with Goethe-

"Wie das Gestirn,
Ohne Hast,
Aber ohne Rast,
Drehe sich jeder
Um die eigne Last"

-which, being interpreted, runs, "Like a star, without haste, but without rest, let each revolve about his own weight," or, as we should like more freely to say, "Let every man's life, starlike, turn on the axis of his own real personality." For has it not, as a spiritual philosophy, had a deeper sense that, just as his awakened spirit does so, man comes more near his spiritual perihelion? Has it not more clearly realised that, while the fashion of the world passeth away, personality, as that whereby man is able to will in conformity with the supreme Eternal Will, is that which "endureth for ever"? Has it not found always more reason for standing firm, with 
a poet of a late time, by those "high instincts," "those first affections," which go to form "the fountain-light of all our day" in making up for us a wondrous personality? Turning from the superficialism of the mechanical philosophy, on the one hand, and from the lack of real standing-ground for man in the pantheistic philosophy - surfeited with Deity - on the other, it has been more wisely able than before to find a real place for personality in man-in man who is a personality which no theory can shatter-personality being still for it, as for the peerless poet of an earlier time, "la rosa in su la cima" _ "the rose upon its top." Nowise shall personality show itself in us as it will in our faith in the spiritual and eternal order of things-our faith in the ideal, which cannot be broken or lost, for the ideal is no more to us a visionary and exterior thing, but something which is internal and immanent in our conscious and aspiring life.

With the personality of Jesus Christ the crown and climax of this problem of the active and originating power of personality are, for the philosophy of religion, reached, for, as we contemplate the Person of the Son of Man, does not a new and everlasting glory of personality for, and in, man burst upon our view? Where shall we find a life that so subjected, as did $\mathrm{He}$, the actual to the ideal? Even Ritschl has been able, to his honour be it said, to make a perfectly clear and 
peculiar place for Christ among religious founders in virtue of Christianity, on his conception of it, making His person an element or factor in its philosophy of the universe or Weltanschaunng. Do we not then feel anew that not only must "the ideal self" be, as Professor Lloyd Morgan properly remarks, "an object of desire," but of intense and all-consuming desire? Yes, for what perfection of finite personality can there be for us save free and progressive companionship with that Infinite Person, wherein freedom, harmony, and security are alone for us to be found? What is the true and precise end of moral development but just the development of that free, moral personality of which we have spoken, acting, of course, in no isolated way, but in and through society? What other moral ideal could satisfy alike the reason and the affections but just that reality and perfection of the personal character of which we have spoken-an ideal, of course, progressively realised wherever true individuality is found. This reality and integrity of the self or individual-and of a priori consciousness in the individual as such-we thus maintain, giving way as little to the running of these rational elements back into the Divine Mind with pantheistic idealism, as to resolving them into accumulations of experience by agnostic evolutionism. And it is because it rests with each one, as life's great moral achievement, to constitute or erect himself 
such an ideal moral personality-yes, to rear such a moral fabric as this ideal self or person out of all the unpromising material of natural feeling, will, and impulse,- that there is ethical force and solemnity in the poet's word to every man-

"To thine own Self be true."

True to that self we must be just because that self is one so real and true. Never so true to it are we as when we make it no self-centred ego, but a self that seeks its home, its vital breath, its native air, in God, even that God Who works in and through the finite ego both to will and to work for His good pleasure. The self is not then lost, but only gone before: it has become, so to speak, a pioneer of the ideal, to prepare a way or upward track for all that remains of our unsubjected nature, and render it no more disobedient to the heavenly vision that calls it to "come up higher." 


\section{CHAPTER XIII.}

RECENT STUDY OF HUMAN FREEDOM.

Theistic philosophy locates the true life of man in the alluring region of freedom, ruled by his will. It sees that no other philosophy supplies such personal relation betwixt God and man as that theistic doctrine in which we find a true responsibility arise, and worthy conceptions of duty and freedom spring up. It notes how the freewill problem has seized hold on the theologic and philosophic mind of the ages as hardly any other has done, and has enlisted the interest also of minds of juridical, philological, scientific, and medical turn. And, well-worn and profoundly perplexing as may be the theme of freewill, it is yet too obtrusive and of too transcendent moment, for the theistic philosophy of religion, not to deserve our attention to recent thought on the idea of freedom, with its elements of power, independence, and spontaneity, and on the measure of its compatibility with scientific determinism. Not that the deter- 
minist view is to be taken as other than compatible with the theistic position, but that the significance of freewill for belief in a personal Deity-as against any possible outcome of materialistic evolution or physical necessity or force-is more clearly realised. In recent philosophy we sometimes find writerslike Professor Siebeck, for example-make freewill a chief feature of their system, while others-like Professor Seydel-allow no such freedom either to God or man. We maintain for God that infinite freedom which is the equivalent of a self-determination that is perfect. We believe, however, that it is impossible to doubt that the thought of a causal connection of all things has greatly grown in strength and impressive force. It has certainly to be admitted that the idea of moral freedom has, during the last three or four decades, become sensibly diminished. What we contend is that this fact nowise impairs our position in maintaining that this need not be so, and that man at his truest is thoroughly free. We take recent theistic thought to be in agreement with Lotze when he allows a very widely extended sweep or tract for the reign of law, and also when he urges that that sweep is not all-inclusive: what it has insisted upon as being not included is just the moral self or personality. Hence it has recalled us to a sense of the reality of the world of spirit, of what does not pertain to mere mechanism, and to an insistence on our real power of anti-impulsive 
effort. It believes the power of volition which is ours to be far more tremendous in the greatness of its issues than is almost ever realised.

Recent philosophical theism has, as we shall see, not allowed itself to forget how, in our conscious moral responsibility, our conscious freedom. of will is presupposed. Freedom is still, as in Kantian days, the postulate of morality. Freedom was, with Kant, the central conception of his entire practical philosophy. Mansel has in modern days finely said that the freedom of the will, "so far from being, as it is generally considered, a controvertible question in philosophy," is indeed the fundamental postulate without which "all action and all speculation, philosophy in all its branches, and human consciousness itself, would be impossible." It thus at once grows evident that recent theistic philosophy has executed a nobler, because harder, task in that its endeavour to vindicate for man a real freedom immanent in his volitional acts has been made in an age when denials of freedom have been more bold and frequent, and when these have claimed to be the clear utterance of the scientific spirit. These denials, in fact, tell of the wide surrender to a naturalism, in which the one, exclusive reality is the world of appearances and its chain of causal connections. They tell of specious grounds on which some have come to treat freewill as an illusion, self-determination as mere appearance, and 
nature - necessity as base and ground of all our thought and action. But theistic philosophy has found no warrant for the assumption of the passivity of the will by those who carry over the laws of nature-necessity to ethical territory. It claims for the will a true lordship over motive, and denies that it is placed under any unavoidable compulsion. It holds that the will can will in this particular way or otherwise. In inquiring thus whether man is, indeed, in the poet's prescient phrase, "a slave of nature," it has done so under a profound sense that the question is vital and central for man. Modern theistic thought has always more fully recognised what call was presented to it in the physiological determinism of Huxley and Spencer, not to speak of the mechanical determinism of Mill, and the philosophical determinism which, in America more than anywhere else, has engrossed attention since the always to be regretted necessitarianism of Edwards. There is no uncertainty in the Spencerian "Principles of Psychology," to which freewill is simply an illusion, consisting of the supposition that "at each moment the ego is something more than the aggregate of feelings and ideas, actual and nascent, which then exists." The teaching of Mill and Bain need not be recapitulated, whereby, on the philosophical necessity doctrine of the former, "we could foretell his conduct with as much certainty as we can predict any physical event." 
There is certainly no room for a vague indeterminism or a mere groundless pleasure in action or in abstention. Yet we may as well say that we, for our part, are just as far as may be from admitting the Libertarian side to be other than stronger in recent philosophical thought, however confidently some may speak otherwise. The rejoicing of those who, from the scientific side, regard Determinism as one of the conquests (Errungenschaft has been used in Germany) of our later science is an innocuous and premature proceeding with which real science does not trouble itself. That cause has had no reason to droop which has enlisted the support of Lotze, Kuno Fischer, Eduard Zeller, Renouvier, Dr James Martineau, Professor William James, the Right Hon. A. J. Balfour, Professor Upton, Professors Andrew and James Seth, Professor Schiller, and many more hardly less worthy names. As Professor James Seth, of America, has properly said, theistic philosophy has held to freedom as "the supreme category" of the moral self, even against improved modern renderings of Determinism, and has maintained the proper place of contingency in our notion of freedom, differentiating such contingency from mere caprice, or even indefiniteness. There need not, we venture to think, be anything very utopian or fantastic in so doing. Of course, not all forms of recent indeterminism are alike, as it would be enough to show if we recalled the indeterminism 
of Renouvier with its phenomenist basis, and that of M. Fonsegrive and Dr Mach, known as relative -not absolute-indeterminism, not to speak of that of still more recent writers. Nor are all forms of Determinism of the same colour either, for there are those who, like Ribot, adopt a scientific determinism which should be viewed as relative rather than absolute.

With particular power has recent theistic philosophy proclaimed its differentiation of man, in his exercise of rational judgment and choice, from the animal, with which, on one side of his nature, he is correlated, but which he transcends as a being that cannot be holden of natural forces or confined to constitutional spontaneities and automatic responses to environment. It has rightly judged that, as nothing could be more fatal to the true freedom of the will than the soul-cramping Spencerian "Principles of Psychology," which-no less than Spinozism, later as well as earlier-regard freewill as illusory, so nothing must be more strenuously conserved, in face of opposing tendencies in science and philosophy, than that freedom of ourselves, as choosers of our ultimate ends and as centres of volitional execution, in virtue of which we are able to transcend the region of necessity, and to know that Infinite Spirit which is free with a freedom that is absolute. For theistic philosophy sees how little possible any real freedom is to the physical fatalism which makes up the essential posi- 
tion of Spencer, who recalls for us the scientific materialism with which the world is weighted in the view of $\mathrm{F}$. A. Lange and others. It sees how strangely the fact of man's free personality forces itself on Spencer himself, when he, in treating of psychology, so curiously speaks of active energy as welling up from the depths of our consciousness, and of the fountain of power within us - "curiously," we mean, if consistency with himself be considered.

Theistic thought has discerned very clearly that if, as Huxley has said, the progress of science has in all ages meant, and now means more than ever, the extension of the province of what we call matter and causation, and the concomitant, gradual banishment from all regions of human thought of what we call spirit and spontaneity, this expulsion of freedom and spontaneity, than which man has no more priceless powers, only shows how far such science-with its banishment of responsibility and other moral elements-is from being the last and deepest note in human thought. But it has been as far as could be from accepting such a dictum, and has unswervingly maintained the compassing of complete agreement and free interplay between the antagonistic terms of thought just now specified to be the end of true knowledge or science. It has found Huxley himself, quite recently, declaring, in the most unequivocal manner, what amounts to saying that, however the vast evolutionary pro- 
cesses may cover the whole history of man, man's ethical progress is altogether peculiar in that it must be in opposition to the "cosmic process,"must, in fact, be in freedom since under such selfsacrificing motives and sentiments as prove it to be no longer submerged under the process of physical evolution. That indeterminism which offends only the "native absolutism" of our intellect has been pronounced by Professor James, of Harvard, in his own brilliant and forceful manner, less irrational than the determinism which throughout and utterly violates our sense of moral reality. This is not, of course, to sit loosely to that synthesis of the intellectual and the moral judgments unto which we are, in choosing this horn of the dilemma, not yet come. Theistic philosophy has, with less tergiversation perhaps, and greater clearness, defined freedom in recent years as consisting in choosing- not without motive, as Diderot and others imagined, and not in entire indifference of the will, as Tappan represented, but-between possible alternatives, the will being absolutely without compulsion from the outside in the exercise of its determinate preference in presence of the conditions of choice. For it claims for freedom, such velleity, or capacity of alternative choice, carrying, as velleity does, spontaneity with it and adding the possibility of alternative choice thereto.

Theistic philosophy has witnessed a marked advance within the last decade in the psychological 
presentation of the indeterminist position, the old independence of motives, and indifference, on the part of the will, having been so largely left behind. The reasonableness of a relative determinism it may be said to have seen more forcibly demonstrated, and to have found in it a place for the principle of sufficient reason. It has held to freedom, not only as volition which is really inhibition, but also more positively as self-realisation or evolving of spirit. It has-if any will so have it-clung to freedom only as the highest form of causation, not as antithetical to it. Holding to the fact of freedom in the more enlightened form under which it need not mean causeless volition, it has declined to give way to determinism, although granting the more freely admitted presence of law, as ascertained by means of social statistics. For freedom has not meant for it an independence of motives, but our choosing from the midst of motives, and not acting merely as through motors. So far from motive being absent, motive is, as Green puts it, but the will in act, and the will in act is but the assertion of the self as it chooses and proceeds to realise an end and aim. And we are at one with $\mathrm{Dr}$ William G. Ward in thinking that, in those transcendent moments when. supreme volitional effort has borne us whither we otherwise would not have come, such efforts were fruit rather of what we ourselves are than of the motives or reasons by which they are sup- 
posed to have been "caused." Rightly has $\mathrm{Dr}$ Ward maintained that we know them to be due in this way to ourselves. We take it that, for theistic philosophy, God remains the supreme motive, in the spirit of those sublime lines-

"From Thee, Great God! we spring-to Thee we tend, Path, Motive, Guide, Original, and End."

We are free, but God is also free to will and to work in us of His good pleasure. When $\mathrm{He}$ so works in and through us, then is the rightful force of the universe behind our acting as motive. When we are so motived, we are on the summits of spiritual being, acting in perfect accord with the laws of our own being, but also with the laws of God's nature and method.

It has also been a philosophical advance that recent thought has been able to distinguish between choice or the determinative acts of will, and volition or the executive acts, as it has done, and that it has assigned to self-conscious and responsible choice, as obedience to restraint, its recognised importance in the conditioning of moral freedom. What it has properly maintained as its essential conception of freewill is the real contingency of my voluntary -decision-a decision, as we are very soon to show, that must be just as little determined by an inward, as by an external, necessity. For we are at one with those philosophers who hold the one to be just as really determinism as the other. We 
boldly face the break in the chain of causation, whether physical or psychological. We cannot allow that any identity of psychological condition, or any uniformity of physical law, must mean unvarying decision on our part. We are far from saying that the practical exemplification of such freewill is easy, but what we are concerned with is that it is both possible and true. Theistic philosophy has given freer recognition, on the one hand, to that restricted, no doubt, but real power which, as Dr Carpenter and others have shown, will, rational and free, exerts over body, and, on the other hand, to the partial and limited truth in those physiological causes, which, as Dr Maudsley has insisted upon-amid much that is excellent as to body and mind-in a one-sided and incomplete fashion, effect, under certain circumstances or conditions, changes of character, without, however, substantially affecting the position of theists in maintaining the priority of will to character.

No doubt, the delicacy and the exactness of the correspondences between mind and body are much more keenly appreciated than they were, but nothing that science has yet been able to set forth as to these relations of "psychosis and neurosis" is of a kind to invalidate the theistic position in the remotest degree. From such effects of disease or accident neither the non-existence nor even the inaction of the mind has been proved. The unconsciousness which these have induced simply 
emphasises, in a striking manner, the close connection which subsists, in our present state of being and knowledge, between the body and mental activities. We take Theism to have been at one with Janet in the deserved stress he has laid on his third form of determinism - that rational determinism which consists in "the power of acting in accordance with conceptions or ideas." As it has held to the absolute freedom of God, the condition of His active energy, so it has maintained the true self-determining power of the human will, in virtue of which man not only chooses his ends, but also controls his life. This reality of selfdetermination by a permanent self-identical ego has been ably set forth by Martineau and others, in opposition to Bain, and those whose empirical psychology strips our personal causality of all being save that of a series of sequences in time. The reality of freedom, in fact, has been very clearly seen to stand or fall with the reality of personality in man, these two-personality and freedom-really and truly standing or falling with each other. It has thus grown more evident how far recent philosophy of theism has advanced beyond the phenomenalism of Kant, which vitiated for his philosophy the lofty "realm of ends" to which, in his fine insistence on purity of volition as the goal of will, he did not fail to give an abstract recognition.

We are disposed to claim for recent theistic philosophy that, with greater power as a spiritual 
philosophy, it has declared the real, and not merely formal, freedom of man as a spiritual personality -of every man who has chosen so to live. This actual freedom Professor T. H. Green, with his acknowledged power, has brought into prominence in a way for which theistic philosophy deserves, we think, to be grateful, although it must see very clearly how utterly this service is marred by the way in which Green sacrifices freedom on the shrine of character-that thing of necessary causation in his view. For it certainly refuses to follow Green and others who make of man's moral character what Professor Upton properly calls "an inevitable growth," and who treat "heredity and circumstances" as "the sole arbiters of his destiny." But, tempered by regret as our admiration may be, we cannot but admire Green's characteristic presentation of the way in which the motive lies within the man himself. $H$ is is a needed and wholesome presentation in view of recent teachings as to heredity and circumstance in their ethical bearings. It will not do to gloze over the matters we have just been dealing with by saying that selfdetermination combines both the Libertarian and the Determinist views, for the point on which attention must be fixed is that the theistic viewas we apprehend it-postulates a real contingency in our action which is not annulled or effaced by the uniformities or internal necessities of character. To say that I am determined, but only by myself, 
is to come short of the full glory of freedom. There must be perfect scope for moral process and free initiative. This we say boldly, undeterred by the fact that, though the "liberty of indifference" is so far left behind that, while it might be passable to have it singled out in Bradley's 'Ethical Studies,' some recent writers-Professor J. S. Mackenzie, for example-might have been expected to do better than still turn attention to it rather than to the real contingency issue. We can just as little accept this eirenicon as we could the determinism that issued from Schelling's postulation of pretemporal and super-temporal acts of freedom.

We are not disposed to take so lenient a view of determinism in relation to the action of the individual as some recent writers-Professor Caldwell, for example, in his fine work on Schopenhauer's system - and we feel bound to maintain a real subjective possibility of choice for man, a freedom whose reality is no whit impaired by the fact that such freedom is limited in its practical issues by certain internal and external circumstances. Theistic philosophy has more forcefully shown that man's volitions, while accordant in a true sense with law, differ from the changes we see in the physical universe - where necessity is the correlate of law - in being entirely initiated and determined from within, and that, too, in another way than the theory of the automatists supposes. It has had a very clear perception of the freedom 
and spontaneity which mark man off from the animal creation, which latter has, of course, a spontaneity of its own as compared with the world of things inanimate. Such consciousness as the animal may be said to possess is a centre of movement for it, but obviously not a centre comparable to that found in man, reflective and free.

Theistic thought cannot be said to have found any satisfactory rational ground for moral freedom and responsibility in the attitude assumed by so able and recent a writer as Professor Royce, of Harvard, who, viewing us in our time-relations as tied in a hopeless manner to our nervous mechanism, sets forth the identity theory, whereby reality is resolved into dissimilar forms or aspects, and our responsibility is resolved into an unreal and timeless participation in the free choice which he postulates for the Eternal Self. Unlike Royce, Höffding, and Romanes, recent theistic philosophy has, we venture to think, tended towards finding free spirit more truly interpretative of matter. With this freedom of man's will it sees that the absolute knowledge or infinite prevision of Grod no more conflicts than human prescience conflicts with our own free agency. It acknowledges, however, with Mozley, that the truth of man's freewill stands so related to the idea of Divine Power that it cannot, of course, become an absolute truth, any more than in days when Æschylos declared that no one is free save Zeus. Such an absolute liberty it 
does not venture to claim because it sees, with Janet, the futility of claiming a liberty which would be unmanageable by us, while we refused such a liberty as we need. It is content with what he calls "the power of emancipating ourselves from the control of our inclinations." In fact, it cannot postulate a strictly absolute freedom for Deity even, if so be it maintains in their integrity our own freedom and personality. It allows not man's free moral self-determination to be swamped by the causative agency of God, but, while holding, as Martineau has well said, to God as Author of all our possibilities, does yet not make Him responsible for our actualities. The door of philosophical escape from the difficulty of the Divine foreknowledge, in respect of human freedom, which Renouvier has opened, is just to admit that the prescience of Deity is not absolute in character.

Theistic philosophy recognises, as it never did before, how truly this human freedom, as something to be won, is subject to development, as all our powers are. This aspect is properly remarked upon by Trendelenburg, who points out that freewill is no ready-made product any more than is thought, but is a fruit of development ('Logische Untersuchungen,' vol. ii. p. 94). Freedom is not to be thought of only in the light of our immediate actualities, but as that whereunto we may come. The theistic philosophy of religion may be claimed as recognising this aspect of things, whereby free- 
dom is that towards which we are advancing, not merely that whereunto we have attained. "That no mind is free until it becomes free, that moral freedom, if possessed at all, is gained only after a certain psychical development is passed through, is an indisputable conclusion from the study of psychology. If, however, the mind ever attains to moral freedom, it does this in the forth-putting of self-conscious and responsible choice." We accept this fact of choice only to say that it iswhether our scientists have understood the matter or not-a more real, more potent, and more expansive fact, than their theories of heredity or evolution suffice to explain. Hence the ethical culture of the will is now, as the result of the ethical emphasis of Kant-to whom a good will is the one thing of absolute value-and Herbart, more recognised, we believe, as the highest ideal for our ethical personality. We surely better feel the force of Rothe's strenuous ethical insistence on the completely actual power of self-determination as something only acquired in the thorough moral development of the subject himself. For it has become less doubtful to us that freedom grows with every increment of moral power and physical vigour and righteous life.

But, while recent theistic philosophy has advanced in its acknowledgments of the power and scope of heredity, education, and environmentsthe leverage and auxiliary forces of the will-it 
has, with no small skill, opposed the advocates of the doctrine of philosophical necessity in their unduly emphasising these, so that spontaneity becomes eliminated from psychology, and we are left no more creators of our future. We object to heredity, which we admit as an influence, being turned into a fatality, for the race characteristics and the physiological impulses it may bring us cannot be allowed to dominate our moral personality, and beget an irresponsible condition of things. We maintain that life is for freedom, and that the free personal is an irreducible element in the life of man as a moral personality. Yes, an element which has the power to resist and transcend the law of heredity as a fatalistic thing. Heredity just as little explains our free upward choices as it does the outburstings of genius. Heredity, which has so often been called out in this time to curse, has still found voice at times to bless. And then its speech may have been slower, but that which it spake was all the more a strange, inexplicable thing.

We hold that theistic philosophy has maintained the reality of liberty none the less successfully for having more amply acknowledged how that liberty is less abstract in character, more limited in range, more characteristic of the whole of life than of its every act, more dependent than was formerly thought upon environment, education, and the crystallisations of character and experience. We maintain that true 
theistic philosophy is seeing the need to take causal circumstance, limitation, and temptation, all into account if we are really to understand and do justice to the law of freedom in relation to what the poet calls

$$
\text { " the dread strife }
$$

Of poor Humanity's afficted Will

Struggling in vain with ruthless destiny."

But in all this it is only exemplifying, in changed and more real fashion, the quaint poet's words-

"How much, preventing God, how much I owe

To the defences Thou hast round me set;

Example, custom, fear, occasion slow,

These scornèd bandsmen were my parapet.

I dare not overpeep this parapet,

To gauge with glance the roaring gulf beyond,

The depths of sin to which I had descended,

Had not Thou me against myself defended."

Thus it accords with one who said, "My freedom is an island of small extent in an ocean of necessity which opposes, on every side, an inexorable bar to my finite power." But it is precisely within those limitations against which our spirits chafe that our true, free destiny is realised.

We contend that theistic philosophy has endorsed the forceful manner in which Martineau has shown how vain is the attempt of that distinguished psychologist, Professor Sidgwick, to hold the Determinist problem in neutral solution, when he urges that freewill is a fact, or else moral judgment, 
4I8 RECENT STUDY OF HUMAN FREEDOM.

with its "presence of a personal power of preference," becomes a "delusion." We maintain, further, that it has been rightfully claiming true freedom for man's will with all the powers and consequences which such a claim implies, unhindered in the least by any evolutionary theories as to the time and the manner in which the sense of freedom and responsibility become his. It finds that, when evolution has finished its work, the fact of freedom abides. It is the freedom of rational self-direction attained through obedience to the emancipating law of reason, as it frees from the sway of blind impulse. It is, in our view, the perfectly realisable freedom of a real self, not a self composed merely of a compact majority of existent desires.

There can be no great occasion now to go into the discussions of Hamilton and Mill, who were in substantial agreement-more so than the latter was himself always aware - as to whether we are in freedom wholly free from causation. But we have not got beyond the need to recall, what Zeller says in the last chapter (of the second volume) of his 'Vorträge und Abhandlungen,' that "we are ourselves the only cause (Ursache) of whose mode of action we have immediate knowledge through inner intuition" (Anschauung). Green we take to have made a noteworthy advance on Mill when he emphasised the fact that, in contending for freedom, we are not driven to shun the Scylla of determinism only to fall into the Charybdis of indeterminateness, 
since there is that true via media in which freedom in the self-conscious subject means freedom in, but not from, motive. What we do here decidedly object to in Green is the way in which he immolates the self on the shrine of character. We object to be told that "the action is as necessarily related to the character and circumstances as any event to the sum of its conditions." We object to being told that "he, being what he is, and the circumstances being what they are at any particular conjuncture, the determination of the will is already given, just as an effect is given in the sum of its conditions." What right has the self to be sunk in the character in this fashion, and made identical with it? We maintain that the man-the self-is always more than the words, more than the works, more than the character, and we give an emphatic non sequitur to Green's absurd supposition that, because we do so, the self therefore stands out of all relation-or even out of most real and intimate relation-to character. We certainly maintain for this self an original spring and freedom of movement which cannot be gauged by any record of its own past. We regard as significant the statement of Professor Henry Sidgwick when, in the chapter on Freewill in his 'Methods of Ethics,' he says, "that, in fact, ' responsibility,' ' desert,' and similar terms have to be used, if at all, in new significations by Determinists."

We do not suppose it can be doubted that theistic philosophy has been wisely led when it has in 
its recent stress planted firmer feet on the whole history of humanity as its proof of human freedom, whereof the very laws and languages of mankind are witnesses. For our part, we are free to grant that, not without some plausibility and force has recent monism argued against indeterminism as making every action scientifically indeterminable and morally indifferent. But, admitting will in its freedom to be not independent of the action of spiritual law, to which it may offer obedience, we yet cannot consent to determinism under an overshadowing influence of the law of causality as found by science in the material world, and as bound in the very nature of the forces concerned.

Pfleiderer has, when treating of the philosophy of religion, expressed, with his accustomed lucidity and force, this increased psychological place which has been found for character-as against severe indeterminist theory-whereby freedom is no more "an acting from the pure indeterminedness of a merely possible or unreal ego," and its every act no more "an uncaused decision from a state of pure undeterminedness." It is in some such way that we can allow a certain truth to Schiller's fine negation in "Wallenstein" of an absolute freedom of will :-

“ Hab' ich des menschen Kern erst untersucht? So kenn' ich auch sein Wollen und sein Handeln."

Have I the human kernel first examined?

Then know I, too, the future will and action. 
Professor James Sully, in his 'Psychology,' seems to follow Volkmann in respect of the "semblance of indeterminateness," holding the action to be always the resultant of the factors engaged, or, as Volkmann has it, of the collective internal movement.

All this sort of justice, which is, rightly enough, claimed for character, is not, however, to be carried to any lengths that would be incompatible with the position of $\mathrm{Mr}$ Balfour. In his recent article in 'Mind,' when speaking of the freedom of the man of whom it is impossible to say "that he ought, and therefore he can, for at any given moment of his life his next action is, by hypothesis, strictly determined," $\mathrm{Mr}$ Balfour goes on to show how man's responsibility is destroyed by a theory which, though making his action the outcome of his character, treats his character itself as "the outcome of causes over which he has not, and cannot by any possibility have, the smallest control." What spontaneity and grace, we ask, would be left to human action, when we should be made so completely the creatures of habit and passion? The truth is, no inward necessity, such as character, can for a moment be allowed to obscure or exclude the real contingency in our acts of choice. Yet, if things go on as they at present appear, this dependence of will upon character must rapidly become the conventional one. It seems to make the matter easy of comprehension; and it is well adapted to 
an age somewhat indolent, deeply imbued with scientific habits of thinking, and not over strenuous in its moral moods.

We find another instance of this treatment of character in Professor S. Alexander, of Manchester, to whom freedom's sense means sheer delusion, and character is everything. This mechanical mode of thinking we shall discuss and criticise presently in connection with other recent writers who occupy this position. Meanwhile we express our agreement with Professor Upton when, in a recent article, he says-"While our character determines the nature of our temptations, we are, I believe, clearly conscious that it is not the character, but the self which has the character, to which the ultimate moral decision is due. In every moral crisis of a man's life he rises in the act of moral choice above his own character, envisages it, and passes moral judgment on the springs of action or desire which he feels present within him; and it is because a man's true self can thus transcend and judge his own character, that genuine moral freedom and moral responsibility become possible and actual."

It will be seen how very far indeed is our position from amounting to an unqualified endorsement of the positions advocated or expressions adopted by defenders of the doctrine of philosophical necessity like C. E. Plumptre, in his recent 'Natural Causation,' by whom spontaneity and the choices 
of reason are, virtually at least, eliminated, and to whom man, as the resultant of the past, is no free electing ego, but the mere creature of conditions. It was a mere absurd and arbitrary $a$ priori materialism that led Professor Clifford to maintain that volition has no power to influence matter; yes, it was "the mere omniscience of an a priori materialism." As Dr George Matheson has well said, "the ideas of cause and power would never have been even suggested by the objects of nature but for the presence within us of a determinative will," and man's sense of freedom has been "most strongly felt" just "where his power to recognise causes is the widest and the most unerring." Theistic philosophy has not been so walled in by any adamantine necessityframed of pre-conditions and ambient circumstances-as to be unable to sing-

"Stone walls do not a prison make,

Nor iron bars a cage;

Minds innocent and quiet take

That for a hermitage.

If I have freedom in my love,

And in my soul am free,

Angels alone that soar above,

Enjoy such liberty."

The incomprehensibility of this freedom, as Lotze has, in his 'Philosophy of Religion,' in the clearest manner pointed out, need cause no offence, since it is of the very nature of morally free choice 
that it be not comprehensible-flowing, that is to say, from a set of pre-existing conditions in some necessary way.

When we find so acute a thinker as Mr G. F. Stout, the able editor of 'Mind,' but lately saying, in reference to the contention for contingent freedom, that "we might as well argue that the fall of a penny is not causally determined, because when we throw it we do not know whether head or tail will turn up," we seem to find only the traces of those mechanical modes of deterministic thinking which would be in place were man indeed a "penny," and not a personality.

We pass over the strangely inconsistent attempt of Kant to combine freedom and necessity in man, so that he ended by making freedom - which he excludes from the external world, as subject to the law of necessity - a wholly ineffective thing, in his anxiety to maintain freedom, while touching natural necessity as little as might be. Man is, with him, now an intelligence (Wesen an sich), free, independent, supersensuous, and now a being belonging to the world of sense (Sinnenwesen), subject, as such, to the laws of nature or natural causation. The nature of man is thus disrupted, desire is reduced to mere natural appetence, and the pure self-determining reason is divorced from desire, which last assumes so necessary a character. Defective and inadequate Kant's doctrine of freedom could only be: the serial self-determination, 
of which we have spoken, Kant never knew, though he sets the empirical will under the sway of natural causation. Though he sought the noumenal, he had chosen so to cleave the noumenal and phenomenal in two, that he was quite unable to attain to a law of real freedom. Hence, while freedom might be to him an abstractly conceivable thing -conceivable in transcendental fashion-the compatibility of a certain place for natural causation with a true doctrine of freedom never could be his. It is due to Kant, however, to say-as we have in our chapter on the Moral Argument donethat the sacred worth of human personality found conspicuous recognition in his system, which is something to be thankful for, notwithstanding the difficulty in which this dualistic tendency lands his ethical treatment. This regard for personality is evident from his insisting, when dealing with the 'Foundation for the Metaphysics of Morals,' that humanity be always treated as end, never as means. But as for freedom, we see the Kantian conception of it to be one-sided, even in an ideal sense, for it is on his conception realised only in an abstract and purely rational manner. Because the Kantian conception of freedom is so lacking in the concreteness of its reference, it is not the freedom of the actual self, the sinning and suffering self, that we know so well in life's experience. No, only a phantom or abstraction of it, even though it be a rational one. 
Nor do we dwell on the peculiar pre-destiny by which, while professing to save freedom, the naturalistic theism of Schelling handed our earthly life over, bound hand and foot, to determinism. It is in Fichte we see the fact of the free will become the chief and outstanding fact of the world. It is in Hegel that we find the announcement that "the truth of necessity is freedom," which is not to say that we find the Hegelian recognition of freedom a real and satisfactory recognition of the freedom of the will. With Hegel pure self-consciousness is an absolute capacity of abstracting from every determination, and is, consequently, an indeterminate thing, to which, standing by itself, Hegel gives not the name of freedom. He adds another element to this abstract universal, which may be designated the particular, as giving definite direction to the will, though not rescuing it from contingency or caprice.

This particular must be so taken up into the universal, as to issue in rational self-determination, wherein freedom is realised. But Hegel, in so doing, gives up care for the individual, and, in attempting to bridge the chasm between reason and desire, he subsumes the individual under the Absolute in a way which leaves the active human will lost in a dialectical haze. Because the Christian philosophy of religion seeks to have us, in our impulses and desires, not simply intellectualised or rationalised, but spiritualised or sanctified, it 
brings to us such a vision of goodness as begets at least what the poet of the "In Memoriam" finely styles

"the vague desire

That stirs an imitative will."

It restoreth the soul to a real freedom - the freedom of the spirit: it allows not to rest in a merely formal freedom, though reason rule therein.

Recent philosophical theism has rigorously exposed the thoroughgoing determinism of Schopenhauer, who, diverging from the mode of Kant and Schelling, attributes freedom to man's entire action or "free doing" rather than to his essence or being, and assigns his action to the sphere of necessity. It has been shown how he neglects the obvious necessity of existence prior to operation, and how he does not seem able to be quite fair in treating of the part played by motives in our freedom of choice-not freedom of spontaneity in his sense. The subserviency of reason to will, which is so marked a feature in Schopenhauer's philosophy, leads him to ground any spontaneity we possess in will rather than in intellect. In this way he easily comes short of doing justice to freedom on its intellectual or theoretic side, and his shortcoming is not less conspicuous as touching man's free practical activity. He forgets that, as Professor James has well said, "in these critical moments, what consciously seems to be in question is the complexion of the character itself. The pro- 
blem with the man is less what act he shall now resolve to do than what being he shall now choose to become." Yes, for we certainly retain an ethical freedom for man, and not merely for his will or volition. It is "only," as one has said, "in the schools that the freedom and correlative responsibility of man are restricted to the will. The moral judgments of the race attribute to him an ampler freedom and a wider responsibility. Indeed those noble moral affections which are independent of the will create, when expressed in acts, a far warmer and intenser moral approval than any similar acts of mere volition which are not inspired by these affections."

Recent theistic philosophy not only rejects, as we regard the case, the mechanical standpoint of Dr Paul Rée, to whom the will is not free, and should not be thought of as free in the sense of an absolute beginning (ein absoluter Anfang), but it also maintains that volition, so far from being causeless, is only free from compelling causes. It holds that the inciting motive may be perfectly clear to us, and the influence of our free will be yet clearer to us, as it prefers this motive to others, and decides in face of opposing inward wishes and contrary inclinations. Such an absolute commencement as Rée represents for its "free" action it declares to be a manifest misconception and absurdity: the freedom it claims is, with Green, not some unmotived and inexplicable willing, but only that of 
action which is the free product of reflection exercised in midst of diverse motives. This theoretic freedom of the will it maintains inviolate, even while granting the presumptive certainty of man's action from the already formed character and condition of the will with much greater readiness than was formerly the case-a readiness grounded in the recognition that character, in so influencing action, does so in a sense that savours not of physical necessity.

Determinism is, no doubt, right enough in laying stress on the way in which a man's character is what his acts of will have made it, since these give to the will a fundamental direction. But character is not something that is ever at any time closed. Man's most peculiar work is just the upbuilding of character-his main enterprise for splendour and extent, as Emerson rightly said-and he builds it by conscious will. For this, personality equips and befits him. Yes, and even from his failures he may rise to its realisation through penitence and repentance, for which determinism, it must be said, leaves no real room. What indeed do we in our repentance but just freely negate our own doings or misdeeds, and charge upon ourselves the fault of having placed our freedom of will, in uncompelled fashion, at service of unrighteousness? The sting lies, of course, precisely in this, that we could have willed otherwise. What we distinctly complain of is the way in which the-no doubt relative but- 
incalculable element in character is overlooked, so that place is not left for the free, unexpected moves of will upward. We deny the right by which this incalculable element is interpreted as a chance element, and maintain that, in what is contingent, the result is reached-when true freedom is realisedalong the highest lines of reason. We come back to say that theistic philosophy finds, as we view the case, that Rée's contention that responsibility is an illusion, which ceases as soon as man sees that actions are really necessary, is, while not without a certain amount of truth in the reasonings urged in its behalf, maintained by him in a way which shows a lack of force or insight, inasmuch as the consciousness of responsibility, as fact, abides or persists.

Our philosophy has likewise found that Paulsen, who has quite recently treated the freedom of the will as a scholastic whim or a metaphysical phantom, has been able to do so only because he has adopted the falsity which lies in the significance he imports into the term, and because he has, by a very palpable misconception, regarded freedom as meaning freedom from cause in a way and sense which all will disown save the chosen "few" who follow Rée and himself in foisting it upon unwilling adversaries.

Our latest theistic philosophy has not, we venture to think, experienced any hesitation in leaving behind the positions of the Danish philosopher, Höffding, when, in this connection, he has construed 
freedom of the will to be willing without cause in independence of everything antecedent, and when he has, further, represented the theory of freedom as making man something merely accidental, since not thus subject to the law of causality. Theistic speculation maintains, as we believe, a more intellectual ground for its doctrine of freedom than Höffding would allow, and it does not admit any disharmony between the intellectual and the moral life. It denies that freedom is rightly interpreted by Höffding as simple denial of the law of causality, or that he is warranted in regarding the will as in no sense creative, only modifying and selective, because of the mechanised realm in which his thought moves. When he further avers that freewill severs man from his kind (Gattung), breaks up the unity of being, and does not regard being in its totality (als eine Totalität), theistic philosophy has no difficulty in discerning the pantheistic totality in whose interest his affirmation seems to be made, and as little in repelling the suggestion of any severance from human kind. Yes, of course, since freedom really relates the individual to the whole -only doing so in freedom, and with such relative independence as is allowed by those impulses and laws that bind him to his race.

We hold, as a great form of limitation, that man by his own individuality moves in a restricted and determinate circle of possibilities. We have not to think, however, of individuality as something 
finished and complete, but as a mere foundation or groundwork, so to speak, out of which possibilities shall arise. When Höffding so greatly minimises responsibility (ein Tausendstel der Handlung), because the individual is so small a part of the whole, theistic philosophy allows that only little is determined purely by our self-determination, and much effected through our diverting our inclinations, but it yet preserves the fact of freedom, which it has found Höffding fail successfully to impugn.

Professor A. Riehl, with his Spencerian tendencies, or, more strictly, approximations to agnosticism in the Kantian or Epistemological sense, has also given the freedom of the will very decided treatment, viewing it as illusion, though appearing to the actor as free. Riehl shows Rée to have been mistaken in thinking that, while philosophers have shown the will to be not free, they had not shown why it appears free. But Riehl, who is here very penetrating, does not, like Rée, treat responsibility as illusion, but argues that responsibility is impossible on a theory of indifference. It is precisely because we are not free that, on his novel and striking presentation, we are responsible, that is, to the universal mind or society, which seems to provide a morality which some philosophers are unable to transcend. With no lack either of ability or of confidence, Riehl delivers his paradoxical utterances to the effect that 
action is freer, the more it is controlled; that nothing is less in our power than will; that experience is unable to confirm the freedom hypothesis, for the self-consciousness is, with him, "necessarily incomplete and at the same time partisan." Now, Riehl is probably well-advised in impugning the testimony of consciousness, if he can, since that testimony has been so strongly in favour of freedom, but we demur to his inferences or suggestions as to consciousness, involving, as they do, a lack of understanding of the real grounds on which freedom is held. Riehl, like many another, rides off on an assumption of the matter, and will have none of consciousness, in his eagerness to sacrifice personality to phenomena.

We plainly assert that, all modern influences and tendencies notwithstanding, these attempts to turn consciousness into a liar from the beginning do not carry for us a hopeful outlook. We should like to know what is to remain stable for us if things are not to be taken for what they are-if the deeply-seated intuition that the will is free is to be lightly dismissed as among the apparencies of feeling? What valid reason can be adduced why such a congruous and harmonious fact as this of freedom may not be truly and vigorously attested by feeling or consciousness without any further proof? Such demand for proof is simply futile and absurd, and grounded in lack of understanding of the conditions of the case. We use plainness 
of speech, because nothing is here more necessary and desirable, however much we feel and appreciate the desire of aloofness from the partisan spirit. It is surely right that in such matters men should know where we are to be found. We are bold enough to affirm that, were the witness of consciousness more complete, it would be to show that the potentialities of freedom which are ours are in reality greater than we have known. It is the possibility, as Professor Sidgwick has said, of action in conformity with practical reason, with which we are here concerned, and it is thus impossible not to maintain free choice, "however strong may be my inclination to act unreasonably, and however uniformly I may have yielded to such inclinations in the past."

Indeterminism, in the sense of having no respect to motive or pre-established character, is declared by Riehl not to exist; on which it is sufficient to remark that if it did, it would not be that for which we contend, and which Riehl has failed to refute. For, as he desiderates proof rather than mere assertion in others, we are entitled to expect the same from himself, and not indeterminism of the "man of straw" type. Besides, Riehl's determinism, whose chains are of his own forging, has really far more of a fatalistic tinge than he is himself aware, and has poor warrant for the responsibility he would retain. At the same time, let it not be thought that, in saying all this, we are either for- 
getful or inappreciative of all that may be secured in the way of ethical result by attention to those psychological conditions and exercises on which deterministic theory has laid stress.

It is in a like tone to that of those deterministic philosophers, of whom we have just spoken, that Dr F. H. Bradley has recently allowed himself to speak of Freewill as, "in short, a mere lingering chimera," and as something which "can merely mean chance," thereby proving only that there are depths in the moral consciousness of freedom which even Dr Bradley has not sounded. Yes, moral glories in man's self-determination, whose very greatness - though unperceived by him - largely consists in that the issues cannot be foreseen or foretold. Dr James Croll combats the indeterminist position on the ground that illusory belief in an undetermined will is due in reality to determination arising from psychological states that come not into distinct and conscious view, and which deeper introspection, as he thinks, would lay bare. We regard his presentation of the case for philosophical determinism as far more able than convincing.

Let it now be plainly said that we are not going to allow our thought to rest in the inadequacy that feels not the self-activity of the soul-so true and essential in freedom. Already it must be very evident what a will-o'-the-wisp is the freedom which such deterministic writers are at vehement pains to deny: we know no reason why theistic 
philosophy should not allow a series of antecedent selves, and their determinative effect, on will and its choices; we know, however, that this does not exhaust the problem, for character is not to be merged in mechanism, and our free self-activity is not to be blindly sacrificed at the shrine of mechanical determinism.

Highly unsatisfactory and perfectly futile is the way in which Dr Croll attempts, in the interests of philosophical determinism, to escape this mechanical conception, by treating necessity as the certainty that is in things themselves, and not imposed from without. It is surely not a great thing if we claim that the latest theistic philosophy has advanced with increasing confidence beyond the recognition of the mechanical aspect of the process - true so far as it goes - as being neither the whole nor the highest part of all that is involved in this moral problem. It has maintained the difference of immanent cause, as free, from that which is mechanical, so that freedom is no more upset by the law of causation, as some have so persistently supposed. It has more successfully vindicated subjective causation or subjective determinism, in the interests of spontaneity or self-initiative, as opposed to mechanical causation. It has postulated intelligent Will as the primal Force of the universe, and has pondered the alternative so well set before it by $\mathrm{Dr}$ Matheson, that "if we reject this view, we render every sphere of creation incomprehen- 
sible, but no sphere so incomprehensible as the province claimed by the evolutionist, for we shall be confronted by the spectacle of a creation out of nothing unparalleled in the annals of religion-a creation which has brought the sense of freedom out of the depths of slavery, and has fashioned the consciousness of will out of those lifeless materials whose distinctive feature is the absence of volition." We think it has not failed to note the significance of such a contention as that of Simmel in his Moralwissenschaft - to which Professor J. S. Mackenzie has properly directed attention in 'Mind'-that Determinism never can be proved.

It will, then, be very evident that, in maintaining the positive metaphysical doctrine of freewill, the worth of virtuous training and habits is acknowledged, to use the words of Professor William G. Ward, as "not less inestimably great" from the Libertarian side than on the Deterministic hypothesis. In so maintaining the freewill premiss to the theistic conclusion, we only need, and only care, to deal with actual psychical fact as we find it in ourselves and in others, at their and our best. There can, in our view, be no doubt of the deepening conviction, on the part of recent theistic philosophy of religion, that. ethical and religious vitality are only to be maintained by a real freedom of the will being conserved, in face of every opposing tendency, whether pantheistic, or positivist, or pessimistic. 
We say "real freedom," for, call it an abgeleitete Absolutheit or derived freedom as you will, it is with this we are concerned. We find no reason to deny that our freedom is a conditioned one, for its circle of possibilities is restrained by the nature of our own individuality. This, of course, is something which every man brings into the world with him. Not that our individuality is some readymade product, since we bring, so to speak, only a first projection of it, which awaits developing, and shaping, and correcting, under life's manifold influences. Besides his personal character, man has a nature character of corporeal kind, springing out of his connection with nature, which connection, let it be said, has a limiting effect on his freedom. No subsequent developments, indeed, which man may make can escape the effects of this original imprint of individuality upon him.

Every one has, as Professor A. Dorner, of Königsberg, has very properly insisted - in his lucid and massive volume of philosophical ethics ('Das Menschliche Handeln') recently publishedhis own peculiar predispositions as an individual, so that, not as man in general, nor as personality in general, but only as individual personality can he perfect himself to an harmonious totality. Not, of course, that this individuality is to be conceived as mere ready-made product, for it is rather only a noble and swelling germ in the view of our wisest philosophy of individualism. The sphere of 
its realisation of freedom is, of course, a social one, and there is no denying the emphasis on the solidarity of man alike in the historical and the scientific thought of to-day. In fact, the tendency is towards a determinism that does injustice to the individual. Surely we can maintain the freedom of the individual, and yet do justice to such concrete forms of reason as we have in all that is "creedal" and institutional. We can as little allow man's freedom and personality to be merged, by any philosophical idealism, in God, as we can consent to their being dissipated by Determinism in Nature. But even such real freedom, as we hold, will be, as it is always in order for us to be reminded, not the highest, not the ultimate category of life: we await release from that resistance which freewill still implies, and which will fade and disappear before that perfectness of freedom which comes through love and the enlargements of our spiritual nature. Then the will, having done all, shall stand-perfect witness to our freedom.

Of a truth, it is practice, as Wuttke said, that makes the master, and the morally mature is master over his will. Every perfect gift is from abovethis, we may not forget, is true of freedom. We need power from above, for it must be plainly said that the limitations to our freedom of greatest magnitude are those which have been imposed by sin. Its limiting hand is already upon us if we are not free to behold and acknowledge how it has ham- 
pered the thought and the will of man, and sent its enfeebling darts through all his feelings, impulses, strivings, experiences. Yes, religion, too, has its determinism, and there its results may be seen down to the deepest working of the will. But it must be overcome by that higher nature in man which, working under the law of conscience, draws him towards God and goodness. This is that ideal self towards which the actual self is-rightly directed-ever tending. When the power to make our wills one with the Divine Will shall come in as with a flood, we shall still freely and consciously will the good.

Such free willing of the good, with the supreme Entschluss or resolution it involves, remains for us the highest here possible. Such freedom will yet, at best, be but a forecast or foreshadowing of the glorious liberty that awaits the children of God. But it will still be freedom that is unimpaired, amid the strange, unlimited ways in which the grace of the Almighty Sovereign and Father of men invests the hidden realm of freedom. Yea, so true abide the lines of the German poet-

"Man kann in wahrer Freiheit leben, Und doch nicht ungebunden sein." 


\section{CHAPTER XIV.}

RECENT SURVEYS OF THE REIGN OF LAW IN MAN.

WE do not suppose it will be questioned that, in recent thinking, Law has not been regarded as the narrow thing it would be so far as the bounds of our experience go, but has been believed in as a vast principle reaching in its reign to every region of the universe whither thought can penetrate. Of course, this is the case, as we have just said, rather as a mental conviction than an induction from facts, which it can be said to be only on a basis so small as to be merely fractional in extent. This great conviction of the universality of law has been attended with no small confusion of thought, not only among scientific but also theistic writers. In some ways too, let us add, with a weakening of ethical law or idea itself such as was neither needful nor warranted, even though we grant that the study of cosmical laws may proceed without ethical preoccupation. Still, there is the fact of this vastly increased 
recognition of cosmic law, with its principles of uniformity, conservation, and evolution. Certainly we reject that as an absurd obscuration of the subject which tacitly assumes physical law as the norm of law, and shuts the eye of reason to the laws of persons and of ideas, real as the laws of things. We are not concerned to deny the prevalence of law over inner as well as outer experience, for it has become less surprising, since Kant expounded for us the philosophy of law, to find that "the Moral Laws are undemonstrable, and yet apodictic, like the Mathematical Postulates." If we maintain the unity of law, we do so only as a unity amid diversity. We are thus at one with the poet, -

"God is law, say the wise, O soul! and let us rejoice;

For if He thunder by law, the thunder is still His voice."

Zeller, speaking historically in an academic contribution, utters the needful reminder that it was the conception of the divine law which first led over (hiniiber-leitete) to that of natural law, the representatives of which latter, we may add, do not always realise what it owes to religious ideas and representations. Law, as we take it, has been more carefully distinguished as a relation, not an entity - as thought rather than thing. As Professor A. Riehl has said, "there are not first laws, then things and processes subject to them. Laws are the relations of things." This is like the 
conception of Law laid down by J. G. Fichte, in his 'Science of Rights,' namely, as a "relation between personal beings." So that law, in our conception of it, must always be joined to being, of which, in fact, it is just the expression. Theistic philosophy has rightly resisted the hypostatising of abstraction under the phrase natural law, for it has not suffered itself to forget that all such natural laws are results or consequents of reality, and not its basis. These laws have their rise in the nature of things, but men mistakenly fancy that reality, whensoever it appears, must come under the form of previously existent law. The truth is, these natural laws spring simply from what things are, and tell only of what things are, not of what they must be.

Theistic thought may claim to have found itself in happy agreement with the most eminent of modern jurists when, in expounding the principles of jurisprudence as a science, they yet have taken law, in the true sense of moral law, as something which can only be addressed to persons who are capable, in virtue of intelligence and will, of obeying or disobeying it at their pleasure. This fact may help it to retain a clear vision of how divergent is such spiritual law from physical laws, since spiritual law runs up into that higher sphere in which a real-however responsive in result - dualism subsists between two wills.

The reign of law in the spiritual world is really 
one whose kingdom is to come. The laws of conscience or the moral faculty may not be allowed to bear the stamp of axiomatic or mathematical certainty, yet they do exhibit a constancy accountable only by the remarkable persistence of the moral ideal. The reign of law in the physical world, Dr Carpenter, the author of 'Mental Physiology,' thinks, would be better spoken of as government according to, than by, laws. For in Law-the form in which Ultimate Reality is manifested to our consciousness by external phenomena-we have, as one has well said, but "another name for the union of Reason and Will, wherein consists Personality." Recent theistic philosophy of religion has advanced in making good its contentions for a theory of ethics that shall lead us from law up to an Agent or personal Lawgiver-from what Chalmers styled "the judge within the breast" up to the "notion of a Supreme Judge and Sovereign Who placed it there" -not only as against modern materialistic and agnostic systems of ethics, but also in the face of the plausible ethics of Pantheism. As against this last, it has more forcefully expounded the law of right as for it an ethical law-a moral law in the real sense of the term, and not a natural lawethical because its ought lays moral obligation on us with the hand of a Higher Will. It has found, with Dorner, that man possesses conscience less than conscience possesses him; it has found, in fact, Passavant, Auberlen, Schöberlein, and others, de- 
clare in striking terms the upward path by which conscience leads to the knowledge of God. With no lack of power, it has driven home the necessity that the spring or source of ethical obligation be sought in nothing lower than some hyperphysical entity, which shall be nothing less than the Ultimate Reality.

It is with law operative in us as rational beings we have here to do, not as of necessity, but, under the obedience of enlightened conscience, of voluntary choice and acceptance. For, as Hofmann said, conscience is our first and our final resort in the field of duty. Let a man but doubt the reality of such moral law as we have been speaking of in the world, let him sit loosely to its claims upon his homage and obedience, and life is emptied of moral content and worth for him - his moral world is hopelessly shipwrecked. It is not to be thought of as law created by man's reason-a task to which reason is quite unequal: it is that pre-existent thing the majesty of whose authority reason does but recognise. It is, in fact, that strange, ideal law which conscience lays on us as something unconditionally obligatory, because by it, as true principle of our being, we are to be impelled ever forwards on the path of moral perfection, and advanced beyond that which is towards that which ought to be. It is the reign of the inner law of individual conscience (das Gewissen), passing out into criticism of the outer law or Sittlichkeit, as De Wette already seems to have perceived. 
Whence, then, we may ask, hath man this ethical law? And the deep answers, "It is not in me": earth and sky alike know it not; but whoso shall search the spirit of man shall find it graven on fleshly tablets of the heart. Whoso, let us add, shall try to escape or supersede it, shall, as Kant said, be guilty of moral fanaticism. For in the true no less than eloquent words of another, "The rule of right, the symmetries of character, the requirements of perfection, are no provincialisms of this planet: they are known among the stars: they reign beyond Orion and the Southern Cross : they are wherever the universal Spirit is: and no subject mind, though it fly on one track for ever, can escape beyond their bounds."

It was by Julius Müller very properly pointed out, in reference to Kant's apostrophe to Duty, how very real-in content, not mere unconditional form-is the moral order revealed by the law. And our late theistic philosophy of religion has maintained, with increasing skill and clearness, after every appeal to evolution and every utterance of agnostic ethics, that man is still and always a personal power and a responsible agent, conscious of being bound by ethical law whose moral authority for him no sophistries as to accumulations of expediency, or crystallisations of the experience of the past, have been able to shake. And it has, with unrelaxing moral force, insisted that this consciousness of an internal law of duty, be the element of 
obligation derived in whatever way it may, lands us in the recognition of a righteous moral Governor, who is God over all.

A Providence of natural law has plainly enough been proved, but that is by no means sufficient. We claim a reign of spiritual law, acting in accordance with our needs as spiritual beings. Yes, and a real reign it must be, in which the freedom of God to act for and upon us shall in no wise be unwarrantably fettered. We regard it as no other than a most unwarrantable assumption to suppose that the material laws of the universe must bind, rather than subserve, the free action of God. If there seems a chasm between the natural world and the spiritual, of whose making is it but our own? Strangely true it is that, because we have disjoined the natural and the spiritual, we project this sundered feeling or relation from ourselves into God. That is anthropomorphism with a vengeance, and none the less is it so, that it claims the sympathy of scientific materialism. Mansel did not fail to point out how little absolute morality is the result of Divine command, or even of Divine creation, since it must be taken to exist co-eternally with Deity. Law is seen to be, in the words of a philosophical writer, "eternal in God the Supreme Reason," and the will of God seen to act always " in conformity with the law eternal in the reason of God." The fact has been more clearly apprehended that law, as conscience, belongs to the august realm 
of personality, and compels to a belief in correspondent objective Reality. This working of moral law through our personality was very explicitly pointed out by Kant, who believed the life to which such moral law calls us to be one that is independent of animal nature, and even of the whole world of sense.

Now, it has been better shown how ethical standards have grown clear or dim according as the idea of a personal God has become more or less pure and vivid. We deem ourselves, then, justified in claiming that theism has not been content to treat this authoritative thing called conscience in the Spencerian mode of something merely adventitious, but has insisted on regarding it as something which, carrying with it the dread sense of ethical obligation, rests on the facts of personality, freedom, and responsibility. It has found conscience to be no expression of mere external law, but of law which is involved in the fact and the freedom of our personality. It has more nobly held, with one who has ably treated of the 'Types of Ethical Theory,' that our sense of moral obligation carries with it the postulate of objective authority and is to be trusted, and that this sense of the right consists not of mere subjective suggestion, but carries in it the "solemn persuasion" which belongs to any revelation of right from a "higher personality." It has thus, so far from leading thought to rest-as it is so fre- 
quently content to do-in impersonal law, brought us a deepened sense of Personality-supreme and perfect-as that of which Law in reality testifies.

But then we may say there has been a steady advance in the perception that conscience is, as it has been finely expressed, "the entering into the individual of the objective law of right, the authority of which is intrinsic and unconditioned; which is its own evidence, its own justification; and which would subsist to all eternity, as it has subsisted from all eternity, though Christianity and all other religions were swept into oblivion." For, has not theology been gaining a surer hold of this inherent character of law, as something which may be thought of apart from its being imposed by the Divine Will, to which, however, in its normal exercise it is inalienably conformed? Not in will, indeed, but in reason, do we ground the universe, and it is by His reason that the will of God is energised. We accept the declarations of ethical law when, as Dr W. L. Courtney and others have well pointed out, moral law has so deeply felt "an absolute and self-conscious Spirit" to be its own presupposition, without which Absolute Personality ethical law would lack its necessary sanctions, its pinion, and its promise.

"The whole system of our belief," as Sidgwick once said, "as to the intrinsic reasonableness of conduct must fall, without a hypothesis unverifiable by experience, reconciling the individual with the 
Universal Reason, without a belief, in some form or other, that the moral order which we see'imperfectly realised in this actual world is yet actually perfect. If we reject this belief, the cosmos of duty is thus really reduced to a chaos; and the prolonged effort of the human intellect to frame a perfect ideal of rational conduct is seen to have been foredoomed to inevitable failure." The considerations that inspired the writing of these words abide, and make the truth they contain not less real and binding to-day.

We accept the fine delineation of Dorner, in his 'Ethics,' of the self-deification that should result from the failure of morality to include in the love of goodness also the love of the primal source of goodness, the personal God. We take it that theistic philosophy welcomes ethical law as a principle of life and love rather than as a mere imperative, with what Darwin styled its "imperious word 'ought.'" We believe that, with more open vision, it recognises the spiritual source and authority of that spiritual law by which man rules himself and directs the natural forces within him, which spiritual source and authority it finds again in the personal God. And so we think it safe to say that recent theistic philosophy of religion has found fruitful advance in its enlarged recognition alike of the authority of ethical law, and of the amazing multiplicity of its applications, calling, as these do, for the deepest insight in endeavours 
to reconcile religious truth with ethical conception and law. For we cannot but think that it has more clearly discerned the capabilities of these two as destined to dwell together in perfect reconciliation, while it has become more quick to perceive their constant need of mutual adjustment. On the side of ethical law, of which we are here speaking, it has, for example, found itself in perfect accord with what Kant, in the Vorrede of his 'Religion within the Limits of pure Reason,' was able to urge, that "ethic issues inevitably (unumgänglich) in religion, by extending itself to the idea of a sovereign moral Lawgiver, in Whose will that is the end of creation which at the same time can and ought to be the end of man."

Recent theistic philosophy has not suffered itself to share the Spencerian forgetfulness of the great and distinguishing feature of rational, as opposed to animal, life-namely, the adjustment of conflicting principles, in the mighty endeavour after character and self-originated excellence, to inward ethical law. Does it not more clearly perceive such law of life and of growth to be

"Mirror of Earth, and Guide

To the Holies from sense withheld"?

Frank has been at pains to show what conflict there is; as Wuttke said, it amounts to insoluble contradiction, the higher and more distinctly the moral consciousness is developed. We may not 
forget, however, that the law of duty, to which we are to be subject, is really so glad and joyous a thing that Wordsworth was able rightly to say of it-

"Flowers laugh before thee in their beds, And fragrance in thy footing treads."

May we not say that it is just the crowning work of that Christian personality, which Christianity has come to develop in us, to call forth what perhaps can only be termed an ethical tact or wisdom that shall guide us aright amid the pressures and confusions and complications that so often make the way and knowledge of present duty difficult and uncertain? The theistic philosophy has, we believe, felt the wisdom of the Wordsworthian saying that-

\section{" to the solid ground}

Of Nature trusts the mind that builds for aye,"

and hence it has sought to put its religious representations on stronger, because more natural, grounds. But it has not allowed man's judgments and choices to be robbed of their ethical character by reducing his life to automatic movement within the sphere of natural law, but has more successfully vindicated his powers of rational self-direction under inspiration of the law of duty, "stern daughter of the voice of God," as against the force of impulsive principles or the stimulus of entourage or environment. It has looked upon the solidarity 
of the universe, has found the moral law rooted in its very structure, and has met the idea of right as something undecomposable, sovereign, unique in man. But this idea of obligation - as something in us, though not of us - it seems to find spring up within the human mind itself, even though it has its ground in God, so truly has it declared man to participate in the Divine Nature.

This implication of a Supreme Governor in the notions of duty and obligation is already found in the 'Ethics of Theism' of Leitch and in other British writers, but it has since been greatly elaborated and strengthened in the mode of its presentation. Nor have Gass and others in Germany neglected to emphasise the process of culture required in respect of conscience. Martensen has shown the dependence of this process of conscience development on Knowledge and on Will, and Hofmann has given expression to its need of the revelation given in Scripture as its norm, regulator, corrective, and co-efficient. We find an advance to have been made in the vindication of the validity of conscience, under the rigorous handling of $\mathrm{Dr}$ Martineau, in view of evolutionary inquiry into its origin. Theistic philosophy feels the significance of what he says, in the second volume of his 'Study of Religion,' to the effect that " the moral law first reaches its integral meaning, when seen as impersonated in a Perfect Mind, which communicates it to us, and lends it power over our affec- 
tions sufficient to draw us into Divine Communion." Hence the intimate relation with Ultimate Reality into which it has found the moral consciousness bring us: with the poet we are brought, in our growing harmony with Divine Law, at length to say-

"Our wills are ours, to make them Thine."

Yes, we will say that conscience still summons men, in this late age, to repentance because of their evil courses and their shortcomings in respect of the moral ideal. May we not, then, say that our late theistic philosophy has yielded, in accordance with the spirit of its time, nobler recognition to the presence and working in man of "the inward sovereign spirit of the universe that has ever moved onward from chaos to cosmos, from lifelessness to life, from the outer to the inner"? May we not say it has passed out of the sphere of those contradictions, in which the conceptions of mere absolute law are so apt to be overtaken, into the higher region where law seems a self-imposed or self-originated thing, and the ethical is apprehended as love? May we not say it has found, for science and for faith, for religion and for knowledge, a reign of spiritual laws in the natural world, so real, that each and all of these are led up to higher life in "that God which ever lives and loves"? May we not say that this presence of spiritual law in man carries within itself the promise and the potency of immortality? 
We must, then, account that an unworthy philosophy of religion which should not make ready and ample recognition of the inspirations and upliftings, nay, the redemptive and transfiguring influences, of Divine law in man. At the same time, it is to be acknowledged how great has grown the conflict of faith-the faith which transcends the thought of the worlds as ordered by law, by law that virtually, in the waxing light of science, takes the place of God. But not after this fashion does our philosophy of religion resolve all into law and disavow Deity, for is He not to it the law itself, and law of all laws? What is law for us as spiritual beings but just truth as it is in God the Supreme Reason? Thus the supreme law for us is that which we call love. That which men call love is to be conceived as law, of which it is the spiritual fulfilling. Not as fiat, nor as arbitrary exercise of Divine Will, are these things so, but as grounded in eternal reason. And if law has no higher idea than the "respect-inspiring" idea of personality, this is because the personality behind it is that of the Absolute Reason. Not in any mere abstractness or impersonality of law does theistic philosophy rejoice, but in spiritual law which is for us the will of a Supreme and Personal Being. Hence the validity and reality of such laws as those of prayer, of service, and of sacrifice, which are not less truly laws because they are, from the standpoint of Nature, supernatural. In fact, no perfect moral action can be ours which does not so relate itself to 
One Who is basis and end of ethical law. And it so relates itself that the perfect compatibility of grace with law is always more fully confirmed in experience.

How free man is we have elsewhere shown, but that does not keep him from being under an absolute reign of law. His is the dread power to disobey the law written within him on sacred tablets of the heart. His, too, the need and capability of spiritual growth-a need and presence of law in respect of progress most clearly recognised by Him Who had many things to say unto $\mathrm{His}$ followers, which they at that time were not in fit state to receive. Theistic philosophy is, then, just as convinced of the reign of spiritual law in man as it is of the physical providence or working of God by natural law, which Dr John Young, in his 'Creator and Creation,' and later writers have so confidently maintained. The law that so reigns within is law that Love has made, and therein we may rejoice in law. Yes, to us, as to the poet Browning, all may be love, yet all is still law. Better than Browning's recognition is the remembrance of the unity presented to Christ in the physical and the spiritual orders: they were one to Him because God was One, and in and over them both. And so for Him between them contradictoriness there was none. As strange as it is true abides the fact that love can be enjoined, can be the object of law. When men tell us that 
there is no speck of matter, no point in space, no flowering blossom, no twinkling star, where natural law is not found, they tell us something that is no more true than that

" Every virtue we possess,

And every conquest won,

And every thought of holiness,"

are solely the result of the working of the law of the spirit of life in Christ Jesus, making us free from the law of sin and death.

The spiritual law of which we have been speaking is nowise to be regarded as an arbitrarily imposed enactment, for it is really the organic law of the soul's true life. Made we are for fellowship with the Divine: nothing less is our destiny; and this is why we are under a reign of spiritual law -law that is so much larger than our earthly life as to run onward and upward into the sphere of endless existence. These things being so, theistic philosophy finds in them abundant reason and justification for the reign of spiritual law under which we have been placed. And that law means a true and spiritual survival of the fittest, for whoso builds the sacred edifice of his life by taking heed thereto shall be as one that builds his house upon a rock that never shall be moved. 


\section{CHAPTER XV.}

RECENT RECOGNITION OF MAN'S REDEMPTIVE NEEDS.

Theistic philosophy of religion in these last days has very clearly discerned alike the hope and the need of redemption in some real and helpful sense from without the race-from above, while openly acknowledging that it lies beyond its province to pronounce on the nature and methods of the Divine activity in the redemptive interference. It surely cannot find any difficulty in seeing that the ideas of shortcoming and of consequent propitiation must soon arise in the experience of man, as he fails to realise a purposeful obedience to the Deity disclosed to his dim and early conceptions. It has more carefully recognised that, as we pass upward out of the stages of nature-religion, the redemptive interference, craved by man but issuing really from God, becomes less conceived as deliverance from external evils such as are found in nature and life, and more as redemption from the moral evil found 
in man-sad fruit of sin and disobedience. What William Law, in his 'Spirit of Love,' said, with the fine spiritual insight which characterised him, remains true for the philosophy of religion in its newer phases-namely, that the ground and nature of the Christian mysteries are understood by remembering that these mysteries "are in themselves nothing else but what the nature of things" may require, having "all their power" in a "natural way or true fitness of cause for its effect," but mysterious to us, because done in a way and manner above what reason or nature can suggest.

The theistic philosophy of religion has not been betrayed, by the necessary boldness of its philosophical speculations, into losing its consciousness of $\sin$ or treating as illusory the pangs of guilt, for it has not relaxed, only enlarged, its consciousness of God. Hence it owns that redemption and restoration of lost harmony are man's needs, and not merely spiritual development and communion with the Eternal. It perceives the deep need the world still hath of "the crucifix that came of Nazareth," and of a true Philosophie der Erlösung, or gospel of redemption, if that hydra-headed monster called sin is to be met and overcome. Besides, it has more explicitly regarded the Divine informing purpose which, in the religion of revelation moved onward, always onward, in satisfying natural needs, to a redemptive culmination, as that which forms its great distinguishing feature when 
compared with other religions. It sees in these other religions, with Lenormant, the expectation of a Redeemer, the aspiration towards a higher spiritual law, a certain consciousness of the need of redemption, and a streak of hope of the same in their sky. It sees, with Francis William Newman, in speaking of 'The Soul,' that "if theology is a science of God, it cannot omit to treat of the bright or sullied state of the mirror, in which alone God's face is to be seen." It has certainly found no valid reason why the creatures, who by their thoughts of Him have wronged the Sovereign Good, should not have their thoughts righted by $\mathrm{Him}$, and their transgressions covered by $\mathrm{His}$ historical intervention. But theistic philosophy of religion holds that, in compassing these ends, we may not lay down a priori the ways and bounds in which the redemptive energy shall work through and beyond nature's sequences. It has seen that the only real restoration of sinful man has as its postulate the revelation of God Himself, and not of $\mathrm{His}$ mere truth or precept, as that revelation appears to us in the redemption of Jesus-mirror of the love of God for man. For it has clearly apprehended what Dorner distinctly declared-that the perfecting of the self-revelation of God meant nothing else than the incarnation of God.

Recent theistic philosophy of religion has maintained with more informed intelligence the reality 
of the fact of sin-fons et origo malorum-alike in the race and in the individual, so resisting every pantheistic tendency to reduce sin to a necessary element in the Divine process. It has maintained a chastened sense of sin's real relation to God, to Whom as personal Deity we sustain our first and, perhaps we should say, our only real-relation. It has, in fact, found sin, or the problem of moral evil, to be the sore of the ages. None, perhaps, may fully solve it for us, least of all can any who shirk the facts of its deep-seated hold and universal sway. Side by side with this it has more boldly faced the pessimistic aspects of man's progress, and has more simply and courageously declared man's need of redemption in face of every ineffective effort after self-redemption. It has done so because it knows no despair either of man's capabilities, or of God's powers of redemption. Yes, and to be able in such a time to know and believe alike in the Divinely redemptive forces and in man's capacity for receptiveness of these redeeming powers cannot be a thing of small moment. It has more clearly perceived that no abstract and air-drawn theories of the ultimate perfectibility of mankind can suffice, while full and thorough reckoning is not made with those universal facts of sinful need and inability, whereby man's action has become perverted and the life of his soul embittered. Because we have hope in 
the goodness of God, we must not shirk the weary and the heavy weight of this sinful, unintelligible world.

More unequivocal has now grown the testimony of the philosophy of religion to the need of Divine intervention and of spiritual aid, in virtue of the vigour with which $\sin$ has worked its way into the natures of man-moral, physical, and intellectual. Always more conspicuously has the truth stood out, not as a doctrine of revelation, but as a fact of observation and experience, that the very earliest springs of our moral life seem tainted with the presence of evil in such wise as to point for its genesis or rise to something that lies behind our own free conscious self. And the race is seen to be as truly wound around to-day with a sense of uneasiness and guilt-like a Laocoon in serpent embrace-as in any less enlightened, less refined time. "Remorse," it is seen and felt, "is not repentance, and even repentance washes out no stain. Self-forgiveness is impossible. The trumpet is always sounding; every day is a judgment day; and every one of us goes to the left. Gehenna is only the logical goal of sin." This fact of ceaseless judgment should hardly appear arbitrary or strange to men at least before whose bar of mortal judgment the Maker and Lord of all is being tried, "every day that passes, every hour that flies." There is a world of inner fact-none the less real that it is inner-in which we still, no 
less than the king in "Hamlet," have our being, and wherein we say, with him-

\section{"What rests?}

Try what repentance can : what can it not?

Yet what can it, when one can not repent?

$\mathrm{O}$ wretched state! O bosom, black as death !

O limëd soul, that struggling to be free, Art more engaged!"

Let there be no mistake here. Remorse is a plant that still, in this late age, springs up on the soil of our violated moral ideals, and penitence is still a hand that indicates the out-reaching of desire after return to the true ideal. The soul that has sought out delightful, but selfish, paths for itself is still awaking to keen spiritual hunger and profound self-abasement :-

"' Make me a cottage in the vale,' she says,

'Where I may mourn and pray.

Yet pull not down my palace towers, that are

So lightly, beautifully built :

Perchance I may return with others there,

When I have purged my guilt." "

We therefore say, in a word, that no study of the atonement or redemption wrought of Jesus has at all enabled us to dispense with the sense of sin; it has rather deepened than destroyed it. Not that there has not in our time been far larger and more generous acknowledgment of the impulse towards good, and the progress in politics and philosophy, science and art, that have never been wanting in the pre-Christian and non-Christian worlds, but 
only that just in our time, with its fuller acknowledgment of these merits, have there been a more distinct sense and a clearer recognition of their insufficiency to compass the redemption of the world, and a more emphatic witness of history than ever before, that in every nation and in every individual reside deep needs of a redemptive process for the restoration of spiritual harmony. Not less needful is the redemptive process seen to be for every human society than for every individual soul, for not otherwise can the life of self-renouncing love - only true and worthy ideal - be really attained. The sense of moral failure has been too deeply graven on the world's heart, and the community of moral need between men of every nation has been too deeply felt, for any doubt to remain of the appalling need of redemption to the race, as to the individual.

Recent philosophy of religion has, in fact, found the ethnic faiths so singularly unable to handle the problem of evil in its nature, origin, and consequences, as to make one feel almost like entering a new and higher world when we pass into the sphere of the teachings of Christian Doctrine on sin, alike as it affects man and as it disorders the realm of God's moral government. Here the theistic philosophy of religion of recent times has been met by the Christian theology of the period, and by it has been taken up into those truths into which of itself it could not come. With Mozley, 
in his 'Lectures and other Theological Papers,' it has then seen that "Christianity is founded upon certain great primary wants and affections of the human soul, which it meets, to which it corresponds, and of which it furnishes the proper objects and satisfactions." Among the things it has most plainly seen have been that "there is the feeling after a God; there is the instinct of prayer; there is conscience and the sense of sin; there is the longing for and dim expectation of immortality." And it has more carefully observed how "Christianity supplies the counterpart of these affections and wants of the soul," and how it is "as supplying this counterpart that it recommends itself in the first instance to us" - the religion of redemption. The religion of redemption it is seen, $\kappa a \tau^{\prime} \dot{\epsilon}^{\prime} \xi o \chi \chi^{\prime} \nu$, to be, for very different in source and centre and progressive principle it is from Buddhism or any other suggested redemptive parallels. This is none the less truly the case, if it be even so that "the new gospel of self-redemption through resignation and self-annihilation finds among the representatives of modern culture more reverent hearers than the Gospel - ancient yet ever young - of redemption through Jesus Christ." The Christian philosophy of religion has, as we think, more patiently viewed the negative aspect or form of redemption whereby it appears in the desire merely to escape the world. The positive form it has more explicitly treated as it shows itself in realised and harmonious union 
with the Divine or Absolute Life, in the sphere where nought avails but the faith that works through love. For it knows that such new and larger consciousness of God, as springs out of this redemptive indwelling of God in man, it was the design of the redemptive work of Christ to create. "But the sacred happiness of a heart which knows it is known of God, is not derived from approving its own attainments, but from the very acting of its insatiable desires, and from its sympathy with the sources of life and joy. Its outcry is after Perfection. It longs after God's own holiness: for this it would give earth and heaven. It no sooner effects one conquest than it aspires after another." Yes, and it is to be added that "the consciousness of this infinite longing to be more and more like to the Only Perfect One seems to be the essence of a good conscience." It is just these deep redemptive needs which the Spirit of Jesus is here to satisfy, to meet in most real and actual manner. But it will be in the case of those whose needs are so real, and who do not empty of real spiritual content such factors as sin, repentance, moral responsibility, and freedom, that such redemptive process will have its most glorious and perfect result. Further, we dare to say that if any one can persuade himself that such perfect issue is capable of attainment through any Hegelian theories of immanence and unity 'twixt God and man, he is simply hugging to 
himself a fond philosophic delusion. Fearless and thoroughgoing must be our method here, and room for dallying there is none. The interests of truth and spiritual reality are before all names, even the greatest. The redemptive vocation and perfect redemption that await man have therefore been more justly and largely presented in our time in their relation to man's free unswerving effort after a spiritual ideal, the redemptive process being crowned at last by recovery of such nature as God designed, and by such spiritual consummation as the angel-song of Faust presents-

"Wer immer strebend sich bemüht,

Den können wir erlösen."

"Who ever strives forward, with unswerving will, Him can we aye deliver."

In order to the accomplishment of this great end, we are with Pfleiderer when he lately said that the reverse side of universal sin and need of redemption " is found in the universal ability of all men to be redeemed, which is based on the indestructible essence of the Divine Image that is in every man, and, even amidst the thornthicket of $\sin$ and worldly lust, never becomes entirely extinct, but remains the living germ of a better future, of a new man in God." Yet, not as effected by natural power of our own, is the redemptive result in its positive aspects to be conceived, but only as requiring the highest concur- 
rence of the self-surrendered will with the working of the Divine Spirit of Jesus Christ. We may freely allow that the moral senses, inward bearings, hygienic and educational aspects of redemption, have of late been much more properly emphasised, without going so far as those who - Pfleiderer, for example - in their stress on the ethical conception of education, clearly seem to us to fail at least of setting our self - sacrifice and voluntary obedience in their proper relation of dependence, for their practical power and real spiritual efficacy, on the one sacrifice of Jesus and the virtue that flows therefrom. Éven a Schopenhauer has been able to see clearly enough the utter inability of man to achieve his own redemption or work out salvation for himself in such a way.

To a Christianly theistic philosophy of religion the revelation of God given in Christianity is not a revelation for revelation's sake or instruction's sake alone, but is also, and much more, a revelation of love, a revelation designed towards redemptive ends. Conditioned as salvation may be by man's will, man is yet unable to restore the rent bond of fellowship betwixt himself and God. If it depended on him alone, he must remain without redemption. God is working unchangeably for the fulfilment of those spiritual ends which are dearer to Him than any other. All things are mediated by Christ, but God is to be thought of as ceaselessly active. As Amiel has said,-_"To win 
true peace, a man needs to feel himself directed, pardoned, and sustained by supreme power, to feel himself in the right road, at the point where God would have him be,-in order with God and the universe." Yea, and though severe words have been lately written as to what science may say concerning the mediatorial and priestly functions of Jesus, it will possibly be time enough to resolve these into superfluities and profanities when we have become rid of such sense of sin and guilt as are still left to us in this time. We still expect science to proceed in a scientific manner, and include the most real facts and demands of the religious interest and conscience in its consideration. That is to say, in so far as such matters come within the scope of its inquiry at all. We certainly do not believe that the spiritually enlightened consciousness of man will be able to remain long without postulating redemptive provision in a deeper sense than subjective change in the sinner himself merely would imply - even in that true sense in which a real change of relation betwixt the sinner and Deity is effected by the strong Son of God; for, unless we are prepared to turn our backs upon the unequivocal testimony of the collective experience of the Christian centuries, nothing can be plainer than that the purest, saintliest, and most spiritually illumined souls still crave, always have craved-in more or less conscious ways-such an objective ground of pardon, such an outer spring 
of cleansing, purification, and moral virtue, as is afforded in the sacrifice of Jesus, Saviour of men.

We, for our part, are inclined to think that modern philosophy of redemption does not always sufficiently realise what a strongly natural basis mediation has-a basis bringing it within the scope of Natural Religion-as, in fact, the natural outcome of one of the deepest spiritual desires of men. Some effort after mediation is met wherever religion enshrines a Personal Deity. And surely the human need has grown always more manifest to us of means whereby the conditions of moral and spiritual recuperation shall be maintained, and this need is plainly one not to be met by theory of any sort, but by deep-seated atoning fact. Yes; and so not merely the need, but the Divine meeting of that need, have grown always more conspicuous under the developing disclosures of Love Divine, so that a philosophy of atonement is now possible and justifiable.

The Christian philosophy of religion rejoices in the greater stress on the historical and ethical aspects of Christ's redemptive work which recent years have witnessed, without, however, succumbing to the Ritschlian tendencies to sit loosely to the relation of that redemptive work to sin. We can surely say so much in agreement with Frank's recent 'Geschichte und Kritik' without needing to commit ourselves to all his inveighing against the sterility of Ritschlianism. For he is in our view a 
strange thinker who can find in Ritschl a satisfying attitude towards the Divine displeasure in view of sin as present, as palpable, and as perfectly real, fact. We may maintain the ethical emphasis in Christianity, may uphold the importance of mystical union with God, and may yet feel that sin is not a matter to be lightly passed over, nor Christ's relation to it a vague and unimportant thing, nor the most exalted communion with God that can possibly be depicted a secure possession and undoubted possibility, until some radical and thoroughgoing solution of $\sin$ and guilt has been furnished from the redemptive work of the historic Christ. The historic basis need be no occasion of stumbling, as being but the point dappui on which our speculative and ethical philosophy must of necessity rest, in virtue of Christianity being essentially redemption from sin through the man Christ Jesus, and of its revelation having a continual tendency to become inward and natural.

In its individual operation, the redemption proceeds from the sphere of the inner spirit-from the psychological into the ethical, and, in certain ways and degree, into the physical also. To this last, to wit, the redemption of the body, belongs, in an institutional sense, the redemption of the Church, which is His Body,-a redemption whose need is deeply realised in Christian philosophy, if the Church, as loyal to her risen and living Head, is to become unworldly and spiritual. All these are 
but parts of the one great redemptive process, and the grace of God is here for the healing of all that is rent and broken. It is here to impart energy to the spirit in that warfare against the flesh from which there is no sign of discharge to time, enlightenment, or culture. Still does the alien flesh continue to show that resistance to the Spirit which recalls the lines of Goethe-

"Dem Herrlichsten, was auch der Geist empfangen Drängt immer fremd und fremder Stoff sich an."

This conflict calls to a positing of reason, spirit, God, rather than body, flesh, nature. For still those two, flesh and spirit-borne, as said Plato, as by steeds in opposite directions-meet and clash amid the quivering of our whole being. What man is he who does not know how powerless in those supreme hours of life is anything short of the grace of Jesus Christ to enable us to triumph, and-like the poet's warrior- "through the heat of conflict" keep "the law in calmness made" ?

The Christian philosophy of religion is wise enough to see very clearly how the notion of those who take God's historical action in redemption to have been put forth for the purpose of creating moral power is a notion which simply destroys itself. It puts into the action what should be put into the Divine reason, character, and mind revealed to us in and through the action. It fails to do justice to the Godward aspect-for such there is and must certainly be-of the sacrificial work by which 
THE MEDIATIONAL ASPECTS OF REDEMPTION. 473

the Redeemer frees us from our enthralment. In the mediational work of redemption it is God Whom we see in Christ reconciling the world unto Himself, and in the very principles of the atonement $\mathrm{He}$ must be just as really present as $\mathrm{He}$ was in its original spring or motive, so that into the mediation shall enter nothing which "would only distress and insult Him." For all that, there has been no lack in our time of a deep entering-with Sch leiermacher, Rothe, Macleod Campbell, Edwards, and othersinto a sense of the fellow-feeling (Mitgefiihl) with sinful men shown by Christ as humanity's Centre and Representative - a sympathetically vicarious apprehension of $\sin$ on His part nothing short of perfect. Like Dante, when he saw the two complementary natures of Christ-human and Divine-in the eyes of Beatrice, we, under His moving power, at once worship and follow Him Who, one coherent Personality to us, is both ideal Man and "strong Son of God."

"Come in lo specchio il Sol, non altrimenti

La doppia fiera dentro vi raggiava, Or con uni or con altri reggimenti."

Of which for the present we shall adopt Dugdale's rendering,- " Like the Sun shining on a mirror, so the double-natured creature threw its beams through those eyes, now with the acts of one nature, now with those of the other."

And the uniqueness of Christ as the sin-bearer our late Christian philosophy of religion has found to be as real and striking a phenomenon as ever it 
was to saint or thinker of an earlier time. Only, His redemption is less mechanically conceived: the redemptive process, by which forgiveness is achieved, is thought of in a less arbitrary and juridical fashion, and forgiveness itself is conceived as but the gateway to life-the life in God of which we have spoken. Our religious philosophy and our spiritual life have surely found courage enough whole-heartedly to accept both facts or ends of the redemptive process as brought out in the couplet,-

\section{" He died that we might be forgiven, \\ He died to make us good."}

Without being careful to theorise overmuch, we are with such acceptance pretty well content. Such vicariousness as is implied in His suffering is seen to be no arbitrary enactment, but part of a universal necessity or law that marks every step of spiritual advance. Our world of to-day has no more spiritual principle than that of redemption by sacrifice - no principle of greater potency and promise. On that principle, the principle of sacrifice-gateway to larger life-the God who "gave" His only begotten Son for us has set His seal, and the purity, energy, fruitfulness, and attractiveness of our lives can be derived from no other source than this fount of sacrifice. It is that these ends of life may be realised in us that the mighty consecrations of God are upon us, and we bear in our bodies the marks of the Lord Jesus. But who does not know 
the need for stern self-questioning here, that the Divine glory and counsel in us be not hindered?

Deeper than usual is Schopenhauer religiously when he says that "the inmost kernel of Christianity is the truth that suffering-the Cross-is the real end and object of life," even if his understanding of the case be not quite ours. Such an end suffering is, only because in the fiery ordeal spiritual force will be set free for, and within, the soul. Spiritual energy will be thereby generated, spiritual freedom will be born. Yes, without suffering, in some shape or another, there is for us no spiritual mint to make fresh and lasting endowments possible for the enrichment of the soul. The new births of spiritual power must ever have their attendant pangs of pain or sorrow. And the deeper the pangs the greater the power. Not only, then, is the law of sacrifice for us the deepest in the universe-law of heaven and of God-but it is a law under whose actual experience and inner working we must be continually coming, as we reach after life's supreme realisation or attainment. And, though the clear intellectual apprehension of the significance of this spiritual principle or law is no uncommon thing in our time, we are compelled to the belief that any deep or striking exemplification of it is the rare accomplishment of those who are, alas! always too few.

If, as the Rev. C. Voysey remarks in his recent 'Theism,' "the Christian does not really worship 
and love the same God as the Theist does," did it never-we may ask, although his treatment is practical rather than theoretical and scientificoccur to Mr Voysey, in his anxiety "to avoid mistakes," how largely this may be the result only when the God of the Christian has his representation at Mr Voysey's hands? It may not be amiss in this connection to recall what Dr Dale has said in his 'Christian Doctrine,' that "Theism may be as serious an obstacle to the reception of the Christian Gospel as Atheism; for the God of many theists is a God so remote from man that it is inconceivable to them that $\mathrm{He}$ should have become 'flesh' at the impulse of an infinite love for our race, and should have lived a life of conflict and of suffering, and died a death of shame and horror for our salvation." Yes, it is faith in the redeeming Christ that pours vigour and reality into our belief in God. To the Christian philosophy of religion there is for humanity one perfect ideal-that which has become real in the person of Christ-which it has found no sufficient reason to give up. There is for it one ideal Mediator, whose mediation and worship it has found no adequate cause-after the so-called evolution of the Christ myth - to abandon. There is for it, too, one ideal harmony or redemption, which, individual, yet catholic, definite, and practical, is that effected in Him.

We are fully conscious how far removed is all this from such a "philosophy of redemption" 
(Philosophie der Erlösung) as that propounded by Mainländer, who would have us wait for that ideal socialistic state in which the great longing will be to have our names blotted out of the Book of Life. For redemption, with him, really lies in the path to non-being. The will to die is the strange philosophy of redemption brought us by this disciple of the philosopher who gave us the will to live. Of course, he would have us still retain life that we might help the hastening of redemption for others, even though redemption, full and final, comes by death. Concerning which philosophy of redemption it is to be said that, far removed from it as east from west stands the theistic philosophy of religion, finding its redemption, not by destroyal or even disparagement of man's personality, but by the very development of it as highest flowering of the redemption that is by faith in Christ.

When God was, in the fulness of the time, made manifest in Him, when the gift unspeakable,-

"God's Presence and His very Self, And Essence all-divine,"

-when, we say, such gift "did flesh and blood refine," that we might become one with Him, the most thrilling point was reached in the religious evolution of the race. Yea, and never must it be lost sight of, that behind and below all theorisings of the schools is the fact that God really stands to us in an atoning attitude-that there is indeed atoning fact in God. For sinners at least-what- 
ever might have been the case with pure spiritssuch a God as might content the theist will not suffice: God must be known as He appears in Christ Jesus. If the facts of $\mathrm{His}$ earthly life and its intercessory continuity are anything at all, they are facts, and not merely speculative doctrines. They are facts which make religion possible in the future to the spirit of man-at least the future of spiritual man.

But all that has now been said neither was, nor is, to supersede, only to start, movement of the soul forward into light and life and order, and to make boundless growths for it possible. For what philosophy of religion can doubt that, after all, as Mozley once said, justice and mercy and mediation are each and all of them but fragments? "What indeed are they but great vistas and openings into an invisible world in which is the point of view which brings them all together?" No fear of Patripassianism must keep us from holding, as men now more readily do, that the love of God does suffer thwarting, defeat, and anguish at the hands of sinful men. It has even been said that " theology has no falser idea than that of the impassibility of God. If $\mathrm{He}$ is capable of sorrow, $\mathrm{He}$ is capable of suffering; and were $\mathrm{He}$ without the capacity for either, He would be without any feeling of the evil of sin or the misery of man. The very truth that came by Jesus Christ may be said to be summed up in the passibility of God." Patience may here 
have a perfect work in respect of those "broken lights" of redemptive principle and process which must always come immeasurably short of the Lord of Light and Truth Himself. A redemption which shall be worthy of Him must always transcend our poor representations of it, must always remain in the region of love's ideal, and the sphere of atoning fact that seeks to realise such ideal. Thus is the ideal propitiated. Nowhere is it more permissible to recall, with the poet, how overgrown all here is with theory, but yet how "green" abides "the golden tree of life."
"Grau, theurer Freund, ist alle Theorie, Und grün des Lebens goldner Baum."
"Grey, friend, is all theory; green
Is the golden tree of life."

And we dare to say that the remedy for the wrestlings and perplexities of this time must be found in a deeper assertion of the Divine life within the soul of the age. The soul of the age must be more willing to lose all that it may find the life in which is light. It must suffer itself to be more penetrated with the Goethean sentiment-

" Und so lang Du das nicht hast,

Dieses 'Stirb und Werde'!

Bist Du nur ein trüber Gast

Auf der dunklen Erde."

"Till this truth thou knowest :

'Die to live again'-

Stranger-like thou goest

In a world of pain." 
For who can doubt that when the redemptive grace of God shall have more profoundly penetrated the soul of the age, its speculative thought shall fulfil its function with transfigured power? Yea, there shall no anti-theistic philosophy stand before it. May its baptism of light and power speedily come! 


\section{CHAPTER XVI.}

RECENT THOUGHT ON THE SPIRITUAL NATURE, AFFINITIES, AND GOAL OF MAN.

RECENT theistic philosophy of religion has had no light and easy task in cleaving a way of advance for itself. It has often seemed so otiose, notwithstanding the advances we have set forth, that the difficulties do not always appear so great as they have really been. The immensities of the physical universe have, in the name of science, been thrust upon the spirit of man by Agnosticism and Materialism, the evolutionary philosophy, so called, of the Spencerian school, in ways by which man has not only been cast down from the centre of the spatial universe, but the kinship of man, so called "miniature of God," with ultimate Divine Reality, has been lost in terms of purely natural being.

What hath not science wrought! Our notions of origins-of man and the cosmos-it has simply revolutionised; the dislocation of the former hell and heaven, those last resorts of realism, is another 
of the feats of star-eyed science: it has given us a new heaven-no closed solid vault with much joy and no progress - and a new earth-no stationary stage dissociate from suns that blaze and stars that whirl through infinite space. Science, upsetting former notions of topographic sort, with their sometimes crude and almost "peep-show" character, has made imagination reel before the magnitudes of the universe in time and space. It has, with its astronomic synthesis of an uncomputed wealth of ultra-terrestrial life, dispersed the lingering notion of the world-systems of the universe as only infinite mechanism.

"Think you this mould of hopes and fears

Could find no statelier than his peers

In yonder hundred million spheres?"

It has brought home, even to the dense and unprogressive thought of the Churches, such facts as that nothing in the world is single, that nothing in the universe is stationary, and that evolution may possibly be an all-inclusive law of the universe, since, as it is said in 'Faust' -

"Still quiring as in ancient time

With brother spheres in rival song, The sun with thunder-march sublime

Moves his predestined course along."

"Die Sonne tönt nach alter Weise

In Brudersphären Wettgesang, Und ihre vorgeschrieb 'ne Reise,

Vollendet sie mit Donnergang." 
It has made the theologic mind rub its eyes and look out, and see creation evolved out of its morning mist. It has stilled the soul into deepest awe before its mighty disclosures of the sweep and uniformity of law. It has wrested the rule of the world, no more the small cabinet world of an earlier time, out of the hands of God, and transferred it to physical law. All this hath science done - at least, nought of all this has been left undone in the name of science. And, if our reverence has outlived these disenchantments of science, it has been to exclaim-

"Lo, these are but the outskirts of His ways, And how small a whisper do we hear from Him !"

If our vision has not become dimmed to the unity of the Cosmos which science has established, it has been that we might look on that unity and see it to be spiritual. But first let us say that, to the results of a science whose arrow "flieth by day," it only needed that Criticism add the reducing of the revelation records to a state of fluid, and the devastation of former faith would be complete. It only needed those defects and flaws historical, literary, scientific, moral, and religious even, to which the attention of the age has been directed, to be set forth in the way they have been, for not only the hold on Biblical theism to be relaxed, but also the real strength of theism as grounded in pure or natural reason to be left all unperceived. It has been in such an 
atmosphere that the theistic interpretation of the world has been called in late times to vindicate the spiritual nature and capacities of man - his imageship of the Divine,-and right nobly has it done so. Its metaphysic of man is one in which the immanent relation of God to humanity-that immediate relation despite which the knowledge of God yet comes to us mediated by our physical, social, mental, and spiritual relations - is held to be the sustaining principle of all that man is. Yes, God Himself is the ultimate basis of man's being : it is God that worketh in man to will and to work for His good pleasure. Theism has shown less leaning to the former conception of those who viewed

"Our natural world too insularly,"

and has widened its view of nature as that which, in a large sense, is inclusive of man, "the roof and crown of things." It sees, with Professor Calderwood, in a recent paper before the Royal Society of Edinburgh, " that man belongs to nature, and in respect of his whole being comes within the scope of science," as it also perceives that "an evolution theory must include man, or acknowledge that it is not a theory of existence as a whole." It thus takes man to be what Professor Edward Caird, in his work on Kant, saysnamely, a being who doubly presupposes Nature, both because he is a spirit finding its organism in an animal body, and because he finds the presup- 
position and environment of his life in the system of Nature. It sees the spiritual man to be but the true blossoming of man as natural-

"Man builds the soaring spires,

That sing his soul in stone : of earth he draws,

Though blind to her, by spelling at her laws,

His purest fires."

It has set forth man's relation to nature-in which last it sees no reason to resent the intrusion of personal elements-so that to him, with Carlyle, as child of nature, the universe is "not dead and demoniacal, a charnel-house with spectres, but Godlike and my Father's." Nature for it exists not for itself, but for that which is spiritual. The Hegelian conception of nature as seeking a certain return into the spiritual is not to be thought of as without any foothold in fact or reality. No; there is too much of God in it for that. In fact, we go on, with the poet of the "Paradiso," to affirm that-

"If the world below would fix its mind

On the foundation which is laid by Nature, Pursuing that, 'twould have the people good."

"E se il mondo laggiù ponesse mente $\mathrm{Al}$ fondamento che Natura pone, Seguendo lui, avria buona la gente."

If nature were all-nature blind and unconscious we mean-then would Schopenhauer be certainly justified in claiming that nothing here is worth our effort, but that the world is bankrupt at all 
ends, and life a business which does not pay expenses. We have seemed to hear our late theistic philosophy asking, with an incredulous air,-

"Are God and Nature then at strife That Nature lends such evil dreams?"

Of course they are not at strife; but they speak of separate themes in diverse tongues. We have found science return to find that, spoil-laden and laurelcrowned, for her "a thousand things are hidden still." We do not account our recent theistic philosophy of religion forgetful of a greatness beside which astronomic immensities pale their fires-the greatness of the spiritual, the glories of revelation and redemption, and the grandeurs of immortality. We maintain the primacy of mind and its manifestations undisturbed by measureless masses of matter. We claim to be more and other than so many pinions and wheels in some vast mechanism reaching from minutest atoms up to mighty clusters of suns. So much at least of spiritual law have we found in the natural world. It is because nature is so instinct with life, with spirit, that we can hold converse with it: the goings forth of our spiritual being are that they may meet the Divine or Eternal Spirit which breathes in Nature. Thus, indeed, has been realised in our theistic philosophy of religion what Fichte was able so well to point out when he said that "the dead inert mass which choked up space has vanished, and instead thereof flows and waves and rushes the eternal stream of 
life and power and deed. All is quick, all is soul, and gazes upon us with bright spirit-eyes, and speaks in spirit-tones to the heart." For it sees, with the poet of the "Inferno," how Nature appears, to a thoughtful philosophy, to take her course - not in one place only-from the understanding and thought of God, and from His workmanship-

"Filosofia, mi disse, a chi la intende,

Nota non pure in una sola parte,

Come natura lo suo corso prende

Dal divino intelletto e da sua arte."

We venture to express the belief that it has been coming nearer to a worthy conception of Nature as rooted in the Divine-the Infinite Life which transcends Nature-and as having the Spiritual for its bloom and flowering-a spiritual blossoming seen in man who transcends nature while remaining bound to it. For God, the God of Love, is to theistic philosophy the unifying Spirit, under Whose Leadership the world-process of development is carried on. Hence to it, in Dante's words, -

"'Thus do these organs of the world proceed,

As thou beholdest now, from step to step,

Their influences from above deriving,

And thence transmitting downwards."

"Questi organi del mondo così vanno,

Come tu vedi omai, di grado in grado,

Che di su prendono, e di sotto fanno."

It has more clearly brought out the conscious affinity of man for this Divine Life so revealed in nature, and has even sought to carry these spiritual and 
personal elements - in which it believes the realm of reality to have been reached-up to the theistic fulness to which they seem to serve as finger-posts. For, not without this spiritual rendering of nature by the theist can we reach a God who shall be Personal Reason - such theistic interpretation of nature the only one which satisfyingly sets forth the world, as spiritual, in its relations to us. It would know by what right the name Nature is given to nature minus God, as though Natureany more than man - were a soulless thing. It takes the world to be one vast Whole, the Soul of which is God. Still more would it exhibit this affinity as manifested in Providence and Biblical Revelation. And it has led us to ask ourselves whether it was really a rational tendency that led us, from the fact that science showed us the work of the created universe to be so vastly more wonderful than we had supposed, to suspect that there was no Worker behind it all? Of those two interpenetrating, interacting worlds betwixt which we move, but which do not exist merely for us, it has bidden us ask-

"What marvel, then, that their gigantic shades
Should cross each other?"

It has keenly inquired whether the fact that the world without us has to be interpreted in terms of the reason or mind within us does not, as Spencer has said, suggest a spiritualistic rather than a 
materialistic aspect of the universe. It has done so, while keeping itself free of the Spencerian waverings towards a purely materialistic homogeneity. Yea, it has believed, with Thomas Hill Green, that without such mind nature would simply not be, and has held to that spirituality of nature in virtue of which it reveals the immanence of eternal intelligence.

\section{"One impulse from a vernal wood \\ May teach you more of man, \\ Of moral evil and of good, Than all the sages can."}

It has not, as we suppose, viewed Nature as the book of the revelation of the Spirit, but at least it looks upon it as the illuminated table of its contents which Novalis took it to be. It has believed that for the varied facts and forces of the world, such a ground and centre of unity as must be sought in an organic whole of reason can alone be found in God, the Infinite Spirit or Absolute Personality.

But, while theistic philosophy has been more fully demonstrating how reason is, more than before, in some real senses finding God, it has been more keenly realising how truly it takes One higher than we to complete the lacunæ of our knowledge. For it takes a Christ to find for us the Father, our relationship to Whom is for it the highest to be found in man. Yes, what higher revelation can there be for me than to know that the Spirit 
of the universe is my Father? What more thrilling, ennobling, exalting truth can be mine than to know that $\mathrm{He}$, on Whose hand worlds on worlds are hanging, sustains to me-to the least of all the saints - all those unspeakably real and intimate, all those ineffably sacred and tender, relations, which are summed up in Fatherhood in its infinite perfection? True, this sacred and inexpugnable conviction may be no mere result of my gazing upon worlds that stand out in space-immensities, but is it any less real because of that? Is there any rational justification for my putting this revelation of Spirit - Infinite Spirit to spirit finite but real - behind anything which the mere study of Nature may teach me? If not, then I am entitled to oppose this positivism of spirit to any scientific absolutism that would confine me within the unrelaxing grasp of cold Nature, and within the teachings of verifiable science. Yet it should be observed that we insist on these spirit-revelations as strangely ours when we stand in the presence and are within the influences of Nature. We have, in so doing, not been unmindful of the fact that it is precisely in respect of this moral and spiritual nature of God that the force of theistic reasoning has been slowest of admission by scepticism. Its vital importance, however, theistic philosophy has well realised. For it has more clearly apprehended the supreme thought of Christ's theistic teaching to be this thought of God, not 
as mere causa causarum, not as substance nor as World-Governor, but as the Father everlasting, in Whose love the spirit of man, yearning in its orphanhood, finds rest and satisfaction. It has not overlooked the all-embracing thought, the loving will, and the sympathetic feeling, which make up the spiritual essence of such Divine Fatherhood. It sees in that Father, Who is the Spirit of all things living, the unity or spiritual bond whereby all thoughts and things are gathered into one. It thus exclaims :-

"Therefore to whom turn I but to Thee, the ineffable Name? Builder and Maker, Thou, of houses not made with hands! What, have fear of change from Thee Who art ever the same? Doubt that Thy power can fill the heart that Thy power expands?"

And it has remained too sane and rational, meanwhile, to be scared by the word mysticism, whose meaning it sees rather sadly misunderstood. We account it wise enough to perceive that the inner essence and soul of religion always must be that mysticism wherein religion moves and has its being; and to discern the essential glory of such mysticism to be that it claims for the soul a communion with the Divine so direct and high as to be beyond the reach of sense or the logical understanding; best of all, claims this communion on grounds of sheer and unquestioned fact. And so for it, as for Amiel, austere monologue is found to have passed into dialogue, reluctance into docility, re- 
nunciation into peace, the sense of painful defeat into that of recovered liberty. Not that it shares any blindness to the weakness and defect of mysticism, for it is impossible that it should not perceive and lament the mystic lack of reasoning power and of universal ground of appeal. But it sees, for all that, the powerful and needful elements of a rational mysticism-without due recognition of which any religious philosophy must remain defective-especially when these elements of the religious feeling or consciousness are purged of pantheistic leanings or tendencies. In all this, therefore, it eschews the mysticism that simply says, as it is in 'Faust,' "feeling is all" (Gefiuhl ist alles), for intellect and thought are for it never so estranged from feeling as such mystic stress on immediacy would imply. It has attained a deepening sense that, in our explicit recognition of our sonship to this Divine Father, and in our realisation of true communion with the Father of Spirits, will be found the essential meaning of prayer-a meaning in which it includes action real, direct, and free, of the Absolute Spirit on the finite Spirit as the result of prayer and aspiration.

In relation to the position of those who hold that prayer may be offered for spiritual benefit simply because the suppliant's own heart will thereby be influenced, it has been said,_- "What! can a man go, as if before God, and say,- 'O God, I ask Thee to subdue this or that evil desire, knowing 
that Thou hearest not, but hoping that by this conscious fiction I shall call my own soul into action'?" If God is no more in Providence than such prayer should imply, $\mathrm{He}$ is a manifest and even ridiculous superfluity. And, looking to the way in which the natural world subserves the spiritual, theistic philosophy has still postulated a free relation to the world for God. Rightly so, for no study of phenomena has ever yet brought out any such really necessary connection in the events or occurrences around us as would make the influence and action of an unseen and Almighty Will an impossibility, any more than will and action are impossible on our part in our limited degree and finite way. The close affinity and interaction between faith and prayer is too important to be here overlooked, and Bishop Monrad, in his "World of Prayer,' has finely insisted on the need to rise in prayerful power through increased vigour of faith. We do not know any reason for allowing science, or anything else, to drive the basal thought of our being from us, which is, that we are made in the image of God, and which enables us to understand how, amid His systems of inexorable law, God remains that free and infinite Spirit Who can hear and help us. Man's life is the riddle it is, because, as Goethe said, man is offspring of two worlds-the finite and the infinite. But man can raise himself above nature, can lift himself to God, and how then shall he leave nature untranscended by his God, as 
hopelessly immersed in it? Theism has found a spiritual faculty in man, which makes him quite other than agnostic, lacking the capacity to explain the realm of spiritual things; but it has not found that, because this spiritual faculty is his, the need is superseded that his knowing be critical in mode. It finds in man, as a centre of spiritual life, God so consciously realised as the true ideal of the human spirit as to be called Father. It has passed out of the old exclusive stress on man's nothingness apart from God, that it might lay, in its optimistic spirit grounded in this high relationship of man-part though he be of the great world-process - new emphasis on the unmeasured moral might of man as possessed by Christ and indwelt by His Spirit. It will thus be seen how firmly it has grounded its faith in the soul, as what has been termed " unitary substratum of all mental phenomena," in face of agnostic denial here. Still it can say with Gratry, in his 'Connaissance de l'Âme,' “Mais, d'un autre côté, et bien evidemment, mon âme n'a pas toute l'unité, toute la simplicité, toute la concentration qu'elle cherche"; and, as he immediately adds, " par la foi, l'espérance, et l'amour, et par le sacrifice de l'égoïsme, par l'attraction de la prière et la pratique de la volonté de mon Dieu, je me recueille vers Dieu, et vers les autres cœurs, et vers mon propre cœur; je me recueille vers ma source, et je m'enracine dans la vie." It sees the partial truth of pessimism to lie just in the incapacity with which 
the things of earth are stamped to satisfy the spirit of man. In face not only of pessimism but also of agnosticism, it has maintained, not alone as regards the race but for individual man, an attitude unweariedly optimistic, and has more distinctly evinced the superiority of its optimism to that of agnostic evolution in the unwavering manner in which its faith in the infinite capacities and possibilities of the soul has kept before man, as the untouched goal of his aspirations, the highest spiritual ends-the ends of spiritual perfection achieved through Immortality. Yes, for it hesitates not to accept the word of M. Secrétan, that "perfection is eternal." It has taught us to

$$
\text { "rest in faith }
$$

That man's perfection is the crowning flower Towards which the urgent sap in life's great tree

Is pressing,--seen in puny blossoms now, But in the world's great morrows to expand With broadest petal and with deepest glow."

Hence we deem ourselves justified in affirming that the immense hopefulness, the intense spring or impulse, and the inspiring thoroughness of the theistic faith, have been so surely known and felt that religion, no less than theology, has become quickened.

Recent theistic philosophy of religion has, we are inclined to think, laid more satisfactory hold on the reality of a Philosophy of History, in which the theistic idea is seen to carry with it the Spiritual Presence which is the Spring of spiritual impulse, 
and the Source of organic growth. Yes, the Spiritual Presence whereby the Kingdom of Heaven is for ever coming amongst us-whereby, too, the harmonisation of the spiritual and industrial functions of society, as it marches on to its most comprehensive development, is more completely secured. We thus pass from the unity of God, as we have seen it, to a resultant unity in History. For in the great historic movement, as the philosophy of history interprets it, or traces out its rationality, it is to such unity we are led amid all the diversities of phenomena. And for the philosophical historian, history is no history at all until there is this rational comprehension of it. The great importance of studying the rise and genetic connection of facts was explicitly pointed out by Trendelenburg ('Logische Untersuchungen,' vol. ii: pp. 388, 395).

It is upon such a philosophy of history as we have spoken of that our philosophy of religion must rest, and our justification of the multiform developments of religion proceed. The broad survey of history suggests to theistic philosophy a predestined goal towards which the ofttimes unconscious movements of men and nations end. Just this future of the universe indeed ought more to engage our attention, for the world, as it now is, exists and makes for that future, yes, makes for it with a swiftness which at least ensures the instability of the present. Nor has it been content with such ill-defined and shadowy forecasts of the future of 
the race as those marked out by Kant, Jouffroy, Herder, Guizot, and others, but has sought the true destination of mankind, as organised, harmonised, and illumined by the Spirit proceeding from the Power that makes for righteousness, truth, and love in the world. We are by no means forgetful, in saying this, what a deep natural sense it has at the same time had of the difficulty of attaining such a Philosophy of History in view of the sophistries and subtleties that only too easily find their way into such speculations, and of the too frequent triumphs disclosed of might and rude violence over virtue and right. Nor do we overlook that, even if the setting up of a heavenly kingdom upon earth were taken to be the end of history, it cannot be so taken without due consideration and disposal of the seemingly different end to which the whole rich development of man's own proud culture is making. We are not even oblivious of the contention - the unreasoned and unwarranted assumption rather, of the late Professor Clifford, in the interests of dogmatic atheism-that the notion of a guiding power or providence in history is immoral, and constitutes a paralysis of human effort, though it is too palpably at variance with fact and human experience to deserve any very serious attention. We remain keenly sensible of the conflicting elements and obstacles in our faith in Providence, as that sweet and puissant Force by which the inexorable rigour of fate or destiny 
is softened for us. But if the universe is not to be simply meaningless to us, then do we more firmly maintain that only the spiritual world or Kingdom of God, transforming rather than destroying, absorbing rather than extinguishing, will suffice as its adequate goal-adequate to its toil, and pain, and promise. Yes; and though we speak of "promise," let it not be thought that we mean the philosophy of history to signify any miraculous gift of prophecy, rather than a divining of the plot of the historical drama we see. As Bunsen remarks, in his 'God in History,' only that which is can be satisfactorily reduced to formulas. But; for all that, we see the "history of the world"-the whole present order of things-to be insufficient to prove "the judgment of the world," and we take it to point onwards to a completer vindication of the moral order. This is so even while we admit the sense in which this saying of Schiller is true-that the world's history is its judgment.

We certainly do not think theistic philosophy has sympathised with the view of those who would wrench History from all connection with Philosophy, and who would bring its events within the range of mechanical necessity, until History should be virtually reduced to a department of physics. Not even those who would tie history down to narrative, leaving philosophy severely alone-like Thiers-can escape philosophy of history any more than did he. The theistic philosophy of religion 
must find itself ill content without synthetic efforts in the sphere of History. From the facts as material-sifted, marshalled, classified, set in due relations -there must result a philosophy. How diverse these philosophies of history may be, such names as Bunsen and Buckle, Comte and Kant, Taine and Renan, Hegel and Schelling, Schiller and Schlegel, may suffice to suggest. We are with Guizot in holding that while history may be confined to facts, facts are yet so little of a visible and material character in all possible cases that there are facts, hidden and moral, which are every whit as real as any facts of battle or any acts of government. Certainly in our historic dealings we must see to it that goodness remains for us the sovereign greatness. We see the theistic philosophy of religion reject the defective theory of such a materialistic civilisation as would have satisfied Comte and the deterministic Buckle - to whose constructive synthetic work a value not small may be allowed-and assert the reality and primacy of the spiritual. No doubt, Hegel and Comte are right in viewing the question of a philosophy of history so largely from the view-point of European history, nor can it be doubted that the progress involved would not have been to them the entity it appears to be to some recent thinkers, but would have remained an end calling for some more exact definition. Though we do not forget his striking reduction of the freedom involved, yet we find 
Comte leaning too much to the purely intellectual side or condition of progress. Though we are not unmindful of Hegel's arbitrary and illusive treatment of subordinate processes or details - for it is not to be denied that such Willkiir manifests itself in his constructive thought, which really follows what ought to be under dialectical treatment -yet we find Hegel doing better in defining the progress in terms of freedom, and in showing how such progress may be put to the proof as to whether there has been a bringing nearer of what ought to be.

Surely we may say that, with the enlarged exhibition by modern thought of the historic tendency of all things towards nobler conditions and the investing of the principle of right with greater respect and authority, the utter inadequacy of a 'philosophy of history on the basis of its being viewed as the product of merely physical causes, or treated as a purposeless ocean-swell of mortal endeavour, has been made more thoroughly manifest. "History without God," as Dr Pusey in an eloquent passage once said, "is a chaos without design, or end, or aim." And Niebuhr declared History to be, of all kinds of knowledge, "the one which tends most decidedly to produce belief in Providence." Very finely has Pfleiderer described what has been due to Hegel in this connection by his setting forth of the working of the Sovereign Reason of the world in all its devel- 
opments: it has been to Hegel we have owed the "deeper insight" into historical life and orderly development of "nations and ages," the "more penetrating glance" through all confused phenomena into the "essence of man and things," the "unprejudiced appreciation" of the need for conflict and opposition, and the more "intelligent reverence" for the great figures of history who, in the hands of a Higher Power, have waked in us the mighty hopes that make us men. Pfleiderer does not think historians like Ranke, Baur, or Carlyle, "conceivable without the Hegelian philosophy of history," which last is for him, it would seem, a kind of fountain "whence," in Dante's phrase, "all knowledge sparkles forth" (onde ogni scienzia disfavilla). And the statement of Pfleiderer may be fitly supplemented by our recalling how much the history of philosophy, as exemplified in Erdmann, Kuno Fischer, and Zeller, has owed to Hegelian impulse. Certainly Hegel's merits deserve these acknowledgments of Pfleiderer, even if we be not unmindful of the measure of truth in the estimate of Karl Schwarz-whom Pfleiderer so warmly eulogises - when, in his 'Geschichte der Neuesten Theologie,' he speaks of Hegel's philosophy of history as having corrupted (verunreinigen) the history of philosophy, and rendered parched (ausdörren) the philosophy of history. It has been a fruitful issue that Hegel has brought out the evolution of rational freedom through idea, 
nature, and spirit, so that there shall be seen, as he says, the glory of the idea mirroring itself in the history of the world. The justification of God in history, with Hegel, lies just in this world-process of development and realisation of spirit; if, to this elimination of fortuitous or chance elements, we can add a theistic interpretation of this Idea of Hegel, our philosophy of history shall do well.

Certainly we now more vividly realise what a broadening movement is the historic one, free from fatalism and its false presuppositions. So true it abides through the stages of its evolution and broad but slow development, that,-

"Wie die Welt läuft immer weiter, Wird stets die Geschichte breiter"-

but the history is still a process of Divine education, the comprehension of which is our philosophy of history. Surely we may affirm that the necessity and rationality of the world's historic movement, regarded as a spiritual result achieved by domination over mechanical forces, reached under the prevalence of spiritual law, regulated by the supremacy of reason, and controlled by the Spirit of Truth, have, in their progressive, struggling aspect, been more forcibly shown, and the need more uniformly exhibited of such a spiritual link or nexus as that termed in 'Faust' "das geistige Band." If God is God at all, must not recognition of $\mathrm{Him}$ in history be a prime principle of any true philosophy 
of history? Is not God to be found there in time as truly as in nature $\mathrm{He}$ is found in space? Gloatz has remarked on the way in which the philosophy of religion has felt need for more explicit recognition of history as its presupposition, such recognition including the history of the immediate Godconsciousness present in the religions. Also, how religion in its historical development, growing always more clearly conscious of its own essence, runs out really, taken in respect of the History of Religion, into the History of the Philosophy of Religion ('Spekulative Theologie,' Erster Band, i. 23).

We take it to be now well understood how little any branch of philosophical doctrine can be duly appreciated and understood apart from its history. The freedom, no less than the necessity, of all this historic movement of which we have spoken, theistic philosophy of religion has kept in the essential place it merits. For there have not been wanting those who have clearly felt that man is not really free, so long as he is not completely master of all that pertains to the region of natural character, and who have consequently maintained, as we here do, that less than such an idea of freedom as that now depicted leaves him at the mercy of his mere interests, submerges him under the course of the exterior world, as though it were all matter of necessity that these things should be so. Hence the progress we depict is not even-paced and 
mechanical, for the spiritual ideals of mankind are advanced, and the springs of their spiritual energy are renewed, in such hours as men think not. We find not the spiritual forces uniformly victorious, nor all movement to mean progress, but it traces some final triumph of the powers that make for spiritual evolution. We, for our part, do not pretend to adhere to the notion of a continuously progressive historical movement in any sense that would exclude the presence of reactionary moments and factors: no, we account the historic movement as at certain times too plainly cyclical or gyratory to leave us with more than a balance in favour of progress. Reversionary types of things will, it would seem, be always too possible for any such theory of an absolutely continuous progress, though it is not, on the other hand, to be thought that human life and history are but an aimless whirl or " eddy of purposeless dust." No, it is precisely the progress which is being attained through all the advance towards a freedom, an ethical freedomalways better organised and more decisive-which is for us the providential stamp of the Higher Agency at work in history. We lay this stress on "ethical" freedom, for it is impossible to overestimate the significance of advance in ethical insight and intuition for historical progress in general. History is, in fact, more than philosophy teaching, as Bolingbroke said, by examples; it is ethics or morality teaching after the same manner. 
In all the stress we have been laying on the spiritual, it is not meant that mechanical or material forces are unreal and of no account, but only that the spiritual are the highest-a "highest" reached in and through the material, dull, and inert, as matters may appear to us. Certainly no power or force can, to theistic philosophy, assert itself as the right save as it is spiritual no less than it may be material. And it is far less with conditions of material happiness than with moral perfection we have here to do. The changes and progress, of which ultimate historic movement is made up, are, in its view, as we take it, dynamic manifestations expressive of thought and its determinations in virtue of its finding a Dynamic Reason disclosed by its study of reality as it appears in the universe. Yes, for why should not ideal plan and law obtain in the history of man as in the development of the individual, though he sin against them? Why should we not postulate a presidency of Deity-His directive agency -in all that reconstruction of society for which our time is making, as surely as we may and do for the great movements of past European history? Of course, a philosophy founded only on the most recent period of European history would be so imperfect, in its dissociation from the past, as to be fallacious, and yet the philosophical aspect of the most recent period may have its own instructive teaching for us as to the conditions of religion and 
civilisation in such a new time. Our knowledge of His way and purpose may remain incomplete, but it is another and very different thing from the irrationality of those who assert that no revelation of Him is to be found in history, and deny any accomplishment of $\mathrm{His}$ will $-\Delta$ iòs $\delta^{\prime}$ 'ं $\tau \epsilon \lambda \epsilon i \epsilon \tau o$ $\beta o v \lambda \eta^{\prime}$ - in the great world drama. Knowledge, power, social obligation and justice, spiritual life and human sympathy and philanthropic endeavour, are the results which we claim, in distinctly enlarged measure, for the great spiritual development of which we have spoken - a development proceeding under fundamental moral law, and pointing, as its necessary presupposition, to the activity of a Personality not without likeness to our own. For personality in this large sense we take as, in Bunsen's phrase, "der Hebel der Weltgeschichte" or the lever of universal history, and the race is to us inspired by inflow of spiritual energy from a Being that transcends it. "The wisely ordered march of history," as a modern apologist has said, "through the midst of all the turmoil brought about by the arbitrary conduct of so many millions of free men, can only be explained as resulting from the all-ruling providence of a personal God. It would be impossible, in the face of human freewill, for the unconscious wisdom of nature to retain the mastery over the course of events." Hence we regard theistic philosophy as having a right to demand the warrant of the Spencerian philos- 
ophy to treat all history as but so many episodes in the gigantic movement of Nature-as only so many meaningless and immaterial accidents in the mighty and universal process which is to it the main concern - a right it is bound to exercise. Beyond the complicating and counteracting forces of evil it finds the spiritual forces that make ultimate development in the religious evolution. Behind our periods of social restlessness or lethargy, of movement or stagnation, it finds some ground of ultimate advance. And in so far as the theistic philosophy of religion contends for a force in history not ourselves, which makes for righteousness, it does and can contend for this only as there is love in God which will not let the world go from its altruistic and harmonising influences. For in the philosophy of history-if such there be-there is for it no more final note than that of Redemption, wherein God is seen reconciling the ages unto Himself through that Son, Who lives along and rules them all. It thus comes in its teleological view at length to say, with the philosophy of history of the poet of the "In Memoriam,"-

"I see in part

That all, as in some piece of art, Is toil coöperant to an end."

Yes, for otherwise the workings of God in history would become for it, in the words of the poet of the "Paradiso," "not works but ruins"-

"Non arti ma ruine." 
Recent theistic philosophy of religion, in pursuance of its lofty spiritual view of man's nature and destiny, as we have in this chapter sought to present it, has not 'only been unable to abandon the belief in Immortality, but has even held it with new light and breadth. Looking at immortality in the light shed upon it by reason or the unaided human intellect, we find that philosophical thought has viewed the belief in it as more than ever rationally necessary and consistent-the most consistent hypothesis in view of all the facts of the world and of man's nature and life. It has more firmly grasped this faith as the culmination of a spiritual philosophy, and, notwithstanding the pretensions of some of the more thoroughgoing evolutionists, it has not found modern science adverse to the spiritual nature and destiny of man. Its hope for the future life-

"Derives it not from what we have The likest God within the soul?"

Or are we to treat that in us which is likest to God as a lying thing? It agrees, as we suppose, with an American writer on the philosophy of religion, who maintains that the foundations of a future life do "lie outside of revelation," and who holds immortality to give "promise of revelation" rather than revelation to lay the "foundations of immortality." It holds, as against those who, with Goethe, take existence to be a duty, were it but for a moment, 
that life here can never be morally and spiritually satisfying-at least in any permanent way-without relation to the future life. It has never yet seen or found any satisfactory way or mode by which man's present life can be made wholly selfenclosed in respect of the world to come. Kant for this very reason dealt with the soul's immortality as a postulate of the pure practical reason, since perfect accordance with the moral law, such as is commanded and as must therefore be attainable, calls for a duration adequate to "an infinite progress towards perfect harmony with the moral law" - a progress "possible only if we presuppose" the existence of a rational being to be "prolonged to infinity." When the materialism of to-day tells us that our bodily organisation is all that we conceivably are, we prefer to remind ourselves of the saying of Joubert: "I, whence, whither, why, how? These questions cover all philosophy, - existence, origin, place, end, and means." We do not regard it as open to doubt that there has in our time been clearer recognition of the naturalness of man's longing for immortality - as something rooted in his condition - as seen in his sense of progress and individuality, his desire for real and right reputation, his craving, nay, ineluctable demand for justness in the judgments of his work, his yearning for moral perfection, and his necessity for love, as that which is at least imperishable as 
the force or matter which is to the materialist eternal. The confident assertions of Vogt, Moleschott, and Büchner, that science scorns belief in the future life, have grown more discredited, and have given way before the more modest contentions of Spencer and Huxley that science is, in the matter of immortality, powerless, for lack of evidence, either to affirm or deny. The truth of the matter is that science cares only for phenomena -for Werden or becoming - among which things the soul is not to be classed. The soul belongs to a higher order of changeless and abiding reality than the order of science, commonly so called. It does not seem to us, however, either possible or wise to make quite so much as Hettinger does of the argument that "the very idea of immortality which the soul possesses, and its intense longing for its possession, prove the fact."

We are in midst of that scientific temper of mind in which the spiritual vaticinations, the sentimental longings, the moral aspirations, and the intuitional convictions, are being simply crushed out by the agnostic attitude that disclaims any knowledge of, and denies any place to, such things. It is not easy to meet this gran rifuto of life and spiritual advance, this craving for positive demonstration, and every attempt to meet it must proceed on lines moral as well as intellectual. Must not the aim of a true philosophy of religion be to conjoin, to the scientific quest of truth of purely 
intellectual kind, a power of absorption and assimilation of all new knowledge in which ethical elements shall have free play and large scope? Clearly patience will have a perfect work ere this state of mind at last be met and satisfied. Meanwhile, theistic philosophy has been patiently considering the bearing of all known facts, whether of metaphysics or of empirical and rational psychology, on the belief of immortality. The whole tendency of recent researches in science has been towards the position that life is before organisation, which it impels and directs on rational lines-that the soul is, in that "yonder-minded" being, man, to be by no means regarded as inseparably bound up with the body.

Theistic philosophy, at any rate, has not forgotten how strangely out of place have been the objections to the imponderable and immaterial soul from the side of a physical science which seems to have been wonderfully oblivious of the fact that, as Lewes pointed out, the forces of modern science itself are as transcendental as anything in the scholastic philosophy. The main object of science is, according to Professor Huxley, to reduce the fundamental incomprehensibilities of the world to the smallest possible number, but, when science shall have done her best, there will remain - wherever no arbitrary limit or unmeaning arrest is laid upon thought - a desire to know which will and must carry us beyond the possibilities of the present, and will 
point to immortality. The mysteries of the world of nature without, no less than the mysteries within the soul, press upon the thinking spirit of man, and impel to thought of immortality. Who then shall say that the stars of modern astronomic science do not, in their stately march, send forth hints of infinity, and radiate light on the progress and diversified occupation that belong to immortality? Who shall say that the veil which hides the life immortal from our view is not so near and thin that our vision cannot pierce it through? May we not, with newer light and greater cogency, ask in words that Herder was able to use, "Shall that force be lost which we are compelled to regard as the purest, the most active of all the forces of which we have any knowledge? Shall the power be annihilated that overcomes and makes subordinate to itself the forces deployed in lower forms of organisation-the power that can behold and even overrule itself - that can know, love, imitate God?"

In perfect keeping with the scientific doctrine of the conservation of energy, theistic philosophy has maintained the persistence and permanence of that substratum or entity, which we call the soul, in the super-terrestrial life, for there that law, if a law of the universe, ought most of all to hold. Recent theistic philosophy has even, it may be said, found, in the matter of immortality, science itself setting about the task of deducing "the pro- 
gressive existence of the soul as an inference from the law of evolution." Has it not found a Darwin declaring it to be to him "an intolerable thought" that a belief so strong and instinctive as that of immortality should give way to that of "complete annihilation after such long-continued slow progress"? It has not found the argument for immortality, which it discerns lying hid in the evolutionary interpretation of man's life, to be a thing developed as yet in any full or satisfying way, but it sees in it the promise and the potency of more convincing things to come. Why should the law and spirit of progress be held down to the narrow limits of this earthly existence? Or what sort of evolutionary thought is it which is content to lay such hand of restraint upon the ascending thought and spirit of man? Or what but the hope of immortality - as lived in God - can redeem our future personal progress and culture from being a miserably selfish, fruitless, and unnatural thing? Welcome is every light of science that may help to correct our conceptions of the life immortal, but a bootless task have they undertaken who think, in the name of science, to promulgate a truncated evolution, and cancel belief in the world to come.

Recent theistic philosophy has connected its doctrines of immortality, in opposition to the non-theistic philosophies that would resolve it into what, to use a phrase of Renan, seems to us but a "simulacrum of immortality" - the mere expression of man's 
desire to live - more closely with man's relation to God as originally made in the Divine image, so that immortality is his instinctive quest. It has not, for all that, expected the full-blown knowledge of immortality in man $a b$ initio, as something that did not share in the growth and progress of all things else. Such an expectation it sees to be highly unscientific and unwarranted. Yet it has been more swift to recognise how native to man really is the longing after immortality of which we have been speaking, amounting, one might almost say, to a rational instinct, since the idea of immortality has been better seen to lie at the basis of rational life. There is, says Dr Mulford, in his 'Republic of God,' a "will that in its purpose does not yield to mortal wrong. There is a joy that is not of emulation. There is a freedom that is other than the mere struggle for existence in physical relations, and is not determined in its source or end by the finite conditions."

Perhaps it may not be amiss here to say that, whatever might be urged in favour of such attempts as have sometimes been seen in recent years to set the persistence of the soul after death in what might seem firmer theological foundation by finding for it a physical or material seat, theistic philosophy has very decidedly discountenanced such contentions, by reason of the utter insufficiency of scientific support for such definite localisation as these physical theories postulate. No doubt, 
modern scientific thought makes it always harder to conceive conscious psychic existence without the connection of a brain, by which our conscious states are determined, but then our philosophy is quite opposed to the too current mode of setting matter and spirit into real opposition. Because we hold to the basal spiritual character of that which is material, we reject a material seat and find the seat of that spiritually developing principle called the soul in the soul itself, with its grand potenciesboth spiritual and material. John Fiske, in his 'Destiny of Man,' says that "the Platonic view of the soul as a spiritual substance, as an effluence from Godhood which under certain conditions becomes incarnate in perishable forms of matter, is doubtless the view most consonant with the present state of our knowledge."

Theistic philosophy of religion has more distinctly felt that the theme of immortality, though one outwith the region of physical science, as belonging to a sphere where science has as yet no foothold, grows more certain as an inference of our own rational and spiritual constitution, which craves a further chance of development than the present life affords-an inference taken, that is to say, in conjunction with the character of God as known by us.

"Du hast Unsterblichkeit im Sinn, Kannst du uns deine Gründe nennen? Ja wohl, der Hauptgrund liegt darin, Das wir sie nicht entbehren können." 
That is to say, "Can you tell the grounds of your belief in immortality? The weightiest is just this, that we cannot do without it." Or, in the words of a poet of our own-

"Whatever crazy sorrow saith, No life that breathes with human breath Has ever truly long'd for death.

'Tis life, whereof our nerves are scant, Oh life, not death, for which we pant; More life, and fuller, that I want."

When the harp of life becomes here broken, what reason is there that the soul should not find for itself other ways or modes of showing its inherent energies and activities in perpetuated life? We know no reason why we should not make our own the words of the philosopher Fichte when, speaking of "The Vocation of the Scholar," he says: "My work must go on to its completion, and it cannot be completed in time;-hence my existence is limited by no time, and I am eternal: with the assumption of this great task, I have also laid hold of eternity." And he continues: "My will, secure in its own firm purpose, shall soar undisturbed and bold over the wreck of the universe: for I have entered upon my vocation, and it is more enduring than ye [the elements] are: it is eternal, and I am eternal, like it."

There surely can be no doubt that the Christian philosophy of religion has in recent times linked our belief in immortality to our faith in God in 
a way that is perfectly natural and normal. Not only so, but the actual advantages accruing to our unselfish ideals, in matters of morality and religion, from such facts as those of God and Immortality not being more obtrusively thrust upon us have been very explicitly and forcibly set forth, and cannot legitimately be brushed aside. It surely must be allowed that, as the true or infinite ideal for man has, as we hold, been made more real and vivid in this time, so as a double consequence his ideal aspirations must have become quickened, and his apprehensions of the idea of an immortal life strengthened. It has, we suppose, been more cordially welcomed as an accepted fact that the impulse towards immortality reaches its highest strength only as man attains his largest spiritual development, where the desirableness of life as itself a good is most felt. Hence, though we grant that there may be nothing in the conception of evolution, abstractly considered, which is incompatible with the extinction of the race and the cessation of its history, may we not very well question whether it would be at all consistent with rational possibility to postulate such an issue in face of the actual development and the spiritual capabilities of the race? We, for our part, regard the true philosophy of religion as having borne a deeper feeling of persuasion that "to deny the everlasting persistence of the spiritual element in Man is to rob the whole process of its meaning." Even so 
unprejudiced a writer on this score as John Stuart Mill has expressed the possibility of such existence in the clearest terms.

"If the present contain all man's treasure,

How light were his loss or his gain, Though he ransacked the roses of pleasure,

Or gleaned all the gall-nuts of pain."

The loss of individual immortality has been loudly proclaimed, no doubt, from the extreme evolutionary side, which has yet allowed a certain race-immortality; but recent theistic philosophy has, we venture to think, more unequivocally affirmed the inseparability of the race from the individual, for which last it claims a sacred and eternal worth, and has more emphatically declared its belief in personality after death-a true personal immortality, not an immortality of vital force or impersonal life. When Emerson says that "everything connected with our personality fails," he simply makes a sad mistake. For the individual life is not to be simply lost in God-merged in Him in some pantheistic sort. So far is personality from failing that it is just that which - because it is true personality and has a really altruistic character-must endure for ever, and increase with the increase that is of God. Immortality is not simply some vague and isolated existence that awaits us, but is something with which history must reckon, for the progress of the present must run on beyond the gulf 
of the grave, and the perfection of the race must be found in its unity in Jesus Christ.

When we turn to Haeckel, we find his naturalistic pantheism affirming, in the interests of a supposed monism, that immortality in a scientific sense is conservation of substance, and therefore the same in his view as conservation of energy or of matter as defined by physics or chemistry respectively. We say "supposed" monism, for who knows whether a system is really monistic or not which takes the liberty to unite energy to matter and does not take the trouble to tell us of what sort this energy is, or whither it may go? The theistic philosophy of religion certainly fulfils Haeckel's expectation that his view be rejected as materialism, whose God is only the infinite sum of forces purely natural. Instead of sharing the uncertainty of a recent writer who thinks it matters nothing whether theism is true or not should it be that we perish helplessly with our organisms, it feels profoundly sure that being cannot be broken-as Goethe said, "Kein Wesen kann zu Nichts zerfallen."

If our evolution is to be of a rational sort, theistic philosophy sees it must demand, in view of the discords, woes, confusions, maladjustments, of the present, such ulterior issue and completed result as only that bloom of evolution, Immortality, can yield - the freedom of the Fenseits, the Beyond. So that it is as far as may be from seeing any such pantheistic triumph as that foreshadowed in the 
words of Strauss, when he said that "the Beyond is the One in all, but in the form of a future it is the last enemy which speculative criticism has to fight with, and if possible to overcome." It sees it will not do to leave each of us standing before this great Beyond, in Mephistophelean helplessness, exclaiming,-

"And though I fret and worry till I'm weary, When? How? and Where? remains a fatal query."

"Und wenn ich Tag und Stunden mich zerplage, Wann? Wie? und Wo? das ist die leidige Frage."

It sees such hope of harmony to come, as Immortality affords, to be the motive power or mainspring of all human activity, and so cannot consent to any view of the universe on which it should, looked at in the highest light, be able to dispense with man as essential to it. "His destiny," as Hettinger has said, "is to occupy the borderland where matter and spirit meet, the lowest in the order of Spirits, the highest of corporeal forms, in whom the marriage between Spirit and nature is consummated. Man was to be the keystone in the arch of God's creation, binding together the two worlds of Spirit and matter in a close and living union. Therefore he was not created for a momentary existence on earth, and then to disappear for ever, or only to survive as an incomplete being. He dies, but he will rise again to be the living link, the harmonising chord of these two great 
realms throughout eternity" ('Natural Religion,' edited by Bowden, pp. 252, 253).

Theistic thought has had the satisfaction to find Fiske declare that "the materialistic assumption that there is no such state of things, and that the soul accordingly ends with the life of the body, is perhaps the most colossal instance of baseless assumption that is known to the history of philosophy." So with Professor Le Conte and others who approach the subject from the scientific side. Says Le Conte, in his 'Evolution and its Relation to Religious Thought': “Without spirit-immortality this beautiful cosmos, which has been developing into increasing beauty for so many millions of years, when its evolution has run its course and all is over, would be precisely as if it had never been-an idle dream, an idiot tale signifying nothing." When theistic philosophy has been confronted with materialistic science as represented by Büchner and the like, who dismiss all thought of the future life on purely negative and inferential grounds, it has been with great power shown how severely deficient were the notions of human personality on which the materialistic assumption rested. Also, that what materialistic evolution leaves all unexplained is just the native tendency and inherent instinct in man, in respect of personal existence beyond the grave.

Recent theistic philosophy of religion has certainly not shown any lessening grasp of the im- 
pregnable basis on which rests its faith in man's survival or a future life. That basis is clearly grasped, in its metaphysical aspect, as grounded in the fact that, because God ever lives-and we live here in Him-we shall live in Him hereafter also. Of Immortality taken in this sense, Dr Matheson very rightly asserts that it is "unopposed by any law of physical science, uncontradicted by any testimony of evolution," and effected by the "main agent in the process of development-that primal force of the universe which is everywhere persistent and immortal." We have had no semblance of sufficient reason-either from the materialistic or the pantheistic side-for supposing that death terminates our personality or self-hood: we have an inexpugnable conviction of such capabilities of larger life as cannot be satisfied here, but demand an eternal sphere. Pantheism, too polite and wise to dismiss the term immortality, has in recent times shown how little care-in its inadequate psychological hold on the persistence and significance of self-hood-it has to preserve the real self-conscious personality of individual man. The possibility of immortality for mind has, we believe, been, from the psychological and metaphysical side, more clearly seen to call for yet deeper study of the nature of the World-Ground, and of the relations of mind to this Universal Being.

In its great upward striving and endeavour, theistic philosophy regards the modern tendency 
to reduce the future life to a mere fanciful and inconsequential possibility with feelings somewhat akin, perhaps, to those with which Napoleon is reported to have said concerning the circumscribed life-duration of a great picture, "Quelle belle immortalité"! Yes, unsubstantial it is as the Comtist subjective immortality, and it leaves man on our hands as himself vanity of vanities. But the difficulties of maintaining faith in the life immortal-a true Himmelfahrt or ascent for the spirit of man-are yet real and great, and may not be minimised, meeting us, as they do, from the side of science, the side of morality, and the side of religious sentiment itself. On the other hand, while the doctrine of immortality may have been cast into the caldron of speculation, it is to be said that it has come forth purified and strengthened by philosophy, by religious thought, and not leastthough seldom so presented-by modern science itself. Even though our peering into that illimitable world is through the bars of our present prisonhouse, we see what may stimulate to hope, to effort, and to progress.

Theistic philosophy has very clearly perceived what-as Stahl remarked-a refutation of pantheism that individualism is which, disclosed in nature, shines pre-eminently in man. It surely sees that, as De Tocqueville said, the Almighty does not generalise, but to Him "one ever counts for one." Has it not always more clearly seen, when Hegel- 
ianism would carry us away, as with a flood, the personality of the depreciatingly termed mere individual-though theistic philosophy ascribes a universal side or nature also to every finite existence-to find no real or proper resting-place in that philosophy, where it seems to lie outwith the absolute idea which Hegel so fascinatingly expounds? We, for our part, are bold enough to claim for recent theistic philosophy a more keensighted recognition of the fact that here, in the matter of immortality, as earlier in the case of the Being of God, the full proofs and real evidences can never be poured into the theoretic moulds of language, which is but a poor inadequate interpreter of the vaticinations and experiences of the spiritual nature of man. We do not care to conceal our view that a very inadequate service is performed when theism is left as a thing of mere argumentative form, for, besides those demonstrations which - as Dante said - are "the eyes of philosophy," theistic thought has its hours when, caught up into regions of transcendent speculation, it dreams dreams and sees visions of supreme reality and supernal purpose which it is not lawful-for it is not possible-to utter.

"Here sits he, shaping wings to fly;

His heart forebodes a mystery;

He names the name Eternity."

Possibly we may not reckon ourselves of them that hope to add one cubit to the height of the argument 
for immortality, which, however it may and ought to be articulated and cherished by us, grows in its hold upon us less by the power of reasoning from without than by inward revelation or spiritual reflection on the living movements of the Providence that encompasses us on every side. We have found $\operatorname{Dr}$ A. Réville, in a critique of the part of the 'Dogmatik' of Strauss bearing on this theme, saying that "a belief in immortality is a result of an intuition of the future, and not the conclusion of a syllogism. If I am to have a firm hope of my own personal immortality, I must have reached that height in the spiritual life-that moral and religious attitude-in which this earthly life, and all that it can offer me, is with me inferior to the destiny to which I feel myself invited." We regard Lotze as rightly interpreting the tendency of modern religious thought, when, in his philosophy of religion, he maintains that it is content with the general faith in future existence, in retribution, and in a constant process of perfection. It may do, possibly, for a poet of to-day to say-

"We children of Beneficence

Are in its being sharers;

And Whither vainer sounds than Whence

For word with such wayfarers."

But it will not do for the philosophy of religion, and yet we must be content here to say that where, and with what environments, our future life, indestructible in its communion with God, will be, 
theistic philosophy, in its consciousness of how far the last word on the subject is from having been spoken, may not now tell. But to the modern voices which ask-

"What need have we

Of thoughts that wander through Eternity?"

we can at least affirm the need and certainty that such life will be, as the natural expansion and completion of the present; we can more firmly assert this as a corollary of the truth of the Being of a personal God, carrying with it its implication of a spiritual government. Our whole moral sense would be shocked, and our faith in the rationality of the theistic evolution outraged, if such a deeplyrooted conviction as that of immortality were to prove without real ground or eternal part in the process of the suns and the aims of the universe. This we say while not forgetful how apt the case is to appear as one of obscurum per obscurius to that scientific habit of mind which finds in God no more than a tendency in the universe. "Mais qui osera dire qu'une telle forme est impossible à l'art divin?"

"I, being simple, thought to work His will, And have but stricken with the sword in vain; And all whereon I lean'd in wife and friend Is traitor to my peace, and all my realm Reels back into the beast, and is no more. My God, Thou hast forgotten me in my death : Nay-God my Christ-I pass, but shall not die." 
It is impossible that they who utter such longings of man's heart should perish. What, indeed, should all that is best in us rise up to exclaim against a God or Creator who should leave us, with these infinite yearnings, to perish? And so the theory of those who-the Conditional Immortality School -would make Immortality an importation into man's own spirit from without, has for us seemed always less rational, and less consistent with the natural spring and impulse of personal spirit in the progressive life of man. Above all conditions or states in which he may be found must be placed in primary importance the essential and transcendent powers of man as, in the intrinsic nature of his spirit, we find him. It were an utterly improbable thing that that deep-seated and intrinsic nature of his should be annulled in virtue of certain conditions in the short span of his earthly life. The theistic philosophy of religion believes in the prophetic element it finds in man, and, rising on the wings of his aspirations after the ideal and the perfect-after God and truth and goodness-soars towards his eternal destiny. To it between terrene and post-terrene virtue, discontinuity there is none, and therefore the only rationally possible-possible, of course, it is and no more-theory of conditional immortality is that which makes man lose immortality in course of time through the self-destroying power of sin. 
Que cura fuit vivis eadem sequitur tellure repostos. Say we with George Herbert,-

"Sweet spring, full of sweet days and roses,

A box where sweets compacted lie, My music shows ye have your closes, And all must die.

Only a sweet and virtuous soul,

Like season'd timber, never gives ;

But though the whole world turn to coal, Then chiefly lives."

It will thus be seen how the cry of immortal life voiced by our deepest nature makes another thing of our philosophy than "a meditation on death and annihilation." That voice transcends, but does not contradict, any utterance of science: it is a voice which speaks of harmony, of interpretation and of adjustment in respect of all the strange, sad facts of man's spirit and life. May we not say that, though recent theistic philosophy has had a clearer discernment of the abstract possibility of theistic thought being constructively reared without this reference to immortality, it has yet more deeply felt that, for vivifying and inspiring power, the note of personal immortality must still, in the face of those who would end the cosmos in a grand anti-climax, be the last utterance of a true and thorough spiritual philosophy? May we not affirm that it has seemed to it a strange, irrational, and impossible supposition that just here, in the highest, should real correspondence, 
real harmony, real development, fail and come to naught? May we not say that, when it has been sought to draw forth a non liquet on the subject of personal immortality, theistic philosophy has found the possibilities and probabilities founded on the many presumptions in its favour along the lines of recently strengthened analogical evidence and of metaphysical and teleological argument, so overwhelming as to be unable to do otherwise than declare it, not, perhaps, an ordinarily demonstrable truth, but a supremely reasonable belief? If, therefore, we grant, with Ulrici, Fechner, Lotze, and Teichmüller, among philosophers of recent date, that proof or demonstration is, in the strict sense, impossible here, yet we cannot, while agreeing with Professor Pfleiderer as to personal immortality being a hope, regard all statement of this conviction and the grounds on which it is based, as quite so tentative and wanting in scientific character as Pfleiderer represents. The proofs for immortality may not be of the exact kind which we call demonstrative, but that does not keep them from being so convincing and rational that in their strength man may yet, to use the words of the poet Campbell, in sablest hours of earth-

"'The darkening universe defy

To quench his Immortality,

Or shake his trust in God."

Still less can we agree with the cheerless result of Dr Bradley's idealism when, at the close of his 
thoughtful work on 'Appearance and Reality,' he says, "a future life must be taken as decidedly improbable." On the contrary, we hold that, to a purely natural theism, immortality is pledged by the goodness of the Deity, and it is demanded by the disorders and unexplained confusions of the world that now is. Surely it is no great undeserved compliment to the wisdom of the Deity to believe that this world is more than a comedy of errors. Shall we dare pronounce this universe of ours one huge blunder, which, had the power been ours, we should have blotted out for ever? More keen-sighted has our recent Christianly theistic philosophy of religion been to perceive what good reasons there may be for no more minute or detailed insight having been granted us into the nature of the life to come. It has, too, been more content to rest in the love of the Divine Father, of Whose ordering that life will be, and to cherish a firmer faith in that law of spiritual continuity whereby the eternal morrow shall mean the perfecting of the unfinished salvation and character of to-day. Hence it has been gradually recovering the confidence in a future life which the excessive dogmatism of so-called Christian systems had weakened in the minds of men. It has, in fact, maintained so deepening a hold, through every darkness and obscurity, upon the love of the Living Father, as to be able to say that, as for it, its unquenched hope is to behold His face in righteousness, and, 
in awaking after His likeness, to be therewith satisfied.

"And shall I find no Father? Shall my being Aspire in vain for ever, and always tend

To an impossible goal, which none shall reachAn aim without an end?

Or, shall I heed them when they bid me take No care for aught but what my brain may prove? I, through whose inmost depths from birth to death Strange, heavenward currents move ;

Vague whispers, inspirations, memories, Sanctities, yearnings, secret questionings, And oft amid the fullest blaze of noon, The rush of hidden wings?

Nay ; my soul spurns it! Less it is to know

Than to have faith: not theirs who cast away

The mind God gave them, eager to adore

Idols of baser clay.

But theirs, who, marking out the bounds of mind, And where thought rules, content to understand, Know that beyond its kingdom lies a dread Immeasurable land."

Because the theistic advances of recent times have been what in this and previous chapters we have tried to portray, we close this work with the comforting reflection that, although philosophy is more than the individual philosopher, the theistic philosopher can yet to-day, with more piercing glance and more penetrative insight, with greater sweep of vision and more dauntless confidence of faith, make his own, notwithstanding those per- 
plexities of the cosmos that remain,-for still, as Dante says, "insensate he who thinks with mortal ken to pierce Infinitude,"

"Matto è chi spera, che nostra ragione Possa trascorrer la infinita via,"-

the beautiful prayer of Geibel, with its fine spiritual daring and rich theistic sentiment, of which we venture to subjoin a rendering of our own in the form in which it was long ago cast off in leisure moments :-

" Herr, den ich tief im Herzen trage, sei Du mit mir!

Du Gnadenhort in Glück und Plage, sei Du mit mir !

Im Brand des Sommers, der dem Manne die Wange bräunt,

Wie in der Jugend Rosenhage, sei Du mit mir!

Behüte mich am Born der Freude vor Uebermuth,

Und wenn ich an mir selbst verzage, sei Du mit mir!

Gieb deinen Geist zu meinem Liede, dass rein es sei,

Und dass kein Wort mich einst verklage, sei Du mit mir!

Dein Segen ist wie Thau den Reben! Nichts kann ich selbst;

Doch dass ich kühn das Höchste wage, sei Du mit mir!

O Du mein Trost, Du meine Stärke, mein Sonnenlicht,

Bis an das Ende meiner Tage, sei Du mit mir!"

Lord, Whom in depth of heart I bear, be Thou with me! Thou Fort of grace in peace and plague, be Thou with me! When shine of summer sun the cheek of man doth brown, As when with roses fenc'd in youth, be Thou my crown! Preserve me, Well of Joy! lest I should haughty be, And if I of myself despair, be Thou with me!

Thy Spirit to me give, that pure my song may be, And that no Word may e'er accuse, be Thou with me! Thy blessing be as Vine-dew! Self can nothing be ; But that I may the highest dare, be Thou with me! O Thou my Consolation, Strength, and Sunlight free, On to the end of life's brief day, be 'Thou with me! 


\section{INDEX OF AUTHORS AND SUBJECTS.}

Abbot, Dr Francis E., 90, 214, 294. Abgeleitete Absolutheit, 438 .

Abgrund, ro.

Absolute, the, 28, 30, 5I, 75, 9I, 95, 105, I33, I52, 222-224, 229, 259, 273, 275, $285,289,297-299,304,307,309,3$ ro, $324-326,328,359,378,3^{81}, 3^{82}, 3^{89}$, 426.

Absolutism, scientific, II8, 406, 490.

Accident, apotheosis of, 192, 409.

Acosmism, 30r, 3 r 3 .

Adam, 340.

Adaptations, I80, 190, 202, 209.

Adjustment, Spencer on, 209.

Aschylos, 413.

Esthetic, 38, 121, I99, 269, 330.

Etiological inquiry, I75.

Affections, the, II7-II9, 320, 396, 397, 428, 456,465 .

Agnosticism, 38, 57, 91, 95, 99, 122, I23, I39, 201, 352, 48I, 494, 495, 5 ro.

Huxley's, 99.

impossibility of, I22, I23, 494, 495 . the Absolute of, 75, 9r, 96, 123, 303, $38 \mathrm{I}$.

$\dot{a} \lambda \eta \theta \iota v o ́ s, \dot{o}$, rIg.

Alexander, Prof. S., of Manchester, 422.

Altruism, 72, 73, 132, 181, 507, 518.

Amiel, 286, 348, 468, 49r.

Analogy, 52, 56, 6I, 290, 302, 529 .

'Analytik,' Kant's transcendental, 95.

Ancestor-worship, 47, 58.

Animal int

Animism, 26, 47.

Annihilation, $465,513,528$.

Anschauung, $4 \mathrm{r} 8$.

Anselm, 217-219, 239, 240.

Anthropocosmic theism, 65, I22.

Anthropomorphism, 9.4, 109, 280, 302, 447 .

Antiquity of man, 340 .

Anti-theistic theories, 38, 369, 480 .

An-und-für-sich, 372.

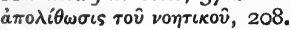

Apologetic, II, 337.

'Appearance and Reality,' Dr F. H. Bradley's, 298, 372, 389, 530 .

Apperceptions, 374 .

"Apriorism," I48.

Aristotle, 176.

Arnold, Matthew, 40, 67, 109, 276.

Art, 463 .

Aryan conception, 65 .

Aseität, Iro.

Aseity, Iro, I66, 290.

Astronomy, 482, 486, 512.

Atavism, 49.

Atheism, 82, 251, 497. of consciousness, Schelling's, $5 \mathrm{I}$.

Atonement, 459, 46 $, 464,467,468,470$, $473,477,478$.

philosophy of, $459,465,470,475,477$.

Atrophy, 260.

Attributes of Deity, 94 .

Auberlen, 444.

Aufhebung, 3ㄱ.

Augustine, 40.

Ausdruck, 207, 3 II.

Aussage, 3II.

av่тáркєєа, 390.

Authority, reason and, 345 . religion and, 386 .

Automatism, 4I2, 452 .

Autonomy, 262, 344, 347 .

Azara, 55.

Baader, 6I, 283, 286.

Bahnsen, 134 .

Bain, Prof., I50, 367, 375, 402, 410.

Bala, 42.

Balfour, Arthur James, 90, 263, 34I, 345, 403,421 .

criticism of, 293.

Banks, Prof. J. S., 79, 126.

Baur, 50r.

Bavinck, Prof., of Kampen, 259.

Beatrice, Dante's, 473. 
Becoming, 90, I05, 510.

Begleiterscheinungen, 372.

Being, 89-9 I, 93, 96, 100, 103, r 10.

Absolute, 90, 96, 103, I Io, I I I, 326, 327.

Hegel on, 93, 94, ro2, ro4, ro5.

Bender, Dr, of Bonn, 35.

Bertrand de Born, 376 .

Beschränkung, $29 \mathrm{I}$.

Bewusstsein iiberhaupt, $35^{8}$.

Biedermann, 79, 228, 229, 3ro, 321 . evil and, 138 .

personality and, criticised, 279, 309, 3ro.

Biological science, 40, r83, r94.

Bobba, r27.

Body, mind and, 377, 409, 484. redemption of the, $47 \mathrm{I}$.

Bolingbroke, 504 .

Bonn, 35.

Boston, 294.

Bouchitté, I27.

Bowen, Prof. Francis, of Harvard, 294.

Bowne, Prof. Borden P., of Boston, 79, 294.

Bradley, Dr F. H., 298, 302, 378, 389, 412, $435,530$.

Braniss, 88.

Broca, I95.

Browning, I06, II2, 456.

Bruce, Prof. A. B., 79, 90.

Büchner, 73, I00, 190, 204, 510, 521.

Buckle, 499 .

Buddhism, 28, ro8.

Bunsen, history and, 498, 499, 506. on India, 29.

Burns, 250.

Busse, Dr Ludwig, I09, I39.

Butler, A. J., 376.

Butler, Bishop, 248.

Caird, Principal John, 79, 90, r84. on basis of religion, 35 .

on design, 184 .

on religion, 30 .

on the ontological argument, 237 .

Caird, Prof. Edward, 27, 484.

criticism of, 33 .

on Christianity, 66.

on the moral argument, 244.

Calderwood, Prof. Henry, 90, 340, 341, 484.

Caldwell, Prof. W., 94, 4r2.

Campbell, Macleod, 473 .

Campbell, Thomas, 529 .

Carlyle, 485,501 .

Caro, M., 233, 234.

Carpenter, Dr, 206, 409, 444.

Carus, Dr Paul, xo8, 317, 367, 368.

Causa causarum, 49 I.

Causal axiom, Spencer on the, $145,160,163$. idea, the, I45, I50, $\mathbf{x}_{53} \mathrm{I}_{55}, \mathrm{x}_{57}, \mathrm{I}_{92}$.

law, the, I49-I5I, I53, I54, I57, I6o, I62, I63.

problem, the, I46, I49, I 53, I59, I6o, $\mathrm{r} 62, \mathrm{r} 63$.
Causalbegriff, $\mathbf{5 4}$.

Causality, freedom and, 407, 409 .

Hume on, 146.

Kant on, I46, I $50-\mathrm{r}_{52}, \mathrm{I}_{54}, \mathrm{I}_{6}$.

Lotze on, I49, 150, 163 .

Mansel on, 142 .

Martineau on, $\mathbf{I}_{5}$.

metaphysic of, I42, I44, I49.

Mill on, $146,163,180$.

Prof. Riehl and, $x 62,163$.

Prof. Romanes and, 164 .

Prof. Royce and, r6r.

Science and, I44, I54, I57.

Ulrici on, I5o.

Causation, efficient, 143, I54, I76, г96. principle of, $\mathrm{I}_{42}, \mathrm{I}_{53}, \mathrm{I}_{55}, \mathrm{I} 62,405$, 407.

volitional type of, $x 48, x 64$.

Cause and effect, I45, I53, I56, I65. efficient, 143, I54, I7 I, I96.

Prof. Flint on, 157 .

final, I74, I77, r9I, I92, 208, 212, 2 r4.

Cave, Principal Alfred, 79.

Cazenove, Dr, 239.

Certitude, 386.

Chalmers, Dr Thomas, 255, 444 .

Chalybäus, ro5. on Hegel, 93.

on personality of God, 29 r.

Chemistry, 519.

Christ, 396, 456, 465, 466, 468, 470, 472, $473,476,489,494,519$.

Christ-consciousness, $382,383,388$.

Christian Doctrine, 385,464 .

'Christian Doctrine,' Dr Dale's, 476. history of, $3^{85}$.

Christianity, 4r, 66, 73, 80, 382, 465, 47r. as teleological, $4 \mathbf{I}$. sin and, 465, 468, 47x, 478 .

Christlieb, 345 .

Church, redemption of the, $47 \mathrm{r}$. thought of the, 482 .

Civilisation, 499, 506.

Clarke, I49, 2 I8.

Clifford, Prof., 367, 369, 372, 423, 497.

Cobbe, Miss, 299.

Cocker, Dr, 294.

Cognition, theoretic, 36,3 r6, 346.

Coleridge, 22 r.

Communion, 312, 47I, 525 .

Comparative method in mythology, 52 . psychology, 339 . religion, 22.

Complexity of modern problems, 355 . of personality, $324,369,394$. of religious devotion, 48 .

Comte, 73, r46, I63, 200, 220, 221, 369, 499, 500,523 .

Concreteness, 97, ro4, 268, 439.

Conditional immortality, 527.

'Connaissance de Dieu,' Gratry's, 232.

' Connaissance de l'Âme,' Gratry's, 494.

Conscience, authority of, $243,249,261,445$. Butler on, 248. 
Conscience, Chalmers on, 255 .

cognition and, 253.

dignity of, 252, 254 .

Dorner on, 252, 444 .

Erskine on, 256.

ethical energy of, 253,454 .

Gass on, 453.

Hofmann on, 445 .

Martensen on, 453 .

Martineau on, $257,448$.

moral, the, $45 \mathrm{I}$.

Newman on, 25 I.

origin and nature of, 254 .

reason and, 253 .

theology and, 249, 260.

Wuttke and, 25 I.

Consciousness, $8,353,356-360,362-365$, $37 x, 377,382$.

Absolute, the, 8, 285, 297, 316, 325, 379.

Christian, the, $382-384$.

Cousin on, 356 .

matter and, $367-369$.

origin of, $357,358,383$.

philosophy of, $355,367,383$.

Prof. James on, 362,363 .

race, 364 .

relative, 316,320 .

religious, the, 379,382 .

Conservation of energy, $5 \mathrm{I} 2,5 \mathrm{I} 9$.

Contingency in freewill, 4IO, 4II, $42 \mathrm{I}$.

Continuity, spiritual, 527,528 .

Convertibility of forces, 144 .

Copenhagen, 369 .

Corneille, 392.

Cosmic consciousness, 306 . process, 190, 306, 406. theism, 273, 275.

' Cosmic Philosophy,' Fiske's, 273-275, 306.

Cosmological proof, the, I58-161, I63-166, I68.

Courtney, Dr W. L., 449.

Cousin, I49, 23I-233, 335. eclecticism of, $23 \mathrm{I}$.

Crantz, 55.

Creationism, 98, 104, 106, 107, 110, 186, $288,456,483$.

'Creator and Creation,' Dr John Young's, 456.

Creed, 77, 439.

Criticism, Biblical, 483 .

'Critique of Judgment,' Kant's, 174, 177, 244.

'Critique of Practical Reason,' Kant's, 246, 249.

'Critique of Pure Reason,' Kant's, r20, I76.

Croll, Dr James, $158,435,436$.

Crusius, 150.

Cudworth, 2 I8.

Culture, Christianity and, 7r, 72.

Cumulative character of theistic arguments, II6.

Czolbe, r93.
Dale, Dr R. W., 476.

Dante, 170, 375, 376, 473, 487, 501, 524, 532.

Darwin, $183,188,190,192,195,450,513$. on origin of species, $\mathbf{1} 88$.

Darwinism, Wallace on, I93, 34r.

Das Dasein Gottes, 120.

Das geistige Band, 502.

Das Gemeine, I.

Das Gewissen, 445 .

'Das Menschliche Handeln,' Prof. A. Dorner's, 438.

'Das Wesen der Religion,' Dr Bender's, 35.

Davidson, Dr W. L., I24.

De Biran, Maine, $148,164,231$.

De Born, Bertrand, 376.

De la Saussaye, Prof. P. D. Chantepie, on religion, 23.

De Tocqueville, 523 .

De Wette, 445 .

Deductive demonstration of God, II5.

Deism, 207, $3^{\text {I3 }}$.

'Della Filosofia della Rivelazione,' Gioberti's, 235.

Der Gedanke, 205.

Der Hebel der Weltgeschichte, 506.

Descartes, 218, 219, 224.

Design, evolution and, 205, 208, 209. immanence and, 179, 190, I97, 198.

law and, r99, 200.

Lotze on, 182, 213 .

personality and, 2 I2.

principle of, 179,182 , 190, r9r.

Prof. Flint on, 178, 179, 182.

Prof. Royce on, $188,191$.

Rev. J. Morris on, I78, I87, 213.

Romanes on, 210.

Strauss on, 215.

Trendelenburg on, I82, I9r.

Destiny, 457, 520, 527 .

'Destiny of Man,' Fiske's, 515.

Determinism, 399, 403, 4II, 4I7, 4I9, 434$437,439$.

Dr James Croll's, 435, 436.

Dr Paul Rée's, 428, 429.

Prof. A. Riehl's, 434.

Ribot's, 404 .

Schelling's, 412, 426, 427 .

Schopenhauer's, 427.

Deus absconditus, r16.

Deus ex machinâ, 247.

Deussen, I34.

Development, 54, เо9, 196, 326, 359, 487, 5 I5.

Dialectic, 337, 342, 377, 426, 500 .

Dichotomy, 380 .

Diderot, 406.

Die Enge des Berousstseins, 355.

Die Erkennbarkeit Gottes, 95.

'Die Grundbegriffe der Gegenwart,' Ix.

'Die Worte des Glaubens,' Schiller's, 323.

'Die Zukunft der Religion,' A. Schweizer's, 70. 
Diman, Prof., 90, 122.

Ding-an-sich, 307.

Doctrine, History of, 385 .

Dogmatics, Natural Theology and, 6.

Dogmatik, 309, 525 .

Dogmatism, 315, 497 .

Dorner, I. A., 79, 128, 228, 252, 373, 444, 450,460 .

on conscience, 252,444 .

on ethics, $45^{\circ}$.

on final cause, r9r.

on ontological proof, 228.

on personality in God, 288 .

Dorner, Prof. A., of Königsberg, $43^{8}$.

"Double-aspect" theory, 369, 4'3.

Dowden, Prof. E., quoted, 285 .

Drews, Dr Arthur, 282.

Du Bois-Reymond, 368 .

Du Prel, 36r.

Dualism, 64, 92, 100, 105, 257, 327, 389 .

'Dualism and Monism,' Prof. Veitch's, 3I9.

Dugdale, 473.

Dysteleology, 209.

Eclecticism, 23I.

Edinburgh, I94, 340, 484 .

Education, 468.

Edwards, Jonathan, necessitarianism of, 402. atonement and, 473 .

Edwards, Principal, of Bala, criticism on, 42.

Ego, transcendental, 373-375.

Egoism, IIo.

Ein absoluter Anfang, 428.

Ein iiberwundener Standpunkt, I.

Ein urspriingliches Gottesbewusstsein, 59.

Eliot, George, II 3 .

Emanationism, I05, I66.

Embryology, 392.

Emerson, 12, 76, I17, 245, 298, 336, 429, 518.

Empirical psychology, 5II.

Ens rationis, 95.

Ens realissimum, $\mathbf{1} 59$.

Ente realissimo, 236.

Entheism, ro8.

Entourage, 452.

Entschluss, 440.

Environment, 43, I8I, 356, 404, 4I5, 4I6, 525 .

Epistemology, 375 .

"Epistle to a Young Friend," by Burns, 250.

Erdmann, 227, 501 .

Erfahrung, 287.

Erhebung, 70.

Errungenschaft, 403 .

Erscheinung, 144.

Erskine of Linlathen, 256.

Eschatology, 70.

Essence of being, 91, 93, 95, 258, 270, 286, 309.

of God, 9r, 93, 95, 286, 309 .

of personality, 270,314 .
Essence of religion, 30, 32, 35, 36, 40, 43, 44 .

of teleology, 197, 201.

Eternity of matter, I06, I48.

Ethical freedom, 504 .

law, 442, 444, 446, 448, 450, 456 .

theism, 2, 243, 256, 257, 260, 26r, 263.

'Ethical Studies,' Bradley's, 412.

Ethics, agnostic, $444,446$.

metaphysic and, 220.

of Dorner, 450 .

of Leitch, 453 .

pantheistic, 444 .

reason and, 445,447 .

religion and, $62,63,257,259,45 \mathrm{r}$.

Ethnic religions, 22, 25.

Ethnographical theory, 47.

Ethological aspect of teleological proof, 175 .

Eucken, Prof., of Jena, II, 37.

Eudæmonism, 247.

European history, 499, 505 .

Eutaxiology, 170, I77.

Evil, moral, 138,139 .

natural, 136, r 37 .

problem of, 140.

reality of, 137 .

Evolution, conscience and, 446, 452, 453. design and, 208.

immortality and, 513 .

man and, 339-34r, 487, 493 .

natural, 52 .

of life, 40 .

of religion, $33,5 \mathrm{I}$.

philosophy of, $354,437,521$.

theistic, 504, 507, 526 .

'Evolution and its Relation to Religious

Thought,' Prof. Le Conte's, 521.

- Evolution and Man's Place in Nature,'

Prof. Calderwood's, 34r.

'Evolution of Religion,' criticism of Prof.

E. Caird's, 33.

Evolutionism, 80, I01, 106, 306, 397, 400, $437,446,495$.

Experientialism, $\mathrm{I} 47, \mathrm{I} 48$.

Extra-mundane Deity, I52, 301, 307.

Fairbairn, Principal, 71, 79, Iro, 127.

Fairbrother, W. H., 296.

Faith a basal activity, 3I, 44, 343, 344 .

complexity of, $35,36,43$.

conflict of, 45I, 472 .

theoretic reason and, 4, 342-345.

Fatalism, 404, 4r6, 434, 502.

Fatherhood, the Divine, 489-492, 494.

'Faust,' 348, 467, 482, 492, 502.

Fechner, 48, 79, 290, 291, 367, 529. on origin of religion, 53 . on religious faith, 53 .

Feeling, the religious, 492 . thought and, 35, 44.

Fénelon, 23I, 336 .

Ferrier, 18, 90, I0I. consciousness and, 355 . ontological cast of, 237. 
Fetichism, 49, 57, 346 .

Fichte, I. H., 90, 288. personality and, 288.

Fichte, J. G., 79, I04, I35, 426, 486. freewill and, 426. idealism and, 285. immortality and, 516 . law and, 443. personality and, $283,292$. rationalism and, 343 .

Final cause, Dorner on, I9r. Trendelenburg on, I9I.

Final causes, 174, 177, 191, 192, 208, 212, 214.

Finiteness, 280, 389, 490.

First Cause, the, I45, I49, I53, I55, I64.

' First Principles,' Spencer's, 382.

Fischer, Kuno, 233, 403, 501 .

Fischer, K. Phil., 226, 291.

Fisher, Prof. G. P., 79, 294.

Fiske, Prof. John, 98, I09, I83, 273-275, $308,341,35^{8}$. criticism of, 274 . on the soul, 515,521 .

Flint, Prof. Robert, 55, 90, 128. cause and, 157 . design and, $172,178,182$. idea of God and, II8, 123. moral argument and, 243.

Natural Theology and, 6. nature and art and, $\mathbf{1} 78, \mathbf{1} 79$. ontological argument and, 239. speculative theism of, 297.

Fonsegrive, M., 404.

Force, conception of, 94 .

Le Conte on, 92 . matter and, 94, 98, г02-104, 106, го8. omnipresent, 98.

psychic states and, 359, 370, 37I, 373, 374 . reason and, 337 .

Foreknowledge of God, freedom and, 4 I3.

Form, force and, in nature, 40, $17 \mathbf{r}$.

Fortlage, roo.

Fouillèe, M., 222.

'Foundation for the Metaphysics of Morals,' Kant's, 425 .

'Foundations of Belief,' A. J. Balfour's, 293, 344.

Fragmentary character of revelation, 478 .

Frank, 288, 289, 45I, 470. personality and, 288, 289 .

Fraser, Dr J. G., 58.

Fraser, Prof. Campbell, 79, ro3.

Frauenstädt, I34.

Freedom, causality and, 407, 43r.

Dr Paul Rée on, 428-430.

Green and, 4II, 418, 4I9, 428.

Hegel and, 30, 426, 500 .

history and, 500, 502-504.

Kant on, 4I 5, 424, 425, 427 .

Lotze on, 423, 424 .

man's, I3, 3II.

Mansel on, 40 .
Freedom, personality and, 400, 4 r6. psychology and, 4I5, 4r6.

Riehl on, $432-434$.

Schelling on, 4 12, 426.

science and, 399 .

theistic philosophy and, 438-440.

Freewill, Dr F. H. Bradley on, 412, 418 . evolution and, $4 \mathrm{r} 6,420,437,50 \mathrm{r}$.

Fichte and, 4.26.

Prof. Höffding on, 43r, 432 .

Prof. Sidgwick on, 4 I9. significance of, $40 \mathrm{r}, 427$.

Fürsichsein, 280.

Future life, 518, 519, 520, 522, 525, 527, 530. science and the, $5 \mathrm{I}_{3}, 5 \mathrm{I} 5,5 \mathrm{I} 9$.

Galuppi, 234, 236.

Gass, 453 .

Gattung, 43r.

Gaunilo, 222.

Gedanke, 205.

Gefiihl, 492.

Gehenna, 462.

Geibel, Emmanuel, $53^{2}$.

Genesis of evil, 137,462 . of mind, $354-359$.

of morality, Pfleiderer on the, 63 .

of religion, 5o, 66 .

Geological science, 40.

'Geschichte der neuesten Theologie,' by Karl Schwarz, 5or.

'Geschichte und Kritik der neueren Theologie,' Frank's, 470.

Gesinnung, 248.

Gillespie, 2 r8.

Giltigkeit, 162.

Gioberti, 234, 235.

Glaubenslehre of Dorner, 374. of Strauss, $4 \mathrm{I}$.

Gloatz, Paul, 79, 503.

Glückseligkeit, 248.

God as Moral, 245, 259, 260. as Spirit, I02, 308 .

God-consciousness, 125, 38I, 386, 388, 459 .

'God in History,' Bunsen's, 498.

God-Man, the, ro5. Principal Edwards on the, 42.

" Gods of Greece," Schiller's, 64 .

Goering on cause, 163 .

Goethe, II7, I37, 25I, 339, 395, 472, 508, 5 I9.

on the commonplace, $\mathbf{r}$.

on the infinite, 90, 493.

on truth and form, 77 .

progress and, 73,479 .

'Golden Bough,' Dr J. G. Fraser's, 58.

Goodness, Divine, 128, 389, 440, 462. eternal, 140. sovereign, 499 .

Grace, $440,456,472,480$. freedom and, 440 . law and, $45^{6}$.

Gratry, 232, 336, 494 .

'Great Enigma,' W. S. Lilly on the, 280. 
Greek thought, 63,65 .

Green, Prof. T. H., 79, 333, 407, 489 . merit of, $4 \mathrm{II}, 4 \mathrm{r} 8$.

criticism of, on freedom, $4 \mathrm{Ir}, 4 \mathrm{I} 8,4 \mathrm{I}$, 428.

criticism of, on personality, 269, 393 .

Greg, W. R., 298.

Grösse, 68.

Grotius, I49.

Growth, 345, 359, 360, 496, 502, 504 .

Gruppe, 55 .

Guizot, 497, 499.

Günther, ro5.

Haeckel, ro, 98, r9o, 209, 519.

Hamilton, Sir William, I22, I43, 216, 418.

"Hamlet," 463.

Hanne, 282.

Happiness, 248, 466, 505 .

Harris, Prof. Samuel, 79, 90, 294, 334, 364. law and, 447.

reason and, 334 .

Hartmann, 70, 7I, I34, I63, I85, 272-274, 29I, 292.

unconscious Will and, 272, 273.

Harvard, 64, 294, 362, 406 .

Heaven, Kingdom of, 496 .

Hebrews, the, 6r, 64, 65 .

Hedonism, 250, 262.

Hegel, 16, 79, 104, 218, 226, 295, 306, 325, $347,426,499,500,502$.

Chalybäus on, 93 .

on being, 93, 94, 102, 104, 105.

on emotion and thought, 44 .

on freedom, $30,426,500$.

on idea of God, 24.

on nature, 485 .

on ontological argument, 223, 226.

on personality of God, ro4.

on philosophy of history, 500, 50 .

on Spirit, 30 .

on the Absolute, criticism of, 288,307 .

on thought and reality, IO2.

on Universal, ro4.

Rosmini on, 236.

Hegelianism, 103, I04, 133, 223, 295, 297,

3I9, 426, 466, 485, 501, 524 .

Hell, 48I.

Hellenes, 64 .

Hellwald, 54 .

Henotheism, 49

Heraclitus, 324 .

Herbart, 4I5. causation and, $146,149,163$.

Herbert, George, 528 .

Herder, 497, 512 .

Heredity, 4II, 4I5, 4I6.

Herrmann, 349 .

Hettinger, 226.

immortality and, 5 ro, 520 .

Himmelfahrt, 523 .

Hindu thought, 63.

Hinton, James, 160 .

Historic Christ, the, $473,476,478$.
History, Bunsen on, 498, 499, 506 .

Comte on, 499, 500.

difficulties of, 497 .

European, 499, 505.

freedom in, 500, 502, 503, 504 .

genetic study of, 496 .

Guizot on, 497, 499.

personality and, 506 .

philosophy of, $496,497,498,499,502$.

Gloatz on, 503 .

Hegel on, 500, 50r, 502.

necessity of, $496,498,499$.

Schwarz on, 501 .

predestined goal of, 496 .

progress of, 502, 504, 505 .

rational comprehension of, 496 .

Spencer's treatment of, 506 .

Thiers on, 498.

unity in, 496.

universal, 506 .

witness of, 502 .

History of Doctrine, 385 .

of Philosophy, the, 496, 498, 503 .

of Religion, the, 2I, 69, 503 .

' History of Materialism,' Lange's, 8o.

' History of Speculative Philosophy,' Chaly. bäus on, 291.

Hobbes, I49.

Hodgson, Dr Shadworth, $37 \mathrm{r}$.

Höffding, Prof., of Copenhagen, 367, 369 . freedom and, $413,430-432$.

Hoffmann, Franz, 307 .

Hofmann on conscience, $445,453$.

Hume, r46-r $48, r_{50}, 363$. sensationalism of, 99 .

Huxley, Prof., 99, 190, 194, 340, 402, 405, 5 ro, 5 rr.

Hygiene, 468.

Hypnotism, 393.

Ideal, the, 24r, 258, 348, 396-398, 463, 504 .

the moral, 258, 262, 397, 398, 463 . the spiritual, 24I, 396, 398, 504 .

Idealism, 80, $137,286,529$. absolute, 34, 371, 389 .

Hegel's, 288.

moral, 260 .

ontological, 234-236.

pantheistic, 397 .

Rosmini's, 235, 236.

Royce's, 346.

Idealistic philosophy, defect of, 288, 307, 367.

virtue of, 223.

Idea of God, 24, 108, 183, 308, 329, 330.

'Idea of God,' Dr Paul Carus on the, ro8.

'Idea of God,' Prof. John Fiske on the, 183 , 308.

Identity theory, 369, 4I3.

'lliad,' r29.

Illingworth, 297.

Immanence, conscience and, 9, 6r. Deity of, $9,42,64,93$. 
Immanence, fact of evil and, 3I4.

Fiske on, criticism of, 42 .

Krause on, 286, 287.

pantheism and, 93, 397.

purposive design and, 42, 190, 197, 198. the ideal and, 397,398 .

Immortality, 13, 2I4, 349, 465, 508, 509, $512-514,528,529$.

Comte on, 523 .

conditional, 527.

evolutionism and, $61,511-513,515$.

faith in God and, 516 .

grounds of, $508-5 \mathrm{II}, 5 \mathrm{I} 6$.

Herder on, 5 12.

Hettinger on, 510, 520 .

individual, 518,519 .

Kant and, 509.

metaphysic of, 5 II, 522 .

mind and, 511,522 .

natural, $465,514,517$.

necessary, 515, $5 \mathrm{I} 6$.

personal, $5^{18}, 5^{28}$.

Pfleiderer on, 529.

Prof. Le Conte on, 521.

race, 518 .

revelation and, 508 .

science and, 486, 528 .

Impassibility of God, 478.

Impersonal, the, 169, 185, 266, 278, 298, $309,335,364,390,449,518$.

"In Memoriam," the, 427, 507 .

Incarnation, the, $37,97,460$.

Indeterminism, 403, 407, 420, 434 .

Dr Mach's, 404.

Fonsegrive's, 404.

Renouvier's, 4r4.

India, 28, 29.

Individual, the, I04, $397,426,439,518$, 524 .

Individualism, $386,438,523$.

Individuality, 104, 312, 364, 386, 438, 509 .

Induction, $116,44 \mathrm{I}$.

Industrialism, 496.

Inferential knowledge, 370, $37 \mathrm{r}$.

"Inferno," 376, 487.

Infinite, the, 279, 280, 285, 295, 314-316, $391,487,490,519,532$.

Infra-personal, the, 300 .

Ingersoll, $3 \mathbf{x}$.

Inhibition, 407.

'Introduzione allo Studio della Filosofia,' Gioberti's, 235 .

Intuition, 124-126, 239, 312.

Prof. J. S. Banks on, I26.

Intuitional Argument, Prof. Knight on the, criticised, I23.

Inwardness, 312.

Israel, 64.

Iverach, Prof., 90.

Jacobi, 79, 283. religion and, 48.

James, Prof. William, of Harvard, 118, 362, $403,406,427$.
Janet, M. Paul, 8I, 375.

final causes and, rgr.

liberty and, 4 Io.

Jena, $\mathbf{I}$.

Jenseits, 5 I9.

Jesus, 75, 460, 463, 466, 468.

Jevons, Prof., 148, 203.

Jones, Prof. Henry, Io2.

Joubert, 32I, 509.

Jouffroy, 497 .

Judaism, 64 .

Juridical mind, the, 399 .

Jurisprudence, 443 .

Justice, attribute of, II2, II3. retributive, II3.

Kaftan, Prof. Julius, of Berlin, 79, 349.

Kahnis, 290.

Kampen, 259.

Kampf, 89.

Kant, 79, 108, 120, 135, 146-148, 150, I51, 163, I76, 217-219, 222, 225, 226, 233 , $282,365,366,373,410,415,427,44^{2}$, $446,45 \mathrm{I}, 484,497,499$.

cosmological proof and, $154, \mathbf{r} 6 \mathbf{r}$.

freedom of, criticism of, $401,4 \mathrm{I}_{5}, 424$, 425 .

immortality and, 509 .

metaphysic of, 220, 249.

moral argument of, criticised, 424, 425 .

moral ideal and, 247, 259, 448 .

ontological argument and, 218, 219, 222.

personality and, 282, 366, 376 .

phenomenalism of, roo, 4 IO.

rationalism of, 99,333 .

relation of ethics and religion in view of, 451 .

space and time with, 322.

teleological proof and, 174, 175, 177 .

Transcendental Esthetic of, 269.

Kantianism, I03, I46-148, 152, 160, I73,

$174,223-225,238,240,246-250,354,371$, $376,401,425$.

Kant's 'Analytik,' 95.

'Critique of Judgment,' 174, 177.

'Critique of Practical Reason,'246, 249.

'Critique of Pure Reason,' I20, I76.

'Metaphysic of Ethics,' 249.

'Philosophy of Law,' 442.

Kellogg, Dr, of Toronto, 79. on development of religion, 29. on thought of India, 28.

"Keraunological," the, Irg.

Kidd, Dr James, criticism on, 63.

Kierkegaard, 349 .

Kinetic power of reason, 350 .

Kingdom of Heaven, 13, 496.

Kingdom, the spiritual, $\mathbf{x}_{3}$.

Kleutgen, 237.

Knight, Prof. William, 123, 269.

and Kant, criticism on, 247 .

personality and, 259.

teleology and, criticism of, 205. 
Knowledge, faith and, 344 .

Koenig, Dr, on causality, I 54 .

Königsberg, 230, 250, 438.

Krause, 79, 124, 286.

' Kritik der reinen Vernunft,' Kant's, 248.

Ladd, Prof. George T., of Yale, 279, 294. Lange, F. A., 80, 405 .

Laocoon, 462.

Laurie, Prof. S. S., of Edinburgh, 342.

Law, I46, I48, 152, I53, I57, 160, 162, 163, I99, 340, 359, 44I-443,446, 447, 456, 483,493 .

absolute, 44I, 442, 444, 446, 449, 453, 482,483 .

cause and, I49-I5I, I53, I54, I62, I63.

cosmic, 44I, 442, 450, 493.

design and, r99.

ethical, $450-45^{2}, 456$.

Fichte on, 443 .

grace and, 456 .

inward, 442, 462.

love and, 456 .

material, 443,447 .

moral, 442, 444, 446, 447.

natural, $340,443,447,456$.

objective, $443,445,493$.

personality and, 447,448 .

philosophy of, Kant's, 442.

physical, 442, 483 .

Prof. Samuel Harris on, 447.

reason and, 445 .

Riehl on, 442.

spiritual, $443,447,455,457,486$.

theology and, $449,45 \mathrm{I}$.

uniformity of, 449 .

unity of, 482 .

universality of, $39,359,400,482,483$.

Law, William, natural religion and, 7 . spirit of love and, 459 .

Lawgiver, moral, 444, 45I.

Le Conte, Prof., causality and, I45.

force and, 92 .

immortality and, 52I.

theism and, I05.

'Lectures and other Theological Papers,' Mozley's, 465.

Leibnitz, I34, I47, I49, 218, 2 I9, 23 I.

Leitch, 453.

Lenormant, 460 .

Leopardi, I34.

Lerminier, 232.

Lessing, 394.

Lewes, 73, 367, 372, 5 II.

Libertarianism, 403, 4II, 437.

'L'Idée de Dieu,' 233.

Lilly, W. S., 280.

Lipsius, 79, 279, 310, 321.

on Divine personality criticised, 279, 3 Io.

Littlejohn, Dr, 90.

Littré, 220.

Locke, r49.
'Logische Untersuchungen,' Trendelenburg's, 78, 90, 205, 4I4, 496.

Logos, Eternal, 25.

Lotze, Io, 79, 90, I46, I63, 269, 279, 290, 3I3, 319, 365, 379, 400, 403, 423, 525,529 .

belief in God and, 54 .

design and, I82, $2 \mathrm{I}_{3}$.

freedom and, 400, 403 .

metaphysic of, criticism of the, I49.

personality and, criticism of, 3 OI.

realism of, ro3.

the soul and, 359 .

the ultimate of, 34 .

Love as attribute, IIO-II2, 325, 487.

Lowell, 368.

Lubbock, Sir John, 55 .

Luthardt, 226, 227.

M'Cosh, Dr, 345.

Mach, Prof. Ernst, 368.

Mach, Prof. F. J., 404.

Mackenzie, Prof. J. S., 412, 437.

Mainländer, 477.

Malebranche, 230, 23r, 235.

Mamiani, 236, 237.

Man, final cause and, 183,487 . ideal, 396-398.

metaphysic of, 220, 22I, 392, 484 . nature and, $352,484-487,489,490$. prophetic element in, 527 .

Manchester, 422.

Mansel, 79, 122, I42, I56, 244, 279, 353, $354,40 r$.

causality and, I42, I56.

freedom and, 401 .

moral argument and, 244 .

morality and, 447 .

personality and, $279,353,354$.

Maret, M., 232.

Martensen, Io9, 352, 453.

Martineau, Dr James, 79, 90, I50, 294, 390, 403, 4I4, 4I7, 453 .

Divine Personality and, 294, 295.

ethics and religion and, 257.

freedom and, 403, 410, 4I7.

moral obligation and, $257,448,449$. religion and, 36,257 .

transcendence and, 3 I3.

Materialism, Ioo, 318, 352, 400, 447, 48I, 489, 510, 519, 521, 522.

'Materialism of the Present Day,' M. Janet on, 375 .

Mathematics, II 5, 442, 444 .

Matheson, Dr George, 79, 90, 203, 297, 423, $436,522$.

Matter, energy and, 5I9.

eternity of, ro6.

forms of, 40, I7 I.

mind and, I02, I96, 362, 486.

mystery of, IO2.

Rothe on, ro4.

spirit and, I03, 39r.

Weisse on, ro4. 
Maudsley, Dr, 377, 409.

Mechanicalism, I3, 22, 41, 43, I66, I96, I98, 396, 400, 402, 436, 482, 498, 502, 504,505 .

'Médée,' Corneille's, 392.

Mediation, $469,470,473$.

Medical mind, the, 399 .

Memory, $35^{8}$.

'Mental Physiology,' Carpenter's, 444.

Mephistopheles, 520.

'Metaphysic of Ethics,' Kant's, 249.

'Metaphysica nova et vetusta,' Prof. Laurie on, 342.

Metaphysics, 9I, 220-222, 337, 390, 5I I.

'Methods of Ethics,' Prof. Henry Sidgwick's, 4I9.

' Microcosmus,' Lotze's, 54, 360, 378.

Mill, John Stuart, I I2, I43, I47, I50, I57, I80, I85, 356, 402, 4I8, 518 . causation and, 146, 163. utilitarianism of, 187 .

Mind, r96, I97, 362 . matter and, 102, 196, 362, 486.

'Mind,' A. J. Balfour in, $42 \mathrm{I}$.

G. F. Stout in, 424 .

Prof. J. S. Mackenzie in, 437.

'Mind in Matter,' Rev. J. Tait of Montreal, on, 38.

Minto, Prof., I 57.

Miracle, 305, 312.

Mitgefühl, 473 .

Moleschott, 5 Io.

Monism, 14, 70, 105, 108, 286, 308, 319, 336, $367,371,420,5$ r9.

Monotheism, 27,65 .

Monrad, Bishop, of Denmark, 493.

Montreal, 38.

Moral argument, Chalmers on, 255.

Erskine on, $25^{6}$.

Flint on, 243.

Kant on the, 244,425 .

Mansel on the, 244,447 .

Newman on, 243, 252.

rise of the, 243 .

Schenkel on, 243 .

value of the, 243 .

Moral consciousness, the, 26r, 263, 45r.

Deity, 245, 259, 260.

evil, 138, 139.

ideal, Kant on the, 259, $26 \mathrm{r}$.

imperative, $245,246,249,448,453$.

law, 442, 444, 446, 447 .

order, the, $285,450,464,493$.

personality, $39 \mathrm{r}-396,400$.

sentiment in idealistic philosophy, 8.

Morality, freedom and, 40r.

happiness and, $248,250$.

Mansel on, 244,447 .

Religion and, $62,45 \mathrm{r}$.

'Moralwissenschaft,' Simmel's, 437.

Morell, 79.

Morgan, Prof. Lloyd, 99, 339, 397.

Morris, Dr, 90.

Morris, Rev. J., 178, 187, 212.
Morris, Rev. J., design and, I78, 187, 212.

Motive, 407, 408.

Mozley, 2r, 4r3, 464, 478 .

on Christianity and man's primary needs, 465

on natural and revealed, $2 r$.

Mulford, Dr Elisha, 392, 514.

Müller, Julius, 287, 388, 446.

Müller, Prof. Max, 79 .

Mutability, 139.

Mysteries, the Christian, 459, 5 г2.

Mysticism, 34, 286, 49r, 492. defects of, 492.

need and virtue of, $49 \mathrm{r}, 492$.

Mythology, 52, 308 .

Nägeli, 195.

Napoleon, 523 .

Natura naturans, 180.

Natura naturata, r8o.

Natural, revealed and, 2r, 22.

selection, I80, I88, I93-I95, 203. spiritual and, 447 .

'Natural Causation,' Plumptre's, 422. evil, 136, 137.

law, 442, 443, 447 .

'Natural Religion,' criticism of the work, $38,277$.

'Natural Religion,' Hettinger's, 520. mediation and, 470 .

no lifeless metaphysical residue is, 4.

" Natural Theology," Chalmers on, 255.

Natural Theology, Ritschlianism and, 4 . what it is, 5 .

Nature and, 69.

Naturalism, 312, 345, 392, 401, 519.

Nature, art and, Prof. Flint on, I78, 179.

God and, 202, 486, 488.

Hegelian conception of, 485 .

intelligence in, 190, 489 .

man and, $185,186,203$.

Matthew Arnold on, 40, 67.

mysteries of, 186,5 I2.

organic, 484 .

Religions, 23, $45^{8}$.

spirit and, 90, 489 .

teleological character of, I78, I83, I89. uniformity of, 200.

unity in, 39.

volition in, 178,184 .

Naturism, primitive, 29.

Naturvölker, 56 .

Necessary datum of consciousness, 382 .

Necessitarianism, 402.

Neo-Hegelianism, 296.

'Neue Darstellung des Sensualismus,' by Czolbe, I93.

Neurosis, 409.

'New Natural Theology,' Rev. J. Morris on a, $178,212$.

Newman, moral argument and, 243, 25r. natural and revealed and, 21, 252

Newman, F. W., II5, 460.

Niebuhr, 500 . 
Nitzsch, C. I., 59, 289.

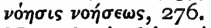

Nomological inquiry, 175 .

Nordau, Max, 133 .

Noumenon, 95, 304, 305.

Novalis, religion and, 67,489 .

Objectivism, $34,47,49,66,68$, roo, ror, 165, $283,299,316,3^{17}, 3^{2} 3,342,3^{80}, 3^{85}$, $387,448,449$.

Obligation, sense of, $37,350,444,445,447$, $448,453$.

Old Testament, 64 .

Ontological proof, Anselm on the, 2I7, 219, $239,240$.

Descartes on, 2r8, 2r9.

Dorner on, 228.

Hegel on, 223.

Kant on, 218, 219, 222.

Principal Caird on, 237.

Prof. Günther Thiele on, 230.

Rothe on, 228.

significance of, 24I, 242.

Weisse on, 226.

Ontologism, 234-237.

Ontology, $3^{86 .}$

Optimism, 494, 495.

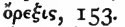

Organic function, 378 , 5 I9. growth, 496.

Origin of conscience, $25 \mathrm{I}-254$.

Origin of religion, empirical, 50,53 .

Fechner on, 53.

naturalistic theories of, 27,60 .

philosophy and, 46, 78 .

species, r88.

Origins of science, 97.

Orr, Prof. J., 79.

Padua, 235.

Pain, I28-13r, I37.

Palæontological races, $5^{8}$.

Paley, I7r, 202.

Pancosmism, 30r.

Panentheism, 286.

Pantheism, 43, 93, 198, 232, 233, 286, 312, $3^{18}, 3^{2} 5,35^{2}, 396,397,444,518,5$ 19, 522,523 .

defects of, $43,93,198,312,390,397$. service of, 42 .

"Paradiso," I I4, I66, 485, 507.

Parker, Theodore, 70, 82, 294. religion and, 70,82 .

Parseeism, 135 .

Pascal, 48, I I7, 343.

Passavant, 444.

Patripassianism, 478 .

Paulsen, IO, I98, I99, 221, 300, 430.

Perception, 224, 257, 340, 370, 394.

Perfection, ultimate, $445,466,495,509$, 5' 9 , 525.

Permanence of religion, $70,73,76,77,82,83$.

Personal character of the religious relation, $32,36,37,40$.
Personality, design and, 2 т2.

genesis of, 366 .

law and, 447, 448.

Maine de Biran and, 23I.

real, $7,266,267,269,278,283,293,303$, 365 .

Personality of God, Biedermann on, 308-3Io.

Chalybäus on, 291.

Dorner on, 288.

fact and significance of, 266 .

Fichte on, 283, 292.

F. H. Bradley on, 298, 299.

Flint on, 297.

Frank on, 288, 289.

History and, 506 .

I. H. Fichte on, 288.

Julius Müller on, 287.

limitation and, 314, 326, 327 .

Lipsius on, 3ro, 3 Ir.

Lotze on, 300, 30r.

Martineau on, 294, 295.

Matheson on, 297.

Nitzsch on, 289.

Pfleiderer on, 300, 30I, 3Ir.

Rothe on, 288, 289.

Schleiermacher on, 286.

self-determination and, 270, 27I, 326, 327.

Strauss on, 290.

Thomasius on, 289.

Ulrici on, 29r.

Weisse on, 288.

Personality of Man, basis of, $265-267$.

Christian, 452, 477 .

Comte on, 369.

Divine personality and, 268, 394 .

fact and significance of, $266,353,354$.

freedom and, $400,448$.

Kant on, 282, 366, 374, 376.

monism and, 367-369.

organic unity of, $374,376,378$.

origin of, $358,366,377,379$.

Prof. A. Dorner on, 438 .

Prof. S. Harris on, 364 .

real, 266, 267, 353, 354, 365, 378 .

science and, $366,377,3^{8} 5$.

Ulrici on, 393 .

Personification, 57, 59 .

Peschel on religion, 54 .

Pessimism, 70, 73, r3 r, I34, I35-r37, I41, 46r, 494, 495.

Peters, Karl, 273.

Pfleiderer, Dr E., 132.

Pfleiderer, Prof. Otto, 79, 90, 97, 228, 282, 292, 301, 308, 312, 319, 467, 500, 501. creation and, ro7.

freedom and, 420 .

God and, 96.

morality and, 63 .

mythology and, $5 \mathbf{r}$.

naturism and, 29.

redemption and, criticism of, 468 .

the Divine Personality and, criticism of, 300,3 II. 
Pfleiderer, Prof. Otto, theistic proofs and, I2I, I28, 529.

Phenomenalism, roo.

Philippi, 289.

Philological mind, the, 399.

Philosophie der Erlösung, 459, 477.

' Philosophie des Selbstbewusstseins,' 230.

'Philosophie und Erkenntnistheorie,' rog.

Philosophy of atonement, 459, 465, 470, 477.

of consciousness, $355,3^{67}, 3^{8} 3$.

of evolution, 354 .

of nature, 485 .

of Religion, 78, 79, 420, 496, 503 .

of religion, Christian, 384,385 .

religion and, 78,79 .

speculative, $88,97,162,288,297,503$.

synthetic, 13 .

theistic, goal of, 89.

task of, 2.

'Philosophy and Religion,' Hinton's, r6o.

'Philosophy of Law,'Kant's, 442.

'Philosophy of Mysticism,' Du Prel's, 36r.

'Philosophy of Religion,' Caird's, 30, 35, 238.

'Philosophy of Religion,' Lotze's, 423.

' Philosophy of Theism,' Fraser's, I03.

'Philosophy of 'Theism,' Ward's, 249, 25 I.

Physics, 498, 519.

Physiological aspects of consciousness, 370 . determinism, 402, 4r6. selection, r94.

Plato, 40, 472, 5 I5.

Plumptre, C. E., causation and, 422.

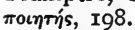

Politics, 463 .

Polytheism, 26, 27, 49, 25 I.

Porter, Dr Noah, 90.

Positivism, 73, ro9, 221, 346.

Post-Kantianism, I49, I62, 223.

Prastabilirte Harmonie, 205.

Prayer, 455, 46.5, 492, 493 .

Pre-Christian religion, 463

Pre-historic religion, 49, 53, 58.

Primitive datum of consciousness, 382 . naturism, 29. religion, $47,50,55$.

' Principles of Psychology,' Spencer's, 377, 402, 404.

Progress, Comte on, 499.

Goethe on, 73.

Hegel on, 499, 500, 50r.

historical, 496, 502, 504, 505 .

law of, r92, 360, 393, 456, 500, 504 .

Progressive life, the, 34r, 39r, 397, 509, $5 \mathrm{II}, 5 \mathrm{I}_{3}, 5 \mathrm{I} 6,5 \mathrm{I} 7$.

Progressiveness of Christianity, 77. of Natural Religion, 6 .

of Theism, I, 212, 39r, 393.

of the universe, II2, I8r, 2 I3. $^{2}$

Progressus ad infinitum, 39r.

Progressus in infinitum, $39 \mathrm{r}$.

" Prometheus Unbound," Shelley's, I I I.

Proofs, theistic, 88, I14, I 16-II9, I21, 122.
Propitiation, idea of, 479 .

'Proslogion,' Anselm's, 217.

Protoplasm, I94, 205.

Providence, 447, 456, 488, 493, 497, 500, 504, 506, 525 .

Psychical, the, 34I, 359, 36r, 370, 37 r, 374, 437,5 r5:

Psychological aspects of consciousness, 287 . basis of things spiritual, $\mathbf{I}_{4} 8,385,386$. of nature, 205 .

Psychology, 35, 386, 415, 416, 420, 421 . character and, 420, $42 \mathrm{r}$.

comparative, 339 .

Cousin's, 356 .

empirical, 5 I I.

freedom and, 4I5, 4I6.

genetic, 354 .

Höffding's, 369.

monistic, 367-37 r.

Prof. James on, 362-364.

rational, $385,5 \mathrm{Ir}$.

Ribot's, 368 .

scientific, $3^{67}, 3^{84}, 3^{85}$.

Spencer's, 373, 377, $3^{82}$.

Sully's, 42r.

Psychosis, 409.

"Purgatorio," 376.

Pusey, Dr, 500.

Pyrrhonism, 57.

Quatrefages, 54 .

Race guilt, 46r, 462, 464, 465, 470 .

Ranke, 501 .

Ratiocination, $\mathbf{1} 6$.

Rationalism, 99, Ir4, Ir6, I49, I50, 242, 278, 343.

Rauwenhoff, Prof., of Holland, 79, 245.

Realism, 8o, 103, 306, 315, 349, 37 I, 48I. Lotze's, ro3.

scientific, 80, 306, 3I5, 37 r.

Reality, basal form of, 224, 28I, 303 .

Reason, absolute, 334, 335, 337, 347 .

authority and, 345 .

Christianity and, 350 .

conscience and, 253.

constructive, 336 .

creative, 334 .

dynamic, 505 .

functions of, 334 .

immanent, $7 \mathrm{I}, 336,347$.

interpretative, 336 .

law and, 337.

nature and, 335 .

practical, 259, 337, $33^{8}$.

pure, $33^{8}$.

real and concrete, 337 .

religion and, $347,349,350$.

science and, 339-34r, 345 .

speculative, $145,342,343,345,347$, 349, 350.

spiritual, $340,342,348$.

supreme, $334,344,345$.

theoretic, $4,342-345$. 
Reason, ultimate, $333,335,336,343-345$. universality of, $12,337,342,347$.

Redemption, 385, 459-46I, 464-47 I, 473, $474,479$.

Jesus and, 46o, 463, 468, 47I, 473, 478.

philosophy of, 470 .

religion of, 465 .

Rée, Dr Paul, 428-430, 432.

Reign of Law, r3, 44I-444, 446, 447, 454, $456,457$.

Relativity, Ior, I38, 316, 320, 404 .

Religion, essence of, $30,32,35,36,40,43$, 44.

Hegel on, 30.

history of, 21, 69, 503 .

morality and, 62, 254 .

nature of, $32,35-37,40,44,45$.

of nature, $23-25,28,29,40,43$.

of redemption, 465 .

origin of, $48,53,57,62,66-68$.

permanence of, $69-71,73,74,76,78$.

'Religion of the Future,' Hartmann's, 70.

'Religion within the Limits of Pure Reason,' Kant's, 247, 45I.

' Religione dell' Avvenire,' Mamiani's, 237.

'Religious Aspect of Philosophy,' Royce's, I88, 346.

Renan, 499, 513.

Renouvier, 403, 404, 414.

Repentance, 429, 454, 463, 466.

'Republic of God,' Dr Mulford's, 392, 514.

Responsibility, moral, 4I9, 422, 430, 432, 466.

Retributive justice, 258,525 .

Revealed theology, natural and, 22.

Revelation, 468, 47 I, 488-490, 508.

Reversionary types, 504 .

Réville, 52, 54, 79, 525 .

Ribot, psychology of, 368, 404.

Riehl, causality and, I62, I63. freedom and, 432-434.

law and, 442.

responsibility and, 434 .

Right, idea of, 453 .

Rights, Fichte on science of, 443 .

Ritschl, 4, 2I, 79, 220, 22I, 292, 349, 396, 470.

Ritschlianism, natural theology and, 4, 2 I. sin and, criticism of, 470 .

\section{Ritual, 77.}

Romanes, 98, I46, I64, 194, 210, 369, 413.

Roskoff, 54, 55.

Rosmini, I32, 235, 236.

Rothe, 79, I38, 288, 289, 4I5, 473. love Divine and, III.

matter and, I04.

ontological proof and, 228. personality and, 288, 289 . religious consciousness and, $3 \mathrm{I}$.

Rousseau, I $30,339$.

Royal Society of Edinburgh, I94, 340, 484 .

Royce, Prof. Josiah, 79, 321, 4I3. causality and, $\mathbf{6} 6 \mathbf{r}$.
Royce, Prof. Josiah, human individuality and, 390 .

idealism of, criticism of, 346 .

teleology and, I88, г9r.

Sacrifice, 470, 473-475, 478 . Jesus and, $472-475,477,478$.

Saisset, M., 233, 308 .

Sartorius, 289 .

Scepticism, I0, I2, 249, 490.

Schauen, 124.

Schein, 303.

Schelling, 79, I35, I79, 307, 315, 343, 412, $427,499$.

freedom and, criticism of, $4 \mathrm{I2}, 426$.

Schenkel, IO4, 243.

Schérer, Edmond, 202, 23I.

Schiller, 33, 64, 72, I I0, I7 I, I8I, 323, 348, 420, 498, 499 .

Schiller, Prof. F. C. S., II2, 403.

Schlegel, 499.

Schleiermacher, 3I, 48, 72, 79, 286, 292, 3I5, $3^{8} 5,473$.

Schöberlein, 444.

Scholasticism of theistic philosophy, 2 .

Scholten, 225.

Schopenhauer, II9, I34, 229, 468, 475, 485 . Determinism and, $4 \mathrm{I} 2,427$.

religion and, 36 .

Unconscious Will of, 272.

Schranken, 283.

Schutzwehr, 220.

Schwarz, Karl, 50I.

Schweizer, A., 70.

Science, aim of, 484,486 .

conscience of, 252,256 .

disenchantments of, 482,483 .

freedom and, 399.

immortality and, 5Io, 5II, 5I $3,5^{\mathrm{I}} 5$, $52 \mathrm{I}$.

personality and, 366 .

theistic philosophy and, 74, 75, 208.

'Science of Rights, 'Fichte's, 443.

Scriptures, the, 388 .

Secrétan, M., 495.

Seeley, Io9.

Selbstziel, 275.

Selbstzweck, 275.

Self, the, $354,357,362,365,366,368,372$ $374,390,424$.

-activity, 258, 270, 320, 34I, 354, 36r, 435 .

-authentication, 388 .

-communication, 304 .

-consciousness, 5I, 59, 9I, I64, 269, $283,342,354,35^{8}, 360,36 \mathrm{r}, 365,374$, $379,380,386,3^{88}, 3^{89}, 426,433$.

-consciousness, Eternal, 246, 392.

-deification, 450.

-determination, 270, 283, 326, 354, 389, $401,4 r_{4}, 424,426$.

-evolution, 93.

-existence, 9I, I67, 280.

-identity, 393 . 
Self-knowledge, 327 .

-limitation, 315, 326.

-objectification, 269.

-possession, 327.

-realisation, $328,378,395,407$.

-recognition, 378 .

-redemption, 46r.

-revelation of God, 3I, 38, 50, 124, 304, 460.

-sacrifice, 468, 474, 475 .

-surrender, 387.

Semitic conception, 65 .

Sengler, 282.

Sensationalism, 99,380 .

Sense-perception, 56.

Seth, Prof. Andrew, 79, 90, 345, 393, 403. personality and, 295,393 .

Seth, Prof. James, 304, 403.

Seydel, 79, 400.

Shakespeare, 134 .

Shelley, xrx, 318.

Sheol, 278.

Sidgwick, Prof., 4r7, 4r9, 434, 449.

Siebeck, 79, 400.

Siloa, 8x.

Simmel, 437.

Sin, 69, 439, 459, 46r, 462 .

pantheism and, $29,461,462$.

ravages of, $69,462,464$.

reality of, $459,46 \mathrm{x}, 462,464$.

religious development and, 69, 464, 470 .

Sinnenwesen, 246, 424 .

Sittlichkeit, 445.

Smith, Prof. H. B., go.

Smith, Prof. Robertson, $5 \mathrm{r}$.

Socialism, 73, 447.

Sociological aspects, 393,439 . manuals, I2.

Sociology, Spencer's, 47.

Solidarity, 452.

Solipsism, 374 .

Son of Man, 396.

Soul, the, 359, 360, 366-369, 494, 5II, 512, 5 I4, 5I5.

F. W. Newman on the, $1 x_{5}, 460$.

Space, 3ro, 320-323, 482.

Kant on, 322,323

'Spekulative Theologie,' by Gloatz, 503.

Spencer, 95, 122, 147, 163, 190, 209, 300, $367,377,3^{8 x}, 402,404,405,45 x, 488$, $506,510$.

causation and, 145 .

psychology of, 377, 402, 404 .

sociology of, 47 .

Spencerianism, super-sensible reality and, 74, 95, 122, 302, 303

Spinoza, r80, 218, 269, 276, 282, 286, 315, 324.

Spirit, characteristics of, ro2, 306.

'Spirit of Love,' Law's, 459.

Spiritualism, 90, 102, 306, 3 $11,364,387$, $388,39 \mathrm{r}, 408,4 \mathrm{rr}, 426,447,47 \mathrm{I}, 488$, $494,495,499,504,505,508,517,526$. Stahl, 523.
Steffens, 305 .

Steigerung, 283, 3 ro.

Sterret, Prof. M., 79, 296.

Stirling, Dr H., 79, 128, 176.

Stöckl, 237.

Stout, G. F., 424

Strauss, 520, 525 .

design and, 215 .

Divine personality and, 290, 326.

fear and, 48 .

life and, 4x.

philosophy and, $\mathbf{r} 33$.

'Study of Religion,' Martineau's, 257, 453.

Subjectivism, II, 12, 43, 96, I00, IOI, I64, I77, 268, 297, 302, 303. 322, 354, 379, 385, $436,469,523$.

Substance, category of, $7,8,103,1 x_{5}, 286$, $324,49 x$. unity of, 366 .

Suffering, ז28-132, $136,137, x_{40}, 200,475$.

Sully, Prof. James, $42 \mathrm{I}$.

Summum bonum, Kant's, 250.

Supernatural, the, $67,76,267$.

natural and, 66.

necessity of the, 66, 267 .

revelation and, $5 \mathrm{I}, 53,67$.

science and, 76,267 .

'Supernatural Religion,' 25.

Supernaturalism, 67, 76, 267 .

Superpersonal, the, 298, 300, 302-304.

Supramanent, God as, 3, 3r3.

Survival, law of, 180, 18I, 193, 194, 254, $457,522$.

Synergy, Comte's, 369 .

Synthesis of apperceptions, 374 . of natural theism, $40,65,324$.

Synthetic philosophy, $\mathrm{r}_{3}$. thought, 40, 324, 342, 347, 406, 499.

Taine, 367, 368, 499 .

Tait, Rev. James, of Montreal, 38,57 .

Tappan, 106.

Teichmüller, 79, 529 .

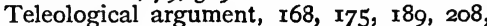
213.

character of Christianity, 70. of the self, 4I.

Teleology, æsthetic, r99. essence of, 197, 20 . unconscious, r98, r99, $2 r_{4}$.

Telepathy, 393.

Tennyson, 26.

'Teodicea,' Rosmini's, 132, 236.

' Teosofia,' 235 .

Thathandlung, 285.

Thätigkeit, 372.

Theism, abstract, 264, 265, 308 . anthropocosmic, $65, \mathbf{2 2 2 .}$

Biblical, 483, 488.

Christian, 238.

cosmic, 273 .

ethical, 243,246, 249, 257, 259, 26r, 263.

Kantian, 245, 247-250, $26 r$. 
Theism, natural, 24, 40 . philosophy of, 103, 109, 246, 271, 374 . progressiveness of, I, 212, 39I, 393. pure, 2, 266, 485 .

rational, 99, II4, I50, 263, 278, 343, 488,492 .

Schellingian, 343 .

science and, 208, 297.

speculative, I04, I4I, 288, 297, 30I.

tenuous, $3^{8}$.

Theistic evolution, $168,178,213,526$.

Theodicy, 132, 138, 236.

Rosmini's, 132, 236.

Theology, 280, 384, 449, 460, 483 . law and, 449 .

Theosophy, 235 .

Thiele, Prof. Günther, 230.

Thiers, history and, 498.

Thomasius, 289.

Thompson, R. A., 238.

Thomson, J. Arthur, on Weissmannism, I94.

Thought, feeling and, 35,44 .

laws of, $348,362-364$.

Prof. James on, 362-364.

substance and, $363,364,366$.

the Absolute and, 102, 224, 268, 347 . will and, 342 .

'Thoughts on Religion,' by Romanes, 146, $x 64$.

'Three Motives and Grounds of Belief,' Fechner's, 53 .

Tiele, $54,57$.

Time, 307, 310, 319, 322, 333 . Kant on, 322, 333 .

Toronto, 28.

Totemism, 49.

Toy, Prof., of Harvard, 64.

Transcendence, 9, 42, 287, 313 . need for, $9,42,3^{\text {I } 3}$. science and, 25.

Transcendental ego, 373 .

Transformation of species, 194.

Trendelenburg, 79, 90, 163, I78, 205, 4I4, 496.

causal relation and, 163 .

philosophical permanence and, 78 . philosophy of design and, 182, I9I.

Tribal religion, 54-56, $5^{8}$.

Trieb, 199.

Triune God, 30I, 324 .

Tulloch, Principal, 238.

Tylor, animism of, 47 .

Tyndall, Prof., 98.

'Types of Ethical Theory,' Martineau's, 448.

Überwundener Standpunkt, $\mathrm{x}$.

Ulrici, IO, 90, I05, II9, 150, 227, 529. on Personality of God, 29I. on the self, 393.

Ultimate Ground, $3^{82}$.

Reality, 28I, 303, 305, 382, 444, 445, $454,48 \mathrm{I}$.

Ultra-personal, the, zor.
Umfassende Macht, 205.

Unconditioned, the, 96, 230, 239.

Unconscious, the, 198, 272, 273, 292.

Unendliches persönliches Gute, 289 .

Uniformity of nature, $186,442,483$.

Unity, psychic, 370, 37r, 374 .

of consciousness, $37 \mathrm{I}$.

of God, 32, 33, 9I, 94, 265.

of law, 483 .

of nature, I03, 489 .

of self or ego, 374,375 .

of substance, 366 .

of truth, $334,335,338$.

of universe, $33,325,489$.

Universal, the, 12, 56, 57, 105, 278, 321, 337 . $342,347,426,44 \mathrm{I}$.

Universality of religion, $12,56,57$.

Universe, theory of the, 149, $157,213,366$, $489,530$.

unfinished, II2, 213, 530 .

Unknowable, the, 300, 303 .

Unumgänglich, $45 \mathrm{I}$.

Upton, Prof., 90, 365, 403, 4II, 422.

Urgrund, II, 6I, 270, 302 .

causal, I43, I44, I56.

metaphysical, 35 .

Urgrund aller Realität, 230.

Ursache, 153, 283, 418.

Ursprung, 153.

Urspriingliches Gottesberwusstsein, 59.

Urzuesen, 274.

Utilitarianism, 187 .

Vacherot, criticism of, 233,234 .

Variations, origination of, 180, I88, 193.

Vatke, 308.

Vedas, 29.

Veitch, Prof. John, 3 rg.

Velleity, 406.

Vergleichbarkeit, 373.

Vernunft, $33^{8}$.

Vicariousness, $473,474$.

'Vocation of Man,' Fichte's, 283.

' Vocation of the Scholar,' 5 I6.

Vogt, 5 ro.

Volition, power of, $148,225,407$. purity of, 4 Io.

Volitional, the, 30, 44, I48, 40I, 404.

Volkelt, 163 .

Volkmann, 42I.

Volo ergo sum, 23 I.

Voraussetzung, 248.

Vorgang, 287 .

Vorrede, $45 \mathrm{I}$.

Vorstellung, 279, 308.

'Vorträge und Abhandlungen,' Zeller's, $372,4 \mathrm{r} 8$.

Voysey, Rev. C., 475.

Waitz, 58.

Wallace on Darwin, 193, 341. on natural selection, 193 .

Wallace, Prof. William, 79 .

“'Wallenstein," Schiller's, 420. 


\section{INDEX.}

Ward, Prof. William G., 25I, 407, 408, 437.

Ward, Wilfrid, 16.

Weisse, 104, 207, 226, 288. on the ontological argument, 226.

Weissmannism, 194 .

Welch, Dr, 90 .

Welt, 380 .

Weltanschauung, 74, 397.

Weltgeist, 288.

Weltschmerz, 13.

Werden, 5 10

Wesen, 286, 309, 5 I9.

Krause on, 286.

Wesen an sich, 424.

Whittier, 140 .

Will, the human, $13,399,401,402,406-410$, 4 I 3,4 I $5,42 \mathrm{I}, 423,426-428,433,436,439$, 440.

Willkiir, 500.

Windelband, roo.

Wirth, 282.
Witness of history, 464, 502 .

'Witnesses to the Unseen, and other Essays,' I6.

Wolff, I49, I50, 218.

Wordsworth, $45^{2}$.

World-consciousness, $380,38 \mathrm{r}$.

World-Ground, 272, 286, 324, 327, 522. as related and revealed, $3,315,320$.

impersonal and unconscious, 184, 272.

'World of Prayer,' Bishop Monrad's, 493.

Wundt, $148,163,367$.

Wuttke, 439, 45I. on conscience, $25 \mathrm{r}$.

Yale, 294.

Young, Dr John, 456.

Zeller, Edward, 79, 120, 305, 372, 403, 418, 442 , 50 .

Zermalmen, $\mathbf{1 2 0}$.

Zeus, 4I3.

Zweckmässigkeit, 206.

THE END. 



\section{THE PROGRESSIVENESS OF MODERN CHRISTIAN THOUGHT.}

By Rev. JAMES LINDSAY, M.A., B.D.,

B.Sc., F.R.S.E., F.G.S.

Crown 8vo, 6s.

Professor Marcus Dods in the 'Expositor' :-“"Mr Lindsay has executed a supremely difficult and delicate task with marked ability and judgment. His aim has been to define and to justify the advance made during recent years in theology........An impossible task to any but a theologian of solid learning, masculine grasp, and fine judgment. Mr Lindsay has proved himself to be such a theologian, and at one step has placed himself in the front rank."

The Rev. Dr Matheson:- "This is one of the best and the most welltimed books that have appeared for many years.......The work of a fresh, vigorous mind, trained by elaborate culture, and chastened by Christian reverence."

Rev. Prinicpal Stewart:- "The idea of the book is excellent and opportune. The treatment is everywhere thoughtful and often highly suggestive. You evince a quite enviable acquaintance with the most recent literature."

The Rev. Professor Flint :- "The subject is most important, and your treatment of it seems to me to be in every way admirable."

The Westminster Review:- "We welcome such a work as Mr Lindsay's as a marked advance on the crude and irrational dogmatism of the popular theology."

The Glasgow Herald:- "His book is the best we have read for a long time."

The Scotsman :- "He is a friend of progress, and defends and defines it, but he is really a cautious and careful thinker, who has read widely on the subject of which he treats.......An interesting contribution to a subject of much importance; and it is treated with such ability and learning, as to make it worthy of the study of the class for whom it has been specially written."

The Expository Times :- "It is a great work."

The Literary World:- "The author is not only thoroughly familiar with the theological thought and literature of the age, but has great powers of synthesis and exposition.......Mr Lindsay's masterly and prescient pages."

Professor Warfield, of Princeton, in 'Presbyterian and Reformed Review':"Mr Lindsay excellently outlines the implications and laws of this progress. . . . Mr Lindsay's book is an excellent statement."

Professor Egbert C. Smyth in the 'Andover Review':- "We are confident that any one who desires a suggestive and helpful introduction to what is highest and best in current theology, can find such a guide in this book."

Theologische Literaturzeitung:- "Ist er, wie überhaupt in bewunderswerther Weise mit der Weltliteratur vertraut, so auch bis auf ihre jüngsten Erzeugnisse in der deutschen Theologie zu Haus."

Deutsche Litcraturzeitung:- "Eine namentlich interessante Schrift. Erfreulich......weil es in klarer, lichtvoller Darstellung den gewaltigen Fortschritt zeigt......erfreulich und wohl für die Lage der englischen Theologie."

WILLIAM BLACKWOOD \& SONS, EDINBURGH AND LoNdoN. 


\title{
ESSAYS, LITERARY AND PHILOSOPHICAL.
}

\author{
By Rev. JAMES LINDSAY, M.A., B.D.,
}

B.Sc., F.R.S.E., F.G.S.

Crown 8vo, 3s. 6d.

Rev. Professor Banks :- "Excellent specimens of appreciative criticism. Its high thinking braces like a tonic."

Professor Edward Dowden:- "I was especially interested in your way of looking at great literature-that interior way which seeks after and finds the mind of a writer behind his art. . . . I rejoiced to see an English critic appreciating the Second Part of 'Faust' at its true worth. . . . In this Essay, and in each of the others, what strikes me most is the faithful submission of the writer's mind to receive a true and full impression, and then the active thought which becomes critical and interpreting."

Rev. Dr George Matheson:- "I have no words to express my admiration of your book. I can say in all sincerity that it has turned my mind into a new chamnel, on whose waters play the beams of morning light."

Rev. Professor Charteris:- "I do not know when I had greater pleasure or felt a stronger stimulus than your Essays brought me......A bright, bracing book, as vivid as it is judicial."

Rev. Dr Hugh Macmillan:- "The book is very charming-full of thought and suggestion-finely conceived and freshly and tersely expressed."

Seotsman:- "Written with a fine breadth of learning."

Glasgow Herald:- "Suggestive, stimulating, and in the best sense original Essays."

Quebec Morning Chronicle:-“"His taste, critical faculty, and admirable judgment, are never at fault, and to these may be added the possession of a pure and convincing style.......Mr Lindsay's literary manner is very superior.

......The brilliant paper on 'Faust' cannot be too highly praised."

Life and Work:-"All of these are subjects which demand the handling of a master, and Mr Lindsay never disappoints."

The Literary World:- "On every page they afford their reader the satisfaction of contact with a full mind, and withal a clear one."

Dundee Advertiser :- "These Essays reveal close study, critical acumen, scholarly appreciation, and a very perfect knowledge of relative criticism."

Aberdeen Free Press :- "We heartily commend his thoughtful and scholarly appreciations."

Ayr Observer:- "The Essays are certainly original.......Worthy of the author of 'The Progressiveness of Modern Christian Thought.' Much higher praise we could scarcely give." 


\section{Catalogue}

$$
\text { of }
$$

Messrs Blackwood \& Sons'

$$
\text { Publications }
$$




\section{PHILOSOPHIGAL CLASSICS FOR ENGLISH READERS.}

EDITED bY WILLIAM KNIGHT, LL.D.,

Professor of Moral Philosophy in the University of St Andrews.

In crown 8vo Volumes, with Portraits, price 3s. 6d.

Contents of the Series.

Descartes, by Professor Mahaffy, Dublin.-Butler, by Rev. W. Lucas Collins, M.A.-Berkeley, by Professor Campbell Fraser.-Fichte, by Professor Adamson, Glasgow. - KANr, by Professor Wallace, Oxford.-Hamilton, by Professor Veitch, Glasgow.-HeaEL, by the Master of Balliol. -Leibiz, by J. Theodore Merz. - Vico, by Professor Flint, Edinburgh.-HoBBEs, by Professor Croom Robertson. - HUME, by the Editor. - SpINoza, by the Very Rev. Principal Caird, Glasgow.-Bacon: Part I. The Life, by Professor Nichol.BAcon: Part II. Philosophy, by the same Author.-Locke, by Professor Campbell Fraser.

\section{FOREIGN CLASSIGS FOR ENGLISH READERS.}

\section{Edited by Mrs OLIPHANT.}

In crown $8 \mathrm{vo}, 2 \mathrm{~s}$. $6 \mathrm{~d}$.

Contents of the Series.

Dante, by the Editor. - Voltaire, by Editor. - Corneille and RAcine, by General Sir E. B. Hamley, K.C.B. -Pascal, by Principal Tulloch. - PetRARCH, by Henry Reeve, C.B.-Gozthe, by A. Hayward, Q.C.-Molière, by the Editor and F. Tarver, M.A.-Montaigne, by Rev.. W. L. Collins, M.A.-Rabelais, by Sir Waiter Besant. - Calderon, by E. J. Hasell. - SAINT Simon, by Clifton W. Collins, M.A. - Cervantes, by the Henry M. Trollope. - MADAME DE SÉvigné, by Miss Thackeray.-LA FoNTAINe, AND OTHER French FABULISTs, by Rev. W. Lucas Collins, M.A.-SchILLER, by James Sime, M.A., Author of 'Lessing, his Life and Writings.'-TAsso, by E. J. Hasell. - Roussead, by Henry Grey Graham. - ALFRED DE MUSSET, by C. F. Oliphant.

\section{ANCIENT CLASSICS FOR ENGLISH READERS.}

\section{Edited bY the Rev. W. LUCAS COLLINS, M.A.}

Complete in 28 Vols. crown 8 vo, cloth, price 2 s. 6 d. each. And may also be had in 14 Volumes, strongly and neatly bound, with calf or vellum back, £3, 10s.

\section{Contents of the Series.}

Homer: The Iliad, by the Editor.HoMer: THE ODYSSEY, by the Editor.Herodotus, by George C. Swayne, M.A.X LL.D. - Euripides, by W. B. Donne.Aristophanes, by the Editor.-Plato, by Clifton W. Collins, M.A.-Lucian, by the Editor. - Eschylus, by the Right Rev. the Bishop of Colombo. - SOPHOCLEs, by Clifton W. Collins, M.A. - Hesiod AND Theognis, by the Rev. J. Davies, M.A.Greek ANTHology, by Lord Neaves.VIRGIL, by the Editor.-Horace, by Sir Theodore Martin, K.C.B. - JuvEnaL, by Edward Walford, M.A. - PLAUTUS AND
Terence, by the Editor.-The CommenTARIES OF CESAR, by Anthony Trollope. -Tacitus, by W. B. Donne.-Cicero, by the Editor. - Pliny's LETTERs, by the Rev. Alfred Church, M.A., and the Rev. W. J. Brodribb, M.A. - LIVX, by the Editor.-Ovid, by the Rev. A. Church, M.A. - Catullus, Tibullus, and ProPertius, by the Rev. Jas. Davies, M.A. - Demosthenes, by the Rev. W. J. Brodribb, M.A.-ARIstotle, by Sir Alex-. ander Grant, Bart., LL.D.-THUCYDIDES, by the Editor. - LuCRETIUs, by W. H. Mallock, M.A.-Pindar, by the Rev. F. D. Morice, M.A.

Saturday Review.- "It is difficult to estimate too highly the value of such a series as this in giving 'English readers' an insight, exact as far as it goes, into those olden times which are so remote, and yet to many of us so close." 


\section{A T A L O G U E}

OF

\section{MESSRS BLACKWOOD \& SONS'}

\section{$P U B L I C A T I O N S$.}

\section{ALISON.}

History of Europe. By Sir Archibald Alison, Bart., D.C.L.

1. From the Commencement of the French Revolution to the Battle of Waterloo.

Library Edition, 14 vols., with Portraits. Demy 8vo, £10, 10s.

ANOTHER EDITION, in 20 vols. crown $8 \mathrm{vo}, £ 6$.

People's Edition, 13 vols. crown 8vo, £2, 11 s.

2. Continuation to the Accession of Louis Napoleon.

LibRARY Edition, 8 vols. 8vo, $£ 6,7 \mathrm{~s} .6$ d.

PeOPle's Edition, 8 vols. crown 8vo, 34s.

Epitome of Alison's History of Europe. Thirtieth Thousand, 7s. 6d.

Atlas to Alison's History of Europe. By A. Keith Johnston. LibraRy Edition, demy 4to, £3, 3s.

People's Edition, 31s. 6d.

Life of John Duke of Marlborough. With some Account of his Contemporaries, and of the War of the Succession. Third Edition. 2 vols. 8vo. Portraits and Maps, 30s.

Essays: Historical, Political, and Miscellaneous. 3 vols. demy $8 v 0,45$ s.

ACROSS FRANCE IN A CARAVAN : BeING some Account OF A JOURNEY FROM BORDEAUX TO GENOA IN THE "EsCARGOT," taken in the Winter 1889-90. By the Author of 'A Day of my Life at Eton.' With fifty Illustrations by John Wallace, after Sketches by the Author, and a Map. Cheap Edition, demy 8vo, 7s. 6 d.

ACTA SANCTORUM HIBERNIÆ; Ex Codice Salmanticensi. Nunc primum integre edita opera CAROLI DE SMEDT et JOSEPHI DE BACKER, e Soc. Jesu, Hagiographorum Bollandianorum; Auctore et Sumptus Largiente Joanne Patricio Marchione Bothae. In One handsome 4to Volume, bound in half roxburghe, $£ 2,2 \mathrm{~s}$.; in paper cover, $31 \mathrm{~s}$. $6 \mathrm{~d}$.

ADOLPHUS. Some Memories of Paris. By F. Adolphos. Crown 8vo, 6s.

AIKMAN.

Manures and the Principles of Manuring. By C. M. Arkman, D.Sc., F.R.S.E., \&c., Professor of Chemistry, Glasgow Veterinary College; Examiner in Chemistry, University of Glasgow, \&c. Crown 8vo, 6s. 6d.

Farmyard Manure: Its Nature, Composition, and Treatment. Crown 8vo, 1s. 6d.

AIRD. Poetical Works of Thomas Aird. Fifth Edition, with Memoir of the Author by the Rev. Jardine Waldace, and Portrait. Crown Svo, 7s. $6 \mathrm{~d}$. 


\section{ALLARDYCE.}

The City of Sunshine. By Alexander Allardyce, Author of 'Earlscourt,' \&c. New Edition. Crown 8vo, 6s.

Balmoral : A Romance of the Queen's Country. New Edition. Crown 8vo, 6s.

ALMOND. Sermons by a Lay Head-master. By HeLY HбтcHinson Almond, M.A. Oxon., Head-Master of Loretto School. Crown 8vo, 5s.

ANCIENT CLASSICS FOR ENGLISH READERS. Edited by Rev. W. Lucas Collins, M.A. Price 2s. 6d. each. For List of Vols., see p. 2.

ANDERSON. Daniel in the Critics' Den. A Reply to Dean Farrar's 'Book of Daniel.' By RoBerT ANDERsoN, LL.D., Barrister-at-Law, Assistant Commissioner of Police of the Metropolis; Author of 'The Coming Prince,' 'Human Destiny,' \&c. Post 8vo, 4s. 6d.

AYTOUN.

Lays of the Scottish Cavaliers, and other Poems. By W. Edmondstoune Aytoun, D.C.I., Professor of Rhetoric and Belles-Lettres in the University of Edinburgh. New Edition. Fcap. 8vo, 3s. 6d.

ANOTHER EDITION. Fcap. 8vo, 7s. 6d.

Cheap Edition. is. Cloth, 1s. 3d.

An Illustrated Edition of the Lays of the Scottish Cavaliers. From designs by Sir Nown Paton. Cheaper Edition. Small 4to, 10s. 6d.

Bothwell : a Poem. Third Edition. Fcap., 7s. 6d.

Poems and Ballads of Goethe. Translated by Professor Aytoun and Sir THEOdore Martin, K.C.B. Third Edition. Fcap., 6s.

The Ballads of Scotland. Edited by Professor Axtoun. Fourth Edition. 2 vols. fcap. 8vo, 12s.

Memoir of William E. Aytoun, D.C.L. By Sir Theodore MaRTin, K.C.B. With Portrait. Post 8vo, 12s.

\section{BACH.}

On Musical Education and Vocal Culture. By ALBERT B. BACH. Fourth Edition. 8vo, 7s. 6d.

The Principles of Singing. A Practical Guide for Vocalists and Teachers. With Course of Vocal Exercises. Second Edition. With Portrait of the Author. Crown 8vo, $6 \mathrm{~s}$.

The Art Ballad : Loewe and Schubert. With Musical fllustrations. With a Portrait of LoEwE. Third Edition. Small 4to, $5 \mathrm{~s}$.

BEDFORD \& COLLINS. Annals of the Free Foresters, from 1856 to the Present Day. By W. K. R. BeDFord, W. E. W. Collins, and other Contributors. With 55 Portraits and 59 other Illustrations. Demy 8vo, 21s. net.

BELLAIRS. Gossips with Girls and Maidens, Betrothed and Free. By Lady Bellairs. New Edition. Crown 8vo, 3s. 6d. Cloth, extra gilt edges, $5 \mathrm{~s}$.

BELLESHEIM. History of the Catholic Church of Scotland. From the Introduction of Christianity to the Present Day. By ALPHONS BEL. LESHEIM, D.D., Canon of Aix-la-Chapelle. Translated, with Notes and Additions, by D. Oswald HUNTER Blair, O.S.B., Monk of Fort Augustus. Cheap Edition. Complete in 4 vols. demy 8vo, with Maps. Price 21s. net.

BENTINCK. Racing Life of Lord George Cavendish Bentinck, M.P., and other Reminiscences. By JoHs KENT, Private Trainer to the Good. wood Stable. Edited by the Hon. Francis LAwLEx. With Twenty-three full. page Plates, and Facsimile Letter. Third Edition. Demy 8vo, 25s. 
BEVERIDGE.

Culross and Tulliallan; or, Perthshire on Forth. Its History and Antiquities. With Elucidations of Scottish Life and Character from the Burgh and Kirk-Session Records of that District. By DAvid BEvERIDGF. 2 vols. 8vo, with Illustrations, $42 \mathrm{~s}$.

Between the Ochils and the Forth; or, From Stirling Bridge to Aberdour. Crown 8vo, 6s.

BICKERDYKE. A Banished Beauty. By JoHs BICKERDYKe, Author of 'Days in Thule, with Rod, Gun, and Camera,' 'The Book of the All. Round Angler,' 'Curiosities of Ale and Beer,' \&c. With Illustrations. Crown $8 \mathrm{vo}, 6 \mathrm{~s}$.

\section{BIRCH.}

Examples of Stables, Hunting-Boxes, Kennels, Racing Establishments, \&c. By JoHs BIRCH, Architect, Author of 'Country Architecture,' \&c. With 30 Plates. Royal 8vo, 7s.

Examples of Labourers' Cottages, \&c. With Plans for Improving the Dwellings of the Poor in Large Towns. With 34 Plates. Royal 8vo, 7s.

Picturesque Lodges. A Series of Designs for Gate Lodges, Park Entrances, Keepers', Gardeners', Bailiff's', Grooms', Upper and Under Servants' Lodges, and other Rural Residences. With 16 Plates. 4to, 12s. 6d.

BLACK. Heligoland and the Islands of the North Sea. By William George Black. Crown 8vo, 4s.

\section{BLACKIE.}

Lays and Legends of Ancient Greece. By JoHN STUART BLACKIE, Emeritus Professor of Greek in the University of Edinburgh. Second Edition. Fcap. 8vo, $5 \mathrm{~s}$.

The Wisdom of Goethe. Fcap. 8vo. Cloth, extra gilt, 6s.

Scottish Song: Its Wealth, Wisdom, and Social Significance. Crown 8vo. With Music. 7s. 6d.

A Song of Heroes. Crown 8vo, 6s.

John Stuart Blackie: A Biography. By ANNa M. Stoddart. With 3 Plates. Third Edition. 2 vols. demy 8vo, 21s.

Popular Eidion. With Portrait. Crown 8vo, $6 \mathrm{~s}$.

BLACKMORE. The Maid of Sker. By R. D. BLACKMore, Author of 'Lorna Doone,' \&c. New Edition. Crown 8vo, 6s. Cheaper Edition. Crown 8vo, 3s. 6d.

BLACKWOOD.

Blackwood's Magazine, from Commencement in 1817 to December 1896. Nos. 1 to 974 , forming 160 Volumes.

Index to Blackwood's Magazine. Vols. 1 to 50 . 8vo, $15 \mathrm{~s}$.

Tales from Blackwood. First Series. Price One Shilling each, in Paper Cover. Sold separately at all Railway Bookstalls.

They may also be had bound in 12 vols., cloth, 18s. Half calf, richly gilt, $30 \mathrm{~s}$. Or the 12 vols. in 6, roxburghe, 21s. Half red morocco, 28s.

Tales from Blackwood. Second Series. Complete in Twentyfour Shilling Parts. Handsomely bound in 12 vols., cloth, $30 \mathrm{~s}$. In leather back, roxburghe style, 37s. $6 \mathrm{~d}$. Half calf, gilt, $52 \mathrm{~s} .6 \mathrm{~d}$. Half morocco, $55 \mathrm{~s}$.

Tales from Blackwood. Third Series. Complete in Twelve Shilling Parts. Handsomely bound in 6 vols., cloth, 15s.; and in 12 vols., cloth, 18s. The 6 vols. in roxburghe, $21 \mathrm{~s}$. Half calf, $25 \mathrm{~s}$. Half morocco, $28 \mathrm{~s}$.

Travel, Adventure, and Sport. From 'Blackwood's Magazine.' Uniform with 'Tales from Blackwood.' In Twelve Parts, each price 1s. Hand. somely bound in 6 vols., cloth, 15s. And in half calf, $25 \mathrm{~s}$. 
BLACKWOOD.

New Educational Series. See separate Catalogue.

New Uniform Series of Novels (Copyright).

Crown 8vo, cloth. Price 3s. 6d. each. Now ready:-

The MaId of Sker. By R. D. Blackmore. Reata. By E. D. Gerard.

\begin{tabular}{l|l} 
Wenderholme. By P. G. Hamerton. & Beggar my Neighbour. By the Same. \\
The Story of Margrédel. By D. Storrar & The Waters of Hercules. By the Same
\end{tabular} Meldrum.

Miss Marjoribanks. By Mrs Oliphant.

The Perpetual Curate, and The Rector. By the Same.

Salem Chapel, and The Doctor's Family. By the Same.

A Sensitive Plant. By E. D. Gerard.

LADY LEE's Widowhood. By General Sir E. B. Hamley.

Katie Stewart, and other Stories. By Mrs Oliphant.

Valentine and his Brother. By the Same.

Sons and Daughters. By the Same.

MARMorne. By P. G. Hamerton.

Standard Novels. Uniform in size and binding. Each complete in one Volume.

FLORIN SERIES, Illustrated Boards. Bound in Cloth, 2s. 6d.

Tom Cringle's Log. By Michael Scott.

The Cruise of the Midar. By the Same.

Cyril Thornton. By Captain Hamilton.

AnNals of the Parish. By John Galt.

The Provost, \&c. By the Same.

Sir ANdrew Wylie. By the Same.

The Entail. By the Same.

Miss Molly. By Beatrice May Butt.

Reginald Dalton. By J. G. Lockhart.

Fair to See. By L. W. M. Lockhart.

Mine Is Thine. By the Same.

Doubles AND Quits. By the Same.

Altiora Peto. By Laurence Oliphant.

PicCadilly. By the Same. With Illustra. tions.

LADY BABY. By D. Gerard.

The Blacksmith of Voz. By Paul Cushing.

The Dilema. By the Author of 'The Battle of Dorking.'

My Trivial Life and Misfortune. By A Plain Woman.

Poor Nellie. By the Same.

\section{SHILLING SERIES, Illustrated Cover. Bound in Cloth, 1s. 6d.}

The Rector, and The Doctor's Family. Sir Frizzle Pumpkin, Nights at Mess, By Mrs Oliphant.

The Life of Mansie Wauch. By D. M. The Subaltern. Moir.

Mu F. Hardman.

Pen Owen. By Dean Hook.

ADAM Blair. By J. G. Lockhart.

LADY LEE's WIDOW HoOD. By General Sir E. B. Hamley.

SALEM Chapel. By Mrs Oliphant.

The Perpetual Curate. By the Same.

Miss Marjoribanks. By the Same.

Joнn: A Love Story. By the Same.

BON GAULTIER'S BOOK OF BALLADS. Fifteenth Edition. With Illustrations by Doyle, Leech, and Crowquill. Feap. 8vo, 5s.

BRADDON. Thirty Years of Shikar. By Sir Edward Braddon, K.C.M.G. With Illustrations by G. D. Giles, and Map of Oudh Forest Tracts and Nepal Terai. Demy 8 vo, $18 \mathrm{~s}$.

BROUGHAM. Memoirs of the Life and Times of Henry Lord Brougham. Written by Himself. 3 vols. $8 \mathrm{vo}, £ 2,8 \mathrm{~s}$. The Volumes are sold separately, price $16 \mathrm{~s}$. each.

BROWN. The Forester: A Practical Treatise. on the Planting and Tending of Forest-trees and the General Management of Woodlands. By James Brown, LL.D. Sixth Edition, Enlarged. Edited by JoHN NisBET, D.CEc., Author of 'British Forest Trees,' \&c. In 2 vols. royal 8vo, with 350 Illustra. tions, $42 \mathrm{~s}$. net.

BROWN. Stray Sport. By J. Moray Brown, Author of 'Shikar Sketches,' 'Powder, Spur, and Spear,' 'The Days when we went Hog-Hunting.' 2 vols. post $8 \mathrm{vo}$, with Fifty Illustrations, $21 \mathrm{~s}$.

BROWN. A Manual of Botany, Anatomical and Physiological. For the Use of Students. By Robert Brows, M.A., Ph.D. Crown 8vo, with numerous Illustrations, $12 \mathrm{~s}$. $6 \mathrm{~d}$ 
BRUCE.

In Clover and Heather. Poems by Wallace Brdce. New and Enlarged Edition. Crown 8vo, 3s. 6d.

$A$ limited number of Copies of the First Edition, on large hand-made paper, 12s. 6d.

Here's a Hand. Addresses and Poems. Crown 8vo, 5s. Large Paper Edition, limited to 100 copies, price 21s.

BUCHAN. Introductory Text-Book of Meteorology. By AlexANDER BUCHAN, LL.D., F.R.S.E., Secretary of the Scottish Meteorological Society, \&c. New Edition. Crown 8vo, with Coloured Charts and Engravings.

BURBIDGE.

[In preparation.

Domestic Floriculture, Window Gardening, and Floral Decorations. Being Practical Directions for the Propagation, Culture, and Arrangement of Plants and Flowers as Domestic Ornaments. By F. W. Burbidge. Second Edition. Crown 8vo, with numerous Illustrations, 7s. $6 \mathrm{~d}$.

Cultivated Plants: Their Propagation and Improvement. Including Natural and Artificial Hybridisation, Raising from Seed, Cuttings, and Layers, Grafting and Budding, as applied to the Families and Genera in Cultivation. Crown 8vo, with numerous Illustrations, 12s. 6d.

BURGESS. The Viking Path: A Tale of the White Christ. By J. J. Haldane Burgess, Author of 'Rasmie's Büddie,' 'Shetland Sketches,' \&c. Crown $8 \mathrm{vo}, 6 \mathrm{~s}$.

BURKE. The Flowering of the Almond Tree, and other Poems. BURROWS. By Christian Burke. Pott 4 to, $5 \mathrm{~s}$.

Commentaries on the History of England, from the Earliest Times to 1865. By Montagu Burrows, Chichele Professor of Modern History in the University of Oxford; Captain R.N.; F.S.A., \&c. ; "Officier de l'Instruction Publique," France. Crown 8vo, 7s. 6d.

The History of the Foreign Policy of Great Britain. Demy $8 \mathrm{vo}, 12 \mathrm{~s}$.

BURTON.

The History of Scotland: From Agricola's Invasion to the Extinction of the last Jacobite Insurrection. By JOHN HILL BuRTON, D.C.L., Historiographer-Royal for Scotland. New and Enlarged Edition, 8 vols., and Index. Crown 8vo, £3, 3s.

History of the British Empire during the Reign of Queen Anne. In 3 vols. 8 vo. $36 \mathrm{~s}$.

The Scot Abroad. Third Edition. Crown 8vo, 10s. 6d.

The Book-Hunter. New Edition. With Portrait. Crown 8vo, 7s. 6d.

BUTCHER. Armenosa of Egypt. A Romance of the Arab Conquest. By the Very Rev. Dean Butcher, D.D., F.S.A., Chaplain at Cairo. Crown $8 v 0,6 \mathrm{~s}$.

BUTE. The Altus of St Columba. With a Prose Paraphrase BUTT. and Notes. In paper cover, 2s. $6 \mathrm{~d}$.

Theatricals : An Interlude. By Beatrice May Butt. Crown 8vo, 6s.

Miss Molly. Cheap Edition, 2s.

Eugenie. Crown 8vo, 6s. 6d.

Elizabeth, and other Sketches. Crown 8vo, 6s.

Delicia. New Edition. Crown 8vo, 2s. 6d.

CAIRD. Sermons. By JoHN CAIRD, D.D., Principal of the University of Glasgow. Seventeenth Thousand. Fcap. 8vo, 5s. 
CALDWELL. Schopenhauer's System in its Philosophical Significance (the Shaw Fellowship Lectures, 1893). By Wrulram CaLdweld, M.A., D.Sc., Professor of Moral and Social Philosophy, Northwestern University, U.S.A. ; formerly Assistant to the Professor of Logic and Metaphysics, Edin., and Examiner in Philosophy in the University of St Andrews. Demy 8vo, 10s. 6d. net.

CALLWELL. The Effect of Maritime Command on Land Campaigns since Waterloo. By Major C. E. CAllweld, R.A. With Plans. Post 8vo, 6s. net.

CAMPBELL. Sermons Preached before the Queen at Balmoral. By the Rev. A. A. Camprell, Minister of Crathie. Published by Command of Her Majesty. Crown 8vo, 4s. 6 d.

CAMPBELL. Records of Argyll. Legends, Traditions, and Recollections of Argyllshire Highlanders, collected chiefly from the Gaelic. With Notes on the Antiquity of the Dress, Clan Colours, or Tartans of the Highlanders. By Lord ARCHIBALd CAMPBExL. Illustrated with Nineteen full-page Etchings. 4 to, printed on hand-made paper, $£ 3,3$ s.

CANTON. A Lost Epic, and other Poems. By William Canton. Crown 8vo, $5 \mathrm{~s}$.

CARSTAIRS.

Human Nature in Rural India. By R. Carstairs. Crown $8 \mathrm{vo}, 6 \mathrm{~s}$.

British Work in India. Crown 8vo, 6s.

CAUVIN. A Treasury of the English and German Languages. Compiled from the best Authors and Lexicographers in both Languages. By Joseph CAUvin, LL.D. and Ph.D., of the University of Göttingen, \&c. Crown 8 vo, 7s. 6 d.

CHARTERIS. Canonicity ; or, Early Testimonies to the Existence and Use of the Books of the New Testament. Based on Kirchhoffer's 'Quellensammlung.' Edited by A. H. CharTeris, D.D., Professor of Biblical Criticism in the University of Edinburgh. 8vo, 18s.

CHENNELLS. Recollections of an Egyptian Princess. By her English Governess (Miss E. Chennerus). Being a Record of Five Years' Residence at the Court of Ismael Pasha Khédive. Second Edition. With Three Portraits. Post 8vo, 7s. 6d.

CHESNEY. The Dilemma. By General Sir George Chesney, K.C.B., M.P., Author of 'The Battle of Dorking,' \&c. Now Edition. Crown $8 \mathrm{vo}, 3 \mathrm{~s} .6 \mathrm{~d}$.

CHRISTISON. Life of Sir Robert Christison, Bart., M.D., D.C.L. Oxon., Professor of Medical Jurisprudence in the University of Edin. burgh. Edited by his SoNs. In 2 vols. 8vo. Vol. I.-Autobiography. 16s. Vol. II.-Memoirs. 16s.

CHURCH. Chapters in an Adventurous Life. Sir Richard Church in Italy and Greece. By E. M. CHURCH. With Photogravure Portrait. Demy 8vo, 10s. 6d.

CHURCH SERVICE SOCIETY.

A Book of Common Order: being Forms of Worship issued by the Church Service Society. Seventh Edition, carefully revised. In 1 vol. crown 8vo, cloth, 3s. 6d.; French morocco, 5s. Also in 2 vols. crown 8vo, cloth, 4s. ; French morocco, 6s. 6d.

Daily Offices for Morning and Evening Prayer throughout the Week. Crown 8vo, 3s. 6d.

Order of Divine Service for Children. Issued by the Church Service Society. With Scottish Hymnal. Cloth, 3d. 
CLOUSTON. Popular Tales and Fictions: their Migrations and Transformations. By W. A. Clouston, Editor of 'Arabian Poetry for Eng. lish Readers,' \&c. 2 vols. post 8vo, roxburghe binding, $25 \mathrm{~s}$.

COCHRAN. A Handy Text-Book of Military Law. Compiled chiefly to assist Officers preparing for Examination; also for all Officers of the Regular and Auxiliary Forces. Comprising also a Synopsis of part of the Army Act. By Major F. Cochran, Hampshire Regiment Garrison Instructor, North British District. Crown 8vo, 7s. 6d.

COLQUHOUN. The Moor and the Loch. Containing Minute Instructions in all Highland Sports, with Wanderings over Crag and Corrie, Flood and Fell. By JoHN CoLQunoun. Cheap Edition. With Illustrations. Demy 8vo, 10s. 6d.

COLVILE. Round the Black Man's Garden. By Lady Z. CoLviLE, F.R.G.S. With 2 Maps and 50 Illustrations from Drawings by the Author and from Photographs. Demy 8vo, $16 \mathrm{~s}$.

CONDER. The Bible and the East. By Lieut. - Col. C. R. Conder, R.E., LL.D., D.C.L., M.R.A.S., Author of 'Tent Work in Palestine,' \&c. With Illustrations and a Map. Crown 8vo, 5s.

CONSTITUTION AND LAW OF THE CHURCH OF SCOTLAND. With an Introductory Note by the late Principal Tulloch. New Edition, Revised and Enlarged. Crown 8vo, 3s. 6d.

COTTERILL. Suggested Reforms in Public Schools. By C. C. Cotterill, M.A. Crown 8vo, 3s. 6d.

COUNTY HISTORIES OF SCOTLAND. In demy 8vo volunies of about 350 pp. each. With 2 Maps. Price 7s. 6d. net.

Fife and Kinross. By Eneas J. G. Mackay, LL.D., Sheriff of these Counties.

Dumfries and Galloway. By Sir Herbert Maxwell, Bart., M.P.

CRANSTOUN.

The Elegies of Albius Tibullus. Translated into English Verse, with Life of the Poet, and Illustrative Notes. By James CRANSToun, LL.D., Author of a Translation of 'Catullus.' Crown 8vo, 6s. $6 \mathrm{~d}$.

The Elegies of Sextus Propertius. Translated into English Verse, with Life of the Poet, and Illustrative Notes. Crown 8vo, 7s. 6d.

CRAWFORD. Saracinesca. By F. Marion Crawford, Author of 'Mr Isaacs,' \&c., \&c. Eighth Edition. Crown 8vo, $6 \mathrm{~s}$.

CRAWFORD.

The Doctrine of Holy Scripture respecting the Atonement. By the late Thomas J. CrawForD, D.D., Professor of Divinity in the University of Edinburgh. Fifth Edition. 8vo, 12s.

The Fatherhood of God, Considered in its General and Special Aspects. Third Edition, Revised and Enlarged. 8vo, 9s.

The Preaching of the Cross, and other Sermons. 8vo, 7s. 6d.

The Mysteries of Christianity. Crown 8vo, 7s. 6d.

CROSS. Impressions of Dante, and of the New World ; with a Few Words on Bimetallism. By J.'W. Cross, Editor of 'George Eliot's Life, as related in her Letters and Journals.' Post 8vo, $6 \mathrm{~s}$.

CUMBERLAND. Sport on the Pamirs and Turkistan Steppes. By Major C. S. Cumberland. With Map and Frontispiece. Demy 8vo, 10s. 6d.

CURSE OF INTELLECT. Third Edition. Fcap. 8vo, 2s. 6d. net. CUSHING. The Blacksmith of Voe. By PadL CUshing, Author of 'The Bull i' th' Thorn,' 'Cut with his own Diamond.' Cheap Edition. Crown 8vo, 3s. 6d. 
DAVIES.

Norfolk Broads and Rivers; or, The Waterways, Lagoons, and Decoys of East Anglia. By G. Christopher Davies. Illustrated with Seven full-page Plates. New and Cheaper Edition. Crown 8vo, 6s.

Our Home in Aveyron. Sketches of Peasant Life in Aveyron and the Lot. By G. Christopher Davies and Mrs Brovghall. Inlustrated with full-page Illustrations. 8vo, 15s. Cheap Edition, 7s. 6d.

DE LA WARR. An Eastern Cruise in the 'Edeline.' By the Countess DE LA WARR. In Ilustrated Cover. 2s.

DESCARTES. The Method, Meditations, and Principles of Philosophy of Descartes. Translated from the Original French and Latin. With a New Introductory Essay, Historical and Critical, on the Cartesian Philosophy. By Professor Veitch, LL.D., Glasgow University. Eleventh Edition. 6s. 6d.

DOGS, OUR DOMESTICATED : Their Treatment in reference to Food, Diseases, Habits, Punishment, Accomplishments. By 'Magenta.' Crown 8vo, 2s. 6d.

DOUGLAS.

The Ethics of John Stuart Mill. By Charles Douglas, M.A., D.Sc., Lecturer in Moral Philosophy, and Assistant to the Professor of Moral Philosophy in the University of Edinburgh. In 1 vol. post 8vo.

[In the press. : A Study of his Philosophy. Crown 8vo, 4s. 6d. net.

DOUGLAS. Chinese Stories. By Robert K. Douglas. With numerous Illustrations by Parkinson, Forestier, and others. New and Cheaper Edition. Small demy $8 \mathrm{vo}, 5 \mathrm{~s}$.

DOUGlas. Iras: A Mystery. By Theo. Douglas, Author of 'A Bride Elect.' Crown 8vo, 3s. 6d.

DU CANE. The Odyssey of Homer, Books I.-XII. Translated into English Verse. By Sir CHARLEs DU CANE, K.C.M.G. 8vo, 10s. 6d.

DUDGEON. History of the Edinburgh or Queen's Regiment Light Infantry Militia, now 3rd Battalion The Royal Scots; with an Account of the Origin and Progress of the Militia, and a Brief Sketch of the Old Royal Scots. By Major R. C. Dudaron, Adjutant 3rd Battalion the Royal Scots. Post 8vo, with Illustrations, 10s. 6d.

DUNSMORE. Manual of the Law of Scotland as to the Relations between Agricultural Tenants and the Landlords, Servants, Merchants, and Bowers. By W. Dunsmore. 8vo, 7s. $6 \mathrm{~d}$.

\section{ELIOT.}

George" Eliot's Life, Related in Her Letters and Journals. Arranged and Edited by her husband, J. W. Cross. With Portrait and other Illustrations. Third Edition. 3 vols. post $8 \mathrm{vo}, 42 \mathrm{~s}$.

George Eliot's Life. With Portrait and other Illustrations. New Edition, in one volume. Crown $8 v 0,7 \mathrm{~s} .6 \mathrm{~d}$.

Works of George Eliot (Standard Edition). 21 volumes, crown 8vo. In buckram cloth, gilt top, 2s. 6d. per vol.; or in roxburghe binding, 3s. 6d. per vol.

Adam Bede. 2 vols.-The Mill on the Floss. 2 vols.-Felix Holt, the Radical. 2 vols.-Romola. 2 vols.-Scenes of Clerical Life. 2 vols. Middlemarch. 3 vols. - Daniel Deronda. 3 vols.-Silas Marner. 1 vol. -Jubal. 1 vol,-The Spanish Gipsy. 1 vol.-Essays. 1 vol.-TheophrasTus SUCH. 1 vol.

Life and Works of George Eliot (Cabinet Edition). 24 volumes, crown $8 \mathrm{vo}$, price $\& 6$. Also to be had handsomely bound in half and full calf. The Volumes are sold separately, bound in cloth, price $5 \mathrm{~s}$. each. 
ELIOT.

Novels by George Eliot. Cheap Edition.

Adam Bede. Illustrated. 3s. 6d., cloth.-The Mill on the Floss. Illus. trated. 3s. 6d., cloth.-Scenes of Clerical Life. Illustrated. 3s., cloth.Silas Marner: the Weaver of Raveloe. Illustrated. 2s. 6d., cloth.-Felix Holt, the Radical. Illustrated. 3s. 6d., cloth.-Romola. With Vignette. 3s. 6d., cloth.

Middlemarch. Crown 8vo, 7s. 6d.

Daniel Deronda. Crown 8vo, 7s. 6d.

Essays. New Edition. Crown 8vo, 5s.

Impressions of Theophrastus Such. New Edition. Crown 8 vo, 5s.

The Spanish Gypsy. New Edition. Crown 8vo, 5s.

The Legend of Jubal, and other Poems, Old and New. New Edition. Crown 8vo, 5s.

Wise, Witty, and Tender Sayings, in Prose and Verse. Selected from the Works of George Eliot. New Edition. Fcap. 8vo, 3s. 6d.

ESSAYS ON SOCIAL SUBJECTS. Originally published in the 'Saturday Review.' New Edition. First and Second Series. 2 vols. crown 8 vo, 6s. each.

FAITHS OF THE WORLD, The. A Concise History of the Great Religious Systems of the World. By various Authors. Crown 8vo, 5s.

FALKNER. The Lost Stradivarius. By J. Meade Falkner. Second Edition. Crown 8vo, 6s.

FERGUSON. Sir Samuel Ferguson in the Ireland of his Day. By LADY Ferquson, Author of 'The Irish before the Conquest,' 'Life of William Reeves, D.D., Lord Bishop of Down, Connor, and Drumore,' \&c., \&c. With Two Portraits. 2 vols. post 8 vo, 21s.

\section{FERRIER.}

Philosophical Works of the late James F. Ferrier, B.A. Oxon., Professor of Moral Philosophy and Political Economy, St Andrews. New Edition. Edited by Sir Alexander Grant, Bart., D.C.L., and Professor Lushington. 3 vols. crown 8 vo, $34 \mathrm{~s}$. $6 \mathrm{~d}$.

Institutes of Metaphysic. Third Edition. 10s. 6d.

Lectures on the Early Greek Philosophy. 4th Edition. 10s. 6d. Philosophical Remains, including the Lectures on Early Greek Philosophy. New Edition. 2 vols. 24s.

FLINT.

Historical Philosophy in France and French Belgium and Switzerland. By ROBERT Flint, Corresponding Member of the Institute of France, Hon. Member of the Royal Society of Palermo, Professor in the University of Edinburgh, \&c. 8vo, 21s.

Agnosticism. Being the Croall Lecture for 1887-88.

Theism. Being the Baird Lecture for 1876. Ninth Edition, Revised. Crown 8vo, 7s. 6d.

Anti-Theistic Theories. Being the Baird Lecture for 1877. Fifth Edition. Crown 8vo, 10s. 6d.

FOREIGN CLASSICS FOR ENGLISH READERS. Edited by Mrs Oliphant. Price 2s. 6d. For List of Volumes, see page 2.

FOSTER. The Fallen City, and other Poems. By Will Foster. Crown 8vo, 6s. 
FRANCILLON. Gods and Heroes ; or, The Kingdom of Jupiter. By R. E. Francillon. With 8 Illustrations. Crown 8vo, $5 \mathrm{~s}$.

FRANCIS. Among the Untrodden Ways. By M. E. Francis (Mrs Francis Blundell), Author of 'In a North Country Village,' 'A Daughter of the Soil,' 'Frieze and Fustian,' \&c. Crown 8vo, 3s. 6d.

FRASER.

Philosophy of Theism. Being the Gifford Lectures delivered before the University of Edinburgh in 1894-95. First Series. By AlExander Campbell Fraser, D.C.L. Oxford; Emeritus Professor of Logic and Metaphysies in the University of Edinburgh. Post 8vo, 7s. 6d. net.

Philosophy of Theism. Being the Gifford Lectures delivered before the University of Edinburgh in 1895-96. Second Series. Post 8vo, 7s. 6d. net.

FRASER. St Mary's of Old Montrose : A History of the Parish of Maryton. By the Rev. William Ruxton Fraser, M.A., F.S.A. Scot., Emeritus Minister of Maryton; Author of 'History of the Parish and Burgh of Laurencekirk.' Crown 8vo, 3s. 6d.

FULLARTON.

Merlin: A Dramatic Poem. By Ralph Macleod FullarToN. Crown 8vo, $5 \mathrm{~s}$.

Tanhäuser. Crown 8vo, 6s.

Lallan Sangs and German Lyrics. Crown 8vo, 5s.

GALT.

Novels by JоHN GALT. With General Introduction and Prefatory Notes by S. R. CRockETT. The Text Revised and Edited by D. Storrar Meldrum, Author of 'The Story of Margrédel.' With Photogravure Illustrations from Drawings by John Wallace. Fcap. 8vo, 3s. net each vol.

Annals of the Parish, and The Ayrshire Legatees. 2 vols.-Sir Andrew Wylie. 2 vols.-The Entail; or, The Lairds of Grippy. 2 vols.-The Provost, and THE LAST OF THE LAIRDS. 2 vols.

See also Standard Novels, $p .6$.

GENERAL ASSEMBLY OF THE CHURCH OF SCOTLAND.

Scottish Hymnal, With Appendix Incorporated. Published for use in Churches by Authority of the General Assembly. 1. Large type, cloth, red edges, 2s. 6d.; French morocco, 4s. 2. Bourgeois type, limp cloth, Is.; French morocco, 2s. 3. Nonpareil type, cloth, red edges, 6d.; French morocco, Is. 4d. 4. Paper covers, 3d. 5. Sunday-School Edition, paper covers, Id., cloth, 2d. No. 1, bound with the Psalms and Paraphrases, French morocco, 8s. No. 2, bound with the Psalms and Paraphrases, cloth, 2s.; French morocco, 3s.

Prayers for Social and Family Worship. Prepared by a Special Committee of the General Assembly of the Church of Scotland. Entirely New Edition, Revised and Fnlarged. Fcap. 8vo, red edges, 2s.

Prayers for Family Worship. A Selection of Four Weeks' Prajers. New Edition. Authorised by the General Assembly of the Church of Scotland. Fcap. 8vo, red edges, 1s. 6d.

One Hundred Prayers. Prepared by the Committee on Aids to Devotion. $16 \mathrm{mo}$, cloth limp, $6 \mathrm{~d}$.

Morning and Evening Prayers for Affixing to Bibles. Prepared by the Committee on Aids to Devotion. Id. for 6, or Is. per 100 .

GERARD. Reata: What's in a Name. By E. D. Grarard. Cheap
Edition. Crown 8vo, 3s. 6d.

Beggar my Neighbour. Cheap Edition. Crown 8vo, 3s. 6d. The Waters of Hercules. Cheap Edition. Crown 8vo, 3s. 6d. A Sensitive Plant. Crown 8vo, 3s. 6d. 
GERARD.

A Foreigner. An Anglo-German Study. By E. Gerard. Crown 8vo, 6s.

The Land beyond the Forest. Facts, Figures, and Fancies from Transylvania. With Maps and Illustrations. 2 vols. post 8vo, 25s.

Bis : Some Tales Retold. Crown 8vo, 6s.

A Secret Mission. 2 vols. crown 8vo, 17s. GERARD.

The Wrong Man. By Dorothea Gerard. Second Edition. Crown 8vo, 6s.

Lady Baby. Cheap Edition. Crown 8vo, 3s. 6d.

Recha. Second Edition. Crown 8vo, 6s.

The Rich Miss Riddell. Second Edition. Crown 8vo, 6s.

GERARD. Stonyhurst Latin Grammar. By Rev. John Gerard. GILL Second Edition. Fcap. 8vo, 3s.

Free Trade: an Inquiry into the Nature of its Operation. By Richard Gill. Crown 8vo, 7s. 6d.

Free Trade under Protection. Crown 8vo, 7s. 6d. GORDON CUMMING.

At Home in Fiji. By C. F. Gordon Comming. Fourth Edition, post 8vo. With Illustrations and Map. 7s. 6d.

A Lady's Cruise in a French Man-of-War. New and Cheaper Edition. 8vo. With Illustrations and Map. 12s. 6d.

Fire-Fountains. The Kingdom of Hawaii: Its Volcanoes, and the History of its Missions. With Map and Illustrations. 2 vols. 8vo, 25s.

Wanderings in China. New and Cheaper Edition. 8vo, with Illustrations, 10s.

Granite Crags: The Yō-semité Region of California. Illus. trated with 8 Engravings. New and Cheaper Edition. 8vo, 8s. 6d.

GRAHAM. Manual of the Elections (Scot.) (Corrupt and Illegal Practices) Act, 1890. With Analysis, Relative Act of Sederunt, Appendix con taining the Corrupt Practices Acts of 1883 and 1885, and Copious Index. By J. Edward Graham, Advocate. Svo, 4s. 6d.

GRAND.

A Domestic Experiment. By SARAH Grand, Author of 'The Heavenly Twins,' 'Ideala: A Study from Life.' Crown 8vo, 6s.

Singularly Deluded. Crown 8vo, 6s.

GRANT. Bush-Life in Queensland. By A. C. Grant. New Edition. Crown 8vo, 6s.

GRANT. Life of Sir Hope Grant. With Selections from his Correspondence. Edited by HenRr Knolurs, Colonel (H.P.) Royal Artillery, his former A.D.C., Editor of 'Incidents in the Sepoy War;' Author of 'Sketches of Life in Japan,' \&c. With Portraits of Sir Hope Grant and other Illustrations. Maps and Plans. 2 vols. demy 8vo, 21s.

GRIER

In Furthest Ind. The Narrative of Mr EDward CarlyoN of Ellswether, in the County of Northampton, and late of the Honourable East India Company's Service, Gentleman. Wrote by his own hand in the year of grace 1697 . Edited, with a few Explanatory Notes, by SydNey C. Grier. Post 8vo, 6s.

His Excellency's English Governess. Crown 8vo, 6s.

An Uncrowned King: A Romance of High Politics. Crown $8 \mathrm{vo}, 6 \mathrm{~s}$.

GUTHRIE-SMITH. Crispus: A Drama. By H. GuthrieSмiтн. Fcap. 4to, 5s. 
HAGGARD. Under Crescent and Star. By Lieut.-Col. ANDREw HAGGARD, D.S.O., Author of 'Dodo and I,' 'Tempest Torn,' \&c. With a Portrait. Second Edition. Crown 8vo, 6s.

HALDANE. Subtropical Cultivations and Climates. A Handy Book for Planters, Colonists, and Settlers. By R. C. Haldane. Post 8vo, 9s.

HAMERTON.

Wenderholme: A Story of Lancashire and Yorkshire Life. By P. G. Hamerton, Author of 'A Painter's Camp.' New Edition. Crown $8 \mathrm{vo}, 3 \mathrm{~s} .6 \mathrm{~d}$.

Marmorne. New Edition. Crown 8vo, 3s. 6d.

HAMILTON.

Lectures on Metaphysics. By Sir William Hamilton, Bart., Professor of Logic and Metaphysics in the University of Edinburgh. Edited by the Rev. H. L. Mansel, B.D., LL.D., Dean of St Paul's ; and Jorn Vertch, M.A., LL.D., Professor of Logic and Rhetoric, Glasgow. Seventh Edition. 2 vols. 8 vo, 24 s.

Lectures on Logic. Edited by the SAME. Third Edition, Revised. 2 vols., $24 \mathrm{~s}$.

Discussions on Philosophy and Literature, Education and University Reform. Third Edition. 8vo, 21s.

Memoir of Sir William Hamilton, Bart., Professor of Logic and Metaphysics in the University of Edinburgh. By Professor VeITCE, of the University of Glasgow. 8vo, with Portrait, 18s.

Sir William Hamilton: The Man and his Philosophy. Two Lectures delivered before the Edinburgh Philosophical Institution, January and February 1883. By Professor Vertch. Crown 8vo, 2s.

HAMLEY.

The Operations of War Explained and Illustrated. By General Sir Edward Bruce Hamley, K.C.B., K.C.M.G. Fifth Edition, Revised throughout. 4to, with numerous Illustrations, 30 s.

National Defence ; Articles and Speeches. Post 8vo, 6s.

Shakespeare's Funeral, and other Papers. Post 8vo, 7s. 6d. Thomas Carlyle: An Essay. Second Edition. Crown 8vo,

On Outposts. Second Edition. 8vo, 2s.

Wellington's Career; A Military and Political Summary.

Lady Lee's Widowhood. New Edition. Crown 8vo, 3s. 6d. Cheaper Edition, 2s. 6d. Our Poor Relations. A Philozoic Essay. With Illustrations,

The Life of General Sir Edward Bruce Hamley, K.C.B. K.C.M.G. By Alexander InNes Shand. With two Photogravure Portraits and other Illustrations. Cheaper Edition. With a Statement by Mr EDward HAMLEY. 2 vols. demy 8vo, 10s. $6 \mathrm{~d}$.

HARE. Down the Village Street: Scenes in a West Country Hamlet. By ChristopHer Hare. Second Edition. Crown 8vo, 6s.

HARRADEN. In Varying Moods : Short Stories. By BEATRICE HarradeN, Author of 'Ships that Pass in the Night.' Twelfth Edition. Crown
8vo, 3s. 6d.

HARRIS.

From Batum to Baghdad, via Tiflis, Tabriz, and Persian Kurdistan. By WALTER B. HARRIS, F.R.G.S., Author of 'The Land of an African Sultan; Travels in Morocco,' \&c. With numerous Illustrations and 2 Maps. Demy 8vo, 12s. 
HARRIS.

Tafilet. The Narrative of a Journey of Exploration to the Atlas Mountains and the Oases of the North-West Sahara. With Illustrations by Maurice Romberg from Sketches and Photographs by the Author, and Two Maps. Demy 8vo, 12s.

A Journey through the Yemen, and some General Remarks upon that Country. With 3 Maps and numerous Illustrations by Forestier and Wallace from Sketches and Photographs taken by the Author. Demy 8vo, 16s.

Danovitch, and other Stories. Crown 8vo, 6s.

HAWKER. The Prose Works of Rev. R. S. HAWKER, Vicar of Morwenstow. Including ' Footprints of Former Men in Far Cornwall.' Re-edited, with Sketches never before published. With a Frontispiece. Crown 8vo, 3s. 6d.

HAY. The Works of the Right Rev. Dr George Hay, Bishop of Edinburgh. Edited under the Supervision of the Right Rev. Bishop Strain. With Memoir and Portrait of the Author. 5 vols. crown 8vo, bound in extra cloth, $£ 1,1$ s. The following Volumes may be had separately-viz. :

The Devout Christian Instructed in the Law of Christ from the Written Word. 2 vols., 8s.-The Pious Christian Instructed in the Nature and Practice of the Principal Exercises of Piety. 1 vol., 3s.

HEATLEY.

The Horse-Owner's Safeguard. A Handy Medical Guide for every Man who owns a Horse. By G. S. Heatley, M.R.C.V.S. Crown 8vo, 5s.

The Stock-Owner's Guide. A Handy Medical Treatise for every Man who owns an Ox or a Cow. Crown 8vo, 4s. $6 \mathrm{~d}$.

HEDDERWICK. Lays of Middle Age; and other Poems. By JAMks HeDderwick, LL.D., Author of 'Backward Glances.' Price 3s. 6d.

HEMANS.

The Poetical Works of Mrs Hemans. Copyright Editions. Royal 8vo, 5s. The Same with Engravings, cloth, gilt edges, 7s. 6d.

Select Poems of Mrs Hemans. Fcap., cloth, gilt edges, $3 \mathrm{~s}$.

HERKLESS. Cardinal Beaton: Priest and Politician. By JoHN Herkless, Professor of Church History, St Andrews. With a Portrait. Post 8vo, 7s. 6 d.

HEWISON. The Isle of Bute in the Olden Time. With Illustrations, Maps, and Plans. By JAMes KING Hewison, M.A., F.S.A. (Scot.), Minister of Rothesay. Vol. I., Celtic Saints and Heroes. Crown 4to, 15s. net. Vol. II., The Royal Stewards and the Brandanes. Crown 4to, 15s. net.

HIBBEN. Inductive Logic. By JoHN Grier HibBen, Ph.D., Assistant Professor of Logic in Princeton University, U.S.A. Crown 8vo, 3s. 6d. net.

HOME PRAYERS. By Ministers of the Church of Scotland and Members of the Church Service Society. Second Edition. Fcap. 8vo, 3s.

HORNBY. Admiral of the Fleet Sir Geoffrey Phipps Hornby, G.C.B. A Biography. By Mrs Fred. Eanrton. With Three Portraits. Demy 8vo, $16 \mathrm{~s}$.

HUTCHINSON. Hints on the Game of Golf. By Horace G. Hutchnson. Ninth Edition, Enlarged. Fcap. 8vo. cloth, is.

HYSLOP. The Elements of Ethics. By JamES H. HysLor, Ph.D., Instructor in Ethics, Columbia College, New York, Author of 'The Elements of Logic.' Post 8vo, 7s. 6d. net.

IDDESLEIGH.

Lectures and Essays. By the late EARL of IDdesLeigh, G.C.B., D.C.L., \&c. 8vo, 16 s.

Life, Letters, and Diaries of Sir Stafford Northcote, First Earl of Iddesleigh. By ANDREw Lave. With Three Portraits and a View of Pynes. Third Edition. 2 vols. post 8vo, 31s. 6d.

Popular Edition. With Portrait and View of Pynes. Post 8vo, 7s. 6d. 
IGNOTUS. The Supremacy and Sufficiency of Jesus Christ, as set forth in the Epistle to the Hebrews. By Ignotus. Crown 8vo, 3s. 6d.

INDEX GEOGRAPHICUS : Being a List, alphabetically arranged, of the Principal Places on the Globe, with the Countries and Subdivisions of the Countries in which they are situated, and their Latitudes and Longitudes. Imperial 8vo, pp. 676, 21s.

JEAN JAMBON. Our Trip to Blunderland ; or, Grand Excursion to Blundertown and Back. By JeAN JAMBON. With Sixty Illustrations designed by Charles Doyle, engraved by Dalziel. Fourth Thousand. Cloth, gilt edges, 6s. 6d. Cheap Edition, cloth, 3s. 6d. Boards, 2s. 6d.

JEBB. A Strange Career. The Life and Adventures of JoHN Gladwyn JEBb. By his Widow. With an Introduction by H. Rider HaGgard, and an Electrogravure Portrait of Mr Jebb. Third Edition. Demy 8vo, 10s. 6d. Cheap EDition. With Illustrations by John Wallace. Crown 8vo, 3s. 6d.

Some Unconventional People. By Mrs Gladwyn JeBb, Author of 'Life and Adventures of J. G. Jebb.' With Illustrations. Crown 8vo, 3s. 6d.

JENNINGS. Mr Gladstone: A Study. By Louis J. Jennings, M.P., Author of 'Republican Government in the United States,' 'The Croker Memoirs,' \&c. Popular Edition. Crown 8vo, 1s.

JERNINGHAM.

Reminiscences of an Attaché. By Hubert E. H. Jerningham. Second Edition. Crown $8 \mathrm{vo}, 5 \mathrm{~s}$.

Diane de Breteuille. A Love Story. Crown 8vo, 2s. 6d. JOHNSTON.

The Chemistry of Common Life. By Professor J. F. W. Johnston. New Edition, Revised. By Arthur Herbert ChURCH, M.A. Oxon.; Author of 'Food : its Sources, Constituents, and Uses,' \&c. With Maps and 102 Engravings. Crown 8vo, 7s. 6d.

Elements of Agricultural Chemistry. An entirely New Edition from the Edition by Sir Charles A. CAMERoN, M.D., F.R.C.S.I., \&c. Revised and brought down to date by C. M. Alkman, M.A., B.Sc., F.R.S.E., Professor of Chemistry, Glasgow Veterinary College. 17th Edition. Crown 8vo, 6s. 6d.

Catechism of Agricultural Chemistry. An entirely New Edition from the Edition by Sir Charles A. CAMEron. Revised and Enlarged by C. M. AIkmaN, M.A., \&c. 95th Thousand. With numerous Illustrations. Crown 8vo, 1s.

JOHNSTON. Agricultural Holdings (Scotland) Acts, 1883 and 1889 ; and the Ground Game Act, 1880 . With Notes, and Summary of Procedure, \&c. By Christopher N. Johnston, M.A., Advocate. Demy 8vo, $5 \mathrm{~s}$.

JOKAI. Timar's Two Worlds. By Madrus JokaI. Authorised Translation by Mrs Hegan Kennard. Cheap Edition. Crown 8vo, 6s.

KEBBEL. The Old and the New : English Country Life. By T. E. KEBBEL, M.A., Author of 'The Agricultural Labourers,' 'Essays in History and Politics,' 'Life of Lord Beaconsfield.' Crown 8vo, $5 \mathrm{~s}$.

KERR. St Andrews in 1645-46. By D. R. KERR. Crown $8 \mathrm{vo}, 2 \mathrm{~s} .6 \mathrm{~d}$.

KINGLÄKE.

History of the Invasion of the Crimea. By A. W. KINGLAKE. Cabinet Edition, Revised. With an Index to the Complete Work. Illustrated with Maps and Plans. Complete in 9 vols., crown $8 \mathrm{vo}$, at $6 \mathrm{~s}$. each.

History of the Invasion of the Crimea. Demy 8vo. Vol. VI. Winter Troubles. With a Map, 16s. Vols. VII. and VIII. From the Morrow of Inkerman to the Death of Lord Raglan. With an Index to the Whole Work. With Maps and Plans. 28s. 
KINGLAKE.

Eothen. A New Edition, uniform with the Cabinet Edition of the 'History of the Invasion of the Crimea.' $6 \mathrm{~s}$.

Cheaper Edition. With Portrait and Biographical Sketch of the Author. Crown 8vo, 3s. 6d.

KIRBY. In Haunts of Wild Game: A Hunter-Naturalist's Wanderings from Kahlamba to Libombo. By Frederick VAUGHAN KIRBY, F.Z.S. (Maqaqamba). With numerous Illustrations by Charles Whymper, and a Map. Large demy $8 \mathrm{vo}, 25 \mathrm{~s}$.

KLEIN. Among the Gods. Scenes of India, with Legends by the Way. By Augusta Krein. With 22 Full-page Illustrations. Demy 8vo, $15 \mathrm{~s}$.

KNEIPP. My Water-Cure. As Tested through more than Thirty Years, and Described for the Healing of Diseases and the Preservation of Health. By/Sebastian KNeipP, Parish Priest of Wörishofen (Bavaria). With a Portrait and other Illustrations. Authorised English Translation from the Thirtieth German Edition, by A. de F. Cheap Edition. With an Appendix, containing the Latest Developments of Pfarrer Kneipp's System, and a Preface by E. Gerard. Crown 8vo, 3s. 6d.

KNOLLYS. The Elements of Field-Artillery. Designed for the Use of Infantry and Cavalry Officers. By HENRY KNollys, Colonel Royal Artillery; Author of 'From Sedan to Saarbrick,' Editor of 'Incidents in the Sepoy War,' \&c. With Engravings. Crown 8vo, 7s. 6d.

LANG. Life, Letters, and Diaries of Sir Stafford Northcote, First Earl of Iddesleigh. By ANDrew Lang. With Three Portraits and a View of Pynes. Third Edition. 2 vols. post 8vo, 31s. 6d.

Popular Edition. With Portrait and View of Pynes. Post 8vo, 7s. 6d.

LEES. A Handbook of the Sheriff and Justice of Peace Small Debt Courts. With Notes, References, and Forms. By J. M. LeEs, Advocate, Sheriff of Stirling, Dumbarton, and Clackmannan. 8vo, 7s. 6d.

LINDSAY.

Recent Advances in Theistic Philosophy of Religion. By Rev. James Lindsay, M.A., B.D., B.Sc., F.R.S.E., F.G.S., Minister of the Parish of St Andrew's, Kilmarnock. Demy 8vo, 12s. 6d. net.

The Significance of the Old Testament for Modern Theology. Crown 8vo, 1s. net.

The Progressiveness of Modern Christian Thought. Crown $8 \mathrm{vo}, 6 \mathrm{~s}$.

Essays, Literary and Philosophical. Crown 8vo, 3s. 6d.

LOCKHART.

Doubles and Quits. By Ladrence W. M. Lockhart. New Edition. Crown 8vo, 3s. 6d.

Fair to See. New Edition. Crown 8vo, 3s. 6 d.

Mine is Thine. New Edition. Crown 8vo, 3s. 6d.

LOCKHART.

The Church of Scotland in the Thirteenth Century. The Life and Times of David de Bernham of St Andrews (Bishop), A.D. 1239 to 1253. With List of Churches dedicated by him, and Dates. By WILLIAM LOCKHART, A.M., D.D., F.S.A. Scot., Minister of Colinton Parish. 2d Edition. 8vo, 6s.

Dies Tristes: Sermons for Seasons of Sorrow. Crown 8vo, 6s. LORIMER.

The Institutes of Law : A Treatise of the Principles of Jurisprudence as determined by Nature. By the late JAMEs LORIMER, Professor of Public Law and of the Law of Nature and Nations in the University of Edin. burgh. New Edition, Revised and much Enlarged. 8vo, 18s.

The Institutes of the Law of Nations. A Treatise of the Jural Relation of Separate Political Communities. In 2 vols. 8vo. Volume I., price 16s. Volume II., price $20 \mathrm{~s}$. 
LUGARD. The Rise of our East African Empire: Early Efforts

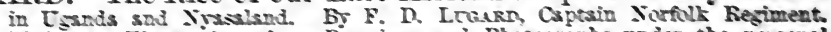
With 100 Miustritions from niswinss and Photosraph under the personsl

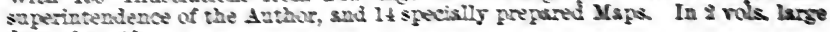
demy Sirat 4 A

\section{MCHESTEY.}

Jiriam Cromwell. Roralist: A Romance of the Great Rebel-

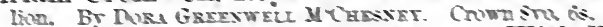

Kathleen Clare: Her book, 163-41. With Frontispiece, and

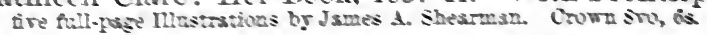

M'COMBIE. Cattle and Cattle-Breeders By Wilum M'Cosmm, Tilyfucr. New Edition, Filsrget, with Memoit of the Anthor by Jaxns

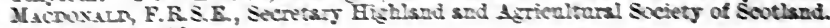
croves sio, is oil.

M'CRIE

Works of the Rer. Thomss MC Crie, D.D. Uniform Edition. i ruls erown stre ots.

Life of John Knox. Crown sro, 6s. Another Edition, 3s. 6d.

Life of Andrew Melrille. Crown sro, 6s.

History of the Progress and Suppression of the Reformation in Ixig in the sixteenth Century. Crom sno ts

History of the Progress and Suppression of the Reformation in spain in the sirteesth Cestury. Cown shy ss ed.

IICRIE The Public Worship of Presbrterian Scotland. Historicilly trested. With oupions Sotes Anpendices, sma Index. The Foarteenth

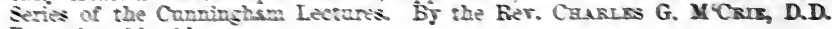
Demis sin, lis id.

MACDONALD. A Manual of the Criminal Law (Scotland) Pro-

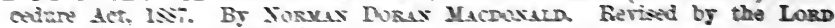

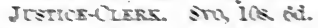

MACDOXALD AND SINCLAIR. History of Polled Aberdeen smi Anzus cattic. Giving sn Acovont of the Crivin, Impovement, snd Charse.

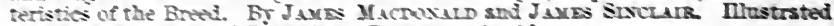

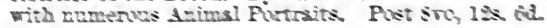

MACDOTGALL ATn DODDS. A Manual of the Local Gorern-

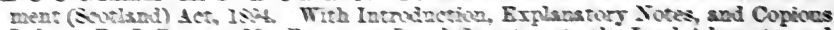
Index By J. PArrex MACDuteald. Lessi Secretsiry to the Lond Adveeste, snd

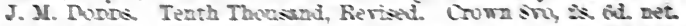

MACINTYRE Hindu-Koh: Wanderings and Wild Sports on

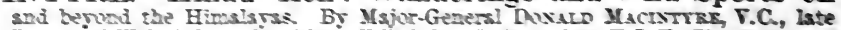
Prince of Wsies' Ow2 Givorkst, F.R.G.S. Inilicated to H.R.H. The Priver of

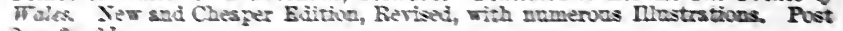
sinz ss ia.

MACKAY.

A Manual of Modern Geography; Mathematical, Physical,

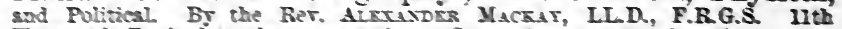

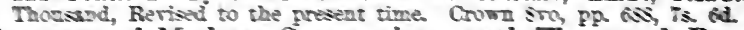

Elements of Modern Geography. 55th Thousand, Revised to

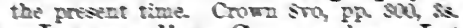

The Intermediate Geography. Intended as an Intermediate Buols between the Author's 'Outlines of Gengraphy' snd 'Elements of Geo-

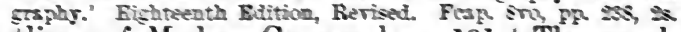

Outlines of Modern Geography. 191st Thousand, Revised to the present time. Fesp swo, $\mathrm{Fp}$ is, is

Elements of Physiography. New Edition. Rewritten and

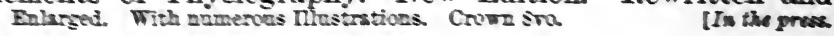


MACKENZIE. Studies in Roman Law. With Comparative Views of the Laws of France, England, and Scotland. By Iord MAckenzis, one of the Judges of the Court of Session in Scotland. Sixth Fdition, Edited by Jorn Kirkpatrick, M.A., LI.B., Advocate, Profossor of History in the University of Edinburgh. Svo, 12s.

MACPHERSON. Glimpses of Church and Social Life in the Highlands in Olden Times. By Alexander Macpherson, F.S.A. Scot. With 6 Photogravure Portraits and other full-page Illustrations. Small 4to, 25s.

M'PHERSON. Golf and Golfers. Past and Present. By J. Gordon M'Pukrson, Ph.D., F.R.S.E. With an Introduction by the Right Hon. A. J. Balrour, and a Portrait of the Author. Fcap. Svo, Is. 6d.

MACRAE. A Handbook of Deer-Stalking. By Alexander MACRAE, late Forester to Lord Henry Bentinck. With Introduction by Horatio Ross, Esq. Feap. Svo, with 2 Photographs from Life. 3s. 6d.

MAIN. Three Hundred English Sonnets. Chosen and Edited by Darid M. Main. New Edition. Fcap. Svo, 3s. 6d.

MAIR. A Digest of Laws and Decisions, Ecclesiastical and Civil, relating to the Constitution, Practice, and Afrairs of the Church of Scotland. With Notes and Forms of Procedure. By the Rev. William MaIr, D.D., Minister of the Parish of Earlston. New Edition, Revised. Crown 8vo, 9s, net.

MARCHMONT AND THE HUMES OF POLWARTH. By One of their Descendants. With numerous Portraits and other Illustrations. Crown 4to, 21s. net.

MARSHMAN. History of India. From the Earliest Period to the present time. By John Clark Marshuan, C.S.I. Third and Cheaper Edition. Post 8vo, with Map, 6s.

MARTIN.

The AEneid of Virgil. Books I.-VI. Translated by Sir THEoDORE Martin, K.C.B. Post Sro, 7s. 6d.

Goethe's Faust. Part I. Translated into English Verse. Second Edition, crown Svo, 6s. Ninth Edition, feap. 8vo, 3s. 6d.

Goethe's Faust. Part II. Translated into English Verse. Second Edition, Revised. Fcap. 8vo, 6s.

The Works of Horace. Translated into English Verse, with Life and Notes, 2 vols. New Edition. Crown 8vo, 21 .

Poems and Ballads of Heinrich Heine. Done into English Verse. Third Edition. Small crown $8 \mathrm{vo}, 5 \mathrm{~s}$.

The Song of the Bell, and other Translations from Schiller, Goethe, Uhland, and Others. Crown 8vo, 7s. 6d.

Madonna Pia : A Tragedy ; and Three Other Dramas. Crown 8vo, 7s. 6d.

Catullus. With Life and Notes. Second Edition, Revised and Corrected. Post 8vo, 7s. 6d.

The 'Vita Nuova' of Dante. Translated, with an Introduction and Notes. Third Edition. Small crown 8vo, 5s.

Aladdin: A Dramatic Poem. By Adam Oehlenschlaegrer. Fcsp. 8vo, 5s.

Correggio: A Tragedy. By Oehlenschlatger. With Notes. Fcap. 8vo, 3s.

MARTIN. On some of Shakespeare's Female Characters. By Helena Faucit, Lady Martin. Dedicated by permission to Her Most Gracious Majesty the Queen. Fifth Edition. With a Portrait by Lehmann. Demy $8 \mathrm{vo}, 7 \mathrm{~s}, 6 \mathrm{~d}$.

MARWICK. Observations on the Law and Practice in regard to Municipal Elections and the Conduct of the Business of Town Councils and Commissioners of Police in Scotland. By Sir JAMes D. MARWICK; LL.D., Town-Clerk of Glasgow. Royal 8vo, 30s. 


\section{MATHESON.}

Can the Old Faith Live with the New? or, The Problem of Evolution and Revelation. By the Rev. George Matheson, D.D. Third Edition. Crown 8 vo, $7 \mathrm{~s}$. $6 \mathrm{~d}$.

The Psalmist and the Scientist; or, Modern Value of the Religious Sentiment. Third Edition. Crown 8vo, $5 \mathrm{~s}$.

Spiritual Development of St Paul. Third Edition. Cr. 8vo, 5s.

The Distinctive Messages of the Old Religions. Second Edition. Crown $8 \mathrm{vo}, 5 \mathrm{~s}$.

Sacred Songs. New and Cheaper Edition. Crown 8vo, 2s. 6d.

MAURICE. The Balance of Military Power in Europe. An Examination of the War Resources of Great Britain and the Continental States. By Colonel MaURICE, R.A., Professor of Military Art and History at the Royal Staff College. Crown 8vo, with a Map, 6s.

MAXWELL.

A Duke of Britain. A Romance of the Fourth Century. By Sir HeRBert Maxwell, Bart., M.P., F.S.A., \&c., Author of 'Passages in the Life of Sir Lucian Elphin.' Fourth Edition. Crown 8vo, 6s.

Life and Times of the Rt. Hon. William Henry Smith, M.P. with Portraits and numerous Illustrations by Herbert Railton, G. L. Seymour, and Others. 2 vols. demy 8 vo, $25 \mathrm{~s}$.

PopUlar EDITION. With a Portrait and other Illustrations. Crown 8vo, 3s. 6d.

Scottish Land-Names: Their Origin and Meaning. Being the Rhind Lectures in Archæology for 1893. Post 8vo, 6s.

Meridiana: Noontide Essays. Post 8vo, 7s. 6d.

Post Meridiana: Afternoon Essays. Post 8vo, 6s.

Dumfries and Galloway. Being one of the Volumes of the County Histories of Scotland. With Four Maps. Demy 8vo, 7s. 6d. net.

MELDRUM.

The Story of Margrédel : Being a Fireside History of a Fifeshire Family. By D. StorRar Meldrum. Cheap Edition. Crown 8vo, 3s. 6d.

Grey Mantle and Gold Fringe. Crown 8vo, 6s.

MERZ. A History of European Thought in the Nineteenth Century. By JoHN Theodore Merz. Vol. I., post 8vo, 10s. 6d. net.

MICHEL. A Critical Inquiry into the Scottish Language. With the view of Illustrating the Rise and Progress of Civilisation in Scotland. By FrANCISQUE-MICHEL, F.S.A. Lond. and Scot., Correspondant de l'Institut de France, \&c. 4to, printed on hand-made paper, and bound in roxburghe, $66 \mathrm{~s}$.

MICHIE.

The Larch: Being a Practical Treatise on 'its Culture and General Management. By Christopher Y. Michie, Forester, Cullen House. Crown 8vo, with Illnstrations. New and Cheaper Edition, Enlarged, $5 \mathrm{~s}$.

The Practice of Forestry. Crown 8vo, with Illustrations. 6s.

MIDDLETON. The Story of Alastair Bhan Comyn; or, The Tragedy of Dunphail. A Tale of Tradition and Romance. By the Lady MidDLETON. Square 8vo, 10s. Cheaper Edition, $5 \mathrm{~s}$.

MILLER. The Dream of Mr H-, the Herbalist. By HugH MrlLer, F.R.S.E., late H.M. Geological Survey, Author of 'Landscape Geology.' MINTO. With a Photogravure Frontispiece. Crown 8vo, 2s. 6d.

A Manual of English Prose Literature, Biographical and Critical: designed mainly to show Characteristics of Style. By W. MINTo, M.A., Hon. LL.D. of St Andrews; Professor of Logic in the University of Aber. deen. Third Edition, Revised. Crown 8vo, 7s. 6d.

Characteristics of English Poets, from Chaucer to Shirley. New Edition, Revised. Crown 8vo, 7s. 6d.

Plain Principles of Prose Composition. Crown 8vo, 1s. 6d. 
MINTO.

The Literature of the Georgian Era. Edited, with a Biographical Introduction, by Professor KNIGHT, St Andrews. Post 8vo, 6s.

MOIR. Life of Mansie Wauch, Tailor in Dalkeith. By D. M. Morr. With Croikshank's Illustrations. Cheaper Edition. Crown 8vo, 2s. 6d. Another Edition, without Illustrations, fcap. 8vo, 1s. 6d.

MOLE. For the Sake of a Slandered Woman. By Marion Mole. Fcap. 8vo, 2s. 6d. net.

MOMERIE.

Defects of Modern Christianity, and other Sermons. By Rev. ALFred Williams Momerie, M.A., D.Sc., LL.D. Fifth Edition. Crown 8vo, 58.

The Basis of Religion. Being an Examination of Natural Religion. Third Edition. Crown 8vo, 2s. 6d.

The Origin of Evil, and other Sermons. Eighth Edition, Enlarged. Crown 8vo, 5s.

Personality. The Beginning and End of Metaphysics, and a Necessary Assumption in all Positive Philosophy. Fifth Edition, Revised. Crown 8vo, 3s.

Agnosticism. Fourth Edition, Revised. Crown 8vo, 5s.

Preaching and Hearing; and other Sermons. Fourth Edition, Enlarged. Crown 8vo, 5s.

Belief in God. Third Edition. Crown 8vo, 3s.

Inspiration; and other Sermons. Second Edition, Enlarged. Crown 8vo, 5s.

Church and Creed. Third Edition. Crown 8vo, 4s. 6d.

The Future of Religion, and other Essays. Second Edition. Crown 8vo, 3s. $6 \mathrm{~d}$.

The English Church and the Romish Schism. Second Edition. Crown 8vo, 2s. 6d.

MONCREIFF.

The Provost-Marshal. A Romance of the Middle Shires. By the Hon. Frederick Moncreiff. Crown 8vo, $6 \mathrm{~s}$.

The X Jewel. A Romance of the Days of James VI. Crown $8 \mathrm{vo}, 6 \mathrm{~s}$.

MONTAGUE. Military Topography. Illustrated by Practical Examples of a Practical Subject. By Major-General W. E. Montague, C.B., P.S.C., late Garrison Instructor Intelligence Department, Author of ' Campaign. ing in 'South Africa.' With Forty-one Diagrams. Crown 8vo, 5s.

MONTALEMBERT. Memoir of Count de Montalembert. A Chapter of Recent French History. By Mrs Oliphant, Author of the 'Life of Edward Irving,' \&c. 2 vols. crown 8vo, £1, $4 \mathrm{s.}$

MORISON.

Doorside Ditties. By Jkanie Morison. With a Frontispiece. Crown $8 \mathrm{vo}$, 3s. $6 \mathrm{~d}$.

Aolus. A Romance in Lyrics. Crown 8vo, 3s.

There as Here. Crown 8vo, 3s. * * A limited impression on hand-made paper, bound in vellum, 7s. 6d.

Selections from Poems. Crown 8vo, 4s. 6d.

Sordello. An Outline Analysis of Mr Browning's Poem. Crown 8vo, 3s.

Of "Fifine at the Fair," "Christmas Eve and Easter Day," and other of Mr Browning's Poems. Crown 8vo, 3s.

The Purpose of the Ages. Crown 8vo, 9s.

Gordon: An Our-day Idyll. Crown 8vo, 3s.

Saint Isadora, and other Poems. Crown 8vo, 1s. 6d.

Snatches of Song. Paper, 1s. 6d. ; cloth, 3s. 
MORISON.

Pontius Pilate. Paper, 1s. 6d. ; cloth, 3s.

Mill o' Forres. Crown 8vo, 1s.

Ane Booke of Ballades. Fcap. 4to, 1s.

MOZLEY. Essays from 'Blackwood.' By the late ANNE MozLEY, Author of 'Essays on Social Subjects'; Editor of 'The Letters and Correspondence of Cardinal Newman,' 'Letters of the Rev. J. B. Mozley,' \&c. With a Memoir by her Sister, FanNy MozLey. Post 8vo, 7s. 6d.

MUNRO. The Lost Pibroch, and other Sheiling Stories. By NeIl Munro. Crown 8vo, 6s.

MUNRO. Rambles and Studies in Bosnia-Herzegovina and Dalmatia. With an Account of the Proceedings of the Congress of Archæologists and Anthropologists held at Sarajevo in 1894. By RoBERT MuNRo, M.A., M.D., F.R.S.E., Author of 'The Lake-Dwellings of Europe,' \&c. With numerous Illustrations. Demy 8vo, 12s. 6d. net.

MUNRO. On Valuation of Property. By William MUNRo, M.A., Her Majesty's Assessor of Railways and Canals for Scotland. Second Edition, Revised and Enlarged. 8vo, 3s. 6d.

MURDOCH. Manual of the Law of Insolvency and Bankruptcy : Comprehending a Summary of the Law of Insolvency, Notour Bankruptcy, Composition-Contracts, Trust-Deeds, Cessios, and Sequestrations; and the Winding-up of Joint-Stock Companies in Scotland; with Annotations on the various Insolvency and Bankruptey Statutes; and with Forms of Procedure applicable to these Subjects. By James MurDoch, Member of the Faculty of Procurators in Glasgow. Fifth Edition, Revised and Enlarged. 8vo, 12s. net.

MY TRIVIAL LIFE AND MISFORTUNE: A Gossip with no Plot in Particular. By A Plain Woman. Cheap Edition. Crown 8vo, 3s. 6d. By the SAME AUTHOR.

POOR NELLIE. Cheap Edition. Crown 8vo, 3s. $6 \mathrm{~d}$.

MY WEATHER-WISE COMPANION. Presented by B. T. Fcap. 8vo, 1s. net.

NAPIER. The Construction of the Wonderful Canon of Logarithms. By JoHN NAPIER of Merchiston. Translated, with Notes, and a Catalogue of Napier's Works, by WILliaM RAE MACDONALd. Small 4to, 15s. A few large-paper copies on Whatman paper, 30s.

NEAVES. Songs and Verses, Social and Scientific. By An Old Contributor to 'Maga.' By the Hon. Lord NeAves. Fifth Edition. Fcap. $8 \mathrm{vo}, 4 \mathrm{~s}$.

NICHOLSON.

A Manual of Zoology, for the Use of Students. With a General Introduction on the Principles of Zoology. By Henry Allevne Nicholson, M.D., D.Sc., F.L.S., F.G.S., Regius Professor of Natural History in the University of Aberdeen. Seventh Edition, Rewritten and Enlarged. Post $8 \mathrm{vo}$, pp. 956, with 555 Engravings on Wood, $18 \mathrm{~s}$.

Text-Book of Zoology, for Junior Students. Fifth Edition, Rewritten and Enlarged. Crown 8vo, with 358 Engravings on Wood, 10s. 6d.

Introductory Text-Book of Zoology, for the Use of Junior Classes. Sixth Edition, Revised and Enlarged, with 166 Engravings, 3s.

Outlines of Natural History, for Beginners : being Descriptions of a Progressive Series of Zoological Types. Third Edition, with Engravings, 1s. 6d.

A Manual of Palæontology, for the Use of Students. With a General Introduction on the Principles of Palæontology. By Professor $\mathbf{H}$. Alleyne Nicholson and Richard LYDEkKER, B.A. Third Edition, entirely Rewritten and greatly Enlarged. 2 vols. 8vo, £3, 3s.

The Ancient Life-History of the Earth. An Outline of the Principles and Leading Facts of Palæontological Science. Crown 8vo, with 276 Engravings, 10s. $6 \mathrm{~d}$. 
NICHOLSON.

On the "Tabulate Corals" of the Palæozoic Period, with Critical Descriptions of Illustrative Species. Mllustrated with 15 Lithographed Plates and numerous Engravings. Super-royal 8vo, 21s.

Synopsis of the Classification of the Animal Kingdom. 8vo, with 106 Illustrations, 6s.

On the Structure and Affinities of the Genus Monticulipora and its Sub-Genera, with Critical Descriptions of Illustrative Species. Illustrated with numerous Engravings on Wood and Lithographed Plates. Super-royal 8vo, 18s.

NICHOLSON.

Thoth. A Romance. By Joseph Shield Nicholson, M.A., D.Sc., Professor of Commercial and Political Economy and Mercantile Law in the University of Edinburgh. Third Edition. Crown 8vo, 4s. 6d.

A Dreamer of Dreams. A Modern Romance. Second Edition. Crown 8vo, $6 \mathrm{~s}$.

NICOLSON AND MURE. A Handbook to the Local Government (Scotland) Act, 1889. With Introduction, Explanatory Notes, and Index. By J. Badenach Nicolson, Advocate, Counsel to the Scotch Education Department, and W. J. MURE, Advocate, Legal Secretary to the Lord Advocate for Scotland. Ninth Reprint. 8vo, $5 \mathrm{~s}$.

OLIPHANT.

Masollam: A Problem of the Period. A Novel. By Ladrence OLtPBANT. 3 vols. post 8vo, 25s. 6 d.

Scientific Religion; or, Higher Possibilities of Life and Practice through the Operation of Natural Forces. Second Edition. 8vo, 16s.

Altiora Peto. Cheap Edition. Crown 8vo, boards, 2s. 6d. ; cloth, 3s. 6d. Illustrated Edition. Crown 8vo, cloth, 6s.

Piccadilly. With Illustrations by Richard Doyle. New Edition, 3s. 6d. Cheap Edition, boards, 2s. 6d.

Traits and Travesties ; Social and Political. Post 8vo, 10s. 6d. Episodes in a Life of Adventure; or, Moss from a Rolling Stone. Cheaper Edition. Post 8vo, 3s. 6d.

Haifa : Life in Modern Palestine. Second Edition. 8vo, 7s. 6d. The Land of Gilead. With Excursions in the Lebanon. With Illustrations and Maps. Demy 8vo, 21s.

Memoir of the Life of Laurence Oliphant, and of Alice Oliphant, his Wife. By Mrs M. O. W. Oliphant. Seventh Edition. 2 vols. post 8vo, with Portraits. 21s.

Popular Edition. With a New Preface. Post 8vo, with Portraits. 7s. 6d.

\section{OLIPHANT.}

Who was Lost and is Found. By Mrs Oliphant. Second Edition. Crown 8vo, $6 \mathrm{~s}$.

Miss Marjoribanks. New Edition. Crown 8vo, 3s. 6d.

The Perpetual Curate, and The Rector. New Edition. Crown 8vo, 3s. 6d.

Salem Chapel, and The Doctor's Family. New Edition. Crown 8vo, 3s. 6d.

Katie Stewart, and other Stories. New Edition. Crown 8vo, cloth, 3s. 6d.

Katie Stewart. Illustrated boards, 2s. 6d.

Valentine and his Brother. New Edition. Crown 8vo, 3s. 6d. Sons and Daughters. Crown 8vo, 3s. 6d.

Two Stories of the Seen and the Unseen. The Open Door - Old Lady Mary. Paper covers, 1 s. 
OLIPHANT. Notes of a Pilgrimage to Jerusalem und the Holy Land. By F. R. OLiphant. Crown 8vo, 3s. 6d.

OSWALD. By Fell and Fjord; or, Scenes and Studies in Iceland. By E. J. OswaLd. Post 8vo, with Illustrations. 7s. 6d.

PAGE.

Introductory Text-Book of Geology. By David PAGE, LL.D., Professor of Geology in the Durham University of Physical Science, Newcastle. With Engravings and Glossarial Index. New Edition. Revised by Professor LAPWORTH of Mason Science College, Birmingham.

Advanced Text-Book of Geology, Descriptive and Industrial. With Engravings, and Glossary of Scientific Terms. New Edition. Revised by Professor LAPWORTH.

Introductory Text-Book of Physical Geography. With SketchMaps and Illustrations. Edited by Professor LAPWORTH, LL.D., F.G.S., \&c., Mason Science College, Birmingham. Thirteenth Edition, Revised and Enlarged. 2s. 6d.

Advanced Text-Book of Physical Geography. Third Edition. PATON. Revised and Enlarged by Professor LAPwORTH. With Engravings. 5s.

Spindrift. By Sir J. Nown Paton. Fcap., cloth, 5s.

Poems by a Painter. Fcap., cloth, 5s.

PATON. Body and Soul. A Romance in Transcendental Pathology. By Frederick Nore Paton. Third Edition. Crown 8vo, 1s.

PATRICK. The Apology of Origen in Reply to Celsus. A Chapter in the History of Apologetics. By the Rev. J. PATrick, D.D. Post 8vo, $7 \mathrm{~s} .6 \mathrm{~d}$.

PAUL. History of the Royal Company of Archers, the Queen's Body-Guard for Scotland. By James Balfour PAUL, Advocate of the Scottish Bar. Crown 4to, with Portraits and other Illustrations. £2, 2s.

PEILE. Lawn Tennis as a Game of Skill. By Lieut.-Col. S. C. F. Peile, B.S.C. Revised Edition, with new Scoring Rules. Fcap. 8vo, cloth, 1s.

PETTIGREW. The Handy Book of Bees, and their Profitable Management. By A. PETTigrew. Fifth Edition, Enlarged, with Engravings. Crown 8vo, 3s. 6d.

PFLEIDERER. Philosophy and Development of Religion. Being the Edinburgh Gifford Lectures for 1894. By OTTO PFLEIDERER, D.D. Professor of Theology at Berlin University. In 2 vols. post 8vo, 15s. net.

PHILOSOPHICAL CLASSICS FOR ENGLISH READERS. Edited by William Knight, LL.D., Professor of Moral Philosophy, University of St Andrews. In crown 8vo volumes, with Portraits, price 3s. 6d.

POLLARD. A Study in TFor List of Volumes, see page 2. tion of Berlin. By James Municipal Government: The CorporaHealth Committee, and Secretary of C.A., Chairman of the Edinburgh Public Second Edition, Revised. Crown 8vo, 3s. 6d.

POLLOK. The Course of Time: A Poem. By RoBert Pollox, A.M. Cottage Edition, 32mo, 8d. The Same, cloth, gilt edges, 1s. 6d. Another Edition, with Illustrations by Birket Foster and others, fcap., cloth, 3s. 6d., or

PORT ROYAL LOGIC. Translated from the French; with Introduction, Notes, and Appendix. By Thomas SPENcer BAynes, LL.D., Professor in the University of St Andrews. Tenth Edition, 12mo, $4 \mathrm{~s}$.

POTTS AND DARNELL.

Aditus Faciliores: An Easy Latin Construing Book, with Complete Vocabulary By A. W. PotTs, M.A., LL.D., and the Rev. C. DARNELL, M.A., Head-Master of Cargilfield Preparatory School Edinburgh. Tenth Edition, fcap. 8 vo, 3s. 6d. 
POTTS AND DARNELL.

Aditus Faciliores Graeci. An Easy Greek Construing Book, with Complete Vocabulary. Fifth Edition, Revised. Fcap. 8vo, 3s.

POTTS. School Sermons. By the late Alexander WM. Potrs, LL.D., First Head-Master of Fettes College. With a Memoir and Portrait. Crown 8vo, 7s. 6d.

PRINGLE. The Live Stock of the Farm. By RoBert O. Pringle. Third Edition. Revised and Edited by James Macdonadd. Crown $8 \mathrm{vo}, 7 \mathrm{~s} .6 \mathrm{~d}$.

PRYDE. Pleasant Memories of a Busy Life. By David Pryde, M.A., LL.D., Author of 'Highways of Literature,' 'Great Men in European His. tory, 'Biographical Outlines of English Literature,' \&c. With a Mezzotint Portrait. Post 8vo, 6s.

PUBLIC GENERAL STATUTES AFFECTING SCOTLAND from 1707 to 1847, with Chronological Table and Index. 3 vols. large 8vo, £3, 3s.

PUBLIC GENERAL STATUTES AFFECTING SCOTLAND, COLLECTION OF. Published Annually, with General Index.

RAE. The Syrian Church in India. By George MILNE RaE, M.A., D.D., Fellow of the University of Madras; late Professor in the Madras Christian College. With 6 full-page Illustrations. Post 8vo, 10s. 6d.

RAMSAY. Scotland and Scotsmen in the Eighteenth Century. Edited from the MSS. of JoHN RAMBAY, Esq. of Ochtertyre, by ALEXANDER ALLARDYCE, Author of 'Memoir of Admiral Lord Keith, K.B.,' \&c. 2 vols. 8vo, 31s. 6d.

RANKIN.

A Handbook of the Church of Scotland. By JAMEs RankIN, D.D., Minister of Muthill; Author of 'Character Studies in the Old Testament,' \&c. An entirely New and much Enlarged Edition. Crown 8vo, with 2 Maps, 7s. $6 \mathrm{~d}$.

The First Saints. Post 8vo, 7s. 6d.

The Creed in Scotland. An Exposition of the Apostles Creed. With Extracts from Archbishop Hamilton's Catechism of 1552, John Calvin's Catechism of 1556, and a Catena of Ancient Latin and other Hymns. Post 8vo, 7s. 6d.

The Worthy Communicant. A Guide to the Devout Observance of the Lord's Supper. Limp cloth, 1s. 3d.

The Young Churchman. Lessons on the Creed, the Commandments, the Means of Grace, and the Church. Limp cloth, 1s. 3d.

First Communion Lessons. 25th Edition. Paper Cover, 2d.

RANKINE. A Hero of the Dark Continent. Memoir of Rev. Wm. Affleck Scott, M.A., M.B., C.M., Church of Scotland Missionary at Blantyre, British Central Africa. By W. HENRY RANKINE, B.D., Minister at St Boswells. With a Portrait and other Illustrations. Crown 8vo, $5 \mathrm{~s}$.

RECORDS OF THE TERCENTENARY FESTIVAL OF THE UNIVERSITY OF EDINBURGH. Celebrated in April 1884. Published under the Sanction of the Senatus Academicus. Large 4to, £2, $12 \mathrm{~s} .6 \mathrm{~d}$.

ROBERTSON. The Early Religion of Israel. As set forth by Biblical Writers and Modern Critical Historians. Being the Baird Lecture for 1888-89. By JAMEs RoBertson, D.D., Professor of Oriental Languages in the University of Glasgow. Fourth Edition. Crown 8vo, 10s. 6d.

ROBERTSON.

Orellana, and other Poems. By J. Logie RoBertson, M.A. Fcap. 8vo. Printed on hand-made paper. 6s.

A History of English Literature. For Secondary Schools. With an Introduction by Professor MAssoN, Edinburgh University. Cr. 8vo, 3s. 
ROBERTSON.

English Verse for Junior Classes. In Two Parts. Part I.Chaucer to Coleridge. Part II.-Nineteenth Century Poets. Crown 8vo, each 1s. 6 d. net.

ROBERTSON. Our Holiday among the Hills. By JAMES and JANET Logie Robertson. Fcap. 8vo, 3s. $6 \mathrm{~d}$.

ROBERTSON. Essays and Sermons. By the late W. RoBerTson, B.D., Minister of the Parish of Sprouston. With a Memoir and Portrait. Crown 8vo, 5s. 6d.

RODGER. Aberdeen Doctors at Home and Abroad. The Story of a Medical School. By Ella Hill Burton Rodger. Demy 8vo, 10s. 6d.

ROSCOE. Rambles with a Fishing-Rod. By E. S. Roscoz. Crown 8vo, 4s. 6 d.

ROSS AND SOMERVILLE. Beggars on Horseback : A Riding Tour in North Wales. By Martin Ross and E. CE. Somervilue. With Illustra. tions by E. OE. Somerville. Crown 8vo, 3s. 6 d.

RUTLAND.

Notes of an Irish Tour in 1846. By the Duke of Rutland, G.C.B. (Lord John Manners). New Edition. Crown 8vo, 2s. 6d.

Correspondence between the Right Honble. William Pitt and Charles Duke of Rutland, Lord-Lieutenant of Ireland, 1781-1787. With Introductory Note by JoHN DUKE OF RUTLAND. 8vo, 7s. 6d.

RUTLAND.

Gems of German Poetry. Translated by the Duchess of RUTLAND (Lady JoHN MANNERs). $\quad$ [Nevv Edition in preparation.

Impressions of Bad-Homburg. Comprising a Short Account of the Women's Associations of Germany under the Red Cross. Crown 8vo, 1s. 6d.

Some Personal Recollections of the Later Years of the Earl of Beaconsfield, K.G. Sixth Edition. 6d.

Employment of Women in the Public Service. 6d.

Some of the Advantages of Easily Accessible Reading and Recreation Rooms and Free Libraries. With Remarks on Starting and Main. taining them. Second Edition. Crown 8vo, 1s.

A Sequel to Rich Men's Dwellings, and other Occasional Papers. Crown 8vo, 2s. 6d.

Encouraging Experiences of Reading and Recreation Rooms, Aims of Guilds, Nottingham Social Guide, Existing Institutions, \&c., \&c. Crown 8vo, 1s.

SAINTSBURY. The Flourishing of Romance and the Rise of Allegory (12th and 13th Centuries). By George Saintsbury, M.A., Professor of Rhetoric and English Literature in Edinburgh University. Being the first volume issued of "Periods of European Literatore." Edited by Professor SaIntsbury. Crown 8vo, 5s. net.

SALMON. Songs of a Heart's Surrender, and other Verse. By Arthur L. Salmon. Fcap. 8vo, 2s.

SCHEFFEL. The Trumpeter. A Romance of the Rhine. By JosEPH Victor voN ScHEFFEL. Translated from the Two Hundredth German Edition by Jessie BECK and Louisa LoRIMER. With an Introduction by Sir Theodore Martin, K.C.B. Long 8vo, 3s. 6d.

SCHILLER. Wallenstein. A Dramatic Poem. By FrIEdRICH voN Schiller. Translated by C. G. N. LockHART. Fcap. 8vo, 7s. 6d.

SCOTT. Tom Cringle's Log. By Michael Scott. New Edition. With 19 Full-page Illustrations. Crown 8vo, 3s. 6d.

SCOUGAL. Prisons and their Inmates; or, Scenes from a Silent World. By Francrs Scougal. Crown 8vo, boards, 2s. 
SELKIRK. Poems. By J. B. SeLKIRK, Author of 'Ethics and Esthetics of Modern Poetry,' 'Bible Truths with Shakespearian Parallels,' \&c. New and Enlarged Edition. Crown 8vo, printed on antique paper, 6s.

SELLAR'S Manual of the Acts relating to Education in Scotland. By J. Edward GrahaM, B.A. Oxon., Advocate. Ninth Edition. Demy 8vo, 12s. 6d.

SETH.

Scottish Philosophy. A Comparison of the Scottish and German Answers to Hume. Balfour Philosophical Lectures, University of Edinburgh. By ANDREW SETH, LL.D., Professor of Logic and Metaphysics in Edinburgh University. Second Edition. Crown 8vo, 5s.

Hegelianism and Personality. Balfour Philosophical Lectures. Second Series. Second Edition. Crown 8vo, 5s.

SETH. A Study of Ethical Principles. By James Seth, M.A., Professor of Philosophy in Cornell University, U.S.A. Second Edition, Revised. Post 8vo, 10s. 6d. net.

SHADWELL. The Life of Colin Campbell, Lord Clyde. Illustrated by Extracts from his Diary and Correspondence. By Lieutenant-General Shadweld, C.B. With Portrait, Maps, and Plans. 2 vols. 8vo, 36s.

SHAND.

The Life of General Sir Edward Bruce Hamley, K.C.B., K.C.M.G. By Arex. INNEs SHAND, Author of 'Kilcarra,' 'Against Time,' \&c.' With two Photogravure Portraits and other Illustrations. Cheaper Edition, with a Statement by Mr Edward Hamley. 2 vols. demy 8vo, 10s. 6d.

Half a Century ; or, Changes in Men and Manners. Second Edition. 8vo, 12s. $6 \mathrm{~d}$.

Letters from the West of Ireland. Reprinted from the 'Times.' Crown 8vo, $5 \mathrm{~s}$.

SHARPE. Letters from and to Charles Kirkpatrick Sharpe. Edited by ALEXANDER AlLARDYCE, Author of 'Memoir of Admiral Lord Keith, K.B.,' \&c. With a Memoir by the Rev. W. K. R. BEDFoRD. In 2 vols. 8vo. Illustrated with Etchings and other Engravings. $£ 2,12 \mathrm{~s} .6$ d.

SIM. Margaret Sim's Cookery. With an Introduction by L. B. WALFoRd, Author of 'Mr Smith: A Part of his Life,' \&c. Crown 8vo, 58.

SIMPSON. The Wild Rabbit in a New Aspect; or, RabbitWarrens that Pay. A book for Landowners, Sportsmen, Land Agents, Farmers, Gamekeepers, and Allotment Holders. A Record of Recent Experiments conducted on the Estate of the Right Hon. the Earl of Wharncliffe at Wortley Hall. By J. Simpson. Second Edition, Enlarged. Small crown 8vo, 5s.

SKELTON.

The Table-Talk of Shirley. By John Skelton, Advocate, C.B., LL.D., Author of 'The Essays of Shirley.' With a Frontispiece. Sixth Edition, Revised and Enlarged. Post 8vo, 7s. 6d.

The Table-Talk of Shirley. Second Series. Summers and Winters at Balmawhapple. With Illustrations. Two Volumes. Second Edition. Post 8vo, 10s. net.

Maitland of Lethington; and the Scotland of Mary Stuart. A History. Limited Edition, with Portraits. Demy 8vo, 2 vols., 28s. net.

The Handbook of Public Health. A Complete Edition of the Public Health and other Sanitary Acts relating to Scotland. Annotated, and with the Rules, Instructions, and Decisions of the Board of Supervision brought up to date with relative forms. Second Edition. With Introduction, containing the Administration of the Public Health Act in Counties. 8vo, 8s. 6d.

The Local Government (Scotland) Act in Relation to Public Health. A Handy Guide for Connty and District Councillors, Medical Officers, Sanitary Inspectors, and Members of Parochial Boards. Second Edition. With a new Preface on appointment of Sanitary Officers. Crown 8vo, $2 \mathrm{~s}$. 
SKRINE. Columba: A Drama. By JoHN Huntlex Skrine, Warden of Glenalmond ; Author of 'A Memory of Edward Thring.' Fcap. 4to, 6s.

SMITH.

Thorndale ; or, The Conflict of Opinions. By William Sмiтн, Author of 'A Discourse on Ethics,' \&c. New Edition. Crown 8vo, 10s. 6d.

Gravenhurst; or, Thoughts on Good and Evil. Second Edition. With Memoir and Portrait of the Author. Crown 8vo, 8s.

The Story of William and Lucy Smith. Edited by GEorar Merriam. Large post 8vo, 12s. $6 \mathrm{~d}$.

SMITH. Memoir of the Families of M'Combie and Thoms, originally $\mathbf{M}$ 'Intosh and $\mathbf{M}^{\prime}$ Thomas. Compiled from History and Tradition. By William M'Combie SMith. With mllustrations. 8vo, 7s. 6d.

SMITH. Greek Testament Lessons for Colleges, Schools, and Private Students, consisting chiefly of the Sermon on the Mount and the Parables of our Lord. With Notes and Essays. By the Rev. J. Hunter Smith, M.A., King Edward's School, Birmingham. Crown 8vo, 6s.

SMITH. The Secretary for Scotland. Being a Statement of the Powers and Duties of the new Scottish Office. With a Short Historical Intro. duction, and numerous references to important Administrative Documents. By W. C. SMith, LL.B., Advocate. 8vo, $6 \mathrm{~s}$.

"SON OF THE MARSHES, A."

From Spring to Fall; or, When Life Stirs. By "A SoN of THE MARShES." Cheap Uniform Edition. Crown 8vo, 3s. 6d.

Within an Hour of London Town : Among Wild Birds and their Haunts. Edited by J. A. OWEN. Cheap Uniform Edition. Crown 8vo, 3s. $6 \mathrm{~d}$.

With the Woodlanders and by the Tide. Cheap Uniform Edition. Crown 8vo, 3s. 6d.

On Surrey Hills. Cheap Uniform Edition. Crown 8vo, 3s. 6d. Annals of a Fishing Village. Cheap Uniform Edition. Crown 8vo, 3s. 6d.

SORLEY. The Ethics of Naturalism. Being the Shaw Fellowship Lectures, 1884. By W. R. Sorley, M.A., Fellow of Trinity College, Cambridge, Professor of Moral Philosophy in the University of Aberdeen. Crown 8vo, 6s.

SPEEDY. Sport in the Highlands and Lowlands of Scotland with Rod and Gun. By Tom SPEEDr. Second Edition, Revised and Enlarged. With Illustrations by Lieut.-General Hope Crealocke, C.B., C.M.G., and others. $8 \mathrm{vo}, 15 \mathrm{~s}$.

SPROTT. The Worship and Offices of the Church of Scotland. By GEorge W. Sprott, D.D., Minister of North Berwick. Crown Svo, 6s.

STATISTICAL ACCOUNT OF SCOTLAND. Complete, with Index. 15 vols. 8 vo, $£ 16,16 \mathrm{~s}$.

STEPHENS.

The Book of the Farm ; detailing the Labours of the Farmer, Farm-Steward, Ploughman, Shepherd, Hedger, Farm-Labourer, Field-Worker, and Cattle-man. Illustrated with numerous Portraits of Animals and Engravings of Implements, and Plans of Farm Buildings. Fourth Edition. Revised, and in great part Rewritten by James MAcDonald, F.R.S.E., Secretary Highland and Agricultural Society of Scotland. Complete in Six Divisional Volumes, bound in cloth, each 10s. 6d., or handsomely bound, in 3 volumes, with leather back and gilt top, $£ 3$, 3s.

Catechism of Practical Agriculture. 22d Thousand. Revised by James MacDonaLd, F.R.S.E. With numerous Illustrations. Crown 8vo, 1s.

The Book of Farm Implements and Machines. By J. SuIGHT and R. Scott Burn, Engineers. Idited by Henry Stephens. Large 8vo, £2, 2s. 
STEVENSON. British Fungi. (Hymenomycetes.) By Rev. JoHN STEVENSON, Author of 'Mycologia Scotica,' Hon. Sec. Cryptogamic Society of Scotland. Vols. I. and II., post 8vo, with Illustrations, price 12s. 6d. net each.

STEWART. Advice to Purchasers of Horses. By JoHN Stewart, V.S. New Edition. 2s. 6 d.

STEWART. Boethius: An Essay. By Hugh Fraser Stewart, M.A., Trinity College, Cambridge. Crown 8vo, 78. 6d.

STODDART. Angling Songs. By Thomas Tod Stoddart. New Fdition, with a Memoir by AnNa M. Stoddart. Crown 8vo, 7s. 6d.

STODDART.

John Stuart Blackie: A Biography. By AnNa M. Stoddart. With 3 Plates. Third Edition. 2 vols. demy 8vo, $21 \mathrm{~s}$.

Popular EDition, with Portrait. Crown 8vo, 6s.

Sir Philip Sidney : Servant of God. Illustrated by MARGARET L. Hugarss. With a New Portrait of Sir Philip Sidney. Small 4to, with a specially designed Cover. $5 \mathrm{~s}$.

STORMONTH.

Dictionary of the English Language, Pronouncing, Etymological, and Explanatory. By the Rev. JAMES STormontr. Revised by the Rev. P. H. PhelP. Library Edition. New and Cheaper Edition, with Supple. ment. Imperial 8vo, handsomely bound in half morocco, 18s. net.

Etymological and Pronouncing Dictionary of the English Language. Including a very Copious Selection of Scientific Terms. For use in Schools and Colleges, and as a Book of General Reference. The Pronunciation carefully revised by the Rev. P. H. Phelp, M.A. Cantab. Thirteenth Edition, with Supplement. Crown 8vo, pp. 800. 7s. 6d.

The School Etymological Dictionary and Word-Book. New Fdition, Revised.

[In preparation.

\section{STORY.}

Nero; A Historical Play. By W. W. SToRY, Author of

Vallombrosa. Post 8vo, 5s.

Poems. 2 vols., 7s. 6d.

Fiammetta. A Summer Idyl. Crown 8vo, 7s. 6d.

Conversations in a Studio. 2 vols. crown $8 \mathrm{vo}, 12 \mathrm{~s} .6 \mathrm{~d}$.

Excursions in Art and Letters. Crown 8vo, 7s. 6d.

A Poet's Portfolio : Later. Readings. 18mo, 3s. 6d.

STRACHEY. Talk at a Country House. Fact and Fiction. By Sir Edward Strachey, Bart. With a Portrait of the Author. Crown 8vo, 4s. 6d. net.

STURGIS. Little Comedies, Old and New. By Julian Sturgis. Crown 8vo, 7s. 6d.

SUTHERLAND. Handbook of Hardy Herbaceous and Alpine Flowers, for General Garden Decoration. Containing Descriptions of upwards of 1000 Species of Ornamental Hardy Perennial and Alpine Plants; along with Concise and Plain Instructions for their Propagation and Culture. By William SuthrarlaND, Landscape Gardener; formerly Manager of the Herbaceous Department at Kew. Crown 8vo, 7s. 6d.

TAYLOR. The Story of my Life. By the late Colonel Mnadows Taylor, Author of 'The Confessions of a Thug,' \&c., \&c. Edited by his Daughter. New and Cheaper Exdition, being the Fourth. Crown 8vo, 6s. 


\section{THOMSON.}

The Diversions of a Prime Minister. By Basil Thomson. With a Map, numerous Illustrations by J. W. Cawston and others, and Reproductions of Rare Plates from Early Voyages of Sixteenth and Seventeenth Centuries. Small demy 8vo, 15s.

South Sea Yarns. With 10 Full-page Illustrations. Cheaper Edition. Crown 8vo, 3s. 6d.

THOMSON.

Handy Book of the Flower-Garden: Being Practical Directions for the Propagation, Culture, and Arrangement of Plants in FlowerGardens all the year round. With Engraved Plans. By David THomson, Gardener to his Grace the Duke of Buccleuch, K.T., at Drumlanrig. Fourth and Cheaper Edition. Crown 8vo, 5s.

The Handy Book of Fruit-Culture under Glass: Being a series of Elaborate Practical Treatises on the Cultivation and Forcing of Pines, Vines, Peaches, Figs, Melons, Strawberries, and Cucumbers. With Engravings of Hothouses, \&c. Second Edition, Revised and Enlarged. Crown 8vo, 7s. 6d.

THOMSON. A Practical Treatise on the Cultivation of the Grape Vine. By William Thomson, Tweed Vineyards. Tenth Edition. 8vo, 5s.

THOMSON. Cookery for the Sick and Convalescent. With Directions for the Preparation of Poultices, Fomentations, \&c. By Barbara Thomson. Fcap. 8vo, 1s. 6d.

THORBURN. Asiatic Neighbours. By S. S. Thorburn, Bengal Civil Service, .Author of 'Bannú; or, Our Afghan Frontier,' 'David Leslie : A Story of the Afghan Frontier,' 'Musalmans and Money-Lenders in the Panjab.' With Two Maps. Demy 8vo, 10s. 6d. net.

THORNTON. Opposites. A Series of Essays on the Unpopular Sides of Popular Questions. By Lewis Thornton. 8vo, 12s.6d.

TRANSACTIONS OF THE HIGHLAND AND AGRICULTURAL SOCIETY OF SCOTLAND. Published annually, price $5 \mathrm{~s}$.

TRAVERS.

Mona Maclean, Medical Student. A Novel. By Graham Travers. Twelfth Edition. Crown 8vo, 6 s.

Fellow Travellers. Third Edition. Crown 8vo, 6s.

TRYON. Life of Admiral Sir George Tryon. By Rear-Admiral C. C. Penrose Fitzgerald. With Portrait and numerous Illustrations. In one vol. demy 8vo.

[In the press.

TULLOCH.

Rational Theology and Christian Philosophy in England in the Seventeenth Century. By JoHN TULLOCH, D.D., Principal of St Mary's College in the University of St Andrews, and one of her Majesty's Chaplains in Ordinary in Scutland. Second Edition. 2 vols. 8vo, 16s.

Modern Theories in Philosophy and Religion. 8vo, 15s.

Luther, and other Leaders of the Reformation. Third Edition, Enlarged. Crown 8vo, 3s. 6d.

Memoir of Principal Tulloch, D.D., LL.D. By Mrs OLIPHant, Author of 'Life of Edward Irving.' Third and Cheaper Edition. 8vo, with Portrait, 7s. 6d.

TWEEDIE. The Arabian Horse: His Country and People. By Major -General W. TwEedie, C.S.I., Bengal Staff Corps; for many years H.B.M.'s Consul-General, Baghdad, and Political Resident for the Government of India in Turkish Arabia. In one vol. royal 4to, with Seven Coloured Plates and other Illustrations, and a Map of the Country. Price \&3, 3s. net. 
TYLER. The Whence and the Whither of Man. A Brief History of his Origin and Development through Conformity to Environment. The Morse Lectures of 1895. By JoHN M. TyLer, Professor of Biology, Amherst College, U.S.A. Post 8vo, 6s. net.

\section{VEITCH.}

Memoir of John Veitch, LL.D., Professor of Logic and Rhetoric, University of Glasgow. By Mary R. L. BRYce. With Portrait and 3 Photogravure Plates. Demy 8vo, 7s. 6d.

Border Essays. By JoHN VeItch, LL.D., Professor of Logic and Rhetoric, University of Glasgow. Crown 8vo, 4s. 6d. net.

The History and Poetry of the Scottish Border : their Main Features and Relations. New and Enlarged Edition. 2 vols. demy 8vo, 16s.

Institutes of Logic. Post 8vo, 12s. 6d.

The Feeling for Nature in Scottish Poetry. From the Earliest Times to the Present Day. 2 vols. fcap. 8vo, in roxburghe binding, $15 \mathrm{~s}$.

Merlin and other Poems. Fcap. 8vo, 4s. 6d.

Knowing and Being. Essays in Philosophy. First Series. Crown 8vo, 5s.

Dualism and Monism; and other Essays. Essays in Philosophy. Second Series. With an Introduction by R. M. Wenley. Crown 8vo, 4s. 6 d. net.

VIRGIL. The Aneid of Virgil. Translated in English Blank Verse by G. K. RICKARDs, M.A., and Lord RAVEnsworth. 2 vols. fcap. 8vo, 10s.

WACE. Christianity and Agnosticism. Reviews of some Recent Attacks on the Christian Faith. BY HENRY WACE, D.D., Principal of King's College, London; Preacher of Lincoln's Inn; Chaplain to the Queen. Second Edition. Post 8vo, 10s. 6d. net.

WADDELL. An Old Kirk Chronicle : Being a History of Auldhame, Tyninghame, and Whitekirk, in East Lothian. From Session Records, 1615 to 1850. By Rev. P. HATELY WADDELL, B.D., Minister of the United Parish. Small Paper Edition, 200 Copies. Price £l. Large Paper Edition, 50 Copies. Price $£ 1,10$ s.

Waldo. The Ban of the Gubbe. By Cedric Dane Waldo. Crown 8vo, 2s. 6 d.

WALFORD. Four Biographies from 'Blackwood' : Jane Taylor, Hannah More, Elizabeth Fry, Mary Somerville. By L. B. WALFord. Crown $8 \mathrm{vo}, 5 \mathrm{~s}$.

WARREN'S (SAMUEL) WORKS :-

Diary of a Late Physician. Cloth, 2s. 6d.; boards, $2 \mathrm{~s}$.

Ten Thousand A-Year. Cloth, 3s. 6d. ; boards, 2s. 6d.

Now and Then. The Lily and the Bee. Intellectual and Moral Development of the Present Age. 4s. 6d.

Essays : Critical, Imaginative, and Juridical. $5 \mathrm{~s}$.

WENLEY.

Socrates and Christ: A Study in the Philosophy of Religion. By R. M. Wentey, M.A., D.Sc., D.Phil., Professor of Philosophy in the University of Michigan, U.S.A. Crown $8 v 0,6 \mathrm{~s}$.

Aspects of Pessimism. Crown 8vo, 6s.

WHITE.

The Eighteen Christian Centuries. By the Rev. James Wніте. Seventh Edition. Post 8vo, with Index, 6s.

History of France, from the Earliest Times. Sixth Thousand. Post 8vo, with Index, 6s. 


\section{Books Published by William Blackwood and Sons.}

WHITE.

Archæological Sketches in Scotland-Kintyre and Knapdale. By Colonel T. P. WHITE, R.E., of the Ordnance Survey. With numerous Illus. trations. 2 vols. folio, $£ 4,4 \mathrm{~s}$. Vol. I., Kintyre, sold separately, £2, $2 \mathrm{~s}$.

The Ordnance Survey of the United Kingdom. A Popular Account. Crown 8vo, 5s.

WILLIAMSON. The Horticultural Handbook and Exhibitor's Guide. A Treatise on Cultivating, Exhibiting, and Judging Plants, Flowers, Fruits, and Vegetables. By W. Williamson, Gardener. Revised by Malcolm Duns, Gardener to his Grace the Duke of Buccleuch and Queensberry, Dalkeith Park. New and Cheaper Edition, enlarged. Crown 8vo, paper cover, 2s. ; cloth, 2s. $6 \mathrm{~d}$.

WILliamson. Poems of Nature and Life. By David $\mathbf{R}$. Williamson, Minister of Kirkmaiden. Fcap. 8vo, 3s.

WIILLS. Behind an Eastern Veil. A Plain Tale of Events occurring in the Experience of a Lady who had a unique opportunity of observing the Inner Life of Ladies of the Upper Class in Persia. By C. J. Wirts, Author of 'In the Land of the Lion and Sun,' 'Persia as it is,' \&c., \&c. Cheaper Edition. Demy 8vo, 5s.

WILSON.

Works of Professor Wilson. Edited by his Son-in-Law, Professor FErRier. 12 vols. crown 8vo, £2, 8s.

Christopher in his Sporting-Jacket. 2 vols., $8 \mathrm{~s}$.

Isle of Palms, City of the Plague, and other Poems. 4s.

Lights and Shadows of Scottish Life, and other Tales. 4s.

Essays, Critical and Imaginative. 4 vols., 16s.

The Noctes Ambrosianæ. 4 vols., 16s.

Homer and his Translators, and the Greek Drama. Crown $8 \mathrm{vo}, 4 \mathrm{~s}$.

WORSLEY.

Poems and Translations. By Philip Stanhope Worslex, M.A. Edited by EDWARD Worsuey. Second Edition, Enlarged. Fcap. 8vo, 6s.

Homer's Odyssey. Translated into English Verse in the Spenserian Stanza. By P. S. Worsley. New and Cheaper Edition. Post 8vo, $7 \mathrm{~s}, 6 \mathrm{~d}$. net.

Homer's Iliad. Translated by P. S. Worsley and Prof. Conington. 2 vols. crown $8 \mathrm{vo}, 21 \mathrm{~s}$.

YATE. England and Russia Face to Face in Asia. A Record of Travel with the Afghan Boundary Commission. By Captain A. C. YATE, Bombay Staff Corps. 8vo, with Maps and Illustrations, 21s.

YATE. Northern Afghanistan; or, Letters from the Afghan Boundary Commission. By Major C. E. YATE, C.S.I., C.M.G., Bombay Staff Corps, F.R.G.S. 8vo, with Maps, 18s.

YULE. Fortification : For the use of Officers in the Army, and Readers of Military History. By Colonel YULE, Bengal Engineers. 8vo, with Numerous Illustrations, 10s. 



\section{UNIVERSITY OF CALIFORNIA LIBRARY, BERKELEY}

\section{THIS BOOK IS DUE ON THE LAST DATE}

STAMPED BELOW

Books not returned on time are subject to a fine of $50 \mathrm{c}$ per volume after the third day overdue, increasing to $\$ 1.00$ per volume after the sixth day. Books not in demand may be renewed if application is made before expiration of loan period.

Mving 3 gan 
YC 30489 
